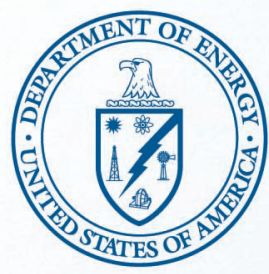

DOE/ID-10997

Revision 3

February 2009

U.S. Department of Energy

Idaho Operations Office

\title{
Idaho National Lahoratory Cultural Resource Management Plan
}

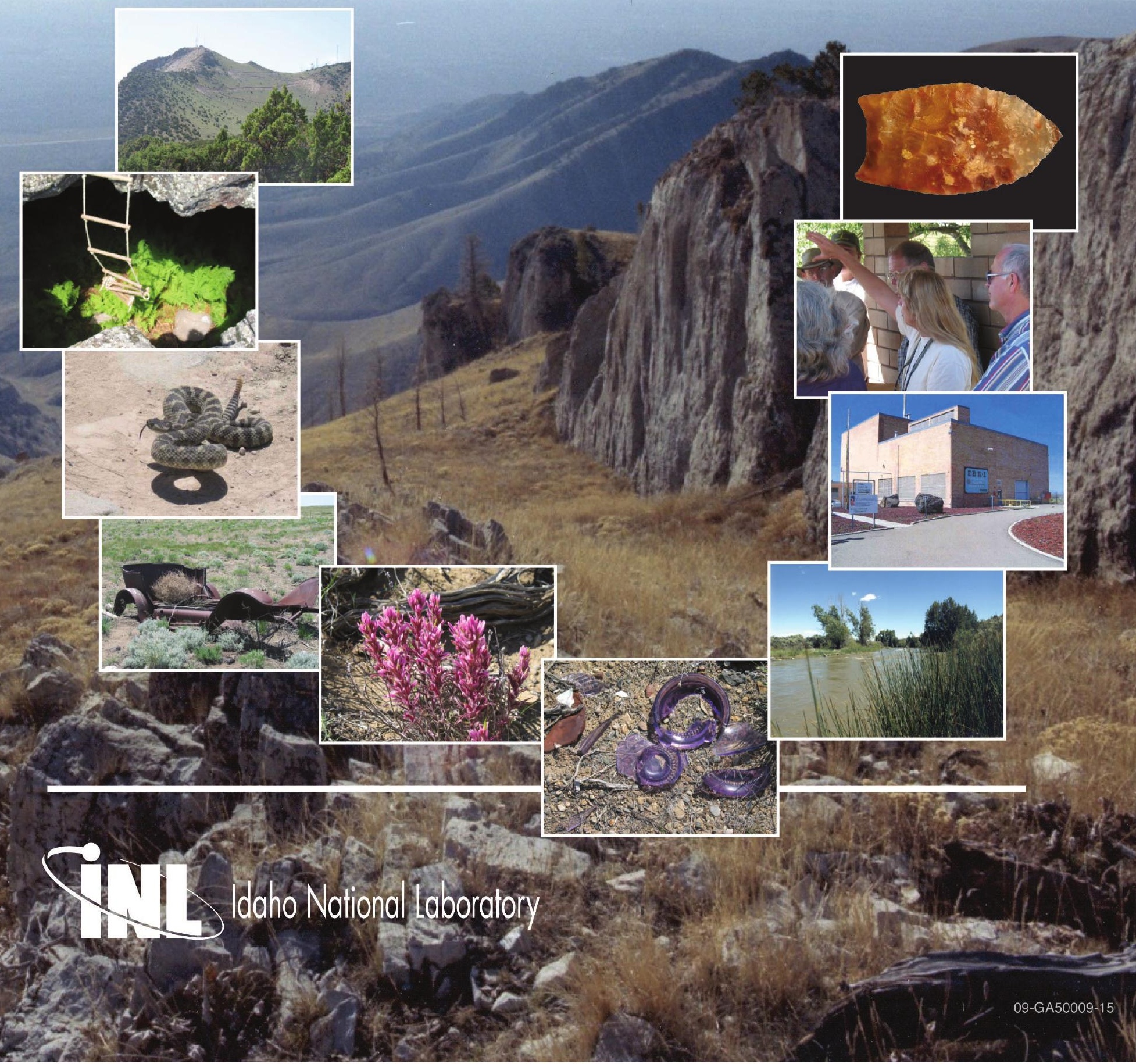


DOE/ID-10997

Revision 3

\section{Idaho National Laboratory Cultural Resource Management Plan}

February 2009

Prepared for the U.S. Department of Energy Idaho Operations Office 



\begin{abstract}
As a federal agency, the U.S. Department of Energy has been directed by Congress, the U.S. president, and the American public to provide leadership in the preservation of prehistoric, historic, and other cultural resources on the lands it administers. This mandate to preserve cultural resources in a spirit of stewardship for the future is outlined in various federal preservation laws, regulations, and guidelines such as the National Historic Preservation Act, the Archaeological Resources Protection Act, and the National Environmental Policy Act. The purpose of this Cultural Resource Management Plan is to describe how the Department of Energy, Idaho Operations Office will meet these responsibilities at Idaho National Laboratory.

This Laboratory, which is located in southeastern Idaho, is home to a wide variety of important cultural resources representing at least 13,500 years of human occupation in the southeastern Idaho area. These resources are nonrenewable; bear valuable physical and intangible legacies; and yield important information about the past, present, and perhaps the future. There are special challenges associated with balancing the preservation of these sites with the management and ongoing operation of an active scientific laboratory. The Department of Energy, Idaho Operations Office is committed to a cultural resource management program that accepts these challenges in a manner reflecting both the spirit and intent of the legislative mandates.

This document is designed for multiple uses and is intended to be flexible and responsive to future changes in law or mission. Document flexibility and responsiveness will be assured through annual reviews and as-needed updates. Document content includes summaries of Laboratory cultural resource philosophy and overall Department of Energy policy; brief contextual overviews of Laboratory missions, environment, and cultural history; and an overview of cultural resource management practices. A series of appendices provides important details that support the main text.
\end{abstract}




\section{CONTENTS}

ABSTRACT

ACRONYMS, ABBREVIATIONS, AND SYMBOLS . ix

GLOSSARY xxiii

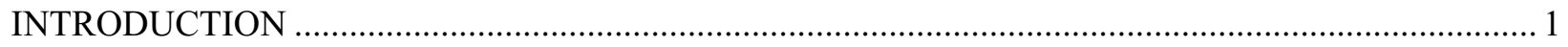

Legal Basis for Cultural Resource Management ..................................................................... 1

DOE Cultural Resource Management Philosophy .................................................................... 2

Purpose of this Cultural Resource Management Plan ......................................................................... 3

Scope of this Cultural Resource Management Plan ........................................................................ 3

Organization of this Cultural Resource Management Plan ........................................................ 4

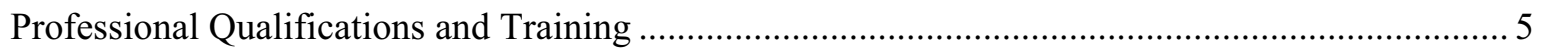

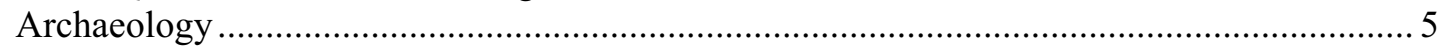

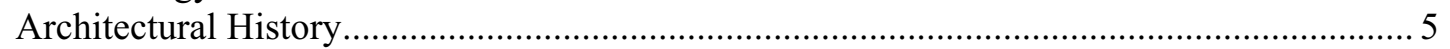

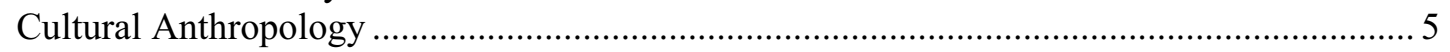

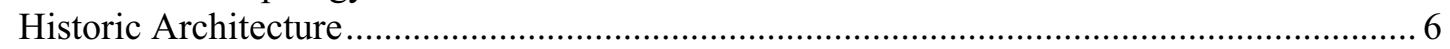

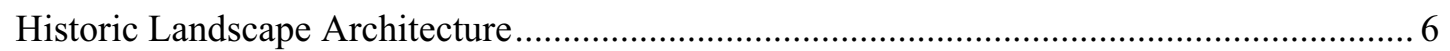

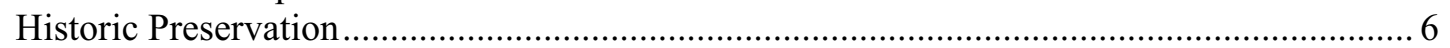

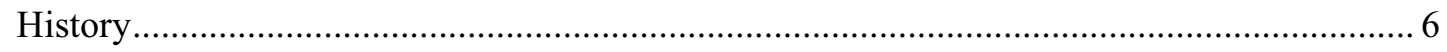

CULTURAL RESOURCES OF THE IDAHO NATIONAL LABORATORY ..................................... 9

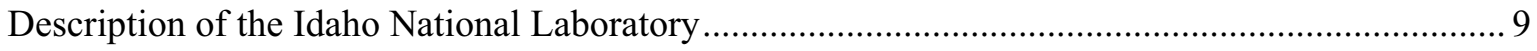

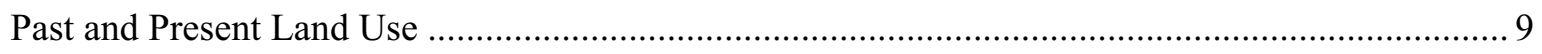

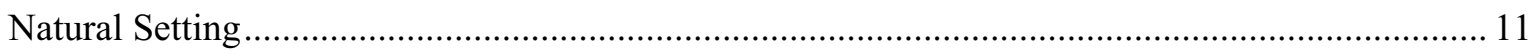

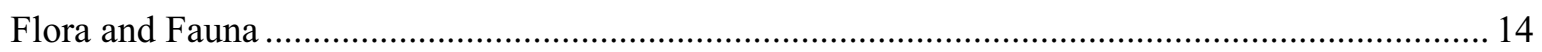

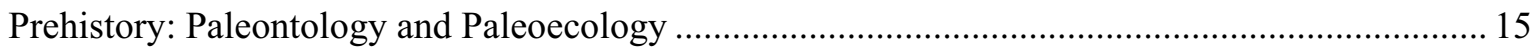

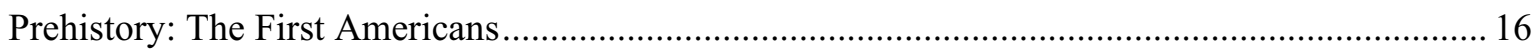

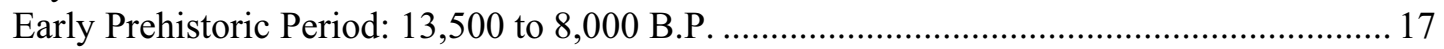

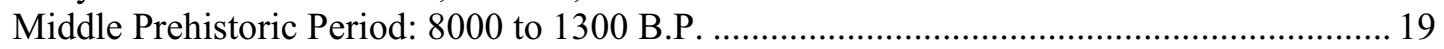

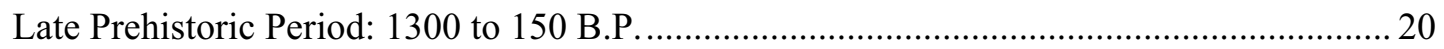

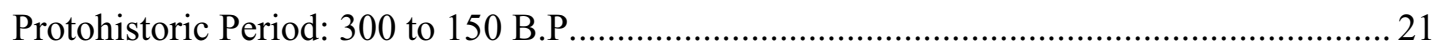

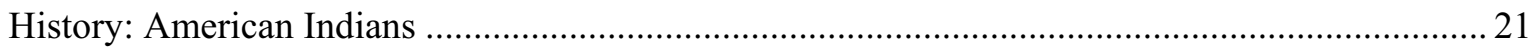

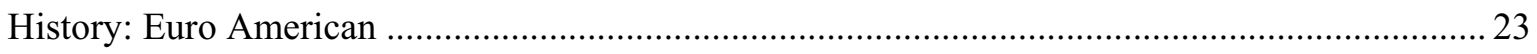

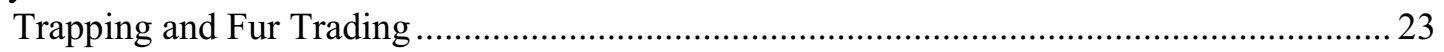

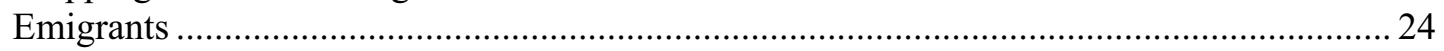

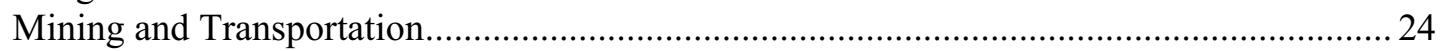

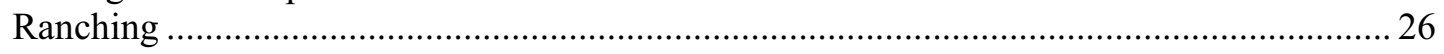

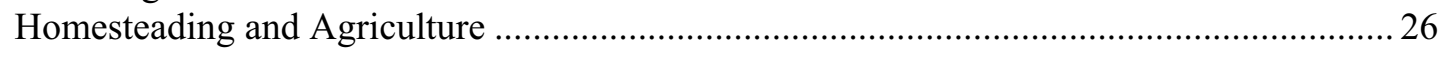

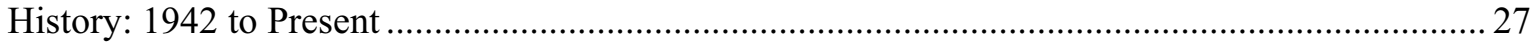

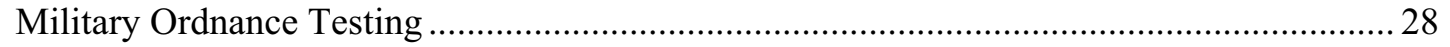

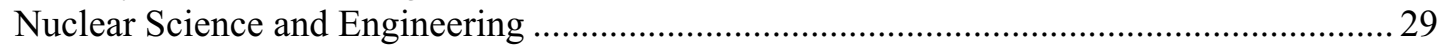

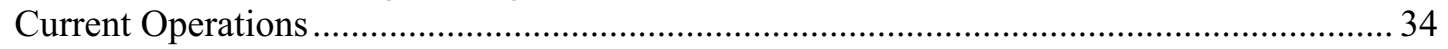


IDAHO NATIONAL LABORATORY CULTURAL RESOURCE MANAGEMENT 35

Past, Present, and Potential Effects of INL Activities on Cultural Resources.................................. 35

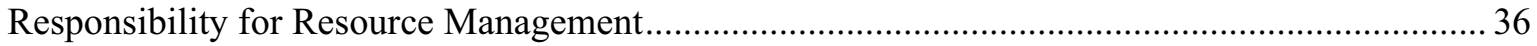

Primary Activities of the INL Cultural Resource Management Office .......................................... 36

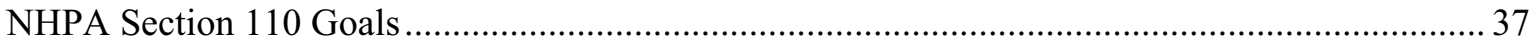

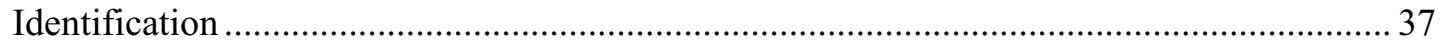

Evaluation and Nomination to the National Register of Historic Places ................................ 39

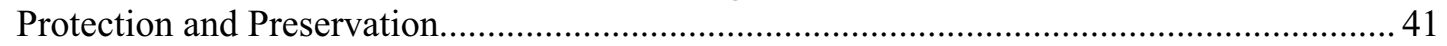

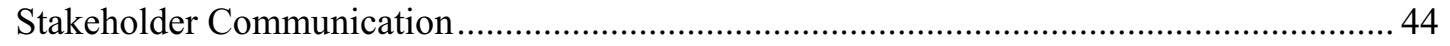

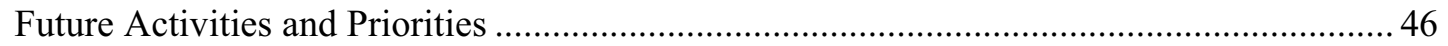

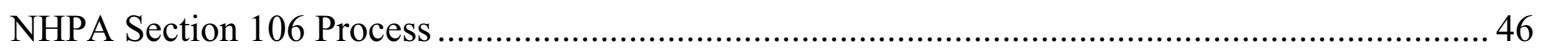

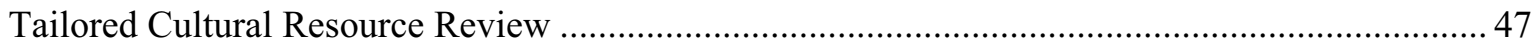

Activities and Properties Exempt From Cultural Resource Review ................................... 47

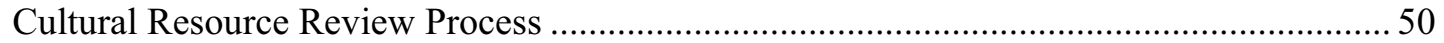

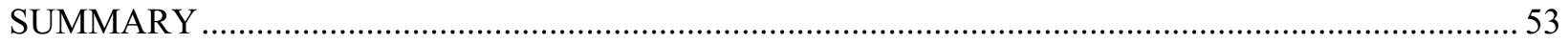

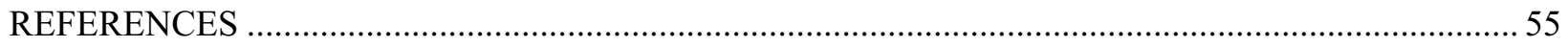

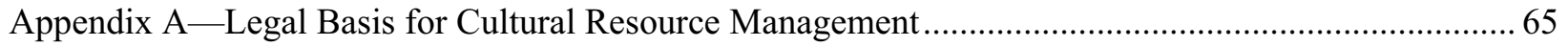

Appendix B - American Indian Interests: DOE Policy and Regulatory Guidance ................................ 83

Attachment 1-U.S. Department of Energy American Indian and Alaska Native Tribal

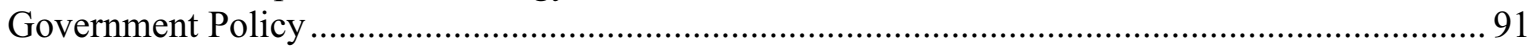

Attachment 2-Agreement-in-Principle between the Shoshone-Bannock Tribes and the United

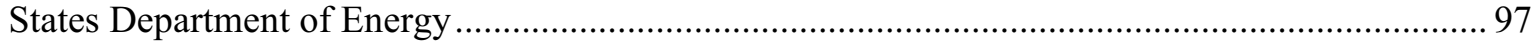

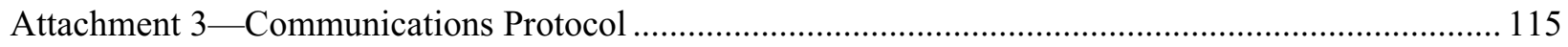

Attachment 4-Memorandum of Agreement Between United States Department of Energy, Idaho

Operations Office and the Shoshone-Bannock Tribes.............................................................. 123

Appendix C-Standards and Procedures for the Management of INL Archaeological Properties .......... 129

Appendix D - Strategies and Procedures for the Management of INL Historic Architectural

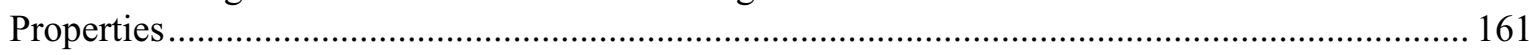

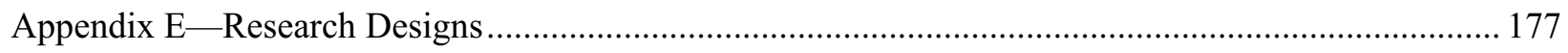

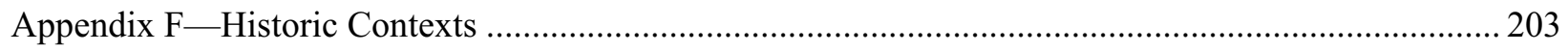

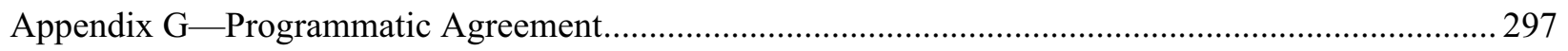

Appendix H-Inventory of Known INL Archaeological Resources ................................................... 305

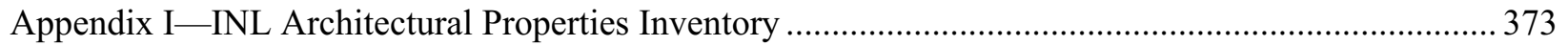


Appendix J—INL Cultural Resource Projects

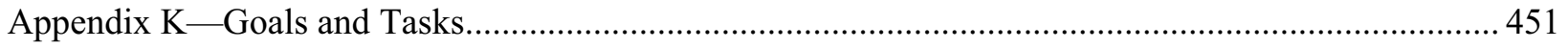

Appendix L_-Idaho National Laboratory Cultural Resource Monitoring Plan...................................... 457

\section{FIGURES}

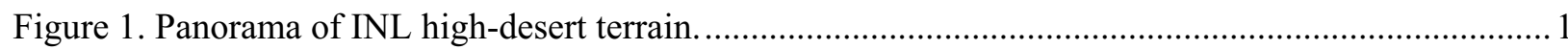

Figure 2. Official seal of the U.S. Department of Energy................................................................ 1

Figure 3. Physiographic setting of Idaho National Laboratory showing locations of major

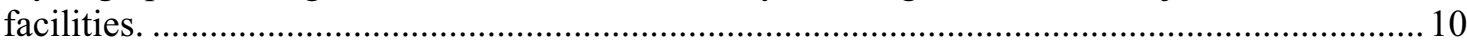

Figure 4. Big Southern Butte viewed from the Big Lost River. ........................................................ 12

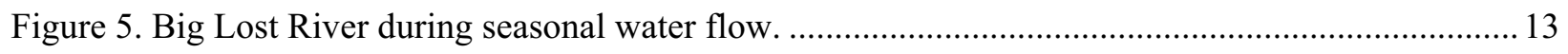

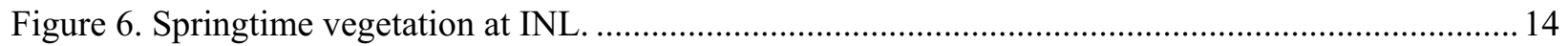

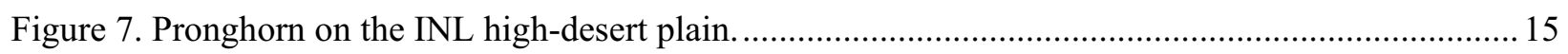

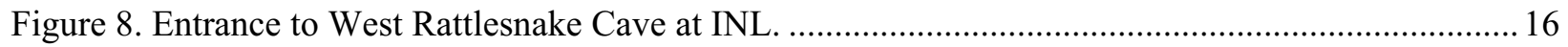

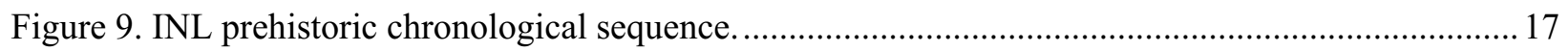

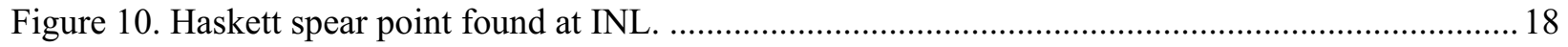

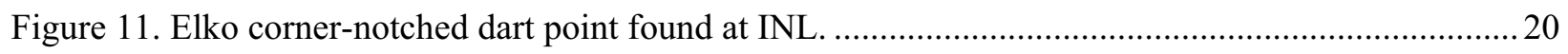

Figure 12. Late prehistoric small arrow points and point fragments found at INL.................................20

Figure 13. Big Lost River during seasonal storm and high water flow. ................................................2 24

Figure 14. Reenactment of an emigrant wagon train at Goodale's Cutoff. .............................................2 24

Figure 15. Historic INL trails with dates that indicate the year in which roads and trails were surveyed, not necessarily the year they were first used...........................................................25

Figure 16. Headgate from early 1900s irrigation project in the area now known as INL........................27

Figure 17. Historic artifacts from a failed homestead in the area now known as INL.............................27

Figure 18. Sixteen-inch naval gun being tested at area now known as INL during the Vietnam

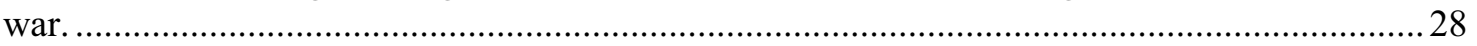

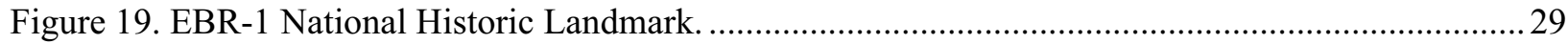

Figure 20. Promotional poster for the USS Nautilus nuclear-powered submarine program. .....................30

Figure 21. Aerial photo of the LOFT facility (demolished in 2006) and ANP hangar at TAN................. 31

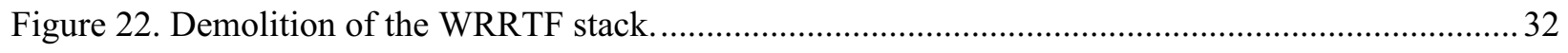

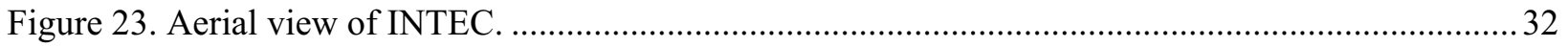


Figure 24. Aerial view of MFC.

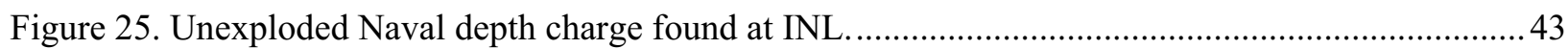

Figure 26. Tour of archeological and historical sites at INL. ............................................................ 46

Figure 27. National Historic Preservation Act Section 106 review process. ............................................ 48

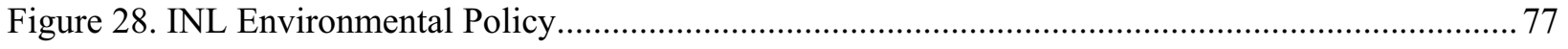

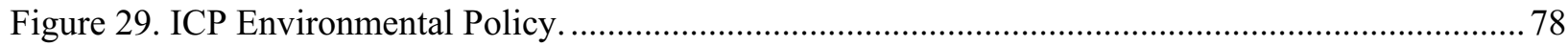

Figure 30. Bechtel BWXT Environmental Policy. ............................................................................... 79

Figure 31. INL Cultural Resource Management Office project summary............................................ 147

Figure 32. Standard report format for INL archaeological investigations.......................................... 148

Figure 33. INL CRM Office permit application for archaeological investigations. ............................... 150

Figure 34. INL CRM Office user agreement for sensitive cultural resource data. ................................ 151

Figure 35. Intermountain Antiquities Computer System forms, INL variation.................................... 152

Figure 36. Example of completed Idaho Historic Sites Inventory form............................................. 175

Figure 37. Theoretical organization of prehistoric archaeological sites in a subsistence and

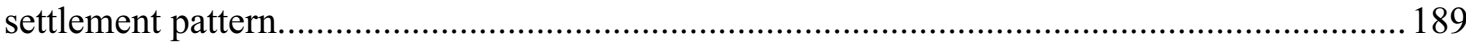

Figure 38. Example of INL Cultural Resource Management Office field monitoring form. .461

\section{TABLES}

Table 1. Property types for which actions are exempt from review. .49

Table 2. INL activities exempt from review (no activities at EBR I are exempted)...............................51

Table 3. Summary of DOE-ID building survey and assessment. ...................................................... 165

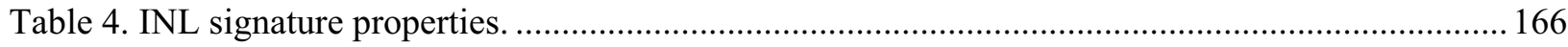

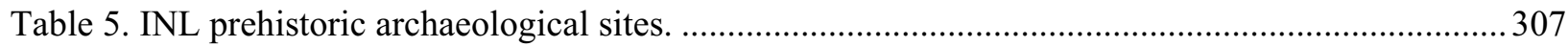

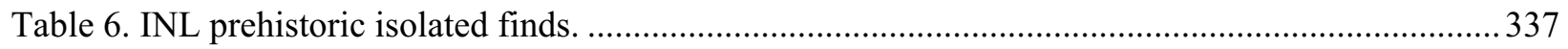

Table 7. INL historic and multi-component archaeological sites and isolated finds..............................367

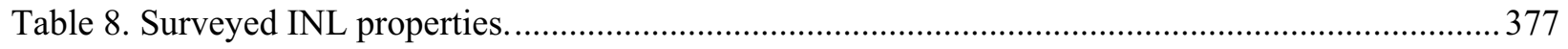

Table 9. INL Cultural Resource Management Office archaeological investigations............................... 409

Table 10. Early INL archaeological investigations and subcontracts.................................................. 434

Table 11. INL Cultural Resource Management Office architectural investigations...............................439 


\section{ACRONYMS, ABBREVIATIONS, AND SYMBOLS}

The acronyms, abbreviations, initialisms, and symbols contained in the following list include those used to denote terms in both the body of this document and the appendices, with the exception of form examples (e.g., Figure 31) where both the acronym and full term are provided. Symbols are provided at the end of this list.

A1W large ship reactor (A for aircraft carrier, 1 for first model, and $\mathrm{W}$ for the designer, Westinghouse)

A\&M Assembly and Maintenance building (TAN-607)

ACETS Advanced Combined Environments Test Station

ACHP Advisory Council on Historic Preservation

ACRS Advisory Committee on Reactor Safeguards

A.D. Anno Domini (in the year of the Lord)

Admin administration (administrative)

AEC Atomic Energy Commission (also "USAEC," DOE predecessor)

AEF Argonne Experimental Facility

AFSR Argonne Fast Source Reactor

AIP Agreement-In-Principle

AIRFA American Indian Religious Freedom Act

ALARA as low as reasonably achievable

ALPR Argonne Low Power Reactor

AMWTP Advanced Mixed Waste Treatment Project

ANCR Aerojet Nuclear Company Report (technical report designation)

ANL Argonne National Laboratory

ANL-W Argonne National Laboratory-West (now MFC)

ANLW Argonne National Laboratory-West (archaeological field or project designator)

ANP Aircraft Nuclear Propulsion

ANPP Aircraft Nuclear Propulsion Program

anti-C anti-contamination (protective clothing)

APEX Atomic Products Division of General Electric (technical report designation)

APMP Architectural Properties Management Plan

ARA Army Reactor Area (renamed the Auxiliary Reactor Area)

ARPA Archaeological Resource Protection Act of 1979

ARVFS Advanced Reentry Vehicle Fuzing System

ATR Advanced Test Reactor

B building (designator) 
BCP Baseline Change Proposal

BEA Battelle Energy Alliance, LLC (INL contractor)

BIA Bureau of Indian Affairs

bldg. building

BLM Bureau of Land Management

BLR Big Lost River

Blvd. boulevard

BM Bingham County

BORAX Boiling-Water Reactor Experiment

B.P. before present (i.e., before 1950 A.D.)

BRB B. Robert Butler (cultural resource investigator)

BRX Boiling-Water Reactor Experiment (archaeological field designator)

BT Butte County

BV Bonneville County

BWP Buried Waste Program

BWXT BWX Technologies, Inc.

C Celsius

C1W cruiser ship reactor ( $\mathrm{C}$ for cruiser, 1 for first model, and $\mathrm{W}$ for the designer, Westinghouse)

ca. circa, in approximately, around (abbreviation for Latin "circum")

CAB Citizens Advisory Board

CAES Center for Advanced Energy Studies

CCD Corrosive Chemical Disposal Area

CDC Capsule Driver Core

CERCLA Comprehensive Environmental Response, Compensation, and Liability Act

CERT Controlled Environmental Radioiodine Tests

cf. compare (Latin abbreviation for "conferre")

$\mathrm{CF} \quad$ Central Facilities Area building designation

CFA Central Facilities Area

CFLUP Comprehensive Facility and Land Use Plan (INL)

CFR Code of Federal Regulations

CFRD corporate funded research and development

CITRC Critical Infrastructure Test Range Complex (formerly PBF) 
CL

$\mathrm{cm}$

Co.

COM

CP-1

CPP

Cr.

CRBR

CRCE

CRM

CRMO

CRMP

CRWG

CWI

$\mathrm{D}_{2} \mathrm{O}$

D\&D

D\&D

DC

D.C.

DCS

DD\&D

DEQ

DEW

DOD

DOE

DOE-HQ

DOE-ID

DOE/ID

E

E-85

EA

EBOR
Clark County

centimeter

Company

communication

Chicago Pile \#1

Chemical Processing Plant (used primarily as an SSC designation)

creek

Clinch River Breeder Reactor

Cavity Reactor Critical Experiment

cultural resource management (also "Cultural Resource Management," e.g., INL CRM Office)

Cultural Resource Management Office (also "CRM Office")

Cultural Resource Management Plan

Cultural Resources Working Group

$\mathrm{CH} 2 \mathrm{M} \bullet \mathrm{WG}$ Idaho, LLC (ICP contractor)

deuterium oxide (also "heavy water," two parts deuterium and one part oxygen)

decontamination and dismantlement

decontamination and demolition

Defense Communication (technical report designation)

District of Columbia

distributed control system

deactivation, decontamination, and demolition

Idaho Department of Environmental Quality

Defense Early Warning (later the Ballistic Missile Early Warning System)

Department of Defense

Department of Energy

Department of Energy, Headquarters

Department of Energy, Idaho Operations Office

Department of Energy, Idaho Operations Office (technical report designation)

east

mixture of $85 \%$ ethanol and $15 \%$ gasoline based on volume

environmental assessment

Experimental Beryllium Oxide Reactor

Experimental Breeder Reactor (e.g., EBR-I) 
EBWR Experimental Boiling Water Reactor

EC environmental checklist (INL document designator)

ECCS Emergency Core Cooling System

ECF Expended Core Facility

ECW ECW Press (Essays on Canadian Writing, et seq.)

ed. edition

EFS Experimental Field Station

e.g. for example (Latin abbreviation for "exempli gratia")

EG\&G EG\&G Technical Services, Inc. (originally Edgerton, Germeshausen, and Grier, Inc., former INEL contractor)

EH Environmental, Safety, and Health (DOE-HQ division)

EHS Earl H. Swanson (cultural resource investigator)

EIS environmental impact statement

EM Environmental Management Office of the Department of Energy

EMS Environmental Management System

e-mail electronic mail (also "E-mail")

EO Executive Order

EOCR Experimental Organic Cooled Reactor

EPA Environmental Protection Agency

ER environmental restoration

ERDA Energy Research and Development Administration (DOE predecessor)

ESRF Environmental Sciences and Research Foundation

et al. and others (abbreviation for Latin feminine plural "et aliae," masculine plural "et alil," or neutral plural "et alia")

etc. $\quad$ and so forth (abbreviation for Latin "et cetera")

ETR Engineering Test Reactor

ETRC Engineering Test Reactor Critical Facility

et seq. and those that follow (abbreviation for Latin "et sequens")

EXT external (INL technical report designation)

FAA Federal Aviation Administration

FAST Fluorinel Dissolution Process and Fuel Storage (project and facility, CPP-666)

FAV Fast Attack Vehicle (canceled project)

Fax facsimile

FCF Fuel Cycle Facility (renamed "Fuel Conditioning Facility")

FDP Fluorinel Dissolution Process 
FETF Flight Engine Test Facility (now FET)

FFA/CO Federal Facility Agreement and Consent Order

FONSI finding of no significant impact

FPR fuel processing restoration

FRAN Fast Burst Reactor (nuclear effects reactor)

FS\&R Filling, Storage, and Remelt System

ft feet (foot; also “, ")

FY fiscal year

GCRE Gas-Cooled Reactor Experiment

GDE guide (INL document designator)

GE General Electric Company

GIS geographical information system

Govt government

GPS Global Positioning System

$\mathrm{H}_{2} \mathrm{O} \quad$ water (two parts hydrogen and one part oxygen)

HABS Historic American Buildings Survey

HAER Historic American Engineering Record

HAPMP INEEL Historic Architectural Properties Management Plan for U.S. Department of Energy, Idaho Operations Office (INEEL/EXT-02-1338)

HBIS Historic Building Inventory Survey

HEPA high efficiency particulate air

HETO Heritage Tribal Office (formerly Tribal CRM Office)

HFEF Hot Fuel Examination Facility

HIST history (archaeological project designator)

HPIL Health Physics Instrument Laboratory

HPTF Howe Peak Transmitter Facility

HTGR High Temperature Gas Cooled Reactor

HTRE Heat Transfer Reactor Experiments

I-131 iodine-131

I.C. Idaho Code

ICDF Idaho CERCLA Disposal Facility

ICP Idaho Cleanup Project

ICPP Idaho Chemical Processing Plant (also "Chem Plant," now INTEC) 
ID

ID

IDO

IDT

i.e.

IEDF

IEEE

IET

IF

IFR

IHS

IHSI

ILTSF

IMACS

in.

Ind.

Inc.

INEC

INEEL

INEL

INL

INTEC

IRC

ISF

ISFF

ISM

ISO

ISU

ITDF

IWPF

JCAE

JF

JFK
Idaho

Idaho Operations Office (DOE)

Idaho Operations Office reports (issued by DOE and its predecessors for DOE Technical Information Division distribution)

Idaho Department of Transportation

that is (abbreviation for Latin "id est")

INEEL Engineering Demonstration Facility

Institute of Electrical and Electronics Engineers

Initial Engine Test

Idaho Falls, Idaho

Integral Fast Reactor

Idaho Historical Society

Idaho Historical Sites inventory

Intermediate Level Transuranic Storage Facility

Intermountain Antiquities Computer System

inch (also ["])

individual

Incorporated

Idaho Nuclear Energy Commission

Idaho National Engineering and Environmental Laboratory (now INL)

Idaho National Engineering Laboratory (now INL)

Idaho National Laboratory (formerly NRTS, INEL, and then INEEL)

Idaho Nuclear Technology and Engineering Center (formerly ICPP)

Idaho Research Center

Intermediate-Scale Facility (waste disposal demonstration site)

Idaho Spent Fuel Facility

Integrated Safety Management

International Standards Organization

Idaho State University

Idaho Transportation Department facility

Idaho Waste Processing Facility (PREPP-II)

Joint Committee on Atomic Energy, U.S. Congress (now dissolved)

Jefferson county

John Fitzgerald Kennedy (thirty-fifth president of the United States, 1961 to 1963). 
JGF

$\mathrm{km}$

$\mathrm{kV}$

L

LAK

LAN

LCCDA

LCRE

LDRD

LESAT

LITCO

LLC

LLMWPF

LMFBR

LMIT

LMITCO

LOFT

LPTF

LRD

LT

LWP

$\mathrm{m}$

$\mathrm{M} \& \mathrm{O}$

MCP

MDA

Met Lab

MFC

mi

Mil.

Misc.

MIT

MK

ML
John G. Franzen (cultural resource investigator)

kilometer

kilovolt

series designator for nonnuclear, large-break, loss-of-coolant accident teaching reactors

L. A. Kingsbury (cultural resource investigator)

local area network

Liquid Corrosive Chemical Disposal Area

Lithium Cooled Reactor

laboratory-directed research and development

Lockheed Environmental Systems and Technologies Company

Lockheed Idaho Technologies Company (contractual company name of LMITCO)

Limited Liability Company

Low Level Mixed Waste Processing Facility

Liquid Metal Fast Breeder Reactor

Lockheed Martin Idaho Technologies Company (abbreviated form of LMITCO used primarily as a document or activity designator)

Lockheed Martin Idaho Technologies Company (former INL M\&O contractor)

Loss of Fluid Test

Low Power Test Facility

laboratory requirements document (INL document designator)

long-term

laboratory wide procedure (INL document designator)

meter

management and operating (contractor)

management control procedure (INL document designator)

mass detonation area

Metallurgical Laboratory

Materials and Fuels Complex (formerly ANL-W)

mile

military

miscellaneous

Massachusetts Institute of Technology

Morrison Knudsen Corporation (now Washington Group International, Inc.)

Mobile Low-Power reactor (e.g., ML-1) 
MOA memorandum of agreement

MOU memorandum of understanding

MTA Mobile Test Assembly

MTR Materials Test Reactor

MWSF Mixed Waste Storage Facility

$\mathrm{N} \quad$ north

NA not applicable

NAGPRA Native American Graves Protection and Repatriation Act

$\mathrm{NaK} \quad$ sodium-potassium alloy, used as a reactor coolant

NARA National Archives and Records Administration

NASA National Aeronautics and Space Administration

n.d. no date

NDGPS National Defense Global Positioning System

NE Nuclear Energy, Science, and Technology Office of the Department of Energy

NEA Nuclear Energy Agency

NEPA National Environmental Policy Act

NESHAP National Emissions Standards for Hazardous Air Pollutants

NHPA National Historic Preservation Act

NIQI Northern Intermountain Quaternary Institute

NIOSH National Institute of Occupational Safety and Health

No. number (also “\#”)

NOAA National Oceanic and Atmospheric Administration

NODA Naval Ordnance Disposal Area

Nos. numbers

NOTF Naval Ordnance Test Facility

NOX mixed oxides of nitrogen $\left(\mathrm{NO}, \mathrm{NO}_{2}, \mathrm{~N}_{2} \mathrm{O}\right)$

n.p. no publisher

NPG Naval Proving Grounds

NPR New Production Reactor

NPS National Park Service

NRB National Register bulletin

NRC Nuclear Regulatory Commission

NRF Naval Reactors Facility

NRHP National Register of Historic Places 
NRT

NRTS

$\mathrm{NuPac}$

NW

NWCF

NWI

OCVZ

OECD

OMRE

Ord

ORNL

$\mathrm{OU}$

p.

$\mathrm{P}$

PA

$\mathrm{P} \& \mathrm{~W}$

PBF

PCB

PDD

PEW

Ph.D.

PIP

PL

PL

$\mathrm{PM}$

PNDR

POL

pp.

PPCo

PREPP

Prog

PS

PTI

PTR
Nuclear Reactor Testing

National Reactor Testing Station (now INL)

Nuclear Pacific (manufacture of casks)

northwest

New Waste Calcining Facility

Northwind Environmental, Inc. (subcontractor and cultural resource investigator)

organic contamination in the vadose zone

Organization for Economic Cooperation and Development

Organic Moderated Reactor Experiment

ordnance

Oak Ridge National Laboratory

operable unit

page

policy (DOE)

programmatic agreement

Pratt and Whitney Aircraft Division (United Aircraft Corporation)

Power Burst Facility (now CITRC)

polychlorinated biphenyl

program description document (INL document designator)

process equipment waste

Doctor of Philosophy

program improvement plan

Portable Low-Power reactor (e.g., PL-3)

Public Law

Portable Medium Power Nuclear Power Plant (e.g., PM-2A)

Partnership in Natural Disaster Reduction (replaces ACETS)

policy (INL document designator)

pages

Phillips Petroleum Company

Process Experimental Pilot Plant

program

policies and standards of performance

Protective Technologies Idaho

Phillips Technical Report (PPCo internal report) 


\begin{tabular}{|c|c|}
\hline PUREX & Plutonium and Uranium Extraction \\
\hline PWT & portable water treatment \\
\hline Quad. & quadrant \\
\hline $\mathrm{R}$ & range \\
\hline R. & river \\
\hline $\mathrm{R}-2$ & Swedish test reactor designation \\
\hline RadCon & Radiological Control \\
\hline RAL & Remote Analytical Laboratory (CPP-684) \\
\hline RCRA & Resource Conservation and Recovery Act \\
\hline Ref. & reference \\
\hline RESL & Radiological and Environmental Sciences Laboratory \\
\hline Rev. & revision \\
\hline RMF & Reactivity Measurement Facility \\
\hline ROB & Research Office Building (at IRC) \\
\hline ROW & right of way \\
\hline RSTA & Reactives Storage and Treatment Area \\
\hline RTC & Reactor Technology Complex (formerly TRA) \\
\hline RWMC & Radioactive Waste Management Complex \\
\hline S1W & $\begin{array}{l}\text { Submarine Thermal Reactor (also "STR"; S for submarine, } 1 \text { for first model, and W for } \\
\text { the designer, Westinghouse) }\end{array}$ \\
\hline S5G & $\begin{array}{l}\text { Submarine Reactor (high-speed submarine; } S \text { for submarine, } 5 \text { for fifth model, and } G \text { for } \\
\text { the designer, General Electric) }\end{array}$ \\
\hline SA & spreading area \\
\hline SAB & spreading area $\mathrm{B}$ \\
\hline SAIC & Science Application International Corporation (involved in radioactive waste technology) \\
\hline SARA & Superfund Amendments and Reauthorization Act \\
\hline SAREF & Safety Research Facility \\
\hline SAT & Save America's Treasures \\
\hline SCADA & $\begin{array}{l}\text { Supervisory Control and Data Acquisition (INL electrical power consumption } \\
\text { computerized system) }\end{array}$ \\
\hline SCIE & Scientech, Inc. \\
\hline SDA & Subsurface Disposal Area \\
\hline SE & southeast \\
\hline Sec & section \\
\hline Sept. & September \\
\hline
\end{tabular}


SERDP Strategic Environmental Research and Development Program

Sho-Ban Shoshone-Bannock Tribes

SHPO State Historic Preservation Office

SIS Special Isotope Separation

SJM Susanne J. Miller (cultural resource investigator)

SL Stationary Low Power reactor (e.g., SL-1)

SM Stationary Medium Power reactor (e.g., SM-1)

SMC Specific Manufacturing Capability

SNAP Systems for Nuclear Auxiliary Power

SNF spent nuclear fuel

SNM special nuclear material

SNTP Space Nuclear Test Program

SPERT Special Power Excursion Reactor Test

sq. $\quad$ square (also “2”)

SSC structure, system, or component

SSC Super Conducting Supercollider (canceled project)

SSSTF Staging, Storage, Sizing, and Treatment Facility

STAR Safety and Tritium Applied Research Facility (TRA-666)

STC Science and Technology Campus

Stat. statute

STD standard (INL document designator)

STEP Safety Test Engineering Program

STF Security Training Facility (former EOCR reactor building)

STGWG State and Tribal Government Working Group

STR Submarine Thermal Reactor

SUSIE Shield Test Pool Facility

SW southwest

SWEPP Stored Waste Examination Pilot Plant

SWPP service waste percolation pond

T township

$\mathrm{T} \quad$ trailer or temporary structure (designator)

TAN Test Area North

TB temporary building (designator)

Temp. temporary 
TERO

TETF

THPO

THRITS

TMI

TNT

TRA

TRANSCOM

TREAT

TRL

TRU

TRUPACT

TSA

TSF

TST

U-235

UAV

UCNI

UGV

UK

$\mathrm{U}$ of I

UREP

U.S.

USA

USAEC

USC

U.S.C.

USDOE

USFS

USGPO

USGS

U.S.G.S.

USS
Tribal Employment Rights Ordinance

Totally Enclosed Treatment Facility

Tribal Historic Preservation Office

Thermal Reactor Idaho Test Station

Three Mile Island

trinitrotoluene

Test Reactor Area (now RTC)

Transportation Communication

Transient Reactor Test Facility

Tritium Research Laboratory

transuranic (an element with an atomic number greater than 92, the atomic number of uranium)

transuranic waste package containers

Transuranic Storage Area

Technical Support Facility

test (archeological field project designator)

uranium-235

unmanned aerial vehicle

unclassified controlled nuclear information

unmanned ground vehicle

unknown

University of Idaho

Utilities Replacement Expansion (also “Enhancement”) Project

United States

United States of America

U.S. Atomic Energy Commission (also “AEC,” DOE predecessor)

United States Code (also “U.S.C.”)

United States Code (also "USC")

U.S. Department of Energy (also “DOE”)

U.S. Forest Service

U.S. Government Printing Office

United States Geological Survey (also “U.S.G.S.”)

United States Geological Survey (also "USGS”)

United States Ship 
UTM

$v$.

$\mathrm{VCO}$

VIS

VMF

VVE

W

WAG

WCF

WEDF

WERF

WINCO

WIPP

WM

WMC

WMF

WMO

WOW

WRC

WROC

WRRTF

WTB

WW2

YDB

ZPPR

ZPR

$\&$

$\mathrm{X}$

0

,

$<\quad$ less than

$\leq \quad$ less than or equal to

west

waste area group

waste management

Wireless Test Bed

World War II

Zero Power Reactor

and

by

greater than

feet (foot; also "ft") universal transverse mercator (map measurement)

against (abbreviation for Latin "versus")

Voluntary Consent Order

misnomer for "InelViz" (software developed for INL to display meteorological data and plume dispersion modeling data)

Vehicle Monitoring Facility

Vapor Vacuum Extraction

Waste Calcining Facility

Waste Engineering Development Facility

Waste Experimental Reduction Facility (now WROC)

Westinghouse Idaho Nuclear Company, Inc. (former ICPP M\&O contractor)

Waste Isolation Pilot Plant (DOE facility in New Mexico)

Waste Management Complex (building designation)

Waste Management Facility (building designation)

Waste Management Office

Woman Ordnance Worker

Weapons Range Complex

Waste Reduction Operations Complex (formerly WERF)

Water Reactor Research Test Facility

yard B, west side of CPP-601

Zero Power Plutonium Reactor

degrees (temperature) 


$\begin{array}{ll}\# & \text { number (also "No.”) } \\ \% & \text { percent } \\ + & \text { plus }\end{array}$

square (squared, also "sq.") 


\section{GLOSSARY}

The terms defined in this glossary fall under one of two general categories: (1) terms that are sufficiently technical in nature as to merit clarification; (2) commonly used terms that convey a meaning within this document that differs from or is more specific than that conveyed elsewhere.

abrader. Small, generally flat piece of stone that exhibits linear grooves produced by the repeated rubbing (abrasion) of bone or wood to fashion needles, arrow shafts, perforators, etc.

adaptation. The process of change in response to environmental conditions or other external stimuli.

adverse effect. A type of impact that may alter, directly or indirectly, any of the characteristics of a historic property that qualify the property for inclusion in the National Register of Historic Places. This includes any impact that would diminish the integrity of the property's location, design, setting, materials, workmanship, feeling, or association. Adverse effects may also include reasonably foreseeable effects caused by an undertaking that may occur later in time, be farther removed in distance, or be cumulative. Consideration is given to all qualifying characteristics of a historic property, including those that may have been identified subsequent to the original evaluation of the property's eligibility for the National Register [36 CFR $\S 800.5(a)(1)$; see 36 CFR $\S 800.5(a)(2)$ for examples].

Advisory Council on Historic Preservation (ACHP; also referred to as "Advisory Council"). An independent federal agency that advises the U.S. president and U.S. Congress on historic preservation and oversees review under Section 106 of the National Historic Preservation Act (NHPA). The Advisory Council is made up of a 20-member panel of presidential appointees, as well as agency heads, parties named in the NHPA, and a small staff with offices in Washington, D.C., and Denver, Colorado. [National Preservation Institute, "Integrating Cultural Resources in NEPA Compliance," September 2003]

aeolian. Pertaining to, caused by, or carried by the wind.

alluvial. Deposited by flowing water, as in a riverbed, a floodplain, a delta, or a fan.

altithermal. A climatic period corresponding to the archaic cultural periods from 7500 to 3500 before present (B.P.). The altithermal climate was an extended warming period with apparent long droughts resulting from the shift of major latitudinal wind patterns.

American Indians. Of, or relating to, persons whose ancestors aboriginally occupied the Americas (also referred to as Native Americans or Indians).

anthropology. The scientific and humanistic study of human kind's present and past biological, linguistic, social, and cultural variations from an all-encompassing holistic approach, with major subfields of archaeology, physical anthropology, cultural anthropology, and anthropological linguistics.

archaeological context. The physical setting, location, and cultural association of artifacts and features within an archaeological site.

archaeological site. A definable area containing artifacts and/or features representative of human activities preserved in a geological context. Any place or locality where there is evidence of past human activity. An archaeological site can be as ephemeral as a surface scatter of flakes covering a few square feet to the remains of an earthlodge village covering several tens of acres. Sites can include, but are not limited to, stone circles, lithic scatters, campsites, rockshelters, caves, quarries, burials, pictographs, vision quest structures, buffalo jumps, sheepherding camps, homesteads, and historic trash dumps. For practical purposes at INL, artifact concentrations of $\geq 10$ items are classified as sites. 
archaeology. The scientific study of the physical evidence of past human societies. Archaeology's initial objective is the construction of descriptive cultural chronology; its intermediate objective is the description of past lifeways; and its ultimate objective involves discovery of the processes that underlie and condition human behavior.

archaic period (also middle prehistoric period). A cultural manifestation and ecological adaptive strategy dating between 8000 to 1300 B.P. on the northeastern Snake River Plain. It is divided into three subperiods: early ( 8000 to 5500 B.P.), middle (5500 to 3500 B.P.), and late (3500 to 1300 B.P.). These subperiods are based on changes in projectile point structure and form. This Archaic lifeway is characterized by varied resource utilization, including seasonal round adaptations, big and small game hunting, and gathering of vegetal and seed foods.

architectural property. Various types of buildings, structures, and objects serving human needs related to the occupation and use of the land. Their function, materials, date, condition, construction methods, and location reflect the historic activities, customs, tastes, and skills of the people who built and used them. On the INL, this term generally refers to post-1942 structures, buildings, and objects.

area of potential effect. A geographic area within which an undertaking may directly or indirectly cause alterations in the character or use of any historic properties in the area. [36 CFR $\S 800.16(\mathrm{~d})$ ]

assemblage. A discrete collection of artifacts from a given site, stratum, or area. A group of artifacts related to each other based upon recovery from a common archaeological context.

assessment. Evaluation of a federal project in regard to the effect it may have on cultural resources. Under 36 CFR 800.5, assessment is defined as application of the "Criteria of Effect" (36 CFR 800.9a) in consultation with the State Historic Preservation Office.

artifact. Any object manufactured, used, or modified by humans.

basalt. A dark-colored igneous rock of volcanic origin. Fine-textured varieties were used by prehistoric people in stone tool manufacture in the INL region.

biface. A chipped stone artifact that has been flaked on both sides.

Boreal. Of or pertaining to northern forest areas and tundra of the North Temperate Zone and Arctic region.

cairn. A memorial or landmark consisting of regular or irregular piles of locally available rock. Cairns are used as trail markers or burial markers or to mark offerings, sacred places, or caches.

categorical exclusion. Refers to a category of actions under NEPA which neither individually nor cumulatively have a significant effect on the human environment and for which, therefore, neither an environmental assessment nor an environmental impact statement is required.

Cenozoic. The latest of four geologic eras encompassing the last 65 million years.

Clovis point. A fluted lanceolate projectile point often found at mammoth kill sites dated ca. 13,000 to 13,500 B.P. and associated with the Clovis technology, which is among the earliest known in the western hemisphere and marks the earliest known human occupation of the INL landscape.

Cody complex. Late Paleo-Indian cultural complex dating approximately $10,500-8,800$ B.P. characterized by parallel-flaked lanceolate projectile points and tanged, asymmetric Cody knives. 
complex. A term used to integrate a number of traits or items that are known to be associated with one another. A temporal continuity represented by persistent configurations in single technologies or other systems of related forms.

compliance. Adherence to specific provisions of any law, executive order, regulation, authorization, or similar legal instrument. In cultural resource management, compliance is most commonly used to mean documented observance of the regulated procedural requirements of the National Historic Preservation Act, although the word is generally not favored by the Advisory Council due to its connotations of resistance and coercion. [Bureau of Land Management Cultural Resource Management Manual, 8100, 1988]

conservation. The protection, preservation, data recovery, and management actions directed toward cultural resources. The term is based on the premise that cultural resources are nonrenewable and emphasizes use and taking action.

consultation. The process of seeking, discussing, and considering the views of other participants, and, where feasible, seeking agreement with them regarding matters arising in the Section 106 process. [36 CFR $\S 800.16(\mathrm{f})$ ] With respect to Native Americans, official consultation is a government-togovernment interaction.

consulting parties. Persons or groups the federal agency consults with during the National Historic Preservation Act Section 106 process. They may include the State Historic Preservation Office; the Tribal Historic Preservation Office; American Indian tribes and native Hawaiian organizations; representatives of local governments; applicants for federal assistance, permits, licenses, and other approvals; or any additional consulting parties. [Based on $36 \mathrm{CFR} \S 800.2(\mathrm{c})$ ]

Additional consulting parties may include individuals and organizations with a demonstrated interest in the undertaking due to the nature of their legal or economic relation to the undertaking or affected properties, or their concern with the undertaking's effects on historic properties. [36 CFR $\S 800.2(\mathrm{c})(6)$ ]

cultural resources. Unique and nonrenewable evidence of past human activity identifiable through field surveys, historic documentation, or oral evidence. This includes archaeological, historical, and architectural sites, structures, districts, and natural and cultural landscapes with important public or scientific uses or value, as well as objects, locations, and landscapes of importance to a culture or community for traditional, religious, or other cultural reasons.

culture. The integrated system of learned behavior patterns that is characteristic of the members of a society and not the result of biological inheritance.

debitage. Lithic waste material (i.e., flakes) resulting from stone tool manufacture and/or maintenance.

determination of eligibility. A decision that a district, site, building, structure, or object meets or does not meet the National Register of Historic Places criteria for evaluation. [36 CFR § 60.3(c)]

diagnostic artifact. An artifact with characteristic traits such that it can be placed in a specified cultural context, time period, and geographic area.

early prehistoric period (also paleo-Indian tradition or period). An archaeological period and cultural manifestation comprising several cultures and complexes that date to at least 13,500 B.P. and end about 8,000 years ago. This period is best known for the nomadic hunters of now-extinct big game at the close of the Pleistocene or glacial period. 
effect. Alteration to the characteristics of a historic property that qualifies it for inclusion, or eligibility for inclusion, in the National Register of Historic Places. [36 CFR § 800.16(I)]

environmental assessment (EA). A concise public document for which a federal agency is responsible. The EA serves to:

- Briefly provide sufficient evidence and analysis for determining whether to prepare an environmental impact statement (EIS) or a finding of no significant impact (FONSI)

- Aid an agency's compliance with the National Environmental Policy Act (NEPA) when no EIS is necessary

- Facilitate preparation of an EIS when one is necessary.

The EA includes a discussion of the need for the proposed undertaking and alternatives, a discussion of the environmental impacts of the proposed action and alternatives, and a list of agencies and persons consulted. [NEPA; 40 CFR 1508.9]

ethnography. The systematic description of human cultures based on anthropological fieldwork.

Euro American. European immigrants to the Americas who settled in Idaho in the early to mid 1800s.

evaluation. The process of determining eligibility of a property for listing on the National Register of Historic Places. [Based on criteria set forth in 36 CFR Part 60.4]

fauna. A Latin term that refers to animals.

finding. Factual assessment by a party, usually an agency, that is subject to review by other parties to the National Historic Preservation Act Section 106 process. [Based on ACHP, "Section-by-Section Questions \& Answers," www.achp.gov/106q\&a.html]

feature. Nonportable evidence of human activities produced by activities such as digging pits for storage, setting posts or foundations for houses, or constructing hearths for cooking. Features are often distinguished by soil discolorations or artifact concentrations.

federal undertaking (see "undertaking"). A broad range of federal activities, including construction, rehabilitation and repair projects, demolition, licensing, permitting, loans, loan guarantees, grants, property transfers, and many other types of federal involvement. Sponsoring agencies are obligated to consider the potential effects of proposed undertakings on historic properties and seek the input of the Advisory Council on Historic Preservation when adverse effects are anticipated.

fire hearth. A feature preserved in an archaeological site consisting of the remains of a fireplace. Stone liners and charcoal are commonly found in fire hearths.

floodplain. The portion of a river valley adjacent to the channel, built of sediments deposited by a stream and covered with water when the river overflows its banks at flood stages. INL floodplain deposits are characterized by extensive gravel deposits.

flora. A Latin term that refers to plants.

flute. A flake scar that runs from the base of a projectile point down the middle portion toward the tip on both sides. It is a characteristic trait of the Clovis and Folsom projectile points. 
Folsom point. A spear point characterized by a single, well-made flute on each side and fine pressure flaking. Folsom points were made from about 11,200 to 12,900 B.P. and are generally found in western North America, often in association with extinct forms of bison.

geographic information system (GIS). The computer hardware, software, and procedures designed to support the capture, management, manipulation, analysis, and display of spatial data. GIS is useful in planning and managing problems related to elements on a landscape such as modeling, creating maps, and understanding complex events (e.g., population trends, weather, traffic patterns, location of critical facilities of certain types, and floodplain histories).

Great Basin. The area of internal drainage in the western United States comprising Nevada, eastern California, southeastern Oregon, southern Idaho, and western Utah.

historic architectural property. Any manmade building, structure, or object that is either on or eligible for listing on the National Register of Historic Places.

historic context. An organizing structure for interpreting history and grouping information about historic properties that share a common theme, geographical location, and time period. [National Register bulletin (NRB) 16A, "How to Complete the National Register Registration Form," Appendix IV, p.2]

An important theme, pattern, or trend in the historic development of a locality, state, or the nation at a particular time in history or prehistory. [NRB 30]

historic landscape. A geological area that historically has been used by people or shaped or modified by human activity, occupancy, or intervention and which possesses a significant concentration, linkage, or continuity of areas of land use, vegetation, buildings and structures, roads and waterways, and natural features. [NRB 30]

historic period. A period described by written documents, such as the period in southeastern Idaho coinciding with the arrival of Lewis and Clark, which represents the beginning of recorded accounts and events in the area (circa 150 B.P. onward).

historic property. Any prehistoric or historic district, site, building, structure, or object included in or eligible for inclusion in the National Register of Historic Places. It includes artifacts, records, and remains that are related to and located within such properties and properties that are of traditional religious and cultural importance to an American Indian tribe or a native Hawaiian organization and meet National Register criteria. [36 CFR § 800.16(1)]

Any property listed in or eligible for the National Register. The listed properties are of local, regional, and/or nationwide importance. [NHPA, Section 106]

Holocene. An epoch of the Quaternary period from the end of the Pleistocene, approximately 12,000 B.P. to the present time.

hunter-gatherer lifestyle. A subsistence lifestyle is adapted to the exploitation of different resources in different areas and during different seasons of availability.

ignimbrite. Opaque, glassy volcanic rock favored for prehistoric stone tool manufacture in the INL region.

incised. A decoration found on pottery and consisting of lines drawn into wet clay. When fired, the arrangement of lines leaves a permanent design on the vessel surface. Also, marks made on bone. 
Indian Tribe (see "Tribes"). Legal definition for the governing body and group of people of any American Indian tribe, band, nation, or other group that is recognized as an American Indian tribe by the Secretary of the Interior and for which the United States holds land in trust or restricted status for that entity or its members. Such term also includes any native village corporation, regional corporation, and native group established pursuant to the Alaska Native Claims Settlement Act. [43 USC 1601 et seq.]

integrity. The ability of a property to convey its significance through its location, design, setting, materials, workmanship, feeling, and association. [NRB 15, "How to Apply the National Register Criteria of Evaluation," p. 44] Also, authenticity of a property's historic identity, evidenced by the survival of physical characteristics that existed during the property's historic or prehistoric period. [NRB 16A, "How to Complete the National Register Registration Form," Appendix IV, p.2]

intensive survey. A field survey of a given area using transect intervals that do not exceed 20 meters and that results in a full inventory of cultural resources.

inventory. The process and product of locating cultural properties within appropriate contexts and identifying or documenting them sufficiently for National Register eligibility decisions. The inventory process includes archival checks, literature reviews, field surveys, and descriptive documentation.

isolates/isolated find. Archaeological evidence of limited human activity. On INL, practically defined as an occurrence of less than 10 artifacts.

Keeper of the National Register of Historic Places. The individual delegated the authority by the National Park Service to list properties and formally determine their eligibility for the National Register of Historic Places. [Based on 36 CFR § 60.3(f)]

lacustrine. Pertaining to or produced by a lake or lakes.

Lake Terreton. An extensive shallow inland lake that covered a large portion of the northeastern Snake River Plain during the Pleistocene period.

lanceolate. Lance- or leaf-shaped, referring to projectile points. Most commonly used in reference to flaked stone knives (bifaces) or projectile points that are long, slender, and come to a point at one or both ends.

late prehistoric period. A cultural manifestation dating between 1300 and 150 B.P. on the northeastern Snake River Plain and marked by adoption of the bow and arrow. It is divided into two subperiods: late prehistoric I (1300 to 750 B.P.) and late prehistoric II (750 to 150 B.P.), based on changes in projectile point structure and form. Prehistoric ceramics also emerge as diagnostic artifacts of this period.

lava tube. During basaltic eruptions, fast-moving lava crusts over and forms tunnels filled with fastmoving streams of lava. As an eruption wanes, the lava in these tunnels drains out, leaving empty caves known as lava tubes within the cooled flows.

lifeway. The "what" and "who" of human culture, including settlement pattern, population density, technology, economy, organization of domestic life, kinship, social stratification, ritual, art, and religion.

lithic. Of or relating to stone.

locus. A predicted archaeological site locality.

material culture. All physical items made or modified by human beings. 
memorandum of agreement (MOA). A document that records the terms and conditions agreed upon to resolve the adverse effects of an undertaking upon historic properties. [36 CFR $\S 800.16(0)$ ]

memorandum of understanding (MOU). Similar to a MOA, a document expressing an understanding among parties regarding regulations, actions, relations, etc.

midden. An accumulation of debris by biological agents such as packrats or humans. It may include plant matter, bone, and shell fragments. For prehistoric sites, a layer of soil stained to a dark color by the decomposition of organic refuse such as food bones, fragments of stone tools, charcoal, pieces of pottery, or other discarded materials. For historic sites, a similar layer of soil, but with appropriate historic material remains, often in a much thinner deposit.

middle prehistoric period. A cultural manifestation and ecological adaptive strategy dating between 8000 to 1300 B.P. on the northeastern Snake River Plain. It is divided into three subperiods: early ( 8000 to 5500 B.P.), middle (5500 to 3500 B.P.), and late (3500 to 1300 B.P.). These subperiods are based on changes in projectile point structure and form. This Archaic lifeway is characterized by varied resource utilization, including seasonal round adaptations, big and small game hunting, and gathering of vegetal and seed foods.

mitigation. Action that reduces or compensates for the damage caused to historic or prehistoric properties during a federal undertaking. Examples of mitigation include project modification to avoid properties, detailed documentation of properties, relocation of structural properties, and salvage of properties through controlled excavation and data recovery.

multi-component. A descriptive term for archaeological sites that exhibit artifacts from more than one cultural time period.

National Historic Landmark. A building, site, structure, object, or district that is officially recognized by the U.S. government for its historical significance. All NHLs are listed in the National Register of Historic Places. On INL, Experimental Breeder Reactor-I is an NHL.

National Park Service (NPS). A bureau of the United States Department of the Interior that manages national parks, monuments, and historic sites. The NPS acts as a steward for historic areas in the National Park System, administers preservation programs, maintains the National Register of Historic Places, sets standards for preservation-related activities, and provides technical preservation information and guidance.

National Register criteria. The criteria established by the Secretary of the Interior for use in evaluating the eligibility of properties for the National Register of Historic Places. [36 CFR § 800.16(r)]

National Register of Historic Places (NRHP; also referred to as "National Register"). A list of formally nominated and recognized properties judged important to national and local history due to their significance to American history, architecture, archaeology, engineering, and culture. The National Register is maintained by the U.S. Department of the Interior, National Park Service. It was created by the NHPA in 1966 and authorized and expanded by 36 CFR 60, which also describes the protocol for nomination to the National Register. 36 CFR 63 provides the procedures for federal agencies and state historic preservation offices to follow when agreement is reached on the eligibility of property to the National Register.

Native American (also American Indian). Of, or relating to, a tribe, people, or culture that is indigenous to the Americas. 
northwestern plains. The area somewhat arbitrarily described as including all of Wyoming, the drainage of the Yellowstone and Madison Rivers up to the Missouri River in northern Montana, western South Dakota and Nebraska, the southwestern corner of North Dakota, and the area along the northern border of Colorado.

object. A material item of functional, aesthetic, cultural, historical, or scientific value that may be, by nature or design, movable yet related to a specific setting or environment. [36 CFR $\S 60.3(\mathrm{j})$ ]

obsidian. Volcanic glass that, because it can be worked to an extremely sharp edge and point, was highly prized for chipped stone implements in the INL region.

obsidian hydration. The technique of dating obsidian artifacts by measuring the microscopic amount of water absorbed from the surface into the rock.

oral history. Verbally transmitted information about past events. Although information about unwritten events can be useful, such history is subject to the vagaries of human perceptions and mental recall.

paleo-Indian period (also early prehistoric period). An archaeological period or tradition comprising several cultures and complexes that date to at least 13,500 B.P. and end about 8,000 years ago. This period is best known for the nomadic hunters of now-extinct big game at the close of the Pleistocene or glacial period.

petroglyph. Any form of prehistoric rock art or carvings that are ground, etched, or carved onto a stone surface. Carvings in rock thought to express artistic or religious meaning.

pictograph. A rendering, often painted on the walls of caves or on cliffs, which represents a form of nonverbal communication often employed by prehistoric people. Paintings on rock thought to express artistic or religious meaning.

Pioneer Basin. An area in southeast Idaho that includes the Big Lost River and its small tributaries as they flow across the northeastern Snake River Plain.

Plano. Several lanceolate-type projectile points representative of a variety of cultures dating from around 12,000 to 8,000 B.P. These cultures were known for big-game hunting, and most known sites are associated with extinct bison kills. A variety of Plano-age projectile points have been defined and include Plainview, Scottsbluff, Agate Basin, Hell Gap, Alberta, Eden, and Angostura.

Pleistocene. A geologic epoch, usually thought of as the Ice Age, which began about 1.6 million years ago and ended with the melting of the large continental glaciers, creating the modern climatic pattern about 12,000 years ago.

pluvial. Of or pertaining to rain. Also refers to the wetter periods during a major, extended dry period.

Prehistoric period. The period prior to the historic, before any written languages were present (in Idaho, before 150 B.P.).

preservation. Cultural resource identification, evaluation, recordation, documentation, curation, acquisition, protection, management, rehabilitation, restoration, stabilization, maintenance, research, interpretation, conservation, and education and training. Any combination of the aforementioned activities. [NHPA, Section 301 (8)]

programmatic agreement. A document that records the terms and conditions agreed upon to resolve the potential adverse effects of a federal agency program, complex undertaking, or other situations in accordance with 36 CFR $\S 800.14(b)$. [36 CFR $\S 800.16(t)]$ Within the context of this document, a 
programmatic agreement is a document executed between an agency or facility and advisory groups that may take the place of multiple memoranda of agreement when actions are programmed, repetitive, or perceived to have similar impacts on cultural resources.

projectile point. Any stone, bone, metal, or wood spear point, dart point, or arrow point.

protection (legal definition). The review process of the Advisory Council on Historic Preservation regarding federal undertakings as codified in 36 CFR 800, "Procedures for the Protection of Historic and Cultural Properties." [Wendorf 1978]

protohistoric period. A period represented in the archaeological record that occurs between prehistory and history, during which a culture has not yet developed writing, but other cultures have noted its existence in their own writings. At the INL, indigenous cultures adopted European trade items and influence before the actual arrival of Euro-American settlers.

provenience. The location of an artifact or object described in terms of map grids, stratified levels, and/or depth from ground surface. It provides for scientific control of artifacts and associations once the items have been removed from the context of the site. The three-dimensional location of an artifact or feature within an archaeological site, measured by two horizontal dimensions and a vertical elevation.

Quaternary period. The most recent geologic period, dating from approximately two million years ago to the present. The Quaternary subsumes the Pleistocene and Holocene epochs.

radiocarbon analysis (dates, dating). A physiochemical method of estimating the length of time since the death of an organism. A process that provides dates by counting the radioactive decay of carbon in the remains of once-living plants and animals (e.g., charcoal, wood, bone, shell). Originally it was believed that the decay rates were constant through time, but recent comparative work has shown this is not the case. Therefore, carbon decay rates must be calibrated, leading to significant differences in radiocarbon years and calibrated, or calendar years; the older the material, the greater the difference. Unless otherwise specified, dates in this document reflect actual calibrated calendar years before present.

reconnaissance survey. A field survey of a given area using transect intervals that exceed 20 meters and that results in a general understanding of the cultural resources.

riparian. A vegetative zone that parallels a perennial water course.

scraper. A stone implement used to remove fat from the underside of a skin, smooth wood, scrape leather, etc. Different types are described in terms of the shape and/or position of the cutting edge, e.g., side scraper, end scraper, snubnosed scraper, thumbnail scraper, scoop scraper.

seasonal round. Scheduled movement of human groups through various ecozones in the course of a year. Movement carefully planned to coincide with the seasonal availability of specific floral and faunal resources.

Section 106. The section of the National Historic Preservation Act that requires federal agencies to take into account the effects of their undertakings on historic properties and afford the Advisory Council on Historic Preservation a reasonable opportunity to comment. [NHPA, Section 106; also 36 CFR Part 800, "Protection of Historic Properties"]

Section 110. The section of the National Historic Preservation Act that sets out the broad historic preservation responsibilities of federal agencies and is intended to fully integrate historic preservation into ongoing programs of all federal agencies. [NHPA, Section 110; also introduction to the Secretary of the Interior's "Standards and Guidelines for Federal Agency Historic Preservation Programs"] 
sensitivity. A generalized evaluation of the likelihood of encountering cultural resources within a given geographic locale. Areas known to contain high densities of cultural resources are considered to be archaeologically sensitive.

settlement pattern. The distribution of human populations throughout their habitat.

shadscale. Plant community consisting of low shrubs such as bitterbrush and rabbitbrush, usually consistent with high-desert steppe environments.

significance. The importance of a historic property in one or more areas, such as history, architecture, archeology, engineering, or culture. [NRB 16A, "How to Complete the National Register Registration Form," Appendix IV, p. 3; also based on NRB 15, "How to Apply the National Register Criteria for Evaluation," p. 7]

sink (sinks, sink area). Low areas on the northeastern Snake River Plain near the foothills of the Lemhi and Lost River ranges where the Big Lost River, Little Lost River, and Birch Creek cease all overland flow and sink through porous basalt bedrock into the Snake River Plain aquifer.

site. The location of a significant event; prehistoric or historic occupation or activity; or building or structure, whether standing, ruined, or vanished. The location itself possesses historic, cultural, or archeological value regardless of the value of any existing structure. [NRB 16A, "How to Complete the National Register Registration Form," Appendix IV, p. 3] For practical purposes, on INL, a site exhibits a concentration of 10 or more artifacts or fewer items in an active geologic setting (e.g., active sand dune).

Snake River Plain. Broad curved depression extending more than 500 kilometers across southern Idaho. It is marked by basaltic lava flows, prominent volcanic buttes, alluvial and lacustrine features, and deposits of aeolian silts and sands within a semiarid sagebrush-steppe vegetation community.

stakeholder. Those individuals, groups, host communities, and other entities in the public and private sectors that are interested in or affected by Department of Energy activities and decisions.

State Historic Preservation Office (SHPO). The office designated pursuant to Section 101(b)(1) of the National Historic Preservation Act to administer a state historic preservation program. In Idaho, the SHPO is a program of the Idaho State Historical Society. [36 CFR $\S 800.16(v)$ ]

stewardship. To protect and manage property through the philosophy of cultural resource management and law and with the premise that cultural resources are a national heritage. This governmental, corporate, and individual responsibility has been translated into actions where individuals and groups have assumed on-the-ground responsibilities (monitoring, patrolling, rehabilitation, education, and interpretation) for specific prehistoric and historic sites.

strata. The various layers of human or geological origin that comprise archaeological sites.

structure. A construction made for purposes other than creating shelter, such as a bridge. [NRB 16A, "How to Complete the National Register Registration Form," Appendix IV, p. 4]

subsistence. The obtaining of food and shelter necessary to support life.

surface site. An area in which archaeological remains occur on stable ground surfaces.

territory. The familiar surroundings or home range that is claimed by a group of people.

test excavation. A small-scale, controlled excavation unit placed within an area that is thought to contain buried cultural material. On INL, these are commonly conducted in $1 \times 2$-meter units or in $30 \times 30$ centimeter square-shovel probes within which soil is removed in 10-centimeter levels. 
Tribes (see "Indian Tribe"). American Indians that are federally recognized, such as the ShoshoneBannock Tribes.

typology. The study and systematic classification of types. The study of the differences and similarities exhibited in cultural materials. The ordering of artifacts based on form, function, technology, material, color, shape, or any other qualifiable characteristic(s).

undertaking (see "federal undertaking"). A project, activity, or program funded in whole or in part under the direct or indirect jurisdiction of a federal agency. This includes activities carried out by or on behalf of a federal agency; carried out with federal financial assistance; requiring a federal permit, license, or approval; and subject to state or local regulation administered pursuant to a delegation or approval by a federal agency. [36 CFR $\S 800.16(\mathrm{y})]$

United States Department of the Interior. Federal agency whose land-managing responsibilities are generally administered through the National Park Service, Bureau of Land Management, and Bureau of Reclamation. The Interior Department has strong cultural resource advisory, regulatory, and preservation responsibilities for all federal lands through its offices of Departmental Consulting Archaeologist and Archaeological Assistance, National Park Service programs, National Register of Historic Places, Historic Preservation Fund, and close working relationship with the Advisory Council on Historic Preservation. 


\section{Idaho National Laboratory Cultural Resource Management Plan}

\section{INTRODUCTION}

The Department of Energy (DOE) recognizes the importance of cultural resources to its stakeholders and of preserving those resources for present and future generations. DOE is also committed to compliance with legal mandates that require consideration of cultural resources. This section of the Idaho National Laboratory (INL) Cultural Resource Management Plan (CRMP) outlines DOE's commitment to and basic philosophy of cultural resource management at INL (see Figure 1).

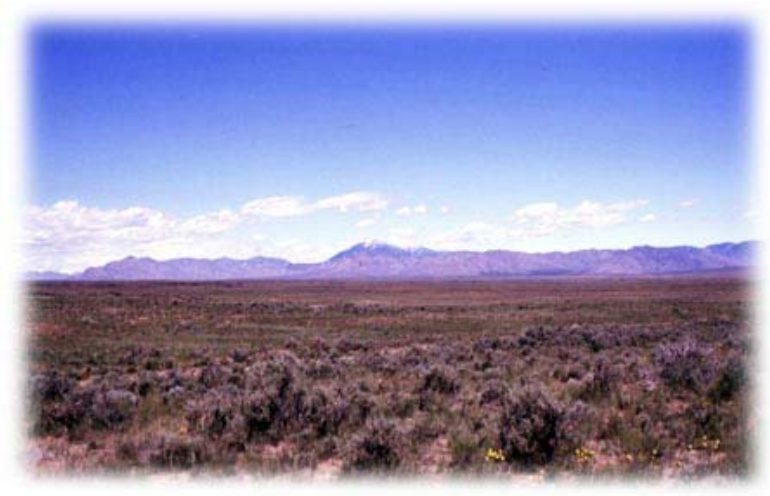

Figure 1. Panorama of INL high-desert terrain.

Cultural resources at INL include, but are not necessarily limited to, the following broad range of items and locations:

- Archaeological materials and sites that date to the prehistoric, historic, and/or protohistoric periods

- $\quad$ Standing structures, buildings, objects, and records that are over 50 years of age, of exceptional importance, important through their association with momentous events (e.g., Cold War, reactor testing, and World War II), and/or contain significant workmanship and design

- Cultural and natural places, landscapes, select natural resources, and sacred areas or objects that have importance for American Indians and others.

\section{Legal Basis for Cultural Resource Management}

As a federal agency, DOE has been directed by the U.S. Congress and the U.S. president to provide leadership in the preservation of prehistoric, historic, and other cultural resources on lands it administers and to manage these resources in a spirit of stewardship for future generations (see Figure 2). The management of INL cultural resources is driven and guided by various federal laws, regulations, executive orders, DOE directives, supplementary State of Idaho statutes and legislation, and INL procedures.

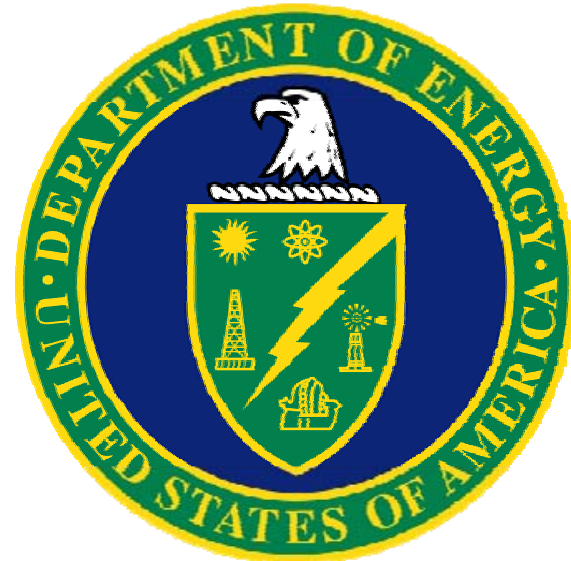

Figure 2. Official seal of the U.S. Department of Energy.

Several laws direct the inventory of cultural resources on federal land, guide the nomination of sites to the National Register of Historic Places, establish mechanisms to protect cultural resources during land-use activities, and levy legal penalties as a consequence for their unmitigated destruction. Preeminent among these are the National Environmental Policy Act of 1969 (NEPA), the Archaeological Resource Protection Act of 1979 (ARPA), and the National Historic Preservation Act of 1966 (NHPA), as amended, and their implementing regulations.

NEPA outlines the federal policy of general environmental protection by requiring information 
gathering, planning, and assessment in advance of projects or actions that occur on federal land or are federally licensed or funded. It requires the use of natural and social sciences in planning and decision-making with regard to project impacts on the environment and extends protective provisions to important historic, cultural, and natural aspects of our national heritage. Federal agencies must prepare detailed environmental impact statements (EISs) and environmental assessments (EAs) outlining the scope, environmental impacts of, and alternatives to the action planned and allow for and consider public comments.

ARPA establishes definitions, permit requirements, and criminal and civil penalties, among other provisions, to strengthen the basic tenets of the Antiquities Act of 1906. Felony-level penalties are established for the unauthorized excavation, removal, damage, alteration, or defacement of any archaeological resource located on public or American Indian lands. This act also prohibits the sale, purchase, exchange, transportation, receipt, or offering of any archaeological resource obtained in violation of any provision of the act. Finally, ARPA fosters increased cooperation and exchange of information between governmental authorities, the professional archaeological community, and private individuals possessing collections of archaeological resources and data.

NHPA establishes the National Register of Historic Places and defines historic properties as those that meet National Register criteria and are, therefore, eligible for listing on the National Register. Properties that are eligible for listing are afforded the same protection under the law as those that are listed. NHPA Sections 106 and 110 are particularly important for the identification, management, and protection of INL's cultural resources. Together these provisions of law direct federal agencies, like DOE-ID, to assume responsibility for the significant cultural resources under their stewardship and consider these resources in day-to-day operations as well as long term planning.

The protective provisions of NHPA apply only to those resources that are determined to be eligible or potentially eligible for nomination to the National Register of Historic Places. Many American Indian sacred sites, traditional cultural areas, and sites or features of local interest are not eligible for listing on the National Register, but nonetheless are cultural resources and are no less important to local tribal people and stakeholders. Other laws, such as the NEPA, American Indian Religious Freedom Act, and the American Folklife Preservation Act, recognize their importance and the Department of Energy, Idaho Operations Office (DOE-ID) is committed to their protection at INL (NHPA provides direction for integrating NEPA and NHPA Section 106 requirements. However, categorical exclusions under NEPA do not apply under NHPA.)

Appendix A provides an annotated list of laws, regulations, policies, Executive Orders, and INL procedures that guide the management of cultural resources at INL. Appendix B includes summaries of the DOE policy and DOE-IDspecific programs and regulatory guidance that illustrate DOE's commitment to protecting American Indian interests. Appendices C and D provide descriptions of how requirements and commitments regarding the protection of cultural resources are implemented at INL.

\section{DOE Cultural Resource Management Philosophy}

The INL CRMP was initiated by and reflects the philosophy of DOE-ID, as stated in the following directive:

The INEL [Idaho National Engineering Laboratory, now known as the Idaho National Laboratory] possesses a rich and varied prehistory and history. It must be emphasized that cultural resources are limited and nonrenewable; that once damaged or destroyed, the information those resources contained is irretrievably lost. Since the INEL has been a federal reservation for over 50 years where public access has been restricted, we are in a unique position to implement management programs which can protect these resources and the information that can be learned from 
them for the future. As with all other relevant federal regulations, DOE-ID is committed to rigorous compliance (DOE-ID 1990).

Indeed, in the years since this 1990 memorandum was issued, DOE-ID has taken many steps to integrate cultural resource management into INL missions and activities. Department of Energy, Headquarters (DOE-HQ) has facilitated this effort through ongoing activities to raise the level of awareness within the entire DOE complex concerning the importance of the agency's cultural resource-related legal responsibilities. These efforts have culminated in the issuance of a formal DOE policy governing cultural resources (DOE P 141.1, 2001). This policy formalizes DOE's goal to preserve and protect INL cultural resources within a collaborative framework consisting of INL representatives, stakeholders and preservation partners.

\section{Purpose of this Cultural Resource Management Plan}

This CRMP outlines the necessary processes and procedures for maintaining INL cultural resources in a spirit of stewardship for future generations and in a manner that is consistent with the intent of executive and legislative mandates and DOE directives. To be useful for this purpose, the CRMP must:

- Respond to existing and changing Executive Orders and federal, state, and DOE requirements for historic preservation and fulfill federal stewardship responsibilities

- Outline processes to identify, evaluate the importance of, and take appropriate action for protection of INL cultural resources in accordance with legal requirements, regulations, professional standards, and stakeholder wishes

- Outline a process for communicating and consulting with the Idaho State Historic Preservation Office (SHPO), the Advisory Council on Historic Preservation (ACHP or Advisory Council), the Shoshone-Bannock
Tribes, and other INL stakeholders as mandated by law

- Provide INL employees and decision-makers with guidance on regulatory compliance as it pertains to management of INL cultural resources

- Serve as a tool for managing cultural resources during activities that span from day-to-day work to long-term land-use planning

- Serve as a reference tool for individuals with responsibility for INL cultural resources

- Provide an effective balance between DOE's ongoing missions and programs and the preservation and enhancement of cultural resources

- Encourage and enhance educational, interpretive, and research opportunities for DOE-ID-managed cultural resources consistent with DOE management objectives.

Ultimately, this CRMP is intended to meet the following INL cultural resource management objectives:

- Serve as a management commitment by DOEID and the INL Cultural Resources Management (CRM) Office

- Streamline the compliance process regarding properties managed by DOE-ID

- $\quad$ Serve as the foundation for the 2004 programmatic agreement between DOE-ID, the Idaho SHPO, and the Advisory Council.

The content of this CRMP is responsive to guidance issued by DOE-HQ (DOE 1995), but the overall format closely follows earlier draft INL plans (cf. Miller 1995).

\section{Scope of this Cultural Resource Management Plan}

This CRMP encompasses INL properties in support of INL's missions as a national laboratory, which are managed under the direction of DOE-ID by management and operating $(\mathrm{M} \& \mathrm{O})$ contractor Battelle Energy Alliance, LLC (BEA). This CRMP also encompasses those properties in 
support of the INL environmental cleanup mission, which are managed under the direction of DOE-ID by Idaho Completion Project (ICP) contractor $\mathrm{CH} 2 \mathrm{M} \downarrow \mathrm{WG}$ Idaho, LLC (CWI), and the Advanced Mixed Waste Treatment project contractor, Bechtel BWXT Idaho, LLC (BBWI). ${ }^{1}$

The Naval Reactors Facility (NRF), which is managed by DOE-Bettis, is also located at INL and is therefore described in this CRMP. However, NRF and the cultural resources within its administrative boundaries are specifically excluded from management under this CRMP.

\section{Organization of this Cultural Resource Management Plan}

The INL CRMP is intended to be a dynamic, flexible document suitable for multiple uses. It is designed to accommodate updates in response to changes in regulations, legislation, DOE mission, or progress in INL cultural resource programs. The main body of the document, which is divided into five sections with supporting subsections, is general in scope and, as a result, somewhat abbreviated.

The section titled "Cultural Resources of the Idaho National Laboratory" follows this section. It provides a broad description of the environment, cultural history, and past and present INL missions with special attention to the important cultural resources located at INL.

The next section, titled "Idaho National Laboratory Cultural Resource Management," is the "working" portion of the plan where the cultural resource management program (CRM program) is outlined. This section includes, but is not limited to, general descriptions of responsibilities for cultural resource protection and management, compliance strategies, and future goals and objectives. This section is followed by the "Summary" section and "References" section.

1. Unless otherwise specified, subsequent references to INL staff and management include ICP and other contractor personnel conducting work at INL.
Following the "References" section is a series of appendices. Referred to throughout the document, these appendices address specific topics with details and supporting material that enhance the general descriptions contained within the main body of the document. The appendices are designed for separate distribution for clarification or information on specific aspects of INL cultural resource management. The appendices will also be reviewed each year and updated as needed. The following topics are addressed in the appendices:

- Appendix A-Annotated summary of the statutory and regulatory basis for cultural resource management, including sections on DOE and INL policies and requirements

- Appendix B-Summary of American Indian interests, including sections on DOE policy and DOE-ID-specific programs and regulatory guidance

- Appendix C-Strategies and procedures for the management of archeological resources

- Appendix D-Strategies and procedures for the management of historic architectural resources

- Appendix E-Research designs employed by the archaeology and history programs

- Appendix F-Historic contexts that provide supplemental historical information about the area now encompassed by INL

- Appendix G-Sitewide programmatic agreement

- Appendix H-Inventory of known archaeological resources at INL

- Appendix I-Inventory of DOE-ID architectural properties

- Appendix J-Inventory of cultural resource projects

- Appendix K-Schedule of activities and priorities

- Appendix L-INL cultural resource monitoring plan. 


\section{Professional Qualifications and Training}

Professional qualification standards for cultural resource investigators are an important element of the Secretary of Interior's standards and guidelines for all federal historic preservation programs nationwide. As such, all INL cultural resource investigations must comply with those qualification standards, which ensure that a consistent level of expertise is applied nationally to the identification, evaluation, registration, documentation, treatment, and interpretation of cultural resources. They also assure credibility in the practice of historic preservation at all levels.

Professional qualification of cultural resource investigators is also a key factor in DOE-ID and BEA's ability to conduct autonomous management of INL's cultural resources because the Idaho SHPO has made retention of qualified internal INL cultural resource staff a condition for allowing DOE-ID and its contractors the autonomy for the decision-making processes outlined in this plan (Idaho SHPO, May 22, 2003). In addition, the Idaho SHPO has refused to review cultural resource studies conducted by persons who do not meet the minimum qualification standards as set forth in 36 CFR Part 61, "Professional Qualification Standards."

The following subsections describe the minimum qualifications to supervise and report on cultural resource studies at INL and to make recommendations based on those studies.

\section{Archaeology}

Archaeology is the study of past human lifeways through the systematic observation, analysis, and protection of their material remains. The professional standard for archaeologists calls for a graduate degree in archaeology, anthropology, or a closely related field, plus all of the following:

- At least one year of full-time professional experience or equivalent specialized training in research, administration, or management
- Demonstrated ability to carry research to completion

- At least one year of full-time professional experience at a supervisory level in the study of archaeological resources of the prehistoric or historic periods.

\section{Architectural History}

Architectural history is the study of the development of building practices through written records and design, and the examination of structures, sites, and objects in order to determine their relationship to preceding, contemporary, and subsequent architecture and events. Professionals in this field must have a graduate degree in architecture or art history, historic preservation, or a closely related field, with coursework in American architectural history. In lieu of the aforementioned graduate degrees, professionals must have an undergraduate degree in architectural history, art history, historic preservation, or a closely related field, plus one of the following:

- At least two years of full-time experience in research, writing, or teaching in American architectural history or restoration architecture with an academic institution, historical organization, agency, museum, or other professional institution

- Substantial contribution through research and publication to the body of scholarly knowledge in the field of American architectural history.

\section{Cultural Anthropology}

Cultural anthropology is the description and analysis of cultural systems, which includes systems of behavior (economic, religious, and social), values, ideologies, and social arrangements, and includes the study of past societies. Minimal professional qualifications include a graduate or undergraduate degree in anthropology or a closely related field such as ethnography, plus both of the following:

- Minimum of two years of full-time professional experience applying the theories, methods, and practices of cultural 
anthropology to the identification, evaluation, registration, documentation, or treatment of historic and prehistoric properties

- Products and activities that demonstrate the successful application of acquired proficiencies in the discipline to the practice of historic preservation.

\section{Historic Architecture}

Historic architecture is the practice of applying artistic and scientific principles to the research, planning, design, and management of the built environment with specialized training in the principles, theories, concepts, methods, and techniques of preserving historic buildings and structures. The minimum professional qualifications in historic architecture are a professional degree in architecture or a state license to practice architecture, plus one of the following:

- One year of graduate study in architectural preservation, American architectural history, preservation planning, or a closely related field, with emphasis on detailed investigation of historic structures, preparation of research reports on such structures, and preparation of plans and specifications for preservation projects

- Minimum of one year of full-time professional experience on historic preservation projects with the same emphasis as the one-year graduate study.

\section{Historic Landscape Architecture}

Historic landscape architecture is the practice of applying artistic and scientific principles to the research, planning, design, and management of both natural and built environments with specialized training in the principles, theories, concepts, methods, and techniques of preserving cultural and historic landscapes. Professionals in this field must have a five-year professional degree in landscape architecture, plus both of the following:

- Three years of full-time professional experience applying the theories, methods, and practices of landscape architecture to the identification, evaluation, registration, documentation, or treatment of historic properties

- Products and activities that demonstrate the successful application of acquired proficiencies in the discipline to the practice of historic preservation.

The three years of full-time professional experience may be replaced with one year of comparable experience if it is accompanied with a state-recognized license to practice landscape architecture. The other qualification requirements still apply.

\section{Historic Preservation}

Historic preservation is the application of strategies that promote the documentation, protection, treatment, continued use, and interpretation of prehistoric and historic resources. Professional standards in this field call for a graduate degree in historic preservation or a closely related field of study, plus both of the following:

- Two years of full-time professional experience applying the theories, methods, and practices of historic preservation to the identification, evaluation, registration, documentation, or treatment of historic properties

- Products and activities that demonstrate the successful application of acquired proficiencies in the discipline to the practice of historic preservation.

The graduate degree may be replaced with an equivalent undergraduate degree if it is accompanied by four years of the aforementioned full-time professional experience, products, and activities.

\section{History}

History is the study of the past through written records, oral history, and material culture and the examination of that evidence within a chronological or topical sequence in order to interpret its relationship to preceding, 
contemporary, and subsequent events. The minimum professional qualifications in history are a graduate degree in history or a closely related field. In lieu of the graduate degree, the professional must have an undergraduate degree in history or a closely related field, plus one of the following:

- At least two years of full-time experience in research, writing, teaching, interpretation, or other demonstrable professional activity with an academic institution, historical organization, agency, museum, or other professional institution

- Substantial contribution through research and publication to the body of scholarly knowledge in the field of history.
DOE-ID has contracted with the BEA Cultural Resources Management Office (CRMO) to manage and protect cultural resources under DOE-ID's jurisdiction. The BEA CRMO professional staff, who meets these standards, is committed to maintaining a CRM program that accepts these challenges in a manner reflecting the resources' importance in local, regional, and national history. 
CULTURAL RESOURCES OF THE IDAHO NATIONAL LABORATORY

This section describes the natural INL environment and past and present human land use. Contextual overviews of this lengthy span of occupation are introduced along with summary descriptions of the cultural resource base. Preliminary research designs are included in Appendix E and more detailed historic contexts are provided in Appendix F.

\section{Description of the Idaho National Laboratory}

INL is a federal reserve with an area of approximately $2300 \mathrm{~km}^{2}\left(890 \mathrm{mi}^{2}\right)$ covering portions of five counties on the northeastern edge of the Snake River Plain in southeastern Idaho (DOE-ID 1996; Irving 1993). INL, which is currently under DOE-ID jurisdiction, supports activities and research that include, but are not limited to, nuclear energy research and development, Department of Homeland Security technologies development and demonstration, and environmental cleanup and restoration. With the exception of areas permitted for livestock grazing through the Bureau of Land Management (BLM), limited hunting overseen by the Idaho Department of Fish and Game, and travel along public highways, general public access to much of the INL area has been restricted since the 1940s.

\section{Past and Present Land Use}

During World War II, the U.S. Navy set aside the core area of what was to become INL, through public land withdrawal and purchase, the Naval Proving Grounds (NPG), a naval ordnance testing range, and aerial bombing practice range. Beginning in 1949, the Atomic Energy Commission (AEC), a predecessor agency to DOE, increased the size of the NPG, designated the new larger area as the National Reactor Testing Station (NRTS), and began important nuclear energy research and engineering. In 1974, changing missions led DOE to rename the NRTS reserve to the Idaho National Engineering Laboratory (INEL). In 1975, it was designated as a
National Environmental Research Park, recognizing the ecological diversity and research potential of the large and relatively undisturbed land area included within its boundaries. In 1997, increasing emphasis on environmental restoration and stewardship was reflected in another name change to the Idaho National Engineering and Environmental Laboratory (INEEL). In 1999, the U.S. Secretary of Energy designated a large portion of INEEL as a "Sagebrush-Steppe Ecosystem Reserve," recognizing the important and largely undisturbed natural resource inventories located there. Then, in February 2005, with the separation of the national laboratory and environmental restoration missions into two separate contracts, INEEL was renamed INL, its current designation.

Several geographically separated facility areas exist at INL. Some remain active; others have been remediated in accordance with federal requirements and are marked only by soil caps and monuments. One facility, the Experimental Breeder Reactor I (EBR-I), is designated as a National Historic Landmark and has been converted to an interpretive center for the public. As originally and intentionally designed, INL facility areas stand in relative isolation to each other, separated by large expanses of undeveloped high-desert terrain dotted with auxiliary structures, roads, and trails (see Figure 3). Primary INL areas are:

- Army (Auxiliary) Reactor Area

- Central Facilities Area

- Critical Infrastructure Test Range Complex

- Experimental Breeder Reactor I

- Idaho Nuclear Technology and Engineering Center

- Materials and Fuels Complex

- Naval Reactors Facility

- Radioactive Waste Management Complex

- Reactor Technology Complex

- Test Area North. 


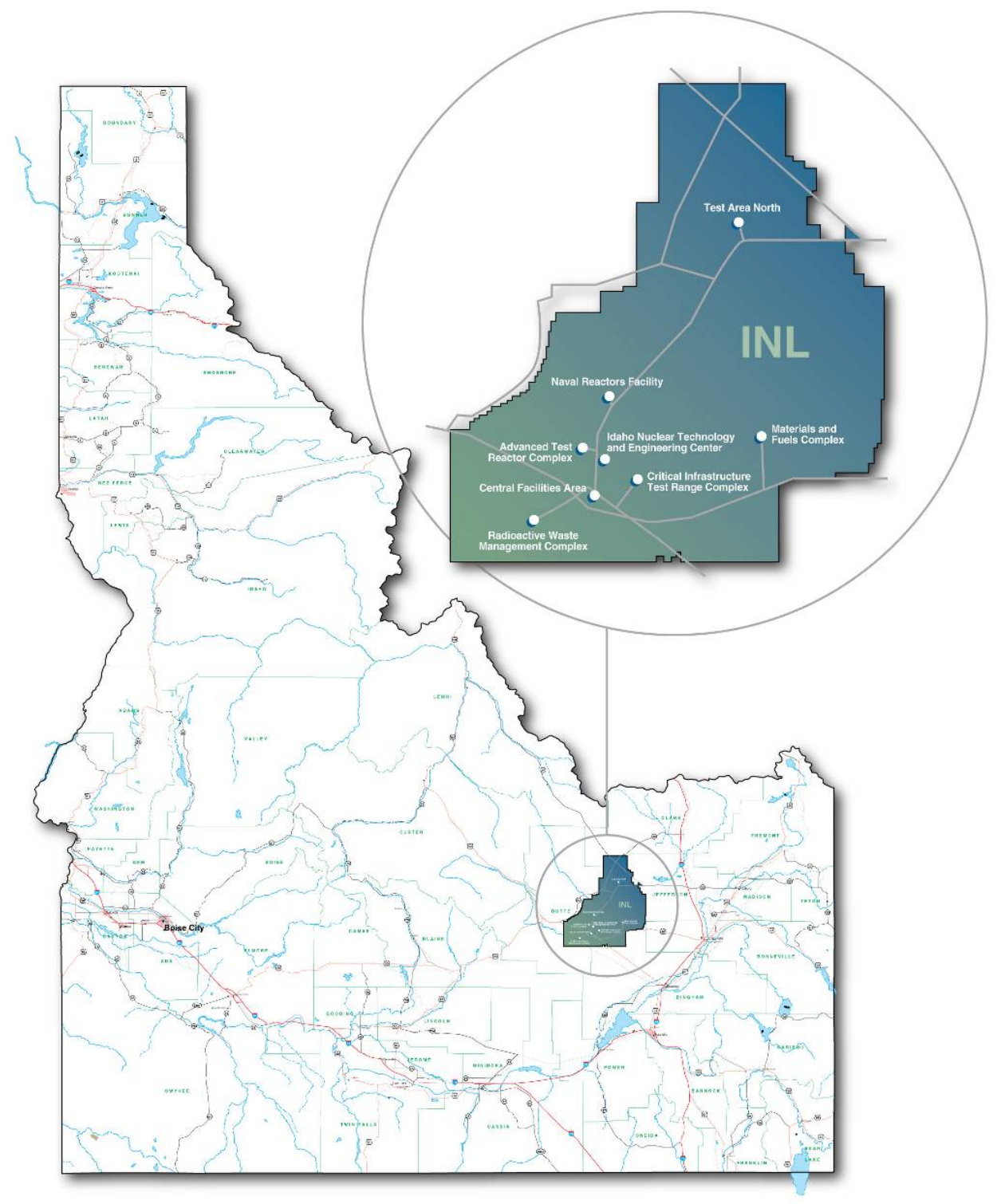

Figure 3. Physiographic setting of Idaho National Laboratory showing locations of major facilities. 
INL lands and facilities are under the direction of DOE-ID, with the exception of NRF, which is under the direction of DOE's Office of Naval Reactors. Day-to-day operations are managed by contractors selected by the Department of Energy.

Prior to 1949 , the region that now includes INL was utilized by explorers, Oregon Trail emigrants, ranchers, homesteaders, canal builders, and stagecoach and freighter companies. Old trails, basalt foundations, trash dumps, and canal works are a testament to the tenacity of these early historic occupants. At the same time, and extending at least as far back as 13,500 years ago, American Indian hunter-gatherers found a multitude of useful resources on the high desert that would become INL. Remnants of their activities suggest that prehistoric groups visited the area regularly, but probably seasonally, for thousands of years.

The sections to follow present additional details on past land use at INL and the cultural resources that preserve a record of it. The descriptions begin with an overview of the natural setting and landscape, which have been important in different ways to the people who have travelled through, lived, and worked in the region.

American Indian prehistoric and historic land use, which is tied so intimately to the resources that the landscape offered, is described next. Euro American immigrants made various attempts to use INL lands during the historic period. These efforts, which are subsequently described, may have failed, at least in part, because of a general lack of understanding of the high-desert setting and landscape. The final land use description in this section focuses on more recent historic activities associated with INL and its predecessors. Historical highlights drawn from the World War II and nuclear science and engineering contextual period of significance (1942 to 1970) are provided for major INL facilities and programs. (More detailed historic contexts are presented in Appendix F, primarily for the period extending from World War II to the present.) This most recent account of historical INL land use concludes with the potential impacts to all types of cultural resources as a result of ongoing and future INL operations.

\section{Natural Setting}

INL is located in the northeastern portion of the Snake River Plain near the foothills of the Little Lost, Lemhi, and Bitterroot mountains in southeastern Idaho (Bonnichsen and Breckenridge 1982; Kuntz et al. 1984; Link and Hackett 1988; Nace et al. 1972; Nace et al. 1975). The general region is a high altitude "cold desert" or, more accurately, a sagebrush-grassland steppe, with minimal precipitation of $23 \mathrm{~cm}$ (9 in.) annually, mostly falling as winter snow and early spring and late fall rains. Seasonal and daily temperature extremes vary widely.

The Snake River Plain is a large topographic depression approximately 50 to $100 \mathrm{~km}$ (31 to 62 mi) wide that extends from the Idaho communities of Payette in the west, to Twin Falls in the south, and up to Ashton $300 \mathrm{~km}$ (186 mi) northeast, forming a curved swath across southern Idaho (Hackett and Morgan 1988; Kuntz 1978). The Plain is divided into two distinct parts: the western Snake River Plain (Payette to Twin Falls) and the eastern Snake River Plain (Twin Falls to Ashton), which are defined by geologic and geophysical features unique to each (Kuntz 1978). The eastern Snake River Plain, where INL is situated, is a broad, flat Cenozoic volcanic feature that is filled by thick sequences of rhyolitic tuffs overlain by 1 to $2 \mathrm{~km}$ ( 0.6 to $1.2 \mathrm{mi}$ ) of basaltic lava flows and interbedded sediments (NRF Geotechnical Investigation 1991).

The northern border of the eastern Snake River Plain near INL is formed by the northernmost extent of the fault-block mountains of the Basin and Range Province (Lost River, Lemhi, Bitterroot). Far to the south of INL, faultblock mountains of this province also form the southern boundary of the eastern Snake River Plain. To the west, the rolling terrain of the Plain itself continues uninterrupted. The Yellowstone Plateau lies to the east-northeast and is an extension of the Snake River Plain (Kuntz 1978) and the geologic events that created it. Mountain ranges to the east of the INL region are part of the northern Rocky Mountain Province. 
At INL, the Snake River Plain is composed of many superimposed flows of basaltic lava extruded from low-shield volcanoes, fissures, and tubes over the past two million years during the Quaternary period (Greeley 1982; Mabey 1982; Morgan and Hackett 1989). Over time, these original lava flows have weathered, alluvial and lacustrine deposits have accumulated on top of them in low-lying areas, and a widespread but variable veneer of aeolian sediment has been deposited across the entire region. The result is a subdued modern topography and landscape typified by low, rolling hills punctuated by occasional volcanic features. Elevations range from 1454 to $1652 \mathrm{~m}$ (4769 to $5387 \mathrm{ft}$ ) above sea level with isolated rhyolitic domes, or buttes, which reach a maximum height of $2304 \mathrm{~m}$ (7557 ft).

The topographic results of Quaternary volcanic activity on INL are quite uniform across the area. Common features include low-relief pressure ridges, pressure plateaus, collapse depressions, and fissures (Greeley 1982). Though pronounced changes in topographic relief are generally rare, several striking volcanic features are present. The most prominent of these are three buttes (Big Southern Butte, Middle Butte, and East Butte) that dominate the horizon from any vantage point on INL (see Figure 4). These buttes served as important prehistoric and historic landmarks and appear on the earliest maps of this area (Preston 1978).

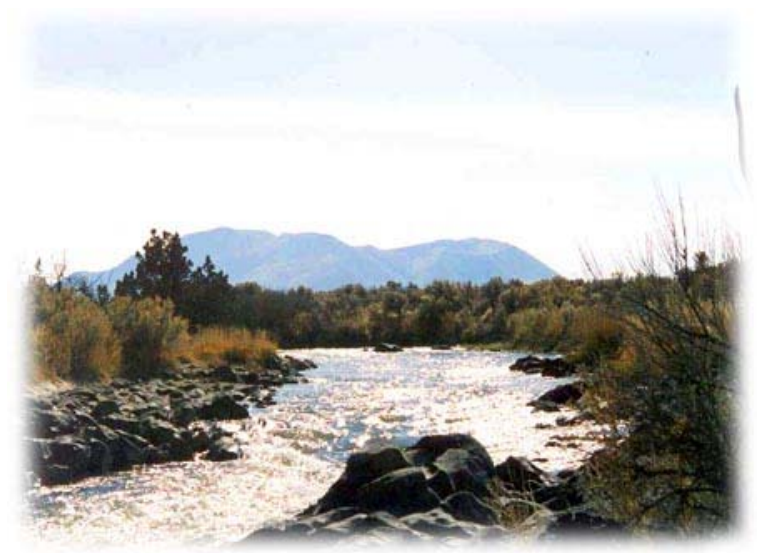

Figure 4. Big Southern Butte viewed from the Big Lost River.
The Big Southern Butte, just south of the southwestern INL boundary, is a 300,000-year-old rhyolite dome complex and largest of the three buttes. It rises $760 \mathrm{~m}(2,493 \mathrm{ft})$ above the Snake River Plain and has a diameter of $6.5 \mathrm{~km}(4 \mathrm{mi})$ at its base (Kuntz et al. 1989; Spear and King 1982). It consists of two coalesced domes that grew by internal expansion and an uplifted section of older

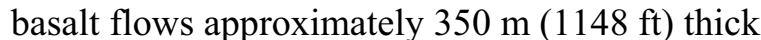
on its northern flank (Spear and King 1982). The Middle Butte and East Butte are within INL boundaries. The Middle Butte is an uplifted block of basalt lava flows with a rhyolite core. Its exact age has not been determined. The lava flows capping the Middle Butte are approximately $75 \mathrm{~m}$ ( $246 \mathrm{ft}$ ) thick and the presence of a rhyolite core is inferred from magnetic and gravity data (Kuntz et al. 1989; Spear and King 1982). The East Butte is a 600,000-year-old rhyolite dome. It rises approximately $350 \mathrm{~m}(246 \mathrm{ft})$ above the surrounding terrain and was formed by the same geologic processes that created the Big Southern Butte-subsurface expansion of highly viscous lava (Kuntz et al. 1989).

Other unique volcanic features in the area include rifts, lava tubes, craters, and locally prominent pressure ridges. All of these features exhibit a high density of prehistoric archaeological sites, reflecting their use as vistas, shelters, and hunting and ambush sites; and as areas where water, plant and animal foods, and other raw materials of economic and cultural importance might be found.

One of the most obvious raw materials important for local hunter-gatherers and available on and near INL is stone appropriate for toolmaking. Some stone materials produced a very sharp but delicate edge and were commonly used in the manufacture of projectile points and knives. These materials include obsidian, which is available at the Big Southern Butte just south of INL, and ignimbrite (or welded tuff), which is available at Howe Point on the north end of INL. When a task called for an abrader, other volcanic rocks available on INL were sought, such as scoria and pumice. 
While volcanic features dominate much of the contemporary landscape of INL, a large portion of the facility is contained within what is known as the Pioneer Basin (Butler 1968). This basin incorporates three important features: the alluvial deposits of the Lost Rivers (Big Lost River, Little Lost River, and Birch Creek), the sink areas of these same watercourses, and the lake bed of ancient Lake Terreton.

The Big Lost River enters INL at its southwestern border and flows northeast approximately $48.3 \mathrm{~km}(30 \mathrm{mi})$ through the Laboratory. This river channel is presently dry throughout most of the year, but probably flowed year-round before upstream irrigation and increased aridity depleted local waterflows (see Figure 5). The river also flooded, occasionally severely, in the recent and distant geologic past. Evidence of these events is seen in the extensive deposits of alluvial material that have accumulated near the watercourse and in some expanses that extend up to $8 \mathrm{~km}(5 \mathrm{mi})$ away. The myriad of abandoned stream channels and meander scars that cross the Big Lost River floodplain also testify to higher water levels in the past. These alluvial features probably gained much of their present character during the Pleistocene epoch when higher moisture levels increased stream flow and provided the energy necessary for their creation (Pierce and Scott 1982).

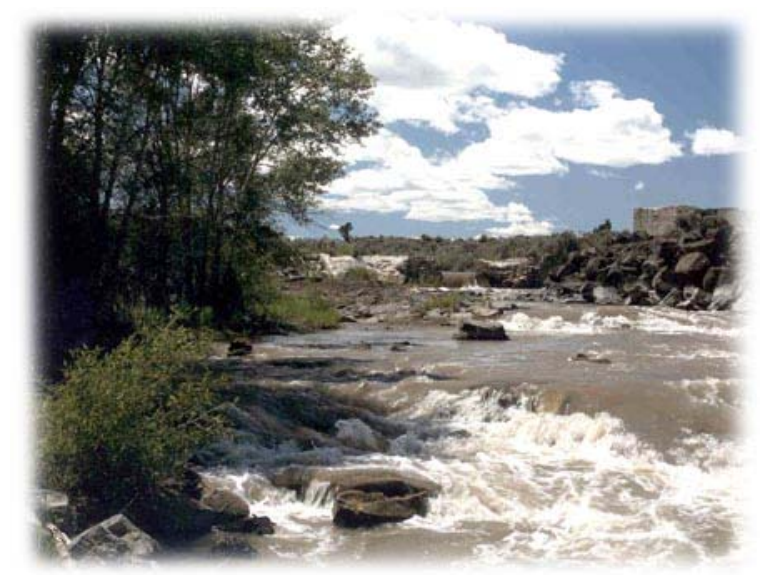

Figure 5. Big Lost River during seasonal water flow.
The Big Lost River, the Little Lost River, and Birch Creek all terminate in sink areas near the northern INL boundary. It is here that the watercourses cease all overland flow and enter the Snake River Plain aquifer by seeping through fine sediments and porous basalt bedrock. If unimpeded by modern water control projects, most surface water on INL would eventually drain to one of these areas (Lewis and Jensen 1984).

During the Pleistocene epoch, when high discharge from the Big Lost River combined with increased flows from the Little Lost River and Birch, Beaver, and Camas creeks, the sink areas were completely submerged by the waters of Lake Terreton. This shallow inland lake once covered approximately $233 \mathrm{~km}^{2}\left(35 \mathrm{mi}^{2}\right)$ of INL landnow occupied by sagebrush grassland, playas, and low dunes - and extended far to the east (Butler 1978; Nace et al. 1975). While the lake probably reached maximum extent at the close of the last glacial period, paleontological studies (Bright and Davis 1982) suggest that the basin may have partially filled as recently as 700 years ago. Decreases in the amount of available moisture during the Holocene epoch and as a result of modern water diversion practices have transformed the lake into a dry and relatively barren expanse of silts, clays, and sand dunes. Usually, the only standing water held by the basin today occurs intermittently in early spring in years when runoff is high and the sinks become marshy.

The basaltic plains of INL also contain a number of scaled down and isolated versions of Pleistocene Lake Terreton. The area commonly known as Rye Grass Flats near the main INL entrance is one example. Playas such as this generally occur in low-lying areas atop the older lava flows. However, unlike Lake Terreton, which depended on the discharge of local rivers and streams, the moisture levels in these features are maintained exclusively through the seasonal flow of intermittent drainages or high precipitation rates. Today, the small playas rarely hold water; but in the past, when effective moisture levels were higher, each of the basins probably offered a shallow, semi-reliable, seasonal water source. The grasses and forbs that would have thrived in the moisture-laden soil would have attracted game 
animals, and a rich aquatic community would have been supported as well. Prehistoric cultural materials found in abundance near the playa deposits offer evidence to suggest that hunters once took advantage of this suite of useful resources.

The relatively permanent water sources at the Big Southern Butte, the Lost Rivers, the sinks, and, during prehistoric times, Lake Terreton, were essential and well known to the inhabitants occupying or crossing the Snake River Plain. There are high concentrations of prehistoric sites in those areas, and well-used early historic trails and wagon and stage roads connect them (often replaced by modern railroads and highways). Many of these areas contain evidence of historic attempts to store water and divert streams for agriculture.

A discontinuous layer of windblown Holocene sands and silts covers many of the topographic features of the northeastern Snake River Plain. These aeolian deposits are derived from distant upwind sources and from the eroded rocks of nearby mountain ranges and then redeposited by mountain streams at the northern margin of the Snake River Plain. The thickness of these deposits is variable, ranging from a thin dusting on top of the more recent lava flows to accumulations of more than $3 \mathrm{~m}(10 \mathrm{ft})$ in low-lying areas and at flow margins (Nace et al. 1975). Wind action has also produced and continues to influence a series of dune fields in the north-central portion of INL downwind from the sinks and the Lake Terreton basin. The abundance of prehistoric sites in this area indicates that human populations apparently took advantage of the relative comfort provided by these accumulations of soil and sand and, at times, the nearby aquatic resources.

\section{Flora and Fauna}

Plant life at INL is strongly influenced by climate and topography and is generally similar to other cool desert environments of the Great Basin and the Columbia Plateau. Communities range from shadscale steppe at lower altitudes, to several sagebrush- and grass-dominated communities, to juniper woodland along the foothills of the nearby mountains and buttes. Although the relative dominance and boundaries of these general communities have expanded and contracted in response to variation in available moisture and temperature regimes, palynological data indicate their continued presence since the late Pleistocene glacial periods (Davis and Bright 1983).

A total of 20 to 22 distinct vegetation cover types have been identified on present-day INL (McBride et al. 1978). Although the specific makeup of each cover type varies according to differences in soil composition and available moisture, big sagebrush (Artemesia spp.) is a component of almost every identified community and occurs on approximately $80 \%$ of INL (French et al. 1965; Harniss and West 1973). A variety of grasses, cacti, forbs, and low shrubs dominate the understory in nearly every cover type (see Figure 6).

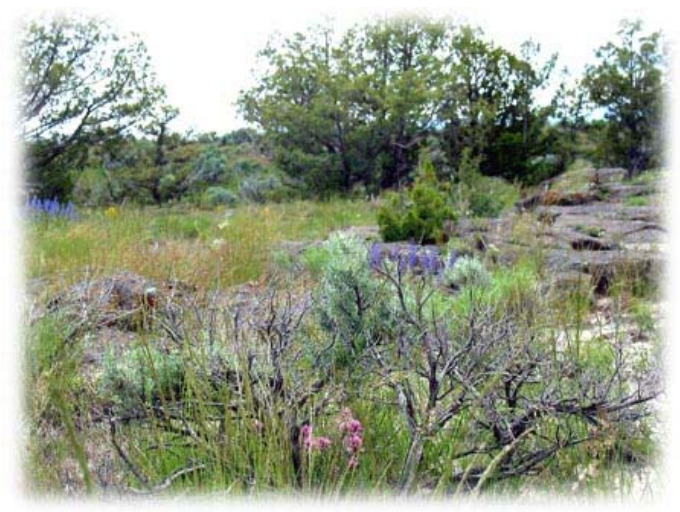

Figure 6. Springtime vegetation at INL.

Differences in vegetation cover are significant in the archaeological study of INL because many of the vegetation communities and their corresponding topographic situations provide microenvironments within the basaltic terrain. In turn, these microenvironments provided people with a number of opportune camping locations. Pressure ridges, in particular, offered shelter throughout much of the area. These protected areas were probably attractive mainly as shelter from prevailing winds, but they also tend to trap moisture in deep aeolian deposits and, thus, support a variety of useful plants in the spring and early summer. The Big Lost River channels, sink areas, and playas would have also provided a 
variety of useful vegetable materials and water for people and livestock. The variety of native plant species on the eastern Snake River Plain and INL (Atwood 1970) can be surprising to the casual modern observer, but a great number of these were known and used in a variety of sophisticated ways by indigenous people (Anderson et al. 1996).

A total of 219 resident and seasonal vertebrate species live on or frequent INL today (Arthur et al. 1984; Reynolds et al. 1986). Birds constitute the largest single class of wildlife in this census, although many of these are migratory. Small mammals are the most common year-round residents. Of particular cultural interest are species that are known or expected to have been utilized by people. Many of these, including mammoth and camel, are now extinct in North America. However, archaeological sites near INL, such as Bison Rockshelter and Veratic Rockshelter (Swanson 1972), Owl Cave (Butler 1978, 1986; Miller 1982, 1990), and Jaguar Cave (Dort 1975; Guilday and Adams 1967; Kurten and Anderson 1972), provide evidence of these animals' past presence and indications of their importance to prehistoric people. It is certain that many species also provided welcome meals and useful products for early historic explorers, Oregon Trail emigrants on their way through the area, and early homesteaders who tried to make a living there.

The most abundant big game animal currently in residence at INL is the pronghorn (Antilocapra americana) (see Figure 7). It is estimated that up to $40 \%$ of the pronghorn population of Idaho (as well as many from Montana) may utilize the area during the winter months (Hoskinson and Tester 1980).

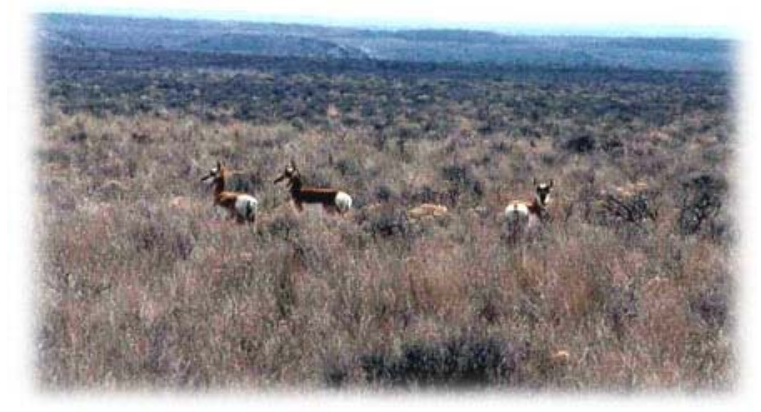

Figure 7. Pronghorn on the INL high-desert plain.
Deer, elk, and mountain sheep are also occasionally observed at INL. Other big game animals, such as bison, no longer inhabit the area, but were also utilized by prehistoric and early historic populations. Bison Rockshelter, Veratic Rockshelter, Owl Cave, and Wilson Butte Cave contained bison remains with associated cultural materials. Test excavations at a small prehistoric site near the INL Critical Infrastructure Test Range Complex (CITRC; formerly Power Burst Facility $[\mathrm{PBF}]$ ) also indicate that bison were once hunted within INL boundaries (Ringe 1988).

\section{Prehistory: Paleontology and Paleoecology}

Fossils of several different time periods have been found in southern Idaho near and within INL boundaries, from truly ancient marine invertebrates in the limestones of the central and eastern mountains to packrat middens and trees a few centuries old on the basaltic plains. Fossils of interest from the Pleistocene and Holocene have primarily been recovered from lake, marsh, and river deposits of the Snake River and Lost River systems; lava tubes, rockshelters, and caves; and archaeological sites. These finds and a few subsequent investigations allow a glimpse into the prehistoric biology and ecology of the Snake River Plain. They guide present and future scientific work and form the basis for interpretation of past conditions.

Much of the paleoecological work has centered on the eastern Snake River Plain Pleistocene and Holocene epochs. This work has been research oriented and conducted at lava caves (see Figure 8) and rockshelters on the Plain proper as a paleontological effort or in conjunction with archaeological investigations (cf. Bright and Davis 1982; Butler 1968, 1972, 1978; Davis and Bright 1983; Dort and Fredlund 1984; Dort and Miller 1977; Fredlund and Dort 1986; Miller 1982, 1983, 1990; White et al. 1984). 


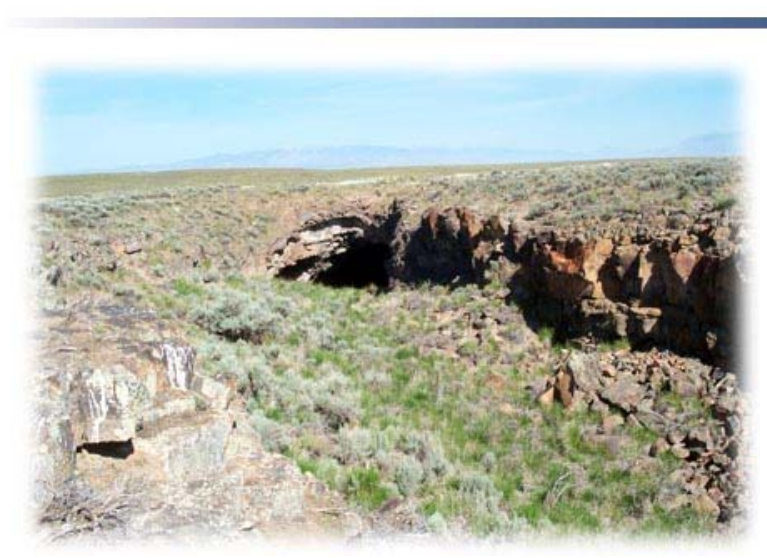

Figure 8. Entrance to West Rattlesnake Cave at INL.

Gradually, as a result of this paleoecological work and other investigations, a panorama of the western North American Pleistocene-Holocene transition is beginning to emerge. It begins with the recession of major continental glaciers and a decline in montane glaciation, followed by a period of increased aridity.

The last of the Pleistocene megafauna, such as mammoth (Mammuthus columbi), large bear (Arctodus simus), camel (Camelops hesternus and Camelops sp.), and dire wolf (Canis dirus), became extinct by 9000 before present (B.P.). Boreal species such as caribou (Rangifer tarandus) were isolated at higher altitudes or displaced to northern latitudes. Major inland pluvial lakes, probably including Lake Terreton on INL, shrank and vegetation zones were altered. Although the climatic mechanisms responsible for this change are poorly understood, severe seasonal temperature fluctuations and lack of effective moisture are recognized at a number of paleontological and paleoecological sites. The altithermal (i.e., warming period), which varies in timing and severity with geographic location, appears to be a drier period than present. The effects of the altithermal reached a maximum at approximately 7000 B.P. in western North America. Climatic adjustments following the altithermal period-interpreted to be a continuation of an interglacial period-led to the establishment of modern conditions.

\section{Prehistory: The First Americans}

Systematic archaeological investigation of southeastern Idaho prehistory began in 1958 . Since that time, several major excavations have been completed, including:

- Wilson Butte Cave southwest of INL (Gruhn 1961, 1965)

- Birch Creek sites, Bison Rockshelter, and Veratic Rockshelter north of INL (Swanson 1972)

- Wasden site and Owl Cave just east of INL (Butler 1978; Butler 1986; Miller 1982, 1990)

- Wahmuza site to the south of INL (Holmer 1986b; Jimenez 1986).

Three decades of intensive survey and test excavation projects on INL (cf. Miller 1995; Reed et al. 1987a, 1987b; Ringe 1995) have also contributed to a greater understanding of the region. These projects have helped to document human use of the eastern Snake River Plain by hunting and gathering populations for a span of at least 13,500 years and provide the basis for regional chronological sequences (cf. Butler 1986; Franzen 1981; Ringe et al. 1988; Swanson 1972) and analyses of settlement and subsistence (cf. Reed et al. 1987a, 1987b; Marler 2004; Ringe and Braun 1993; Ringe 1995).

The prehistoric cultural chronology (see Figure 9) for southeastern Idaho is broken into three major periods; (1) early prehistoric, (2) middle prehistoric, and (3) late prehistoric. These periods were marked by major changes in weapon systems and in the types of projectile points that were used (Ringe et al. 1988). A fourth period, the protohistoric, began with the first appearance of Euro-American trade goods in archaeological assemblages that still reflect a reliance on traditional practices of hunting and gathering. The most recent cultural period recognized in southeastern Idaho is the historic, which was marked by the presence of Euro-American people and the first written records in the region. 


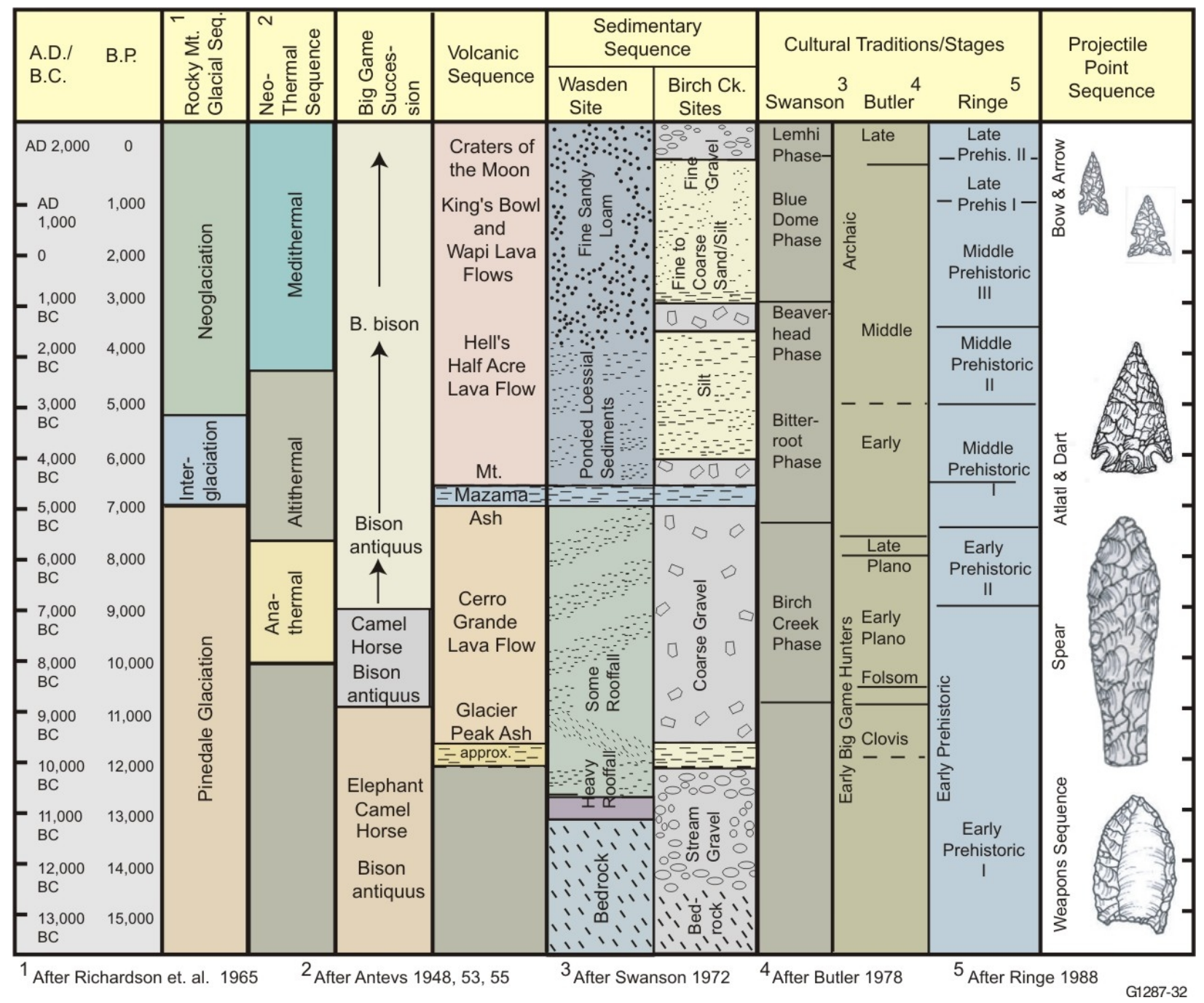

Figure 9. INL prehistoric chronological sequence.

\section{Early Prehistoric Period: 13,500 to 8,000 B.P.}

One of the most significant features of eastern Snake River Plain prehistory is its time depth. The earliest reliable evidence of human occupation in the region consists of surface finds of Clovis spear points that have been dated elsewhere at about 13,500 years B.P. (Marler 2004). Environmental conditions during the terminal Pleistocene epoch were probably considerably cooler and wetter than they are today. However, palynological (pollen) studies in the region (Davis and Bright 1983) indicate that vegetation during this time was essentially modern. The principal difference between then and now is in the distribution of vegetation zones.

During the Pleistocene epoch, the mountains north of the Snake River Plain were wooded and glaciated (Knoll 1977), and the mountain valleys probably supported an alpine tundra biome (Sadek-Kooros 1972). Many of the higher prominent points on the Plain may have also supported a coniferous forest (Bright 1966). The Plain itself was characterized by sagebrushgrassland steppes, much as it is today (Bright and Davis 1982). Small internal playas probably held shallow stands of water, and equally shallow Lake Terreton was probably at maximum extent, covering more than $91 \mathrm{~km}^{2}\left(35 \mathrm{mi}^{2}\right)$ in the 
northeastern portion of INL and extending a considerable distance to the east (Bright and Davis 1982). This environment supported a diverse fauna, including now-extinct forms of mammoth, camel, and horse, whose fossils have been found on INL, and also several modern species, such as bison and mountain sheep (Ringe et al. 1987). The regional archaeological record indicates that the economy of early prehistoric people was based mainly on this large game, although it is certain that a wide variety of smaller animals and local plant resources was also exploited. The sagebrush grasslands and internal playas of the area would have provided excellent browse for Pleistocene animals and productive hunting and gathering opportunities for people.

Large lanceolate spear points of several varieties are the diagnostic artifacts of the early prehistoric period, suggesting that a spear hunting technology was in place. The earliest known point styles, Clovis and Folsom, are leaf shaped in outline and exhibit characteristic channel-flake scars (i.e., flutes) that extend from the base to near the tip of the implements. The best information on the dates associated with these early implements comes from the Wasden site and Owl Cave, a collapsed lava blister near INL (Butler 1978, 1986; Miller 1982, 1990). The earliest cultural levels at Wasden revealed fragments of fluted points in association with the remains of mammoth, bison, and camel. Uncalibrated radiocarbon dates place this association between 10,000 and 12,000 B.P. Several Folsom points and two even older Clovis points have also been recovered from undated surface contexts on INL (Butler 1970; Marler 2004; Reed et al. 1987a, 1987b; Ross et al. 1986).

Around 11,000 B.P., fluted points became rare in the archaeological record and unfluted lanceolate and stemmed forms began to occur in significant numbers until approximately 8000 B.P.

This change may be related to the extinction of some forms of Pleistocene megafauna and a concurrent change in the style of weapons used to bring down the creatures that remained. From approximately 12,000 B.P., the environment gradually warmed, although cold pulses were still common (Currey and James 1982). These changing conditions may have contributed to the demise of some megafauna species. Mammoths were gone from the Plain by approximately 11,000 B.P. and others, such as the camel and Pleistocene horse, were gone by 9000 B.P. (Ringe et al. 1987).

Projectile point styles from this time are lanceolate in outline, and many are stemmed or shouldered. Most point styles are called by names originally coined in the northwestern plains where a number of well-stratified and dated sites have been investigated. This includes lanceolate varieties, such as Agate Basin and Milnesand, and stemmed or shouldered varieties known as Alberta, Eden, Scottsbluff, and Hell Gap (Frison 1978; Wormington 1957).

Two lanceolate point varieties known as Haskett and Birch Creek were initially defined and continue to be found in many cave and surface sites on the Snake River Plain and INL (see Figure 10). Haskett points were first recognized in south-central Idaho where they were associated with bison bones and radiocarbon dates between 9800 and 10,000 B.P. (uncalibrated) (Butler 1978; Sargeant 1973). They also have a wide distribution in surface sites throughout the region, including

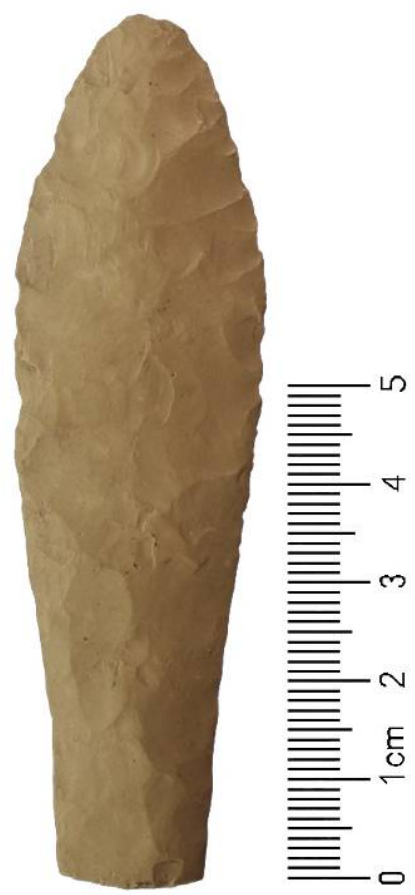

Figure 10. Haskett spear point found at INL. 
INL (Marler 2004; Reed et al. 1987a, 1987b). Birch Creek points were found in direct association with a series of 8000 -year-old bison kills at the Wasden site and Owl Cave (Butler 1978, 1986; Miller 1982) and at Bison Rockshelter and Veratic Rockshelter in the Birch Creek valley (Swanson 1972). Evidence from all locations, dated or not, suggest that the people who used these points were relying heavily on animal species such as bison and mountain sheep, which survived the transition from the Pleistocene to the Holocene epoch.

\section{Middle Prehistoric Period: 8000 to 1300 B.P.}

The close of the early prehistoric period and the beginning of the middle prehistoric period was marked by a major change in projectile point structure and form, probably corresponding to a major shift in hunting technology. Large spear points characteristic of the earlier period were almost entirely replaced by smaller notched and stemmed forms. This transition probably represents the adoption of an atlatl (i.e., spear thrower) technology, which may have been more effective in exploiting newly evolved species that survived the Pleistocene-Holocene transition. The presence of ground stone in middle prehistoric contexts at some sites such as Wilson Butte Cave (Gruhn 1961) and the Birch Creek Rockshelters (Swanson 1972) also suggests that plant foods such as camas may have gained increased importance during this time. However, available evidence suggests that hunting remained a dominant economic endeavor. Thus, the middle prehistoric period on the eastern Snake River Plain was marked by some changes in lifestyle, but it did not represent a major break from the previous early prehistoric period.

The environment during the middle prehistoric period was one of transition. A general warming trend continued, reaching a point of maximum warmth and dryness at approximately 3800 B.P. (Currey and James 1982), but available evidence seems to indicate that these conditions did not produce dramatic environmental changes in the area. Pleistocene Lake Terreton probably declined to its present seasonally marshy state, and the internal playas held little, if any, standing water. However, pollen profiles indicate that modern xeric (i.e., dry) vegetation was present throughout the interval (Davis and Bright 1983). This essentially modern habitat supported many animals that were of economic importance to human populations, including modern bison and antelope on the grasslands and mountain sheep, elk, and deer in the higher elevations.

Middle prehistoric projectile point forms suggest that this was a time of some cultural reorganization and mobility. The archaeological record reflects this in a proliferation of point styles, which appear to have correlates in both the northwestern plains and the Great Basin. It appears that people from these surrounding areas were moving in and out of the eastern Snake River Plain, perhaps in response to deteriorating environmental conditions (Benedict 1979; Madsen 1982).

The diagnostic time markers of the initial portion of the middle prehistoric period are Bitterroot or Northern Side-Notched points (Greiser 1984; Gruhn 1961; Swanson 1972) and sporadic stemmed-indented base points that resemble the Pinto series of the Great Basin (Holmer 1986a). Both forms occur in prehistoric contexts ranging from 8000 to 6000 B.P. at sites such as the Birch Creek Rockshelters (Swanson 1972) and further south at Weston Canyon Rockshelter (Miller 1972). At both of these sites, mountain sheep appear to have been the preferred prey in an economy that continued to be focused on the acquisition of game animals.

Between approximately 6000 and 3500 B.P., large side-notched points decreased in frequency, and around 5000 B.P., stemmed-indented base points became the dominant style of dart in the region. Large corner-notched varieties and new small lanceolate forms also made their first appearance around 4000 B.P., but did not become dominant until later (see Figure 11). Once again, mountain sheep and bison appear to have been the favored game. 


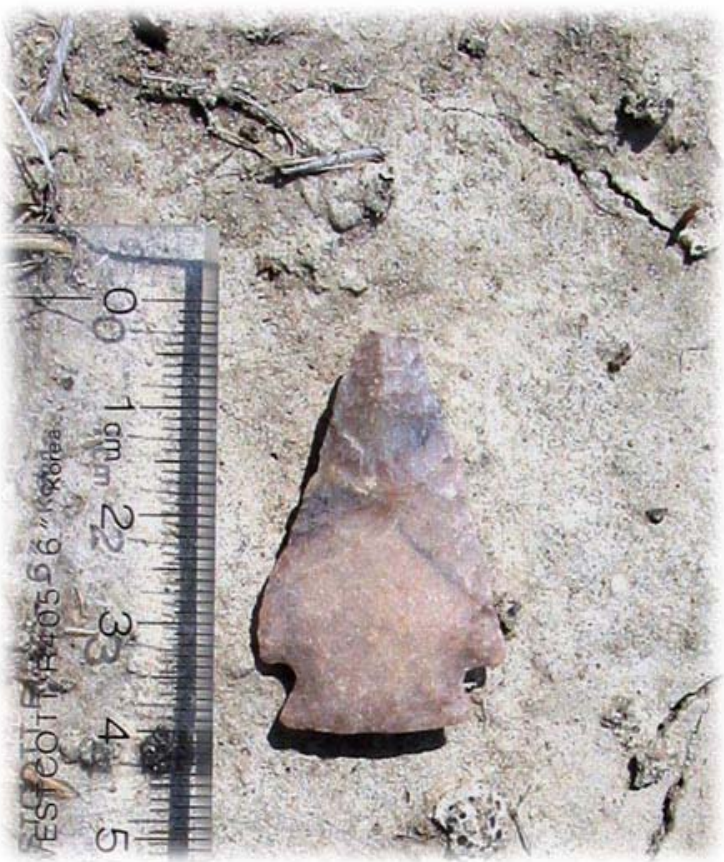

Figure 11. Elko corner-notched dart point found at INL.

During the latter part of the middle prehistoric period, from approximately 3500 to 1300 B.P., eastern Snake River Plain assemblages continued to contain a wide variety of point styles, although the predominant type changed from stemmedindented base to large corner-notched points. These resemble the Elko series in the Great Basin (Holmer 1986a; Thomas 1981) and the Pelican Lake type in the northwestern plains (Greiser 1984; Reeves 1983). Lanceolate points such as the Wahmuza lanceolate (Holmer 1986b) and the Humboldt (Holmer 1986a) or McKean lanceolate (Greiser 1984) are also common in middle prehistoric assemblages. No major changes in the basic hunting adaptation are indicated during this subperiod.

\section{Late Prehistoric Period: 1300 to 150 B.P.}

The late prehistoric period is the best represented and the most debated on the eastern Snake River Plain. It embraces Swanson's Lemhi Phase in the Birch Creek valley (Swanson 1972), Gruhn's Dietrich Phase on the Plain (Gruhn 1961), and Jimenez's Ahvish Phase in the Snake River bottoms (Jimenez 1986). The period is marked by another probable change in weapon technologyadoption of the bow and arrow, probably used concurrently with the atlatl and dart weaponry of the earlier middle prehistoric period.

Archaeologically, the late prehistoric period is recognized by a general decrease in projectile point size (see Figure 12). Small corner-notched points that closely resemble the Rosegate Series of the Great Basin (Thomas 1981) occurred first and remained dominant until approximately 700 B.P. Small points with low side notches known as Avonlea in the northwestern plains (Greiser 1984) also occurred between 1300 and 700 B.P. These two styles were followed by small side- and trinotched arrow points. Known as Desert SideNotched points (Holmer 1986a; Thomas 1981), they dominate assemblages from approximately 700 to 300 B.P. when stone-tipped arrows began to be replaced by firearms of Euro American manufacture.

Aboriginal ceramics also appear as diagnostic time markers of the late prehistoric period. This pottery commonly occurs in eastern Snake River Plain assemblages after 700 B.P., but evidence from the Wahmuza site suggests that ceramics were in use at the much earlier date of approximately 1,200 B.P. (Holmer 1986b). Finally, the larger lanceolate and corner-notched forms of the middle prehistoric period also continue to persist in small numbers throughout the entire late prehistoric period.

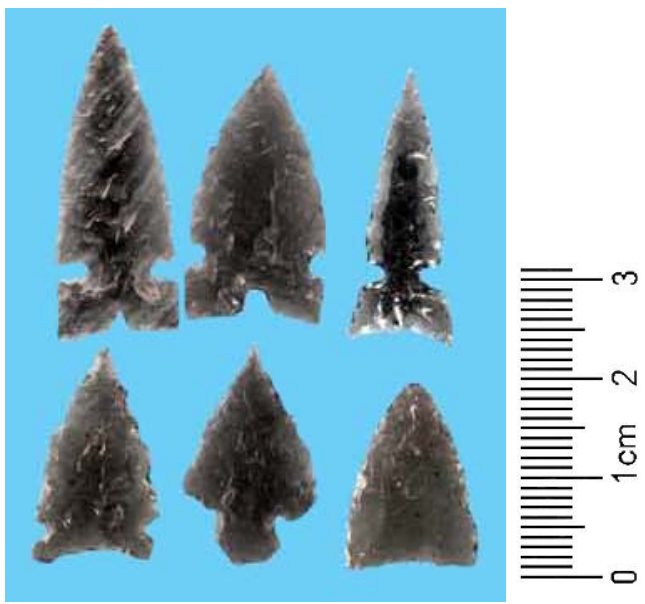

Figure 12. Late prehistoric small arrow points and point fragments found at INL. 
Modern environmental conditions prevailed throughout the entire late prehistoric period, except for a few cold pulses and a brief period of increased moisture at 700 B.P. when Lake Terreton is thought to have once again filled its shallow basin (Davis and Bright 1983). A typical Holocene fauna, including modern bison, was also present throughout this period.

Available evidence suggests that subsistence continued to be based on large game hunting. Plant foods must have also played some role in late prehistoric economics; however, there is little evidence to suggest that they were as important in the diet as they were in the Great Basin, the Columbia Plateau, and even in southwestern Idaho. When they are found in the eastern part of the state, plant processing tools usually consist of mortars and pestles, which would have been used to process root crops such as camas or bisquitroot. The scarcity of grinding stones on the INL suggests that seed products were not common dietary elements, perhaps because they are generally more costly than root crops or big game animals in terms of pursuit and processing time relative to caloric returns (cf. Simms 1984).

Excavations at the following sites provide some indication of the overall economic activities of late prehistoric populations:

- Wahmuza site (Holmer 1986b), an open campsite on the Fort Hall bottoms of the Snake River

- Baker Caves (Plew et al. 1987), a series of three small lava tubes on the Snake River Plain east of Minidoka

- Aviators' Cave on INL (Lohse 1989).

The excavated assemblages from these sites suggest that people were spending the winter months at camps along the Snake River where they probably relied on stored foods, such as bison, deer, and camas or bisquitroot. These stored resources were obtained on an annual subsistence round that probably included the INL area. During the winter, these people also probably made short forays into the surrounding sagebrush grasslands and mountain ranges to obtain fresh meat, and apparently did some fishing in nearby rivers and streams. During the warmer months, people apparently dispersed to hunt and gather throughout the region and probably created many of the sites found on INL as they foraged.

\section{Protohistoric Period: 300 to 150 B.P.}

The nomadic hunting and gathering lifestyle of the late prehistoric period continued in southeastern Idaho even after the introduction of European horses and trade goods about 200 to 300 years ago. However, adoption of the horse by some groups at this time led to significant changes in aboriginal lifeways. These changes included increases in exploitative range, interaction with other groups, warfare, and changes in leadership roles.

\section{History: American Indians}

INL is included within a large territory once inhabited by two linguistically distinct American Indian groups - the Shoshone and the Bannock. Both aboriginal groups (and a variety of subgroups within the Shoshone family) shared a common way of life that allowed them to effectively utilize a wide variety of locally available resources. Early explorers, anthropologists who visited the area, and tribal oral histories have left a record of these groups that is incomplete but still useful in providing clues about the lifeway that was practiced. Because of the overall continuity expressed in the prehistoric record of the area, the information provided by these early historic and tribal sources is also important in the inferential interpretation of archaeological sites.

Prior to the introduction of the horse, the sociopolitical organization of the Shoshone and the Bannock Tribes was fluid. Individuals and even entire families could move as freely from one social unit to another as they moved from one food resource to another (Liljeblad 1957). The introduction of equestrian mobility by the $18^{\text {th }}$ century caused development of a more distinct, formalized band organization. Use of horses allowed the Shoshone and Bannock Tribes to increase their exploitative range, to congregate in larger groups for longer periods of time, and to protect their possessions from groups of 
marauding Blackfoot Indians who also frequented the area (Steward 1938).

The absence of a restrictive sociopolitical organization is a reflection of the highly nomadic lifestyle of the Shoshone and Bannock Tribes. The groups were continually on the move in order to utilize a variety of seasonally available resources, and, in contrast to their linguistically related kin in the Great Basin, probably enjoyed a relative abundance of food and other material resources. A large proportion of this general abundance was found in and near rivers and streams (e.g., Snake River and Big Lost River) that flowed through even the driest and most desolate parts of southern Idaho. This led to an entire complex of subsistence, religious, and social activities that centered on the riverine habitat (Clark 1986). Consequently, many of the larger Shoshone and Bannock villages were located near waterways. However, because the dispersed nature of the resource base required these groups to be highly nomadic, these villages were not occupied on a continuous, year-round basis. Instead, they were probably utilized again and again only during the winter months when weather forced less mobility. During the remainder of the year, native groups apparently dispersed to utilize resources that were often found far from these wintering grounds.

This unique seasonal round, as augmented by the horse, has been documented by early anthropologists (Murphy and Murphy 1960, 1986; Steward 1938). These researchers report that the Shoshone and the Bannock Tribes of southeastern Idaho gathered in large winter villages, primarily along the Snake River in the Fort Hall area. During the winter, they lived on stores of meat, fish, and plant foods. In addition, they fished in nearby streams and made short forays into neighboring areas to supplement their supplies with fresh meat. When winter came to a close, the people split into smaller groups and traveled to other areas in southern Idaho as resources became seasonally available.

Many different areas were visited during these annual expeditions. In the spring, groups traveled to salmon fishing areas along the Snake River west of Twin Falls and to the camas prairies in central Idaho near Fairfield and Dubois (Murphy and
Murphy 1960). Two main routes were followed during this springtime expedition: one followed the Snake River, and then north by a number of routes; and the other proceeded from the Fort Hall and Idaho Falls area across to the Big Lost River and then west, skirting along the southern edge of the mountains. This latter route may have caused American Indians to pass directly through the INL area.

In the late summer and early autumn, big game hunting became an important activity, and most groups moved east to participate. Many followed a trail from the Idaho camas prairies east along the edge of the mountains to the Big Lost River. From there, the routes separated depending on the destination. Some groups traveled up the Little Lost River, crossed east to the Lemhi River and over Lemhi Pass, and continued east onto the Great Plains. Other groups headed toward the Snake River near Idaho Falls, and then north over Monida Pass. Still others followed a route along the Snake River to the Jackson Hole and Yellowstone area. Some groups also returned to Fort Hall and then went south to the Bear River Valley and into northern Wyoming. Finally, some groups chose to go north to the Salmon River area for the late season salmon run.

It is important to stress that these are only the major routes and destinations and that the small groups probably ranged widely throughout the entire region. It is also important to note that the Snake River Plain forms a natural east-west corridor for trade and travel and an area that must be traversed for north-south travel along the river valleys. As such, it was frequented by other groups as well as the Shoshone and Bannock Tribes. For example, the Nez Perce from northern Idaho frequently came into southeastern Idaho to trade and travel to the Great Plains.

Geographically, the INL area appears to have served as a natural corridor for the seasonal movements of the Shoshone and Bannock Tribes. Although there are no large winter villages reported in the area, some relatively large camps were observed by visitors. In the early 1830 s, Warren A. Ferris encountered over 200 American Indians traveling near the three buttes and also reported a camp consisting of nearly 200 lodges on 
the Big Lost River (Ferris 1940, pp. 185 and 186). Natheniel J. Wyeth also reported American Indians camped near the Big Lost River (Wyeth 1899 , p. 228). Although the INL area was probably not used as a wintering ground, it seems certain that it was frequently visited, either in transit to other areas, as a destination for groups interested in obtaining obsidian from the Big Southern Butte or Howe Point, or for those attracted by food resources such as bison, which are reported to have existed in great numbers in the INL area (Haines 1969; Ross 1956; Work 1923).

A list of animals utilized by the American Indians of southeastern Idaho, as reported ethnographically (Shimken 1947; Steward 1938), would include all of the following and more: ants, badgers, bears, beavers, birds, bird eggs, bison, caterpillars, chipmunks, cicadas, crickets, deer, doves, eagles, elk, fish, grasshoppers, ground squirrels, marmots, mountain lions, mountain sheep, muskrats, owls, packrats, pronghorn, quail, rabbits, and sage grouse. The Shoshone and Bannock people also knew and utilized many plants for food and other practical purposes (Anderson et al. 1997). Indeed, it is likely that virtually every plant on the high desert was used in some way at some time of the year. Most, if not all, of these animals and plants continue to be available on or near INL and are still important to tribal members.

From approximately 1810 to 1850 , the American Indians in southeastern Idaho remained relatively undisturbed by the small groups of trappers, traders, miners, and emigrants who worked on or simply passed through ShoshoneBannock territory on their way to California, Washington, and Oregon. However, conflicts began to arise after gold discoveries and EuroAmerican settlement in the 1860 s. In the late $1860 \mathrm{~s}$, treaties were signed between the Tribes and the U.S. government in an attempt to reduce conflicts.

\section{History: Euro American}

From 1805, when Lewis and Clark explored what is now central Idaho, until gold was discovered in the early 1860 s, exploration and development in southeastern Idaho was sparse. The socioeconomic development that was once dependent on trapping and fur trading became dependent on more abundant resources such as water, land, and minerals. Cattle and sheep were soon introduced, and while agriculture eventually became the leading economic force in southeastern Idaho as a whole, another resource-peoplebecame instrumental in INL development.

\section{Trapping and Fur Trading}

Settlement of the American West owed itself, as much as anything, to a hat. The hat was made of a beaver pelt, and, during the 1820 s and 1830 s, no dedicated follower of fashion would settle for anything less (Reisner 1979). Therefore, it is no surprise that the first Euro Americans to explore the INL region were the trappers, also known as mountain men. In 1816, Donald Mackenzie organized the Snake River Expeditions to explore territory that includes what we now call INL. He was followed in 1823 by Antoine Goddin, who trapped beaver extensively in the Little Lost River region (Hammer 1967). Osborne Russell spent time on the eastern Snake River Plain in late 1835 and described in his journal (one of the more reliable for this time period) large buffalo herds, the three buttes, and the Lost River sinks (Haines 1969). In 1834, a trading and supply post, Fort Hall, was established south of INL's present-day boundary by Nathaniel Wyeth (Trego n.d.). Today, the remains of this early establishment are located within the boundaries of the Fort Hall ShoshoneBannock Reservation.

While mountain men are generally credited with opening the door to settlement of the American West, it may be more accurate to say that they nearly slammed it shut. Indeed, the terrors they endured were hardly apt to draw settlers, and the written accounts they left had to weigh heavy on the settlers' minds. These accounts described arid plains that could support little more than wild bunchgrass; entire regions that alternated between fierce heat and stinging cold; incessant winds; streams that flooded a few weeks each year and went dry the rest (see Figure 13); hostile Indians, grizzly bears, and 


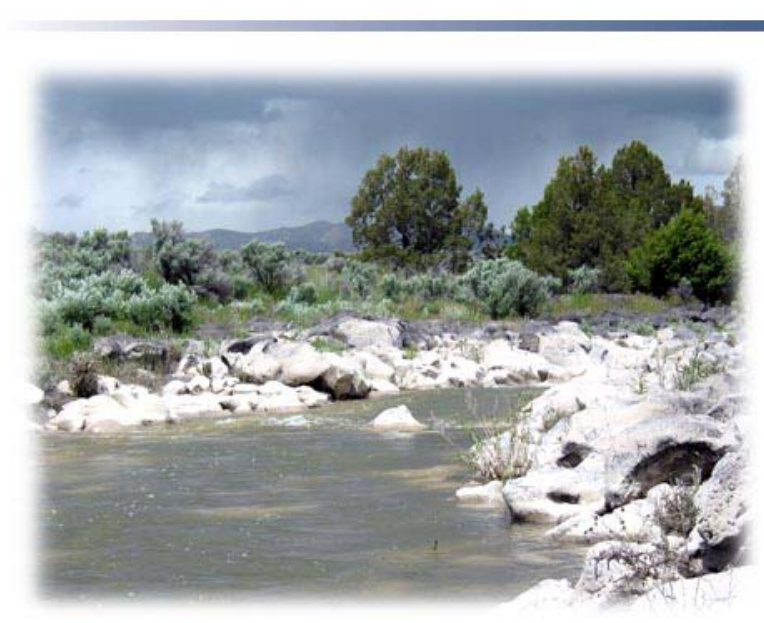

Figure 13. Big Lost River during seasonal storm and high water flow.

wolves; grasshopper plagues; hail, followed by drought, followed by hail; and flecks of precious metal that never panned out. Although they made it clear that it was possible to live off the land in better years, the life these rugged individuals ledthat of trapper, hunter, fortune seeker - was not what the vast majority of American emigrants sought (Reisner 1979).

\section{Emigrants}

Eventually, as promises of abundant land, game, rivers, ores, and agreeable climates in California, Oregon, and Washington spread, a thin ribbon of civilization began to trickle out to the resource-rich west, especially from the east. This trickle eventually became a stream with the establishment of the Oregon Trail in 1836. In order to avoid Indian hostilities along the Snake River, Tim Goodale established a northern extension of the Oregon Trail through the area along an established fur-trading route, and emigrant wagons used it as early as 1852 . A portion of Goodale's or Jeffrey's Cutoff (Dykes 1989; Idaho Historical Society n.d.; Merrill 1990) is still recognizable in the southwestern corner of INL (see Figure 14 and Figure 15).

Later, the cutoff was used for cattle drives from Idaho, Washington, and Oregon to shipping points in Wyoming. After heavy herd stock losses occurred in the $1880 \mathrm{~s}$, cattle drives were curtailed and seasonal sheep drives traversed the route.

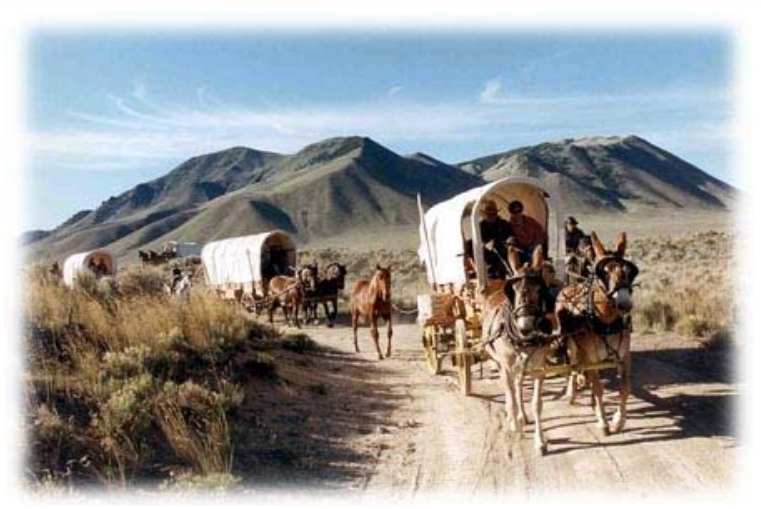

Figure 14. Reenactment of an emigrant wagon train at Goodale's Cutoff.

\section{Mining and Transportation}

In the 1860 s through the 1880 s, discoveries of gold and other precious metals in central Idaho brought many miners, and boomtowns sprang up in areas just north and west of present day INL boundaries. These mid- to late-1800s mining booms created a need for transportation systems between the newly established mining towns north of INL, such as Mackay and Leadore, and their supply stations in older towns, such as Idaho Falls to the east and Blackfoot further to the south. Freighting and staging became a major business, and a number of companies were formed in order to meet the demand for mining equipment, passenger service, dry goods, and other supplies. Old wagon roads and trails became stage and freight lines virtually overnight (see Figure 15), and several new trails were forged across the desert (Trego 1935).

Because of the freshwater springs that bubble from its slopes within the otherwise dry desert, the Big Southern Butte served as a stop for nearly all stage, freight, and later rail lines. Berryman and Rogers, Joe Skelton, and Henry Leatherman, three of the earliest freighters to cross the desert from Idaho Falls and Blackfoot to Arco, all used the Big Southern Butte as a way station (Olsen 1978; Trego 1928).

- In the 1890 s another way station or stage station was established along the banks of the Big Lost River approximately 2 miles north of the RWMC. This station, known as the Powell 


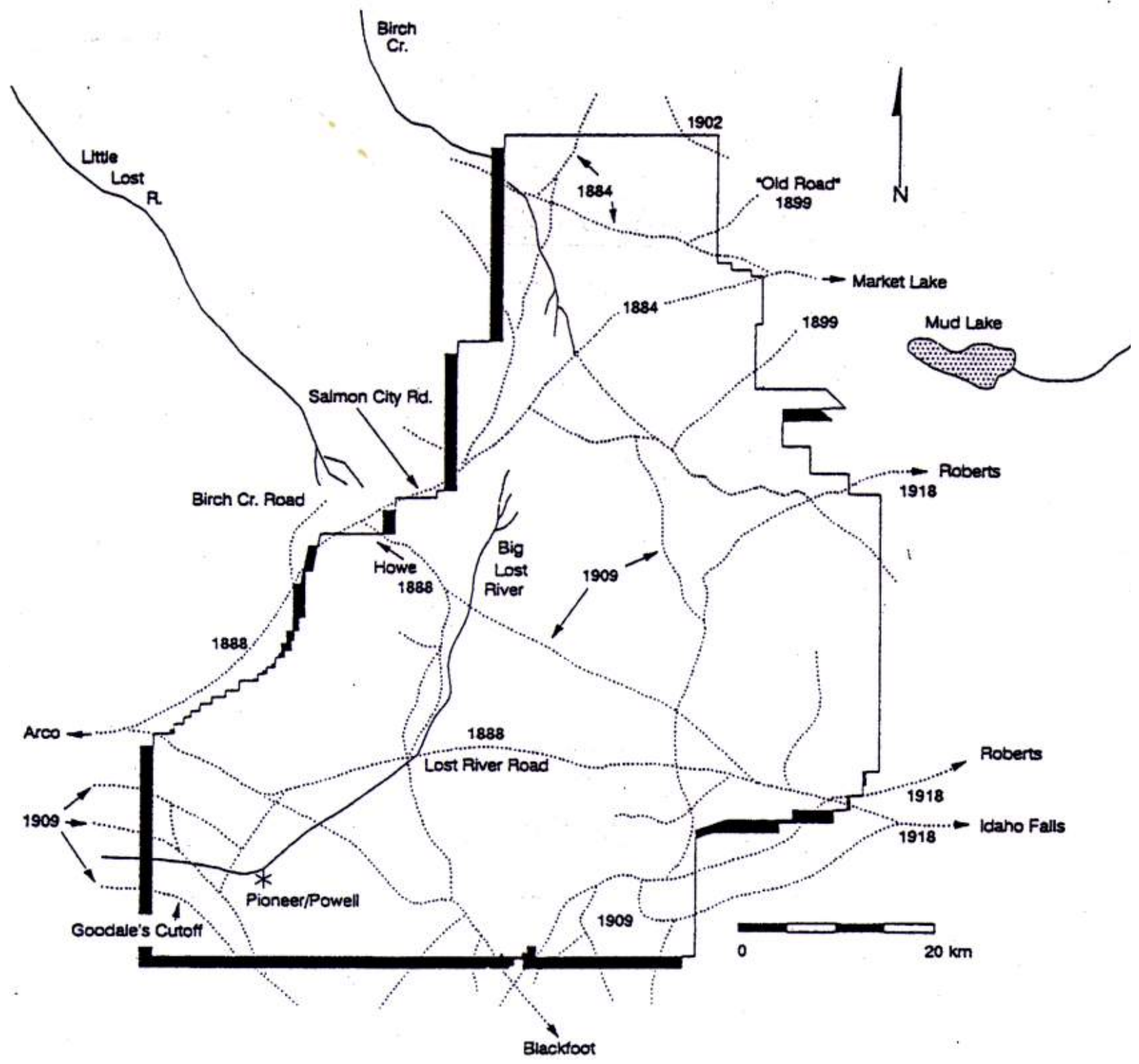

Figure 15. Historic INL trails with dates that indicate the year in which roads and trails were surveyed, not necessarily the year they were first used. 
Stage Station, was located along a trail or route that ran parallel and several miles to the north of Goodale's Cutoff. George W. Powell, the proprietor of this station, constructed a rock building that housed a store and post office. Powell also maintained the only known bridge crossing of the Big Lost River in the area (Gilbert 2009).

A second stage station known as the Birch Creek Stage Station existed at the north end of INL along the banks of Birch Creek. Established as early as 1884 , it was a stopover for travelers and freighters bound for the mining camps in the Birch Creek and Salmon River valleys.

In 1901, completion of the Oregon Shortline railroad between Blackfoot and Arco signaled the end of stage and freight lines in the area (Sedgewick n.d.). As horse-drawn wagons became obsolete, many drivers increasingly relied on small farms and ranches in the area.

Eventually, many of the mining boom towns folded when initial expectations of productivity in the surrounding mines were not realized (Bottolfsen 1926a).

One last minor boom occurred in 1925 when gold was discovered in the Lost River sinks, but within a month it was realized that the gold was in such minute quantities that extraction was economically infeasible (Crowder 1981; Olsen 1978).

\section{Ranching}

As transportation through the desert became more reliable, settlers began to make their way into the area. Many of these early occupants began ranching in the northern reaches of present-day INL. Sources report that there were six or seven ranches in operation on the Little Lost River and Birch Creek in 1882 (Edelman n.d.). Among these early cattlemen were:

- The Hawley brothers, whose descendents still operate a large ranch on the Little Lost River near Howe (Edelman n.d.)

- The Hollands, who also raised cattle near Howe and routinely ran their stock between there and the Big Southern Butte (Gerard 1982; Pettite 1977)

- Dave Wood, who maintained several ranches in the area, one of which was located on the Birch Creek sinks (Oberg 1970)

- Frank Reno, whose family still operates a ranch in the Birch Creek sinks area today (Edelman, n.d.).

The disastrous winters of the 1880 s killed so much stock that the local cattle industry never quite recovered, and sheep were moved into the grazing areas once dominated by cattle.

Major sheep drives across the INL area began in the $1860 \mathrm{~s}$, and the growth of this new industry paralleled that of the cattle industry (Wentworth 1948). As the demand for mutton and wool increased and sheep became a profitable commodity, many cattle ranchers added flocks to their cattle herds or completely switched to raising sheep. By the early 1900s, sheep were very common in the area and are still moved today from pastures near the Big Southern Butte across the INL area to Howe. Many of the isolated historic sites encountered within INL boundaries are remnants of the small temporary camps created by sheep and cattle drovers as they moved their stock through the region around the end of the $19^{\text {th }}$ century.

\section{Homesteading and Agriculture}

While the northern portion of what is now INL was used primarily by ranchers, the western and northeastern portions were geared toward homesteading and agricultural pursuits. The first settlers in the area were members of the Church of Jesus Christ of Latterday Saints who established residence near the northeastern boundary in 1855 (Clements n.d.). In these early days, farming was oriented toward family subsistence because transportation systems were not adequate to ship any supplies or produce in or out of the area. After freight and wagon lines became firmly established in the 1880 s, settlers came to the area in larger numbers and began to farm for commercial as well as subsistence purposes. 
Most of the homesteaders arriving in the late 1800s settled along the Big Lost River. The first permanent settlers arrived in 1878, and the first official water right claim was recorded in 1879 (Bottolfsen 1926b). Many settlers were prompted to move into the area by the Homestead Act of 1862 , which allowed the head of a family to obtain 160 acres of land by residing on it and cultivating it for a period of five consecutive years. The Desert Claim Act of 1877 also encouraged settlement in the Big Lost River area by permitting families to acquire 640 acres of land if water could be brought to it (Bottolfsen 1926b).

Water was a rare commodity in the desert areas of the eastern Snake River Plain and the success of farming efforts in the area hinged on the homesteaders' ability to obtain it. With passage of the Carey Land Act in 1894 (Scott 1983; Williams 1970) and passage of the Desert Reclamation Act in 1902, the federal government stepped in to assist homesteaders in this endeavor. The 1894 act set aside one million acres of public land in Idaho for homesteading, provided the settlers participate in state-sponsored irrigation projects; and the 1902 act provided the funding necessary to reclaim these arid and semi-arid acres (see Figure 16).

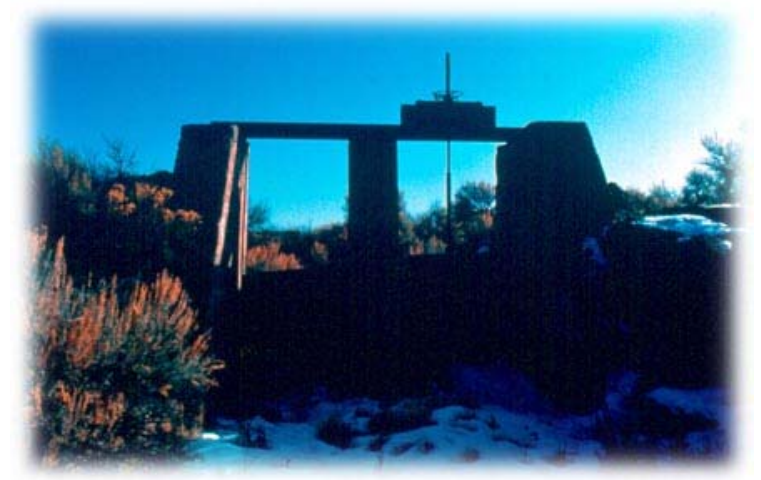

Figure 16. Headgate from early 1900s irrigation project in the area now known as INL.

Southeastern Idaho was a major beneficiary of this federal aid and, as a result, the years from 1905 to 1920 saw a dramatic upswing in agricultural activity on land within and around the present-day INL boundaries. The population of Idaho Falls quadrupled from approximately 1,262 in 1900 to 4,827 in 1910, and this growth is directly attributed to the promise of irrigable land. Irrigation companies formed, and with financial backing by the federal government, proceeded to start construction on a number of dams, including the Mackay Dam on the Big Lost River upstream of INL, and canal projects that brought muchneeded water to homesteaders (Pettite 1983). The town of Powell - later named Pioneer - sprang up along the Oregon Shortline Railroad in the southwestern portion of INL to supply local residents with necessary mercantile goods and serve as a stock-shipping station (Gerard 1982; Schmalz 1963). Unfortunately, gross miscalculations of precipitation and water flow in the area coupled with ignorance of the fractured bedrock strata and porous gravels of the Big Lost River led to the failure and ultimate abandonment of all but a few of these projects in the 1920s (Pettite 1983; Staley 1978). Many of the small homesteads on and around INL were forced to fold, although a few notable exceptions in the Mud Lake area east of INL and far upstream in the Big Lost River valley continued to flourish. Many of the historic sites located within INL boundaries are representative of these short-lived efforts to reclaim the high desert for agricultural purposes (see Figure 17).

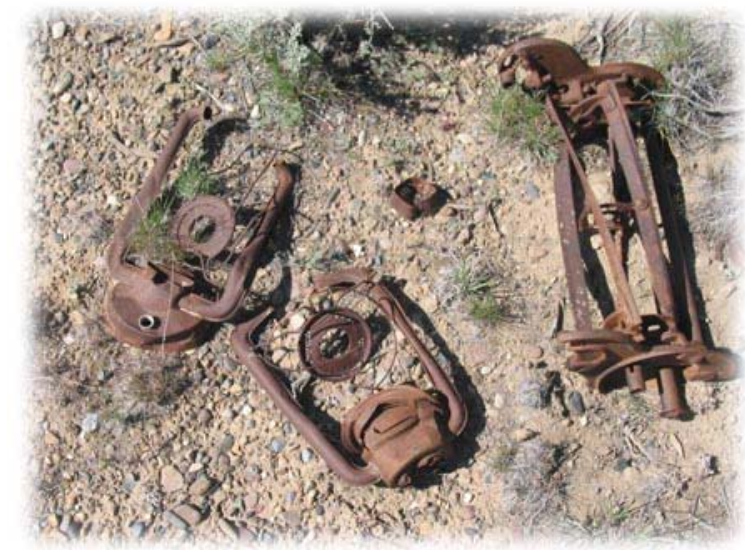

Figure 17. Historic artifacts from a failed homestead in the area now known as INL.

\section{History: 1942 to Present}

In 1942, the U.S. Navy established a presence on what is now INL to test naval ordnance. After 
World War II, nonnuclear military munitions testing continued until the AEC acquired the former ordnance test area for development of a remote installation devoted to testing and developing nuclear reactor technologies.

Prototypes of the nation's three commercial power reactor concepts - the pressurized water reactor, the boiling water reactor, and liquid-metal-cooled breeder reactor-were first developed and tested at this National Reactor Testing Station (now INL). Since its formation as the NRTS in 1949, basic research critical to design, safe operation, and licensing of nuclear power and propulsion reactors has taken place at INL.

\section{Military Ordnance Testing}

During World War II, the U.S. Naval Ordnance Plant was established in Pocatello, Idaho, as a place to manufacture, assemble, and reline Navy weapons. Nearly all of the naval ship guns used by the Pacific Fleet were eventually sent to the plant for relining. Before the guns could be shipped back for active duty, they had to be test fired to ensure that their aim was true. The Arco Naval Proving Ground (NPG) was established some 60 miles northwest of Pocatello as a remote place to test the guns for combat readiness. While operating during World War II, it was one of only six such facilities in the United States and the only one capable of test firing the Pacific Fleet's 16inch battleship guns.

The Arco NPG included some 270 square miles of land and infrastructure, including operational support facilities and housing for military and civilian personnel. This infrastructure is primarily located at what is today the INL Central Facilities Area (CFA), but also included rail lines and roads for gun transport and downrange activities and various targets, spotting towers, and detonation areas. The Army Air Corps, flying out of Pocatello, also established two practice bombing ranges near the Arco NPG at this time, one located southwest of CFA and the other southeast (Braun 1996; Scientech Inc. 1993; Stacy 2000).

After the end of World War II, ordnance testing at the Arco NPG continued in the form of explosives storage and transportation tests.
Structures were built and then loaded with explosives that were intentionally discharged to assess the effects to the structures and surrounding area of such explosions and to determine safe storage of military ordnance. One such test occurred on August 29, 1945 when 250,000 pounds of TNT were detonated. The explosion created a mile high smoke and dust cloud and a crater fifteen feet deep. Another test on October 31,1946 , detonated 500,000 pounds of excess high explosives to determine the safe distance for explosive ordnance storage in the open. At the time, this was believed to be the world's largest conventional ordnance explosion (Wylie, Appendix B; also EG\&G Idaho 1986). Craters and debris from this and other ordnance tests still remain on the INL landscape.

Between 1968 and 1970, during the Vietnam War, massive 16-inch naval guns were again heard on the Idaho desert (see Figure 18). A naval firing site, located southwest of CFA, was established and used for test firing the battleship New Jersey's armament. Since AEC research facilities were then scattered throughout the original downrange area of the Arco NPG, the guns tested at that time were aimed in the opposite direction. From the firing site located a few miles south of CFA, the guns were aimed southward across uninhabited territory toward the Big Southern Butte. Craters can still be found on the northern flank of the butte (Braun 1996; Coloff 1965).

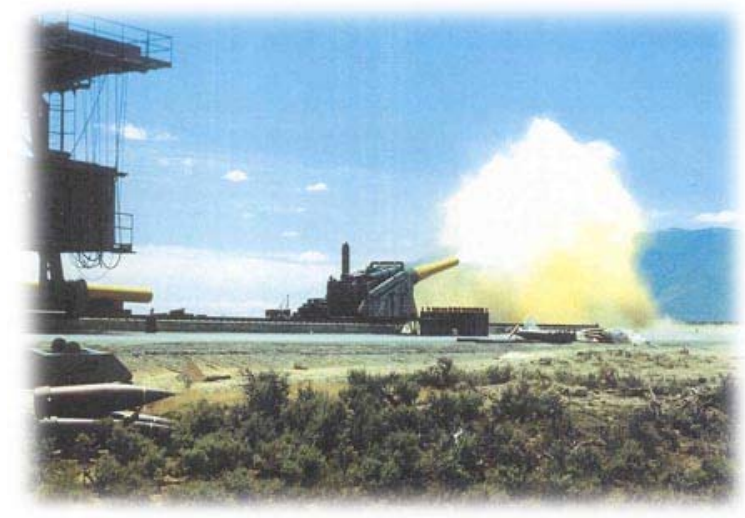

Figure 18. Sixteen-inch naval gun being tested at area now known as INL during the Vietnam war. 
Arco NPG land and infrastructure were acquired from the Navy by the AEC in 1949 and formed the nucleus of the future INL.

\section{Nuclear Science and Engineering}

The federal government initially established INL as the NRTS in 1949. Its purpose was to provide an isolated location where prototype nuclear reactors could be designed, built, and tested. The Naval Proving Ground buildings acquired by the AEC became known as the Central Facilities Area. As its name suggests, CFA served as a centralized support services facility for the reactor testing operations, containing such jointly used services as a fire department, medical dispensary, cafeteria, crafts shops, and motor vehicle repair and maintenance facilities (Braun 1996). Since establishment of the NRTS, 52 "firstof-a-kind" reactors have been constructed at INL.

The following contextual overview and the supporting text in Appendix $\mathrm{F}$ focus on major nuclear-era research and testing programs by facility area and are not intended as a comprehensive history. A more complete and definitive context, including an inventory of INL buildings administered by DOE-ID for post-1942 INL activities, can be found in the INL historical context report (Arrowrock 1997). Additional detail is provided by a popular history of INL (Stacy 2000) and several Historic American Engineering Record reports (Pace, Braun, and Gilbert 2006; Stacy 1994, 1997a, 1997b, 1997c, 2005a, 2005b).

Experimental Breeder Reactor I. The first reactor built at INL, Experimental Breeder Reactor I (EBR-I), reached initial criticality on August 24, 1951, and achieved many historical firsts during its operational lifetime. On December 20, 1951, shortly after initial startup, the facility became the first reactor in the world to produce usable quantities of electricity. Subsequently, in 1953, EBR-I proved the concept that reactors designed to operate in the high-energy neutron range are capable of creating more fuel than is consumed (i.e., breeding). This was an important concept in the 1950s because uranium, the main ingredient in reactor fuel, was thought to be in short supply. In 1955, EBR-I inadvertently experienced a core meltdown and proved that the consequence of such an event was not necessarily catastrophic (Braun 2006B). In July of 1963, EBR-I became the first reactor in the world to generate usable electricity with plutonium as the major fuel component and, later, also demonstrated the feasibility of using liquid metal as a reactor coolant. The reactor was decommissioned in 1964, named a National Historic Landmark on December 21, 1965, 14 years after its first historic event occurred, and opened for public visitation in 1975. In 1979 it was recognized as an American Society of Mechanical Engineering Landmark and in 1985 was awarded the same honor by the American Nuclear Society (Braun 2006A; Braun 1994; INEL 1969) (see Figure 19).

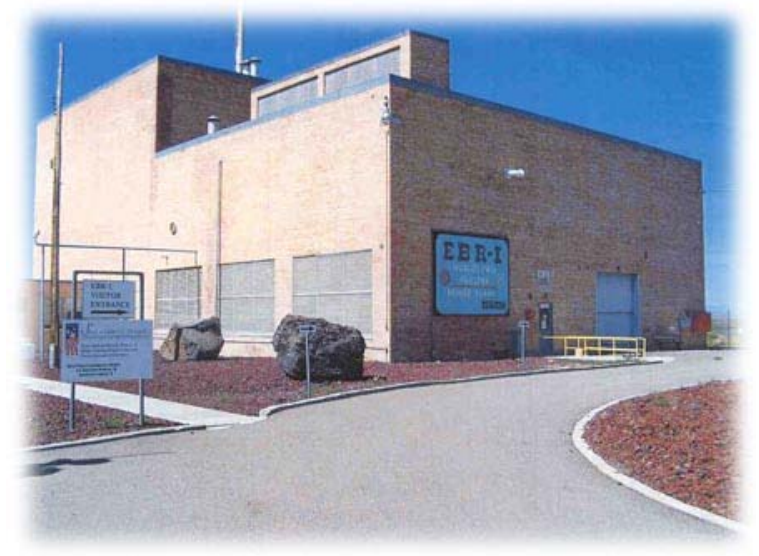

Figure 19. EBR-1 National Historic Landmark.

Reactor Technology Complex. The first reactor built expressly for testing reactor core and fuel materials, the Materials Test Reactor (MTR) achieved startup on March 31, 1952, at the INL area now known as RTC (formerly the Test Reactor Area [TRA] $]^{2}$ ). Experiments conducted at MTR influenced the choice of fuel elements and core structural materials for every reactor constructed in the United States since MTR startup. After more than 125,000 operating hours, MTR was finally shut down on April 25, 1970, and was formally decommissioned in 1974. Until

2. Unless otherwise specified for historical purposes, the INL area originally known as TRA is primarily referred to in this section by its current designation of RTC. 
2007, the MTR building was maintained and used for office and laboratory space and storage.

To enhance the nation's reactor testing capability, the Engineering Test Reactor (ETR) was completed in 1957, just a few hundred feet south of MTR at RTC. At the time of initial operation, ETR was the largest and most technically advanced materials test reactor in the world. Like the older MTR, the original ETR mission was to evaluate fuel, coolant, and moderator characteristics for future reactor designs. The demand for expanded and more technically advanced reactor testing capability was so great that even before ETR became operational, planning was underway for yet another, even more advanced test reactor at INL.

Construction on the Advanced Test Reactor (ATR) began in 1961, and at that time it was the largest single construction project ever undertaken in the state of Idaho. Located approximately 200 yards north of the old MTR reactor building, ATR began operation in 1967. ATR performed experiments similar to those conducted at the MTR and ETR facilities, with the U.S. Navy as the primary customer. ETR was shut down for the last time in 1982. It and MTR now stand vacant and are awaiting demolition. ATR remains in operation, still performing its materials testing mission. Since the 1950s, the RTC reactors have made vast and fundamental contributions to the development of nuclear science and engineering (Braun and Marler 1996; INEL 1969).

\section{Radioactive Waste Management Complex.}

RWMC was established in the southwestern corner of INL in 1952 to accommodate increasing amounts of radioactive wastes being generated by the new reactors. From 1954 to 1970, transuranic (TRU) wastes from the nation's national defense programs were disposed of in the RWMC's Subsurface Disposal Area (SDA) (DOE-ID 1996). In 1970, TRU wastes began to be stored aboveground in an expanded TRU waste storage area (INEL 1969). At the facility's Stored Waste Examination Pilot Plant (SWEPP), the TRU waste has been vented, examined, and certified for eventual disposal at a permanent national repository, such as the Waste Isolation Pilot Plant in New Mexico. The Advanced Mixed Waste Treatment Project (AMWTP), which began operation in 2003, expanded the complex's waste management operations to include treatment of 65,000 cubic meters of INL low-level and TRU waste currently stored at the Transuranic Storage Area and prepare the wastes for shipment out of Idaho. RWMC presently consists of the SDA, the TRU waste storage area, an administrative complex, and the operations zone. Although most of the above-ground structures were built after 1970 , many of the features at RWMC are important for the role they have played in the development of radioactive waste management technology.

Naval Reactors Facility. Also in the early 1950s, work began at INL to develop and test reactor prototypes for the U.S. Navy. The initial power run of the prototype reactor (S1W) for the world's first nuclear submarine, the USS Nautilus, was conducted at INL on May 31,1953, proving that atomic propulsion of ships was possible (see Figure 20).

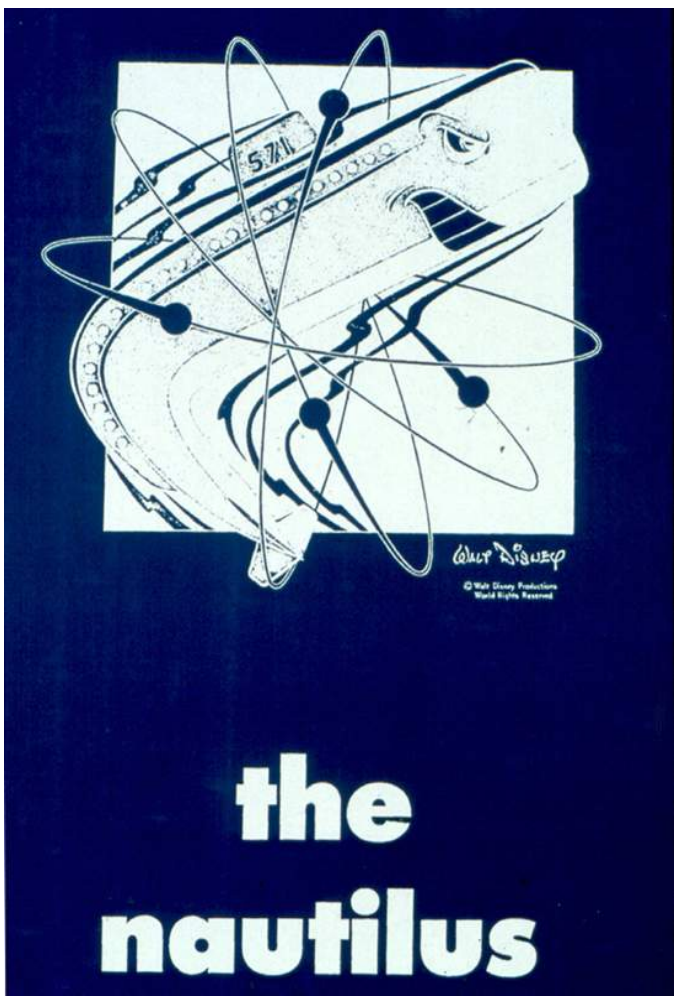

Figure 20. Promotional poster for the USS Nautilus nuclear-powered submarine program. 
The U.S. nuclear Navy was born and, in 1958, a propulsion reactor prototype designed for use in surface ships (A1W) was also designed and built at NRF. The A1W prototype facility consists of a dual-pressurized water reactor plant within a portion of steel hull designed to replicate the aircraft carrier, USS Enterprise.

A1W was the first ship propulsion system designed to have two reactors providing power to the propeller shaft of one ship. The $\mathrm{S} 5 \mathrm{G}$ reactor is a prototype pressurized-water reactor designed to operate in either a forced or natural circulation flow mode. Coolant flow through the reactor is caused by thermal circulation rather than pumps. The S5G prototype plant was installed in an actual submarine hull section capable of simulating the rolling motions of a ship at sea (INEL 1969). These prototypes were used for many years to train naval personnel. A historic context and building inventory assessment report that addresses the historical significance of NRF facilities has been completed under the direction of DOE's Office of Naval Reactors.

Boiling Water Reactor Experiment. In 1953, the first of five reactors was constructed at the Boiling Water Reactor Experiment (BORAX) area to prove the feasibility of reactors in which the coolant and moderator boils in the reactor core and passes steam directly to the turbine for power generation. The BORAX tests also attempted to demonstrate the efficiency of power production from this type of direct-cycle system. After BORAX I was deliberately destroyed in 1954 to determine this type of reactor's safety under extreme conditions, BORAX II was constructed in the same area for further safety parameter tests and to experiment with new core combinations.

The next reactor in the series, BORAX III, was built in 1955 to determine if boiling water reactors could generate power. The determination was made when BORAX III became the first reactor to light an American town (Arco, Idaho) on July 17, 1955.

BORAX IV operated from 1956 to 1958 and demonstrated the stability of ceramic cores of uranium-thorium oxide fuel elements. The last reactor in the series, BORAX V, produced superheated dry steam wholly by nuclear means for the first time in order to increase the efficiency of this type of design and reduce the costs of nuclear power.

Although no surface structures remain from the BORAX programs, there is no question of the importance they had in the development of reactor safety parameters and the nuclear power program (INEL 1976).

Test Area North. In the 1950s and early 1960s, the Aircraft Nuclear Propulsion (ANP) program was conducted at TAN (see Figure 21). During the course of this program, which was designed to prove the feasibility of nuclear-powered aircraft, three Heat Transfer Reactor Experiments (HTREI,-II, and -III) were conducted. Although no nuclear-powered aircraft were ever built, HTRE test results proved the feasibility of using heat from nuclear power to operate aircraft turbojet engines and resulted in a myriad of other scientific contributions. Three additional low-power reactors were operated in support of this program; the Shield Test Pool Reactor, the Critical Experiment Tank, and the Hot Critical Experiment.

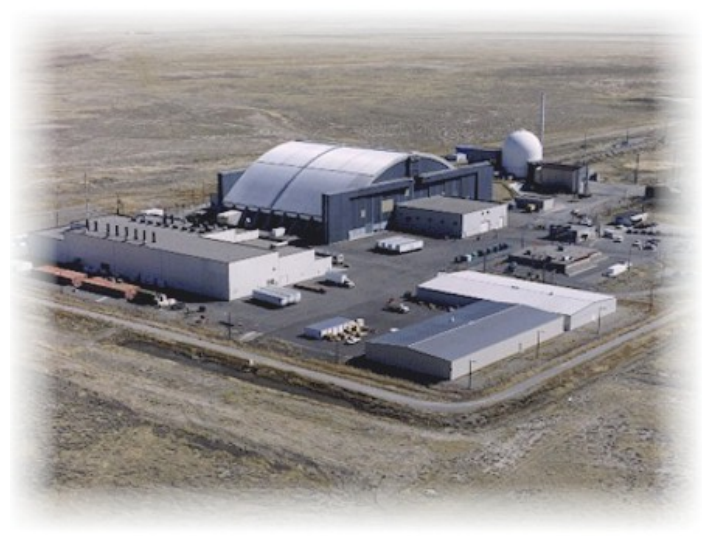

Figure 21. Aerial photo of the LOFT facility (demolished in 2006) and ANP hangar at TAN.

Following the development and success of the Intercontinental Ballistic Missile program, the need to restock conventional weapons arsenals, and the desire to pursue space exploration, the ANP program was terminated in 1961 by presidential Executive Order. Two prototype nuclear aircraft engines used in the HTRE tests are presently on public display near the EBR-I reactor 
complex. Although many of the structures associated with the ANP have either been demolished or stand vacant, the ANP hangar, designed to house prototype aircraft, still exists and supports ongoing programs at TAN (Braun 2006a).

The Loss of Fluid Test (LOFT) program was first conceptualized in 1962, shortly after the demise of the ANP, but underwent an extensive series of modifications before actual testing began at TAN in 1976. LOFT consisted of a series of simulated loss-of-coolant accidents. In 1978, the first nuclear tests began at the LOFT containment facility. The LOFT reactor was the only nuclear reactor in the world capable of repeatedly simulating loss-of-coolant incidents similar to those that might occur in commercial power reactors. In 1979, the LOFT scientists and reactor played a vital role in predicting activity within the Three Mile Island (TMI) reactor core as scientists struggled to manage and control the TMI reactor core meltdown. Successful testing continued at LOFT until 1982, when an international consortium took over operations and continued testing until 1986, when the program officially ended. The Water Reactor Research Test Facility (WRRTF), originally constructed to house reactor shielding tests associated with the ANP program, was reused during the LOFT program to conduct nonnuclear simulations of thermal-hydraulic features of commercial nuclear reactors. After a long history of significant contributions to nuclear science and engineering, many structures associated with LOFT and other, less significant programs now lack missions and have been vacated and demolished (INEL 1969; Stacy 1994) (see Figure 22).

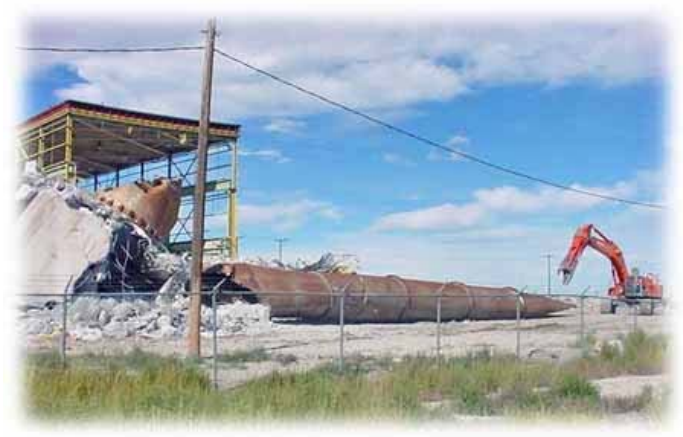

Figure 22. Demolition of the WRRTF stack.
Idaho Nuclear Technology and Engineering Center. In 1953, INL's most important reactor support facility, the INL area now known as INTEC (formerly the Idaho Chemical Processing Plant $[\mathrm{ICPP}]^{3}$ ), began the process of recovering and reprocessing unburned, enriched uranium from "spent" reactor fuel elements. INTEC was initially designed and built as a five-year demonstration facility, but the Cold War nuclear arms race led to an increased demand for nuclear fuel, and INTEC soon became a fullscale production facility (see Figure 23).

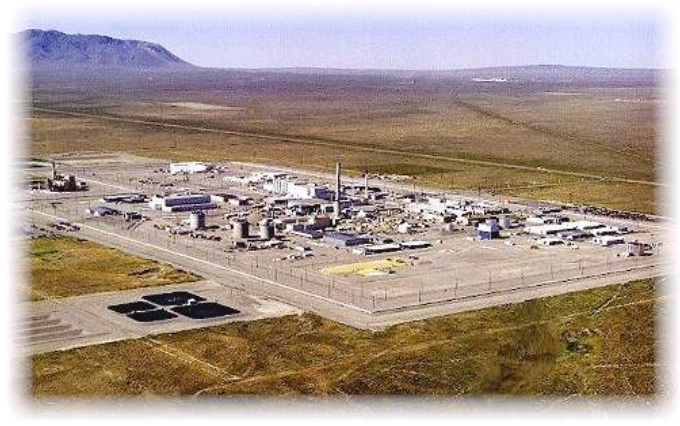

Figure 23. Aerial view of INTEC.

Spent reactor fuel elements were transported to INTEC to extract enriched uranium, which was then shipped to another national laboratory at Savannah River, Georgia, for use as fuel in reactors producing plutonium and tritium for nuclear weapons.

In addition to its groundbreaking work in fuel reprocessing technology, INTEC became a leader in the development of new technologies to manage nuclear wastes.

The waste calcining facility (WCF), developed at INTEC in the mid-1950s, transformed highly acidic radioactively contaminated liquid wastes into granular pellets that are much safer and easier to store until radioactive components in the waste are rendered safe through natural decay. INTEC calcining operations continued after WCF closure with its successor, the New Waste Calcining Facility (NWCF). Although fuel reprocessing at

3. Unless otherwise specified for historical purposes, the INL area originally known as ICPP is primarily referred to in this section by its current designation of INTEC. 
INTEC ended in 1992 and the final waste calcining campaign occurred in June, 2000, their contributions to the history of nuclear science have been significant. (INEL 1969; Pace and Braun 2000; Stacy 1997).

Army Reactor Area. Work began at the Army Reactor Area (ARA) in 1957 to develop compact, portable reactors to generate electricity in remote locations. This work culminated with one watercooled reactor and two gas-cooled reactors, which were constructed at three of the four ARA sites (ARA-II, ARA-III, and ARA-IV). Support facilities, including a hot cell, were located at ARA-1, a nearby area south of ARA-II. In January 1961, an incident at the Stationary Low Power reactor (SL-1), located at the ARA-II facility, resulted in a steam explosion, leading to the first fatalities in U.S. history directly related to nuclear reactor operations.

After nearly nine years of operation, the army program at ARA was terminated in 1965 due to reactor maintenance problems, an inability to define a current mission, and questions related to cost effectiveness. After the Army terminated its reactor programs, the name was changed to the Auxiliary Reactor Area, and the remaining facilities were used for a few years in support of various other research programs. After standing vacant for several years, decontamination and dismantlement of the ARA structures began in 1993 (INEL 1962; Stacy 1997).

\section{Critical Infrastructure Test Range}

Complex. In 1955, the INL area now known as the Critical Infrastructure Test Range Complex (CITRC) was established as the Special Power Excursion Reactor Test (SPERT) area to implement the AEC's water-cooled reactor safety testing program. Four SPERT reactors were designed, built, and operated in the 15-year period between initial startup of SPERT-I on June 11, 1955, and final shutdown of SPERT-IV in 1970. The purpose of the SPERT reactors was to study a wide range of variables such as core configuration, plate design, coolant flow, and reflector moderator and temperature coefficients. In general, research was directed toward "runaway power," which was the major safety concern at that time.
Following shutdown of SPERT-IV, the SPERT area was renamed the Power Burst Facility (PBF) in 19704 and SPERT-II, -III, and -IV were converted to the Waste Engineering Development Facility, the Waste Experimental Reduction Facility, and the Mixed Waste Storage Facility for the treatment, storage, disposal, and recycling of radioactive hazardous, mixed, and industrial and commercial wastes. These three facilities were colocated at the Waste Reduction Operations Complex (WROC).

The SPERT I reactor was demolished in 1985; however, at the PBF reactor, just north of SPERT I, studies continued on the effects of abnormal conditions on nuclear fuels (INEL 1969). After years of successful operation and failed attempts to attract new programs, the PBF reactor at CITRC is presently being decontaminated and dismantled while some of the remaining offices and infrastructure at CITRC are being used by Department of Homeland Security programs.

Materials and Fuels Complex. In 1953, the same year that Argonne's EBR-I proved the breeding concept, design began on the next generation of breeder reactors. It was planned that Experimental Breeder Reactor II (EBR-II) would serve as both a prototype for commercial breeder reactors and as a testing and development center for fuel reprocessing technologies. Construction began in 1961 at the INL area now known as $\mathrm{MFC}^{5}$ (formerly Argonne National LaboratoryWest [ANL-W]) (see Figure 24), and EBR-II achieved criticality in 1963. In 1964, the first fuels were reprocessed and the reactor began producing electricity. Eventually EBR-II produced enough electricity to provide power to the entire INL. The original design tests were accomplished by 1965 , and the reactor was then used as an irradiation

4. The PBF area in which the SPERT and PBF reactor facilities operated has been renamed CITRC. Unless otherwise specified for historical purposes, the area formerly designated as $\mathrm{PBF}$ is primarily referred to in this section by its current designation of CITRC. The SPERT and PBF reactor facilities within CITRC are referred to by their original designations.

5. Unless otherwise specified for historical purposes, the INL area originally known as ANL-W is primarily referred to throughout this document by its current designation of MFC. 


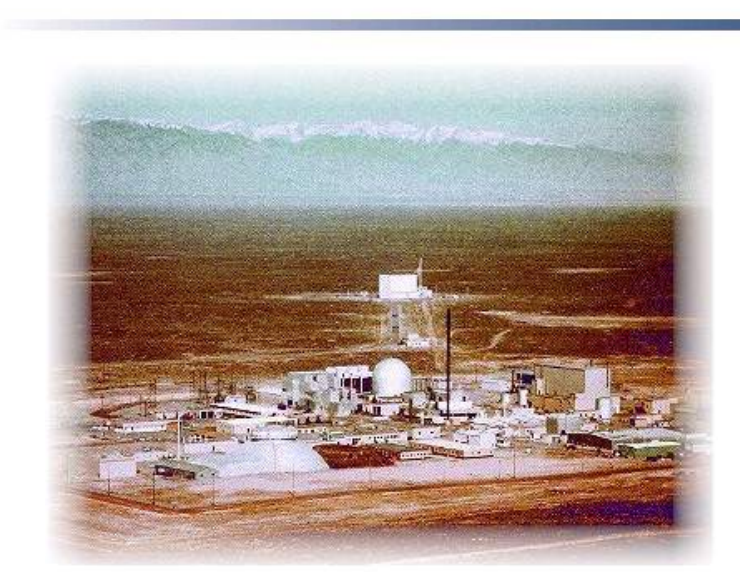

Figure 24. Aerial view of MFC.

facility for the testing of reactor components. EBR-II was shut down for the last time in 1994. Other major reactor experiment facilities at MFC include the Zero Power Plutonium Reactor (ZPPR) that physicists used to mock up different fuel and control elements and test them at low power and the Transient Reactor Test Facility (TREAT) that Argonne built to better understand how fast neutrons behaved during an excursion. (INEL 1969).

Miscellaneous Programs. Other reactor concepts tested at INL include the Organic Moderated Reactor Experiment (OMRE), constructed southwest of CFA and operated from 1957 to 1963 . The OMRE was designed to test the use of liquid hydrocarbons as a coolant and moderator. After deactivation in 1963, the facility remained unused until 1977, when it was finally dismantled.

The Experimental Organic Cooled Reactor (EOCR) was built adjacent to the OMRE facility and was designed as a continuation of the OMRE studies. EOCR was approximately $90 \%$ complete when the program was canceled in 1962 and, though the reactor was in place, it was never brought to criticality (INEL 1969). The EOCR reactor building was subsequently used briefly for office space, then was renamed as the Security Training Facility and used to train Laboratory security forces. After standing in the desert for 38 years, the EOCR facility was removed in 1999.

\section{Current Operations}

The LOFT facility at TAN was the last new reactor testing facility to be constructed at INL, and the years following the end of the LOFT program saw a continuing decline in the reactor testing mission.

ATR is the only DOE-ID reactor currently operating, and all other remaining INL reactor facilities are in various stages of shutdown and DD\&D or awaiting new missions. Fuel processing and waste calcining at INTEC have ended, and the original Waste Calcining Facility and Fuel Reprocessing Complex have undergone or are undergoing DD\&D. Hazardous and radioactive waste management, environmental cleanup, environmental technology development, and longterm environmental stewardship have assumed greater importance over the years. The labor force at INL (including the NRF and then-Argonne) peaked in 1992 with some 12,700 employees (Stacy 1999). In the intervening years the number of employees has declined to a current sitewide total of approximately 6600 , including NRF. This reduction, and the consolidation of activities, resulted in some of the built environment standing unused and vacant. However, the nation's energy and security concerns have resulted in new and revitalized INL missions and growth.

In 2002 DOE named INL the lead Laboratory for the development of the next generation of nuclear reactor technology and for the development and testing of Homeland Security technologies. In addition, INL management and staff are actively seeking and attaining new scientific research and engineering projects in governmental, private sector, and international arenas. As such, INL plays a key role in the advancement of America's scientific and technological infrastructure. To support these and other mission-critical programs and activities and to replace older buildings and structures that have been removed or that are presently undergoing deactivation, decontamination, and demolition (DD\&D), some new construction has recently been completed, such as the Center for Advanced Energy Studies (CAES) and new laboratory facilities at both RTC and MFC. Between 2009 and 2015, many more new structures are planned (Braun, 2006a; INL Strategic Plan 2009-2015, 2008). 
IDAHO NATIONAL LABORATORY CULTURAL RESOURCE MANAGEMENT

This section summarizes the overall approach to managing cultural resources at INL. Topics include the effects of activities on cultural resources; management responsibility; and overall management of cultural resources-identification, evaluation, and protection. Appendices C and D complement this general description by providing strategies and procedures for the management of archaeological and historic architectural resources. Future priorities for the INL CRM Program are outlined in Appendix K.

\section{Past, Present, and Potential Effects of INL Activities on Cultural Resources}

INL remains an active scientific facility where programs and projects are in constant change. Historically, INL missions have also varied tremendously, resulting in a variety of needs by multiple tenants and organizations. INL-related activities have had an undeniable impact on cultural resources of all types. In some cases, the impacts have been beneficial. For instance, restrictions on grazing and other public access and development for portions of INL have protected exposed surface artifacts at thousands of prehistoric and historic archaeological sites, and general maintenance activities and reuse have prolonged the life of many historic buildings and structures.

However, some impacts have been damaging to INL cultural resources. For example, at times reuse of buildings where historically important activities took place has meant the removal of original equipment and systems associated with those activities. In other instances, historic buildings have been demolished to eliminate or reduce maintenance costs and potential contamination problems or to make room for newer facilities, while archaeological sites and sensitive American Indian sites have been adversely affected by ground disturbance associated with facility and infrastructure construction.
In general, the potential impacts to cultural resources at INL fall into the following categories:

- Natural forces (e.g., wind erosion, water erosion, flooding, range fires, animal activity, and gravity)

- Vandalism (e.g., graffiti, unauthorized artifact collection, unrestricted offroad vehicle use, and neglect)

- Construction (e.g., facilities, roads, utilities, wells, landfills, borrow pits, fencing, trenching, and other structures that disturb the ground and impact the landscape)

- Maintenance and renovation (e.g., scavenging equipment, neglect, and removal or alteration of historic features)

- Deactivation, decontamination, and dismantlement (e.g., asbestos abatement, landscape changes, demolition of buildings and other structures, and disposal of historic data)

- Habitat modification (e.g., spread of noxious and/or exotic weeds, flood control, fire rehabilitation, introduction of hazardous materials, artificial changes such as manmade ponds, and grazing)

- Contamination (e.g., radiological, industrial, and mixed waste pollutants)

- Operations (e.g., security activities, environmental monitoring, and cleanup)

- Emergency response (e.g. fire fighting and containment, and flood control).

Depending on facility missions over time, some activities tend to have greater cumulative impacts on cultural resources than others.

After initial passage of the National Historic Preservation Act in 1966 and the National Environmental Policy Act in 1969, INL began to incorporate cultural resource concerns into land use and management decisions. Today they are routinely considered an integral part of operations and environmental stewardship at the Laboratory (Environmental Policies, Appendix A). 


\section{Responsibility for Resource Management}

Comprehensive planning is especially important for DOE because the agency manages large amounts of land distributed over a broad and diverse geographic area. The wealth of cultural resources potentially impacted by activities on DOE lands is also diverse and region specific. Because of the wide variety of its holdings, DOEHQ has delegated primary responsibility for cultural resource management to local DOE field offices. DOE operations office managers, field office managers, and lead program secretarial officers assume primary responsibility for implementing cultural resource policies. At INL, the Environmental Technical Support Division of DOE-ID takes responsibility for oversight of the INL CRM Program through a designated cultural resources coordinator. The INL CRM Office, which is operated by DOE-ID's M\&O contractor, is responsible for day-to-day cultural resource management at INL and implementation of this Plan. This office is staffed with professional archaeologists, preservationists, anthropologists, and historians who meet Secretary-of-Interior qualification standards or are closely overseen by staff who meet the standards.

Cultural resource concerns and responsibilities are also integrated into broader DOE objectives through a Cultural Resource Management Program based at DOE-HQ. The DOE director of the Office of Health, Safety, and Security; the director of the Office of Management and Administration; and the designated federal preservation officer are responsible for developing and coordinating cultural resource management and historic preservation policy and guidance with broad DOE impact. Other offices that provide policy and guidance of value in the cultural resources arena include the DOE Office of History and the Assistant Secretary for Congressional and Intergovernmental Affairs; the latter provides input concerning relationships with American Indian governments and other public interest groups.

\section{Primary Activities of the INL Cultural Resource Management Office}

Federal law directs that cultural resources be considered and protected if possible during daily operations and project planning and implementation on INL. The most effective protective measures are "active" and include resource inventories, National Register nominations, site monitoring, scientific research, and public education. "Reactive" measures are also taken to protect resources. This includes activities such as site avoidance during ground disturbance, archaeological investigations to mitigate adverse impacts, preparation of Historic American Engineering Record documentation, and a variety of other activities outlined in Appendices $\mathrm{C}$ and $\mathrm{D}$.

The INL CRM Office coordinates cultural resource-related activities at INL with oversight by the DOE-ID cultural resources coordinator. The activities of the INL CRM Office - set forth by law, regulation, and guidance - fall into three very broad cultural resource management categories:

(1) identification, (2) evaluation, and

(3) protection. The staff is also dedicated to sound overall management and resource protection or enhancement, and elements of these objectives infuse all INL cultural resource management efforts.

The overall mission of the INL CRM Office, as outlined in this plan, is to provide a professional approach to managing the cultural resources under DOE-ID's jurisdiction in coordination with and support of current and emerging Laboratory missions and programs.

As such, INL cultural resources are managed in such a manner as to:

- Promote appreciation and awareness of the value and sensitivity of cultural resources on INL

- Encourage management accountability for INL cultural resources 
- Achieve compliance with the spirit and intent of applicable executive and legislative mandates

- Foster innovative and cost-effective methods for taking cultural resources into early and careful consideration during INL undertakings in harmony with the overall DOE mission.

\section{NHPA Section 110 Goals}

NHPA Section 110 is intended to ensure that historic preservation is fully integrated into the ongoing programs of all federal agencies. It sets forth broad responsibilities and a few specific benchmarks to fulfill this goal. In a broad sense, the statute requires federal agencies to assume responsibility for identifying and protecting historic properties and avoid unnecessary damage to them. Agencies are also charged with the affirmative responsibility for considering projects and programs that further the purposes of the NHPA and the statute declares that the costs of preservation activities are eligible project costs in all undertakings.

1992 amendments to the Act further strengthened the provisions of Section 110 and established specific benchmarks for compliance. In this context, the stature requires the head of each federal agency to assume responsibility for the preservation of historic properties owned or controlled by the agency, establish a broad preservation program for historic properties, and to the maximum extent feasible, to use historic properties available to it in carrying out its responsibilities, including construction, lease, or purchase of new properties. It further directs that preservation-related activities, and all other activities that may impact historic properties, be carried out in consultation with other federal, state, and local agencies; American Indian tribes; and the general public. Finally, it directs federal agencies to establish preservation programs to identify, evaluate, and nominate properties under their jurisdiction to the National Register and to maintain and manage such properties in a manner that considers their preservation. Finally, agency procedures for compliance with Section 106 of the Act are to be consistent with regulations issued by the Advisory Council on Historic Preservation.
DOE is committed to a comprehensive cultural resource management approach that addresses all cultural resources at INL in full compliance with all Sections of the NHPA. A broad range of ongoing INL CRM Office activities fulfill Section 110 requirements. This includes, but is not necessarily limited to: archaeological survey and recording of previously unknown resources, assessment and updated documentation of previously recorded archaeological resources, National Register nominations, artifact analyses, and archival research. All of these activities enhance resource protection and preservation.

\section{Identification}

Efforts to identify cultural resources have been ongoing at INL for more than three decades. Appendices $\mathrm{H}$ and I provide lists of the cultural resources that have been identified during this time, organized according to resource type. Every year more resources are added to this inventory through two basic processes. In one process, resources are inventoried for purposes of longterm planning and compliance with provisions in the National Historic Preservation Act and the Archaeological Resources Protection Act that require federal agencies to ultimately locate and evaluate the cultural resources on lands under their jurisdiction. In the second process of identification, cultural resources that may be subject to impact as a result of INL activities are inventoried.

Methods for identification of cultural resources at INL vary according to the type of resource under consideration. For the most part, archaeological sites are identified through intensive, systematic pedestrian surface survey in most INL areas. Historic architectural properties, structures, and objects generally exhibit some type of surface manifestation as well, but not always, and INL historic data are often consulted to assist with identification of these cultural resources. Direct communication is necessary to identify and characterize most American Indian cultural resources such as sacred sites or traditional use areas. Even in areas that are widely recognized as sensitive to the Shoshone-Bannock Tribes, detailed inventory of the resources, tangible and 
intangible, of potential concern and importance is impossible without tribal input.

DOE-ID's commitment to locating cultural resources at INL is critical to their long-term stewardship. The archaeological sites, historic architectural properties, traditional cultural areas and sacred American Indian sites scattered over the entire Laboratory cannot be understood in isolation. All are part, and only part, of larger human systems adapted specifically to the highdesert landscape through several distinct time periods. Since the area is so large and its cultural history so complex, effective stewardship is only accomplished through an ongoing program of resource identification using existing historic contexts and research designs and through incorporation of the resulting information into new and/or updated contexts and research designs.

General cultural resource identification efforts are also important for overall land-use planning. In this case, surveys can be targeted in areas where there are special concerns, such as:

- Zones that are subject to high levels of natural erosion where cultural resources may be subject to unmitigated impact

- Areas that are targeted for environmental cleanup

- Areas where future development may occur

- Areas that are poorly understood and underrepresented in existing cultural resource inventories

- Areas that hold promise for development to enhance public understanding of INL's cultural resources.

For these types of identification efforts, it may be appropriate to target specific types of cultural resources, such as scientific equipment, important American Indian plants, age/gender-related items, or any other resource that is poorly understood. The goal of every effort is enhanced understanding of the resource base.

Predictive modeling can further enhance the value of existing cultural resource inventories for land-use planning by providing information on the expected density and distribution of resources in areas that have not been surveyed. This information can be useful for planning future DOE activities to minimize damage to cultural resources. At facilities like INL, with significant land holdings and numerous cultural resources, this type of predictive modeling effort is a valid way of working to satisfy the statutory requirements for $100 \%$ inventory of DOE-ID cultural resource holdings

Research. There are two primary approaches to conducting cultural resource research on INL:

1. Develop strong research-based relationships with universities and provide support to other non-INL historical and archaeological researchers based on qualified and valid proposals. Work to develop joint funding proposals in areas of mutual interest and benefit with these external entities and join in the solicitation of support for research that fills gaps in the understanding of INL cultural resources.

2. Explore ways to optimize basic cultural resource research goals through the required compliance activities that demand most INL CRM Office resources. This can be done by conducting information-gathering activities under an umbrella of thoughtful research designs (see Appendix E) and historical contexts (see Appendix F). In this way, sufficient and sophisticated information can be gathered, and time and funding can be used optimally. This approach allows recovery of the basic data needed to describe, characterize, and protect INL cultural resources while maintaining legal compliance and contributing to the regional scientific information base.

Unanticipated Discoveries. Even after advance surveys and other identification efforts, cultural resources are occasionally identified unexpectedly during implementation of INL projects. This is particularly true for archaeological and paleontological sites, which may have little or no surface manifestation, but important historic objects and data may also be discovered during a project. 
The INL Stop Work Authority provides mechanisms for protecting inadvertently discovered cultural materials from further damage. Through training, all INL employees are informed of their right and indeed, their obligation, to stop any work process that could adversely impact safety or the environment, including exposing or threatening resources of cultural importance. Employees are also generally encouraged to contact the INL CRM Office informally whenever they have questions or concerns about cultural resources or if they find something they think may be of interest. As a final check for archaeological resource protection, environmental checklists that cover activities involving ground disturbance also include reminders of the INL Stop Work Authority.

When INL employees suspect sensitive cultural materials have been uncovered or previously identified cultural resources are being subjected to unanticipated impacts, they are trained to stop or redirect their activities and immediately contact the INL CRM Office. When contacted, the INL CRM Office will advise the employee to establish a 30 - to 50 -meter protective buffer around the exposed archaeological or paleontological materials or to isolate significant data or objects. The DOE-ID cultural resources coordinator will be contacted and will schedule a site visit to evaluate the situation within two working days of the discovery. Once notification has been made through the INL CRM Office, the DOE-ID cultural resources coordinator will, in turn, notify other interested parties as the situation demands. For all archaeological sites, interested parties will include, but not necessarily be limited to, the Advisory Council, Idaho SHPO, and Shoshone-Bannock Tribes. An invitation to consult on the resolution of adverse effects to the identified resource and participate in any associated activities will be included with this notification. Within two working days of the notification, interested parties will be asked to inform the DOE-ID cultural resources coordinator of their intentions to participate. When human remains are included in the find, the DOE-ID cultural resources coordinator will also notify the appropriate county sheriff's office and initiate compliance with the Native American Graves Protection and Repatriation Act, as appropriate.

Emergency Situations. Another means of identifying cultural resources at INL is through inventories and assessments completed in response to emergency situations. Emergency response activities are those activities declared by the U.S president, a tribal government, or the governor of a state, as necessary to safeguard human health and the environment during declared disasters, emergencies, or national security threats. Emergencies at INL may be caused by either natural or manmade events.

During emergency situations at INL, no actions necessary to preserve human health or property will be delayed to comply with historic preservation requirements. However, INL emergency responders can carry on the spirit of the mandates by consistently trying to minimize the overall impact of their activities. Emergency responders are also reminded that activities completed in anticipation of emergency situations (flood control, controlled burns, etc.) and those conducted after termination of the emergency are not exempt from cultural resources review.

Although activities conducted in the midst of an INL emergency are exempt from cultural resource review and consideration, the aftereffects of those activities must be evaluated. As soon as conditions allow after an emergency has ended, the INL CRM Office conducts archive searches and field inventories, as appropriate, to evaluate the impact to cultural resources. Once the scale of impact is determined, communication, and when necessary, formal consultation, is initiated with the Idaho SHPO, Shoshone-Bannock Tribes, and other interested parties and stakeholders to develop strategies for any needed mitigation.

\section{Evaluation and Nomination to the National Register of Historic Places}

Evaluation of INL cultural resources for nomination to the National Register involves determining the significance of those resources. Methods for determining the significance of cultural resources at INL play an important role in both long-term planning and project-specific 
impact assessments. Regulations promulgated by the National Historic Preservation Act provide a general approach for evaluating significance. According to 36 CFR 60.4, "Criteria for Evaluation":

The quality of significance in American history, architecture, archeology, engineering, and culture is present in districts, sites, buildings, structures, and objects that possess integrity of location, design, setting, materials, workmanship, feeling, and association and:

- That are associated with events that have made a significant contribution to the broad patterns of our history; or

- That are associated with the lives of persons significant in our past; or

- That embody the distinctive characteristics of a type, period, or method of construction, or that represent the work of a master, or that possess high artistic values, or that represent a significant and distinguishable entity whose components may lack individual distinction; or

- That have yielded, or that may be likely to yield, information important in prehistory or history; or

- That have achieved significance within the past 50 years if they are of exceptional importance.

In addition to meeting one or more of the aforementioned criteria, properties must possess integrity in order to be eligible to the National Register. Integrity is defined as (Advisory Council 1991):

The authenticity of a property's historic identity, evidenced by the survival of physical characteristics that existed during the property's historic ...period. If a property retains the physical characteristics it possessed in the past, then it has the capacity to convey association with historical patterns or persons, architectural or engineering design and technology, or information about a culture or people.

Integrity has seven qualities that apply to historic architectural properties:

1. Location

2. Design

3. Setting

4. Materials

5. Workmanship

6. Feeling

7. Association, which is the "direct link between a property and an event, or person...for which the property is significant... and is sufficiently intact that it can convey that relationship" (Advisory Council 1991).

A property normally must meet at least two of the seven qualities to be eligible for the National Register.

Clearly, some important cultural resources at INL will not meet any of the evaluation criteria or will lack sufficient integrity. For instance, the significance of a traditional cultural area lies with those who have traditional ties there and can only be established by communicating directly with them. Therefore, while the National Register criteria are useful, they are not necessarily used alone in the process of evaluating significance at INL. Appendices E and F contain research designs and historic contexts that provide the background necessary to evaluate the significance of INL archaeological and architectural properties. Significance evaluations play an important role in identifying cultural resources that should be protected from impact during INL-sponsored activities. These evaluations are also an important part of general cultural resource management activities at INL. Significance is documented through data collection and established within the framework of historic contexts and research designs developed for each type of cultural 
resource known at INL. Some properties exhibit characteristics that make them eligible for nomination to the National Register of Historic Places, while others do not, but they are no less important in the overall management scheme.

INL's first reactor facility, EBR-I, is listed on the National Register as a National Historic Landmark, and DOE-ID intends to nominate other properties in the future. Possible strategies include nomination of:

- Multiple historic buildings and structures

- The nuclear-powered jet engines presently on display at the EBR-I complex

- Goodale's Cutoff of the Oregon Trail

- The Middle Butte Cave rock art site and traditional cultural area.

National Register nominations require detailed documentation in a format specified by the National Park Service. Data collection is often necessary to accumulate the required information. Methods for collecting data to meet eligibility requirements vary for archaeological sites, historic architectural properties, and traditional use or sacred areas. For archaeological sites, data necessary for nomination may be collected via:

- $\quad$ Surface mapping

- Artifact collection, when necessary for research purposes or to protect cultural resources

- Test excavations

- Laboratory analyses.

Information in local archives and repositories may also be of value in understanding archaeological sites and historic architectural properties from the historic period. Information on resources from the more recent past is also available from current and former INL employees and in archival form, including collections that are housed and maintained at INL.

Finally, information on traditional use areas and sacred sites, beyond general statements about large regions and features, is only available through communication with the local land users.

\section{Protection and Preservation}

Elements of resource protection and preservation are included in every aspect of the CRM Program. The paragraphs to follow include descriptions of program elements that are part of long-term planning and the overall management goal of maintaining resource preservation.

Monitoring. The purpose of the comprehensive sitewide cultural resource monitoring program is to identify, track, and reduce impacts to known resources throughout INL. The INL CRM Office conducts monitoring activities for DOE-ID to determine the effectiveness of DOE-ID and contractor policies and to safeguard cultural resources from destruction and deterioration caused by natural or human processes. Each year, the INL CRM Office selects a few locations for monitoring based on such factors as-stakeholder feedback, National Register status/eligibility, ease of public access, history of adverse effects, and proposed work in the area. INL monitoring forms are completed and a report submitted to DOE-ID, who then undertakes appropriate actions to address findings following the process outlined in the INL Monitoring Plan in Appendix L.

The INL CRM Office staff has conducted monitoring of several historic architectural properties and has identified impacts to resources. INL management has been notified of the impacts and is addressing these issues.

Another key element of the sitewide monitoring program is that INL is a restricted area and an active security force monitors the entire Laboratory via ground patrols and security surveillance of public points of access. When encountered, trespassers are removed immediately. Largely as a result of these restrictions, many archaeological sites on INL are relatively undisturbed. In addition, vandalism of cultural resources seldom occurs because of their location in a secured area.

The INL CRM Office has notified INL security forces when discovering unlawful intrusions during archaeological site monitoring, which resulted in increased security patrols in some areas, the placement of additional "No 
Trespassing" signs in others. INL security officials are also valuable partners in investigations of cultural resource damage and they have assisted in the identification and punishment of vandals. In other instances gravel barriers have been established to prevent stream erosion on highly significant archaeological locations, and barriers have been installed to prevent unauthorized access.

Project Files and Databases. Archival systems are created to protect, conserve, and make available information of value. The INL cultural resource management project files include a library of cultural resource investigations at and around INL and comprehensive databases and forms for cataloging cultural resources. Presently, the databases contain administrative, locational, and descriptive information and archaeological data that are tied to the geographical information system (GIS) in use at INL. Regular updates to the databases and GIS files ensure that records searches and ongoing survey efforts are based on the most current information. A new electronic system integrates the cultural resource information into a single system that is easy to use and maintain. This electronic system enhances the usefulness of the information; however, it does not replace the hardcopy cultural resource investigation records. These archived materials are stored in INL CRM Office project files. Duplicates of these hardcopy records are also maintained to a large extent at the Idaho SHPO and, for archaeological sites, at the Earl H. Swanson Archaeological Repository in the Idaho Museum of Natural History, Pocatello, Idaho.

Confidentiality. Archaeological records, such as those preserved within the INL CRM Office project files, are exempt from the Freedom of Information Act and are released on a strict needto-know basis. At INL, this information is recognized as "sensitive unclassified information" that can be distributed for "official use only." The restrictions on distribution of archaeological site information are designed to protect these sensitive resources from looting and vandalism. Similar safeguards are also extended to all known American Indian cultural resources on INL.
To meet the criteria for confidentiality established by law (ARPA, NHPA, American Indian Religious Freedom Act [AIRFA]) and by DOE directives regarding sensitive unclassified information, the INL CRM Office limits the circulation of detailed maps and site locational information. When not in use, this information is maintained in secure files in the INL CRM Office. When it is provided to INL project managers who need it for planning purposes, it is clearly labeled for "official use only." Reports that are placed in public reading facilities as part of the NEPA review process are also carefully screened to remove all detail on resource location.

In contrast to archaeological and sensitive tribal resources, the locations of historic architectural properties are widely known by INL employees and the general public. However some restrictions on the distribution of information have recently been established in response to national security concerns.

Curation. DOE is responsible for all artifacts and samples collected from INL and for their supporting documentation and must curate them in a repository that meets federal standards issued under 36 CFR 79, "Curation of Federally-Owned and Administered Archaeological Collections." This is an ongoing responsibility as collection of artifacts and samples may occur under limited circumstances as part of the overall INL CRM Program. Those collections that have already been made are located at the Earl H. Swanson Archaeological Repository in the Idaho Museum of Natural History on the Idaho State University campus in Pocatello, Idaho, and are managed according to terms expressed in a curation contract between the repository and DOE-ID. Identification of post-1942 artifacts is conducted by a team comprised of INL CRM Office professionals and knowledgeable scientists and engineers. Once identified, the artifacts are tagged with information, such as year made and associated program, entered into the INL historical database, and moved to interim storage. Identification of a curation facility for post-1942 artifacts is ongoing.

Permitting. Most cultural resource investigations at INL are conducted in-house through the INL 
CRM Office. This group is staffed with professionals who meet the qualification standards established by the Secretary of Interior for federal historic preservation programs (36 CFR 61 - see Appendix A Investigations by outside agencies, universities, or subcontractors are required to be permitted and are tracked and coordinated through the INL CRM Office where records are also maintained.

Reuse. A culture of government properties reuse began at INL in 1949 with AEC's acquisition of the World War II Naval Proving Ground and associated infrastructure, including architectural properties, for its reactor development and testing program. Although property reuse continues to be encouraged, the waning early nuclear mission, combined with increasing environmental concerns beginning in the late $1960 \mathrm{~s}$, has resulted in mixed success for this endeavor.

Reactor development and new construction at INL peaked in the late 1960s, and INL contractors began to seek external programs and customers to reuse existing INL architectural properties. A program known as "Work for Others" trained and encouraged employees to market INL staff and property capabilities to a wide variety of other government agencies and private businesses. As a result of this marketing effort, some INL employees worked on external programs for agencies such as the Department of Defense, and several INL structures were reused. For example, a large hangar located at TAN is now used by the U.S. Army for its Abrams tank armor project.

In addition to active marketing efforts, a program was developed to identify "excess" INL architectural properties that were no longer needed and to screen those properties for reuse by all federal agencies. However, in addition to reuse, there also exists a need to clean up "legacy" waste left by past processes and, by the late 1980s, compliance with environmental laws and regulations became DOE's paramount concern. In the early 1990s, many of the "Work for Others" programs and customers were gone and DOE transferred INL landlord responsibilities, including the management of INL architectural properties, from reactor development to environmental remediation and, later, to environmental management (Stacy, 2000 and personal communication with Ken Moor).

The mission of the Environmental Management Program is to treat and/or remove INL hazardous, radiological, and mixed wastes and identify contaminated architectural properties for DD\&D. Properties identified as contaminated include those that contained materials such as asbestos, petroleum products, acids and bases, radionuclides, unexploded ordnance and explosive residues (see Figure 25), polychlorinated biphenyls (PCBs), and heavy metals (Arrowrock, 2003). Although this meant that virtually all historic INL buildings and structures were slated for DD\&D, internal and external opportunities for reusing them continue to be pursued.

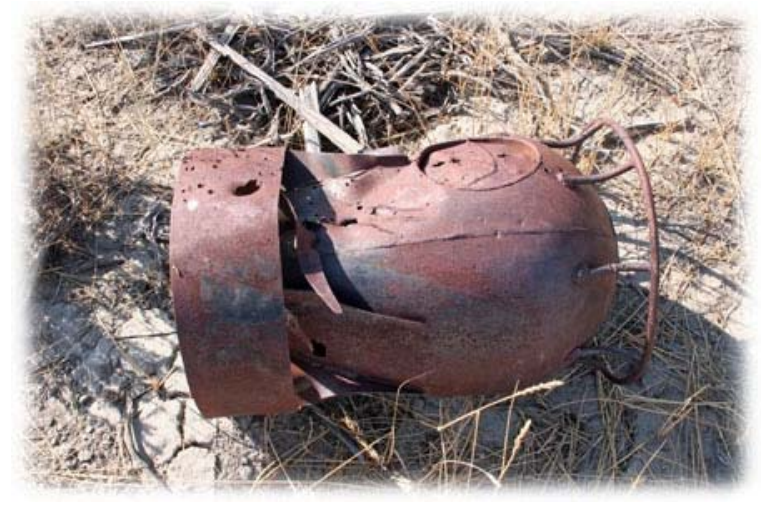

Figure 25. Unexploded Naval depth charge found at INL.

In 2002, the Secretary of Energy designated INL as DOE's lead laboratory for the development of the next generation of nuclear reactors and, at the same time, accelerated environmental cleanup. Landlord responsibilities shifted from environmental management to DOE's Nuclear Energy Program and, in 2003, a transition team was formed to identify properties to transfer to the Nuclear Energy Program for continued use or reuse. This effort is ongoing and is intended to remain flexible as the new nuclear mission and necessary funding evolve and new customers and uses for some properties are identified, while the potential for reuse of other properties fades. 


\section{Stakeholder Communication}

Both the NHPA (36 CFR 800.8) and NEPA, along with various executive orders and DOE policies, require stakeholder communication and systematic planning as keys to their successful implementation. Systematic planning for public participation in INL cultural resource management helps DOE ensure that such participation takes place in a productive manner. It further helps ensure that the public's interests regarding cultural resource preservation and interpretation is considered as INL executes its primary missions.

The list of stakeholders and potential stakeholders is as varied as the resources themselves, including such diverse groups as local historical societies, museum associations, Oregon Trail enthusiasts, INL retirees, historical and scientific researchers, American Indian tribes, and the general public. These diverse stakeholders are involved at appropriate levels and at appropriate times, including during an annual meeting to discuss recent and future activities regarding INL cultural resource management.

Effective identification and management of diverse cultural resources, such as American Indian cultural and traditional sites and one-of-akind reactor facilities, that are of importance to living people requires well-planned communication with these stakeholders. The values and concerns associated with these resources cannot be understood unless the people who use and value them place them in appropriate context. Groups such as the INL Retirees Association, local and state historical societies, and professional organizations provide insights and information relevant to the management and disposition of post-1942 cultural resources.

American Indian Interests. As a federal agency, DOE recognizes its trust responsibility to American Indian tribes. In the spirit of that responsibility, DOE-ID has been active in outreach efforts with the Tribes. This has facilitated ongoing communication with the Shoshone-Bannock Tribes to identify and protect significant tribal resources at INL. A signed Agreement-In-Principle (AIP) with the ShoshoneBannock Tribes (DOE-ID 2007) commits DOE-ID to conducting INL activities in a manner that protects the health, safety, environment, and cultural resources of the Tribes and outlines efforts to help them maintain economic self-sufficiency (see Appendix B).

Cultural resource protection is an important part of the AIP and is coordinated through the INL Cultural Resources Working Group (CRWG) with membership from the Shoshone-Bannock Tribes, DOE-ID, and the INL CRM Office. This group meets regularly to address issues and opportunities in a timely manner and in an environment of mutual respect. Recurring topics of discussion include cultural resource protection, Native American Graves Protection and Repatriation Act (NAGPRA) requirements, educational outreach, and overall management of INL cultural resources, particularly sites and areas that are culturally important to them.

Tribal input is actively solicited for new and ongoing INL projects, and working guidelines developed by the CRWG facilitate these interactions. Under these guidelines, designated tribal point(s) of contact receive regular reports on INL CRM Office activities that address field projects and resources of importance to them. Invitations to comment on, visit, observe, and/or assist in any of the described activities are implicit in all communications. If required by law or requested by the Tribes, formal consultation may follow at any time. The holistic view regarding cultural resources and cooperative spirit embodied in this group are designed to enhance understanding and appreciation of all types of cultural resources within the INL community and the Tribes.

Ongoing communication and consultation with the Shoshone-Bannock Tribes on cultural resource matters through the CRWG has resulted in the identification of several major areas of interest. In general these are:

- Protection of the integrity of archaeological sites and objects

- Treatment of archaeological sites and objects during impact assessments and scientific research 
- Protection of the environment and landscape that houses tribally important plants and animals, prehistoric resources, traditional cultural places, and sacred sites

- Treatment of human burials and burial items

- Return of cultural patrimony and human skeletal remains (i.e. repatriation)

- Access to and free use and protection of traditional cultural places and sacred sites.

A variety of procedures has been developed and activities are conducted by the INL CRM Office and DOE-ID to address the aforementioned areas of interest (see Appendix B for details). For example, the Tribes are involved in the protection and treatment of archaeological sites through the INL CRM Office's routine communications including the CRWG meetings, archaeological survey reports, and various environmental documents. In the future, this communication should also help in the identification and ultimate protection of other types of resources that are of importance to the Tribes. The CRWG Communication Protocol also outlines a general process by which the Tribes are immediately brought into consultation whenever human remains are discovered at INL. Finally, the Middle Butte Cave Agreement signed between DOE-ID and the Tribes in 1994 maximizes tribal access to an important INL cultural area within the limits of safety, health, and national security.

INL Archives. INL support service organizations have primary responsibility for the retention and preservation of official DOE-ID records related to INL and perform these responsibilities using National Archives and Records Administration (NARA) guidelines and disposition schedules. Many active records with significant historic value are maintained at INL facilities and include such materials as photographic negatives and prints, architectural and engineering drawings, extensive library holdings that include technical and nontechnical reports and documents, oral histories, and other historical INL data. These materials are maintained in the INL records storage building, Technical Library, INL CRM Office, and other dedicated storage areas. Many of the unclassified holdings are also available to employees through the INL Intranet system and may, with permission, be made available to non-INL researchers and scholars.

The INL CRM Office is developing a formal INL Archive Management Plan to identify and manage the important, irreplaceable information represented by INL archival materials. The goal of this Plan is to preserve all of the records, both at INL (active records) and in permanent federal storage at NARA-approved centers in Seattle, WA, and Washington, DC (inactive records), and make them available to INL employees, stakeholders, and the public, to the extent that security requirements allow, as a foundation for information dissemination about INL history, past programs, and associated structures and artifacts. An addition to the INL Records Storage Center in Idaho Falls has been requested to house the INL Archives and is planned for construction before 2015. (INL Strategic Plan).

Training and Public Outreach. Training and public outreach are essential cultural resource management activities with the following two compatible goals:

1. Educate people about local history and prehistory and recruit participation in cultural resource preservation

2. Educate people about the letter and intent of the laws protecting cultural resources and make them aware of the penalties for their violation.

Training-The INL CRM Office holds training sessions with INL project managers, environmental coordinators, field workers, and others as applicable, to increase knowledge, awareness, and appreciation of INL cultural resources, requirements for historic preservation, and their responsibilities to comply with these requirements.

The INL CRM Office has featured articles and photographs in INL publications and other external publications to highlight important historic INL events, persons, artifacts, and INL CRM Office activities. INL CRM Office personnel also conduct training activities, such as 
mentoring college students and educating local high school students and teachers.

Public Outreach-Access to an INL facility for educational and interpretive purposes began in 1975 with the opening of the EBR-I National Historic Landmark Visitors Center. The goal of this interpretive program is to educate the public about INL history and science in general. Grants have been secured to preserve the EBR-I structure and to update its exhibits in partnership with the "Save American Treasures" Program, Murdock Trust, Idaho Heritage Trust, and Museum of Idaho located in Idaho Falls.

INL CRM Office staff have also developed many effective tools to enhance knowledge of INL resources and promote cultural resource protection. Forums for such discussions include national, regional, and local professional conferences where facility history, archaeological research, and management strategies and tools are explained and shared. In addition, in 1999, a public history was prepared to commemorate INL's $50^{\text {th }}$ anniversary. This book was widely distributed to INL employees, libraries, and schools and is provided to others by request.

Other efforts are oriented toward members of the general public in communities surrounding INL. Tours of INL cultural resource sites have proven to be an especially popular and effective means of educating and communicating with the public (see Figure 26). Signs erected in 2007 at the public Rest Area, located adjacent to Highway 20 on the banks of the Big Lost River, describe the area geology, flora, fauna, and historic, present, and future INL activities.

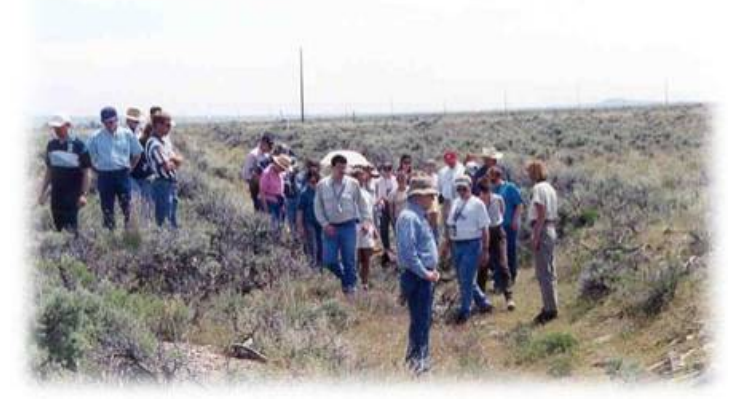

Figure 26. Tour of archeological and historical sites at INL.
Throughout the year, INL CRM Office staff also visit many local schools and civic groups to give presentations on a wide variety of topics. Presentations are tailored specifically for different audiences and have included regional prehistory and history, nuclear history, careers in archaeology and history, cultural resource management and compliance, archaeological resource protection, artifact illustration, and American Indian resources and sensitivities.

Partnerships with local museums, interpretive societies, historical societies, and the Idaho State Tourism Office have resulted in an expansion of the Public Education and Interpretation Program at the EBR-I Visitors Center. The center now includes interactive displays, educational videos, traveling exhibits, and outdoor classrooms. The INL CRM Office plans to continue this expansion at EBR-1 with additional interpretive and educational tools, such as a nature trail (Braun and Marler, 1999). These partnerships will continue to educate residents and visitors about INL history; they will also be the driving force behind the nomination of Highway 20 from Idaho Falls to Arco and Highways 22 and 33 along INL's north and west boundaries as scenic and historic byways. A final outreach-related goal is to continue to improve the ongoing oral history program to capture important first-hand stories about INL land use and history.

\section{Future Activities and Priorities}

In addition to the general cultural resource management goals described throughout the preceding text, there are a number of specific activities that could be enhanced or initiated to achieve those goals. Proposed future activities will be prioritized in the INL CRM Office annual work plan based on input from the Idaho SHPO, Advisory Council, Shoshone-Bannock Tribes, and other stakeholders. A list of recurring activities and proposed future activities is provided in Appendix K.

\section{NHPA Section 106 Process}

Timely and consistent consideration of cultural resources in the day-to-day operation of INL is one of the most basic goals of cultural resource management at the Laboratory. It is also 
a requirement of NHPA Section 106, which requires federal agencies to consider the impact their activities will have on properties that are either listed on or eligible for listing on the National Register, and to afford the Advisory Council ample opportunity to comment on the proposed activities. Such consideration and comment are to be completed prior to initiation of the activities.

The NHPA Section 106 process is the legal mechanism used to determine if adverse effects to historic properties will occur and, if so, the nature and extent of the adverse effects, and to consult with the Idaho SHPO and other interested parties to develop strategies to mitigate those effects. Legally, the consulting parties have 30 days to review and comment at each step in the process. Figure 27 illustrates the Section 106 review process.

Since only 8 to $9 \%$ of the 890 -square-mile reserve has been inventoried for archaeological resources and only DOE-ID-owned buildings have been inventoried within the built environment, DOE-ID must also ensure no cultural resources are inadvertently destroyed, transferred, or altered during ongoing operations. Both of these related concerns are met through a cultural resource review process that requires INL CRM Office involvement whenever a project is proposed that meets any of the following thresholds:

1. Ground disturbance outside the boundaries of fenced INL facility areas or within $50 \mathrm{ft}$ of existing buildings or landscaped areas within unfenced facility areas

2. Demolition, major structural or landscape modification, or permanent closure of extant buildings and structures and/or removal of original equipment, features, or data

3. Any activities that may affect the EBR-I facility area, a National Historic Landmark

4. Any ground disturbance within or around CITRC, where sensitive cultural remains have been inadvertently discovered in disturbed and undisturbed contexts

5. Any activities proposed for known or suspected zones of American Indian sensitivity and high resource density.

\section{Tailored Cultural Resource Review}

In the past, INL has followed the Section 106 process on a project-by-project and property-byproperty basis. This has been cumbersome and has the potential to result in costly project delays.

Therefore, one of the main purposes of this plan is to tailor the Section 106 process to meet INL needs.

The cultural resource review process at INL is usually initiated through completion of an environmental checklist. Under the INL NEPA compliance program, every reasonably foreseeable DOE-ID-sponsored action on or off INL is preceded by preparation of an environmental checklist that assesses the potential impact of the proposed work for a wide variety of environmental issues and assigns a level of documentation (i.e., categorical exclusion, environmental assessment, or environmental impact statement) required for implementation. The list of threshold activities mandating cultural resource review, as listed above, is included in procedures that provide direction and guidance for preparing environmental checklists at INL. Thus, even those INL activities that are categorically excluded from NEPA review are screened for their potential impact to cultural resources.

\section{Activities and Properties Exempt From Cultural Resource Review}

INL is an active scientific and engineering facility where thousands of work orders are processed each year. To further streamline the Section 106 process, it is appropriate to define lists of activities and properties that are exempt from further cultural resource review. Thus, INL NEPA compliance personnel are also provided with a categorical list of property types that are not, themselves, considered significant or potentially eligible for nomination to the National Register under the National Historic Preservation Act. As such, actions that affect the aforementioned property types are exempt from review. These property types are listed in Table 1. 


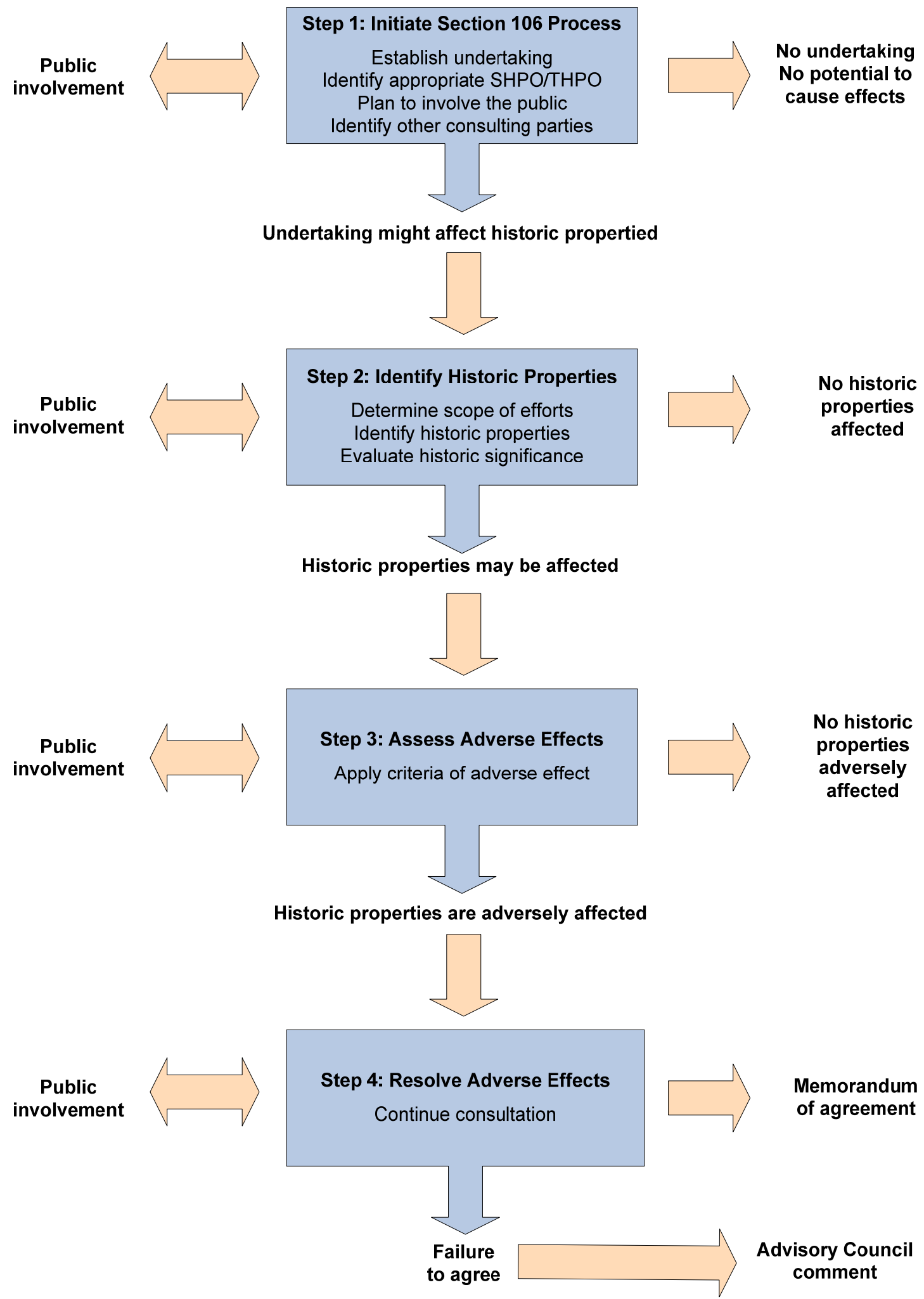

Figure 27. National Historic Preservation Act Section 106 review process. 
Table 1. Property types for which actions are exempt from review.

\section{Property Type}

1. Post- 1970

buildings, with exceptions

2. Subsurface structures

3. Storage tanks

4. Wells and boreholes

5. Utility poles and towers

6. Utility structures

7. Mobile trailers

8. Isolated finds
Description

Activities or actions associated with buildings and structures constructed after 1970 are exempt from review, with the following exceptions: A property built after 1970 may be subject to review if it has been determined the exceptional historical importance of the property makes it eligible for inclusion on the National Register of Historic Places (e.g., LOFT buildings and structures).

These structures have minimal or no visible surface manifestations and include earthen and concrete-lined trenches, French drains, underground tanks, vaults, underground pipelines, sewer lines, and other structures that are typically located below ground and were never intended to be routinely accessed by people.

These structures include surface and subsurface utility tanks used in routine facility operations. Associated concrete slab foundations, scaffolding, piping, or spill-management retaining walls are also included.

These structures include characterization wells, monitoring wells, drinking water wells, industrial water wells, injection wells, and various types of test wells and boreholes. Wells associated with homesteading and other early historic uses of the area are not included.

These structures include power lines, microwave towers, seismic data collection and transmission facilities, and other types of communication towers.

These structures provide housing or control of utility equipment or access to underground utility equipment, such as pump houses, electrical substations, boiler tanks, or equipment monitoring shacks.

These structures are used for temporary office space and/or storage.

These archaeological resources consist of $<10$ artifacts and no architectural features. They are unlikely to yield any information beyond that collected during initial recording.
Most of the properties included on the exemption list are associated with the modern built environment at the Laboratory. While these resources may contribute to overall landscapes under different historic contexts and research designs, they are not likely to yield any additional information important in understanding those landscapes.

Generally, actions on property types 1 through 7 require no further NEPA or INL CRM Office consideration. (Certain exceptions apply to property type 1, as described in Table 1.) Proposed INL activities that may impact them can be completed without further cultural resource review. However, any proposed new construction of these property types or large-scale modification or demolition will be evaluated for potential effects to archaeological and American Indian resources.

The INL CRM Office is involved in projects that may impact property type 8 even though this property type is exempt from NHPA Section 106 cultural resource review. This is because information on the location and official status of archaeological resources is distributed for "official use only" and is available only through consultation with the INL CRM Office. As needed and on a case-by-case basis, such properties will 
be reevaluated for eligibility by INL CRM Office professionals. If it is determined that the status of those properties has changed, then compliance processes outlined in this plan will be invoked.

In addition to exempt property types, INL NEPA personnel are also provided with a list of some routine INL activities that do not pose a threat to cultural resources. Projects that involve activities on this list are exempt from further cultural resource review. However, they are still covered by procedures that require employees to stop work and contact the INL CRM Office if cultural materials are unexpectedly encountered during any activity. Activities exempt from cultural resource review at INL are listed in Table 2.

Exemption lists are subject to annual stakeholder review along with other aspects of the overall CRM Program. Despite the exemptions for certain activities and property types, the INL CRM Office conducts a large number of cultural resource reviews each year. Most of these reviews are prompted by one of the threshold criteria listed in the previous description. However, some reviews are associated with exempt activities and resources, particularly those that involve archaeological resources that are ineligible for nomination to the National Register or Isolated Finds. Appendix J provides a list of the cultural resource reviews conducted over the past three decades.

\section{Cultural Resource Review Process}

INL NEPA compliance personnel or project managers initiate the cultural resource review process as early as possible in the planning phase of a project. Typically, they begin during the preparation of an environmental checklist, which provides the INL CRM Office with information on the nature and extent of the proposed activity. Exact dimensions and locations for all aspects of the proposed work (e.g., access roads, laydown areas, utility upgrade or removal, and proposed replacement or refinishing products) must be provided. INL CRM Office staff members use this information to determine if the proposed activity is an "undertaking" as defined in the National Historic Preservation Act and if so, to establish its "area of potential effect." The next review process steps for INL CRM Office staff are to determine whether the area in question has ever been surveyed for cultural resources, and if so, whether the survey met the minimum requirements described in Appendices C and D, whether there are any previously identified cultural resources in the proposed project area, and if the affected property is listed on an existing inventory.

Because the INL CRM Office maintains a complete record of INL cultural resource investigations and comprehensive resource inventories, most of these questions can be answered by accessing the INL CRM Office files. Other sources of information that may be utilized include early land survey records, county land ownership records, local libraries and information repositories, current and former employees, local historians, and researchers who previously conducted investigations at INL.

If these literature and records reviews indicate that the proposed project area and/or affected historic resource type is unsurveyed, has only been partially surveyed, was originally surveyed using methods less stringent than those described in Appendices $\mathrm{C}$ and $\mathrm{D}$ and in use today, or was completed more than 10 years ago, INL project, program, and facility managers must provide support for completion of a cultural resource survey, evaluation, and, when necessary, mitigation. Early planning is crucial for timely completion of this work and implementation of the proposed project.

There are three possible outcomes at the end of the previously described scoping and identification efforts of the cultural resource review process. In broad outline, they are similar to those listed in the guidelines for implementation of Section 106 of the National Historic Preservation Act. This is intentional; they have been developed for compliance with this law. However, at INL there are resources (e.g., traditional American Indian gathering sites or sacred areas) that are not necessarily eligible for listing on the National Register. Although these resources may not be eligible, DOE-ID is obligated to consider them under requirements 
Table 2. INL activities exempt from review (no activities at EBR I are exempted).

\begin{tabular}{|c|c|}
\hline Activity Type & Description \\
\hline $\begin{array}{l}\text { 1.Emergency } \\
\text { response }\end{array}$ & $\begin{array}{l}\text { Activities declared by the U.S. president, a tribal government, or the governor of a state as } \\
\text { necessary to safeguard human health and the environment during declared disasters, } \\
\text { emergencies, or national security threats (including EBR-I). }\end{array}$ \\
\hline $\begin{array}{l}\text { 2. Routine } \\
\text { maintenance } \\
\text { activities }\end{array}$ & $\begin{array}{l}\text { Activities that include, but are not limited to, normal custodial services; electrical and } \\
\text { plumbing installation or repair; repair of fire suppression systems, alarms, or } \\
\text { communication systems; moving or assembly of interior furnishings; resurfacing of road, } \\
\text { sidewalk, and parking areas; routine decontamination (through such activities as wiping } \\
\text { down with rags, using strippable latex, and minor vacuuming, but excluding scabbing) of } \\
\text { the surfaces of equipment, rooms, or other interior surfaces. }\end{array}$ \\
\hline $\begin{array}{l}\text { 3. Replacement in } \\
\text { kind }\end{array}$ & $\begin{array}{l}\text { Replacement of fixtures or components of a property, such as matching paint with } \\
\text { existing or similar paint color, refinishing materials with existing or similar colors, or } \\
\text { replacing or installing carpeting with water-soluble glue. This exemption includes } \\
\text { refinishing with products that have improved safety, environmental, or health } \\
\text { considerations over the existing or original, as long as the color of the refinishing product } \\
\text { is similar to or matches the existing original color. }\end{array}$ \\
\hline $\begin{array}{l}\text { 4. Energy } \\
\text { conservation } \\
\text { measures }\end{array}$ & $\begin{array}{l}\text { Activities that Include, but are not limited to, modifications to heating, ventilation, and air } \\
\text { conditioning systems; insulation to roofs, crawl spaces, walls, and floors; and caulking } \\
\text { and weather stripping that are not visible or do not significantly alter or detract from those } \\
\text { qualities that make the property eligible for nomination to the National Register of } \\
\text { Historic Places. }\end{array}$ \\
\hline 5.Security systems & $\begin{array}{l}\text { Installation, maintenance, or repair of security systems, including computer security, } \\
\text { detection, monitoring, surveillance, and alarm systems. }\end{array}$ \\
\hline 6. Safety systems & $\begin{array}{l}\text { Installation, maintenance, and repair or modification of personnel safety systems and } \\
\text { devices within the built environment, such as radiation monitoring devices; emergency } \\
\text { exit lighting systems; protective additions to electrical equipment; improvements to } \\
\text { walking and working surfaces; and installation of protective railings, guards, or shielding. }\end{array}$ \\
\hline $\begin{array}{l}\text { 7. Asbestos } \\
\text { abatement }\end{array}$ & $\begin{array}{l}\text { Removing or fixing asbestos for safety and health concerns, including lagging, insulating, } \\
\text { painting, pipe and duct work, and panel removal. None of these activities may cause } \\
\text { structural modifications or alter character-defining features. Asbestos abatement activities } \\
\text { strictly associated with the DD\&D of properties and that result in permanent, significant } \\
\text { structural modification or alteration of the property are not included in this exemption. }\end{array}$ \\
\hline $\begin{array}{l}\text { 8. Internal } \\
\text { reconfiguration of } \\
\text { active laboratories }\end{array}$ & $\begin{array}{l}\text { Changes to the internal configuration of active laboratories or other existing experimental } \\
\text { or testing properties within the built environment to accommodate new experiments or } \\
\text { tests. }\end{array}$ \\
\hline $\begin{array}{l}\text { 9. Ground } \\
\text { disturbance within } \\
\text { fenced facility } \\
\text { perimeters }\end{array}$ & $\begin{array}{l}\text { Modifications to the ground surface within existing facilities (TAN, EBR-I, WRRTF, } \\
\text { NRF, RTC, INTEC, RWMC, MFC) or within } 50 \mathrm{ft} \text { of existing buildings in unfenced } \\
\text { facility areas (CFA, ARA, BORAX). All activities under this exemption are subject to the } \\
\text { INL Stop Work Authority (see Appendix A) should cultural resources be unexpectedly } \\
\text { encountered at any time. This exemption does not apply to the CITRC facilities. }\end{array}$ \\
\hline
\end{tabular}


other than the NHPA, such as the tribal Agreement-in-Principle and NEPA. The tailored process outlined in this plan is also used to assess effects to noneligible resources. The three possible outcomes are:

1. No Resources Affected. No cultural resources are present within the area of potential effect for the proposed undertaking; or cultural resources are present in the area, but the proposed undertaking will have no effect on the characteristics that make the resources culturally important.

2. No Adverse Effect. Cultural resources are present within the area of potential effect, and the proposed undertaking does not meet the criteria of an adverse effect, or the undertaking can be modified or conditions put in place to avoid the adverse effect.

3. Adverse Effect. Cultural resources are present within the area of potential effect, and the proposed undertaking may alter, directly or indirectly, any characteristic of a property that make it culturally important.

Because of the apparent and natural distinctions among the disparate types of cultural resources found at INL, customizing the NHPA Section 106 process and other requirements in a manner that benefits both DOE and the resources is complex. Therefore, while undertakings are reviewed for potential effects on cultural resources and any given project will only have one effect determination, tailored resource-specific strategies and procedures have been developed. Appendix C relates detailed procedures for identifying, evaluating, and consulting on historic and prehistoric archaeological sites. Appendix D describes customized management approaches and strategies for INL's unique built environment.

For each undertaking, DOE will consider potential effects on all types of cultural resources, and will consult stakeholders accordingly. If it is determined that no resources will be affected by an undertaking or that no adverse effect will occur, documentation of negative findings or avoidance or protective measures will be maintained in the INL cultural resource management archives. This information will be provided to the Idaho SHPO, Shoshone-Bannock Tribes, stakeholders, and consulting parties in a general annual report.

In those instances when the effects of an undertaking will be adverse, measures to minimize or mitigate the potential impact will be developed in consultation with the Idaho SHPO, ShoshoneBannock Tribes, and other interested parties and stakeholders. However, for historic property types in the built environment that have been fully inventoried and evaluated, mitigation will follow strategies outlined in Appendix D. 


\section{SUMMARY}

DOE-ID recognizes and accepts cultural resource stewardship responsibilities and the broad stakeholder interest in the resources in their care and control. DOE-ID also recognizes and accepts responsibility for the identification, evaluation, and protection of all INL cultural resources. These responsibilities are promulgated under three major federal laws (NHPA, ARPA, and NEPA) and their implementing regulations; Executive Orders; State of Idaho statutes; and DOE-HQ policies, orders, and directives. To meet these obligations and to enhance overall INL mission goals, a dynamic and evolving CRM program has been instituted at INL. Inventories of INL cultural resources are ongoing, as are cultural resource monitoring and public and employee awareness and education. Applicable laws and procedures are enforced and stakeholders are kept apprised of activities.

Through the INL CRM program, DOE-ID and the INL CRM Office recognize and integrate the following diverse factors and issues that promote, guide, and require the protection and preservation of cultural resources:

- Complying with federal laws and regulations, state statutes, and DOE policies and orders concerning historic preservation and environmental protection to support INL and DOE missions and programs

- Responding to the need for information and support demanded by a research and development facility such as INL, with its large land area, diverse resources, and varied programs, to meet short-term goals and anticipate and plan for long-term and future activities

- Interacting with non-INL offices and agencies that oversee and influence the management of INL cultural resources

- Interacting with Tribes and stakeholders in a spirit of trust and openness to ensure balance and effectiveness in the management of INL cultural resources

- Meeting the popular and nearly universal appeal of prehistory and history by sharing and promoting the fascinating 13,500 year history represented at INL.

This Cultural Resource Management Plan is the INL CRM Office's primary mechanism for integrating cultural resource identification, evaluation, and protection into the INL mission and consolidating historic preservation activities into INL routine management and project-specific activities. As such, this plan addresses:

- Activities that support the mission and vision of the Laboratory, while complying with federal, state, and local regulations and requirements for cultural resource protection

- Activities that meet the practical challenges to preserving INL's unique cultural landscape

- The need to facilitate and participate in INL programs and missions and the opportunity to conduct both cultural resource management and historical and scientific research through standardized practices, contexts, and research designs

- Specific future activities and long-term goals needed to ensure programmatic continuity.

This plan is intended to be a living document, flexible and responsive to change. It is designed to accommodate revision based on:

- New and revised laws, regulations, procedures, and agreements

- INL CRM Office annual plans and reports, and input and suggestions from oversight groups, stakeholders, and other interested parties

- Changes in INL programs, management alignment, physical structure and landscape

- Acquisition, through inventory and research, of new knowledge about INL cultural resources; application of this information to prediction, planning, and land-use on INL; and sharing of this information through such mechanisms as the compliance process, nominations to the National Register, technical and managerial reports, and popular and professional publications and presentations 
- Continuing participation of American Indians in INL cultural resource management through participation in the Cultural Resource Working Group; solicitation of regular commentary on INL CRM Office plans, mitigation proposals, research and testing excavations, and treatment of sites and artifacts; and by working with American Indian authorities to obtain information about traditional land and resource use in order to protect and interpret areas and resources of concern.

As the dynamic INL CRM Program evolves, its overarching goal will remain support of the overall INL mission through the protection of the valuable, irreplaceable cultural and historical resources present at INL. 


\section{REFERENCES}

The following is a list of references used in the body and appendices of the INL Cultural Resource Management Plan. Additional references are provided in Appendix F, "Historic Contexts."

36 CFR 18, "Leases and Exchanges of Historic Property," Code of Federal Regulations, Office of the Federal Register.

36 CFR 60, "National Register of Historic Places," Code of Federal Regulations, Office of the Federal Register.

36 CFR 60.4, "Criteria for Evaluation," Code of Federal Regulations, Office of the Federal Register.

36 CFR 61, "Procedures for Approved State and Local Government Historic Preservation Programs," Code of Federal Regulations, Office of the Federal Register.

36 CFR 63, "Determinations of Eligibility for Inclusion in the National Register of Historic Place," Code of Federal Regulations, Office of the Federal Register.

36 CFR 65, "National Historic Landmark Program," Code of Federal Regulations, Office of the Federal Register.

36 CFR 67, "Standards for Rehabilitation," Code of Federal Regulations, Office of the Federal Register.

36 CFR 79, "Curation of Federally-Owned and Administered Archeological Collections," Code of Federal Regulations, Office of the Federal Register.

36 CFR 800, "Protection of Historic and Cultural Properties," Code of Federal Regulations, Office of the Federal Register.

43 CFR 3, "Preservation of American Antiquities," Code of Federal Regulations, Office of the Federal Register.

43 CFR 7, Subparts A and B, "Protection of Archaeological Resources Uniform and Supplemental Regulations," Code of Federal Regulations, Office of the Federal Register.

43 CFR 10, "Native American Graves Protection and Repatriation Act," Final Rule, Code of Federal Regulations, Office of the Federal Register.

Advisory Council 1991, "Balancing Historic Preservation Needs with the Operation of Highly Technical or Scientific Facilities," Advisory Council on Historic Preservation, Washington, D.C., U.S. Government Printing Office, 1991.

Anderson, J. E., K. T. Ruppel, J. M. Glennon, K. E. Holte, and R. C. Rope, 1996, Plant Communities, Ethnoecology, and Flora of the Idaho National Engineering Laboratory, Environmental Science and Research Foundation Report Series, Number 005.

Arthur, W. J., J. W. Connelly, D. K. Halford, and T. D. Reynolds, 1984, Vertebrates of the Idaho National Engineering Laboratory, DOE/ID-12099, U.S. Department of Energy, Idaho Operations Office, Idaho Falls, Idaho.

Arrowrock Group Inc., 2003, The Idaho National Engineering and Environmental Laboratory, A Historical Context and Assessment, Narrative and Inventory, INEEL/EXT-97-01021, Boise, Idaho, developed for the Idaho National Engineering and Environmental Laboratory.

Atwood, N. D., 1970, "Flora of the National Reactor Testing Station," Brigham Young University Science Bulletin, Biological Series, Brigham Young University, 11: 1-46. 
Benedict, J. B., 1979, "Getting Away From It All: A Study of Man, Mountains, and the Two-Drought Altithermal," Southwestern Lore, Vol. 54, No. 3, pp. 11-12.

Bonnichsen, B. and R. M. Breckenridge (ed.), 1982, Cenozoic Geology of Idaho, Idaho Bureau of Mines and Geology Bulletin No. 26, Moscow, Idaho.

Bottolfsen, C. A, 1926a, Little Bits of Lost River History, Arco, Idaho: Arco Advertiser.

Bottolfsen, C. A., 1926b, "Pioneer Lore," Blackfoot Daily Bulletin, Blackfoot, Idaho, January 18, 1926.

Braun J.B., 2006a, Change As An Historic Feature in the Preservation of Places Related to Science and Technology, Unpublished Master's Thesis: Goucher College, Baltimore, MD.

Braun, J. B., 2006b, Experimental Breeder Reactor I Preservation Plan, INL/EXT-06-11909, U.S. Department of Energy, Idaho Operations Office, Idaho Falls, Idaho.

Braun, J. B., 1996, Idaho National Engineering Laboratory Historic Building Inventory Survey Phase I, INEL-96-0498, U.S. Department of Energy, Idaho Field Office, Idaho Falls, Idaho.

Braun, J. B. and C. F. Marler, 1996, Idaho National Engineering Laboratory Historic Building Inventory Survey Phase II, (draft), INEL-96/0374, U.S. Department of Energy, Idaho Operations Office, Idaho Falls, Idaho.

Braun, J. B., 1994, Historic Resource Management Plan for Historic Architectural Properties on the INEL, (draft), DOE/ID-10462, U.S. Department of Energy, Idaho Operations Office, Idaho Falls, Idaho.

Bright, R. C. and O. K. Davis, 1982, "Quaternary Paleoecology of the Idaho National Engineering Laboratory, Snake River Plain, Idaho," American Midland Naturalist, Vol. 108, No. 1, pp. 21-23.

Bright, R. C., 1966, "Pollen and Seed Stratigraphy of Swan Lake, Southeastern Idaho: It's Relation to Regional Vegetational History and to Lake Bonneville History," Tebiwa, Vol. 9, No.2, pp. 1-47.

Butler, B. R., 1986, "Prehistory of the Snake and Salmon River Area," Handbook of North American Indians, Volume 11: Great Basin, W. L. D’Azevedo (ed.), pp. 127-134.

Butler, B. R., 1978, A Guide to Understanding Idaho Archaeology: The Upper Snake and Salmon River Country, 3rd ed., Special Publication of the Idaho Museum of Natural History, Pocatello, Idaho.

Butler, B. R., 1972, "The Holocene or Postglacial Ecological Crisis on the Eastern Snake River Plain," Tebiwa, Vol. 15, pp. 49-63.

Butler, B. R., 1970, “A Report on the 1967-69 Archaeological Survey of the National Reactor Testing Station, Idaho," Tebiwa, Vol. 13, No. 1, pp. 58-75.

Butler, B. R., 1968, "An Introduction to Archaeological Investigations in the Pioneer Basin Locality of Eastern Idaho," Tebiwa, Vol. 11, No. 1, pp. 1-36.

Clark, S. F., 1986, Nineteenth Century Shoshone-Bannock Riparian Adaptation, Unpublished Master's Thesis: Idaho State University, Pocatello, Idaho.

Clements, L. J., n.d., A Collection of Upper Snake River Valley History Plus a Complete Biography of Andrew Henry, Upper Snake River Valley Historical Society, Idaho.

Coloff, S., 1965, “The High and Dry Navy: World War II,” Philtron, October 1965.

Crowder, D. L., 1981, Tales of Eastern Idaho, Idaho Falls, Idaho: Curtiss Press, Inc.

Currey, D. R. and S. R. James, 1982, "Paleoenvironments of the Northeastern Great Basin and Northeastern Basin Rim Region: A Review of Geological and Biological Evidence,” D. B. Madsen 
and J. F. O'Connell (eds.), Man and Environment in the Great Basin, Society For American Archaeology.

Davis, O. K. and R. C. Bright, 1983, Late Pleistocene Vegetation History of the Idaho National Engineering Laboratory, INEL Radioecology and Ecology Programs: 1983 Progress Report, USDOE:RESL, DOE/ID-12098, O. D. Markham (ed.), pp. 162-171.

DOE-ID, 2007, Agreement-in-Principle, December 2007.

DOE-ID, 2000, Institutional Plan, 2001-2005, U.S. Department of Energy, Idaho Operations Office, Idaho Falls, Idaho.

DOE-ID, 1996, Comprehensive Facility and Land Use Plan, DOE/ID-10514, U.S. Department of Energy, Idaho Operations Office, Idaho Falls, Idaho.

DOE-ID, 1990, Management of Cultural Resources at the INEL, U.S. Department of Energy, Idaho Operations Office, Idaho Falls, Idaho.

DOE-ID Memorandum, 1990, "Management of Cultural Resources on the INEEL," A. A. Pitrolo, manager, U.S. Department of Energy, Idaho Operations, Office, Idaho Falls, Idaho, October 12, 1990.

DOE Information Brief, 1999, "Managing Cultural Resources that may Contain Residual Radioactive Material," U.S. Department of Energy, August 1999.

DOE Memorandum EH-231, 1990, "Management of Cultural Resources at Department of Energy Facilities," as revised in 1998, U.S. Department of Energy.

DOE O 1230.2, 1992, “American Indian Policy,” as revised in 1998, U.S. Department of Energy.

DOE P 141.1, 2001, "Department of Energy Management of Cultural Resources," U.S. Department of Energy, Office of Environment Safety and Health.

Dort, W. Jr. and G. G. Fredlund, 1984, "Heavy-Liquid Separation of Microscopic Paleoenvironmental Indicators, Owl Cave, Wasden Archaeological Site, Eastern Snake River Plain, Idaho," Geological Society of America Annual Meeting, Abstracts With Programs, Vol. 16, No. 6, p. 492.

Dort, W., Jr. and S. J. Miller, 1977, Archaeological Geology of Birch Creek Valley and the Eastern Snake River Plain, Idaho, Field Guide, First Annual Field Trip, Division of Archaeological Geology, Geology Society of American, Idaho Falls, Idaho.

Dort, W. Jr., 1975, “Archaeo-Geology of Jaguar Cave, Upper Birch Creek Valley, Idaho,” Tebiwa, Vol. 17, No. 2, pp. 33-58.

Dykes, F. W., 1989, Jeffery's Cutoff: Idaho's Forgotten Oregon Trail Route, Pocatello, Idaho: F. W. Dykes.

Edelman, H., n.d., Reminiscences, Manuscript No. 8, Idaho State University Archives, Eli M. Oboler Library, Pocatello, Idaho.

EG\&G Idaho, 1986, Installation Assessment Report For EG\&G Idaho, Inc., Operations at the Idaho National Engineering Laboratory, EG\&G-WM-6875.

Executive Order 11593, 1971, "Protection and Enhancement of the Cultural Environment," The White House, Washington, D.C.

Executive Order 13007, 1996, "Indian Sacred Sites," The White House, Washington, D.C.

Executive Order 13175, 2000, "Consultation and Coordination with Indian Tribal Governments," The White House, Washington, D.C. 
Executive Order 13287, 2003, "Preserve America," The White House, Washington, D.C.

Ferris, W. A., 1940, Life in the Rocky Mountains, P. C. Phillips (ed.), Denver, Colorado: O. H West Publishing Co.

Franzen, J. G., 1981, A Class I Cultural Resource Inventory of the Burley and Idaho Falls Districts, Idaho, Commonwealth Associates Final Report No. R-2196.

Fredlund, G. G. and W. Dort, Jr., 1986, "Phytolith and Pollen Evidence for Early Holocene Vegetation Change, Owl Cave, Wasden Site, Eastern Snake River Plain, Idaho," Fifty-first Annual Meeting of the Society for American Archaeology, New Orleans, Louisiana.

French, N. R., R. McBride, and J. E. Detmer, 1965, "Fertility and Population Density of the Black-Tailed Jackrabbit,” Journal of Wildlife Management, Vol. 29, pp. 14-26.

Frison, G., 1978, Prehistoric Hunters of the High Plains, New York: Academic Press.

Gerard, H. C., 1982, Wild Horse Jack, privately published, copyright Harry Clay Gerard.

Gilbert, H. K., 2009, “The Powell Stage Station,” INL/EXT-09-15268. Idaho Falls, ID.

Greeley, R., 1982, “The Style of Basaltic Volcanism in the Eastern Snake River Plain, Idaho," Cenozoic Geology of Idaho, B. Bonnichsen and R. M. Breckenridge (eds.), Idaho Department of Lands, Bureau of Mines and Geology, Moscow, Idaho.

Grieser, S. T., 1984, "Projectile Point Chronologies of Southwestern Montana," Archaeology in Montana, Vol. 25, No. 1, pp. 35-51.

Gruhn, R., 1965, "Two Early Radiocarbon Dates From the Lower Levels of Wilson Butte Cave, Southcentral Idaho," Tebiwa, Vol. 8, No. 2, p. 57.

Gruhn, R., 1961, The Archaeology of Wilson Butte Cave, South-Central Idaho, Occasional Papers of the Idaho State College Museum, No. 6, Pocatello, Idaho.

Guilday, J. E. and E. K. Adams, 1967, "Small Mammal Remains from Jaguar Cave, Lemhi County, Idaho," Tebiwa, Vol. 10, No. 1, pp. 26-36.

HABS/HAER Collections, 1983, Reprint from the Federal Register, Vol. 48, No. 190, Thursday, September 29, 1983.

Hackett, W. R. and L. A. Morgan, 1988, Explosive Basaltic and Rhyolitic Volcanism of the Eastern Snake River Plain, Guidebook to the Geology of Central and Southern Idaho, P. K. Link and W. R. Hackett (eds.), Idaho Geological Survey Bulletin 27, University of Idaho, Moscow, Idaho.

Haines, A. L. (ed.), 1969, Journal of a Trapper, by Osborne Russell, Lincoln, Nebraska: University of Nebraska Press.

Hammer, C. G., 1967, "Lost Gold of the Lavas," True West, Vol. 15, No. 2, Austin, Texas: Western Publications.

Harniss, R. O. and E. West, 1973, "Vegetation Patterns on the National Reactor Testing Station, Southeastern Idaho," Northwest Science, Vol. 47, pp. 30-43.

Holmer, R. N., 1986a, "Common Projectile Points of the Intermountain West," Anthropology of the Desert West: Essays in Honor of Jesse D. Jennings, C. J. Condie and D. D. Fowler (eds.), University of Utah Anthropological papers, No. 110, pp. 89-115.

Holmer, R. N. (ed.), 1986b, Shoshone-Bannock Culture History, Swanson/Crabtree Anthropological Research Laboratory Reports of Investigations, 85-16, Pocatello, Idaho. 
Hoskinson, R. L. and J. R. Tester, 1980, "Migration Behavior of Pronghorn Antelope in Southeastern Idaho," Journal of Wildlife Management, Vol. 44, pp. 132-144.

I.C. 18:7027-7028, "Burial Act,” Idaho Code, Chapter 70.

I.C. 67:4113-4129, "Idaho Historic Preservation Act," Idaho Code, Chapter 41.

Idaho Code, Chapter 5, Title 27, "Protection of Graves."

Idaho Code, Chapter 70, Title 18, Section 7035, "Idaho Cave Protection Act."

Idaho State Historical Society, n.d., Goodale's Cutoff, Reference Series, No. 51.

INEL 1985, Thumbnail Sketch 1985, Public Affairs Office, Idaho National Engineering Laboratory.

INEL 1983, Thumbnail Sketch 1983, Public Affairs Office, Idaho National Engineering Laboratory.

INEL 1976, Thumbnail Sketch 1976, Public Affairs Office, Idaho National Engineering Laboratory.

INEL 1969, Thumbnail Sketch 1969, Public Affairs Office, Idaho National Engineering Laboratory.

INEL 1962, Thumbnail Sketch 1963, Public Affairs Office, Idaho National Engineering Laboratory.

INL 2005, INL Comprehensive Facility and Land Use Plan, Facilities and Site Services Directorate, Idaho National Laboratory, http://mceris.inel.gov/, Web page visited September 25, 2005.

INL CRM, 2004, INEEL Cultural Resource Management Program FY04 Annual Report, INEEL/EXT04-02532. January 2005.

INL CRM, 2005, INL Cultural Resource Management Program Annual Report for FY 2005, INL/EXT05-00937. March 2006.

INL CRM, 2007, INL Cultural Resource Management Program Annual Report for FY 2006, INL/EXT07-12134. March 2007.

INL CRM, 2008, INL Cultural Resource Management Program Annual Report for FY 2007, INL/EXT08-14071. March 2008.

Irving, J. S., 1993, Environmental Resource Document for the Idaho National Engineering Laboratory, EGG-WMO-10279.

Jimenez, J., 1986, The Ahvish Phase at Wahmuza and the Numic Affiliation of the Dietrich and Lemhi Phases of Southern Idaho, Unpublished Master's Thesis: Idaho State University, Pocatello, Idaho.

Knoll, K. M., 1977, “Chronology of Alpine Glasier Stillstands, East-Central Lemhi Range, Idaho,” Special Publication of the Idaho Museum of Natural History.

Kuntz, M. A., W. F. Downs, R. P. Smith, and K. L. Ruebelmann, 1989, Geology of the Snake River Plain From Idaho Falls to Arco, Idaho in Snake River Plain-Yellowstone Volcanic Province Field Trip Guidebook T305, K. L. Ruebelmann (ed.).

Kuntz, M. A., B. Skipp, W. E. Scott, K. L. Pierce, H. Prostka, G. F. Embree, and M. H. Hait, Jr., 1984, Preliminary Geologic Map of the Idaho National Engineering Laboratory and Adjoining Areas, Idaho, U.S. Geologic Survey Open File Report 84-281.

Kuntz, M. A., 1978, Geology of the Arco-Big Southern Butte Area, Eastern Snake River Plain, and Potential Volcanic Hazards to the Radioactive Waste Management Complex and Other Waste Storage and Reactor Facilities at the Idaho National Engineering Laboratory, Idaho, U.S. Geologic Survey Open File Report 78-691. 
Kurten, B. and E. Anderson, 1972, "The Sediments and Fauna of Jaguar Cave II: The Fauna," Tebiwa, Vol. 15, No. 1, pp. 21-45.

Lewis, B. D. and R. G. Jensen, 1984, Hydrologic Conditions at the Idaho National Engineering Laboratory, Idaho: 1979 - 1981, U.S. Geologic Survey Open File Report 84-230.

Liljeblad, S., 1957, Indian Peoples in Idaho, Unpublished Master's Thesis: Idaho State University, Pocatello, Idaho.

Link, P. K. and W. R. Hackett (eds.), 1988, Guidebook to the Geology of Central and Southern Idaho, Idaho Geologic Survey Bulletin No. 27.

Lohse, E. S., 1989, “Aviators' Cave,” Idaho Archaeologist, Vol. 12, No. 2.

LWP-2008, 2006, "Utilization and Disposal of Real Property," Rev. 0, Idaho National Laboratory, May $18,2006$.

LWP-6200, “Maintenance Integrated Work Control Process,” Rev. 0, Idaho National Laboratory, pending.

LWP-8000, 2005, “Environmental Instructions for Facilities, Processes, Materials, and Equipment," Rev. 0, Idaho National Laboratory, September 29, 2005.

LWP-14002, 2005, “Stop Work Authority,” Rev. 0, Idaho National Laboratory, September 29, 2005.

LWP-14101, 2005, “Field Work,” Rev. 0, Idaho National Laboratory, September 29, 2005.

LWP-21220, “Work Management,” Rev. 0, Idaho National Laboratory, pending.

Mabey, D. R., 1982, Geophysics and Tectonics of the Snake River Plain, Idaho, Cenozoic Geology of Idaho, B. Bonnichsen and R. M. Breckenridge (eds.), Idaho Bureau of Mines and Geology Bulletin, Vol. 26, pp. 139-153.

Madsen, D. B., 1982, “Get It Where the Getting's Good: A Variable Model of Great Basin Subsistence and Settlement Based on Data From the Eastern Great Basin," Man and Environment in the Great Basin, D. B. Madsen and J. F. O’Connell (eds.), Society for American Archaeology Papers, No. 2.

Marler, C. F., 2004, A Paleoindian Context for the Idaho National Engineering and Environmental Laboratory, Unpublished Master's Thesis: Idaho State University, Pocatello, Idaho.

McBride, R., N. R. French, A. H. Dahl, and J. E. Detmer, 1978, Vegetation Types and Surface Soils of the Idaho National Engineering Laboratory Site, IDO-12084, U.S. Department of Energy, Idaho Operations Office, Idaho Falls, Idaho.

MCP-553, 2006, “Step Back and Stop Work Authority,” Rev. 11, Idaho Cleanup Project, June 7, 2006.

MCP-2477, 2006, "Utilization and Disposal of Real Property," Rev. 9, Idaho Cleanup Project, May 25, 2006.

MCP-2725, 2006, “Field Work,” Rev. 6, Idaho Cleanup Project, December 14, 2006.

MCP-2860, 2004, “Building/Facility Transition,” Rev. 7, Idaho National Laboratory, June 17, 2004.

MCP-3480, 2006, "Environmental Instructions for Facilities, Processes, Materials, and Equipment," Rev. 12, Idaho Cleanup Project, June 14, 2006.

MCP-3562, 2006, "Hazard Identification, Analysis, and Control of Operational Activities," Rev. 10, Idaho Cleanup Project, December 4, 2006.

Merrill, I. R., 1990, Tim Goodale and His Cutoff: A Major Trail Segment During and After the Fourth Emigration Wave, Overland Journal, Vol. 8, No. 3, pp. 9-16. 
Miller, S. J., 1995, Idaho National Engineering Laboratory Management Plan for Cultural Resources, (draft), DOE-ID-10361, Rev. 1, U.S. Department of Energy, Idaho Operations Office, Idaho Falls, Idaho.

Miller, S. J., 1990, Characteristics of Mammoth Bone Reduction at Owl Cave, The Wasden Site, Idaho, R. Bonnichsen and M. H. Sorg (eds.), Bone Modification Center for the Study of the First Americans, Institute for Quaternary Studies, University of Maine, Orono, Maine.

Miller, S. J., 1983, Preliminary Cultural Resources Assessment of Two Study Areas on the Idaho National Engineering Laboratory, Southeastern Idaho, INL Cultural Resource Management Office, Idaho Falls, Idaho.

Miller, S. J., 1982, "The Archaeology and Geology of an Extinct Megafauna/Fluted Point Association at Owl Cave, the Wasden Site, Idaho," J. E. Ericson, R. E. Taylor, and R. Berger (eds.), Peopling of the New World, Ballena Press Anthropological Papers, No. 23, Los Altos, California: Ballena Press.

Miller, S. J., 1972, Weston Canyon Rockshelter: Big Game Hunting in Southeastern Idaho, Unpublished Master's Thesis: Idaho State University, Pocatello, Idaho.

Morgan, L. A. and W. R. Hackett, 1989, "Explosive Basaltic and Rhyolitic Volcanism of the Eastern Snake River Plain," Snake River Plain-Yellowstone Volcanic Province, Field Trip Guidebook T305, K. L. Ruebelmann (ed.), pp. 39-47.

Murphy, R. F. and Y. Murphy, 1986, "Northern Shoshone and Bannock," Handbook of North American Indians, Great Basin, W. L. D’Azevedo (ed.), 11, pp. 284-307.

Murphy, R. F. and Y. Murphy, 1960, "Shoshone-Bannock Subsistence and Society," University of California Anthropological Records, Vol. 16, No. 7, pp. 293-338.

Nace, R. L., P. T. Voegli, J. R. Jones, and M. Deutsch, 1975, Generalized Geologic Framework of the National Reactor Testing Station, Idaho, United States Geological Survey Professional Paper 725-B, Washington, D.C.

Nace, R. L., M. Deutsch, and P. T. Voegli, 1972, Physical Environment of the National Reactor Testing Station, Idaho: A Summary, U.S. Geologic Survey Professional Paper 725-A, Washington, D.C.

Oberg, P. M., 1970, Between These Mountains: History of Birch Creek Valley, Idaho, New York: Exposition Press.

Olsen, G., 1978, “Mackay's Yesterday’s,” Arco Advertiser, Arco, Idaho.

Pace, B. R. and J. B. Braun, 2000, Historic American Engineering Record for INTEC Chemical Processing Facilities, INEEL/EXT-2000-0129, Idaho National Engineering and Environmental Laboratory, Idaho Falls, Idaho.

PDD-1012, 2006, "Environmental Management System," Rev. 11, Idaho Cleanup Project, October 26, 2006.

PDD-8100, “Environmental Management System,” Rev. 0, Idaho National Laboratory, pending.

Pettite, W. S., 1983, Memories of Market Lake, Volume III, privately published, copyright Wm. Stibal Pettite.

Pettite, W. S., 1977, Memories of Market Lake, Volume II, privately published, copyright Wm. Stibal Pettite.

Pierce, K. L. and W. E. Scott, 1982, Pleistocene Episodes of Alluvial-Gravel Deposition, Southeastern Idaho, in Cenozoic Geology of Idaho, B. Bonnichsen and R. M. Breckenridge (eds.), Idaho Bureau of Mines and Geology Bulletin, No. 26. 
Pitrolo, A. A., 1990, "Directive: Management of Cultural Resources on the INEL," U.S. Department of Energy, Idaho Operations Office, Idaho Falls, Idaho, October, 12, 1990.

Plew, M. G., M. G. Pavesic, and M. A. Davis, 1987, Archaeological Investigations at Baker Caves I and III: A Late Archaic Component on the Eastern Snake River Plain, Boise State University Archaeological Report, No. 15.

Preston, R. N., 1978, Early Idaho Atlas, 2nd ed., Portland, Oregon: Binford and Mort.

Public Law 59-209, 1906, “Antiquities Act of 1906," as promulgated in 16 USC 431-433.

Public Law 74-292, 1935, "Historic Sites, Buildings, and Antiquities Act of 1935," as amended, as promulgated in 16 USC 461-467.

Public Law 86-523, 1969, "The Reservoir Salvage Act of 1960," as amended, as promulgated in 16 USC 469-469c.

Public Law 89-508, 1966, "Federal Collections Act of 1966."

Public Law 89-665, 1966, "National Historic Preservation Act of 1966," as amended, as promulgated in 16 USC 470, et seq.

Public Law 91-190, 1969, "National Environmental Policy Act of 1969," as amended, as promulgated in 42 USC 4321 and 4331-4335.

Public Law 93-291, 1976, “Archaeological and Historic Preservation Act of 1974," as amended, as promulgated in 16 USC 469-469c.

Public Law 94-201, 1976, “American Folklife Preservation Act of 1976," as promulgated in 20 USC 2101-2107.

Public Law 95-341, 1978, “The American Indian Religious Freedom Act," as promulgated in 42 USC 1996.

Public Law 96-95, 1979, "Archaeological Resources Protection Act," as amended, as promulgated in 16 USC 470aa, et seq.

Public Law 100-691, 1988, "Federal Cave Resources Protection Act of 1988."

Public Law 101-601, 1990, "Native American Grave Protection and Repatriation Act of 1990," as amended, as promulgated in 10 CFR 3001 et seq.

Reed, W. G., J. W. Ross, B. L. Ringe, and R. N. Holmer, 1987a, Archaeological Investigations on the Idaho National Engineering Laboratory: 1984-1985, Revised Edition, Swanson/Crabtree Anthropological Research Laboratory Reports of Investigations, 87-1, Pocatello, Idaho.

Reed, W. G., J. W. Ross, B. L. Ringe, and R. N. Holmer, 1987b, Annual Review of Archaeological Investigations on the INEEL 1986-1987, Swanson/Crabtree Anthropological Research Laboratory Reports of Investigations, 87-2, Pocatello, Idaho.

Reeves, B. O. K., 1983, Culture Change in the Northern Plains: 1000 B.C. - A.D. 1000, Archaeological Survey of Alberta Occasional Papers, No. 20.

Reisner, M., 1979, Cadillac Desert: American West and its Disappearing Water, New York: Penguin Books USA, Inc.

Reynolds, T. D., J. W. Connelly, D. K. Halford, and W. J. Arthur, 1986, "Vertebrate Fauna of the Idaho National Environmental Research Park," Great Basin Naturalist, Vol. 46, pp. 513-527. 
Ringe, B. L., 1995, Locational Analysis and Preliminary Predictive Model for Prehistoric Archaeological Resources on the Idaho National Engineering and Environmental Laboratory, Master's Thesis: Department of Anthropology, Idaho State University, Pocatello, Idaho.

Ringe, B. L. and J. B. Braun, 1993, "Cultural, Aesthetic, and Scenic Resources," Environmental Resource Document for the Idaho National Engineering Laboratory, Volumes 1 and 2, J. S. Irving (ed.), EGGWMO-10279, Idaho Falls, Idaho.

Ringe, B. L., R. N. Holmer, and W. G. Reed, 1988, "Current Perspectives on the Prehistory of the Eastern Snake River Plain,” Twenty-First Great Basin Anthropological Conference, October 1988, Park City, Utah.

Ringe, B. L., 1988, Test Excavation of Ten Sites Along the Powerline Between PBF and EBR-II, Idaho National Engineering Laboratory, Swanson/Crabtree Anthropological Research Laboratory Reports of Investigations, 88-6, INL Cultural Resource Management Office, Idaho Falls, Idaho.

Ringe, B. L., R. N. Holmer, S. J. Miller, J. Hearst, and W. Akersten, 1987, Archaeological and Paleontological Survey of the Idaho National Engineering Laboratory for the Super Conducting Super Collider, Idaho Museum of Natural History Reports of Investigations, 87-12, Pocatello, Idaho.

Ross, A., 1956, The Fur Hunters of the Far West, K. A. Spaulding (eds.), Norman, Oklahoma: University of Oklahoma Press.

Ross, J. W., B. L. Ringe, W. G. Reed, and R. N. Holmer, 1986, Archaeological Surveys of Three INEEL Gravel Pit Locations, Volume 1, Swanson/Crabtree Anthropological Research Laboratory Reports of Investigations, 86-6, Pocatello, Idaho.

Sadek-Kooros, Hind, 1972, "The Sediments and Fauna of Jaguar Cave, I: The Sediments," Tebiwa, Vol. 15, No. 1, pp. 1-21.

Sargeant, K. E., 1973, The Haskett Tradition: A View from Redfish Overhang, Unpublished Master's Thesis: Idaho State University, Pocatello, Idaho.

Schmalz, B. L., 1963, "Headgates and Headaches: The Powell Tract," Idaho Yesterdays, Vol. 9, No. 4, pp. 22-25.

Scientech, Inc., 1993, Technical Memorandum, "Records Search for the Interim Action to Clean Up Unexploded Ordnance Location at the Idaho National Engineering Laboratory," SCIE-COM-166-92, Idaho Falls, Idaho.

Scott, P. L., 1983, Idaho and the Carey Act, 1894-1930: Reclamation by the States, Unpublished Master's Thesis: University of Utah, Salt Lake City, Utah.

Sedgewick, M., n.d., Manuscript (unnumbered), Idaho State University Archives, Eli M. Oboler Library, Pocatello, Idaho.

Shimkin, D. B., 1947, Wind River Shoshone Ethnogeography, University of California Anthropological Records, Vol. 5, No. 4, pp. 245-288.

Simms, S. R., 1984, Aboriginal Great Basin Foraging Strategies: An Evolutionary Analysis, Ph.D. Dissertation: University of Utah, Salt Lake City, Utah.

Spear, D. B. and J. S. King, 1982, “The Geology of Big Southern Butte, Idaho," Cenozoic Geology of Idaho, B. Bonnichsen and R. M. Breckenridge (eds.), Idaho Department of Lands, Bureau of Mines and Geology, Moscow, Idaho, pp. 395-403.

Stacy, S., 2005a, Historic American Engineering Record - INEEL Power Burst Facility and SPERT I, ICP/EXT-05-00768, Historic American Engineering Record No. ID-33-F, National Park Service. 
Stacy, S., 2005b, Historic American Engineering Record - Idaho National Engineering and Environmental Laboratory - Test Area North, INEEL/EXT-04-02536, Historic American Engineering Record No. ID-33-E, National Park Service.

Stacy, S., 2000, Proving the Principle: A History of the Idaho National Engineering and Environmental Laboratory 1949-1999, DOE/ID-10799, U.S. Department of Energy, Idaho Operations Office.

Stacy, S., 1997a, Historic American Engineering Record for the Advanced Reentry Vehicle Fuzing System, INEL/EXT-97-00066, Historic American Engineering Record No. ID-32-B, National Park Service.

Stacy, S., 1997b, Historic American Engineering Record for the Old Waste Calcining Facility, INEEL/EXT-97-01370, Historic American Engineering Record No. ID-33-C, National Park Service.

Stacy, S., 1997c, Historic American Engineering Record for the Army Reactors Area, INEEL/EXT-9701369, Historic American Engineering Record No. ID-33-D, National Park Service.

Stacy, S., 1994, Historic American Engineering Record for the TAN-629 Hangar, EXT-94-00574, Historic American Engineering Record No. ID-32-A, National Park Service.

Staley, M., 1978, "Water - A History of the Mud Lake Area," Snake River Echoes, Vol. 7, No. 1, pp. 11-12.

STD-101, "Integrated Work Control Process," Rev. 19, Idaho Cleanup Project, October 26, 2006.

Steward, J. H., 1938, Basin Plateau Aboriginal Sociopolitical Groups, Bureau of American Ethnology Bulletin No. 120, Washington, D.C.: U.S. Government Printing Office.

Swanson, E. H., Jr., 1972, Birch Creek: Human Ecology in the Cool Desert of the Northern Rocky Mountains 9000 B.C. - A.D. 1850, Pocatello, Idaho: Idaho State University Press.

Thomas, D. H., 1981, "How to Classify the Projectile Points from Monitor Valley, Nevada," Journal of California and Great Basin Anthropology, Vol. 3, No. 1, pp. 7-43.

Trego, B., 1935, "Pioneer Lore,” Blackfoot Daily Bulletin, April 11, 1935.

Trego, B., 1928, "Pioneer Lore," Blackfoot Daily Bulletin, April 5, 1928.

Trego, B., n.d., Manuscript No. 142, Idaho State University Archives, Eli M. Oboler Library, Pocatello, Idaho.

Wentworth, E. C., 1948, America's Sheep Trails, Iowa State College: Iowa State College Press.

White, J. A., H. G. McDonald, E. Anderson, and J. Soiset, 1984, "Lava Blisters as Carnivore Traps," Contributions in Quaternary Vertebrate Paleontology: A Volume in Memorial to John E. Guilday, H. H. Genoways and M. R. Dawson (eds.), Special Publication of the Carnegie Museum of Natural History, No. 8, Pittsburgh, Pennsylvania, pp. 241-256.

Williams, M. H., 1970, Special Report: The History of Development and Current Status of the Carey Act in Idaho, Idaho Department of Reclamation, Idaho Department of Water Resources, Boise, Idaho.

Work, J., 1923, The Journal of John Work, A Chief Trader of the Hudson's Bay Company During His Expedition From Vancouver to the Flatheads and the Blackfeet of the Pacific Northwest, W. S. Lewis and P. C. Phillips (eds.), Cleveland, Ohio: Arthur H. Clark Co.

Wormington, H. M., 1957, Ancient Man in North America, $4^{\text {th }}$ Edition, Denver Museum of Natural History Popular Series, No. 4.

Wyeth, N. J., 1899, "The Correspondence and Journals of Captain Nathaniel J. Wyeth, 1831-1836," Sources of the History of Oregon, No. 1, Eugene, Oregon: University Press.

Wyle Laboratories., 1993, Interim Ordnance Cleanup Program: Record Search Report. Idaho Falls: U.S. Department of Energy, 1993. 


\section{Appendix A}

\section{Legal Basis for Cultural Resource Management}




\section{Appendix A}

\section{Legal Basis for Cultural Resource Management}

\section{INTRODUCTION}

The following is an outline of federal and state laws and regulations, executive orders, DOE directives, and INL procedures that guide cultural resource compliance and activities at INL.

All work at INL, including research, operations, and maintenance, is performed within an Environmental Management System (EMS) that integrates environmental protection, environmental compliance, pollution prevention, and continual improvement into work planning and execution throughout all work areas as a function of the Integrated Safety Management System (ISMS). ISMS dictates that all work be preplanned in accordance with specific standards and procedures, depending on the nature of the work.

\section{LAWS, REGULATIONS, AND GUIDELINES}

The federal and state laws, executive orders, regulations, and DOE directives summarized in the paragraphs to follow define and mandate the protection of cultural resources on federal land, provide guidelines for agencies and institutions in the implementation of these directives, and define the philosophical basis that underlies the INL Cultural Resource Management Program.

This summary is organized chronologically to give a sense of the development of national thought and legal requirements on cultural resource protection. Several of the earlier acts have been strengthened or superseded by later legislation. Although all laws listed are applicable, those marked by an asterisk $\left(^{*}\right)$ are the leading and most relevant to INL "daily routine" and long-range planning by the INL CRM Office.

\section{FEDERAL LAW}

\section{“Antiquities Act of 1906” (PL 59-209; 16 USC 431 - 433)}

This law is the first federal statute passed to protect antiquities on federal land, protecting all historic and prehistoric cultural properties on federal lands without regard to minimum age. "Objects of antiquity" (including paleontological resources) are to be preserved, restored, maintained, and disturbed only under excavation permit. Artifacts and associated documents are to be cared for in public museums. A system is to be created to establish national historic monuments, and criminal penalties are to be assessed for violations.

Requirements of the Antiquities Act, including the permitting process, have been expanded, strengthened, and superseded by the ARPA. The ARPA definition of antiquities or cultural resources excludes paleontological remains unless they are found in an archaeological context.

\section{"Historic Sites, Buildings, and Antiquities Act of 1935," as amended (PL 74-292; 16 USC 461 - 467)}

This act sets a national policy of preserving historic sites, buildings, and objects of national significance for the inspiration and benefit of the people of the United States. The authority to restore and 
maintain such sites is given to the Secretary of the Interior, who is also designated to oversee a National Survey of Historic Sites and Buildings (now the National Register of Historic Places), the Historic Sites Survey, the Historic American Buildings Survey (HABS), the Historic American Engineering Record (HAER), and the Historic American landscape Survey (HALS).

\section{"The Reservoir Salvage Act of 1960," as amended (PL 86-523; 16 USC 469 - 469c)}

This act mandates the salvage and preservation of historical and archaeological data that might otherwise be lost as a result of federal dam and reservoir construction. The act provides that up to one percent of funds appropriated for any federal project may be authorized to recover, preserve, and protect archaeological and historical data. The act was amended and broadened by the Archaeological and Historic Protection Act of 1974.

\section{* "National Historic Preservation Act of 1966," as amended (PL 89-665; 16 USC 470, et seq.)}

This act outlines the leadership role of the federal government in preservation of prehistoric and historic resources and promotes a policy of cooperation between federal agencies, Indian Tribes, other nations, states, and local governments. The act directs federal agencies to assume responsibility for the preservation of historic properties located on lands that they own or control (Section 110) and requires them to take into account the effects of their actions on those properties (Section 106). In this legal context, "historic properties" are widely varied but all are eligible, or potentially eligible, for listing in a National Register of Historic Places, formally established by the act. Historical buildings, structures, and objects, prehistoric and historical archaeological sites, cultural landscapes, places of traditional cultural significance to Native Americans or other communities, artifacts, and records are eligible for nomination.

The act also provides for the establishment and support of State Historic Preservation Offices, Tribal Historic Preservation Offices, state historic preservation plans, and procedures for forming approved state and local government historic preservation programs. It creates the independent national Advisory Council on Historic Preservation to serve as counsel on historic preservation issues to the president, the Congress, and federal and state agencies. Further guidance for the National Historic Landmarks Program is also provided as well as a directive to inform and educate the public about cultural resources under federal jurisdiction.

The following sections of the act are especially important to the relationship between cultural resource protection and activities on federal land, like INL.

*Section 106-The Advisory Council on Historic Protection (ACHP), created by NHPA, is responsible for implementing Section 106. This important section requires that federal agencies consider the potential impact of their activities on properties listed on or eligible for listing on the National Register and provide the ACHP sufficient information and time to comment on the proposed activities. In most situations, the ACHP only takes an active role in Section 106 reviews when adverse effects on historic properties are unavoidable. Far more active roles are played by other consulting parties such as the SHPO, Indian Tribes, and interested stakeholders.

In addition to providing a review process to be followed for individual federal undertakings, Section 106 also addresses emergency activities and situations where historic properties are inadvertently discovered. Federal agencies can comply with Section 106 by following procedures for individual activities or by developing programmatic agreements for large projects and/or ongoing program activities. 
The programmatic agreement is developed in consultation with the SHPO, the ACHP, Native American Tribes, and other interested groups. Federal agencies can also develop their own substitute procedures (subject to approval by the Advisory Council) or follow a state review system approved by the ACHP and the State. Such tailoring of requirements and processes for INL is captured in this plan (see Appendix G).

Basic compliance with Section 106 involves the following process:

1. Initiation of the Section $\mathbf{1 0 6}$ process. In this initial step, federal agencies must establish the undertaking, identify the appropriate SHPO or Tribal Historic Preservation Office and other consulting parties, and make plans to involve the public. The federal agency official coordinates the steps of the Section 106 process with the overall planning schedule for the undertaking and with any reviews required under other authorities such as the National Environmental Policy Act, the Native American Graves Protection and Repatriation Act, the American Indian Religious Freedom Act, and the Archaeological Resources Protection Act.

2. Identification of historic properties. If the undertaking under consideration has the potential to impact historic properties, a second step in the Section 106 process is initiated. At this time, the federal agency must gather information and determine and document the area of potential effect for the undertaking. Next, steps must be taken to identify historic properties within the area of potential effect and apply the National Register criteria to determine if any of the properties present are eligible for listing on the National Register. This step can involve field studies, archival research, oral history, and various forms of outreach to the public and Indian Tribes.

3. Assessment of adverse effects. If eligible or potentially eligible historic properties are present within the area of potential effect for the undertaking, the federal agency must consult with the SHPO, impacted Tribal Historic Preservation Office(s), and any American Indian tribe or public stakeholder that attaches religious or cultural significance to identified historic properties to determine if they will be adversely affected. The federal agency must also consider any views concerning such effects that have been provided by consulting parties and the public.

4. Resolution of adverse effects. If an adverse effect is determined as a result of the undertaking, the federal agency must continue consultation with the SHPO, impacted Tribal Historic Preservation Office(s) or Indian tribe, other consulting parties, and the public to develop and evaluate alternatives or modifications to the undertaking that could avoid, minimize, or mitigate adverse effects on historic properties. Continued consultation results in notification to the Advisory Council and development of a formal memorandum of agreement that outlines measures that will be taken to protect significant properties.

*Section 110 - This section of the act directs federal agencies to establish programs to locate, evaluate, and nominate eligible historic properties under their jurisdiction to the NRHP. The 1992 amendments strengthen the NHPA by requiring each federal agency to establish a historic preservation program to meet these goals. This requirement is important because it stresses that federal agencies must take an active role in the preservation and management of all significant cultural resources under their jurisdiction, not only those that happen to fall within the path of construction or modification projects.

*Section 112 - This section, added by the 1992 amendments to the NHPA, requires that federal agency and contractor individuals conducting historic preservation activities meet certain professional qualifications and that their activities under the NHPA meet certain standards.

*Section 304 -This section directs federal agencies to "withhold from disclosure to the public, information relating to the location or character of historic resources whenever the head of the agency or the Secretary determines that the disclosure of such information may create a substantial risk of harm, theft, or destruction to such resources or to the area or place where such resources are located." This 
section is also used to protect sensitive information related to historic properties that is provided by traditional cultural leaders.

\section{“Federal Collections Act of 1966" (PL 89-508)}

Historic and prehistoric sites have been clearly defined as resources under the Antiquities Act, the ARPA, and the NHPA, and, as such, their deliberate or inadvertent destruction or disturbance constitutes damage to public property. The Federal Collections Act requires that agencies attempt to collect for damages arising from activities on federal land, including claims resulting from unauthorized or illegal activities that damage or destroy cultural resources; professional archaeological appraisal is required to translate site damage into monetary terms and evidentiary basis for court cases.

\section{* “National Environmental Policy Act of 1969," as amended (PL 91-190; 42 USC 4321 and 4331 - 4335)}

This act outlines the federal policy of general environmental protection by requiring information gathering, planning, and assessment in advance of projects or actions that occur on federal land or are federally licensed or funded. It requires the use of natural and social sciences in planning and decisionmaking with regard to project impacts on the environment, and protective provisions are extended to important historic, cultural, and natural aspects of our national heritage. Federal agencies must prepare detailed statements (EISs, EAs) outlining the scope, environmental impacts of, and alternatives to the action planned, and allow for and consider public comments. The NHPA provides direction for integrating NEPA and NHPA Section 106 requirements. (Categorical exclusions under NEPA do not apply under the NHPA.)

\section{"Protection and Enhancement of the Cultural Environment," 1971 (EO 11593)}

This Executive Order formally designates the federal government as the leader in preserving, restoring, and maintaining the historic and cultural environment of the nation and gives federal agencies the responsibility for locating, inventorying, and nominating to the NRHP those sites that qualify. It also urges caution by federal agencies that, while this inventory and nomination process is going on, eligible properties are not transferred or altered. The primary philosophy and requirements of this order were incorporated into the NHPA 1980 amendments.

\section{"Archaeological and Historic Preservation Act of 1974," as amended (PL 93-291; 16 USC 469 - 469c)}

This act, also known as the Archeological Recovery Act, amends the Reservoir Salvage Act by expanding its provisions to any federal ground-disturbing program or activity or project requiring a federal license. It provides federal agencies with justification for expenditures to mitigate impacts on historic properties that contain scientific, prehistoric, historic, or archaeological data.

\section{"American Folklife Preservation Act of 1976" (PL 94-201; 20 USC 2101 - 2107)}

Within the Library of Congress, an American Folklife Center is established to preserve and present American folklife. It is a matter of concern to the federal government to encourage and support American folklife. 


\section{* "The American Indian Religious Freedom Act," 1978 (PL 95-341; 42 USC 1996)}

This act reaffirms American Indian religious freedom rights under the First Amendment and sets U.S. policy to protect and preserve the inherent and constitutional right of American Indians to believe, express, and exercise their traditional religions. The act prompts federal agencies to avoid interfering with access to sacred locations and traditional resources that are integral to the practice of native religions and directs them to consult with interested American Indian groups and leaders to develop and implement policies and procedures to aid in protection and preservation of cultural and spiritual traditions and sites. The act is not implemented by any regulations.

\section{* "Archaeological Resources Protection Act," 1979, as amended (PL 96-95; 16 USC 470aa et seq.)}

This act establishes definitions, permit requirements, and criminal and civil penalties, among other provisions, to strengthen the basic tenets of the Antiquities Act of 1906. Felony-level penalties are established for the unauthorized excavation, removal, damage, alteration, or defacement of any archaeological resource more than 100 years of age and located on public lands or American Indian lands. The act also prohibits the sale, purchase, exchange, transportation, receipt, or offering of archaeological resources obtained in violation of any provision of the act. Finally, the act fosters increased cooperation and exchange of information between governmental authorities, the professional archaeological community, and private individuals having collections of archaeological resources and data.

\section{* "Federal Cave Resources Protection Act of 1988” (PL 100-691)}

The stated purpose of this act is "...to secure, protect, and preserve significant caves on Federal lands for the perpetual use, enjoyment, and benefit of all people...to foster increased cooperation and exchange of information between governmental authorities and those who utilize caves located on Federal lands for scientific, education, or recreational purposes." The Federal Cave Resources Protection Act does not specifically address archaeological resources, but INL cave sites with archaeological resources benefit from this protection. Regulations have not yet been published.

\section{* "Native American Grave Protection and Repatriation Act of 1990," as amended (PL 101-601; 25 USC 3001 et seq.)}

This act provides for the determination of custody, protection, and repatriation of American Indian human remains, associated and unassociated funerary objects, sacred objects, and objects of cultural patrimony in existing federal collections and establishes criminal penalties for trafficking in human remains or cultural objects. Procedures are also provided for developing permits for excavation of such remains in consultation with appropriate American Indian representatives as well as for handling such remains when they are unexpectedly discovered during federal activities.

\section{* “Indian Sacred Sites,” 1996 (EO 13007)}

Under this broad Executive Order, federal agencies with land management responsibilities must, to the extent practicable and permitted by law, and in keeping with essential agency functions, accommodate access to and ceremonial use of sacred sites by American Indian religious practitioners and avoid adversely affecting the physical integrity of such sacred sites. Where appropriate, agencies must also maintain the confidentiality of sacred sites. 


\section{* "Consultation and Coordination with Indian Tribal Governments," 2000 (EO 13175)}

This Executive Order reaffirms the unique legal relationship between the United States and American Indian tribal governments. It stresses that federal agencies establish regular and meaningful consultation and collaboration with tribal officials in the development of federal policies that have tribal implications, strengthen the United States government-to-government relationships with American Indian tribes, and reduce the imposition of unfunded mandates upon the tribes.

\section{"Preserve America," 2003 (EO 13287)}

Federal agencies have a responsibility to provide a leadership role in preserving America's heritage. Federal agencies must manage the cultural resources under their jurisdiction as assets to their departments and missions while contributing to the vitality and economic well-being of the nation's communities and fostering a broader appreciation for the development of the United States and its underlying values. This Executive Order directs federal agencies to maximize efforts to integrate the policies, procedures, and practices of the National Historic Preservation Act. It directs them to promote the preservation of irreplaceable cultural resources by advancing the protection and continued use of their historic properties and pursuing partnerships with state and local governments, American Indian tribes, and the private sector.

\section{REGULATIONS}

Regulations are promulgated, adopted, and then published in the Code of Federal Regulations (CFR) to direct the implementation of laws. The following CFR citations are most pertinent to cultural resource management.

\section{"Leases and Exchanges of Historic Property" (36 CFR 18)}

This regulation governs the historic property leasing and exchange provisions of the National Historic Preservation Act.

\section{"National Register of Historic Places" (36 CFR 60)}

This regulation addresses nominations by federal, state, and local agencies as well as revision of nominations and removal of properties from the National Register.

\section{* "Procedures for Approved State and Local Government Historic Preservation Programs" (36 CFR 61)}

This regulation establishes standards for the approval and operation of state historic preservation programs, and requires the State Historic Preservation Office to conduct statewide surveys of cultural properties, prepare and implement state preservation plans, and cooperate with federal agencies in Section 106 compliance. Professional qualification standards are also established, ensuring credibility in the practice of historic preservation at all levels and ensuring a consistent level of expertise is applied nationally to the identification, evaluation, registration, documentation, treatment, and interpretation of archaeological and other cultural resources. 


\section{* "Determinations of Eligibility for Inclusion in the National Register of Historic Places" (36 CFR 63)}

This regulation sets forth a process and specific criteria for determining if properties are eligible for nomination to the National Register.

\section{“National Historic Landmark Program” (36 CFR 65)}

This regulation establishes criteria and procedures for identifying properties of national significance and designating them as national historic landmarks. Processes for revising landmark boundaries and/or removing landmark designations are also included.

\section{“Standards for Rehabilitation” (36 CFR 67)}

This regulation establishes procedures and standards whereby owners or holders of long-term leases for historic buildings may obtain certifications to gain federal tax credits for appropriate rehabilitation. Tax deductions for owners who donate interests in cultural resources for preservation purposes are also described.

\section{* "Standards for the Treatment of Historic Properties" (36 CFR 68)}

This regulation contains the standards for historic preservation projects including acquisition, protection, stabilization, preservation, rehabilitation, restoration, and reconstruction. These standards form the basis of the federal preservation program.

\section{* "Curation of Federally Owned and Administered Archaeological Collections" (36 CFR 79)}

This regulation provides standards and guidelines to be followed by federal agencies in preserving and providing adequate long-term curatorial services for archaeological collections of prehistoric and historic artifacts and associated records that are recovered under the NHPA, ARPA, and other antiquities laws.

\section{* "Protection of Historic and Cultural Properties" (36 CFR 800)}

This regulation includes guidelines of the Advisory Council on Historic Preservation to implement Sections 1 through 6 of the NHPA, as amended, and presidential directives issued pursuant thereto.

\section{* "Preservation of American Antiquities" (43 CFR 3)}

This regulation establishes procedures to be followed for permitting the excavation or collection of prehistoric and historic objects on federal lands.

\section{* "Protection of Archaeological Resources Uniform and Supplemental Regulations" (43 CFR 7 Subparts A and B)}

This regulation provides definitions, standards, and procedures for federal land managers to protect archaeological resources and provides further guidance on permitting procedures and penalties. 


\section{* "Native American Graves Protection and Repatriation Act: Final Rule" (43 CFR 10)}

This regulation establishes a systematic process for determining the rights of lineal descendents, American Indian tribes, and Native Hawaiian organizations to certain American Indian human remains, funerary objects, sacred objects, and objects of cultural patrimony with which they are affiliated.

\section{DEPARTMENT OF ENERGY DIRECTIVES}

Cultural resource management direction and guidance specific to DOE is set forth in policy, departmental orders, and memoranda, as well as memoranda from individual field offices. DOE also issues periodic cultural resource management information briefings, including the following topics: National Historic Preservation Act, State and Tribal Historic Preservation Officers, Managing Cultural Resources That May Contain Residual Radioactive Material, Historic Preservation and the DOE Historian, Archaeological Resources Protection Act, Native American Graves Protection and Repatriation Act, and Consultation with Native Americans.

* “Department of Energy Management of Cultural Resources," 2001 (DOE P 141.1)

The purpose of this policy is to ensure that DOE maintains a program that reflects the spirit and intent of cultural resource legal mandates. Two specific goals are outlined:

1. To ensure that Department of Energy (DOE) programs and field elements integrate cultural resources management into their missions and activities and

2. To raise the level of awareness within DOE concerning the importance of the Department's cultural resource-related legal and trust responsibilities.

\section{* “Environmental Protection Program,” 2003 (DOE O 450.1)}

This order provides direction to all DOE elements and contractors that are responsible for the management and operation of departmental facilities. It requires the implementation of sound stewardship practices that are protective of the air, water, land, and cultural resources impacted by DOE operations. These practices must be incorporated into an Environmental Management System that is part of an overarching Integrated Safety Management System (ISMS) that meets or exceeds compliance with applicable resource protection laws, regulations, and DOE requirements.

\section{* “American Indian Policy,” 1992, as revised in 1998 (DOE 0 1230.2)}

This order provides direction to all departmental officials, staff, and contractors regarding fulfillment of trust obligations and other responsibilities arising from departmental actions that may potentially impact American Indian and Alaska Native traditional, cultural, and religious values and practices; natural or cultural resources, and treaty and other federally recognized and reserved rights.

\section{* "Management of Cultural Resources at Department of Energy Facilities," 1990, as revised in 2001 (DOE Memorandum)}

The purpose of this memorandum is to inform all DOE facilities and programs of the requirements for complying with the various executive orders, statutes, and implementing regulations governing the 
management of cultural resources. Included are basic definitions for cultural resources and outlines of consultation requirements with regard to cultural resource compliance and cultural resource preservation planning as required by NHPA. This memorandum also orders the development of facility- and programspecific cultural resource management plans.

\section{"Managing Cultural Resources that may Contain Residual Radioactive Material," August 1999 (DOE Information Brief)}

The issue of radiologically contaminated cultural artifacts and Native American human remains or sacred items impacts relatively few federal agencies. However, as a result of historical operations in support of our national defense and other mission-essential activities, this issue is of particular importance to DOE. Although no radiologically contaminated materials have been identified to date, if such an event were to occur, the processes set forth in DOE Order 5440.5, "Radiation Protection of the Public and the Environment," would be used to ensure radiological protection responsibilities are accomplished, particularly with regard to long-term curation or in situations of possible repatriation under NAGPRA.

\section{* "Management of Cultural Resources on the INEL," October 12, 1990 (DOE-ID Management Directive)}

This directive from A. A. Pitrolo, manager, DOE-ID, represents DOE-ID's response to DOE memorandum, "Management of Cultural Resources at Department of Energy Facilities." The Idahospecific memorandum initiates development and implementation of an INL cultural resource management plan and commits to rigorous compliance with cultural resource legislation.

\section{STATE OF IDAHO}

On the INL site, as on other federal reserves, federal statutes supersede existing state legislation pertaining to cultural resources. However, both sets of statues are complementary and state acts have corollaries at the federal level.

\section{“Idaho Historic Preservation Act," Idaho Code, Chapter 41 (I.C. 67:4113-4129)}

This act establishes protection of archaeological and vertebrate paleontological resources on public (state) lands in Idaho. It provides for the permitting of qualified individuals or institutions to excavate, and establishes penalties for violation of the code. It is superseded by federal law on the INL site.

\section{"Burial Act," Idaho Code, Chapter 70 (I.C. 18:7027-7028)}

Desecration of human burials on public (state) lands is prohibited and penalties are established for unlawful removal of human remains.

\section{“Protection of Graves," Idaho Code, Chapter 5, Title 27}

This law defines permitted activities and establishes guidelines for the legal removal of human remains from Idaho gravesites by qualified archaeologists or law enforcement personnel. Consultation with and written permission of the State Historical Society director and the appropriate tribe is required in cases involving American Indian burials. Human remains and associated items from these gravesites must be reinterred in an area approved by the tribe. 


\section{“Idaho Cave Protection Act," Idaho Code, Chapter 70, Title 18, Section 7035}

It is unlawful to damage caves or their features or contents through vandalism or removal; permission is possible for legitimate entry and collection. The act applies to federal, state, or private caves or their resources. It includes cave features, plants and animals, and archaeological materials. Violation of the act is considered a trespass and malicious injury to property misdemeanor.

\section{INL IMPLEMENTING DOCUMENTS}

The INL environmental philosophy and program are synthesized in the overall INL environmental policy (Figure 28). The policy is a core element of INL's Environmental Management System (EMS) which is integrated with the broad Integrated Safety Management (ISM) system and based on the five core elements of the International Standardization Organization (ISO) EMS Standard (ISO 14001). It is important to recognize that in the context of INL's ISM system, the term "safety" encompasses environmental, safety, health, and quality assurance. The major elements of INL's EMS include policy, planning, implementation and operation, checking and corrective action, and management review. Through implementation of the ISM system and associated EMS, the INL effectively protects workers, the surrounding communities, and the environment, while meeting operating objectives to comply with legal and other requirements. 


\section{Envijonjnental Poljey}

It is INL's mission to ensure the nation's energy security with safe, competitive, and sustainable energy systems and unique national and homeland security capabilities. It is INL's vision that within the next ten years it will be the preeminent nuclear energy laboratory with synergistic, world-class, multiprogram capabilities and partnerships. Among INL's strategic objectives are to develop public trust and confidence in INL and nuclear technology, and to demonstrate world-leading safety, environmental, and operational performance.

To support this mission, vision and strategic objectives, it is INL's environmental policy to conduct research, development and demonstration for energy and national security in a manner that protects and preserves human health and the environment and is in full compliance with applicable environmental laws, regulations, and other requirements. We implement this policy by integrating environmental requirements, pollution prevention, continual improvement into our work planning and execution, and taking actions to minimize the environmental impacts of our operations. We establish and communicate environmental responsibilities, provide environmental training to our workforce, and implement controls to mitigate environmental hazards. Through employee involvement and management commitment to environmental excellence, we will:

- Exercise world-leading environmental stewardship to protect the unique natural, biological and cultural resources of the lands and facilities managed by INL.

- Further demonstrate responsible environmental stewardship through effective resolution of legacy INL environmental issues, both independently and in concert with ICP.

- Establish documented environmental objectives and targets and update them as necessary to reflect INL's changing needs, missions, and goals.

- Measure our environmental performance and monitor our impact on the environment and communicate the results to our employees, subcontractors, stakeholders and the public.

- Promote environmental sustainability, conserve natural resources and energy, minimize toxicity and volume of waste generated, and minimize environmental impacts throughout the lifecycle of INL facilities and operations.

- Conduct all activities and manage hazardous and radioactive materials and wastes in a safe, compliant, and cost effective manner.

- Promptly identify noncompliant conditions and encourage full disclosure and open discussion regarding compliance issues. Aggressively work to resolve identified issues.

- Conduct research and develop technologies to address legacy contamination and minimize impacts on human health and the environment.

- Develop and deploy new and enhanced environmental te customers. Conserve natural resource materials, and using recyclable susing a Continuously improve our environmental management system through self-assessment and corrective action.

This policy applies to all persons working for or on behalf of INL. Every employee and subcontractor is expected to follow this policy and to report environmental concerns to leadership. Leaders shall promote world-leading environmental stewardship, take prompt action to address concerns and issues, and have zero tolerance for noncompliance.

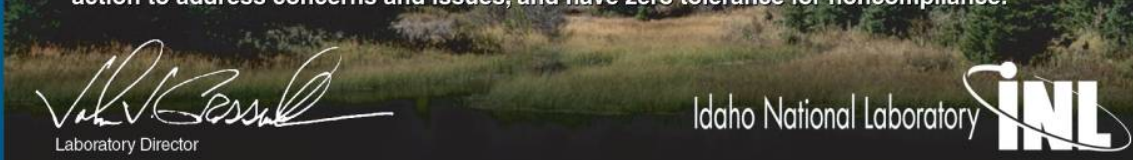

Figure 28. INL Environmental Policy

The Idaho Cleanup Project (ICP) and Bechtel BWXT also rely upon basic environmental policies with standards equal to those adopted by INL. Those policies are reproduced in Figures 29 and 30. 


\section{POL-104: ICP Environmental Policy}

It is the policy of CH2M-WG Idaho, LLC (CWI) to conduct the Idaho Cleanup Project (ICP) in a safe, compliant ${ }_{2}$ and cost-effective manner that protects human health and the environment. We achieve this by integrating environmental requirements and pollution prevention into our work planning and execution, and taking actions to minimize the environmental impacts of our operations. We establish and communicate environmental responsibilities, provide environmental training to our workforce, and implement controls

to mitigate environmental hazards. Through employee involvement and management commitment to environmental excellence, we will:

Identify and comply with all applicable environmental laws and regulations.

Use all means practicable to minimize or eliminate any newly generated wastes. Whenever possible, newly generated wastes shall have a clear disposition path before they are generated.

Protect the unique natural, biological ${ }_{2}$ and cultural resources associated with ICP activities.

Conserve natural resources by reusing and recycling materials, purchasing recycled materials, and using recyclable materials.

Establish documented environmental objectives and targets and update them as necessary to reflect CWI's changing needs, missions, and goals.

Consider the input of our stakeholders when weighing alternative courses of action.

Measure our environmental performance and monitor our impact on the environment and communicate the results to our employees, subcontractors, and stakeholders.

Continuously improve our environmental management system through self-assessment and corrective action.

Communicate this policy to all employees and subcontractors and make it available to the public and our stakeholders.

This policy applies to all persons working on behalf of the ICP. Every employee and subcontractor is expected to follow this policy and to report environmental concerns to management. Managers shall promote environmental stewardship, take prompt action to address concerns and issues and have zero tolerance for noncompliance.

Figure 29. ICP Environmental Policy. 


\section{AMWTP \\ Environmental Policy}

It is the purpose of the Advanced Mixed Waste Treatment Project, and the policy of Bechtel BWXT Idaho, to protect the environment by shipping transuranic waste to an appropriate geologic repository for disposal.

- We will conduct all business activities in an environmentally responsible manner, free from recognized hazards.

- We will comply with applicable environmental, health, and safety laws and regulations; consider the concerns of all stakeholders when evaluating alternative courses of action; and remain alert to new opportunities to enhance environmental soundness.

- We will foster the sustainable use of our earth's resources through reducing the amount and toxicity of trash discarded, reusing items, and recycling materials when economically practicable.

- We will promote effective environmental stewardship by our suppliers, customers, and other business partners.

-We commit to continuous improvement in our environmental management system, pollution prevention practices, and operational activities.

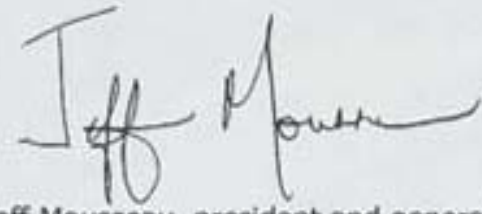

Jeff Mousseau, president and general manager

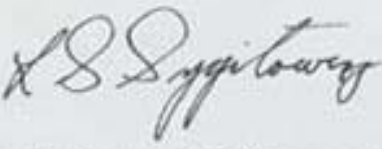

Lee Sygitowicz, ESS\&H manager

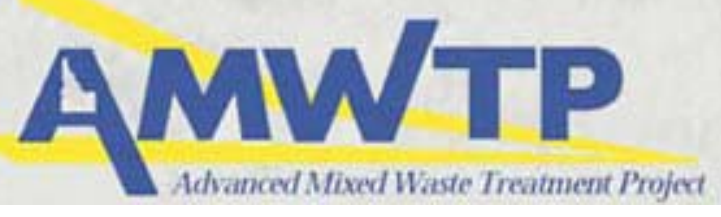

Figure 30. Bechtel BWXT Environmental Policy. 
All work done on INL is controlled by specific company guidelines, as outlined in a series of laboratory-wide manuals and high-level laboratory requirements documents (LRD). LRD-9000, "Laboratory Excellence Conduct of Operations," and LRD-8000, "Environmental Requirements for Facilities, Processes, Materials and Equipment," are particularly relevant to cultural resource management. Applicable high-level guidance is also provided in the program description document, PDD-8100, "Environmental Management System," which outlines a systematic approach to environmental protection and compliance with environmental standards. Work preplanning (depending on the nature of the work) is directed by laboratory-wide procedures (LWP) or management control procedures (MCP) such as LWP-8000, "Environmental Instructions for Facilities, Processes, Materials and Equipment," LWP-6200, "Integrated Work Control Process, LWP-21220, "Hazard Identification, Analysis and Control of Operational Activities, and MCP-2860, "Building/Facility Transition." While work is being performed, numerous additional procedures are adhered to, with LWP-14002, "Stop Work Authority," as one of primary importance to cultural resources. All of these guiding documents and procedures have equivalent corollaries, typically known as management control procedures, in the EMS of the INL cleanup contractor.

\section{* PDD-8100, “Environmental Management System"}

The Environmental Management System at INL is designed to integrate environmental protection, environmental compliance, pollution prevention, and continual improvement into work planning and execution throughout all work areas as a function of the Integrated Safety Management System. The Environmental Management System applies to all company organizations that implement environmental requirements or that have activities, products, or services that have the potential to impact the air, water, land, natural resources, historic or cultural resources, vegetation, wildlife, or surrounding population. Company line management is responsible for communicating relevant environmental requirements and environmental hazards to employees and subcontractors through appropriate company documents. The INL cleanup contractor recognizes the integrating features of an EMS in PDD-1012.

\section{LWP-6200, "Integrated Work Control Process"}

The Integrated Work Control Process is the method by which the Integrated Safety Management System, enhanced work planning, worker safety, and the Environmental Management System are implemented for maintenance and construction work activities. LWP-6200 provides a single process by which all maintenance and construction work on the INL is performed, and by which all work is screened for hazards, including adverse impact to the environment and cultural resources. References are provided for other regulatory requirements (such as environmental compliance) applicable to work performed at INL. For the INL cleanup contractor, Standard 101 (STD-101) fills this important function.

\section{LWP-21220, "Hazard Identification, Analysis and Control of Operational Activities"}

This LWP describes the process for performing hazard identification, analysis, and control for operational activities (all non-maintenance and non-construction activities) and research and development work. This procedure provides the method by which the following functions of the Integrated Safety Management System are achieved: identify the hazards, analyze the hazards, identify standards and requirements, identify controls to prevent or mitigate hazards, and establish safety controls. "Hazards," in the context of this procedure, include anything that could result in a negative environmental, safety, or health impact or non-compliance situation. An exhaustive list of potential work tasks and associated hazards is contained in this document. This list facilitates which department or subject matter expert must be contacted prior to each specific task or activity to ensure that work is conducted in accordance with 
applicable environmental, safety, health, and quality requirements; MCP-3562 describes the INL cleanup contractor's process for these activities.

\section{*LWP-8000, “Environmental Instructions for Facilities, Processes, Materials and Equipment"}

This LWP provides instructions for performing environmental planning, compliance, and protection activities during the course of conducting work. It is used in conjunction with other appropriate instructions (e.g., operations, maintenance, construction, and safety and health procedures), as well as environmental permits. The INL Environmental Checklist is an important tool for identifying and implementing recommendations that arise from this procedure. This guidance is identified as MCP-3480 by the INL cleanup contractor.

\section{*LWP-14002, "Stop Work Authority"}

Every INL employee is granted the authority under LWP-14002 to stop work if any unsafe condition, at risk behavior, or environmental or quality deficiency is noted. In practical terms, if cultural resources are noted in the course of work, the employee should stop work and contact the INL CRM Office. For the ICP, MCP-553, "Step Back and Stop Work Authority," outlines this responsibility.

\section{LWP-14101, "Fieldwork"}

Both INL and ICP have procedures in place for conducting fieldwork in a safe manner. For INL, LWP-14101 provides guidance; for ICP it is found in MCP-2725.

\section{MCP-2860, "Building/Facility Transition"}

This procedure implements the standardized requirements for transitioning a DOE-ID facility from active to inactive status or vice versa. It defines responsibilities, processes, and definitions for determining building characteristics such as size, condition, and contamination levels. The product from this activity is a "Facility Condition Report" that is deployed to guide transition. Program managers are specifically directed to "Determine if any of the process equipment remaining in the facility has historical significance, and if so, who will remove it." Finally, MCP-2860 directs program managers to consider long-term stewardship matters including "....the protection of cultural and ecological resources within areas of stewardship responsibility."

\section{LWP-2008, "Utilization and Disposal of Real Property"}

This LWP describes the process whereby DOE-ID real property is transferred, donated, sold, or destroyed. Any of the first three options can include either arrangements with either internal (DOE) or external (other agencies, private parties, or organizations) entities. The ICP relies on MCP-2477 to govern this process. 
Appendix B

\section{American Indian Interests: DOE Policy and Regulatory Guidance}




\section{Appendix B}

\section{American Indian Interests: DOE Policy and Regulatory Guidance \\ INTRODUCTION}

American Indians tribes have several concerns centered around protection and renewal of their cultures:

- Treaty rights and tribal sovereignty

- Contemporary political and social rights, and economic viability

- Preservation of language and customs

- Freedom to practice native religions and to protect and have access to religious and traditional sites

- Protection of archaeological sites, treatment of human burials and associated artifacts, and repatriation of human skeletons and sacred objects.

DOE-ID has addressed these concerns by:

- Adhering to the U.S. Department of Energy American Indian and Alaska Native Tribal Government Policy (see Attachment 1)

- Entering into an AIP Between The Shoshone-Bannock Tribes and the United States Department Of Energy (see Attachment 2)

- Developing a communications protocol for undertakings involving INL American Indian cultural resources (see Attachment 3)

- Developing an MOA Between the United States Department of Energy, Idaho Operations Office and the Shoshone-Bannock Tribes (Middle Butte Cave Agreement) (see Attachment 4).

\section{SUMMARY OF THE U.S. DEPARTMENT OF ENERGY AMERICAN INDIAN AND ALASKA NATIVE TRIBAL GOVERNMENT POLICY}

The U.S. DOE American Indian and Alaska Native Tribal Government Policy (see Attachment 1) outlines the principles to be followed by DOE in its interaction with federally -recognized American Indian tribes. This policy is based on federal policy, treaties, federal law and DOE's responsibilities as a federal agency to ensure that tribal rights and interests are identified and considered in pertinent decisionmaking processes. Under this policy, DOE will:

1. Recognize the federal trust relationship and fulfill its trust responsibilities to American Indian and Alaska Native nations.

2. Recognize and commit to a government-to-government relationship and institute appropriate protocols and procedures for program and policy implementation.

3. Establish mechanisms for outreach, notice, and consultation, and ensure integration of American Indian nations into decision-making processes. 
4. Comply with applicable federal cultural resource protection and other laws and Executive Orders to assist in the preservation and protection of historic and cultural sites and traditional religious practices.

5. Initiate a coordinated effort for technical assistance, business and economic self-determination development opportunities, education, and training programs.

6. Ensure that the secretary of Energy conducts an annual Tribal Leaders summit for performance review of policy implementation and issue resolution.

7. Work with other federal agencies and state agencies that have associated responsibilities and relationships to their respective organizations as they relate to tribal matters.

\section{SUMMARY OF THE AGREEMENT-IN-PRINCIPLE BETWEEN THE SHOSHONE-BANNOCK TRIBES AND THE UNITED STATES DEPARTMENT OF ENERGY}

The AIP (see Attachment 2) specifically defines a working relationship between the ShoshoneBannock Tribes and DOE-ID. The AIP reflects an understanding and commitment between the Tribes and DOE to facilitate the Tribes' greater level of assurance that activities being conducted at INL address Tribal interests in DOE-administered programs and protect the health, safety, environment, and cultural resources of the Tribes. The AIP states the roles that the Tribes and DOE will play in the following areas:

- Environmental management

- NEPA compliance

- Environmental monitoring

- Release reporting requirements for DOE

- Emergency management

- Protection of cultural resources

- Risk assessment or health studies

- Tribal self-sufficiency.

\section{Protection of Cultural Resources as Stipulated in the AIP}

The AIP recognizes that protection of cultural resources, access to sacred sites and sites of traditional use, and repatriation of American Indian human remains and cultural items are of paramount importance to the Tribes and DOE. As stewards of these important resources at INL, DOE-ID further agrees to continue coordination and consultation with the Tribes in their cultural resource compliance responsibilities and in the continued development of a relationship of trust and openness with the Tribes. Protection of cultural resources entails:

1. Definition of cultural resources. DOE understands the Tribes' position that cultural resources include, but are not limited to, natural resources, sacred sites, traditional cultural properties, camps, burial areas and associated funerary objects, and other items of cultural patrimony to the Tribes. DOE further understands that objects that are of religious, traditional, or historic importance to the Tribes include, but are not limited to, traditional plants, wildlife, and landscapes.

2. Tribal involvement. DOE will provide access to INL cultural resource investigations and opportunities for tribal participation in project planning and determination of effects (NHPA Section 
106). DOE will also provide reasonable opportunity and adequate timeframes for tribal comment and response to specific undertakings. The Tribes will provide timely response to DOE, within 30 days or as otherwise agreed.

3. Consultation. DOE and the Tribes will use the communications protocol (see Attachment 3) as a guide and a starting point, not as a substitute, for achieving the consultation requirements of applicable federal laws, regulations, orders, and policies.

4. Management of discovered human remains and cultural artifacts. In the event that human remains or burial sites are inadvertently discovered, accidentally exposed, or potentially threatened, the Tribes will be contacted immediately and consultation, as outlined in the communications protocol will be initiated (see Attachment 3).

DOE agrees that Tribal representatives will be permitted to view any discoveries of remains and cultural artifacts, will be authorized to do site inspections of any archaeological discovery or excavation, and will be permitted to be present during any archaeological excavation, survey, study, or testing at INL.

5. Tribal access for cultural and religious purposes. The 1994 memorandum of understanding (MOU) between the Tribes and DOE regarding access to the Middle Butte area will continue to be in effect (see Attachment 4). Access to other INL undeveloped areas for cultural or religious purposes will be considered and accommodated on a case-by-case basis.

6. Protection of information. The Tribes, DOE, and DOE contractors will not release or allow the release of any information pertaining to the exact location of any American Indian burial sites, archaeological sites, or significant sites identified as American Indian to the public, unless required by law or legal authority.

DOE will coordinate with the Tribes prior to approving for external publication any documents that have been prepared as a result of the study, analysis, research, or other work done under the direction and control of DOE on or in relation to American Indian human remains or archaeological resources at INL. In the event that the Tribes disagree with portrayal of tribal cultural matters in a DOEcontrolled publication, DOE will provide for inclusion of a tribal historical position in such publication.

\section{COMMUNICATIONS PROTOCOL FOR UNDERTAKINGS INVOLVING AMERICAN INDIAN CULTURAL RESOURCES AT INL}

DOE-ID recognizes and appreciates the need to interact and consult directly with the ShoshoneBannock Tribes regarding the management of cultural resources at INL. A communications protocol (see Attachment 3 ) has been developed cooperatively to accomplish effective and timely communication and to enhance the formal and informal interaction and consultation required to serve the needs of DOE, contractor, and tribal entities who have a stake in the issues. The communications protocol does not supersede or replace any other provisions for consultation with the Tribes or other regulatory agencies under applicable federal laws. Rather, it is intended to supplement them and to provide clarification on how and when communication, interaction, and consultation will occur between DOE-ID and the Tribes regarding INL cultural resources.

\section{Interactions and Consultations}

Differing levels of activity involving cultural resources at INL require a flexible approach to communication, interaction, and consultation. For this purpose, three levels of exchange between DOE 
and the Tribes have been developed, with each level differing according to degree of formality and the personnel involved. Briefly, the three levels of exchange are:

1. Level I: Routine technical communication. This is the most informal level and often involves the direct interaction of DOE-ID or INL CRM Office personnel with personnel from the Heritage Tribal Office (HETO; formerly Tribal CRM Office). Routine communications would usually occur on a daily or weekly basis as needed, and involve telephone calls, electronic mail messages, working meetings, etc. Another mechanism for routine technical interaction is the regular meeting of the INL CRWG, consisting of Tribal, federal, and contractor cultural resource management technical personnel.

2. Level II: Intermediate interaction. The second level of interaction is actually a formal consultation, with the technical cultural resource management personnel for DOE-ID, the Tribes, and the INL CRM Office acting as the designees of their respective agencies. This level is entered into when it is determined (either through Level I interaction or other means) that an undertaking has the potential to affect an American Indian cultural resource. This level is also the level at which formal notification of the Idaho SHPO is made for the purposes of conducting a NHPA Section 106 review of undertaking.

3. Level III: Government-to-government consultation. This is the most formal level of consultation and involves communication between the Tribal chairperson and the manager of DOE-ID. It is utilized when an undertaking will have an "adverse effect" upon an American Indian resource and mitigation needs to be performed, or when American Indian human remains or other cultural items, as defined by NAGPRA, are inadvertently discovered.

\section{MIDDLE BUTTE CAVE AGREEMENT}

In the "Middle Butte Cave Agreement," formerly known as "Memorandum of Agreement Between United States Department of Energy, Idaho Operations Office and the Shoshone-Bannock Tribes," (see Attachment 4), DOE-ID recognizes that certain INL areas have cultural and religious significance to the Tribes. This agreement provides tribal access to the Middle Butte area and other areas that may be identified for access in the future for the performance of tribal sacred or religious ceremonies or other cultural or educational activities.

\section{TRADITIONAL CULTURAL PLACES}

According to the 1990 National Register Bulletin 38, "Guidelines for Evaluating and Documenting Traditional Cultural Properties," a traditional cultural property is a place that is eligible for inclusion in the National Register because of its association with cultural practices or beliefs of a living community that are rooted in that community's history, and are important in maintaining the continuing cultural identity of the community. Non-American Indian places can also be traditional cultural properties. An urban neighborhood that has cultural value - for example, a Chinatown — or a rural community like the traditional communities of the Amish, or a cowboy community in the west can also be eligible for the National Register as a traditional cultural property.

Shoshone-Bannock tribal homelands, including the Fort Hall Indian Reservation, aboriginal territories, and ceded areas, are acknowledged to be the "cultural, political, and economic center of the Tribes and are essential to their survival." INL is located on federal land that is recognized as part of this aboriginal territory and contains cultural resources important to the Tribes. Protection of these cultural resources, access to sacred sites, sites of traditional use, and repatriation of American Indian human remains and cultural items are of paramount importance to the Tribes and DOE (Agreement-In-Principle Between the Shoshone-Bannock Tribes and the United States Department of Energy, August 6, 1998, p. 8). 
DOE-ID recognizes its trust responsibility to prudently manage the natural and cultural resources within its jurisdiction in consultation with the Tribes. Towards that means and for the purposes of this CRMP, the AIP and the communications protocol for undertakings involving American Indian cultural resources at INL will be used to address procedures for all cultural resource issues including, but not limited to, traditional cultural places, sacred sites, and AIRFA and NAGPRA issues. The aforementioned guidelines and policies recognize the importance of procedural flexibility, earliest possible involvement, meaningful and culturally appropriate consultation, early planning consideration, respect for religious and other cultural beliefs, and the legitimacy of confidentiality. DOE understands that, based on confidentiality concerns, it may be inappropriate for the Shoshone-Bannock Tribes to provide maps, descriptions, or lists of known sacred sites or traditional cultural places to non-tribal members. 


\section{Attachment 1}

\section{U.S. Department of Energy \\ American Indian and Alaska Native Tribal Government Policy}




\section{U.S. DEPARTMENT OF ENERGY AMERICAN INDIAN AND ALASKA NATIVE TRIBAL GOVERNMENT POLICY}

\section{BACKGROUND}

Indian nations are sovereign with unique political and legal standing derived from a longstanding relationship as stated in the Purpose Section of this document. The Indian nations retain an inherent right to self-governmental authority, and therefore, Federal activities affecting self-governance rights and impacting upon trust resources require policy implementation in a knowledgeable and sensitive manner protective of tribal sovereignty and trust resources. DOE released its Indian Policy in 1992 and subsequently issued DOE Order 1230.2 that established the responsibilities and roles of DOE management in carrying out its policy. At the request of Indian nations in 1998, the Secretary of Energy agreed to revise the 1992 American Indian Policy and effect comprehensive implementation. This revision was based in part on comments from Indian nations and their leadership and replaces the 1992 Policy that is part of the 1992 Order.

\section{DEFINITIONS}

Indian Nation means any American Indian or Alaska Native Tribe, Band, nation, Pueblo, or other organized group or community, including any Alaska Native village [as defined or established pursuant to the Alaska Native Claims Settlement Act (43 U.S.C. 1601 et seq.)], which is acknowledged by the Federal government to constitute a tribe with a government to government relationship with the United States and eligible for the programs, services, and other relationships established by the United States for indigenous peoples because of their status as American Indian and Alaska Native tribes, Bands, nations, Pueblos or communities.

American Indian and Alaska Native Tribal Government means the recognized government of an Indian nation and any affiliated or component band government of such nation that has been determined eligible for specific services by Congress or officially recognized in 25 CFR Part 83, "Indian Entities Recognized and Eligible to Receive Services from the United States Bureau of Indian Affairs," as printed in the Federal Register.

Trust Responsibility includes, but is not limited to: promotion and protection of tribal treaty rights, federally recognized reserved rights, and other federally recognized interests of the beneficiary American Indian and Alaska Native nations; determining, documenting, notifying, and interacting with tribal governments with regard to the impact of Departmental programs, policies, and regulations to protect American Indian and Alaska Native traditional and cultural lifeways, natural resources, treaty and other federally recognized and reserved rights.

Consultation includes, but is not limited to: prior to taking any action with potential impact upon American Indian and Alaska Native nations, providing for mutually agreed protocols for timely communication, coordination, cooperation, and collaboration to determine the impact on traditional and cultural lifeways, natural resources, treaty and other federally reserved rights involving appropriate tribal officials and representatives throughout the decision-making process, including final decision-making and action implementation as allowed by law, consistent with a government to government relationship.

Cultural Resources include, but are not limited to: archaeological materials (artifacts) and sites dating the to prehistoric, historic, and ethnohistoric periods that are located on the ground surface or are buried beneath it; natural resources, sacred objects, and sacred sites that have importance for American Indian 
and Alaska Native peoples; resources that the American Indian and Alaska Native nations regard as supportive to their cultural and traditional lifeways.

Treaty and Trust Resources and Resource Interests include, but are not limited to: natural and other resources specified and implicit in treaties statutes, and agreements, or lands or other resources held in trust by the United States for the benefit of the tribes or individual Indian beneficiaries, including land, water, timber, fish, plants, animals, and minerals. In many instances, Indian nations retain hunting, fishing, and gathering rights, and access to these areas and resources on lands or waters that are outside of tribally owned lands.

\section{POLICY PRINCIPLES}

\section{DOE RECOGNIZES THE FEDERAL TRUST RELATIONSHIP AND WILL FULFILL ITS TRUST RESPONSIBILITIES TO AMERICAN INDIAN AND ALASKA NATIVE NATIONS.}

The DOE will be diligent in fulfilling its federal trust obligations to American Indian and Alaska Native governments in policy implementation and program management activities. The DOE will pursue actions that uphold treaty and other federally recognized and reserved rights of the Indian nations and peoples. The Department recognizes that some Tribes have treaty-protected and other federally recognized rights to resources and resource interests located within reservation boundaries, aboriginal territories, and will, to the extent of its authority, protect and promote these treaty and trust resources and resources interests, and related concerns in these areas.

When internal policies, regulations, and statutes, or other barriers, prohibit or hinder the DOE trust protection actions or participation in eligible program initiatives, the Secretary will direct the agency to seek corrective protection measures, and tribal government program inclusion.

The DOE is committed to protecting treaty compliance and trust interests of Indian nations during interactions with state and local governments and other stakeholders with regard to DOE actions impacting upon American Indian and Alaska Native governments and peoples. The Department will inform and educate state and local governmental entities and other stakeholders about the DOE's role and responsibilities regarding its trust relationship with Indian nations.

The DOE will seek to determine the impacts of Departmental-proposed legislation upon Indian nations, in extensive consultation and collaboration with tribes. The Secretary will implement this notice and consultation effort consistent with the intent and purpose of this policy.

\section{THE DEPARTMENT RECOGNIZES AND COMMITS TO A GOVERNMENT- TO- GOVERNMENT RELATIONSHIP AND WILL INSTITUTE APPROPRIATE PROTOCOLS AND PROCEDURES FOR PROGRAM AND POLICY IMPLEMENTATION}

The DOE recognizes Ttribal governments as sovereign entities with primary authority and responsibility for the protection of the health, safety, and welfare of their citizens. The Department will recognize the right of each Indian nation to set its own priorities and goals in developing, protecting, and managing its natural and cultural resources. This recognition includes separate and distinct authorities that are independent of state governments.

The Department, in keeping with the principle of self-governance, recognizes American Indian and Alaska Native governments as necessary and appropriate non-Federal parties in the federal decisionmaking process regarding actions potentially impacting Indian country energy resources, environments, and the health and welfare of the cities of Indian nations. The DOE will establish protocols for communication between tribal leaders, the Secretary, and federal officials. The DOE will ensure consistent application of program and policy implementation with Indian nations through periodic review, 
assessment, and collaboration with tribal representatives to audit protocol systems. Principles of consistent policy implementation will be tempered with consideration of the diverse cultures and ideals of the Indian nations.

\section{THE DEPARTMENT WILL ESTABLISH MECHANISMS FOR OUTREACH, NOTICE, AND CONSULTATION, AND ENSURE INTEGRATION OF INDIAN NATIONS INTO DECISION- MAKING PROCESSES.}

To ensure protection and exercise of tribal treaty and other federally recognized rights, the DOE will implement a proactive outreach effort of notice and consultation regarding current and proposed actions affecting tribes, including appropriate fiscal year budget matters. This effort will include timely notice to all potentially impacted Indian nations in the early planning stages of the decision-making process, including predraft consultation, in the development of regulatory policies on matters that significantly or uniquely affect their communities. As appropriate, the DOE will provide delivery of technical and financial assistance related to DOE-initiated regulatory policy, identifying programmatic impacts and determining the significance of the impact. The DOE will continue to conduct a dialogue with Indian nations for long- and short- term decision-making when DOE actions impact Indian nations. The DOE will comply with the consultation and Coordination With Indian Tribal Governments Executive Order 13084, May 14, 1998, and the Government to Government Relations with Native American Tribal Governments Executive Memorandum, April 29, 1994.

The DOE will implement permanent workshops and programs for field and headquarters staff on American Indian and Alaska Native cultural awareness and tribal governance.

Due to the nature of the trust responsibility to tribal governments, performance reviews of consultation activities will be conducted, in collaboration with tribal governments.

\section{DEPARTMENT-WIDE COMPLIANCE WITH APPLICABLE FEDERAL CULTURAL RESOURCE PROTECTION AND OTHER LAWS AND EXECUTIVE ORDERS WILL ASSIST IN PRESERVATION AND PROTECTION OF HISTORIC AND CULTURAL SITES AND TRADITIONAL RELIGIOUS PRACTICES.}

The Department will consult with any American Indian and Alaska Native tribal government with regard to any property to which that tribe attaches religious or cultural importance which might be affected by a DOE action. With regard to actions by DOE in areas not under DOE control or when an action of another federal agency takes place on DOE land, DOE will consult with tribes in accordance with this Policy. Such consultation will include tribal involvement in identifying and evaluating cultural resources including traditional cultural properties; facilitating tribal involvement in determining and managing adverse effects; collaboration in the development and signing of memoranda of understanding with DOE, when appropriate.

Departmental consultation will include the prompt exchange of information regarding identification, evaluation, and protection of cultural resources. To the extend allowed by law, consultation will defer to tribal policies on confidentiality and management of cultural resources. Consultation will include matters regarding location and management methodology; repatriation and other disposition of objects and human remains; access to sacred areas and traditional resources located on DOE lands, consistent with safety and national security considerations; and cultural resources impact assessment of potential loss to tribal communities.

The DOE will comply with current and forthcoming cultural resource protection laws and Executive Orders including Native American Graves Protection and Repatriation Act; Archaeological Resources Protection Act; American Indian Religious Freedom Act; National Historic Preservation Act; National 
Environmental Policy Act, Freedom of Information Act; Privacy Act; Indian Sacred Sites Executive Order 13007; May 24, 1996, Consultation and Coordination with Indian Tribal Governments Executive Order 13084, May 14, 1998; Government to Government Relations with Native American Tribal Governments Executive Memorandum, April 29, 1994; Tribal Colleges and Universities Executive Order 13021; Executive Order 12898 on Environmental Justice.

\section{THE DEPARTMENT WILL INITIATE A COORDINATED DEPARTMENT-WIDE EFFORT FOR TECHNICAL ASSISTANCE, BUSINESS AND ECONOMIC SELF-DETERMINATION DEVELOPMENT OPPORTUNITIES, EDUCATION, AND TRAINING PROGRAMS.}

The Department will implement a consistent national outreach and communication effort to inform tribal leaders and tribal program officials about access to internships and scholarships; availability of technical assistance and training opportunities,; conventional and renewable energy development programs; related tribal business and individual member business enterprise, service-provider, and contracting opportunities.

The DOE recognizes the need for direct funding and technical assistance from applicable DOE-sponsored programs within the Department and the national Laboratories which deal with regulation, energy planning, and development of energy resources on tribal lands and Alaska Native site-controlled and trust lands.

The Department will provide information and outreach programs to tribal and individual member businesses on opportunities to participate, compete, and participate in renewable and conventional energy generation, transmission, distribution, marketing and energy services, grants, and contracts. The Department will assist in development of balanced, sustainable, and viable American Indian and Alaska Native communities by continuing to implement Title XXVI, Indian Energy Resources, of the national Energy Policy Act that provides for the promotion of resource development and energy integration.

The Secretary will create programs that encourage and support the establishment of federal, private, tribal and intertribal partnerships. The Department will provide assistance and coordinate with other federal agencies in the development of energy-related projects.

\section{THE SECRETARY OF ENERGY WILL CONDUCT AN ANNUAL TRIBAL LEADERS' SUMMIT FOR PERFORMANCE REVIEW OF POLICY IMPLEMENTATION AND ISSUE RESOLUTION.}

The Secretary will engage tribal leaders in an annual dialogue, to discuss the Department's implementation of the American Indian and Alaska Native Policy. The dialogue will provide an opportunity for tribal leaders to assess policy implementation, program delivery, and discuss outreach and communication efforts, and other issues.

\section{THE DEPARTMENT WILL WORK WITH OTHER FEDERAL AGENCIES, AND STATE AGENCIES, THAT HAVE RELATED RESPONSIBILITIES AND RELATIONSHIPS TO OUR RESPECTIVE ORGANIZATIONS AS THEY RELATE TO TRIBAL MATTERS.}

The DOE will seek and promote cooperation with other agencies that have related responsibilities. The Department's mission encompasses many complex issues where cooperation and mutual consideration among governments (federal, state, tribal, and local) are essential. The DOE will encourage early communication and cooperation among all governmental and non-federal parties regarding actions potentially affecting Indian nations. The DOE will promote interagency and interdepartmental coordination and cooperation to assist tribal governments in resolving issues requiring mutual effort. 


\title{
Attachment 2
}

\author{
Agreement-in-Principle \\ between the Shoshone-Bannock Tribes \\ and the \\ United States Department of Energy
}




\title{
AGREEMENT-IN-PRINCIPLE
}

\author{
BETWEEN \\ THE SHOSHONE-BANNOCK TRIBES \\ AND \\ THE UNITED STATES DEPARTMENT OF ENERGY
}

December 3, 2007 


\section{AGREEMENT-IN-PRINCIPLE BETWEEN THE SHOSHONE-BANNOCK TRIBES AND THE UNITED STATES DEPARTMENT OF ENERGY}

THIS AGREEMENT-IN-PRINCIPLE (this "Agreement") is entered into between the Shoshone-Bannock Tribes of the Fort Hall Indian Reservation ("Tribes") and the United States Department of Energy (DOE). The Tribes and DOE agree that it is mutually beneficial to continue and improve upon the government-to-government relationship that is founded upon the Fort Bridger Treaty of July 3, 1868, 15 Stat. 673 (the "Treaty"), and which has evolved under a Working Agreement formalized between the parties on September 29, 1992 and three Agreements-in-Principle ("AIPs") signed on August 6, 1998 and September 27, 2000. This Agreement supersedes the Working Agreement of September 29, 1992 and the AIPs of August 6, 1998, September 27, 2000, and December 10,2002, and further defines a working relationship between the Tribes and DOE. This Agreement has no effect on or applicability to the Naval Reactor Facility activities.

\section{PURPOSE AND INTRODUCTION}

This Agreement reflects an understanding and commitment between the Tribes and DOE to increase the Tribes' level of assurance that activities being conducted at the Idaho National Laboratory (INL) site protect the health, safety, environment, and cultural resources and address Tribal interests in DOE administered programs. This Agreement is applicable to actions and operations of DOE and its contractors on the lands of the INL that affect aboriginal and Tribal lands. DOE agrees to facilitate, to the extent practicable, Tribal interface with other federal agencies regarding actions and operations of such agencies on INL and other DOE lands that affect aboriginal and Tribal lands. It is recognized that there are terms unique in their application to this Agreement, and those terms are defined in Attachment 1.

This Agreement is designed to promote increased interaction, understanding, and cooperation on issues of mutual concern. DOE acknowledges its trust responsibility to the Tribes and will strive to fulfill this responsibility through this Agreement, DOE American Indian and Alaska Native Tribal Government Policy and other American Indian program initiatives.

The Tribes are a sovereign government obligated to protect individual and communal interest, both on and off the Reservation, as the successors-in-interest to Indian signatories to the Treaty. Accordingly, the Tribes have the responsibility to protect the health, welfare, and safety of their members, the Tribal homelands, and the environment and cultural resources of the Tribes. The Treaty secured the Fort Hall Indian Reservation (the "Reservation") for the Shoshone and Bannock peoples; and the Reservation, aboriginal territories, and ceded areas (collectively, the "Tribal homelands") are the cultural, political, and economic center of the Tribes and are essential to their survival. DOE recognizes the existence of the Tribes' Treaty rights and interests and is committed to identifying, assessing, limiting, and mitigating impacts of the INL activities on, at, or related to INL, that are under DOE control, which affect areas covered by the Tribes' Treaty rights, including both unoccupied and Reservation lands.

12/03/07 FIVE-YEAR AGREEMENT IN PRINCIPLE - 1 
Therefore, activities on, at, or related to the INL shall prevent endangering the unoccupied lands and Reservation lands of the Tribes', and not impair the Tribes' ability to protect the health, welfare, and safety of the Reservation residents and/or the environment and cultural resources of the Tribes.

Article 4 of the Treaty reserved unto the Tribes and their members hunting, fishing, and gathering rights on unoccupied lands of the United States. The parties recognized that the rights provided by the Treaty extend to areas in Idaho and other states, including but not limited to the Salmon River and Snake River regions which may be affected by activities on, at or related to the INL. These guaranteed Treaty rights are of paramount importance to the Tribes, and support their subsistence and culture. Therefore, the ecosystem in these areas must be protected and to the extent possible, remain productive. The land withdrawal of the INL lands for DOE activities and subsequent declarations have identified the INL as occupied lands. The parties agree that in the event the occupied status of any INL lands may change during the term of this Agreement, DOE will consult with the Tribes regarding the application and exercise of Tribal treaty rights on those lands. Consultation would follow a progressive process that includes: 1) notifications and discussions at a working level; 2) technical briefings and discussions to mitigate impacts and effects; and 3) where required or necessary to resolve disputes, a formal government-togovernment consultation between the Tribal Council and the DOE-Idaho Operations Office Manager.

DOE has the primary responsibility to assure that the health and safety of the public are protected from hazards associated with the activities on, at, or related to INL activities. It is the policy of DOE to meet all applicable health, safety, environmental, and transportation standards. DOE will maintain radiation exposures to workers and the public as low as reasonably achievable (ALARA).

DOE also has the responsibility to protect and manage the natural and cultural resources within its jurisdiction. As stewards of INL lands, DOE strives to protect the natural and cultural resources consistent with the principles of ecosystem management and resource protection, in accordance with the applicable federal laws, regulations, policies, and executive orders. The Tribes are an important resource to help DOE achieve those goals.

\section{PROGRAM IMPLEMENTATION}

DOE and the Tribes recognize that the effectiveness of this Agreement rests upon a commitment by both parties to implement the provisions described within this document. DOE and the Tribes will each develop a Program Implementation Plan (PIP) for their respective organizations within ninety (90) days of signing this Agreement. The Tribes' interests in the AIP will be administered by the Tribal/DOE AIP Program Director. The Director agrees to provide to DOE an accounting of DOE funding authorized and obligated under Cooperative Agreement. The Director will report to the Fort Hall Business Council (the "Council") concerning program/project performance and accomplishments.

Implementation may require that Tribal specialists and/or consultants review the reports and such specialists or consultants will be retained by the Tribes with funds from the Cooperative

12/03/07 FIVE-YEAR AGREEMENT IN PRINCIPLE - 2 
Agreement associated with this Agreement. The Tribes will ensure that specialists and/or consultants retained with Cooperative Agreement funds are appropriately qualified for the work to be performed and that their rates are competitive or otherwise justified as fair and reasonable. Tribal hiring practices shall be followed. Reports generated by the specialists and/or consultants retained with Cooperative Agreement funds will be provided to the DOE within thirty (30) days of receipt by the Tribes. If any report is marked confidential, sensitive, proprietary, or Tribal classified matters, DOE agrees to treat such report as confidential and will not disclose such report without the Tribes' written consent.

The Tribes may independently coordinate and collaborate with INL Oversight Program or other DOE oversight groups or organizations as desired to establish or maintain dialogue between the Tribes and the State to obtain environmental monitoring information and/or other information that has the potential to affect known Tribal interests. DOE representatives will facilitate implementation by assisting the Tribes in securing surveillance and other related environmental monitoring information that is or may become available.

A reciprocal, open, and sincere exchange of information is necessary to satisfactorily discharge DOE and Tribal commitments pursuant to this Agreement. The Tribal/DOE AIP Program Director (Director) will work as a liaison between the Tribes and DOE. The Director will actively communicate information developed under this Agreement to the Council and the Tribal membership. The Director will have primary responsibility for ensuring communicating and promoting Tribal involvement in DOE activities and programs. The Director must also understand and represent Tribal interests to DOE and groups, boards, and committees related to DOE activities. The Tribes may appoint Tribal representatives, other than the Director to represent Tribal interests identified under this Agreement. Furthermore, the Director is expected to function as the primary Tribal Advocate to DOE and to assure Tribal interests are presented and addressed. Meaningful involvement can only occur if the interested/affected population has adequate knowledge about the issues of concern.

The DOE American Indian Program Manager (DOE Program Manager) will provide information to the Tribes, in coordination with the Tribal/DOE Program Director, to support activities and functions. Additionally, the DOE Program Manager will promote Tribal interests, educate, and provide guidance for DOE personnel with regard to the DOE American Indian and Alaskan Native Tribal Government Policy and the contents of this Agreement. This will also include communicating information on the Tribes' concerns to DOE Headquarters (DOE-HQ.) This does not preclude the Tribes from directly communicating with DOE-HQ. The DOE Program Manager will also identify available INL resources in support of mutually agreed upon initiatives and oversee and encourage INL efforts by continuing regular interaction with the designated INL Tribal relations point of contact.

In addition, The DOE Program Manager may also be requested to assist the Tribes on matters within DOE's purview, but outside the scope of the Agreement. This may include facilitation between the Tribes and any DOE contractor, organization, or DOE-HQ.

12/03/07 FIVE-YEAR AGREEMENT IN PRINCIPLE - 3 


\section{ENVIRONMENTAL MANAGEMENT PARTICIPATION}

DOE is responsible for cleaning up the legacy of radioactive and chemically hazardous waste at the INL, preventing further environmental contamination, undertaking environmental restoration, and instituting responsible environmental management, including long term stewardship planning and implementation. DOE prepares environmental management plans to identify, integrate, and prioritize compliance and cleanup activities at the INL and other nuclear facilities and sites, and facilitate budget requests to Congress. The environmental management process and planning relate to the development and implementation of several DOE activities, including but not limited to the following areas: environmental restoration, waste management, decontamination and decommissioning, facility transition, technology development, long term stewardship, and transportation and storage of waste.

The Tribes are the primarily affected tribe with respect to DOE and INL plans and activities, and have a role in DOE's planning and implementation process for environmental restoration, long term stewardship, waste management, and other DOE/INL current and future missions.

The Tribes agree to perform the following tasks in support of the development of the INL plans:

A. Attend and participate as a member in Tribal Working Groups, DOE's INL Environmental Management Citizens Advisory Board ( $\mathrm{CAB})$, the State and Tribal Government Working Group (STGWG), the Natural Resources Trustees Council under CERCLA, and other related environmental management meetings, committees and boards which may be formed or scheduled;

B. Provide written comments and identify concerns to DOE on DOE environmental management documents, reports and implementation within agreed upon time frames;

C. Provide opportunities for DOE and contractor representatives to make presentations to the Council, Tribal personnel, and the Tribal membership regarding Environmental Management (EM) and Nuclear Energy (NE) or other related activities;

D. Provide opportunities for DOE and the Council to participate in Government to Government consultation, when needed or requested, to make good faith efforts to resolve issues of concern in a timely matter;

E. Participate in planning groups or meetings concerning the future site uses, changing missions, and land uses of INL and provide substantive input on the alternatives proposed;

F. Participate in the EM regulatory planning process, where appropriate, including review of proposed environmental restoration and waste management activities at the INL, actions proposed under the Federal Facilities Agreement and Consent Order (FFACO), and other relevant activities at the INL.

12/03/07 FIVE-YEAR AGREEMENT IN PRINCIPLE - 4 
G. Provide comments on technologies and research developed for EM restoration and cleanup activities and nuclear energy restoration and clean up activities.

DOE will provide scheduled briefings regarding the EM regulatory planning process and negotiations of enforceable agreements, including review of proposed environmental restoration and waste management activities at the INL, actions proposed under the FFACO, and other relevant activities at the INL.

\section{NATIONAL ENVIRONMENTAL POLICY ACT (NEPA) PROGRAM INVOLVEMENT}

DOE will involve the Tribes in the NEPA process during the analysis and document preparation stages so that meaningful Tribal input can be incorporated into the draft documents. DOE will offer presentations or briefings for Tribal audiences for those NEPA activities that may affect the Tribes and will facilitate the interface with DOE-HQ. The Tribes will be participants in the normal public process leading to issuance of final Environmental Assessments (EA) and Environmental Impact Statements (EISs). DOE may, at its discretion, hold public meetings at the Tribes' request for EISs on the Fort Hall Indian Reservation for those proposed actions that invoke significant interest or have the potential to directly impact the Tribes. DOE will send the Tribes its annual NEPA Planning Summary each January. This will enable the Tribes to request further information and schedule reviews or consultation. For draft EAs concerning proposed actions that may affect the Tribes, DOE will offer the Tribes a thirty (30) day comment period. DOE will consider any comments received in a timely fashion, prior to final NEPA documentation. DOE will respond to and make a good faith effort to address Tribal concerns through communication with the Tribal/DOE Director or Tribal designee.

The Tribes will strive to provide timely input that constitutes the official Tribal position through the Tribal/DOE Program Director, who will coordinate such position with the Council through the Tribal governmental process. The Tribes agree to participate in NEPA program activities and provide timely critical information required by DOE in order to conduct valid and accurate assessments of potential impacts and Tribal concerns.

\section{ENVIRONMENTAL MONITORING PROGRAM INVOLVEMENT}

Because of the proximity of the Reservation to the INL, the Tribes are interested in the direct effects of the INL and its activities on the health and safety of their people. The Tribes are concerned about background characterization and environmental contaminant levels in the air, water (surface and groundwater), and soils regimes located between the INL and the Reservation, including the transportation corridors within the Reservation. They are also concerned about the INL's effects on the ecosystem. To address and meet these concerns, DOE will do the following:

A. DOE will work in cooperation with the Tribes on the sharing of varying types of environmental monitoring data related to the INL;

12/03/07 FIVE-YEAR AGREEMENT IN PRINCIPLE - 5 
B. DOE will provide published quarterly and annual routine environmental surveillance reports to the Tribes;

C. Other environmental monitoring reports will be provided to the Tribes at their request;

D. DOE will work with the Tribes to identify available reports; and

E. DOE will provide opportunities to the Tribes and Tribal/DOE staff to observe, participate, and collaborate in the environmental surveillance programs at the INL.

Following review of the published reports, the Tribes, their specialists, or their consultants may request specific additional information on environmental surveillance or effluent monitoring by independent entities (e.g., USGS, INL or DOE contractors, and DOE). DOE will ensure that the Tribes or their specialists or consultants have access to any existing appropriate information.

If, upon evaluation, the Tribes determine that additional background sampling and/or environmental surveillance of water, soil, and air for any hazardous or radioactive contaminant is needed to effectively assess any impacts of the INL on the Reservation or regional ecosystems, DOE will enter into good faith discussions with the Tribes to try to resolve their concerns. The Tribes may choose to collect baseline data on hazardous contaminant and/or radiation levels on or near the Reservation or any unoccupied lands, for the purposes of determining both background levels and any elevated levels that may result from other INL activities, identifying impacts associated with transportation of radioactive or hazardous materials, and assessing the need for the Tribes' continued monitoring efforts.

DOE will continue to fully support the maintenance and operation of an Environmental Monitoring Station (EMS) on the Reservation by committing Cooperative Agreement funds and other technical assistance, and supporting the partnership between the Tribes, the INL State Oversight Program, and the National Oceanic and Atmospheric Administration (NOAA). This includes the necessary accommodations to access the existing State/NOAA/INL monitoring network in accordance with DOE security requirements.

DOE will, as resources permit, support the development and implementation of a geographic information system (GIS) as a functional tool for accomplishing the objectives identified in this Agreement.

\section{6. $\quad$ RELEASE REPORTING}

DOE will provide the Tribes with data collected and reported to State and Federal Agencies on routine releases of air pollutants, and hazardous and radioactive substances for compliance with the Comprehensive Environmental Response, Compensation and Liability Act (CERCLA), Superfund Amendments and Reauthorization Act (SARA), and the Clean Air Act. DOE will provide copies of the annual National Emission Standards for Hazardous Air Pollutants (NESHAP) radioactive emissions report and the INL Consolidate Air Emissions Inventory to the Tribes. Other release reports under the Clean Air Act will be provided to the Tribes at their request.

12/03/07 FIVE-YEAR AGREEMENT IN PRINCIPLE - 6 
Unless earlier notification is appropriate under the circumstances or otherwise required by applicable laws, regulations, permits, or DOE Orders, DOE will notify the Tribal/DOE Director and Emergency Management and Response Manager, or such other representatives as may be designated by the Tribes. In the case of an emergency release, DOE will notify the Tribes as soon as possible but at least within 24 hours. Otherwise, notification will be accomplished within 48 hours of knowledge of, (a) any release of a hazardous substance, pollutant, contaminant, or radioactive material at the INL site which exceeds applicable regulations, standards, or permit conditions, or (b) any other unplanned release to the environment reported by DOE to any external regulatory or media for informational purposes.

Notwithstanding the preceding paragraph, DOE will ensure notification of the designated Tribal representatives immediately in the event of any release of a hazardous substance, pollutant, contaminant, or radioactive material involving shipments of hazardous or radioactive substances to or from the INL that may present an imminent and substantial danger to the health or welfare of the Tribes. Additionally, DOE will notify the designated Tribal representative of a release into the environment of hazardous substance, pollutant, contaminant, or radioactive material, or any natural emergency/disaster that occurs on the INL that may present an imminent and substantial danger to the health or welfare of the Tribes.

Guidelines for notification for all non-routine releases and transportation accidents shall be applicable DOE Orders, the EPA Protective Action Guides for Radionuclides, and CERCLA. Section 103 and SARA Section 304 for reportable hazardous substances.

After any 'non-routine release as described above, DOE will, at the Tribes' request, hold a debriefing session with the designated Tribal representatives.

If a DOE-related transportation accident occurs on the Reservation, or a DOE related non-routine release or accident occurs off the Reservation which has been determined to affect the Reservation, DOE shall undertake all remedial action required by law, and ensure adequate follow-up environmental surveillance to determine the levels of contaminants and provide this information to the Tribes and their consultants.

\section{EMERGENCY MANAGEMENT}

The Tribes and DOE agree to meet on a regular basis, and also with the State of Idaho, to ensure open communications and understanding of DOE's Emergency Operations Plan and actions taken in times of chemical or radiological releases for the protection of the public, the environment, and homeland security. DOE will provide timely communication to the Tribes in the event of a chemical, radiological release, or natural emergency situations to ensure that the Tribes have maximum practical time for emergency response and preparedness. The Tribes and DOE agree that Tribal emergency responders and personnel must have proper training on DOE/INL-related types of potential chemical and radiological releases, have training on how to respond to such releases, and be adequately prepared to respond to a radiological transportation incident occurring on the Reservation.

12/03/07 FIVE-YEAR AGREEMENT IN PRINCIPLE - 7 
The Tribes recognize that DOE has already provided significant training to them, and DOE will continue to work with the Tribes to ensure that they have and maintain their capability to respond to transportation and other emergencies. DOE will provide sufficient additional training and timely information in order for the Tribes to maintain an up-to-date Hazard Analysis and current emergency operations plan for the Reservation. DOE will work with the Tribes to promote Tribal capabilities for transportation emergencies preparedness, including assistance in identifying non-DOE sources of funding to support emergency response.

The Tribes will maintain the TRANSCOM system and be provided access to INL VIZ (NOAA developed software system that displays meteorological data and release dispersion modeling), as they are vital components of the DOE Emergency Operations Center. The Tribes also agree to maintain emergency response equipment and a standard of proficiency to ensure an adequate response capability.

\section{PROTECTION OF CULTURAL RESOURCES}

The INL is located on Federal land, which is recognized as part of the aboriginal territory of the Tribes, and contains Native American Indian cultural resources. Neither the Tribes nor DOE wish to disturb these resources, but both recognize that cultural resources may be affected during the course of activities on the INL. Protection of these cultural resources, access to sacred sites and sites of traditional use, and repatriation of Native American Indian human remains and associated cultural items are of paramount importance to the Tribes and DOE. As stewards of the resources on the INL, DOE has a trust responsibility to the Tribes in the management of Native American Indian cultural resources on $\mathbb{N L}$ property and for compliance with cultural resource laws and regulations, executive orders and DOE policy. DOE agrees to continue coordination and consultation with the Tribes in their compliance responsibilities with the laws and regulations, executive orders and memoranda, policies, and DOE Orders. DOE agrees to continue the development of a relationship of trust and openness with the Tribes.

DOE will comply with all applicable federal laws and policies, including but not limited to: The National Historic Preservation Act (NHPA), Native American Graves Protection and Repatriation Act (NAGPRA), Archeological Resources Protection Act (ARPA), American Indian Religious Freedom Act (AIRFA), the DOE American Indian and Alaska Native Tribal Government Policy, Executive Orders and Memoranda, and the DOE Cultural Resource Policy and DOE Orders dealing with the protection of cultural resources as defined.

DOE understands the Tribes' position that cultural resources include, but are not limited to, natural resources, sacred sites, traditional cultural properties, camps, burial area's and associated funerary objects, and other items of Tribal cultural patrimony. DOE further understands that objects of religious, traditional, or historic importance to the Tribes include traditional plants, wildlife, and landscapes. When the DOE or its contractors undertake any survey, study, testing, removal, or excavation of cultural resources on the INL site that has the potential to disturb any of those cultural resources, the DOE will notify the Tribes. DOE will involve the Tribes by providing access, opportunities for participation in project planning, and determining affects to the resource except where Tribal involvement is precluded for national security reasons. DOE will provide the Tribes reasonable opportunity and adequate time frames to comment and

12/03/07 FIVE-YEAR AGREEMENT IN PRINCIPLE - 8 
respond to the undertaking. DOE also agrees to engage in government to government, Section 106 of NHPA, or other applicable consultation where required by applicable federal laws, regulations, Presidential Executive Orders and Memorandum, DOE Policies, and DOE Orders. Further, compliance with Section 106 of the NHPA requires DOE to take into account the effects of the federal undertaking on any historic property or historic resource as defined in Section 301 of the NHPA. The Tribes agree to provide to the DOE any information regarding INL sites of known cultural significance.

DOE and the Tribes will use the INL draft cultural resources consultation procedures as a guide and starting point, not as a substitute, for achieving the consultation requirements of applicable federal laws, regulations, orders, and policies.

The Tribes will provide timely response to DOE, within thirty (30) days or as otherwise agreed, regarding the NHPA Section 106 process reviews for federal undertakings on the INL. Final reports of any such studies, surveys, testing, excavation, or removals of cultural resources will be provided to the Tribes.

In the event that human remains or burial sites are inadvertently discovered, accidentally exposed, or potentially threatened the Tribes will be contacted immediately and consultation, as outlined in the draft cultural resources consultation procedures will be initiated.

DOE agrees that Tribal representatives will be permitted to view any discoveries or remains and cultural artifacts, will be authorized to do site inspections of any archeological discovery or excavation, and will be permitted to be present during any archeological excavation, survey, study, or testing on the INL site.

The 1994 Memorandum of Understanding between the Tribes and DOE regarding access to the Middle Butte area will continue to be in effect. In addition, DOE will negotiate in good faith with the Tribes concerning Tribal access to other undeveloped areas of the INL. Access for cultural or religious purposes for Tribal members will be considered and accommodated on a case-by-case basis. Health, safety, and security may be issues for consideration in granting access.

The Tribes, DOE, and DOE contractors shall not release, or allow the release of, any information pertaining to the exact location of any Native American Indian burial sites, archeological sites, or significant sites identified as Native American Indian to the public, unless required by law or legal authority. The Tribes will maintain documents in a manner which prevents release to unauthorized individuals. DOE will coordinate with the Tribes prior to approving, for external publication, any documents that have been prepared as a result of the study, analysis, research, or other work done under the direction and control of DOE, on or in relation to Native American Indian human remains or archeological resources on or from the INL. Publication of work done on archeological resources under curation will be as set forth in the curation agreement with the Idaho Museum of Natural History. For DOE controlled publications that concern Tribal cultural matters, DOE will provide for Tribal review and comment prior to publication, and DOE will make a good faith effort to ensure that the sensitivity and safety of all materials are not compromised. In the event that the Tribes disagree with portrayal of Tribal cultural matters in a

12/03/07 FIVE-YEAR AGREEMENT IN PRINCIPLE - 9 
DOE-controlled publication, DOE will provide for inclusion of a Tribal historical position in such publication. All parties will maintain documents in a manner which prevents the release of sensitive cultural resource information to unauthorized individuals.

DOE and the Tribes, in coordination with the Management and Operations contractor, will finalize and implement a cultural resources management plan which outlines procedures to ensure appropriate management, consultation, and protection of Native American Indian human remains, sacred sites, archeological sites, and other cultural resource issues.

\section{RISK ASSESSMENT OR HEALTH STUDIES}

Residents of the Reservation shall be considered in all regional health and environmental risk assessments conducted by DOE, its contractors or subcontractors, that encompass areas near or affecting the Reservation, and results of the studies, both preliminary and final, shall be presented to the Tribes.

\section{TRIBAL SELF-SUFFICIENCY}

DOE is committed to working with the Tribes in a variety of areas to enhance Tribal efforts in their career pursuits, and will assist the Tribes in their educational development initiatives to maintain self-sufficiency and economic well-being. DOE will provide guidance, mentoring, and other support through technical assistance programs to Tribal students and other Tribal members in their career pursuits, and will assist the Tribes in their educational development initiatives.

DOE will work with the Tribes to help Tribal members become aware of employment opportunities at the INL and of the knowledge and skills they must acquire in order to qualify for employment. DOE, its contractors, and subcontractors will provide notice to the Tribes, through notice to the Tribal Employment Rights Ordinance (TERO) Office and publication in the Sho-Ban News, of employment opportunities; and DOE and its contractors will consider Tribal member applications in accordance with applicable preference and equal opportunity policies, laws, and regulations. Representatives from the INL will visit the Reservation periodically to brief Tribal members on job opportunities and assist them in preparing applications and other required documents.

DOE agrees to hold annual meetings between Tribal officials and representatives from DOE and the INL contractors and subcontractors to discuss opportunities for small business contracts. In addition, DOE will brief Tribal representatives on the INL Community Assistance Program and provide assistance to the Tribes to the extent allowed by the Stevenson-Wydler Technology Innovation Act.

\section{PROMOTING TWO-WAY INTERACTION, UNDERSTANDING, AND COOPERATION}

DOE and the Tribes mutually agree to work toward the promotion of mutual understanding of each other's duties and responsibilities for the benefit of DOE Operations, activities, and public; and to benefit the Tribes' sovereignty, treaty rights, and protection of its membership and public.

12/03/07 FIVE-YEAR AGREEMENT IN PRINCIPLE - 10 


\section{ACCESS TO DOE AND CONTRACTOR PERSONNEL AND FACILITIES}

In implementing this Agreement, the Tribes' representative should generally contact the DOE Program Manager or the Director for Communications. In those cases where working relationships/lines of communication have been established, coordination between those parties is acceptable. Tribal/DOE Program Director and the DOE Program Manager shall be consulted regarding any agreement or significant .communication between DOE and Tribal personnel, unless otherwise provided in this Agreement.

Any necessary or desired contact between Tribal personnel and DOE contractor personnel and facilities will generally be arranged through DOE. In some cases, where lines of communication have been established between the Tribes and contactor governmental relations or technical personnel, direct contact is acceptable, provided no additional costs result.

To enter the INL or any DOE or INL contractor controlled facilities, Tribal personnel must comply with DOE badging and security requirements as arranged through the DOE Program Manager. Entry to some facilities or portions of facilities may be precluded because of safety or security requirements. Entry to certain areas may require specific safety training. DOE or its contractors will provide any specific safety training required for entry.

\section{CONTROLLED DOCUMENTS}

None of various provisions of this Agreement shall be construed as providing for the release of reports or other information designated as "Classified" or "Unclassified Controlled Nuclear Information" (UCNI) to the Tribes, or waiving any other security requirements. Classified information includes National Security Information (10 CFR Part 1045) and Restricted Data (10 CFR Part 1016). Unclassified Controlled Nuclear Information is described in 10 CFR Ch. X, Part 1017. In the event that information requested under the provisions of this Agreement is determined by DOE to be exempt from disclosure under the Freedom of Information Act, providing the information is not Classified or UCNI, is not controlled by the Privacy Act, and does not contain proprietary information or intellectual property information, DOE may, to the extent authorized by law, provide such information to the Tribes upon receipt of the Tribes' written assurance that the Tribes will maintain the confidentiality of such information.

\section{RESOURCES}

DOE will provide financial assistance to the Tribes for the purpose of carrying out the provisions of this Agreement, provided the U.S. Office of Management and Budget and Congress approve funding requests. The financial assistance will be provided through Cooperative Agreement DE-FC07-03ID14443 (or succeeding agreements) consistent with DOE financial assistance rules set forth in 10 CFR Subchapter H, Part 600. The Tribes' obligations to perform under this Agreement are contingent upon adequate funding by DOE. All funds provided to the Tribes are Federal funds to be administered exclusively by the Tribes consistent with the provisions of the Cooperative Agreement. No provision herein shall be interpreted to require obligation or payment of funds in violation of the Antideficiency Act, 31 U.S.C. Sec. 1341.

12/03/07 FIVE-YEAR AGREEMENT IN PRINCIPLE - 11 


\section{AMENDMENTS AND TERMINATION}

This Agreement shall continue in effect from the date of execution for a five (5) year term, and may be modified as mutually agreed. This Agreement shall only be amended or terminated by the written mutual agreement of both parties; provided, however, that DOE funding obligations under this Agreement may be suspended or terminated by DOE, in whole or in part, if DOE determines in accordance with applicable laws and regulations that the Tribes are not in compliance with the terms and conditions of the Cooperative Agreement or in the event that appropriations are not available.

\section{FOR THE SHOSHONE-BANNOCK TRIBES:}

Signed:

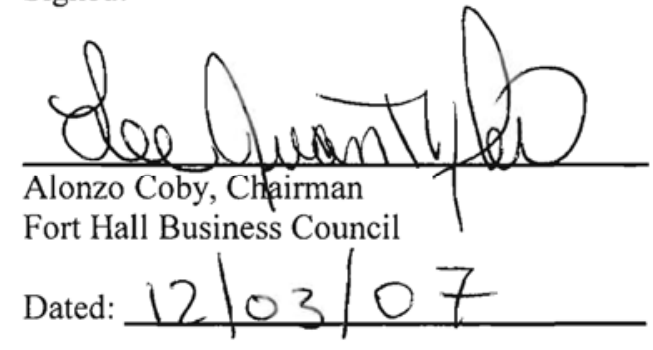

FOR THE U.S. DEPARTMENT OF ENERGY:

Signed:

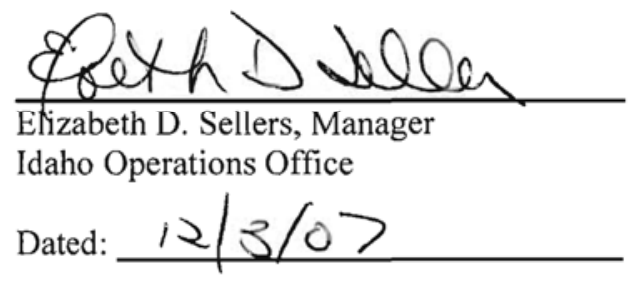


Attachment 1

Page 1 of 2

\section{Terms Defined}

1. Aboriginal Territory - Those lands or areas historically and traditionally occupied, frequented or used by a specific group or Tribe to live or subsist.

2. Ceded Lands - Lands, which are granted, relinquished, assigned, transferred, typically by Treaty. Ceded territories are those lands formerly occupied by Indians that were relinquished to the U.S. government during the Treaty process.

3. Consult (Consultation) - Consultation includes, but is not limited to, prior to taking any action with potential impact upon American Indian and Alaska Native nations, providing for mutually agreed protocols for timely communication, coordination, cooperation, and collaboration to determine the impact on traditional and cultural life ways, natural resources, treaty and other federally reserved rights involving appropriate Tribal officials and representatives throughout the decision-making process, including final decisionmaking and action implementation as allowed by law, consistent with a government-togovernment relationship. For purposes of this Agreement, the consultation process includes: 1) notifications and discussions at a working level;2) technical briefings and discussions to mitigate impacts and effects; and 3) where required or necessary to resolve disputes, formal government-to-government consultation between the Tribal Council and the DOE-Idaho Operations Office Manager.

4. Cultural Resources - For the purposes of this Agreement cultural resources include, but are not limited to: archaeological materials (artifacts) and sites dating to the prehistoric, historic, and ethno historic periods that are located on the ground surface or are buried beneath it, natural resources, sacred objects, and sacred sites that have importance for American Indian and Alaska Native peoples; resources that the American Indian and Alaska Native nations regard as supportive to their cultural and traditional life ways.

5. Historic Properties or Historic Resources - Any prehistoric or historic district, site, building, structure, or objects included in, or eligible for inclusion on the National Register, including artifacts, records, and material remains related to such a property or resource. 16 U.S.C. $\S$ $470 w(5)$.

6. Government-to-Government - This relationship acknowledges Tribal governments as sovereign entities with primary authority for the protection of the health, safety, and welfare of their citizens. Status as a sovereign nation requires the federal government to interact with tribal governments on an official basis, one government to another. Government-togovernment also recognizes a Tribe's right to self-government and self-determination.

7. Reservation Lands - Reservations are established by treaty and specifically sets aside a geographic area for exclusive occupation by a Tribe or Band of Indian people.

12/03/07 FIVE-YEAR AGREEMENT IN PRINCIPLE - 13 
Attachment 1

Page 2 of 2

8. Trust (Responsibility) - Trust Responsibility includes, but is not limited to: promotion and protection of Tribal Treaty rights, federally recognized interests of the beneficiary American Indian and Alaska Native nations; determining, documenting, notifying, and interacting with tribal governments with regard to the impact of Departmental programs, policies, and regulations to protect American Indian and Alaska Native traditional and cultural life ways, natural resources, treaty and other federally recognized and reserved rights.

9. Withdrawal -Withdrawal means withholding an area of Federal land from settlement, sale, location, or entry under some or all of the general land laws, for the purpose of limiting activities under those laws in order to maintain other public values in the area or over an area of Federal land from one department, bureau or agency to another department, bureau or agency. (41 CFR, Section 2300.0-5) 


\section{Attachment 3}

\section{Communications Protocol}




\title{
Communications Protocol August 10, 1999
}

\author{
Communications Protocol for Undertakings Involving \\ Native American Cultural Resources on the INEEL
}

The Department of Energy, Idaho Operations Office (DOE-ID) recognizes and appreciates the need to interact and consult directly with the Shoshone-Bannock Tribes, as well as other tribes, regarding the management of the cultural resources at INL. General provisions for consulting with the Tribes are provided for in the Agreement-In-Principle between DOE-ID and the Tribes, and consultation is required under the American Indian Graves Protection and Repatriation Act (NAGPRA), the National Historic Preservation Act as amended in 1999, Executive Order 13007 and the ensuing DOE American Indian and Alaska Native Tribal Government Policy. To accomplish effective and timely consultation in accordance with the applicable laws involving such consultation, and to enhance the informal interaction needed to serve the needs of the agency, contractor and tribal entities who have a stake in the issues, cultural resource interaction and consultation on the undertakings involving American Indian cultural resources at INL will be conducted in the manner presented here.

These procedures do not supersede or replace any other provisions for consultation with the Tribes or other regulatory agencies under applicable federal or state laws. Rather, they are intended to supplement them and to provide clarification on how and when interaction and consultation between DOE-ID and the Tribes regarding cultural resources at INL will occur. To the extent these procedures are inconsistent with any applicable Federal or state laws, the applicable laws will control.

\section{A. Definitions}

For the purposes of these procedures, the following definitions are provided.

"Cultural resources": "Cultural resources" is a broad term, used generally throughout these procedures, which includes the following:

A. Historic properties as that term is defined in the NHPA [36 CFR 800.2(e)], which includes prehistoric and historic sites, districts, structures or objects, with emphasis on those associated with American Indian origin or culture;

B. Cultural items as that term is defined in the NAGPRA [43 CFR 10.2(d)], which includes human remains, associated funerary objects, unassociated funerary objects, sacred objects, and objects of cultural patrimony;

C. Sacred sites as that term is defined in Executive Order 13007 [Section 1(b)(iii)], which means any specific, discrete, narrowly delineated location of federal land (specifically for the purposes of these procedures, INL) that is identified by an American Indian tribe, or by an American Indian individual determined by the Tribes to be an appropriately authoritative representative of an American Indian religion, as sacred by virtue of its established religious significance to, or ceremonial use by, an American Indian religion;, provided that the Tribe or appropriately authoritative representative of an American Indian religion has informed the agency of the existence of such a site;

D. Traditional cultural properties as that concept is discussed in National Register Bulletin \#38, published by the National Park Service.

"Consultation": This term is used in these procedures to indicate a formal conduct of meaningful dialogue between the Tribal Council and the DOE-ID manager or their duly authorized designees 
with decision-making authority, which is intended to result in a mutually acceptable agreement on the resolution or disposition of an issue related to cultural resources at INL.

"Interaction": This term describes the informal, casual, day-to-day working relationship between the tribal, federal, and contractor technical cultural resources management (CRM) personnel, which is intended to maximize the effectiveness of their working relationships and minimize the administrative barriers to successful, timely, and effective management of cultural resources at INL.

“Undertaking(s)": This term is used as defined in the NHPA and its implementing regulations [36 CFR'800.2(o)].

"Effect" and "Adverse Effect": These terms are used as defined in the NHPA and its implementing regulations $\{36 \mathrm{CFR}$ '800.9]

\section{B. Interaction and Consultation}

Differing levels of activity involving cultural resources at INL require a flexible approach to consultation. For this purpose, three levels of interaction and consultation have been developed, and differ by degree of formality and personnel involved. Technical personnel involved in interaction and consultation should work to avoid the use of a more formal level than is required, in order to make the most effective use of time and resources and to minimize the administrative burden on personnel. However, personnel should use discretion in determining the appropriate level of consultation, and consideration should be given for the need to present an adequately documented record of consultation in the event of disputes. The appropriate level of interaction or consultation to be implemented will be decided by consensus among the tribal, federal and contractor Cultural Resource Management (CRM) technical personnel unless otherwise dictated by law.

\section{Level I: Routine Technical Communication.}

This informal level most often involves the direct interaction of DOE-ID or contractor CRM personnel in the INL Cultural Resources Management Office (INL CRMO) with tribal CRM personnel, or between a subcontractor or other researcher/user personnel and DOE-ID or INL CRMO personnel. Routine interaction would usually occur on a daily or weekly basis as needed, and involves telephone calls, electronic mail messages, working meetings, etc. Another mechanism for routine technical interaction is the periodic meeting of the INL Cultural Resources Working Group (CRWG), consisting of tribal, federal and contractor CRM technical personnel, to discuss issues, activities, project status, or other cultural resource areas of interest.

Two types of formal notification are involved in routine interaction: quarterly summaries of routine, non-impacting undertakings; and notifications of undertakings which occur in previously undisturbed or unsurveyed areas, including caves.

1. Quarterly Summaries of Routine Non-Impacting Undertakings: At the end of every quarter of the federal fiscal year, the INL CRMO will prepare a summary of undertakings at INL that require CRM clearance recommendations or surveys, and which did not affect (as defined in the NHPA) an American Indian cultural resource. This summary will be sent directly to the designated tribal CRM personnel, and to DOE-ID if requested by the DOE-ID cultural resources coordinator. tribal CRM personnel may request additional information about the clearances or surveys related to any of the undertakings listed. This request should be made directly by tribal CRM personnel to the INL CRMO, and the tribal CRM office should provide a courtesy copy of the request to the DOE-ID cultural resources coordinator. 
2. Notification of Undertakings in previously Undisturbed/Unsurveyed Areas: If an undertaking is to take place in an area of INL that has not been previously disturbed in any way, or has not yet undergone any degree of archaeological survey, the INL CRMO will notify the tribal CRM personnel of the undertaking and the location, upon a determination to begin any activity pursuant to the undertaking. The intent of this notification is to allow the Tribes the opportunity to comment on or become otherwise involved in the undertaking at the earliest possible time. The tribal CRM personnel are encouraged to use this opportunity to provide information regarding cultural resources which may assist in the planning or implementation of the work being performed.

This notification may be made by telephone call, faxed message, electronic mail (e-mail) or other informal mechanism. The INL CRMO should have additional information, such as maps, project descriptions, etc., ready to provide to the tribal CRM personnel upon request. As provided in the Agreement-In-Principle, tribal representatives are permitted to inspect, review or be present at and during any archaeological excavation or survey of interest at INL provided adherence to all security, safety, and environmental requirements is met.

DOE-ID recognizes and supports the need for the Tribes to keep certain sensitive or sacred information from being released to non-tribal members, and does not desire to compromise this need. DOE-ID, contractor personnel, and the Tribes should work to communicate the need to avoid certain areas in a sensitive and respectful manner, which also allows project planners to proceed with their planning in a timely manner.

\section{Level II: Intermediate Interaction.}

The second level of interaction is actually a formal consultation between the technical CRM personnel for DOE-ID, the Tribes, and the INL CRMO, acting as the designees of their respective agencies. This level is entered into when it is determined (either through Level I interaction or other means) that an undertaking has the potential to affect an American Indian cultural resource. This level is also the level at which formal notification of the State Historic Preservation Office (SHPO) is made for the purposes of conducting a NHPA Section 106 review of undertaking.

1. Notifications of Undertakings: The notification method will be an immediate telephone call to the tribal CRM office by either DOE-ID CRM or the INL CRMO as soon as possible when either the INL CRMO or DOE-ID determines that an undertaking may have an effect upon an American Indian cultural resource. A formal letter of notification should be sent from the DOE-ID CRM to the tribal CRM office within 10 working days of the notification call, and to the SHPO if the cultural resource affected is a historic property. This letter should include a request for further consultation. INL CRMO should also notify the appropriate contractor management authority, to ensure that their management is aware of the potential effect and the potential need for mitigation measures. If the notification to the SHPO is made for an undertaking involving a historic, but non-American Indian, resource (i.e., a built historic property), the tribal CRM office need not be notified.

2. Emergency Notifications. In the event that an appropriate INL authority declares a site emergency in response to a natural disaster or other threat to the environment, facility, the public, or personnel, the notifications will be conducted in accordance with the INL Emergency Management Plan/RCRA Contingency Plan. Follow-up interaction of CRM personnel to determine if the emergency or emergency response had any effect on American Indian cultural resources or to determine how to mitigate any adverse effects of the emergency or emergency response on those resources will be conducted at Level II as soon as possible following cessation of the emergency status. The DOE-ID cultural resources coordinator should send any formal notification or other documentation to the tribal CRM personnel within 10 working days of the declaration of the emergency. 
3. Inadvertent Discoveries: In the event that an inadvertent discovery of a cultural resource involves human remains or American Indian cultural items as defined in NAGPRA, all parties should initiate Level III consultation, and then proceed as mandated in NAGPRA and its implementing regulations at 43 CFR 10, or as provided in any agreement entered into between DOE-ID and the Tribes pursuant to 43 CFR 10.5(f).

\section{Level III: Government-to-Government Consultation.}

This is the most formal level of consultation, and involves communication between the tribal chairperson and the DOE-ID manager. Such consultation will be utilized when the INL CRMO, in consultation with appropriate parties (including DOE-ID, the tribal cultural resource personnel, the SHPO, and project managers), determines that an undertaking will have an adverse effect upon an American Indian resource, and mitigation needs to be performed, or when American Indian human remains or other cultural items as defined by NAGPRA are inadvertently discovered.

1. Notification of Tribes: In either situation, Government-to-Government consultation shall be initiated with a formal letter of notification from the DOE-ID manager to the tribal chairperson within 10 working days of the determination of the adverse effect, or within the time limits mandated by NAGPRA in the case of an inadvertent discovery of human remains or cultural items. The letter should include a request for technical consultation on mitigation of the adverse effect or on the disposition of the remains or cultural items. In the case of human remains, the letter must include other information as required by NAGPRA's implementing regulations [43 CFR 10.4(d)].

2. Notification of SHPO and others: The DOE-ID cultural resources coordinator should also provide notification to the SHPO or the State Archaeologist, as appropriate and per the requirements of NHPA Section 106. Courtesy copies of all notifications should be provided to the distribution list given at the end of these procedures.

3. Meetings: If the Tribes desire any personal meetings or presentations about the undertaking, the effect, the remains or the resource, DOE-ID and INL CRMO and their respective project managers should coordinate to prepare and deliver the information in a manner and location requested by the Tribes.

4. Technical Mitigation: Once the initial letter of notification and request for consultation has been sent to the tribal chairperson, the respective CRM technical personnel should implement lower levels of consultation or interaction to work out the details of mitigation or disposition, at the discretion of the tribal chairperson and the DOE-ID manager. The cultural resource technical personnel will define the project history, recommend mitigation or disposition alternatives, coordinate with any project or program managers whose projects may be effected by the disposition or mitigation, assist in preparing formal correspondence, provide assistance to the Government and Council officials, and assist in the project mitigation or disposition as deemed necessary by the Government and Council officials.

5. Letter of Proposed Disposition or Resolution: A final letter documenting the agreed-upon course of resolution and any implementation plan developed should be sent from the DOE-ID Operations manager to the tribal chairperson, and should include a courtesy copy to INL CRMO and any appropriate contractor and DOE-ID managers. In the case of an inadvertent discovery of human remains or cultural items, per NAGPRA, DOE-ID will proceed with the specified requirements in NAGPRA's regulations at 43 CFR ' 10.4 et al.

\section{Conflict Resolution}

If resolution or consensus cannot be reached after reasonable effort and discussion on the part of the respective tribal, federal, and contractor CRM technical personnel, the next highest level of consultation will automatically be implemented. If resolution or consensus cannot be achieved at Level III, a 
professional mediator, amenable to all parties, shall be invited to participate in the decision making process.

\section{Revision of Procedures}

These procedures may need to be periodically revised or updated to reflect changes in law, agreement, organization or other factors. Such revision should be accomplished after DOE-ID, INL CRMO and tribal cultural resource personnel agree on the need for changes to these procedures, and should be done in a mutually agreeable manner. DOE-ID will take the lead on preparing the revisions, and distributing drafts to the tribal and INL CRMO cultural resource personnel. Proposed revisions should be reviewed by all appropriate and affected federal agency, contractor, and tribal personnel, including but not limited to project managers, legal advisors, technical personnel, and regulatory personnel. DOE-ID, INL CRMO and tribal cultural resource personnel should consider any comments or suggestions received by reviewers, and incorporate consensually agreed upon changes where appropriate. 


\section{Communications Protocol June 8, 1999}

\section{Correspondence List}

Courtesy copies of relevant correspondence, including letters of notification prepared during Level II or Level III consultation, should be provided to the following list of personnel:

\section{$\underline{\text { DOE-ID }}$}

Environmental Programs manager, tribal liaison officer, cultural resources coordinator

Project manager

Office of Chief Counsel

INL Cultural Resource Management Office

Project manager

Regulatory Affairs manager and other senior level managers (in case of Level III consultation)

$\underline{\text { Tribal }}$

Tribal attorney

Tribal Business Council (in case of Level III consultation)

Tribal cultural resources coordinator

Other (depending on situation and level of consultation)

Idaho State Historic Preservation Office

This distribution list should be kept current, and revised as personnel and titles change. The respective CRM personnel are responsible for notifying the INEEL CRMO of changes as soon as possible. Revisions to the list should be prepared by the INEEL CRMO, and provided to DOE-ID and tribal CRM personnel as soon as possible. 


\section{Attachment 4}

\section{Memorandum of Agreement Between United States Department of Energy, Idaho Operations Office and the Shoshone-Bannock Tribes}




\section{MEMORANDUM OF AGREEMENT BEIWEEN}

\section{UNITED STATES DEPARTMENT OF ENERGY IDAHO OPERATIONS OFFICE}

and the

\section{SHOSHONE-BANNOCK TRIBES}

\section{INTRODUCTION AND PURPOSE}

The United States Department of Energy (DOE), a federal executive agency, through its Idaho Operations Office (DOE-ID), owns and operates the Idaho National Engineering Laboratory (INEL), an approximately nine hundred square mile nuclear facility site in southeastern Idaho. Under the Atomic Energy Act of 1954, as amended, the Energy Reorganization Act of 1974, and the Department of Energy Organization Act, functions performed at the INEL include research and development in nuclear and other energy areas, and projects and programs related to environmental restoration and waste management.

The Shoshone-Bannock Tribes ("Tribes") are a federally-recognized Indian tribe. The Fort Bridger Treaty of July 3,1868, 15 Stat. 673, secured the Fort Hall Reservation as the permanent homeland of the Shoshone-Bannock peoples. The aboriginal rights reserved by the 1868 Treaty extend to areas of land in Idaho and surrounding states, and the Treaty reserved for Tribal members hunting, fishing, and gathering rights on surrounding unoccupied lands of the United States. While the parties acknowledge that the INEL Site is occupied land, it is recognized that certain areas on the INEL Site have cultural and religious significance to the Tribes. The INEL is located within the aboriginal territory of the Shoshone-Bannock Tribes.

DOE Order 1230.2, and DOE's American Indian Policy of November, 1991, establish DOE's commitment to assure that tribal rights and concerns are considered, and to avoid unnecessary interference with traditional religious practices. This policy also provides for access to sacred areas and traditional resources located on DOE lands in accordance with safety, health, and national security considerations.

In order to preserve and protect the cultural and religious interests of the Tribes, DOE and the Tribes are entering into this Memorandum of Agreement ("MOA") to provide the Tribes access to the Middle Butte area, and other INEL areas that may be identified for access in the future, for the performance of Tribal sacred or religious ceremonies, or other cultural or educational activities. The Middle Butte area is defined generally as that area within the boundaries of the INEL, directly south of Highway 20 and east of Highway 26, legally described as Sections $15,16,17,20,21$, and 22 of T 2 N, R 32 E, Bingham County, Idaho. A map of the area is attached hereto and incorporated herein to this MOA. 


\section{LEGAL AUTHORITY}

Legal authority for this MOA is as follows:

A. The Department of Energy Organization Act, 42 U. S. C. Section 7101 et seq., which envisions consultation, coordination, and cooperation with Federal departments and agencies to assure coordinated and effective administration of Federal energy policy and programs. The Act also establishes the statutory responsibility to ensure incorporation of national environmental protection goals of restoring, protecting, and enhancing environmental quality, and assuring public health and safety.

B. DOE Order 1280.1A delegates authority to the Manager of DOE-ID to enter into Memoranda of Understanding.

C. The Tribes as a sovereign government are obligated to protect both the individual and communal interests of the Tribes pursuant to the 1868 Treaty. The Fort Hall Business Council, governing body of the Tribes, has authority under the Tribes' Constitution and Bylaws to enter into agreements.

\section{SCOPE}

This MOA addresses access by the Tribes to the Middle Butte area and other INEL areas that may be identified for access in the future, in a manner which assures that safety, security, and cultural resource protection concerns are met.

\section{GUIDELINES}

DOE-ID and the Shoshone-Bannock Tribes understand that the following guidelines will apply to activities conducted by the Tribes at the INEL:

A. DOE shall provide access to the Middle Butte area for the ShoshoneBannock Tribes. Such access shall be for the purposes of allowing Tribal members to. perform sacred or religious ceremonies or other educational or cultural activities in the Middle Butte area.

B. The Tribes shall notify Protective Technologies Idaho (PTI) Security Headquarters at least 24 hours prior to entry onto the INEL, and shall provide them with the name of the Tribal member who will be responsible for the group, an approximate number of people who will be at the Middle Butte area, and an estimated time of their arrival and departure from the INEL. 
C. DOE shall provide a briefing to the Tribes within 30 days of the signing of this MOA. The briefing will address concerns with unexploded ordnance which exists on the INEL. This briefing may be periodically updated, as necessary. To ensure the members' continued safety, the Tribes agree to apprise all members who may seek access to the Middle Butte area of the potential risks from unexploded ordnance. DOE has not confirmed through ground survey that no unexploded ordnance is in the access area. The access area is as close as two miles from the perimeter of areas known to be used for ordnance testing. The Tribes recognize and assume the risk of the potential for unexploded ordnance and take responsibility for the safety of its people while in the Middle Butte area. The Tribes agree to notify DOE of the location of any ordnance discovered.

D. DOE and the Tribes recognize that there are certain cultural and archaeological resources located on the INEL, and that such resources should be protected from damage, alteration, removal or destruction. Both parties agree to avoid any damage, alteration, removal or destruction of such cultural or archaeological resources, or any other resources which may be encountered at the INEL, and to conduct activities consistent with other applicable requirements, including the National Historic Preservation Act, the Archaeological Resources Protection Act, Native American Grave and Repatriation Act, and any other act preserving cuitural resources. Ceremonial offerings shall be permitted but must be reported to the Tribal Cultural Resource Department and made a part of the Middle Butte area record. Motorized vehicle access shall be limited to existing roadways.

E. This MOA shall not confer any rights upon members of the Tribes for purposes of hunting or fishing on the INEL other than what is reserved by treaty, nor shall it confer any property interest (e.g., an easement or license) to the Tribes.

\section{FUNDING}

This MOA does not in and of itself obligate any funds of the United States.

\section{WORKING AGREEMENT}

The DOE-ID and the Tribes agree that this MOA is not and will not be interpreted as being inconsistent or in violation of any provision of the Working Agreement entered into on September 29, 1992.

\section{AMENDMENT}

This Memorandum of Agreement may be modified or amended by written agreement between DOE and the Shoshone-Bannock Tribes. 


\section{EFFECTIVE DATE}

This Memorandum of Agreement is effective when signed by both parties, and shall continue in effect until mutually terminated by both parties, or upon 30 days' written notice by either party.

Fort Hall Business Council for the Shoshone-Bannock Tribes

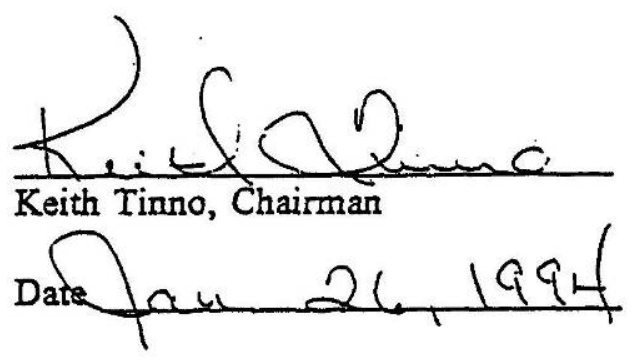

U. S. Department of Energy Idaho Operations Office

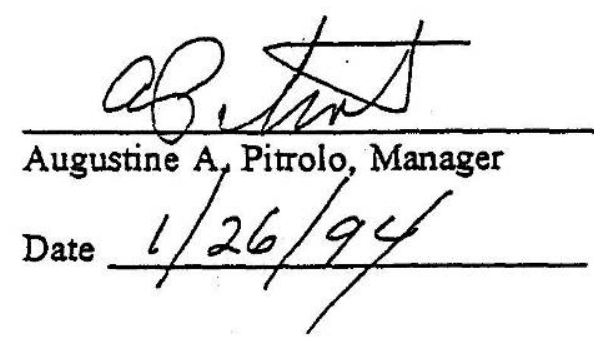




\section{Appendix C}

\section{Standards and Procedures for the Management of INL Archaeological Properties}




\section{Appendix C}

\section{Standards and Procedures for the Management of INL Archaeological Properties}

\section{INTRODUCTION}

This section describes the general professional and program standards for archaeological investigations at INL. Examples of documents that support performance of archaeological investigations at INL, referred to as figures, are presented at the end of the appendix.

The INL CRM Office conducts cultural resource advisory, compliance, and research activities for DOE-ID and manages and coordinates all cultural resource investigations, including oversight of subcontractors and outside researchers in archaeology, history, and paleontology. Similar standards and procedures for the management of INL historic architectural resources are provided in Appendix D.

Standards and guidelines have been issued by the Idaho SHPO through the Idaho Archaeological Survey, Idaho Advisory Council of Professional Archaeologists, national ACHP, and U.S. Department of Interior National Park Service (NPS). All cultural resource management work at INL is and will continue to be performed in a manner consistent with these authorities. This protocol will be reviewed annually and updated as necessary in response to changes in federal, state, and professional guidelines as well as internal and external feedback obtained from experience conducting cultural resource management and scientific activities at INL.

\section{INL ARCHAEOLOGICAL RESOURCES}

INL contains a great number of archaeological sites from the prehistoric and historic time periods and even a variety of industrial archaeological sites from the very recent past. Because modern development within the 890-square-mile facility has been limited in expanse, many of these resources exhibit remarkable integrity. Since the early 1970s, DOE and its contractors have been committed to protecting INL archaeological resources from unmitigated harm during INL activities.

\section{History of INL Archaeological Investigations}

Archaeological investigations at INL, initiated in the late 1950s, have passed through four successive stages. The first stage involved numerous visits to areas where prehistoric sites were known or expected to have occurred. These initial projects were directed by E. H. Swanson, Jr., of the Idaho Museum of Natural History, as part of a larger project to examine prehistoric sites in all of southeastern Idaho (Swanson 1972; Swanson and Bryan 1959; Swanson, Butler, and Bonnichsen 1964; Swanson, Tuohy, and Bryan 1959; Reed et al. 1987). Later, from 1967 to 1972, additional intuitive surveys were conducted on INL lands by individuals under the direction of B. R. Butler in an effort to discover the nature and distribution of archaeological resources in the desert region of the northern Snake River Plain (Butler 1968; Butler 1970; Butler 1978).

The early intuitive surveys directed by Swanson and Butler were important in establishing the archaeological research potential of the INL region, particularly with regard to its prehistoric resources. Many important archaeological sites within caves, atop buttes, and near the margin of Pleistocene Lake Terreton were recorded through their efforts. However, these early surveys stand in contrast to the later 
systematic inventory projects because the latter have shown that INL not only holds many large and complicated prehistoric sites, but also contains thousands of smaller resources that are equally important in understanding prehistoric lifeways. They have also brought attention to INL's inventory of important archaeological resources from the historic period, particularly those related to Carey Land Act-sponsored agricultural pursuits.

Beginning in 1974, INL entered into the modern era of cultural resource management and the second stage in development of the current Cultural Resource Management Program. The cultural resource inventories conducted during the past 25 years are generally more intensive and systematic than previous work. This is largely due to the fact that most have been conducted with the specific goal of meeting regulatory requirements to identify and assess impacts to all cultural resources, rather than simply discovering the largest or oldest sites.

The first surveys of this modern era were supervised by S. J. Miller from 1974 to 1984 and included many small construction projects as well as several larger projects such as INL Perimeter and Grazing Boundaries, the Diversion Area, and the New Production Reactor Areas. Over 400 INL archaeological resources from early prehistoric through historic time periods were systematically recorded as a result of this work (Miller 1983; Miller 1984; Miller 1985; Reed et al. 1987).

Beginning in 1985, the INL Cultural Resource Management Program moved into a third stage of development with the initiation of a subcontract with the Idaho State University Department of Anthropology for large cultural resource inventory projects. R. N. Holmer directed most of these projects through an organization named variously as the Swanson/Crabtree Anthropological Research Lab, the Northern Intermountain Quaternary Institute, and the Center for Environmental Anthropology (see Ringe 1993 for a summary). The first projects involving archaeological test excavation at INL were also completed under this agreement (Wright 1988; Ringe 1988).

The Idaho State University surveys are important because they set a methodological precedent for all subsequent archaeological investigations at INL. The standardized methods employed during these projects are still in use today because they are of sufficient rigor to ensure that all cultural resources with visible surface remains are identified in all project areas. Many large INL survey projects were completed by the teams from Idaho State University from late 1984 through July of 1991, with 1,050 cultural resources recorded. Significantly, subsurface testing was also conducted at 64 prehistoric site locations during this period (Ringe 1988; Wright 1988; Ringe 1990; Henrikson and Holmer 1991; Thompson 1991; Sammons and Furniss 1992).

The fourth and most recent stage in the development of the INL Cultural Resource Management Program began in 1989 with the formation of the INL Cultural Resource Management Office to serve as a focal point for information flow and action regarding cultural resource compliance and research at INL. Since the creation of this team, most archaeological surveys at INL have been conducted in-house. Attention has been directed beyond basic compliance with Section 106 of the National Historic Preservation Act to the full spectrum of cultural resource issues, including public education and outreach, American Indian consultation, site monitoring, compliance with NHPA Section 110, and long-term stewardship (INL CRM 2004, 2005, 2007, 2008).

As the INL Cultural Resource Management Program has matured, initial focus on archaeology has expanded to include an emphasis on archaeological sites, buildings, artifacts, and archives associated with more recent INL history. As a result of the unique nature of the work conducted at INL, many buildings and structures are considered to be historically significant (Arrowrock Group 1997). With increasing emphasis on environmental restoration, there has been a corresponding increase in cultural resource reviews of actions affecting these resources (see Appendix D). 
In addition, stakeholder involvement became increasingly formalized in 1992 with the establishment of a working agreement between the Shoshone-Bannock Tribes and DOE-ID. This agreement has been superseded in successive years by new agreements-in-principle that continue to refine the working relationship between the Tribes and DOE-ID while promoting increased interaction, understanding, and cooperation on issues of mutual concern, such as protection of natural environment and cultural resources (see Appendix J). In the spirit of openness fostered by the agreements (c.f. DOE-ID 2007), and in recognition of the need to often facilitate communication from the ground up, the INL Cultural Resource Working Group was established in 1992. Comprised of preservation professionals from the ShoshoneBannock Tribes, DOE-ID, and the INL CRM Office, the group strives to reduce potential conflicts in the sensitive relationship between steward and stakeholder. The CRWG addresses diverse issues such as, but not limited to, traditional cultural places, sacred sites, cultural landscapes, human remains, and a variety of other resources that fall under the purview of the Native American Graves Protection and Repatriation Act, NHPA, and ARPA.

\section{Archaeological Resource Types}

Through the efforts of the aforementioned preservation professionals, approximately $7 \%$ of INL has been intensively surveyed ( $\leq 20$-meter survey intervals) and another $2 \%$ of INL has been subjected to reconnaissance-level examination (50- to 100-meter survey intervals). Within the 38,752 acres that have been intensively examined and the 13,425 acres that have been less intensively examined are 2,537 identified archaeological resources. The majority of these resources are open sites, exposed at the current ground surface, which consist of campsites, lithic scatters, and rock features from the prehistoric period $(13,500$ to 150 years ago). A preliminary predictive model suggests that there may be as many as 75,000 additional resources of these types as yet undiscovered within the boundaries of INL (Ringe 1995). Lava tube caves also contain sensitive archaeological materials on the INL, including Native American pictographs and burial sites.

Also represented in the inventory of 2,537 known INL archaeological resources are localities that reflect more recent activities including homesteads, irrigation canals and canal construction camps, emigrant trails, stage stops, and railroad sidings, as well as trash dumps and other features associated with U.S. government use of INL after 1942.

\section{INL POLICIES FOR ARCHAEOLOGICAL RESOURCES}

DOE-ID and its contractors follow specific procedures to conduct research, environmental remediation, and operations at INL in a manner that protects human health and the environment in full compliance with environmental laws and regulations (see Appendix A). Cultural resources, including archaeological resources, are an expressed part of the protected environment. Protection is achieved through integration of environmental requirements into work planning and execution and consistent actions to minimize the environmental impacts of INL operations. This integrated approach applies to all INL employees and subcontractors who are also expected to report any environmental concerns to INL management. Management, in turn, is expected to take prompt action to address any concerns or issues.

The INL environmental policy is implemented through internal standards and procedures as summarized in Appendix A. Cultural resource protection is an integral element in these procedural documents and is accomplished through a tailored review process that directly involves the INL CRM Office. 


\section{The Cultural Resource Review Process}

INL is an active scientific and engineering laboratory. Thousands of work orders for projects ranging from lawn mowing to new facility construction are processed each year. Detailed procedures are in place to evaluate the environmental consequences of all activities, large or small.

INL CRM Office review of proposed projects is prompted whenever one of the following basic thresholds is met:

1. Ground disturbance outside the boundaries of fenced INL facility areas or more than $50 \mathrm{ft}$ from existing buildings or landscaped areas in unfenced facility areas

2. Demolition, major structural or landscape modification, or permanent closure of extant buildings or structures (see Appendix D)

3. Any activities proposed for the EBR-I facility area, a National Historic Landmark (see Appendix D)

4. Any ground disturbance within or around CITRC, where sensitive human remains have been inadvertently discovered in disturbed and undisturbed contexts

5. Any activities proposed for known or suspected zones of American Indian sensitivity and/or high archaeological resource density.

Proposed INL projects that meet one or more of these criteria are screened by the INL CRM Office to determine if they will affect cultural resources. Various techniques are employed to make this determination, including archive and record searches, on-the-ground surveys, monitoring of ground disturbance, and consultation. Basic guidelines for the conduct of these activities are provided in expanded discussions to follow and in Appendix D. Archaeological reviews are not completed for projects that occur within highly disturbed areas inside fenced INL facilities (TAN, WRRTF, NRF, RTC, INTEC, RWMC, MFC) or within $50 \mathrm{ft}$ of standing buildings or structures in unfenced INL facilities (CFA, ARA, BORAX). EBR-I and CITRC are exceptions to this general rule because they each contain resources of special concern (National Historic Landmark at EBR-I and American Indian human remains at CITRC). Emergency activities are also exempt from cultural resource review.

In general, all cultural resource reviews for archaeological resources begin with an exchange of information between the INL project manager and the INL CRM Office with the purpose of identifying an area of potential effect for the proposed project. Once this area is defined and the proposed activities within it are clearly understood, the INL CRM Office conducts an archive and literature review to determine the extent and results of any previous archaeological investigations within the project's area of potential effect.

The archive and literature search is designed to evaluate previous efforts to identify cultural resources within the area of potential effect for the proposed project and assess the need for additional archaeological survey, data recovery, and/or consultation. Areas of potential effect for projects proposed outside the boundaries of defined INL facility areas will always be intensively surveyed for archaeological resources before any work begins. In some instances, previously surveyed areas will be reexamined. This may occur if the previous survey was originally conducted more than 10 years ago or is judged to be of less rigor than current requirements call for, if conditions have changed markedly since the original survey was conducted (e.g., range fire), or if the proposed project is located in a highly sensitive area (e.g., CITRC and the Big Lost River). Other situations may call for intensive new surveys of proposed project areas and still others a mix of on-the-ground survey and stakeholder consultation.

Once all archaeological resources are identified within a project's area of potential effect, the INL CRM Office will determine if the proposed project will cause any impacts to the resources through a 
combination of additional archaeological or archival investigation and consultation. Three scenarios are possible for archaeological resources at this point in the cultural resources review process:

1. No cultural resources are present within the area of potential effect for the proposed undertaking, or cultural resources are present in the area but the proposed undertaking will have no effect on them because they are included in the official list of exempt resources (e.g. isolated finds) or they can be avoided by all project activities

2. Cultural resources that are potentially eligible for listing on the National Register are present within the area of potential effect and the proposed undertaking will impact them, but the effect will not be adverse

3. Cultural resources are present within the area of potential effect and the proposed undertaking will adversely impact them

When no archaeological resources have been identified in the project area, the INL CRM Office completes documentation of the identification efforts and a justification of the finding of no effect for inclusion in the INL cultural resource management project files (see Figure 31). These findings are also summarized and included in INL CRM Office yearly activity reports. After documentation is complete, the INL CRM Office provides written notification to the INL project manager with a recommendation that the project can proceed. Clearance recommendations such as this always carry a standard stipulation for stopping work if cultural materials (e.g., bones, obsidian flakes, "arrowheads" or other stone tools, darkened soil horizons, rusty cans, and ceramics) are unexpectedly encountered at any time.

A similar set of procedures is followed when identification efforts reveal archaeological properties that are not eligible for the National Register within the area of potential effect for the project. This includes any of the following types of archaeological resources:

- Isolated finds

- Archaeological resources that have been previously determined through consultation with the Idaho SHPO, Shoshone-Bannock Tribes, and other stakeholders and interested parties to be ineligible for nomination to the National Register or of no significance to the specified cultural group.

These properties are considered to be ineligible for nomination to the National Register because they exhibit no potential to yield additional information (as determined by the original identification effort or some other type of previous archaeological investigation or consultation), setting has no bearing on their significance, and they are not deemed important by the appropriate tribal or stakeholder parties. Therefore, INL project activities will not significantly affect them, and they need not be avoided by project activities. Once documentation of the identification efforts and a justification of the no-effect finding are complete and permanently filed (see Figure 30), the INL CRM Office can recommend clearance for these projects through written correspondence with the INL project manager. Reminders of the INL Stop Work Authority and its applicability to unexpected discoveries of cultural material are also included with each of these clearance recommendations.

Whenever possible, the INL CRM Office will endeavor to avoid impacts to all archaeological resources as a result of INL activities. This is particularly true when identification efforts (i.e. new survey, evaluation of resources recorded during a previous survey, and consultation) within a project's area of potential effect reveal archaeological resources that may be eligible for nomination to the National Register or are significant to a local cultural group. The INL CRM Office takes a very conservative approach to significance evaluations in these, and all, situations. All archaeological sites are considered to be potentially significant until test excavations and/or consultation have been completed to assess their potential for yielding information of value in understanding research questions in history or prehistory 
(See Appendix E) and/or their importance to local cultural groups. Techniques employed to avoid damage to resources evaluated as potentially significant include, but are not necessarily limited to:

- Physical relocation of project activities

- Establishment of minimal buffer zones (30 to 50 meters), depending on the situation, between the archaeological resource and the project activities

- Placement of fences or other permanent markers around the perimeters of archaeological resources to physically prevent unauthorized access or disturbance

- Placement of signs in the project area advising that destruction, alteration, or collection of historic and prehistoric archaeological materials is a federal crime

- Placement of protective fill or other coverings over the surface of archaeological resources to act as a physical buffer between the sensitive materials and the project activities

- Requirements for all project personnel to successfully complete cultural resource awareness training and specific project briefings provided through the INL CRM Office

- Requirements for ongoing and intensive monitoring of project activities by the INL CRM Office to ensure compliance with agreed upon avoidance tactics.

When the setting is an important element in the significance of an archaeological resource, other techniques may be employed to effectively remove the resource from the area of potential effect for the project. Project relocation or physical limitations, restrictions on the timing of project activities, vegetative or landscape screens, and post-project rehabilitation are a few of the options available for preventing impacts in these situations.

Decisions regarding the methods used to avoid adverse impact to significant archaeological sites are made by INL professional archaeologists in regular communication with the Shoshone-Bannock Tribes when the project involves sites of tribal importance and are documented and retained in the INL CRM Office project files. Some survey projects and corresponding recommendations for resource protection are summarized in technical reports that are submitted to the Idaho SHPO, Advisory Council, ShoshoneBannock Tribes, and applicable interested parties.

While avoidance through project modification is the preferred option for avoidance of adverse effects to INL archaeological resources, it is not always feasible. In the case of an unavoidable adverse effect, DOE-ID and the INL CRM Office are committed to direct and meaningful consultation with the Idaho SHPO, Shoshone-Bannock Tribes, and other interested parties and stakeholders to develop measures to minimize or mitigate the adverse impact. The INL CRM Office begins this process by preparing a summary report (see Figure 32).

Decisions about the most appropriate methods for mitigating or minimizing adverse impacts to significant archaeological sites are always made in consultation with the Idaho SHPO, Shoshone-Bannock Tribes, and other stakeholders and interested parties. When this situation arises, the INL CRM Office prepares a summary report for the project according to the standard format presented here as Figure 32. Critical pieces of information included within this technical report are:

- A description of the project and its area of potential effect

- A description of the steps taken to identify archaeological resources within this area

- Descriptions of the affected cultural resources, including site recording forms and significance evaluations

- A description of how the project will affect cultural resources 
- A site treatment plan that proposes measures to be taken to mitigate or minimize adverse effects

- Copies or summaries of any views provided by consulting parties and the public.

Copies of this documentation are provided to the consulting parties for a 30-day review period. During this time, all parties work together to consider the actions proposed by the INL CRM Office to minimize or mitigate impacts to archaeological sites and agree upon a final plan to complete the project. When concurrence is reached, the INL CRM Office provides documentation of all efforts to the INL cultural resource management archives and INL project manager; the project can then proceed under the stipulations for archaeological resource protection outlined in the final plan.

Once the Idaho SHPO has determined that sufficient information has been provided, consulting and interested parties are given 30 days to review this material and provide their views. The Advisory Council is also notified of the finding of adverse effects at this time and may choose to enter the consultation process, notifying all parties and the Secretary of Energy of this fact within 15 days.

Consultation conducted in good faith, as previously described, should lead to agreement on appropriate strategies to mitigate or minimize the adverse effects of the proposed INL project. Commitments are formalized in a memorandum of agreement signed by DOE-ID, the Idaho SHPO, and other involved parties. INL project management is then formally notified that the project can proceed. Monitoring throughout the life of the project helps to ensure that all measures stipulated in the MOA are implemented. If agreement cannot be reached through consultation, DOE-ID will formally ask the Advisory Council to join the consultation. In making a final decision about the project, DOE will carefully consider the comments of all parties to the consultation, including those of the Advisory Council.

\section{STANDARD REQUIREMENTS FOR ARCHAEOLOGICAL INVESTIGATIONS AT INL}

The sections to follow contain descriptions of the policies and procedures employed by the INL CRM Office in the identification, investigation, assessment, documentation, and preservation of INL archaeological resources.

\section{Permitting}

From approximately 1990 on, the in-house staff of the INL CRM Office has conducted most archaeological investigations at INL. All work has followed the requirements and guidelines outlined herein. Permits are not required for internal archaeological investigations completed by the INL CRM Office. Outside agencies, subcontractors, and individuals completing archaeological investigations at INL are subject to permits. For investigations conducted before 1990, the NPS or BLM issued permits for archaeological investigations at INL. Today permits are handled through the INL CRM Office.

The permit process established specifically for INL archaeological investigations by external organizations accomplishes the following:

- Protects archaeological resources from unauthorized or poor-quality research and recovery

- Protects sensitive locational information for INL archaeological resources and ensures it is used for "Official Use Only"

- Allows DOE-ID and the INL CRM Office to track and archive field and laboratory work and acquire information important to the description, protection, and overall management of INL cultural resources 
- Ensures compliance with special INL safety, security, and environmental requirements

- Allows for timely notification of the Shoshone-Bannock Tribes prior to initiation of work and ensures appropriate notifications if sensitive cultural resources or areas are unexpectedly encountered

- Ensures consistency in and informs applicants of INL standards for archaeological field survey, excavations, and research.

An applicant for a cultural resource permit must delineate the scope and purpose of the proposed investigation; demonstrate the necessary professional credentials and adequate support to conduct and complete the work; agree to any stipulations for artifact and/or data security, health and safety, land use, access, and site remediation; and designate an approved repository for documents and artifacts associated with the project, which remain the property of DOE-ID. Cultural resource permit applications must be completed for all proposed activities, including field-oriented projects as well as laboratory analyses. Exchanges of sensitive cultural resource information may require completion of a separate user agreement that designates procedures for handling and protecting sensitive information. Figures 33 and 34 illustrate the necessary paperwork.

\section{Archive and Literature Searches}

The INL CRM Office maintains a comprehensive archive of all archaeological investigations completed at INL, including information on all known archaeological resources. Maintenance of these files is an important function of the INL CRM Office and accomplishes a number of goals, including:

- Helping to ensure overall consistency in cultural resource management and data collection

- Continuing refinement of overall INL CRM Office goals (see Appendix J), research designs (see Appendix E), and historic contexts (see Appendix F)

- Continuing refinement of the INL predictive model for prehistoric archaeological resources and associated research goals

- Preventing duplication of effort in archaeological resource identification

- Contributing to overall compliance with 36 CFR Part 79, "Curation of Federally-Owned and Administered Archaeological Collections."

Archive, literature, and electronic database searches are the first step toward completing any kind of archaeological investigation at INL. Archives maintained in the INL CRM Office and consulted at this time may include:

- INL CRM Office project files, which contain detailed information on all archaeological investigations conducted at INL and all archaeological sites known to occur there

- INL CRM Office electronic databases and geographic information systems (GIS) coverages

- Archaeological sensitivity maps, which divide INL into four differing zones of sensitivity (very high, high, medium, or low) based on the locational tendencies of prehistoric sites previously recorded there

- Historic land use maps, which depict early historic roads, rail lines, trails, and canals crossing INL, along with structures and buildings, as described in various historical documents and sources

- Maps and notes created by surveyors during the original land surveys that began in 1873 and many subsequent land surveys of the INL area 
- Various INL-specific archives, including maps and documents describing post-1942 activities and facilities

- Archaeological reports, documents, and other literature of relevance to INL and the surrounding region.

The archive and literature search is designed to evaluate previous efforts, identify cultural resource themes within an area of interest, and assemble information about any archaeological resources that may have been previously recorded there. In situations where an area of potential effect for a proposed project is being assessed, the archive and literature search serves an important role in assessing the need for additional archaeological survey, data recovery, and consultation.

\section{Archaeological Surveys}

Field activities conducted by the INL CRM Office or by any entity under permit through the INL CRM Office will follow basic safety and security protocols for vehicle operation, communication, and field work, including any unique health and safety requirements associated with specific INL facilities.

Archaeological surveys at INL may be conducted for a variety of reasons. Some are conducted in advance of specific INL projects to assess the potential effects of the proposed activities. However, within available funding, the INL CRM Office also conducts inventories to expand understanding of the overall resource base and enhance long-term planning, overall management, and predictive modeling as a tool for land use decision-making. Since 1984, all archaeological surveys at INL have followed a consistent set of standards and procedures to ensure consistency and replicability.

Nearly two decades of on-the-ground investigations have demonstrated that INL archaeological resources are easily identified through pedestrian survey methods. Even in active geomorphological settings (e.g., after range fires and in the dune fields within the bed of Pleistocene Lake Terreton), INL archaeological resources that span all time periods of human habitation are densely concentrated on the existing surface of the ground ( 40 to 50 resources per square mile). Nearly all appear to have some surface manifestation that can be identified and initially assessed by a pedestrian survey crew. Experience has shown that survey intervals of 15 to 20 meters are ideal for identifying 90 to $100 \%$ of archaeological resources at INL.

The first step in completing an archaeological survey at INL is to establish the boundaries of the area to be surveyed. This will vary tremendously according to the needs of each particular project. For projectspecific archaeological surveys, the entire area of potential effect for the proposed project is always intensively examined and inventoried. Research-oriented surveys will follow the guidelines of a specific research design to establish survey boundaries. Global Positioning System (GPS) technology has proven to be very helpful in establishing the boundaries of all archaeological survey units as well as the archaeological sites identified within them.

To identify archaeological resources within the defined survey area, archaeological survey crews systematically walk over the area in skirmish line fashion. Spacing between individuals in the skirmish line never exceeds 20 meters, and temporary flagging tape or pin-flag markers are often employed to ensure that an area is completely examined. Notations of survey transect orientation, survey participants, field and weather conditions, and other details deemed pertinent are also created by the survey crew leader.

When cultural materials are encountered during the course of a survey, intensive searches in the vicinity are used to ascertain the boundaries of the resource and pinpoint diagnostic artifacts, artifact 
concentrations, cultural features, landmarks, and any areas of post-depositional disturbance. The survey crew leader assigns a temporary field number to the resource and establishes its geographical coordinates.

Prior to conducting formal recording procedures, identified resources are classified generally as "isolates" or "sites," a distinction that applies to all archaeological materials at INL, including prehistoric ( $>150$ years old), historic (50 to 150 years old), and industrial ( $<50$ years old) materials.

In all projects at INL since 1984, archaeological "sites" have been defined as discrete concentrations of ten or more artifacts separated from similar concentrations by natural barriers, such as basalt ridges or the Big Lost River, or by at least 100 meters of open space. In active geologic settings (e.g., sand dunes and burned areas), small concentrations of less than ten items may also be designated as "sites" because of the potential for buried materials. Additionally, resources that contain fire-cracked rock, burned bone, or cultural features (e.g., rock rings, fire hearths, building foundations, trails, and canals) are also classified as "sites" because these items are indicative of fairly intensive activities and often mark the location of buried cultural features.

Occurrences of less than ten artifacts under similar circumstances are classified as "isolates." These small artifact concentrations are restricted to a surface context and thus limited in their value for future research. At the discretion of the survey crew leader, single unmodified lithic flakes and/or tin cans, which would typically be recorded as "isolates," may be simply noted on survey maps as "outliers" to known or newly recorded archaeological sites nearby, and not formally recorded. Multiple flakes or cans and all diagnostic artifacts will always be formally recorded as part of a larger archaeological site or individually as an isolate location.

Formal recording of sites is completed using Intermountain Antiquities Computer System (IMACS) site forms modified to reflect INL needs (see Figure 35). These forms require detailed administrative, environmental, and descriptive information in a standardized regional format. They are designed to obtain the maximum amount of information from each resource without test excavations and with only minimal collection of artifacts. Isolates are documented with an abbreviated version of the standard INL IMACS form (see Figure 35).

Scaled planimetric maps are also prepared for all "sites," while less formal sketch maps are drawn for "isolates." The purpose of these maps is twofold: (1) to locate the resource in relation to features of the surrounding environment, both natural and cultural; and (2) to illustrate the spatial relationships between diagnostic artifacts, artifact concentrations, cultural features, and collected items within the perimeter of the site. To complete this site mapping, datum positions are established at each resource location. To aid in future relocation, prominent modern features, such as power poles or fence posts, are often utilized. In some instances, small cairns constructed of basalt cobbles or pebbles are constructed. Site datum positions are always noted on the INL IMACS form, particularly when they consist of cairns constructed by the survey crew. Directions to all important features of each site are typically obtained with GPS technology, or if necessary, using a compass and hard copy map.

Artifacts and information collected during the survey may be subject to a variety of analyses. At a minimum, this will include basic functional and stylistic description of any collected artifacts and incorporation of each recorded archaeological resource into the comprehensive INL archaeological database and GIS coverage. Other technical analysis (e.g., predictive modeling, GIS analysis, obsidian hydration analysis, and blood protein analysis) may also be conducted. Reporting of all archaeological investigations is mandatory and follows guidelines described in a subsequent section of this appendix. 


\section{Excavations}

Plans for archaeological excavations at INL are reviewed in advance by the Idaho SHPO, ShoshoneBannock Tribes, and INL safety and environmental personnel. These reviews ensure the scientific merit of the proposed investigation, anticipate and address any American Indian concerns, and ensure that all activities fall within INL security, safety, and environmental requirements. Several types of excavation are possible:

- Test excavations

- Full-scale excavations

- Salvage excavations

- Excavations involving human remains

- Paleontological excavations.

These excavations share a common methodological foundation while varying considerably in their overall goals.

\section{Test Excavations}

Test excavations are small in scale and primarily designed to assess future research potential and establish National Register eligibility. At INL, they are patterned after an existing framework established for National Register evaluations of large dispersed artifact scatters (e.g., Henrikson and Holmer 1991; Ringe 1988, 1990, 1992a, 1992b, 1993, 1994; Thompson and Lohse 1992) and are generally guided by the practical objective of determining if buried cultural deposits are present and, if so, to assess their general nature and extent.

This objective is achieved through an approach that involves intensive systematic surface reconnaissance, small systematically placed shovel probes, and formal $1 \times 1-\mathrm{m}$ test units. The exact details of any given test excavation will differ according to the site being investigated and will always be presented in the context of a specific research design. In general however, the use of these basic techniques allows for an expedient yet thorough assessment of the subsurface character of an archaeological site with minimal impact to the cultural deposits and can be used to assess the significance of all types of archaeological resources.

Seven basic tasks are required in the test excavation and site evaluation process:

1. Grid establishment

2. Site mapping

3. Surface artifact collection

4. Shovel probe excavation

5. $1 \times 1-\mathrm{m}$ test unit excavation

6. Artifact analysis

7. Report preparation.

During the first stage of the evaluation, horizontal grid systems consisting of $5 \times 5-\mathrm{m}$ or $10 \times 10-\mathrm{m}$ units oriented to magnetic north are established at each site. Ten-meter intervals between grid lines are utilized only for those sites that are very large and widely dispersed; most sites investigated at INL are discrete enough to be gridded at 5-m intervals. The central datum point at each site (usually designated as 
$1000 \mathrm{~N}, 1000 \mathrm{E}$ ) is tied to the INL GIS through the use of a GPS device. Each site is marked with a permanent datum, typically a steel rebar stake.

During the second stage of evaluation, a planimetric map is prepared that illustrates the position of the site and grid in relation to surrounding features and indicating spatial relationships among artifacts. Surface artifacts are the focus of the third stage in evaluation. At this time, temporally and/or functionally diagnostic surface artifacts are plotted within the site grid, recorded, and collected for later analysis. In addition, approximately $50 \%$ of nondiagnostic surface artifacts, primarily unmodified flakes, may be collected from systematic "checkerboard" samples of the grid units across the entire surface area of the site. This allows for subsequent analysis of the artifacts (e.g., obsidian hydration and faunal and stone tool analysis) and may reveal intrasite patterning that could provide clues to previous areas of activity at the site. In grid units not subject to full collection, artifacts are counted and logged, but not removed from their original positions.

In the fourth and fifth stages of evaluation, attention is given to the subsurface character of each site. Initially, this involves excavation of small shovel probes at regular grid intervals of $5 \mathrm{~m}$ or $10 \mathrm{~m}$ across the site area to determine the depth and lateral extent of the site. All probes are square, measure $30 \times$ $30 \mathrm{~cm}$ and are excavated to at least $30 \mathrm{~cm}$ below existing ground surface or to bedrock, in $10-\mathrm{cm}$ levels. In order to confirm that no cultural materials are present, excavations proceed to at least $10 \mathrm{~cm}$ below the last artifact-bearing level.

Deposits from the test probes are screened through a $1 / 8$-in. (minimum) hardware mesh, and recovered artifacts are logged, bagged, and collected with careful notation of horizontal and vertical provenience. The holes resulting from test-probe excavations are immediately backfilled with original soils captured on a tarp placed beneath the screen. This helps to protect the surface of the site from soil mixing and disturbance from intensive foot traffic during the archaeological evaluation.

The excavation of test pits expands the investigation of a site to an evaluation of its potential significance by increasing subsurface exploration and focusing on features or areas of high artifact concentration. The methods utilized during excavation of $1 \times 1$-meter test pits are identical to those used during shovel testing, with the following important exceptions:

1. First, all $1 \times 1$-meter-square pits are taken to at least $40 \mathrm{~cm}$ below existing ground surface, bedrock, or to $20 \mathrm{~cm}$ below the deepest artifacts. Excavation may proceed in arbitrary 10-cm levels or stratigraphically, as the situation demands.

2. Second, after completion of the excavation, measured profiles are drawn of at least one wall within each pit, soil horizons and/or cultural features are described and may be sampled, and photographs are taken. Several types of field samples may be taken from established $20 \times 20$-cm columns in the test units or in selected other areas. Samples that may be obtained include fine-mesh screen $(<1 / 8$ in. $)$ samples, soil samples, pollen samples, charcoal samples, and samples of organic materials.

3. Third, in contrast to shovel probes, which are systematically placed, the $1 \times 1$-meter pits are typically located intuitively in areas expected to contain subsurface artifacts or features. Clues used to determine the placement of the $1 \times 1$-meter pits are provided by the results of the systematic shovel probes and surface artifacts. When excavation is complete, all $1 \times 1$-meter pits are backfilled with soil captured on tarps placed beneath the screen.

4. Finally, test units are usually seeded with a mixture of native plants to help prevent the spread of noxious weeds. 
Analyses of artifacts and samples recovered from test pits or shovel probes may include any of the following activities, and possibly more. Specialists and/or special facilities may be utilized to complete these analyses:

- Sedimentary and soil chemistry analyses

- Radiocarbon analysis

- Dendrochronological analysis

- Flotation analysis of soil samples for plant macrofossils

- Fine-screening of soil samples for analysis of micro-artifacts

- Pollen analysis

- Stylistic and functional analysis of metal, glass, ceramic, stone, and bone artifacts, including debitage

- Micro-wear analysis of artifacts, particularly stone tools

- Obsidian sourcing and hydration analysis

- Faunal analysis, including, when possible, data on taxa, element, age, sex, season of death, and modification

- Blood protein analysis.

Reporting of test excavations is mandatory and follows the guidelines presented in a subsequent section of this appendix.

\section{Full-Scale Excavations}

As with other types of archaeological excavations at INL, full-scale excavations follow an established data recovery plan and research design reviewed and approved by appropriate consulting parties prior to any ground disturbance. At a minimum, full-scale excavations follow the basic methodological protocols discussed under test excavations. Any deviations from these basics are justified in the project excavation plan and specific research design. Compliance with occupational safety and health rules and INL-specific security, environmental, safety, and health requirements are also monitored and strictly enforced.

\section{Salvage Excavations}

Salvage excavations are typically prompted by an unanticipated discovery of cultural materials during an ongoing INL or ICP project or as a followup to emergency situations where cultural resources have been impacted (e.g., fire or flood). Obviously, each situation and data recovery plan and research design will be unique; but once again, the minimum standards described under the test excavation discussion are followed and basic INL security, safety, and environmental requirements are enforced.

\section{Excavations Involving Human Remains}

Due to the potential cultural, religious, and legal sensitivity connected with excavations involving human remains, it is particularly important that this type of excavation follows a specific plan developed in consultation with the interested parties (i.e., Idaho SHPO, Shoshone-Bannock Tribes, and other impacted groups). If appropriate, the guidance and regulations of the Native American Graves Protection and Repatriation Act (NAGPRA) will be followed.

The following general approach is employed whenever clusters of human-sized bones are encountered at INL: 
1. The finder stops project activities in the vicinity of the bones, establishes a $30 \times 50$-meter buffer around them in a reasonable effort to protect them, and immediately contacts the INL CRM Office, who in turn, immediately contacts the DOE-ID cultural resource coordinator.

2. The DOE-ID cultural resources coordinator notifies the Shoshone-Bannock Tribes and jurisdictional county sheriff's office of the find.

3. As soon as possible and within at least two days of the discovery, the INL CRM Office investigates the find and determines if the bones are human, and if human, determines whether they are ancient or modern, and thereby establishes jurisdiction as either local law enforcement (modern) or INL management (ancient or historic). The INL CRM Office also coordinates visits to and inspections of the area by other interested parties within this window of time.

4. Depending on the nature of the find, the INL CRM Office also recommends additional measures for interim protection of the remains.

5. If the remains fall under jurisdiction of local law enforcement, this procedure ends, although INL CRM Office involvement may continue.

6. If the remains fall under the jurisdiction of DOE-ID, consultation on protection, analysis (possibly including excavation), and disposition commences per the requirements of NAGPRA and its implementing regulations. If the remains are identifiable as American Indian, the Shoshone-Bannock Tribes are closely involved in this consultation along with the Idaho SHPO. If the remains are not American Indian but still historic, record searches and interviews with informants are used to locate parties for consultation.

7. All activities under this procedure are conducted with the utmost respect for the sensitive nature of any finds, the feelings of the parties involved, and within the guidelines of appropriate legal drivers.

\section{Paleontological Excavations}

Some geological contexts at INL have been known to yield plant and animal fossils. The floodplain of the Big Lost River and bed of Pleistocene Lake Terreton are two areas where finds have occurred. Remains of this type are not associated with human activities but do have good potential to yield important information on climate and environment that can be important in understanding human occupation of the area. Like all other excavations at INL, paleontological excavations follow a specific data recovery plan and research design and comply with relevant environmental, safety, and health requirements. Reporting and documenting the find is mandatory and follows established protocols.

\section{Lava Tube Cave Studies}

Lava tube caves at the INL contain archaeological materials, natural features, plants, and animals that are of high sensitivity and also of importance to the Shoshone-Bannock Tribes. Care is taken by the INL CRM Office when entering caves and other personnel are also encouraged to respect the fragile materials located there. The following general protocols are observed when entering INL caves:

- Never enter a cave alone and always consider that snakes, bats, and carnivores make their homes in caves

- Do not utilize caves for leisure activities or horseplay (picnics, resting, music/radios, yelling, running, hide-and-seek, etc.)

- Respect and avoid disturbance to sensitive natural formations, plants, and animals

- Provide adequate supervision for tour groups and do not exceed 25 participants 
- Protect sensitive cultural materials in and around caves (e.g. never touch pictographs, never move artifacts, bones, basalt cobbles or boulders, or historic artifacts, and avoid ground disturbance)

- Protect locational information for caves and distribute for "Official Use Only"

Archaeological excavations in INL caves are infrequent and always coordinated by a detailed research design developed in coordination with the Shoshone-Bannock Tribes.

\section{Significance Evaluations}

Archaeological significance evaluations play an important part in determining which archaeological resources warrant consideration with regard to long-term land-use planning, impact-driven planning, and overall management. Many INL archaeological resources are evaluated against a specific set of guidelines (36 CFR Part 60.4) established to govern nomination to the National Register. Under these guidelines, cultural resources must retain integrity of location, design, setting, materials, workmanship, feeling, and association; and must meet one or more of the following four criteria:

1. Association with events that have made a significant contribution to the broad patterns of our history

2. Association with the lives of persons significant in our past

3. Embodiment of the distinctive characteristics of a type, period, or method of construction; representative of the work of a master; possessing high artistic values; or representative of a significant distinguishable entity whose components may lack individual distinction

4. Yielded or may be likely to yield information important to prehistory or history.

Most archaeological resources are eligible under criterion d, although certain sites may meet any of the criteria. Historic sites may be especially eligible under criteria a and b. Usually, sites that are eligible under criterion $\mathrm{d}$ will be datable, have stratigraphic integrity, and will contain sufficient materials to address one or more of the research questions provided in the Research Design in Appendix E. Subsurface testing may be required to fully assess the National Register potential of many archaeological sites. In accordance with guidance from the Idaho SHPO, all archaeological sites at INL are considered to be eligible to the National Register under criterion $d$ until it is demonstrated that no information remains to be gleaned from their deposits or surface features. Archaeological resources, particularly isolate locations, are considered to be ineligible if they are restricted to a surface context.

Archaeological or other cultural resources that are not eligible for nomination to the National Register may still be considered significant and worthy of preservation under various other legal authorities (NEPA, ARPA, AIRFA, and NAGPRA; see Appendix A).

\section{Collection and Removal of Artifacts}

Artifacts have been collected from INL archaeological resources during past investigations, and similar collections may be assembled in the future under the basic procedures established herein. The following rules will serve as a protocol for future activities:

- The collection of artifacts from INL lands by unauthorized personnel is prohibited by law and actively discouraged by the INL CRM Office. Violations of this rule will be investigated and, when possible, prosecuted under appropriate legal authorities (e.g., ARPA and NAGPRA).

- Although arrowheads collected from the surface on federal lands are specifically exempt from the penalty provisions of ARPA, their unauthorized and nonsystematic collection remains illegal, causes adverse impact, and is punishable under other statutes. 
- In general, artifact collection during INL CRM Office investigations is strongly discouraged. However, INL CRM Office staff and/or individuals under permit from the INL CRM Office may collect artifacts in accordance with established research designs and priorities or if they are judged to be in imminent danger of loss by INL project activities, natural forces, or unauthorized collection.

- Artifact collections created during archaeological surveys or excavations will follow the protocols and guidelines outlined in specific data recovery plans and in accordance with 36 CFR 79.

- All collections will be permanently curated at the Earl H. Swanson Archaeological Repository, located at the Idaho Museum of Natural History at Idaho State University in Pocatello, Idaho. The collections will be maintained under standards established in 36 CFR Part 79 and the authority of a contractual agreement between the curation center and DOE-ID. Collections temporarily stored in the INL CRM Office will remain in secure fireproof storage until they are transferred for permanent curation. Organic materials or otherwise delicate or sensitive materials will be transferred immediately for appropriate storage.

\section{Documentation and Reporting}

Documentation standards for INL cultural resource investigations have been established to ensure that the collected information contributes to a better understanding of the archaeology of Idaho and the nation. Consistent formats are employed to ensure that the assumptions and biases affecting the conduct and results of the reported work are clearly stated and consistently reported. This consistency also helps to ensure that information about INL cultural resources is up to date and easily accessible. Information distributed by the INL CRM Office must undergo appropriate INL security and patent reviews before being disseminated outside the INL system. formats:

Cultural resource investigations conducted at INL are documented in at least one of three basic

1. Summary of Cultural Resource Investigation (see Figure 31) - A broad description of cultural resource investigations completed at INL. If no cultural resources are identified during an archaeological survey of a given INL area, this summary is the only written document prepared.

2. Standard Report of Cultural Resource Investigation (see Figure 32) - A format based closely on documentation requirements distributed by the Idaho SHPO. It is used to document archaeological investigations at INL that result in the recording or re-recording, avoidance, or mitigation of any type of archaeological resource.

3. INL external report-A document that follows a formal INL scientific and technical information format intended for release to entities external to INL. It is used for large projects and those judged to be of potential interest to parties outside of the INL system. Although presenting a different appearance from the previous formats, the content of this type of document closely follows the standards of the Idaho SHPO as provided in Figure 32.

In addition, identified archaeological resources and boundaries of intensively surveyed areas are tracked on paper and electronically in databases and GIS files. 


\section{Idaho National Laboratory \\ Cultural Resource Management Office \\ Summary of Cultural Resource Investigation}

INL CRM Office Project Number:

INL CRM Office Project Name:

Project Description:

Environmental Checklist Number:

Customer/Primary Contact:

Project Location:

Nearest INL Facility:

Type of Cultural Resource Investigation:

Principal Investigator:

Dates of Investigation:

INL CRM Office Permit Number:

Project Status:

Acres Surveyed (Intensive):

Acres Surveyed (Reconnaissance):

Acres Re-surveyed:

Cultural Resources Recorded:

Cultural Resources Re-recorded:

Cultural Resources Excavated:

Cultural Resources Avoided:

Documentation of Investigation:

Assessment of Effects:

Recommended Actions:

SHPO Comments:

Sho-Ban Comments:

Other Stakeholder Comments:

Figure 31. INL Cultural Resource Management Office project summary. 


\section{INTRODUCTION \\ Area of Potential Effects \\ Project Acreage \\ Landowners}

Idaho National Laboratory

Cultural Resource Management Office

Standard Report of Cultural Resource Investigation

STATEMENT OF OBJECTIVES FOR INVESTIGATION

Description of Area Investigated

Amount and Types of Information Collected

LOCATION AND GENERAL ENVIRONMENTAL SETTING

Legal Locations

Setting

PRE-FIELD RESEARCH

Sources of Information Checked

Summary of Previous Investigations

Evaluation of Previous Investigations

EXPECTED HISTORIC AND PREHISTORIC LAND USE AND SITE DENSITY

Known Cultural Resources

Expected Cultural Resources

Known or Expected Distribution of Cultural Resources

Known or Expected General Themes and Time Periods

Known or Expected INL Contexts

\section{METHODS OF INVESTIGATION}

Field Techniques

Surface Conditions

Areas Not Examined

Field Personnel

Dates of Fieldwork

Problems Encountered

RESULTS

All Cultural Resources Identified in the Area of Potential Effects

Cultural Resources Noted But Not Recorded

Summary of Important Characteristics of Identified Resources

National Register Eligibility

Recommendations for Further Investigations

CONCLUSIONS AND RECOMMENDATIONS

Summary of Investigations

Potential Threats to Identified Cultural Properties

Relationship of Identified Cultural Properties to Project Impacts

Avoidance or Mitigation Options

Recommendations for Additional Investigations or Protection Measures

REPOSITORY

REFERENCES

APPENDIX A: Key Information

APPENDIX B: Certification of Results

APPENDIX C: Project Maps

APPENDIX D: Site/Isolate Forms

Figure 32. Standard report format for INL archaeological investigations. 
FOR INL CRM Office Use

(Form Rev. 3, 2009)

Date Received

Date Approved

Project No.

Reviewer

Reviewer

\section{Idaho National Laboratory Cultural Resource Management Office}

\author{
Application for Permit for Cultural Resource Investigations
}

Instructions: Complete and return two copies of this application and required attachments to the Idaho National Laboratory (INL) Cultural Resource Management (CRM) Office, attn. Brenda R. Pace, P.O. Box 1625, Mailstop 2105, Idaho Falls, Idaho, 83415. Incomplete applications will not be considered. Consult the INL CRM Plan (DOE/ID-10997, available online at http://www.inl.gov/technicalpublications/) for standards applicable to work. Use separate pages if more space is needed. Projects requiring transfer of sensitive data must be accompanied by a signed user agreement.

1. Name of applicant (institution, corporation, partnership, individual, or other entity)

2. Mailing address

3. Telephone number(s)

4. Email address(es)

5. Description and purpose of proposed work

6. Location of proposed work (if applicable)

Include the best available locational data (e.g., GPS coordinates, UTMs, township, range and section) as well as a readable copy of a 7. ' $^{\prime}$ topographic map showing specific areas for which permit is desired)

7. Cultural resources involved in proposed work (if applicable)

8. Schedule of proposed work

9. Principal Investigator

Name of individual responsible for planning and generally overseeing proposed work, including supervision of staff and overall responsibility for the professional quality of reports and recommendations.

\section{Field Director(s)}

Name of individual(s) responsible for carrying out field projects or analyses, for technical quality of fieldwork or analyses through direct supervision of all aspects of fieldwork and data gathering, for proposing resource evaluations and recommendations for further treatment, and for preparing field records, descriptive reports, and other documentation.

\section{Permit Administrator}

Name of individual responsible for fulfilling the terms and conditions of the permit (must be legally empowered to obligate applicant organization).

12. Signature of Permit Administrator named above

13. Date signed 
14. Applicant must include the following items with the application form:

a. Description of the purpose, nature, and extent of the work proposed: (include research design, methods, dissemination of results, tribal and stakeholder outreach, provisions for curation, data security, etc.);

b. Summary of organizational capabilities, including information on location(s) and description of facilities and equipment, organizational structure and staffing, and on facilities, equipment and staff to be involved in the proposed work;

c. Summary of organizational experience and history in completing work of the kind proposed, including similar past projects, government contracts, and Federal permits, reports and/or publications resulting from similar work, and any other pertinent organizational experience;

d. For each individual named as responsible for supervisory roles or technical tasks, including those named in 8 and 9 above, a curriculum vitae or similar resume or summary of education, training, and experience in the kind of work proposed and in the role proposed;

e. Comprehensive listing of all individuals that will require access to INL lands or facilities, including the following information: Full name, Social Security Number, Date of Birth, and Citizenship.

f. Signed user agreement for sensitive cultural resource data, as appropriate.

Figure 33. INL CRM Office permit application for archaeological investigations. 
FOR INL CRM Office Use

(Form, Rev. 1, 2009)

Date Received

Date Approved

Project No

Reviewer

Reviewer

\section{Idaho National Laboratory Cultural Resource Management Office}

\author{
User Agreement for Sensitive Cultural Resource Data
}

Instructions: Complete and return two copies of this user agreement to the Idaho National Laboratory (INL) Cultural Resource Management (CRM) Office, attn. Brenda R. Pace, P.O. Box 1625, Mailstop 2105, Idaho Falls, Idaho, 83415. All agreements must be associated with an approved INL cultural resource permit. Applications are available through the INL CRM Office.

1. Name of applicant (institution, corporation, partnership, individual, or other entity)

2. Mailing address

3. Telephone number(s)

4. Email address(es)

5. Description and purpose of proposed work

6. INL CRM Office permit application

Approved _ Attached

\section{Principal Investigator}

Name of individual responsible for planning and generally overseeing proposed work, including supervision of staff and overall responsibility for the professional quality of reports and recommendations.

\section{Project Director(s)}

Name of individual(s) responsible for technical quality of analyses and reports.

\section{Permit Administrator}

Name of individual responsible for fulfilling the terms and conditions of the permit (must be legally empowered to obligate applicant organization).

\begin{tabular}{|l|l}
\hline 10. Signature of Permit Administrator named above & 11. Date signed
\end{tabular}

12. By signing this user agreement, the applicant understands that cultural resource data are protected and not available to the general public. In consideration of access to this information, applicant agrees to:

- Establish appropriate administrative, technical, and physical safeguards to protect the confidentiality of the data and to prevent unauthorized use or access to it;

- Use INL cultural resource data only in compliance with applicable federal and state laws;

- Report any and all data access violations (actual or potential) to the INL CRM Office in a timely fashion;

- Ensure that any publications or reports based on INL data undergo pre-release review through the INL CRM Office;

- Destroy all hard copies or electronic files containing INL cultural resource data, once the project is completed.

The only permissible intended uses for INL cultural resource data is for cultural resource management, research, and education by professionals operating under an approved permit issued through the INL CRM Office. Access to the protected data may be terminated upon violation of any of the above conditions.

Figure 34. INL CRM Office user agreement for sensitive cultural resource data. 
Idaho National Laboratory

Cultural Resource Management Office

Isolated Find Record

State \#:

Project:

Recorder:

Location:

UTM Zone

USGS Quad:

Landowner:

Soil:

Topography:

Slope:

Aspect:

Elevation:

Nearest Water:

Vegetation:

Additional Comments:

Artifacts:

Inferred Function/Description:

Cultural Affiliation:

Dimensions:

Collection?

Sketch?

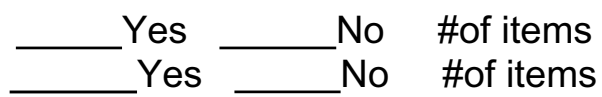

Repository:

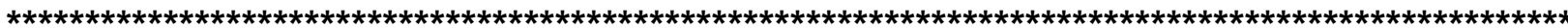

Sketch Map, Artifact Sketch, etc.

Figure 35. Intermountain Antiquities Computer System forms, INL variation. 


\section{Idaho National Laboratory \\ Cultural Resource Management Office}

IMACS SITE FORM

Part A - Administrative Data

*1. State No.:

4. State:

5. Project:

6. Report No.:

7. Site Name:

8. $\square$ Prehistoric $\square$ Historic $\square$ Paleontologic $\square$ Ethnographic

9. Site Type: *10. Elevation:_ft. ${ }^{*} 11$. UTM Grid Zone:

*12. $1 / 4$ of

*13. Meridian:

*14. Map Reference:

15. Aerial Photo:

16. Location and Access:

*17. Land Owner:

*18. Federal Administrative Units:

*19. Location of Curated Materials:

20. Site Description:

*21. Site Condition:

*22. Impact Agent(s):

Excellent (A)

$1 / 4$ of Section

$\mathrm{mE}$

$\mathrm{T}$.

$\mathrm{R}$.

$\mathrm{m} \mathrm{N}$
*3. Temp. No

County: 


\section{Part A - Environmental Data}

*29. Slope:

o

*30. Distance to Permanent Water:

*Type of Water Source:

Name of Water Source:

*31. Geographic Unit:

*32. Topographic Location: PRIMARY LANDFORM:

\begin{tabular}{|l|l|}
\hline & Mountain Spine (A) \\
\hline & Hill (B) \\
\hline & Mesa (C) \\
& Ridge (D) \\
\hline & Valley (E) \\
\hline Plain (F) \\
\hline Canyon (G) \\
\hline Island (H)
\end{tabular}

\begin{tabular}{|l|l|}
\hline & Alluvial Fan (A) \\
& Alcove/Shltr (B) \\
& Arroyo (C) \\
Basin (D) \\
Cave (E) \\
\hline Cliff (F) \\
Delta (G) \\
Monolith (H)
\end{tabular}

Describe.
Site No.(s)

Aspect: 0

(x 100 meters)

Spring/Seep (A)
SECONDARY LANDFORM:

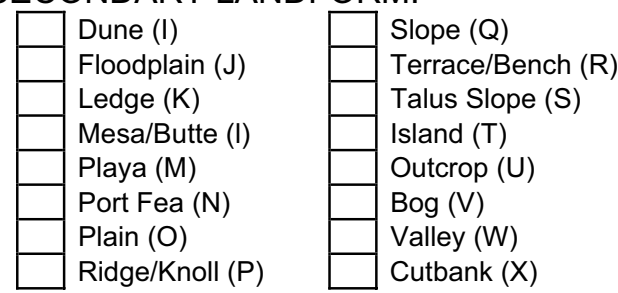

\begin{tabular}{|l|l}
\hline & Riser (Y) \\
\hline & Multiple (1) \\
Bar (2) \\
\hline Lagoon (3) \\
\hline Eph Wash (4) \\
\hline Kipuka (5) \\
\hline Saddle/Pass (6) \\
& Graben (7)
\end{tabular}

*33. On-site Depositional Context:

\begin{tabular}{|l|l}
\hline & Fan (A) \\
\hline & Talus (B) \\
& Dune (C) \\
Stream Terrace (D) \\
Playa (E)
\end{tabular}

Description of Soil:

Residual (U)

34. Vegetation:

*a. Life Zone:

$\square$ Arctic-Alpine (A) $\square$ Hudsonian (B) $\square$ Canadian (C) $\square$ Transitional (D) $\square$ Upper Sonoran (E) $\square$ Lwr Sonoran (F) *b. Community:

\begin{tabular}{ll|lll|}
\hline \multicolumn{1}{|c|}{ Primary On-Site } & & Secondary On-Site & & Surrounding Site \\
\hline Aspen (A) & Other/Mixed Conifer (G) & Grassland/Steppe (M) & Marsh/Swamp (S) \\
Spruce-Fir (B) & Pinyon-Juniper (H) & Desert Lake Shore (N) & Lake/Reservoir (T) \\
Douglas Fir (C) & Wet Meadow (I) & Shadscale Community (O) & Agricultural (U) \\
Alpine Tundra (D) & Dry Meadow (J) & Tall Sagebrush (P) & Blackbrush (V) \\
Ponderosa Pine (E) & Oak-Maple Shrub (K) & Low Sagebrush (Q) & Mountain Brush (W) \\
Lodgepole Pine (F) & Riparian (L) & Barren (R) & Juniper-Sage (2) \\
Describe: & & & \\
\hline
\end{tabular}

*35. Miscellaneous Text

36. Comments/Continuations

List of Attachments

\begin{tabular}{l}
${ }^{P}$ \\
\hline
\end{tabular}

Topo Map Site Sketch
Photos

Artifact/Feature Sketch
Continuation Sheets

Other:

Figure 35. (Continued.) 
1. Site Type

Describe:

\begin{tabular}{l|l|}
\begin{tabular}{l|l|} 
CULTURAL \\
AFFILIATION
\end{tabular} & $\begin{array}{l}\text { DATING } \\
\text { METHOD }\end{array}$ \\
\hline & \begin{tabular}{|l|l|}
\hline \\
\hline
\end{tabular} \\
\hline & CULTURALIATION \\
\hline & \\
\hline
\end{tabular}

DATING METHOD

2. Culture

3. Site Dimensions:

4. Surface Collection/Method:

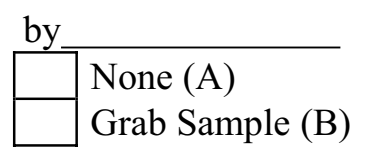

*Area

sq. $\mathrm{m}$

Sampling Method:

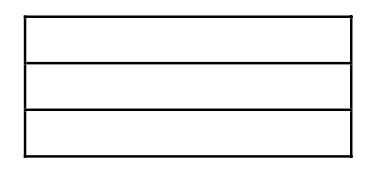

5. Estimated Depth of Cultural Fill: $\square \begin{aligned} & \text { Surface (A) } \\ & 0-20 \mathrm{~cm}(\mathrm{~B})\end{aligned}$ $20-100 \mathrm{~cm}(\mathrm{C})$ $100 \mathrm{~cm}+(\mathrm{D})$ Fill noted but unknown (E) Depth suspected (F) How estimated? (If tested, show location on site map):

6. Excavation Status:

Excavated (A) Tested (B) Unexcavated (C)

Testing Method:

7. Summary of Artifacts and Debris:

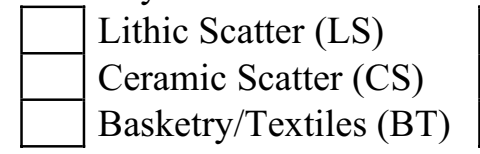

Describe:

Isolated Artifact (IA) Organic Remains (VR) Shell (SL) $\square$ Burned Stone (BS) Ground Stone (GS) Lithic Source(s):
Designed Sample (C)

Complete Collection (D)

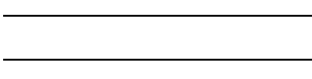

*8. Lithic Tools

\#

TYPE

\#

TYPE

Describe:

*9. Lithic Debitage - Estimated Quantity:

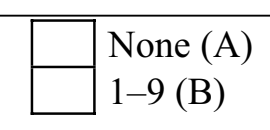

Material Type:
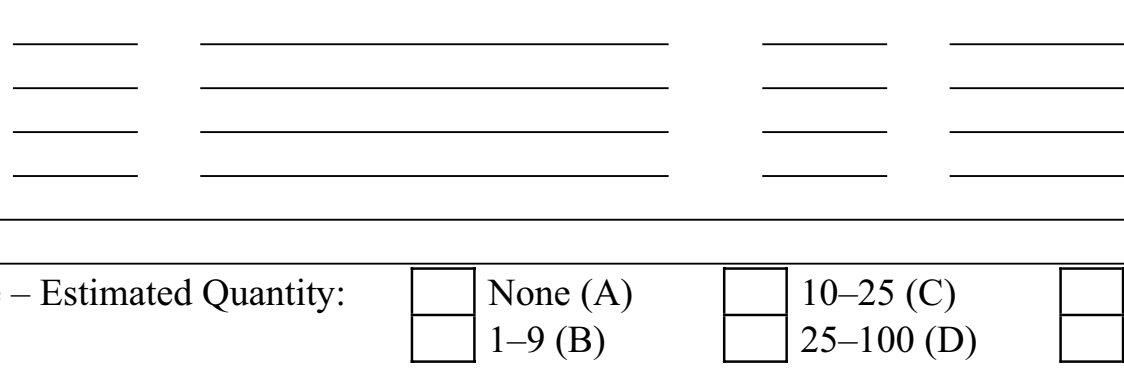

$100-500(\mathrm{E})$

$500+(\mathrm{F})$

Flaking Stages:

Decortication:

(0) Not Present (1) Rare

Secondary

(2) Common

Tertiary

(3) Dominant

Shatter

Core

10. Maximum Density - \#/ sq m (all lithics)

Figure 35. (Continued.) 
Part B - Prehistoric Sites

*11. Ceramic Artifacts: \#

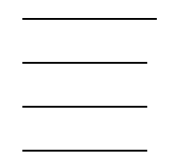

Describe:
Site No.(s)

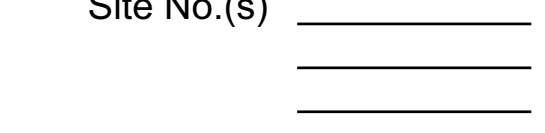

TYPE

TYPE

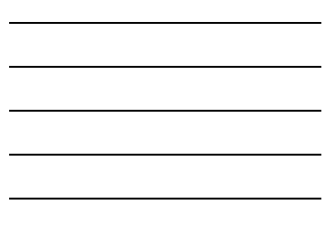

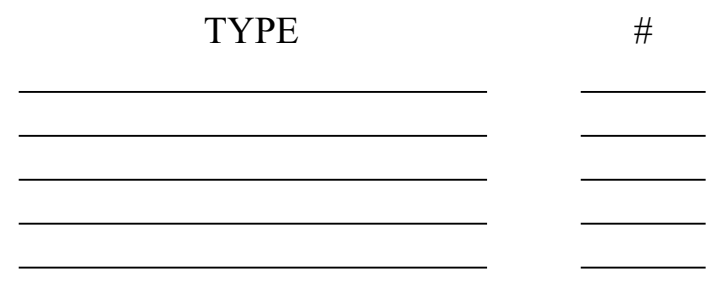

12. Maximum Density - \# / sq m (all ceramics):

*13. Non-Architectural Features (locate on site map):

\begin{tabular}{|c|c|c|c|}
\hline h/Firepit (HE) & Rubble Mound (RM) & Earthen Mound (EM) & ontrol (WC) \\
\hline $\begin{array}{l}\text { Midden (MD) } \\
\text { Depression (DE) }\end{array}$ & $\begin{array}{l}\text { Stone Circle (SC) } \\
\text { Rock Alignment (RA) }\end{array}$ & $\begin{array}{l}\text { Burial (BU) } \\
\text { Talus Pit (TP) }\end{array}$ & $\begin{array}{l}\text { Petroglyph (PE) } \\
\text { Pictooranh (PI }\end{array}$ \\
\hline
\end{tabular}

Describe:

*14. Architectural Features (locate on site map):

\begin{tabular}{llllll}
$\#$ \\
$\square$ \\
\hline
\end{tabular}

15. Comments / Continuations:

Figure 35. (Continued.) 
1. Site Type:

*2. Historic Theme(s):

*3. Culture

\begin{tabular}{|c|c|c|c|}
\hline CULTURAL AFFILIATION & DATING METHOD & CULTURAL AFFILIATION & DATING METHOD \\
\hline & & & \\
\hline & & & \\
\hline & & & \\
\hline & & & \\
\hline
\end{tabular}

Describe:

*4. Oldest Date:

How Determined?:

\section{Recent Date:}

5. Site Dimensions:

*6. Surface Collection/Method:

None $(\mathrm{A})$
Grab Sample (B)

$\mathrm{m}$ by

m *Area: sq. m

Sampling Method:

*7. Estimated Depth of Cultural Fill:

Surface (A)
$0-20 \mathrm{~cm}(\mathrm{~B})$
$20-100 \mathrm{~cm}(\mathrm{C})$ $100 \mathrm{~cm}+(\mathrm{D})$

Designed Sample (C)

Complete Collection (D)

How Estimated? (If tested, show location on site map)

*8. Excavation Status:

Testing Method:

\section{$\square$ Excavated (A) \\ Tested (B) \\ Unexcavated (C)}

*9. Summary of Artifacts and Debris:

\begin{tabular}{|c|c|c|c|c|}
\hline & & & & \\
\hline & & & & 10115 \\
\hline Metal (ME) & Ceramics (CS) & Wire (WI) & Wood (WD) & Kitchen Utensils(KU) \\
\hline Nails (NC,NW) & Fabric (FA) & Tin Cans (TZ) & Rubber (RB) & Car Parts (CR) \\
\hline
\end{tabular}

Describe:

*10. Ceramic Artifacts:

paste

glaze/slip

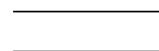

$\overline{ }$

*a. $\overline{\text { Estimated Number of Ceramic Trademarks }}$ Describe:

Figure 35. (Continued.) 
Part C - Historic Sites

*11. Glass Artifacts:

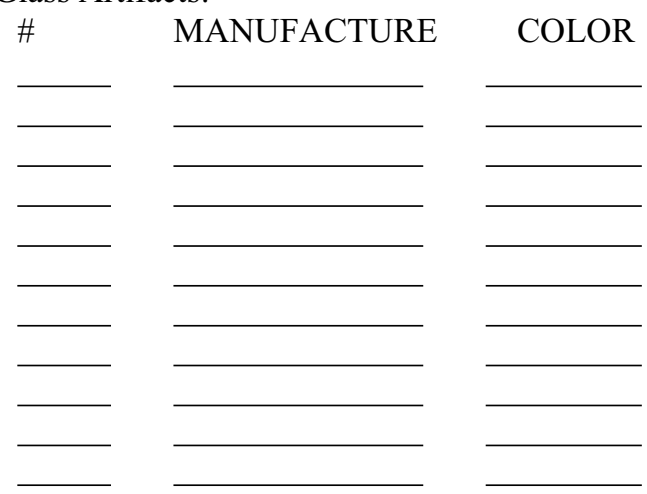

Site No.(s)

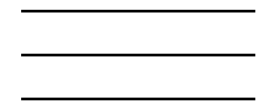

a. Estimated Number of Glass Trademarks:

Describe:

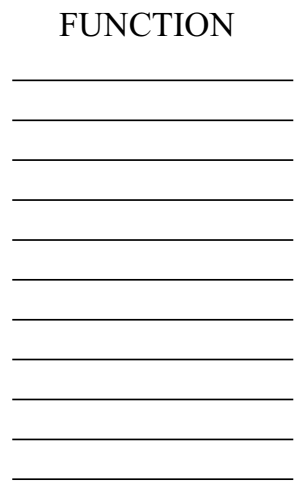

TRADEMARKS

DECORATION
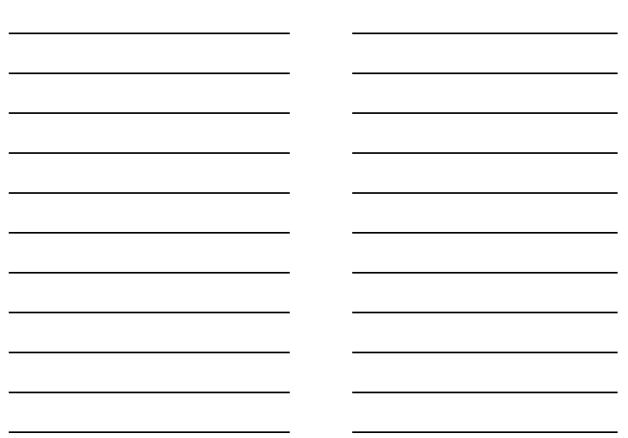

12. Maximum Density - \# / sq m (glass and ceramics):

*13. Non-Architectural Features (locate on site map):

\begin{tabular}{|l|l|}
\hline & Trail/Road (TR) \\
\hline & Mine Tailings (MT,ML) \\
\hline & Rock Alignment (RA)
\end{tabular}

Describe:

\begin{tabular}{|l|l}
\hline & Earthen Dam (DA) \\
Ditch (DI) \\
Inscriptions (IN)
\end{tabular}

Inscriptions (IN)
Hearth/Campfire (HE) Quarry (QU)

Other (OT)

*14. Architectural Features (locate on site map):

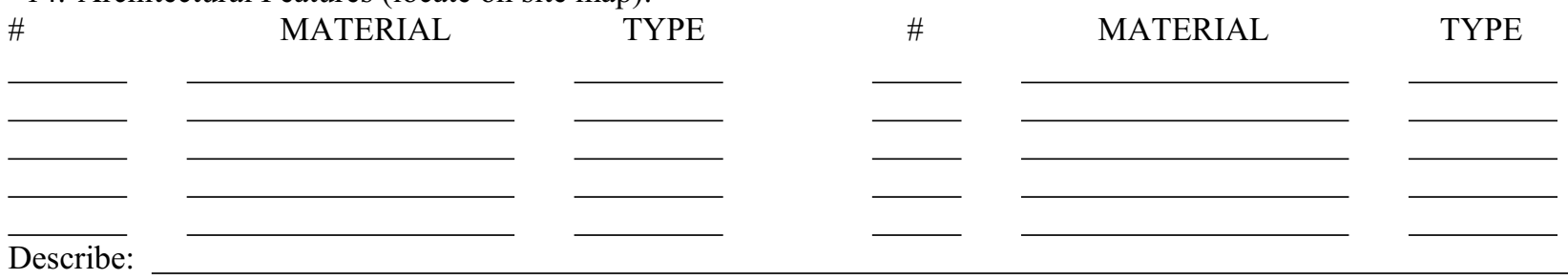

15. Comments / Continuations

Figure 35. (Continued.) 
Part D - Paleontology Locality

1. Type of Locality: _ Invertebrate

2. Formation/Horizon/Geologic Age:

3. Description of Geology and Topography:

4. Location of Outcrop:

5. Map Ref: USGS Quad: $1 / 4$ of $1 / 4$ of $1 / 4$ of sec. 7. Federal Administrative Unit(s)

6. County

8. Specimens Collected and Field Accession No.:

\section{Locality No.}

Trace ___ Other

9. Repository:

10. Specimens Observed and Disposition:

11. Ownership: __ Private _ State _ BLM _ USFS _ NPS _ Ind. _ Mil. _ Other

12. Recommendations for Further Work or Mitigation:

13. Type of Map made by Recorder:

14. Published References:

15. Remarks:

16. Sensitivity:

Critical

Significant

Important

Insignificant

17. Recorded by:

18. Date:

Figure 35. (Continued.) 


\section{Appendix D}

\section{Strategies and Procedures for the Management of INL Historic Architectural Properties}




\section{Appendix D}

\section{Strategies and Procedures for the Management of INL Historic Architectural Properties}

\section{INTRODUCTION}

Since its inception in 1949 as the NRTS, work conducted at INL has had a significant effect on the course of local, regional, national, and international history. Given this, it follows that many of the architectural properties associated with accomplishments in science and engineering at INL are representative reminders of those accomplishments and, as such, are historically important.

Formal recognition of the historic importance of INL programs and structures began in 1966 with the designation of EBR-I as a National Historic Landmark. However, it was not until the early 1990s that further consideration was given to post-1942 INL history and associated structures and artifacts. Increasing awareness of the historical importance of INL came about for a variety of reasons, primary among them were: (1) an increased focus on, and commitment to, compliance with all environmental laws and regulations; (2) the end of the Cold War, as marked by the removal of the Berlin wall; (3) changing INL programs and missions that led to increased alterations and demolition of older INL structures; (4) the $50^{\text {th }}$ anniversary of DOE national laboratories associated with the Manhattan Project; and (5) the $50^{\text {th }}$ anniversary of INL in 1999.

As an active scientific and engineering laboratory and one whose historic mission was the testing and development of nuclear power, INL presents unique challenges to historic preservation. These challenges include radiologically contaminated buildings and equipment, security restrictions, and the nearly constant modification, demolition, and replacement of structures and equipment to meet changing programmatic and mission needs. As a result of these challenges, what began in 1966 as a building-bybuilding approach to historic preservation of the INL built environment has evolved, and is continuing to evolve, into more holistic management strategies and systematic procedures for identifying, evaluating, and protecting important properties within a historic contextual framework. Contexts have been drafted, historic themes identified, and inventories of historic INL architectural properties are being continually expanded following the strategies and procedures outlined herein. These same strategies and procedures will be used to identify, evaluate, document, and protect additional INL architectural properties from the post-1942 era as legitimized through a programmatic agreement contained in Appendix G.

Inventories are ongoing to catalog other important INL architectural properties that may or may not be eligible to the National Register of Historic Places, such as nuclear-era artifacts and photographic and engineering archives. Strategies continue to evolve and be implemented through consultation and interactions at annual meetings that include:

- DOE-ID

- Idaho SHPO

- Shoshone-Bannock Tribes

- INL CRM Office

- Other interested parties. 
The agreed-upon implementation of the prioritized strategies and associated timeframes will be reflected in changes to the activities schedule contained in Appendix L of this document.

\section{INL Historic Architectural Properties}

For INL management purposes, a historic architectural property is defined as any post-1942 manmade structure or object that is either on, or eligible for listing on, the National Register. Examples might include the autopsy and surgical table that was removed to temporary storage prior to demolition of the former dispensary at the Central Facilities Area, the gantry crane used to load and unload ordnance during World War II, or the massive aircraft hangar at Test Area North; in other words, features of the INL "built environment."

\section{History of INL Historic Architectural Investigations}

Recognizing the historic significance of many INL architectural properties and associated artifactsyet lacking an empirical approach to achieve National Register eligibility determinations - in 1993 the INL CRM Office initiated comprehensive surveys of DOE-ID-owned buildings as required by NHPA Section 110 (Braun 1996; Braun and Marler 1996). In 1997, a comprehensive building inventory survey was completed and historic contexts were drafted for use in conjunction with National Register criteria to arrive at eligibility evaluations for DOE-ID buildings. Specifically, the goals of these investigations were to:

- Prepare a contextual history of INL from 1942 to the present

- Prepare a detailed historic properties inventory of all DOE-ID-managed buildings

- Develop significance evaluations for each building based on applicable legal criteria and historic contexts

- Develop mitigation recommendations for each historic building in the event of future adverse effects

- Develop recommendations on ways to satisfy NHPA Section 106 and 110 requirements.

The buildings were inventoried and evaluated in terms of the following four major chronological contexts:

- Ordnance testing: 1942-1949 and 1968-1970

- Nuclear reactor testing: 1949-1970

- Multi-program research: 1971-present

- Waste remediation: 1970-present.

With these contexts, it was determined that the period of historic significance for INL ranged from 1942 with the establishment of the U.S. Navy's ordnance testing program to the end of reactor testing as a primary INL mission in 1970. Due to their continued testing missions, the post-1970 LOFT and PBF reactor programs are exceptions. With completion of the draft INL historic contexts and building inventory and assessments, it became apparent that INL is a historic property through its association with events related to World War II, nuclear reactor testing and development, and workmanship and design of reactor equipment and associated structures. Considering INL as a historic property, as defined by INL boundaries, provides a way to organize information about INL history. (The complete INL historic contexts are contained in Appendix F.) For further information regarding the contexts, methodology, and DOE-ID building inventory see "The Idaho National Environmental and Engineering Laboratory: A 
Historical Context and Assessment, Narrative, and Inventory" (INEEL/EXT-97-01021 1998, revised 2003).

Within the contextual framework, of the 516 buildings surveyed in 1997, approximately 200 were determined to be eligible for the National Register. The survey and inventory were updated in 2003 to reflect changes that have occurred since 1997. For example, since the survey was completed, some of the buildings have been demolished (e.g., those at the former Security Training Facility) and others have been found to be ineligible due to extensive modifications that took place after the INL historic period of significance (1942-1970). Some post-1970 buildings were found to be eligible due to their exceptional significance (e.g., PBF and LOFT reactors), and others were reassessed because the historic context(s) for them had been more fully developed. In FY 2008, an inventory of MFC buildings was completed and added to the overall DOE-ID inventory. Table 3 provides a summary of buildings surveyed and their eligibility to the National Register (INEEL/EXT-96-01021, "The INEEL: A Historical Context and Assessment, Narrative, and Inventory").

Table 3. Summary of DOE-ID building survey and assessment.

\begin{tabular}{lcc}
\hline \multicolumn{1}{c}{ Area } & Total buildings & Eligible \\
\hline Materials and Fuels Complex & 81 & 35 \\
\hline Test Reactor Area & 76 & 59 \\
Idaho Nuclear Technology and Engineering Center & 130 & 23 \\
Sitewide & 23 & 5 \\
Experimental Breeder Reactor I & 2 & 2 \\
Power Burst Facility & 22 & 12 \\
Test Area North & 58 & 27 \\
Central Facilities Area & 74 & 39 \\
Radioactive Waste Management Complex & 48 & 0 \\
Howe Peak & 0 & 0 \\
Total & 433 & 160 \\
\hline
\end{tabular}

Appendix I contains a complete list of surveyed properties by area, including:

- Year built

- Eligibility for the National Register

- Historical context

- Idaho SHPO concurrence with the eligibility determination

- Section 106 status, if appropriate

- Property type

- Present condition

- Proposed disposition

- Owner.

Those properties owned by Environmental Management (EM) are scheduled for eventual demolition. However, they may be removed from the list in the event a reuse for them is identified. Those properties 
owned by Nuclear Energy (NE) have been transferred from EM and the DD\&D list and are continuing in use.

\section{Property Categories}

At INL, processes are in place to protect the integrity of historical properties from activities that could adversely impact a property's eligibility for listing on the National Register. Additionally, the historic property management approach includes property categories under which architectural properties might be considered eligible for listing on the National Register. The four architectural property categories are:

1. Signature Properties. "Signature properties" is a term coined by DOE-HQ that denotes its most historically important properties across the complex (e.g., MTR) and/or those properties that are viewed as having tourism potential (e.g., World War II structures). These properties will be documented through HABS/HAER reports regardless of their ultimate disposition. A list of INL signature properties appears in Table 4.

2. Category 1 Properties. Key individual INL properties (reactor buildings such as ETR) that, through periodic reviews, could be reclassified as signature properties.

3. Category 2 Properties. Contributing INL properties directly associated with signature or key individual properties (control buildings, hot shops, and artifacts such as the TAN shielded locomotive).

4. Category 3 Properties. Contributing INL properties not directly associated with signature or key individual properties (e.g., cafeterias and warehouses).

As conditions change and new information is obtained, individual properties within each category may be reevaluated and reassigned to more applicable categories.

Table 4. INL signature properties.

\section{INL Signature Properties}

INL signature facilities considered nationally, regionally, and locally significant

EBR-I reactor building, annex (EBR-601), and guardhouse (EBR-602)

HTRE engines on display at EBR-I (HTRE 2 and 3)

Chemical processing building (CPP-601)

Loss of Fluid Test facility (TAN-630 and TAN-650)

Materials Test Reactor (TRA-603)

TAN hangar (TAN-629)

TAN hot shop (TAN-607)

INL signature facilities considered locally and regionally significant (CFA World War II buildings)

Marine barracks (CF-606)

Commanding officer's house (CF-607) and Commanding officer's garage (CF-632)

Officers' quarters (CF-613)

Proofing area, which includes the containment wall, gun emplacements, and gantry crane (CF-633)

Pumphouses (CF-642 and CF-651) 


\section{POLICIES AND PROCEDURES FOR MANAGING HISTORIC ARCHITECTURAL PROPERTIES}

\section{Personnel}

All work described in this section will be conducted, or closely overseen, by persons who meet the professional qualifications for such work as described in the Introduction Section of this plan and in Appendix C (36 CFR 61, "Professional Qualification Standards," 1983).

As with archaeological investigations, the INL CRM Office staff has completed most of the INL historic architectural property investigations, particularly those conducted in advance of projects. However, DOE-ID and the INL CRM Office recognize that specialized skills (e.g., archival identification and maintenance and building material conservation) will be required and that no one person has all the necessary skills. To that end, much work has also been completed by subcontractors, and future architectural investigative work may require present INL CRM Office staff to gain new skills or acquire additional staff.

Outside agencies, subcontractors, and individuals completing historic architectural property investigations or research at INL are required to provide evidence of their professional qualifications and demonstrated expertise in their field. In addition, due to the nature of work conducted at INL over the years, a security clearance may also be required, as well as training regarding unique INL requirements and general legal compliance. A permitting system is presently being developed and, when implemented, will outline these and other requirements.

\section{Identification}

Identification is the process of researching, locating, and recording historic architectural properties under DOE-ID jurisdiction at INL for long-term planning needs and in advance of INL projects.

\section{Literature and Records Review}

The first step in the identification process is to search the CRM Office archives to determine whether the area in question has ever been surveyed for historic architectural properties, whether such properties

have been found, and whether these properties have been formally evaluated for or listed on the National Register. If it is determined that a property has not been previously surveyed or evaluated, information will be gathered from technical reports, popular publications, interviews with current and former employees, and any other sources that might assist in the identification process.

\section{Surveys}

The second step in the identification process is to conduct a survey. Surveys include the completion of an Idaho Historic Sites Inventory form, which has been adapted for DOE-ID properties to include information such as building size and typology (see Figure 33 at end of this appendix). In addition, 35-mm black-and-white photographs of the property will be taken. Copies of interviews, literature searches, and surveys, including survey forms and photographs, are maintained in the INL CRM Office. 


\section{Evaluation Process}

Once an architectural property has been identified, the following three-step evaluation process will be followed to determine its historic significance:

1. Collect data on the property to determine its physical integrity, age, and characteristics (with reference to historic contexts, property category, and role within the INL historic landscape). The collection of data for evaluation of architectural properties involves a site inspection and archival research to establish the property's association with historic events, scientific achievements, patterns of history, and architectural design or engineering characteristics. Potential sources of information reside in DOE-HQ archives, INL archives (such as those located in the technical library, CRM Office, photography laboratory, document and records centers, Public Relations, and engineering drawings), and with past and present employees.

2. Identify the appropriate historical context using the characteristics ascertained through Step 1. If there is no previously identified historic context, a new one may be defined, its values identified, and the specific characteristics or data requirements outlined and added to the historic context.

3. Compare the characteristics and integrity of the property with integrity and data requirements of the property category. If the comparison is favorable, the property meets the criteria for the National Register. If the comparison is negative, the property fails to meet the criteria.

\section{Nomination to the National Register of Historic Places}

To date, the first INL reactor, EBR-I, is the only INL property formally nominated to and listed on the National Register. Nomination packages of other eligible INL architectural properties will be made for those that will be retained and preserved, and will be made on standard forms provided for that purpose by the National Park Service. When DOE-ID or any other interested party nominates a property to the National Register, DOE will submit the nomination to their agency official and the Keeper of the National Register for processing. As a courtesy, it will also be submitted to the Idaho SHPO for review and comment by the Idaho Historic Sites Review Board.

\section{Collection and Storage of Artifacts}

Artifacts from the INL World War II heritage and pioneering nuclear era exist across INL. Teams comprised of cultural resource specialists and persons with specific knowledge of INL historic events conduct walkthroughs of buildings and facility areas to identify artifacts for retention and/or collection. Artifacts are tagged for transport to an interim storage facility and tracked through the INL CRM Office database. DOE-ID intends that the artifacts be generally used in interpretive displays to educate the public about INL history and science. Displays will be comprised of both permanent INL exhibits at the EBR-I Visitors Center and traveling displays to other interpretive centers and museums. Some artifacts will be considered for preservation in place due to their size and/or DOE-ID's desire to retain and interpret them in their original setting.

A permanent curation facility for post-1942 INL artifacts has not been identified and may never exist. However, DOE recognizes the need for such a facility, not only for INL artifacts, but for those across the DOE complex. In the meantime, an archival plan will guide the collection of historical INL data, and a collection plan will guide the identification and collection of other World War II and nuclear-era artifacts. 


\section{Reuse of Historic Architectural Properties}

Whenever feasible, DOE-ID will reuse INL buildings, structures, and equipment. Such reuse is guided by internal management control procedures that provide processes for transferring properties from one INL project or program to another; screening to determine interest in reusing properties by other DOE facilities, other federal agencies, and private business; and ensuring that historic significance and features of properties are taken into consideration prior to activities that may affect them. The procedures for internal and external reuse are summarized in Appendix A and include:

- MCP-2860, "Building/Facility Transition"

- LWP-2008 and MCP-2477, "Utilization and Disposal of Real Property"

- LWP-8000 and MCP-3480, "Environmental Instructions for Facilities, Processes, Materials, and Equipment."

In addition to internal procedures, INL infrastructure personnel maintain a comprehensive facilities database. Project personnel use the database extensively to determine surveillance and maintenance schedules, identify available floor space, and determine those properties that have reuse potential. The database includes extensive information such as:

- Year built

- Square footage

- Condition

- Planned disposition

- Cost of maintenance

- Date of deactivation and vacancy, if applicable.

Information regarding INL cultural resources is now included in the INL Comprehensive Facility and Land Use Plan, an interactive database that provides an overview of INL, information about land acquisition and management, information about current and future INL programs and projects, planning forecasts for each area of INL, and detailed information about INL facilities (INL 2005). This information assists personnel such as project managers in their decisions regarding reuse of historic architectural properties.

When a building or structure is determined to be a candidate for reuse, its architectural significance and historic features are considered prior to any alterations that may be proposed. Such consideration is completed by the CRM Office through the cultural resource review process. When feasible, the Secretary of Interior's Standards for Rehabilitation will be followed during the alteration process and, in the interim and when a building is vacated, the Secretary of Interior's guidelines for mothballing historic properties will be followed.

\section{Tailored Section 106 Project Review}

In the past, when INL historic architectural properties were threatened by projects, DOE-ID followed the review process outlined in NHPA Section 106 on a property-by-property, project-by-project basis. This proved cumbersome and had the potential to result in costly project delays. Therefore, one of the main purposes of this plan is to tailor the Section 106 process to meet INL needs. 
The INL-specific process known as a cultural resource review is initiated early in project planning and by either contacting CRM Office staff directly or, if required by internal company procedures, via the INL NEPA compliance process. However, a word of caution is required. Although NEPA and the NHPA have similar goals, obligations of federal agencies to NHPA are independent from NEPA. The NHPA obligations must be met during INL activities, even those that do not require the completion of a NEPA checklist, EA, or EIS. Proposed projects that are not considered to be major actions with significant impacts must still consider the potential for direct, indirect, and cumulative effects on historic INL architectural properties. Also, NEPA categorical exclusions obtained for certain projects, such as those related to environmental cleanup, do not relieve federal agencies of their responsibilities as outlined in the NHPA. The NHPA is not superseded, and procedures to protect and mitigate cultural resources must be applied. In situations where both NEPA and NHPA apply, DOE-ID may choose to substitute NEPA for the NHPA 106 process. If this is the case, DOE-ID will notify the Idaho SHPO and Advisory Council in advance of each project that will be managed in this fashion [36 CFR 800 (c) 8]. "Standards for Developing Environmental Documents to Comply with Section 106" [36 CFR 800.8 (c) 1] will be applied to such environmental documentation.

\section{Cultural Resource Review Exemptions}

INL contains various property types that are elements of, or have features that contribute to, the overall landscape and understanding of INL history. However, due to the dynamic nature of the work conducted at INL and the fact that it is a functioning science and engineering laboratory, some INL property types do not meet National Register criteria. While these properties may contribute to the overall landscape under different historic contexts, they are not likely to yield additional information important to understanding those landscapes and are, therefore, exempt from consideration as potential historic properties.

In addition to exempt property types, some routine INL activities do not typically pose a threat to architectural properties or artifacts. Projects that involve activities on this list are also exempt from the review process. The exempt property types and activities, enumerated in Tables 1 and 2 of this plan, have been reviewed and approved by the Idaho SHPO, Advisory Council, Shoshone-Bannock Tribes, and INL CRM Office professionals. Additions of property or activity types proposed for inclusion on these lists will require similar review and approval (SHPO letter May 22, 2003). Due to its status as a National Historic Landmark, for activities proposed at EBR-I, DOE-ID will follow 36 FR 800.10.

\section{Cultural Resource Review Process}

Caution is exercised during INL project planning to ensure that no historic architectural properties are inadvertently destroyed, transferred, sold, or altered. This requirement is met through the following internal cultural property review process.

Initiating a Review. All work at INL is guided and controlled by various internal standards and procedures, such as:

- PDD-8100, "Environmental Management System"

- LWP-6200 and MCP-6020, "Integrated Work Control Process"

- LWP-21220 and MCP-3562, "Work Management" and "Hazard Analysis and Control of Operational Activities"

- LWP-8000 and MCP-3480, "Environmental Instructions for Facilities, Processes, Materials, and Equipment." 
Compliance with these standards and procedures will require managers working on projects that may affect architectural properties to screen their projects against the exempt property types and activities lists (see Tables 1 and 2 in the "Idaho National Laboratory Cultural Resource Management" Section) and/or complete a NEPA environmental checklist. If it is determined that the project activities are not exempt and may affect a property that is not exempt, the project manager or designee will contact the INL CRM Office to initiate a review. INL CRM Office personnel will determine the area of potential effect, the potential for impact to a historic property by the project, and whether or not that impact will be adverse.

Obtaining Required Information. To initiate and facilitate the review process, at a minimum, the project manager will provide to the INL CRM Office a succinct statement of the work to be performed, which will describe the project, its location, size, and scheduled start and finish dates; the identity of the performing organization and point of contact; and funding to conduct the review. For large or complex projects, additional information may also be requested.

Timing of Reviews. Review requests are to be made to the INL CRM Office early in the project planning process. At least 30 days are to be allowed for completion of the INL CRM Office review. If the INL CRM Office determines that the eligibility and effect findings require Idaho SHPO and/or Advisory Council consultation, additional time will be required to draft a formal letter of consultation and to gather documentation that will aid in the consultation review process. After consulting parties have received sufficient information, they will have 30 days to review the project. On rare occasions, additional 30-day review periods may be necessary depending on timing and the complexity of the project.

\section{Effect Determinations}

Briefly, after compiling and reviewing appropriate documentation as previously discussed, the INL CRM Office will determine if the proposed project will impact historic architectural properties. Three possible effect determinations exist:

1. No historic architectural properties affected. No historic architectural properties exist within the area of potential effect; or historic architectural properties are present, but the proposed undertaking will have no effect on the characteristics that make the properties culturally important. In this case, the project may proceed as planned.

2. No adverse effect. Potentially eligible architectural properties are present in the area of potential effect, the undertaking is not exempt and will affect the historic properties, but the effect is or can be rendered not adverse. The INL CRM Office will work with project managers or their designees to ensure, or to develop strategies to ensure, that project activities will not be harmful to the historic property. When appropriate and if possible, project work plans will be written or adjusted to incorporate applicable avoidance and protective measures that render a potentially adverse effect harmless. Discussion regarding methods used to redesign projects or to turn anticipated adverse effects into no adverse effects will be documented, retained in the INL CRM Office, and summarized in annual reports.

3. Adverse Effect. The project activities are not exempt and will result in damage to one or more historic architectural properties. According to 36 CFR 800, "Protection of Historic Properties," an undertaking has an effect on a historic property when the undertaking may alter the characteristics of the property that may qualify the property for the National Register. The effect is considered to be adverse if it may diminish the integrity of the property's location, design, setting, materials, workmanship, feeling, or association in any of the following ways:

- Destruction, damage, or alteration of all or part of the property 
- Isolation of the property from or alteration of the character of the property's setting when that characteristic contributes to the property's eligibility

- Introduction of visual, audible, or atmospheric elements out of character with the property or the setting

- Neglect of a property resulting in deterioration or destruction

- Transfer, sale, or lease of the property without protective covenants.

In the event that adverse impacts cannot be avoided, DOE-ID will consult with the Idaho SHPO and interested parties to develop measures to minimize or mitigate the impact.

\section{Mitigation}

When an effect on a historic architectural property will be adverse and avoidance or reuse is infeasible, mitigation to minimize the adverse effect will be necessary. Based on the relative importance of the affected property, as defined by the property category, mitigation includes varying types of documentation based on its relative significance. EBR-I is exempt from this process due to its status as a National Historic Landmark.

In the event a project is proposed that will substantially alter or demolish EBR-I, DOE-ID will follow the provisions outlined in 36 CFR 800 . For all other DOE-ID-owned buildings surveyed to date, mitigative recordation will be conducted as follows:

- Signature Properties. DOE-ID will follow 36 CFR 800.3 through 800.7. In addition, the DOE-HQ chief historian will become a consulting party and a signatory to any agreements that may develop. Serious consideration will be given to preservation in place.

- Category 1 Properties. If an architectural property housed a reactor or a significant process (e.g., ETR at RTC or the Fuel Processing Building at INTEC), was constructed during the defined period of significance (1942-1970), or is determined to have exceptional importance, that architectural property will form the primary property in a HABS/HAER study. The primary facility and its historic features will be thoroughly documented to HABS/HAER Level II standards. The complex of buildings, structures, and objects directly supporting the primary facility or process will be incorporated into the HABS/HAER study (HABS/HAER Collections 1983). A single HABS/HAER document might include several Category 1 structures (e.g., the TAN hangar).

- Category 2 Properties. If an architectural property is an integral component in the reactor or process complex (e.g., cooling tower, heat exchanger, or reactor coolant pump house), its interior, when possible, and exterior will be photographed with large-format, archivally processed, black-and-white film. Photographs will include one photograph of each side of the building or structure, oblique photographs showing the relationship of the building or structure to associated buildings or structures, and interior photographs that illustrate historic features. The photographs will be preserved along with architectural and engineering drawings that depict elevations, sections, details, and historic features; and with available historic photographs of construction, manufacture, and other activities or experiments. When a HABS/HAER study is required for the key building or structure in a complex, these photographs and other documents will become part of the study.

- Category 3 Properties. If an architectural property such as a guardhouse, cafeteria, or warehouse was contributing, but was not directly related to the key building or process, it will be documented with 35-mm black-and-white reconnaissance-level photographs and the completion of an Idaho Historic Sites Inventory form. This documentation will be preserved by the INL CRM Office and 
made available to scholars, researchers, and other interested parties. When appropriate, some 35-mm photographs will be included in HABS/HAER reports to illustrate the narrative.

If DOE-ID fails to complete HABS/HAER documentation prior to initiating activities that may adversely impact a Category 2 or 3 historic architectural property, they will provide the Idaho SHPO with the appropriate level of documentation as previously described. Category 1 buildings will not be adversely impacted prior to approval of the appropriate HABS/HAER report by the Idaho SHPO and National Park Service.

If an undertaking is proposed that involves properties that have not been surveyed or evaluated, surveys and evaluations will be completed and, in the event that they will be adversely impacted, the mitigation methodology previously described will be used, or new methodology will be developed in consultation with the Idaho SHPO, Advisory Council, Tribes, and other stakeholders, as appropriate. The new methodology will be incorporated into this plan or a memorandum of agreement will be developed.

\section{Responsibilities and Consultations}

The collection of data and preliminary determination of National Register eligibility are the responsibility of the INL CRM Office on behalf of DOE-ID. Consultation is initiated with the Idaho SHPO, Advisory Council (when appropriate), and other interested parties via a letter report that includes:

- Completed Idaho History Sites Inventory form (Figure 36)

- Determination of eligibility

- 35-mm photographs

- Evaluation techniques used

- The evaluation.

When the consultation process is initiated in response to a proposed project that may result in an adverse impact to a historic architectural property, in addition to the aforementioned information, the INL CRM Office will also include:

- Determination of the effect of the proposed project on historic architectural properties

- Project description

- Description of the area of potential effect

- Strategies developed to mitigate adverse effects of the undertaking.

If, after receiving sufficient information, the Idaho SHPO does not respond within 30 days, SHPO concurrence with the INL CRM Office's preliminary determination of eligibility is assumed. In addition, if the Idaho SHPO and Advisory Council do not respond to findings of effect within 30 days of receiving sufficient information, their concurrence is also assumed. The Idaho SHPO and Advisory Council have 30 days at each step of the process where they are involved. In the event the Idaho SHPO and/or Advisory Council disagrees with DOE-ID or requests additional information, DOE-ID and Idaho SHPO will confer in an attempt to resolve the matter. If DOE-ID and Idaho SHPO still fail to agree on eligibility after discussion and collection of additional data, if needed, DOE-ID will submit a request for formal determination of eligibility to the Keeper of the National Register of Historic Places. If DOE-ID and Idaho SHPO fail to agree on effect, DOE-ID will request the views of the Advisory Council. 


\section{Reporting}

Cultural resource management activities conducted by the INL CRM Office for DOE-ID will be reported annually to the Idaho SHPO, Advisory Council, Shoshone-Bannock Tribes, and interested parties. The report will form the basis for an annual meeting to be held each fiscal year, as deemed necessary. 


\section{IDAHO HISTORIC SITES INVENTORY: INEEL HISTORICAL CONTEXT}

Idaho State Historic Preservation Office

This form documents a building at Idaho National Engineering and Environmental Laboratory. It assesses its eligibility for the National Register of Historic Places and includes other data pursuant to a Programmatic Agreement for INEEL.

\section{PROPERTY DATA}

*Property Name/Area/Bldg. Number TRA Access Control Facility TRA/658

*USGS Map Reference Circular Butte 3 SW Idaho

*Township $\underline{3 N} \quad$ Range 29E Section 14, SW 1/4 of NW $1 / 4$ of SE 1/4, Boise Meridian

UTM: zone $\underline{12} \underline{341500}$ easting $\underline{4827430}$ northing

*County Butte Acres Less than one acre City $\underline{40 \text { miles west of Idaho Falls }}$ *Address Idaho National Engineering and Environmental Laboratory

Historic Context Science/Engineering: Post-Nuclear Research

*Property Type: Building *Total \# features

*Associated bldgs./structures TRA COMPLEX

*Construction Date 1987 Estimated Construction Period 1 story, flat roof $*$ Condition Excellent *Moved: Yes When Style No Style Plan Rectangle,

* Materials Concrete foundation. Concrete walls. Roof is precast concrete with rubber roof membrane and gravel ballast.

*Original Use Govt/Security (control) *Current Use Govt/Security (control)

\section{NATIONAL REGISTER RECOMMENDATION: (check all that apply)}

Individually eligible $\quad \underline{X}$ Not eligible

_ Contributing in a potential district $\underline{X}$ Noncontributing

_ Multiple property study

_ Significant person Historical significance

_ Architectural/artistic values $\mathrm{X}$ Historic landscape

Comment

*Recorded by The Arrowrock Group, Inc. *Phone (208) 344-7371

*Address 1718 North 17th Street, Boise, Idaho 83702 INEEL, Toward a Programmatic Agreement Survey Report \# *Project/Report Title Historic Context of $\underline{\text { Sept. } 19,1997}$

\section{FIELD NOTES/ADDITIONAL INEEL INFORMATION}

Other name(s)

Access restrictions due to contamination yes

IHSI\#

Square footage of building $\quad 4,768$

Future plans Maintain

Historian's type classification Security

REV\#

Historian's recommendation for mitigation upon finding

of adverse impact: This reconnaissance - level survey

SITS\#

Figure 36. Example of completed Idaho Historic Sites Inventory form. 
Appendix E

\section{Research Designs}




\section{Appendix E}

\section{Research Designs}

\section{INTRODUCTION}

This appendix describes the research design that was originally prepared to guide large-scale archaeological inventories conducted in the mid-1980s. This research design was originally prepared and presented in Reed et al. 1987: 115-146. The INL CRM Office will prepare an update to this framework in the future.

\section{RESEARCH DESIGN}

The development of a research design is crucial to the successful completion of cultural resource management projects. Research designs provide a "frame of reference" describing the conceptual assumptions, research goals, hypotheses, methods, and operations of the researchers. Of critical importance is that research designs provide the foundation for determining the legal status of the cultural remains discovered during the project. Archaeological sites are eligible for protection and/or mitigation if they qualify for placement on the National Register of Historic Places. Sites qualify for the National Register if they have the potential for making scientific contributions to our understanding of the "life and culture of indigenous peoples." The principal means of assessing the potential "scientific contributions" of a site is through a well-developed research design (1980 addendum to the 1966 Historic Preservation Act).

The most effective research designs are those developed for ecologically bounded regions rather than for areas conforming to modern political boundaries (Fowler 1982). Physiographic features such as hydrographic basins are appropriate to define these regions because they often correlate with the economic "home range" of many prehistoric and early historic peoples (i.e., the region where most resources were obtained to sustain life on a yearly basis). Therefore, the cultural history of INL acquires meaning only when viewed in a larger context of human adaptation to the distribution and range of resources available in the entire upper Snake River Basin. The research design developed below incorporates hypotheses that have relevance not only to interpreting archaeological sites on INL but also to sites throughout the upper basin and, in some instances, to areas beyond.

It should be noted that research designs are meant to be dynamic statements that are continually updated to incorporate new discoveries and hypotheses. This research design is only the first step toward addressing the diverse potential of the sites on INL, and it should not be viewed as the final word. It is anticipated that it will be refined as more data become available to more accurately reflect the scientific significance, and therefore, the legal status of INL sites and the surrounding area.

It is generally agreed by professional archaeologists that an adequate research design should minimally contain the following elements (following Fowler 1982):

1. A description of the current understanding of the culture history and the distribution of the resource base in the area of concern

2. A description of the general theoretical approach to interpreting the place of prehistoric and historic sites in the culture history of the region

3. An outline of the general areas or domains of research interest, including specific research questions and the types of data necessary to answer those questions 
4. A description of the research strategies necessary to collect the data needed to answer the research questions

5. An operations management plan that describes how the project objectives were completed.

All of the above five elements are presented in this appendix.

\section{Theoretical Orientation}

Cultural materialism (Harris 1979) provides the theoretical framework for the approach taken to interpret the archaeological sites recorded at INL and surrounding region. Both explicit and implicit in the theory are five assumptions that form the framework of the approach:

1. Cultural systems consist of numerous interrelated parts or subsystems such as technology, social organization, and ideology, and changes in one system cause changes in the others in predictable ways

2. Culture is an energy-transforming system of objects and behaviors that draws all of its raw materials and energies from the natural environment via technology; therefore, technology is viewed as the "prime mover" of culture

3. A great deal of cultural behavior is oriented toward energy and raw material acquisition, and most of the archaeological record results from this interaction of culture (via technology) with the natural environment at particular behavioral loci resulting in debris that directly reflects those technological activities

4. When stress is experienced by a culture (e.g., when the acquisition of resources becomes overly difficult due to population pressure or environmental change), that culture will respond by intensifying production (i.e., technological development) and/or by migration to areas where the existing technology is sufficient

5. The spatial and contextual patterns exhibited by the archaeological record reflect the settlement and technological behavior of the culture.

These assumptions outline a theory relating human culture, material remains, and environment. An important implication is that archaeologists should be able to directly interpret subsistence and technological activities from the archaeological record, and, as a result, should be able to indirectly define parameters of the other interrelated cultural subsystems, such as social organization and ideology.

\section{Research Design Organization}

The objective of archaeological research is to answer questions about the histories, lifeways, and processes of cultural change of past and present cultures (Thomas 1979). As previously discussed, the sole reason for conducting cultural resource surveys is to mitigate the adverse effects of development projects on the research potential of archaeological sites or regions; in other words, those sites that appear to have the potential for answering questions about history, lifeway, or process are mandated by law to be preserved or subjected to scientific excavation prior to disturbance. Those questions, therefore, must be designed and organized in a clear and defensible manner, and they must be expressed so that they are answerable. Then, research procedures must be designed to effectively extract the needed information from the total body of observable data.

For projects conducted strictly for academic research purposes, the investigator has the distinct advantage of being able to formulate his interests first, postulate the questions, and then seek the sites or 
regions that have the potential for answering those questions. The research procedures, therefore, can be designed to acquire the data of interest. The ideal approach is reversed for cultural resource projects, such as those at INL. The study region is defined by the project along with portions of the research procedures. Therefore, the addressable research questions are defined by the project parameters instead of by the research interest, as in academic research projects. This reversal of the ideal research approach (i.e., question formulation, research design, and data recovery) results in a situation that is awkward to control. This is so because thousands of research questions could be posited for a project area, yet the discovered archaeological sites may address few, if any. The field archaeologist must be aware of all of these questions so that potentially significant sites can be recognized, but only those questions that directly apply to the observed resources are relevant and need to be developed during the analysis and reporting stages of the project.

The remainder of this section presents research questions that are appropriate for the range of archeological sites known to exist on and around INL. The questions emerge from the overviews previously presented. It should be emphasized that a research design is more than a list of research questions; it must also outline the processes that lead to answers. One of the most difficult aspects of research design formulation is stating questions so that they can be answered. This often leads to questions that appear mundane and of little importance, yet they are crucial for addressing the broader objectives of archaeological research. In response to this, a hierarchical organization of questions and interests has been proposed (Fowler et al. 1981) as an appropriate organization for regional research designs. The organization has been successfully incorporated in several large-scale cultural resource surveys in the Desert West (e.g., Janetski 1981; Janetski and Holmer 1982). The approach organizes research objectives and questions according to the following outline:

\section{Problem Domains \\ Research Topics \\ Research Questions \\ Data Requirements}

Several research topics might be presented under each domain, and several questions under each topic.

\section{Problem Domains}

Problem domains are general categories of research topics that embody all of the objectives of archaeological research: the who, what, where, when, and why of past cultures. The domains currently developed for INL are:

- Chronology

- Settlement and subsistence

- Cultural relationships

- Demography

- Environment

- Technology

- Material culture data recovery techniques. 
There are undoubtedly others that can and will be added, but it is felt that most questions currently being asked of the archeological record in the upper Snake River Basin fall under one of the aforementioned domains.

The problem domain of chronology subsumes questions that address when archaeologically defined cultures existed and how archaeologists recognize those cultures from their material remains. Settlement and subsistence subsumes questions about settlement patterns and economy, demography about population density and distribution, and technology about manufacturing, processing, and resource acquisition techniques. Since cultures do not develop in a vacuum, the problem domains of environment and cultural relationships deal with the physical and cultural surroundings with which groups interacted. New techniques are continually being developed for analyzing archaeological data that are addressed by the problem domain of data recovery techniques.

\section{Research Topics}

Subsumed under each problem domain are several research topics that specify an aspect that is of research interest. For example, inquiries about projectile points and ceramics suggest two topics under chronology (and, perhaps also under technology, material culture, and cultural relationships). Research topics are general statements of overriding problems and are not specific to a time or place. Using the example of projectile points, one topic under chronology should address the temporal meaning of projectile point styles in the upper Snake River Basin. This topic would be accompanied by background information briefly describing the history of research into this aspect of chronology with a summary of what we now know.

\section{Research Questions}

Under each research topic are questions to be answered by investigating the archaeological record. These questions must embody specific hypotheses and must be carefully stated so that they can be answered. Using the example of projectile point chronology, we are interested in knowing if the chronology, as interpreted for the Bonneville Basin, applies to the upper Snake River Basin, or if there is a sequence of styles that more closely resembles the northern Rocky Mountains, the central Great Basin, or the northern plains. This overall interest would be developed in the background discussion accompanying the research topic of projectile point chronology. In order to satisfy this interest, we might wish to discover a well-stratified and deep cave site in the middle of the basin. However, such a site is not absolutely necessary because many, less impressive sites combined might contain adequate information to address the larger interest, or taken singly, to address an aspect of the larger interest. Therefore, the questions should be as narrow and specific as possible; they should not be stated as, "What is the chronology of the basin?" but as a series of questions specific to a projectile point type and time frame. For example, "Do Elko Corner-Notched points in the basin date to 3300 to 1000 B.P. as they do in the central Great Basin and northern Rocky Mountains, or to 7800 to 900 B.P. as they do in the eastern Great Basin?" This question simply requires a yes or no answer to each of its parts. This question would be followed by similarly phrased questions about other point styles; all questions collectively address the research topic of regional projectile point chronology.

\section{Data Requirements}

Each question is followed by the data requirements needed to successfully formulate an answer and specific guidelines on how to recognize sites that potentially contain the data. What is more important is that instructions must be provided that indicate how the data fit together to answer the question. This element is the heart of any research design; it is the bridge between the archeological record and knowledge. 
Returning to the Elko point chronology example, the data requirements should specify a site with the potential for being of Archaic age and containing sealed deposits with datable materials. Guidelines for recognizing such a site would include seeking out rockshelters or lava tubes containing deposits with diagnostic Archaic projectile points or open sites with geological evidence of aggrading deposits. A test excavation would be justified to establish the real potential for answering the question.

\section{INL Research Design}

Each of the problem domains presented thus far can potentially be addressed by the archaeological data recovered during the surveys. Interpretations concerning the potential contribution of the recovered data and recommendations about how that potential can be realized are presented later in this appendix. The research design, as presented in this appendix, is also suitable for evaluating the potential research contributions and, therefore, the legal status of previously recorded INL sites. However, it must be reemphasized that the design is far from complete and is meant primarily to address the range of data recorded during the surveys conducted by the Swanson/Crabtree Anthropological Research Laboratory (Reed et al. 1997).

\section{Problem Domain: Chronology}

Determining the chronological meaning of different styles of stone tools, ceramics, and other artifacts is a critical step toward the interpretation of the prehistory of an area. Only through a detailed understanding of the artifact chronology can the antiquity of most archaeological sites be estimated. Without knowing the age of occupation of sites, little else can be learned about the other problem domains. For this reason, chronology is the most basic of the domains and has the most immediate priority.

There have been several excavations in the upper Snake River Basin that have contributed to our understanding of artifact chronology; however, most were completed before modern approaches to the analysis of style were developed. Reanalysis of those collections along with the collection of new specimens in a controlled manner is essential. Several INL sites could make significant contributions and are therefore protected by law.

Research Topic: Projectile Point Chronology. A generalized projectile point sequence has been proposed for the upper Snake River Basin based on previously excavated sites (Butler 1978); however, a more recent interpretation of the existing data proposes a much tighter sequence of styles based on comparisons with sequences developed for surrounding regions (Holmer 1986). Whereas the "tighter" sequence seems more desirable because it allows more precise age determinations of sites to be made, it is difficult to determine its validity because of the sparse nature of the existing data. It is only through meticulous data collection from the kinds of sites that exist at INL that our knowledge of projectile point sequence can be refined to the point that it is useful for answering basic questions in other domains.

Research Question-What is the age of the stemmed-indented base point in the study area?

The age of stemmed-indented base points has been an enigma for several decades of archaeology in the Desert West. Arguments in the literature debate an early occurrence (8300 to 6200 B.P.) vs. a late occurrence (5000 to 3300 B.P.) in various regions. Recently, Holmer (1986) concluded that stemmed-indented base points occur during both time periods (some regions contain points from only one period, and some both) and that the points of each period are not related to each other but were independently developed styles. He suggests that points of both periods are present in the upper Snake River Basin and that they should be distinguishable from each other by making a few key measurements based on a computerized comparison of the early and late series in other areas of the Desert West. Such a project has not yet been conducted in southern Idaho because of the paucity of well-dated specimens. 
Since numerous stemmed-indented base points occur at INL, sites containing them are especially important to determine if both early and late varieties occur there and how to tell the difference between the two.

Data Requirements: Any site containing stemmed-indented base points that also has the potential for buried deposits and datable materials.

Research Question-What is the age of other stemmed points in the study area?

There are numerous other styles of stemmed point styles reported to have been found in southern Idaho (e.g., Haskett, Birch Creek, Silver Lake, Alberta, and Scottsbluff points). Many of these styles are believed to have been made during the Pleistocene-Holocene transition, while some clearly date much later. Some researchers (e.g., Bryan 1980) argue that some varieties of stemmed points date as early as or earlier than fluted points (11,000 to 10,000 B.P.) and others sustain until 5000 B.P. or even more recently. Some characteristics seem to segregate the earlier from the later varieties (e.g., basal grinding), but only well-dated examples will provide the answer. Several stemmed points have been recovered from INL, and there seems to be great potential for understanding their temporal meaning through careful research.

Data Requirements: Any site with stemmed points especially if there is some potential for dating the age of manufacture (e.g., firehearths).

Research Question-What is the age of the large side-notched point in the study area?

Of all of the point styles common to the upper Snake River Basin, the temporal meaning of certain varieties of large side-notched points (e.g., Northern or Bitterroot Side-Notched points) is probably the best understood (7300 to 4400 B.P.). Other varieties, however, are not so well documented. Those specimens that exhibit a very low notch, such as the Besant and Blue Dome styles, appear to date to a later period (1300 to 3300 B.P.); however, this conclusion awaits further well-controlled data. Numerous points of the low-notch variety have been recovered from INL, and the area clearly has potential to understand their temporal similarities and differences with the high-notch variety.

Data Requirements: Any site with large side-notched points, especially with a potential for a datable context.

Research Question-What is the age of the large corner-notched point in the study area?

Large corner-notched points, known as Elko corner-notched in the Great Basin and as Pelican Lake in the northern plains, commonly occur in contexts dating between 1000 and 3300 years ago over vast areas west of the Mississippi River. Earlier, yet morphologically indistinguishable varieties occur in some areas of the Desert West (e.g., the Bonneville Basin) as early as 8000 B.P. In the upper Snake River Basin, a few specimens have been found in a pre-3300 B.P. context, but the majority seems to occur after that time. The presence of a few specimens in the early context suggests that the longer sequence of the Bonneville Basin might be applicable to INL, yet their paucity in contexts dating earlier than 4000 B.P. may indicate that excavation error or stratigraphic mixing might be the culprit. Since large corner-notched points are the most common style of point found at INL, it is imperative that additional data about their age be collected.

Data Requirements: Any site with datable material that contains large corner-notched points.

Research Question-What is the age of the small corner-notched point in the study area?

Throughout the American West, the replacement of large corner-notched points by small corner-notched points (locally called Rose Spring Corner-Notched points) in the archaeological record 
signifies the adoption of the bow and arrow replacing the atlatl and dart as the principal hunting technology. This appears to have occurred in the upper Snake River Basin between approximately 1500 to 1300 years ago. Although the date of introduction of the style is of interest, the termination date of use of the style is of greater importance to our understanding of the prehistory of the area. In most areas of the Desert West, the small corner-notched points are replaced by small side-notched points between 1000 and 600 years ago. But the pattern in the upper Snake River Basin appears different: small corner-notched points seem to continue until historic times with small side-notched points being added to the repertory of styles made by the more recent inhabitants. Knowing if the small corner-notched points were still being made within the last 600 to 1000 years is critical for interpreting other research questions, especially those concerning cultural relationships.

Data Requirements: Any site with small corner-notched points in a stable context.

Research Question-What is the age of the small side-notched point in the study area?

As mentioned in the previous discussion, small side-notched points begin appearing in the archaeological record of the Desert West after approximately 1000 years ago. By approximately 700 years ago, they are the most common style. Numerous small side-notched point varieties occur that seem to have different temporal and spatial meaning. Point styles include Desert Side-Notched, General and Sierra subtypes, Avonlea, Plains Side-Notched, Prairie Side-Notched, Bear River Side-Notched, Uinta Side-Notched, and Nawthis Side-Notched. These different varieties have been only recently been recognized and most have been recovered during surveys at INL.

Data Requirements: Any site with small side-notched points in a datable text.

Research Topic: Ceramic Chronology. The time depth of ceramic manufacture in the upper Snake River Basin is poorly understood. Like projectile points, there are different styles and manufacturing techniques evident in the ceramics of the upper Snake River Basin that probably have temporal meaning. Three basic styles or types are present:

1. Well-made, thin-walled small globular coiled vessel with limited incised decoration around the rim and occasionally the handles

2. Crudely made medium-sized paddle and anvil globular or conical vessel

3. Crudely made molded and coiled flat-bottomed vessel.

All of these ceramic styles appear to date to within the last 1300 years.

Research Question-What are the dates associated with the manufacture and use of the well-made globular vessels in the study area?

Current evidence suggests that this variety of ceramics was the first made in the upper Snake River Basin beginning sometime shortly before 700 A.D. (Anno Domini [in the year of the Lord]). This style appears to be technologically related to the pottery technology practiced throughout the Southwest U.S. between approximately 500 and 1300 A.D. The local specimens may well be the northern-most example of this technological tradition. Of particular interest is that the manufacture of well-made globular vessels ceased in areas just south of the upper Snake River Basin by approximately 1300 A.D., but perhaps continued locally into early historic times. Knowing the date range of this style of vessel is critical to understanding many questions under other research domains.

Data Requirements: Any site with well-made pottery in a datable context and in association with other artifacts. 
Research Question-What are the dates associated with the manufacture and use of the crudely made globular and conical vessels?

It is generally interpreted that more crudely made pottery (e.g., Promontory Ware) represents the incursion of other groups into the area and date to after 1350 A.D. In many surrounding areas, this style and the crudely made flat-bottomed vessels (see next research question) seem to have replaced the earlier well-made vessels. This does not seem to be the case in the upper Snake River Basin where both occur in a post-1350 context.

Data Requirements: Any site with crudely made globular and conical vessels in a datable context and in association with other artifacts, especially other ceramic styles.

Research Question-What are the dates associated with the manufacture and use of the crudely made flat-bottomed vessels?

Crudely made flat-bottomed vessels (e.g., Intermountain Ware) seem to date after 1350 A.D. and have been interpreted as a Shoshone incursion into the area. As with other crudely made vessels in areas surrounding the upper Snake River Basin, the earlier well-made styles were replaced at that time by the flatbottomed vessel. In the basin, however, the flat-bottomed vessels seem to show up in the archaeological record at that time, but the well-made pottery continued to be made. The apparent contemporaneousness after 1350 A.D. of both types makes the prehistory of the area unique and, if true, is of critical importance to understanding the cultural history of the area.

Data Requirements: Any site with flat-bottomed vessels in a datable context or in the direct context with other pottery types.

\section{Problem Domain: Settlement and Subsistence}

As presented thus far, if we can understand the distribution of archaeological sites (i.e., settlement) relative to the distribution of necessary resources (i.e., subsistence), we can interpret much about the lifeway of the people who left those sites behind. Our ability to accomplish this greatly depends on a detailed understanding of the cultural chronology of the area so that sites of different time periods are not lumped together in a single analysis.

The basic approach to analyzing the settlement and subsistence of a prehistoric time period has been to correlate the presence or absence of sites with existing environmental zones. With some knowledge of past climatic changes (see the environment problem domain), positive and negative correlations lead to interpretations about the importance of specific resources to the regional inhabitants during that period. To make reasonable interpretations, we must also assess the range of activities conducted at each recorded site because environmental variables would be of different importance to different activities (e.g., a fishing site would likely be in a different environmental and topographic location than an antelope hunting blind). Therefore, a settlement and subsistence analysis has three independent variables: time period, ecozone, and activity. The dependent variable in the analysis is the subsistence organization of the groups inhabiting the region at that time. Once categories or scales for each variable have been defined, the analysis becomes a simple statistical exercise; the principal problem, however, is to define meaningful categories or scales for the variables. Research oriented toward defining two of the variables is addressed under other problem domains: the time period under cultural chronology and the ecozone under environment.

A variety of approaches to defining categories of site activities and subsistence organization have been developed. One approach used during several large-scale research projects in the Great Basin seems applicable to the upper Snake River Basin. This is because of the similar range of environments and 
archaeological sites based on a model of hunter-gatherer foragers and collectors (Binford 1980). Binford's field research with the Nunamiut Eskimo and his interpretation of descriptions of other known hunter-gatherer groups led him to argue that subsistence organization can be best interpreted by the logistical complexity of resource acquisition. He proposed a continuum from simple to complex; the simplest involves consumers consistently moving their residences to where food is immediately available, with the most complex involving consumers only occasionally moving their residences but acquiring resources often distant from the residence and transporting them back. The simple end of the continuum, called foraging by Binford, is defined as follows:

[Foragers] typically do not store foods but gather foods daily. They go out gathering food on an encounter basis and return to their residential bases each afternoon or evening... [T] here are apt to be basically two types of spatial context for the discard or abandonment of artifactual remains. One is in the residential base, which is...the hub of subsistence activities, the locus out of which foraging parties originate and where most processing, manufacturing, and maintenance activities take place... [and the other is]...the location. A location is a place where extractive tasks are exclusively carried out [by the foraging party]. (Binford 1980:5)

The more complex end of the continuum, called collecting by Binford, is defined as follows:

[Collectors] are characterized by the storage of food for at least part of the year supplying themselves with specific resources through specially organized task groups. Site implications [are] that special task groups may leave a residential [base] and establish a field camp from which foodprocurement operations may be planned or executed. If such procurement activities are successful, the obtained food (taken at locations) may be field processed [at the field camp] to facilitate transport and then moved to the consumers in the residential base. (Binford 1980:10)

To summarize the difference between foragers and collectors Binford concludes that foragers move consumers to goods with frequent residential moves, while collectors move goods to consumers with generally fewer residential moves. Cultures that move goods to people (collectors) are, in Binford's terms, more logistically organized.

The terms "foraging and collecting" refer only to hunter-gatherers that move their residences at least once during the year. Entirely sedentary groups, such as agriculturalists, are even more logistically organized since the group is committed to stay near their fields and storage facilities for much of the year. Industrialized societies, such as our own, are the most logistically organized because most, if not all, of our consumption involves nonlocal resources brought to us through elaborate logistical systems.

To account for the range of logistical organizations that occurred in the Desert West during prehistoric and early historic times, Holmer (1980: 133) defined harvesters as follows:

Harvesters are characterized by the storage of foods for at least part of the year and relatively large semi-permanent to permanent residential bases tethered to a highly productive ecozone such as a marsh and/or horticultural field. Resources not associated with the focal ecozone are acquired through specially organized task groups that leave the residential base and establish a field camp from which food-procurement operations are executed. The obtained food, taken at locations, may be processed at the field camp and then transported to the residential base for storage and consumption. (Holmer 1980: 1331)

Since simple agriculturalists would often be similarly "tethered" to fields as harvesters are to exceptionally productive ecozones, they should also fall under this category. 
These three idealized subsistence strategies form a continuum from simple to complex. They are:
Simple
1) Foragers - frequent residential moves among resource patches
2) Collectors - occasional residential moves with frequent task group visits to distant resource patches

Complex 3

3) Harvesters - permanent residential habitation near highly productive ecozones with occasional task group visits to distant resource patches.

By constructing this continuum, it is not suggested that a particular culture can be placed at a single point along it. There is clearly a considerable amount of variability within each group. For example, a group may spend much of the year harvesting a single resource but spend the remaining time collecting a variety of resources in a variety of ecozones; or, within a single cultural group, one residential group may be more mobile (foraging) than their relatives (collecting). What is suggested is that, on average, there is an interpretable difference between cultural groups with different logistical organizations. As implied by the definitions of the idealized organizations, we would expect different relative frequencies of the various kinds of sites for each organization. A test to determine if this is reflected in the archaeological record was successfully conducted (Holmer 1981) using 6,000 computer-encoded sites in Utah. The data substantiated predictions about the relative difference in frequencies of residential bases, field camps, and procurement locations between Archaic hunter-gatherers and Fremont horticulturalists. Because of the success of this approach, it has been adopted to address the archaeological record of the upper Snake River Basin. Not only does this approach provide a model for interpreting the logistical organization of resource acquisition, but it also provides a meaningful site typology for use in interpreting sites at INL.

Sites are classified according to the variability in observed artifacts and features that represent the variability of behaviors and activities carried out at the site. The greater the variety of activities, the more likely it was a residential base; the fewer the variety, the more likely it was a specialized resource procurement location. Field camps fall between with some variety of represented activities, but with a clear focus on only one. Stations and caches are specialized hunting and storage sites represented by a very narrow range of activities (see Figure 37 for an illustrated theoretical organization of archaeological sites in a subsistence and settlement pattern).

This discussion must be qualified with a cautionary note regarding the limitations of using surface observations to build a functional site typology and drawing conclusions about the nature of settlement systems based on that typology. Since the assignment of a site to a particular category is based on the material array observed, any alteration of that array may result in an improper categorization. However, the fact that predicted patterns in site distributions are actually reflected in the record suggests that site burial or disturbance may add "noise" to the data, but does not obliterate the underlying pattern.

Site taxonomy is based on the amount of variability in the artifacts and features observed at each site as recorded on the site form. It is not simply the number of different kinds of artifacts, but the number of different activities implied by those artifacts. For example, several different artifact types might be used in the killing and field butchering of an antelope (e.g., projectile points, bifaces, and utilized flakes), but the site simply represents a hunting location. A similar number of artifacts could represent a field camp if more activities are implied, such as a scraper, projectile point, and ground stone. We would be especially convinced that a site containing this inventory was a field camp if there was evidence of a firebasin present (e.g., charcoal or fire-cracked rock). Of course, now the site might be confused with a residential base, but that should show an even broader range and more intense processing of raw materials. 


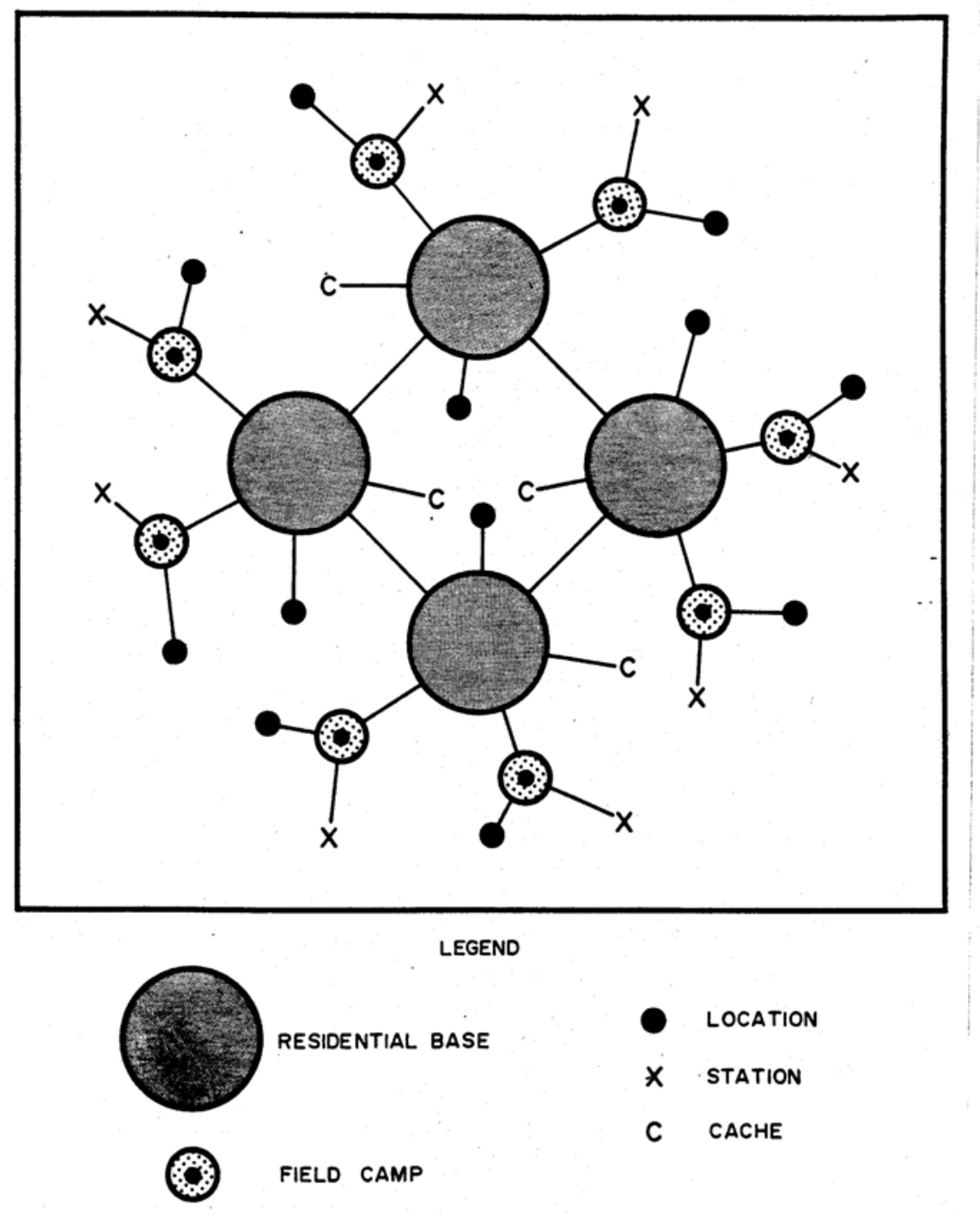

Figure 37. Theoretical organization of prehistoric archaeological sites in a subsistence and settlement pattern.

The five site types are defined as follows:

1. Residential bases are sites that contain artifacts representative of the processing of a variety of resources (e.g., ground stone, scrapers, bifaces, and utilized flakes). They often contain evidence of dwellings, storage, and firebasins.

2. Field camps are sites that contain artifacts representative of the processing of a single resource often accompanied by a firebasin. They may be seed-gathering camps, hunting camps, quarrying camps, or any other single-resource acquisition campsite.

3. Procurement locations are sites that contain evidence of the procurement of a single type of resource with little or no processing implied and no evidence of camping. They may be seed gathering locations, hunting locations, quarrying locations, or any other resource acquisition site. It should be mentioned that many locations (e.g., seed gathering site) may not leave physical remains behind for the archaeologist to observe. 
4. Caches are isolated storage sites with little or no evidence of the processing of resources and no evidence of camping. Those storage facilities that accompany residential base sites are not classified as cache sites unless they are physically separated enough to be distinguished as a separate site.

5. Stations are information gathering and transmitting sites such as vantage points, cairns, and rock art. Some debris may be present as a result of tool manufacture or maintenance, and limited evidence of camping may be present. Rock art sites (e.g., pictographs and petroglyphs) that are isolated from artifacts are classified as stations because of the implied information transmitting characteristics of the site.

A residual category of unusual sites is also necessary to include sites such as trails and canals. Even though the site types are presented in a prehistoric context, they are equally applicable to historic sites. Homesteads are residential bases, line shacks and sheep camps are field camps, agricultural fields and pastures are procurement locations, fire lookout towers are stations and grain elevators are caches.

Research Topic: Paleo-Indian occupations. Currently, very little is known about Paleo-Indian subsistence and settlement in the upper Snake River Basin. Fluted points are commonly found throughout the basin — as witnessed by so many private collectors owning several examples — but only a single site has been professionally excavated providing us with information about the subsistence base of the fluted-point makers. The Wasden Site (Miller 1982) suggests that the occupants of the basin, at approximately 10,500 years ago, were specialized big game hunters subsisting much like their contemporaries in the Great Plains. However, some researchers have argued that large stemmed points were also being made by occupants of the basin at that time and may represent a strategy separate in form, time, and/or space from the fluted points. Whether some stemmed points are contemporary with or later than fluted points, which is the more traditional interpretation, is yet to be satisfactorily determined. It is not until the very last cultural period of the Pleistocene that ground stone shows up in the archaeological record, indicating that the processing of plant foods was becoming an integral aspect of life on the Snake River Plain.

Research Question-Do fluted points always occur in large game hunting contexts or are small game and/or vegetable foods also part of Paleo-Indian subsistence.

Paleo-Indian residential base sites should contain evidence of the range of utilized food resources and of the tools needed for the harvesting and processing of those resources. Presently, we only know about the use of mammoth, but many other species of megafauna resided on the Snake River Plain that may have been utilized, as suggested by the wide variety of species recovered during the excavation of Jaguar Cave. A variety of smaller animals were also present that may have been utilized, and plant foods should have been relatively abundant. Determining the range of resources utilized by the Pleistocene inhabitants will require the excavation of several sites.

Data Requirements: Any site that may have sealed subsurface deposits that occur in an area where points of this age are found. Sites that have high potential for aggrading deposits, such as in the lee of pressure ridges and in lava tubes in flows older than 10,000 years, should be considered to always have this potential.

Research Question-What tool types and food resources occur in association with Paleo-Indian lanceolate and stemmed points?

Paleo-Indian lanceolate and stemmed points have been associated in other parts of the Desert West with a highly specialized adaptation to the lacustrine environment surrounding late Pleistocene pluvial lakes. In the Snake River Plain, these point styles have been found in association with the remains of an extinct form of bison. Whether these point styles represent a continuation of the big game hunting 
tradition, a lacustrine focus, or perhaps both, in the upper Snake River Basin is not known; nor is it known if the same groups that made the fluted points for the hunting of megafauna also made stemmed points for harvesting lacustrine resources (if it turns out that they are contemporary).

Data Requirements: Any site suspected of having sealed subsurface deposits that occur in the area where point styles diagnostic of this period are known, including all of INL).

Research Question-Is there a direct spatial relationship between the Paleo-Indian stemmed points and extinct lacustrine systems?

This question addresses the same objective as the preceding one. If all sites associated with this tradition can be shown to be directly associated with lake shores or marshes that date to the late Pleistocene, the argument for a specialized lacustrine adaptation gains support.

Data Requirements: Two types of localities are needed to address this question: (1) archaeological sites that contain diagnostic materials of this period where the surface of origin for those artifacts can be defined, and (2) selected nonarchaeological locations where extinct lacustrine features (e.g., shore lines and marshes) can be excavated for datable materials. Based on a limited number of excavations, the ages of various exposed surfaces could be determined and their spatial extent mapped. Correlating this with archaeological site distribution would either support or challenge the lacustrine specialization hypothesis.

Research Topic: Archaic Occupations. If the prevailing interpretation of the Archaic lifeway is valid, then the shift in adaptation at the end of the Pleistocene at about 8000 years ago should be accompanied by a broadening of the diet to include many smaller and more expensive food items (in terms of pursuit and processing time relative to caloric returns). Small game and plant foods, along with the technology to acquire and process them, should have become an integral part of the lifeway. However, there is argument (Butler 1978: 68) for the continuation of a big game hunting lifeway without any perceptible broadening of the diet. This suggests that adequate numbers of big game animals continued to be available after the loss of the Pleistocene megafauna. It was not until the altithermal (7500 B.P.) that ground stone becomes a consistent element in artifact inventories. This pattern may be inaccurate because of the limited number of sites excavated from this time period; only through more excavations will we be able to interpret the relative importance of small game and plant foods to the Archaic lifeway.

Research Question-Do ground stone implements commonly occur in early Archaic sites?

If plant seeds were an integral part of the diet during the Archaic, seed processing tools such as grinding stones (i.e., manos and metates) should commonly occur in seed procurement field camps and residential base sites that were occupied during the summer and fall. Several INL areas currently support dense stands of seed-producing plants, such as Indian rice grass, that were commonly eaten by the Archaic inhabitants of other areas of the Desert West. It is feasible that even if plant seeds were integrated into the diet, they may not have been harvested on INL lands because the occupants were elsewhere during the summer and fall months. Only through well-designed data collection projects can this kind of question be answered.

Data Requirements: Any residential base site that contains artifacts diagnostic of the Early Archaic (e.g., Northern Side-Notched and Pinto series) would likely address this question. If properly excavated, the seasonality of site occupation could be determined so that the presence or absence of ground stone could be properly interpreted. Any sites other than residential bases that contain ground stone could also provide important information, especially if buried cultural material is present. 
Research Question-Do ground stone tools commonly occur in Middle Archaic sites?

Following the discussion with the previous question, seed processing may not have been necessary during the Early Archaic, but with the onset of the altithermal, the climatic stress may have required the expansion of the diet to include such high cost resources. If this is the case, ground stone should become a common element in Middle Archaic summer and fall residential bases, and there should be a noticeable increase in seed processing field camps when compared to earlier Archaic occupations.

Data Requirements: Any residential base site that contains artifacts diagnostic of the Middle Archaic (e.g., Gatecliff and McKean series) or any site type dating to the Middle Archaic with ground stone artifacts.

Research Question-Do ground stone tools commonly occur in Late Archaic sites?

With reference to the discussions above, after the altithermal (4500 B.P.), conditions should have improved in the upper Snake River Basin. Therefore, high cost items (e.g., grass seed) might no longer need to be utilized. A shift such as this would be obvious in the archaeological record and would imply a shift in subsistence organization of the area occupants.

Data Requirements: Any site with Late Archaic material, especially with the potential for subsurface deposits and preserved vegetal materials (e.g., a lava tube).

Research Question-Are there periods during the Archaic when the inhabitants were more logistically organized than at other times?

In many areas west of the Snake River Basin, semi-permanent pithouses were being constructed during some periods of the Archaic that appear to represent residence for a minimum of several months. This pattern is different than the interpreted settlement of the Archaic inhabitants of the upper Snake River Basin who apparently never stayed in one place long enough for it to be worth the energy investment to construct a substantial residence structure.

The "nature" of the food resources seems to explain the presence or absence of pithouses (i.e., more or less logistical complexity). On the middle and lower Snake River, salmon are available during certain seasons, and enough can be taken so that, with the proper storage technology, life could be maintained in one place for several months of the year. The availability of salmon, therefore, explains, in part, the presence of many of the pithouse villages along the Snake River in western Idaho. However, a few pithouse villages occur in areas where salmon are not available, such as in Surprise Valley in northeastern California. It appears that a unique combination of lacustrine resources during the Late Archaic resulted in the more complex logistical organization practiced there.

The upper Snake River Basin also has a unique lacustrine environment that may have allowed a logistical complexity sufficient to result in pithouses. Numerous house pits have been observed in the upper basin, but none have ever been excavated and reported in the scientific literature. Areas around the lacustrine systems at INL may provide an excellent opportunity for determining the logistical complexity of Archaic occupants of all periods.

Data Requirements: Residential base sites, especially if they contain evidence of structures, which would most likely be located adjacent to permanent water sources.

Research Topic: Late Prehistoric Occupations. Most prehistorians currently believe that at some time during the last 1,000 years the local Archaic populations were replaced by the Numic-speaking groups that inhabited the area at historic contact (e.g., Shoshone and Bannock Tribes). This interpretation is based primarily on linguistic evidence, although many prehistorians also claim that it is substantiated 
by the archaeological record (Adovasio et al. 1982; Bettinger and Baumhoff 1982; Madsen 1975). Recent reinterpretations (Aikens and Witherspoon 1986) reinforce the replacement theory for much of the Desert West, arguing that Numic-speaking people were better adapted to arid conditions than their predecessors, and that the long droughts of the $13^{\text {th }}$ and $14^{\text {th }}$ centuries A.D. opened the door for their dominance throughout the area. Part of their adaptability involved the use of resources that were somewhat resistant to variations in available moisture, such as grass seeds, nuts, and rabbits. Reliance on these wide-ranging resources means a very different level of logistical complexity and technology than their predecessors. The implications of this theory are that the pre-Numic inhabitants had a more complex logistical organization in which the residential group was tied to the riparian environment, although special task groups would often venture into other environments. The Numic inhabitants were less dependent on the riparian environment, and the residential group commonly moved wherever resources were available throughout the various environments.

If the replacement theory is correct and the replacement occurred because of greater adaptability to arid resources, then there should be a marked difference in the relative frequencies of site types at INL and the surrounding area. It would be predicted that a greater frequency of Numic sites should be residential bases with fewer task-specific camps and procurement locations than for their predecessors, who should be represented by few residential bases and numerous camps and locations.

Data Requirements: All sites that contain Numic artifacts (Desert Side-Notched points and/or pottery) and all sites that contain Late Archaic artifacts (e.g., Elko series points). Sites with buried deposits that might yield subsistence information are especially important for answering this question.

Research Topic: Protohistoric Occupations. Prehistorians refer to the period when the aboriginal lifeway was initially influenced by nonaboriginal technology as the "protohistoric" period. Current evidence suggests that the protohistoric period began in the upper Snake River Basin in the early seventeenth century with the introduction of the horse. Approximately 200 years elapsed before the historic period began with the Lewis and Clark Expedition in 1805. During those two centuries, a dramatic shift in lifeway occurred because of increased mobility, both in distance covered and loadcarrying capacity. The acquisition of the horse precipitated a shift to a more complex logistical organization resulting in much larger residential bases that were quite mobile. This should be evident in the archaeological record, and many of the subtleties should be interpretable through survey and excavation at INL.

Data Requirements: Any site containing evidence of equestrian use (e.g., tipi rings) especially if subsurface deposits are present.

Research Topic: Historic Indian Occupations. Once fur trappers and immigrants traveling the Oregon Trail invaded the area, the aboriginal lifeway again dramatically changed. This culminated with their confinement on reservations. Even with reservation life, American Indians continued to harvest resources from a variety of environments throughout the upper Snake River Basin. For example, they made yearly treks through the INL area to salmon fishing areas on the Lemhi and Salmon rivers. They continue today to hunt, fish, and collect plant resources from much of their aboriginal homeland. Use of traditional resources along with commercial goods involves an increase in logistical complexity, although much of this increase was involuntary for the Shoshone-Bannock Tribes. Evidence of the historic subsistence organization is of considerable importance for developing theory about cultural change, such as when a group is thrust into the twentieth century without their consent.

Data Requirements: Aboriginal sites with historic artifacts (e.g., trade beads and metal or glass points) especially if undisturbed by modern agricultural or pastoral activities. 
Research Topic: Historic Euro American Occupations. When the West was opened for white colonization in the early nineteenth century, a new level of subsistence organization based on agriculture and ranching was introduced. For the first time, residential bases such as farms or ranches were not moved seasonally, and many of the items necessary for life were acquired via technologically or economically complex systems. Irrigation, wagons, steel tools, and the Sears Roebuck catalogue provided the basis for this logistically more complex lifeway. Evidence of this era occurs at INL and can provide valuable information about pioneer life.

Research Question-How much did these early white settlers rely on mail order for their necessities and how much was available in the local environment?

It is difficult to determine from the historic record how self-sufficient the nineteenth century settlers were. Archaeological excavations of their trash heaps and their residences can answer this question.

Data Requirements: Any historic site, including residential bases (e.g., homesteads), field camps (e.g., line shacks and sheep camps), and procurement locations (e.g., fields and irrigation systems).

Research Question: How valuable were iron and steel tools and glass containers?

People without the means to purchase replacement metal tools will repair them until there is nothing left to repair. The same can be said about glass containers; they will be used for a variety of purposes until broken. Much can be determined about the level of logistical needs by examining what is discarded by a historic group. Discarded broken tools that could have been easily prepared indicate a group more logistically organized than a group that utilizes materials until they are spent.

Data Requirements: Any historic site with trash dumps, especially if it is a residential base site.

\section{Problem Domain: Cultural Relationships}

The upper Snake River Basin is in a unique position being located at the juncture (or overlap) of three traditionally defined culture areas: the Great Basin to the south and west, the northern plains to the east, and the American Northwest to the north and west. The upper basin has most often been combined with the Great Basin culture area because the historic American Indian groups of the Snake River Basin spoke languages related to those spoken by other Great Basin groups. However, it is clear in the archaeological record that there were periods when northern plains-related cultures occupied, or at least interacted with the inhabitants of, cultures of the Snake River Basin. Other times, artifact types clearly indicate a Great Basin affiliation. There is little, if any, current evidence for a strong relationship with the Northwest although some artifact styles, most notably fishing gear, indicate contact with that area. The nature of the northern plains, Great Basin, and Northwest relationship is of keen interest to the archaeology of the upper Snake River Basin.

Research Topic: Early Archaic Occupations. The Early Archaic in the upper Snake River Basin is marked by the presence of the Northern Side-Notched point. Its introduction to the area is later than in the northern plains and earlier than the in the Great Basin. Therefore, it appears that the popularity of the style began in the northern plains, moved through the Snake River Basin, and ultimately became popular in the northern and eastern Great Basin. Whether this pattern is a result of the movement of the makers themselves or of the diffusion of a technological development is not known. Also, the style, in unmodified form, persists longer in the Snake River Basin than in surrounding areas. Does this indicate that this area became a homeland for an immigrant population from the plains, or does it mean that the technology suited the occupants' needs and was maintained until their needs changed? Also during the Early Archaic, there appears to be sporadic influxes of Pinto series points, which are common at that time in the eastern and southern Great Basin. Again, does this mean movement of people or diffusion of style 
or technology? Only controlled excavations of sites containing these point styles will shed light on the answer.

Research Question-Does the assemblage of artifacts found in association with large side-notched points suggest a northern plains origin?

If Northern Side-Notched points, especially those found in the earliest occupations, occur in direct association with an assemblage of other tools that is essentially identical to contemporary assemblages on the northern plains, the argument for a plains origin, or at least a strong relationship, is suggested.

Data Requirements: Buried deposits with Northern Side-Notched points in association with other tools, especially in a cave, lava tube, or any open site suitable to have been used as a residential base.

Research Question-Do the artifact assemblages directly associated with Pinto series points suggest an eastern Great Basin origin?

In the eastern Great Basin, Pinto points commonly occur in direct association with ground stone tools, suggesting some reliance on plant seeds. This type of tool is noticeably absent in the Northern Side-Notched assemblages of the northern plains. Controlled excavation of sites where Pinto points are in undisturbed buried deposits should indicate if that lifeway was also practiced in the upper Snake River Basin.

Data Requirements: Sites containing Pinto series points in a buried context, especially if the site was used as a residential base. Caves, lava tubes, or dune areas near water might contain this information.

Research Topic: Middle Archaic Occupations. During the Middle Archaic, stemmed-indented base points became the dominant style of spear point in the upper Snake River Basin. At approximately the same time, similar points were made in the northern plains (e.g., McKean complex) and in the central Great Basin (e.g., Gatecliff series) suggesting that some form of communication or population movement was occurring that involved the upper Snake River Basin. Unlike the Early Archaic period, which involved the sharing of a point style among the northern plains, upper Snake River Basin, and northern and eastern Great Basin, the Middle Archaic pattern involves the northern plains, upper Snake River Basin, and northern and central Great Basin, avoiding the eastern Great Basin. The areas are comparable in size but different in form. Radiocarbon dates suggest that the predominant Middle Archaic pattern resulted from an expansion into the Desert West from the south and west, ultimately from southern California, instead of from the northern Great Plains to the north and east as suggested for the Early Archaic.

Research Question-Does the assemblage associated with the stemmed-indented base point remain relatively consistent across the large area described for the Middle Archaic expansion?

If a direct connection can be made between the Middle Archaic artifact assemblages in the upper Snake River Basin and surrounding regions, an argument would be made that a single culture spanned the entire area. Some variability is expected, of course, because of adaptation to the range of local resources. However, artifacts that often have stylistic elements with no functional value (e.g., beads, basketry, hafted knives, and footgear) should be maintained and reflect cultural relationships.

Data Requirements: Any undisturbed site containing buried Middle Archaic assemblages. Especially important sites would be those that have remained dry since occupation, such as caves, so that perishable artifacts are preserved.

Research Topic: Late Archaic Occupations. The pattern established during the Middle Archaic continues during the Late Archaic, although the predominant point style changes from the 
stemmed-indented base to the large corner-notched points. A vast area of shared technology is suggested by this pattern. Movement of people, diffusion, or a combination of the two probably accounts for this. Of importance is that the eastern Great Basin continued to be excluded and changes that occurred there are obviously independent of those in the central and northern Great Basin, upper Snake River Basin, and northern plains.

Research Question-Are the artifact assemblages common during the Middle Archaic maintained into the Late Archaic?

As previously discussed, if artifacts with distinctive stylistic elements continue to be made during the Late Archaic, the argument for population stability is supported. The explanation for the shift in spear point style would then need to be based on something other than population replacement.

Data Requirements: Sites with buried Late Archaic deposits, especially in a dry cave where perishables would survive.

Research Topic: Late Prehistoric Occupations. The recent literature discussing the late prehistoric in southern Idaho is filled with references to Fremont occupants. The Fremont were semi-sedentary groups in the eastern Great Basin that subsisted on a mixed economy of horticulture and hunting-gathering. That lifeway was never practiced in the upper Snake River Basin; therefore, by a strict definition, the Fremont did not occupy this area. It is clear from the archaeological record, however, that the Fremont did interact with the occupants of the upper Snake River Basin; it is the nature of the interaction that is open for debate. At the same time, the northern plains seem to develop a separate trajectory of development that occasionally intrudes into the upper Snake River Basin. Therefore, any late prehistoric site containing preserved information should be considered significant.

Research Question—Do late prehistoric sites exhibit artifact assemblages similar to Fremont?

There are several characteristic styles of artifacts associated with Fremont sites in Utah that occasionally occur in Late Archaic sites in the upper Snake River Basin. Because of the paucity of excavated sites, we do not know if this is an underlying pattern for the entire time period that suggests Fremont occupants, or, if in only a few sites, some Fremont styles were introduced by trade or limited incursions into the area by Fremont people.

Date Requirements: Any late prehistoric site containing buried deposits, especially in a dry cave where perishables would be preserved.

Research Question-Do any late prehistoric sites contain artifact assemblages similar to the Avonlea of the northern plains?

The introduction of the Avonlea point in the northern plains marks a diversion from the consistency over a large area during the Middle and Late Archaic. The Avonlea point occurs in the upper Snake River Basin, and its relationship to the contemporary Rose Spring Corner-Notched and Desert Side-Notched points is not known.

Data Requirements: Any site with Avonlea points, especially with buried deposits.

Research Topic: Protohistoric Occupations. Once the horse and other items of European origin became available to the native inhabitants of the upper Snake River Basin, the lifeway changed dramatically. Groups became much more mobile, and we might speculate that more groups came through the basin more often; therefore, greater stylistic variability in artifacts should occur. 
Research Question-Can incursions into the upper Snake River Basin be documented by artifacts diagnostic of the Crow, Blackfoot, Nez Perce, and Flathead tribes?

Data Requirements: Any sites dating to the protohistoric period.

Research Topic: Historic Euro American Occupations. After colonizing the Great Salt Lake area, Mormon pioneers expanded into surrounding regions to exploit the available resources. Later, when polygamy was determined to be unconstitutional, refugee polygamists inhabited remote regions removed from the Salt Lake area. The upper Snake River Basin was influenced by these two phenomena.

Research Question-What is the nature of Mormon colonization in the upper Snake River Basin?

Data Requirements: Any historic homestead.

\section{Problem Domain: Demography}

The actual number of people living in the upper Snake River Basin during various prehistoric periods is difficult to estimate from the archaeological record. However, interpretations about relative population density and distribution are feasible, especially in areas like INL where a considerable amount of archaeological survey has been conducted. Numerous factors affect the human use of any area. During some periods, important resources may abound; while at other times, there may be nothing at all to attract people. Catastrophic events, such as volcanic activity or floods, may make some areas unusable for limited periods of time. The actual relationship between people and natural resources is covered under the subsistence and settlement problem domain, while the population density and distribution are covered here.

As of the date of the report (Reed et al. 1987) from which this appendix was derived, approximately $3 \%$ of the 586,000 acres on INL had been surveyed for archaeological resources yielding approximately 1200 sites. This suggests that there are probably more than 30,000 sites at INL that need to be considered prior to any further development. Of the known sites, $0.5 \%$ are Paleo-Indian, $2 \%$ are Early Archaic, 10\% are Middle Archaic, 45\% are Late Archaic, and 40\% are late prehistoric. The remaining $2.5 \%$ are historic or of unknown temporal affiliation.

Research Topic: Paleo-Indian Population Density. A quick review of collections of projectile points from the upper Snake River Basin suggests that the area may have been more densely populated than surrounding regions during the late Pleistocene. Hundreds of fluted Clovis and Folsom points have been found, primarily by amateur collectors. We do not know if this relatively large number reflects a large number of people, a few people who made and lost large numbers of points, or a depositional environment that makes their recovery more likely.

Research Question-Was the INL area as heavily used during the late Pleistocene as other areas in the upper Snake River Basin?

Data Requirements: Any site with Paleo-Indian artifacts, especially if subsurface deposits are present.

Research Topic: Archaic Population Density. Throughout the upper Snake River Basin, there seems to be a dramatic increase in the number of sites that date to the Late Archaic, as interpreted by the presence of Elko corner-notched points. Does this reflect an increase in population size or, perhaps a stable population practicing a more mobile lifeway and leaving more sites behind?

Research Question-Does the dramatic increase in the number of Late Archaic sites over earlier sites indicate greater population density? 
Under the settlement and subsistence problem domain, Late Archaic sites are examined for a shift in subsistence organization. If it is determined that subsistence is essentially the same during that period as in previous periods, then a regional increase in population size or a concentration of regional population in the desert areas of the Snake River Basin might be an acceptable interpretation. Survey and excavation data from INL could make a significant contribution to answering this question.

Data Requirements: Any Archaic site, especially those with buried cultural deposits so that an estimate of length, occupation, and size of group can be made.

Research Topic: Late Prehistoric Population Density. Based on the number of known sites that date to the late prehistoric, it would appear that population size decreased in the upper Snake River Basin after the Late Archaic. As with the previous research topic, this may reflect a changing subsistence organization rather than a population decrease. INL excavation and survey data will help address this topic.

Research Question-Does the population of the upper Snake River Basin decrease during the late prehistoric?

The answer to this question relies heavily on the interpreted subsistence organization covered under the subsistence and settlement research domain. If group size is not increasing and if there is no shift toward greater logistical complexity, an acceptable interpretation would be decreasing population concentration in the Snake River Basin.

Data Requirements: Sites with late prehistoric occupation, especially if subsurface deposits are present that may have information concerning group size and length of site occupation.

Research Topic: Overall Site Density. Based on the current level of survey of INL lands, there is approximately one site for every 15 acres of land. Although most of these $(85 \%)$ are small sites consisting of fewer than 100 stone flakes and tools, this site density rivals culture areas like the Southwest (Arizona and New Mexico) and the Mississippi River area where complex agriculture-based cultures emerged.

Research Question-Why are there so many sites at INL?

An answer to this question may arise through subsistence research, but it may also be answered through demographic studies. It is feasible that there were so many people living in the upper Snake River Basin that the resources on INL had to be relied upon. It is equally feasible that the resources on INL were so desirable that they attracted heavy use of the area.

Data Requirements: All sites that have temporally diagnostic artifacts, especially if accompanied by subsurface deposits that may yield information concerning group size, subsistence activity, and length of stay.

Research Topic: Volcanic Activity and Human Behavior. Numerous volcanic events occurred in and around INL during the late Pleistocene and Holocene that should have affected human adaptation. The Great Rift area, Hells Half Acre field, Cerro Grande area, and more distant Picabo Vent complex must have diverted animals and hunters to adjoining areas, or may have even attracted both with an assortment of geothermal resources and spectacular visual effects. The effect of the flows on human demography is an especially intriguing question that could be answered through research on INL. 
Research Question-What effect have periods of volcanic activity had on regional populations?

It is logical to conclude that volcanic activity would at least temporarily alter the human use of the effected area, and at most, permanently change the use of the area. Excavations of both pre- and post-eruption sites could provide insights into this problem.

Data Requirements: Especially important to answering this question would be sites that are covered by volcanic flows. Since the presence of these features would not be detectable during survey, this kind of site would only be encountered during construction activities. Most post-eruption sites are recorded during survey, and those with subsurface deposits can tell us much about the human use of the area.

\section{Problem Domain: Environment}

The reconstruction of the environment is critical for interpreting human behavior. Humans usually respond adequately to climatic changes by adjusting their subsistence organization and/or technology to suit their changing needs. We know much about global climatic patterns, but little about the local effects of the constantly changing moisture and temperature cycles. Research concerning environmental reconstruction can be conducted at both archaeological sites and other sites where the proper data are preserved. Cave sites (e.g., lava tubes) with long depositional sequences are especially important because they often contain the remains of rodents and other small animals that are sensitive to climatic change. Caves also often trap pollen grains from plants growing in the area and from those brought to the site by prehistoric inhabitants. A climatic sequence based on a 2000-year cycle has been proposed (Butler 1978) based on cycles of small mammals recovered during the excavation of Owl Cave at the Wasden Site located just south of INL. In many ways, it correlates well with interpreted world climatic cycles (Denton and Karlen 1973).

Of particular interest is that projectile point styles always change during interstadials and persist through the following stadial. Theoretically, the carrying capacity of a desert area like INL should decrease during the interstadials, which were generally warmer and dryer, thus stressing the human populations who rely on the natural resources. However, our present understanding of the climatic cycle is poor at best, and if we are to make interpretations about the meaning of artifact style changes, as well as subsistence and demographic changes, we must pursue environmental data as it applies to the local situation. INL sites have a tremendous potential for contributing to this understanding.

Research Topic: Pleistocene Environments. We know that numerous species of animals became extinct near the end of the Pleistocene. The changing environment must have had a dramatic effect on the lifeway of people inhabiting the upper Snake River Basin. It is not known whether the adjustments that people had to make were slow, involving very slight changes over multiple generations, or were dramatic, necessitating a single generation of inhabitants to make significant shifts in the lifeway.

Research Question-How quickly did the Pleistocene megafauna become extinct?

Data Requirements: Pleistocene sites with buried cultural deposits.

Research Topic: Holocene Environments. Since the end of the Pleistocene the Snake River Plain has probably been much like it is now. There were wetter and dryer periods, resulting in the increase and decrease of pluvial lakes that temporarily supported animal and human populations. The history of the pluvial lakes at INL would provide a scale by which to interpret much of the habitation there. Occupation when water was not available is likely to be of a very different kind than when water was plentiful. 
Research Question-What is the sequence of pluvial lake increase and decrease?

Some information is already known about this history, but much of the detail has not been studied. If we are to understand the human occupation of the area, we must know more about this sequence.

Data Requirements: Playa-edge sites, with or without cultural material, which contain datable deposits due to flooding and desiccation.

\section{Problem Domain: Technology and Material Culture}

Aboriginal technology evolved over the 12,000+ years of occupation of the upper Snake River Basin. This is best recorded in stone tool manufacturing because stone is not perishable and the remains of all stages of stone tool manufacture are preserved. Other items in the material culture also show technological development, but most of those are perishable (e.g., basketry and clothing). Different groups developed different solutions to similar problems in the manufacture of various items. INL sites have the potential for addressing several of these.

Research Topic: Stone Tool Manufacture. Most of the tools recovered from archaeological sites are made of stone. This is because stone is an excellent material for tool manufacture and because it is durable, outlasting the more perishable materials of wood and bone. Numerous sources of stone suitable for tools exist in and around the upper Snake River Basin; the most notable near INL is Big Southern Butte, which is a major source of obsidian that was heavily exploited by the prehistoric inhabitants of the region. Studies conducted near there can tell us much about the processes of material acquisition and stone tool manufacture.

Research Question-How are lithic resources acquired, reduced, and transported to the ultimate areas of use?

Sites representing primary reduction of obsidian near Big Southern Butte should tell us much about material acquisition and initial processing. Removal of the reduced material to camp or residential sites would be expected and should be evident in the archaeological record. Detailed analyses of reduction stages, along with source analyses and hydration dating, should provide a detailed history of lithic resource utilization that would be unparalleled in the archaeological literature.

Data Requirements: Any site with obsidian flakes that can be classified to their stage of reduction. This includes sites where lithic materials were being acquired, and those in which obsidian was being used to process other resources.

Research Topic: Basketry Technology. The classification of basketry has been the source of much confusion in reconstructing the prehistory of the upper Snake River Basin. It has been argued (Adovasio et al. 1982) that after 10,000 years of continuity of basketry technology during the Archaic in the eastern Great Basin and the upper Snake River Basin, it disappears from the face of the earth sometime between 1300 and 1800 A.D. Technology has always changed in response to the needs of the people, and it is feasible that basketry technology did the same. However, the apparent loss of a basketry technology in the upper Snake River Basin has not been adequately demonstrated, and some INL sites have tremendous potential for addressing this question.

Research Question-Is there a change in basketry technology anytime after the Pleistocene?

Apparently, the historic groups of the area employed a different basketry technology than did those inhabiting the few prehistoric cave sites that have preserved basketry remains. Any continuity, or lack thereof, is important to understanding the prehistory of the occupation of the area. 
Data Requirements: Any site with preserved basketry remains. This would be expected only in dry cave situations, such as some of the lava tubes at INL.

\section{Problem Domain: Data Recovery Techniques}

It is estimated that approximately $75 \%$ of the stone materials used for tool manufacture in the upper Snake River Basin during prehistoric times was obsidian. Obsidian sources are numerous and each has a unique "fingerprint" of constituent elements. Stone tools and waste flakes can be chemically analyzed and their source determined. In addition, obsidian is an unstable compound that is chemically altered when exposed to air and water through hydration. Therefore, once an obsidian cobble is fractured during tool manufacture, the new surface begins to hydrate, and if the hydration rate is known for that source, an age of tool manufacture can be determined. This type of analysis has a tremendous potential for unraveling the cultural history of the INL sites.

Research Topic: The Sources of Obsidian Used for Stone Tools. Determining the source of the obsidian used for stone tool manufacture can provide insights into many of the other problem domains. It is suggested (Binford 1979) that stone material is acquired while pursuing other resources, especially food. This implies that the sources of the employed stone should reflect the subsistence round (e.g., home range) of the people using those stone resources. If this is true, determining the source of the stone materials will generate a "map" of the home range of the people utilizing those resources. Determining the source of obsidian present at INL sites would provide information about the home range of groups of all ages.

Research Question-What are the sources of obsidian exploited by INL occupants?

It is expected that the pattern of obsidian exploitation changed over time as subsistence patterns changed, yet this is purely conjectural and INL sites can help determine if this expectation is true. It is desirable to determine the source of obsidian from every INL site, especially those that have some temporally diagnostic artifacts such as spear or arrow points or pottery.

Data Requirements: All INL sites that have obsidian artifacts.

Research Topic: The Age of Obsidian Tool Manufacture. Once the hydration rate is determined for a particular obsidian source, that source can be dated by measuring the thickness of the hydration rind and determining the temperature to which that the specimen has been subjected. All flakes and tools can potentially be dated to their time of manufacture. Therefore, all INL sites can potentially be dated to their time of use. If this were accomplished, dramatic advances in understanding the prehistory of the upper Snake River Basin would be achieved.

Research Question-Can we determine the age of obsidian tool manufacture of specimens recovered from the surface of INL sites?

Artifacts recovered from the surface need to be correlated with their subsurface counterparts to determine if the temperature variable is the same in the equation to determine age relative to the hydration thickness.

Data Requirements: All INL sites with obsidian artifacts, especially those with alternate dating potential (e.g., charcoal in firehearths). 


\section{Research Design Summary}

Numerous research questions are presented that address the research significance of the cultural resources observed at INL. A common element is evident in the type of site that can answer many of those questions. That element concerns buried, intact deposits, especially those in the context of datable materials (e.g., fire hearths containing charcoal). Therefore, any site that exhibits the potential for buried deposits is, by law, potentially significant and must be protected or mitigated. Limited test excavations can determine if there are buried cultural deposits and can determine the research potential, and hence, legal status, of the site.

Other sites may also be significant under the law. Those containing artifacts indicating Paleo-Indian occupation, for instance, will always require additional study before destruction. Sites dating to other time periods may be similarly significant, such as sites with stemmed points located adjacent to playas.

The determination of site significance is a complex issue that does not have a formulaic answer. Any site that can potentially answer a question of research interest is, by law, significant. All of the sites determined to be in this category must be mitigated; this may involve further collections from the site, test excavations, or complete excavation. 
Appendix F

\section{Historic Contexts}




\section{Appendix F}

\section{Historic Contexts}

\section{INTRODUCTION}

This appendix presents historic contexts derived from The Idaho National Engineering and Environmental Laboratory, A Historical Context and Assessment, Narrative and Inventory (Arrowrock 2003). This historical information is used to assist with the evaluation of architectural properties from the post-1942 period. Context I also provides a brief pre-1942 summary of the Euro-American expansion into the area now encompassed by INL.

Over the 60+-year history of INL, the Laboratory and the areas and facilities contained within its borders have been subjected to numerous mission and status changes ranging from the Site's initial role as a naval ordnance test facility to that of a preeminent DOE national laboratory. As a result, the Lab and its attendant areas and facilities have been renamed over the years to reflect missions and statuses at the time. Within this appendix, the current Laboratory designation of "INL" is primarily used; however, to retain the technical integrity of the historical framework in which INL areas and facilities are described, the area and facility designations employed are those that were in use during the timeframe being described.

Footnotes from the original Arrowrock 2003 text are provided to illustrate the variety of sources used to compile the following information and to provide pertinent background information.

\section{CONTEXT I: EURO-AMERICAN CONTACT AND SETTLEMENT: 1805-1942}

The period of Euro-American contact in Idaho is generally considered to begin in 1805 with the Lewis and Clark Expedition. The first Euro Americans to have entered INL territory most likely were French-Canadian trappers and other explorers, perhaps around 1820. U.S. Army Captain B.L.E. Bonneville traversed the area in 1832-33 and referred to it as the "Plain of the Three Buttes." Explorers and trappers in the vicinity of INL would have met Shoshone and Bannock peoples gathering plants or hunting.

Large numbers of emigrants followed the Oregon Trail through Idaho beginning in the 1840s. A shortcut known as Goodale's Cutoff was established in the early 1850s; its traces are still visible in the southwestern corner of INL. Later this trail was used when cowboys drove great herds of cattle across the Plain from Idaho, Washington, and Oregon to Wyoming. Sheep drives replaced cattle in the 1880 s. $^{7}$

Two stagecoach lines crossed the area near Twin Buttes, near the southern boundary of what became INL. Transportation became more reliable through the area after freighters began serving miners in the mountain camps north and west of INL. Homesteaders settled in the Big Lost River area in the late 1870s and began the daunting task of farming arid lands. Cattlemen established ranches along the Little Lost River and Birch Creek in the early 1880s.

6. Washington Irving, Adventures of Captain Bonneville (Portland, Oregon: Binfords and Mort, no date, Klickitat Edition), p. 110.

7. See Miller, p. 2-19 for a map of historic trails crossing the INEEL. 
The federal government became involved in the effort to irrigate arid lands when Congress passed the Carey Act in 1894, followed by the Reclamation Act in 1902. These laws provided land and financing for water storage and distribution projects. This federal action might be said to constitute its first "test" in reshaping the landscape at INL. The Big Lost River Irrigation Project included two large tracts of land, one in the south-central portion of the present INL. This experiment in settlement and irrigation ultimately failed. The engineers miscalculated the available water and had a poor understanding of the soils and porous basalt layers that underlay their reservoirs and canals. Settlers drifted away in the $1920 \mathrm{~s}$, having failed to find "salvation from the application of science and engineering expertise" for their project, leaving the land once more very sparsely populated, and having brought no large town to the INL environs. ${ }^{8}$

Considerable historical research has illuminated this context period and provided benchmark dates that mark a more detailed chronology. Historic themes include early exploration and discovery, trapping and trading, the Oregon Trail, mining, cattle and sheep drives, transportation, American Indian relations, settlement, irrigation, and ranching. ${ }^{9}$

\section{CONTEXT II: ORDNANCE TESTING, 1942-1949, 1968-1970 Sub-Theme: World War II}

\section{Naval Proving Ground/Central Facilities}

Introduction: World War II Arrives in the Idaho Desert. Before World War II, the arid lands between Arco and Idaho Falls were used primarily for grazing. Earlier in the century, local irrigation companies had promised settlers water from the Big Lost River, but they failed to deliver it. Disappointed homesteaders relinquished their lands. A few traces of human habitation and enterprise remained on the landscape - the banks of abandoned canals, foundations of former homes and farm buildings, and a few non-native plantings. A new demand for these isolated lands, most of them still in the public domain, arose when the United States entered World War II.

When Nazi Germany invaded Austria in 1938, the U.S. Congress authorized the U.S. Navy to expand its ship and aircraft strength. The Navy built large air bases on the east and west coasts and on the islands of Hawaii and Guam. The Navy also strengthened its support facilities, especially for the West Coast bases, where these were minimally adequate. After Japan attacked the U.S. fleet and air bases at Pearl Harbor, the pace quickened dramatically as the country went to war. The Navy searched everywhere for new locations to accommodate further expansion. Because of wartime shortages of materials and manpower, construction rules specified that new buildings should be basic and strictly functional, without elaboration or unnecessary enhancements. Substitutes were to be sought for scarce materials. ${ }^{10}$

As the war in the Pacific intensified, so did the demand for military support of all kinds: training, ordnance and ordnance testing, gun repair, and research related to safety. The coastal cities had supplied all the facilities and labor that they could, so the Navy looked inland for suitable locations. Congress appropriated funds, and Navy projects were established in several western states. The Sixth Supplemental

8. Hugh Lovin, "Footnote to History: `The Reservoir Would Not Hold Water,'“ Idaho Yesterdays (Spring 1980), p. 14. Lovin's remarks referred to the Blaine County Irrigation Project, which lies northeast of Howe in Butte County.

9. These themes are introduced in Miller, p. 2-18 to 2-21, and supported by an excellent bibliography.

10. United States, Building the Navy's Bases in World War II: History of the Bureau of Yards and Docks and the Civil Engineer. Corps, 1940-1946, Vol. 1 (Government Printing Office: Washington, D.C., 1947), p. 1-13. Hereafter cited as "Building the Navy's Bases." 
National Defense Appropriation Act of 1942 placed two facilities in Idaho. One was a large personneltraining base, Farragut Naval Training Center, at Lake Pend Oreille in north Idaho. The other was the Naval Ordnance Plant at Pocatello, established on April 1, 1942. ${ }^{11}$

The Pocatello Naval Ordnance Plant. The mission of the Pocatello plant was to manufacture, repair, and assemble large-caliber naval guns, mounts, and related equipment required for the Navy's Pacific battleships. A key activity was the relining of major-caliber battleship guns sent to the plant after repeated firings in battle had worn out the rifling in the guns.

The Pocatello site met all the selection criteria. It consisted of 211 acres located three miles north of the town. It was inland and east of the coastal mountain ranges, so it was both isolated and secure. The area contained a plentiful labor supply and space for expansion. The land was marginal for farming and, therefore, less expensive than other potential sites. Ample water was available. Most important, the site was situated near one of the largest Union Pacific railroad terminals in the United States. A transcontinental highway also passed through Pocatello. The plant could easily take delivery of steel, chemicals, ordnance, personnel, and battleship guns shipped from the West Coast. ${ }^{12}$

The plant, built by the Idaho-based Morrison-Knudsen Company, contained large and small gun shops, ordnance storehouses, personnel quarters, machine and proof shops and accessory buildings. While spacious, the Pocatello site lacked one necessary asset: a location nearby to proof-fire the relined guns before declaring them ready to return to the coast and remounting on battleships. The Navy first considered a site near Tabor, Idaho, about forty miles northwest of Pocatello but found the land too uneven and access limited.

The Navy looked further north toward the Arco Desert and found an ideal site. The land was flat, arid, and sparsely populated. A few acres were in private hands, but most of the land was in the public domain. The Navy appropriated about 271 square miles, configured up to nine miles wide and thirty-six miles long at its extreme dimensions. A branch of the Union Pacific Railroad passed near the southern edge of the site on its way from Pocatello to the towns of Arco and Mackay. By building a short spur line, the rails could carry the guns and other traffic between Pocatello and the proving ground - a distance of about sixty-five miles. The Morrison-Knudsen Company built all the buildings at the site. J. A. Terteling Company, another Idaho construction company, did subcontract work there and at the Pocatello plant. The proving ground was finished by August $1943 .{ }^{13}$

The Arco Naval Proving Grounds: 1942-1949. The Arco Naval Proving Grounds facilities were divided into two areas: the Proof Area and the Residential Area. The Proof Area was the business end of the site, equipped to test-fire the guns relined or manufactured at the Pocatello plant, noting their accuracy and consistency. Later during the war the spacious expanse of the desert was the scene of additional missions - bombing target practice, research on the safe design of explosives storage cells, and miscellaneous research on new forms of explosives.

The buildings and structures in the fenced and guarded eighty-five-acre Proof Area included a bank of ten gun emplacements, a concussion wall, control tower, an office building east of the control tower, the

11. Building the Navy's Bases, p. 16-44; 351.

12. Building the Navy's Bases, p. 341; see also Julie B. Braun, Lockheed Idaho Technologies Company Internal Report, INEL Historic Building Inventory Survey, Phase I (Idaho Falls: Sept. 1995), p. 29-30. Hereafter cited as "Braun, Inventory Phase 1."

13. Information on M-K and Terteling companies from "Appendix B," Interim Ordnance Cleanup Program Record Search Report for the Interim Action to Clean Up Unexploded Ordnance Locations at the Idaho National Engineering Laboratory (Idaho Falls: Wyle Laboratories, Scientific Services and Systems Group, Norco, California, for Scientech, Inc., January, 1993). Hereafter cited as "Scientech Report." 
tool room and oil storage tanks west of the control tower, a nearby restroom, five munitions magazines, two electric substations, guardhouse, pumphouse, and two temporary buildings. Railroad trackage supported the movement of guns and equipment around the area. Most of the structures were constructed of reinforced concrete to withstand blast and vibration from proof testing and potential munitions explosions.

The concussion wall, 315-ft long, $15 \frac{1}{2}$ - $\mathrm{ft}$ high, and 8 -ft thick, was reinforced with double rebar placed in a close eight-inch grid. The railroad siding near the gun emplacements was equipped with a 250-ton gantry crane to remove guns arriving from Pocatello. A gun ready to be proofed was positioned on one of the ten emplacements, loaded with a charge, and fired northward. Test operators located within the building behind the concussion wall could observe the firing through narrow window slits.

Downrange, spotters were positioned at observation towers and in communication with the control tower. Aided by rows of marked concrete monuments across the desert, they triangulated the location of impact and recorded the performance of the gun. ${ }^{14}$

Munitions magazines, also located near railroad trackage, were constructed completely of reinforced concrete. They either had earthen berms on the side walls or were built below ground with berms covering the entire building except for the entrance.

The Residential Area supported the Navy, Marine, and civilian personnel who lived and worked at the site-including Women Ordnance Workers, or "WOWs." It contained civilian and officers' houses, associated garages, enlisted personnel barracks, (patrol) dog kennels, a warehouse, commissary, paint house, water tower, deep wells, sanitary sewers, fences, and electrical distribution lines. In 1944 a combination garage, fire station, and locomotive shed was added. On twice-weekly movie nights, the residents moved the locomotive outside, set up a movie projector, and settled down on rows of benches to enjoy the show. ${ }^{15}$

The Residential Area was divided into two complexes, separated by the railroad spur coming in from the Union Pacific branch. The civilian complex was on the south side and consisted of single-family dwellings. They were situated close to one another in an oval, with a circular roadway located on the outer edge and driveways leading to each house. The homes were wood frame, probably of prefabricated materials, and had lawns and fenced gardens. ${ }^{16}$

The officers' houses and the Marine barracks were on the north side of the spur tracks. These buildings were sided with brick veneer and had shutters around the windows. The lawns were landscaped with substantial plantings of trees and shrubs. The base commander's residence (later known as CF-607) had its own matching garage. The barracks was of similar construction and housed approximately twenty Marines. Among other duties, the Marines - and their dogs — patrolled the site perimeter. The kennels were near the barracks. ${ }^{17}$

Within a very short time, the Navy had shaped the desert landscape to accommodate its mission. A road system, water lines, sewer lines, electrical and telephone lines, and the railroad track united the Residential and Proof areas. The Navy named the main roads Lincoln Boulevard, Farragut Avenue, and

14. Margaret and Orville Larsen, interview with Susan M. Stacy, March 19, 1999. For a fuller account of life and operations at the Naval Proving Ground, see Chapter 2, "The Naval Proving Ground," in Stacy, Proving the Principle.

15. Stan Coloff, "The High and Dry Navy: World War II," Philtron (October 1965), p. 3; Stacy, Proving the Principle, p. 11, 12. Hereafter cited as "Coloff."

16. A 1951 photograph shows most of these buildings: INEEL negative number 02974.

17. Coloff, p. 3 . 
Portland Avenue - names that continue in use today. The railroad siding and village was (and still is) called Scoville after John H. Scoville, the officer in charge of construction at the Pocatello plant and the proving ground.

Research and Testing Programs at Arco NPG: 1942-1949. Although a small facility, the Arco NPG was one of only six specialized facilities conducting ordnance experiments during World War II. One of the largest ammunition depots in the United States already existed at Hawthorne, Nevada, but no testing was performed there. Each ordnance testing facility specialized in various types of ordnance. The White Oak, Maryland, site tested underwater mines. At Stump Neck, Maryland, powder testing was the emphasis. The Montauk, New York, site specialized in torpedoes. In 1943 (after the Pocatello plant was constructed) a rocket ordnance test station was established in the Mojave Desert at Inyokern, California. In 1944 the Shumaker, Arkansas, site began large-scale production of rockets. ${ }^{18}$

At Arco, the specialty, but not the only one, was the proof firing of the Navy's 16-inch ship guns. In addition, proof testing was done on lesser-caliber anti-aircraft guns, aiming them high into the air. Between 1942 and 1945, the Arco NPG test fired 1,650 gun barrels, large and small. ${ }^{19}$

The Navy permitted certain U.S. Army activities at the site. Bomb groups and fighter squadrons training at the Pocatello Army Air Base used two areas of the proving ground to practice day and night high-altitude bombing techniques. B-24 Liberator bombers dropped 100-pound sand-filled bombs equipped with black powder spotting charges. The pilots aimed at wooden pyramid targets. ${ }^{20}$

Other areas were used for safety-related detonation research. The Joint Army/Navy Ammunition Storage Board authorized demolition tests to determine safe distances between high explosive munitions magazines. The research questions concerned how best to store explosive shells and cartridges in transit and at docks and depots. Army chemists built test storage cells and bunkers in the desert, packed them with trinitrotoluene (TNT) to simulate an actual storage facility, and ignited nearby "accidental" charges The tests helped the scientists combine concrete barriers with air gaps in designs that would help protect the contents of nearby ammo cells. A test conducted in 1945 exploded 250,000 pounds of TNT stored in an igloo-type storage bunker, incidentally creating a crater fifteen feet deep and a noise heard all the way to Salt Lake City. ${ }^{21}$

Smokeless powder tests were conducted in 1944 and 1945. The tests helped determine whether confinement in a standard reinforced concrete magazine would cause the powder in them to explode, rather than burn. One of the concrete bunkers located near the concussion wall stored the powder in quantities of 500,000 pounds until it was tested.

The researchers tested new types of illuminated projectiles (also called "star shells") and white phosphorus projectiles to determine detonation characteristics. Mass detonation of projectiles took place in 1945. The ammunition was shipped to the Arco site from the depot at Hawthorne, Nevada.

After World War II ended, explosives research continued at the proving grounds. Varying quantities of conventional explosives were used on numerous structures and materials. The tests continue to advance

18. Building the Navy's Bases, p. 339-340, 351-354.

19. Braun, Inventory Phase 1, p. 31-32; and Scientech Report, p. 2-6, 2-7.

20. One area was located five miles northwest of INL's Radioactive Waste Management Complex; the other, centered on today's Highway 20 between East Butte and the site of Argonne West. See Scientech Report, Reference 96, p. 2-74, 6-7.

21. See Scientech Report, Table 2-1, p. 207. 
the safety standards for storing large quantities of explosive materials. The largest powder explosion of the time took place at the site on August 29, 1945. Similar tests continued into $1946 .{ }^{22}$

By 1947, gun proofing activities at the site had significantly diminished. The proving ground absorbed new functions. After the war, naval vessels were decommissioned, and various types of equipment from the ships were sent inland for repair and storage. Pocatello received much of that material, and some of the abundance — nets, floats, mooring rings, buoys — went for temporary storage to the proving ground awaiting sandblasting and repainting. The NPG was designated a depot for stockpiling surplus manganese for the U.S. Treasury.

The research that continued was no longer in connection with the gun plant in Pocatello and went along at a slower pace than before. Some 1948 and 1949 research was classified, the details generally unknown today. "Project Marsh" may have been an effort to develop countermeasures for guided missiles. "Project Elsie" may have tested 16-inch shells made with depleted uranium. ${ }^{23}$

The Atomic Energy Commission Acquires the NPG, 1949. Congress created the Atomic Energy Commission (AEC) in 1946 to develop nuclear energy for peaceful purposes under civilian authority. After evaluating several locations, the AEC selected the Arco NPG in 1949 as the site for a nuclear reactor testing station. The Navy reluctantly gave up the proving ground and its buildings to the AEC. ${ }^{24}$

The houses, warehouse, rail trackage, and the accompanying infrastructure of the Residential and Proof areas became very useful to the AEC as it began to build the country's first and only National Reactor Testing Station (NRTS). This area became the nucleus of what later became known as the Central Facilities Area (CFA). Houses became offices and ad hoc laboratories, storage areas continued to serve construction contractors, and new buildings quickly enlarged the site.

The gun emplacements and concussion wall outlived their function. These assets were not reused, but left in place.

\section{Sub-Theme: Vietnam War}

\section{Navy Proving Ground/Central Facilities}

Vietnam War Ordnance Testing. The Vietnam War revitalized several mothballed ordnance facilities across the United States. The Pocatello Naval Ordnance Plant resumed its work relining 16-inch guns for the USS New Jersey - a battleship sent for special duty in Vietnam. The guns were reworked to extend their range. The Navy used the ship to clear (from off-shore) 200-yard-diameter landing zones in Vietnam's heavily canopied jungles. ${ }^{25}$

In 1968 a new Naval Ordnance Test Facility (NOTF) was constructed at the NRTS. Because nuclear reactors and their associated buildings and structures now occupied the old bombing and gun ranges, the original swath of desert north of CFA could not be used. Guns would have to point south. The Navy built a new gun emplacement northeast of EBR-I, along with a new access road, railroad spur, firing pit, pivot

22. Scientech Report, p. 59-71.

23. Scientech Report, p. 72-73.

24. Richard Hewlett and Frances Duncan, Atomic Shield, 1947-1952: Volume II of a History of the United States Atomic Energy Commission (University Park: Pennsylvania State University Press, 1969), p. 210.

25. Norman Friedman, The Naval Institute Guide to World Naval Weapons Systems, 1991/92 (Annapolis, Maryland: United States Naval Institute, 1991), p. 457. 
point, concussion wall, and equipment shelter. It moved the NPG gantry crane from its original location to NOTF, where it once more unloaded heavy guns for proof testing. The target was the northern flank of Big Southern Butte. ${ }^{26}$

Proof-firing at the NRTS ceased in 1970, before the end of the war. The Indian Head Ordnance Station in Maryland expanded and took over this role for the USS New Jersey and other major battleships.

Most NOTF structures have since been removed from the site except for one gun emplacement and parts of the concussion wall. These are now ruins. The gantry crane returned to its original location at the Central Facilities Area. Impact craters from NOTF gun proofing are still visible on Southern Butte's north-facing flank. ${ }^{27}$

Extant NPG Buildings. Several Arco NPG buildings and structures are extant. The Proof Area retains railroad trackage, parts of the bank of gun emplacements, the concussion wall and the operations building directly behind it, at least one ammo storage bunker, a pumphouse, and the gantry crane.

In the Residential Area, the civilian houses were removed to make way for new requirements of the CFA as the NRTS grew and expanded. Several examples of the redbrick Navy personnel housing remain, including the Marine barracks, officers' quarters, the commanding officer's house, and a garage. Lincoln, Farragut, and Portland roads continue in use.

Significance of the NPG and Recommendations. As one of six specialized ordnance facilities that conducted research and experiments during World War II, the NPG was a fairly rare military feature on the Home Front. Victory in the Pacific theater relied partly on the performance of battleship guns. The NPG was the terminus of an elaborate logistical system that began with the guns on ships like USS Missouri and USS Wisconsin. After repeated combat firing wore out the rifling, the guns were shipped to the coast, sent by rail overland to Pocatello, relined, sent to the proving ground, test-fired, and scored for accuracy. The guns then returned to action the way they had come and entered battle once more. Aside from being a tribute to the logistical excellence of the U.S. military, the NPG's association with the great battleships of the war and with military research are important national historic themes.

The NPG is one of very few sites in Idaho that might interpret for future generations what the state contributed to American victory in the Pacific during World War II. Likewise, it retains a few remnants of a unique "village" of civilians and military personnel arranged for domestic life amidst the firing of battleship guns, bombing practice, and the detonation of vast stores of TNT.

The NPG also provided the core setting for the present-day INL. Infrastructure such as roads and rail sidings influenced the location of later facilities. Beyond the proofing and residential centers, the NPG had altered the desert landscape. Explosives tests and gun firings had produced impact craters and left a variety of ruins on the desert floor - piles of shattered concrete and twisted metal, bomb shells and even unexploded projectiles. The latter was sometimes observed being "initiated by desert heat," a hazardous legacy that remained unattended until many decades later. ${ }^{28}$

26. Stacy, Proving the Principle, p. 17.

27. Braun, Inventory Phase 1, 37; INEEL photos 68-1808, 68-2408, 68-2412, and 68-2866 at the INEEL Photo Archive; Brandon Loomis, "Blast Site - INEL Officials 'Cleaning Up' Land Mines," Idaho Falls Post Register, from clipping file with no date.

28. Scientech Report, Reference 92. 
In 1992 INL contracted with Wyle Laboratories of Norco, California, to clear the desert of explosive debris and scrap metal. Since then, over 1,500 explosive ordnance items have been destroyed and 120,000 pounds of scrap metal cleaned up. ${ }^{29}$

For its many thematic associations, the World War II "Ordnance Testing" context is assessed as historically significant. A HABS/HAER-level document ought to gather together archival resources such as historic photographs, plans, oral histories, military correspondence, and research reports. Material published as Chapter 2 in Proving the Principle is an additional source of interpretation and context that could supplement the HABS/HAER report and be reprinted for public distribution.

Historic preservation planning at INL should preserve the Proof Area in place, aiming to protect it from further decay or destruction. Plans for the Residential Area should continue to reuse and preserve the NPG-era buildings.

The role of ordnance testing at NOTF for the Vietnam War was considerably less important to the prosecution of that war than the previous testing during World War II. Likewise, the impact of this activity on the course of Idaho history was relatively minor. The equipment shelter is not extant. Unless the remaining ruins have retrospective value in interpreting World War II activities, they are not assessed as historically or exceptionally significant in the Vietnam War era of "Ordnance Testing."

\section{CONTEXT III: NUCLEAR REACTOR TESTING: 1949-1970 Preliminary Review of Nuclear Reactors}

The work of "nuclear reactor testing" is best begun with a short introduction to nuclear reactors and related subjects mentioned frequently in this report. Nuclear reactors have several features in common: core, reflector, control elements (i.e., rods), coolants,.

Core. The core is that part of the reactor consisting of the fuel and control elements, a coolant, and the vessel containing these. The design is such to sustain a chain reaction. Neutrons are less likely to split another atom if they travel at their natural rate of speed, which is in the range of millions of miles per hour. To slow them down, the fissionable fuel, such as uranium, is surrounded by a substance that slows, or moderates, the neutrons. Some materials do this well, but others absorb the neutrons, taking them out of play as promoters of the chain reaction.

Reflector. Surrounding the core (of many reactors) is a reflector. One of the challenges in reactor design is to prevent the neutrons from escaping the core and becoming useless to the chain reaction. A single fission event of a uranium atom will produce, on average, about 2.5 neutrons. Each of these are capable of fissioning another atom. If the neutrons escape from the core, they will not be available to continue splitting the uranium atoms. Reflectors bounce the neutrons back into the core of the reactor.

Control Elements. One objective of reactor design is to control the chain reaction at the will of the operator - to control the rate at which neutrons are produced within the core and thus the rate at which the chain reaction proceeds. Control elements are made of materials that absorb neutrons and slow down the reactivity of the fuel. The elements often are in the shape of rods. Operators move one or more control rods into the midst of the fuel where they absorb the neutrons in just the quantity required by the operator to reduce reactivity or shut down completely.

29. Scientech Report, see also Loomis, cited in Note 18 above. 
Heat and Coolants. The supreme reason for requiring perfect control over a chain reaction arises from the fact that every fission of an atom produces a unit of heat. The fissions can occur so fast and in such quantity that the heat can melt the fuel, the moderator, and the container vessel surrounding it. Reactor designers, therefore, must arrange for some reliable method of carrying off the heat. In the case of reactors intended to generate electricity, the heat is the useful part of the reaction. The coolant carries away the core heat and transfers it to a secondary coolant, which then provides the motive force (i.e., steam) to power the turbines of the generation machinery. In many reactors, the coolant can serve a dual function as a moderator.

Reactor "concepts." Reactors can be configured in many possible arrangements and use a variety of materials in any part of its architecture. For example, the coolant can be water, a liquid metal, or gas. A reactor performs differently - and the engineering is very different - depending on the type of coolant (or fuel, or moderator, etc). The literature of nuclear reactors refers to a particular combination of nuclear features as a "concept." Each combination performs quite unlike the other choices, so each "concept" must be studied to discover its characteristics, its advantages for any given purpose, and its disadvantages.

“Excursions" and "Transients." As scientists began their post-war research into reactor concepts, they needed to find out just what the safe operating limits of reactors were. For example, how much heat could build up before a fuel element or its cladding would melt? Many of the safety tests conducted at NRTS dealt with "excursions" and "transients," names used to refer to extreme power levels and heat build-up. For various reasons (such as imperfectly manufactured fuel elements, the behavior of the coolant, failed cladding materials, or some other anomaly) the power level in a reactor can rise sharply and unexpectedly. This can produce dangerous quantities of heat. Much of the early testing and research at INL sought to discover the safe operating limits of reactors and the materials of which they were made. It also was important to study how the design of reactor components could eliminate or reduce the occurrence of such episodes, how to predict reactor behavior under various conditions, and how to use instrumentation and safety systems to prevent accidents.

\section{Sub-Theme: Reactor Testing, Experimentation, and Development}

\section{Central Facilities}

CFA Site Transitions from the Navy to the AEC: 1950-1954. The AEC "inventors" of the reactor testing station decided that the reactor experiments would take place at locations assigned to the sponsor and selected according to safety and other criteria administered by AEC management. The AEC would then supply support services — such as security, laundry, warehousing, dosimeter and health services, fire prevention and suppression, transportation to and from Idaho Falls - to all sponsors from a centralized location.

The NPG complex became that location, equipping the AEC with ready-made buildings, roads, rail spur, yards, security perimeters, electricity, and water from which to launch the rest of the enterprise.

While the transfer of ownership from the Navy to the AEC was still in process, the AEC began evaluating the water supply, building a well for the first reactor experiment, and improving the existing Navy roads and trails. Soon the foundation for EBR-I was under construction. The AEC added new rail spurs and expanded the Scoville electric substation to serve potential reactor sites.

When it came to construction standards and policies, AEC policies were similar to those that governed the armed forces. Shaped by similar congressional mandates and budgets, the AEC required functional and standardized design, ease of construction, safety practices, and careful programmatic and 
fiscal accounting. Adapting NPG buildings for new uses rather than dismantling them was one way to save funds. ${ }^{30}$

Thus NPG dwellings and other buildings were the first home to for the testing station's many central functions. Some of the houses became construction contractor offices. Site engineers made use of the established military grid used by the Navy to define its territory and adapted it to the new requirements of the testing station.

The redbrick officer's residences, garages, and Marine barracks became offices, lunchrooms and security control centers (CF-606, -632, and -607 respectively). The Navy bunkhouse (CF-613) continued to be used as a bunkhouse. One residence (CF-603) was converted into a dispensary. Despite the changes in use, engineers worked carefully to blend new additions and changes with the old. ${ }^{31}$

Buildings in the Proof Area also were recycled for NRTS missions. In the 1950s site engineers remodeled and joined together several extant buildings near the concussion wall and control tower. These structures were originally assigned individual numbers, such as the oil shed (646) and office (684). A portion of this remodel was a new instrument laboratory, numbered CF-633, and a new locomotive shed (no longer extant, built in 1951.) By 1987 all of the buildings attached to the old battery wall had been renumbered as CF-633, and the old 646 and 684 numbers were reassigned to other storage buildings at the CFA. The control tower was logically converted into a fire lookout. The old NPG boiler room (CF-650), located near the battery wall, required few renovations and continued in use until the 1990s.

Over the years the Navy munitions bunkers were used to store hazardous materials. Their heavy-duty concrete construction and berms provided the same protection from chemical explosions as from munitions explosions. One of the bunkers became the Dosimetry Calibrations Laboratory (CF-638) in 1969, providing appropriate shielding from background radiation. The NPG locomotive shed and fire station, located south of the old Marine barracks (CF-606), were converted into craft shops (CF-654, no longer extant).

The NRTS landlords often pointed proudly to their adaptation and reuse of existing buildings for central services as a mark of their cost-saving efforts. They avoided duplication of basic services and preserved resources better directed to the far more costly requirements for nuclear reactor experiments ${ }^{.32}$

Building contractors patterned new NRTS buildings after established military and industrial designs. Such designs were unembellished and functional, based on engineered building plans with virtually no architectural influences. "Industrial Vernacular," a term later coined by industrial archaeologists and architectural historians, describes this type of architecture. ${ }^{33}$ Some of the more permanent structures, such as offices and early reactor buildings, did reflect a few International-Style characteristics of the 1950s, and later Contemporary architecture. Most, however, were plain, box-like structures with flat roofs and concrete walls or corrugated metal siding. These building materials were easily available and relatively

30. United States Department of Energy, National Register of Historic Places Multiple-Property Documentation Form, Historic, Archaeological and Traditional Cultural Properties of the Hanford Site, Washington (Richland, Washington: U.S. DOE, February 1997), p. 6.10; see also "Engineering Aspects of the National Reactor Testing Station" (U.S. Atomic Energy Commission, Idaho Operations Office, October 1951), p. 13. Hereafter cited as "Engineering Aspects."

31. Architectural drawings, Medical Dispensary Remodel (CF-603), on file at EROB, INEEL, Idaho Falls, Idaho. See also Julie B. Braun, LITCO Internal Report, INEL Historic Building Inventory Survey, Phase I (Idaho Falls: INEL, September 1995).

32. "Engineering Aspects," p. 13. See also Braun, p. 46.

33. United States Department of Energy, National Register of Historic Places Multiple-Property Documentation Form Historic, Archaeological and Traditional Cultural Properties of the Hanford Site, Washington (Richland, Washington: U.S. DOE, February 1997), p. 6.9, 6.19, 6.25. 
inexpensive. Good gravel for concrete existed on-site, and the AEC moved a batch plant from one site to another as needed. The railroad provided easy transport of Portland cement, prefabricated metal siding, and framing to each site. ${ }^{34}$

New buildings at the CFA illustrated the site's new nuclear testing mission. Since employees were no longer living on-site (except during the earliest construction phase), none of the new buildings were houses. The domestic-scaled brick Minimal Traditional officers' quarters became a thing of the past. The emphasis was science, engineering, and industry, all of which called for purely functional and impersonal design.

The CFA warehouse (CF-601) and fire station (CF-666), built by AEC contractors in 1950 and 1951 , set the pattern for the vernacular industrial design that became the norm at the NRTS. The warehouse was a concrete masonry or "pumice block" structure, with a built-up flat roof and concrete slab floor. The AEC's Division of Engineering and Construction designed the building, and regional contractors C. B. Lauch and Associates built it. The fire station, designed and constructed by the same group, used similar materials. A 1951 AEC Engineering Division report took pride in the low cost of these buildings, while meeting AEC design requirements at the same time. ${ }^{35}$ The cafeteria and bus station, the two buildings constructed specifically for site employees, followed the same functional and impersonal lines. Both were built of concrete block and exhibited no stylistic adornments.

Several smaller CFA support buildings were constructed of material other than concrete. In 1951 most of the pumphouses, storage buildings, generator buildings, and small repair shops were prefabricated structures of corrugated iron cladding on a steel frame. A few were constructed with wood or asbestos shingle siding, and only one of brick after 1950. The fire station generator building (CF-679) had brick masonry walls, a concrete foundation, and a flat, corrugated-iron-sheet roof. The prefabricated metal building became the norm for most subsequent support facilities on the NRTS. These buildings easily could be constructed, dismantled, or moved and recycled for another use. An example was the lead storage building (CF-687), which was moved from the Idaho Chemical Processing Plant to the CFA in 1952. These structures were - and still are — representative of vernacular industrial architecture. Their use emphasizes the change in approach from the Navy to the AEC. Instead of building for permanence, the AEC preferred to erect prefabricated, temporary buildings. In later decades, rapidly changing technology and concerns about radioactive contamination at the nation's nuclear sites increased the AEC's interest in temporary structures.

CFA New Construction Slows Down: 1955-1970. In the 1960s, few buildings were constructed at the CFA. Most of them were storage buildings. Some reflected the changing concerns and issues of the nuclear industry (and its critics), particularly related to the handling of nuclear waste. One of the first radioactive-waste handling facilities at the NRTS was the "Hot" Laundry Facility (CF-669). Built in 1950, the facility handled all contaminated protective clothing for the entire station. Initially, such lowlevel waste was regarded in the same light as conventional chemical, or even domestic, waste.

The design of the Laundry Facility reflected this thinking. Radioactively contaminated clothes were washed, and the wastewater was carried by a separate sewer line to a trickling-filter sewage plant. The waste entered the same septic tank as other CFA effluent and went to an open drain field. This process had evidently been tested at Los Alamos in 1952 and was considered an effective way to handle low-level waste. Eventually, the hot laundry building, sludge lines, and drain field became thoroughly contaminated. The facility was decontaminated and decommissioned in 1981, when its boiler exploded. A

34. Stacy, Proving the Principle, p. 38-40.

35. "Engineering Aspects," p. 13. 
new hot laundry facility (CF-617) took its place, with its sewage lines going directly to a separate septic tank. The old hot laundry was dismantled in $1992 .{ }^{36}$

As early as 1958, the NRTS reacted to growing national concerns over radioactive fallout from nuclear testing. Site engineers converted an old NPG locker room into a Health and Safety Laboratory (CF-649) for studying radioactivity levels in area plants and animals. Cow's milk from area dairies, feral and domestic rabbits, wild antelope, and native plant species were studied under laboratory conditions. In 1960 these studies discovered a low level of iodine-131 (I-131) in milk from "environmental" cows on nearby farms. Internal reports attributed the rise to an unexplained "special test" conducted at the NRTS. ${ }^{37}$

In 1963, a new and expanded Radiation Environmental Laboratory was built, along with a new Technical Center Laboratory. A 1963 report from the Radiation lab indicated that there had also been an increase of strontium-90 occurring in cow's milk. ${ }^{38}$ Aboveground nuclear testing beyond the boundaries of the NRTS was one likely source of some spikes in I-131 or Strontium-90 levels. ${ }^{39}$ Growing calls for protecting the underlying aquifer from continued disposal of radioactive waste prompted NRTS scientists and site managers to voice their concerns to the AEC.

As the nation's attention grew more focused on environmental quality in the 1970s and 1980s, the role of CFA in environmental monitoring and general administration at INL eventually grew. As reactors closed down at the other activity centers on the site, reactor-support functions would diminish at the CFA.

\section{Sub-Themes: Reactor Testing, Experimentation, and Development and Commercial Reactor Safety}

\section{EBR-I, Argonne National Laboratory West}

Argonne National Laboratory: An Introduction. The origin of the Argonne National Laboratory places into a national context the purpose of the National Reactor Testing Station. ${ }^{40}$

On December 2, 1942, in the basement of Stagg Field at the University of Chicago, Enrico Fermi and a team of researchers conducted the experiment that produced the world's first self-sustained nuclear chain reaction. The Chicago Pile \#1 (CP-1) experiment was part of the Manhattan Project, the government's secret effort to produce an atomic weapon. The scientists who conducted the experiment were members of the Metallurgical Laboratory (Met Lab), one of several secret research facilities involved in the bomb project.

The secret project responded to political and scientific events in Europe in the 1930s after Otto Hahn and Fritz Strassman discovered nuclear fission. Physicists worldwide understood that controlled nuclear

36. For early national perspective, see A.D. Mackintosh (Superintendent of New Facilities Design and Construction at Oak Ridge National Laboratory), "Architectural Problems in Atomic Labs," Architectural Forum (January 1952), p. 159. For CFA laundries, see the Idaho Operations Office, Engineering and Construction Division report by A. L. Biladeau, "Radioactive Waste Removal in A Trickling Filter Sewage Plant," May 1953. See also the EG\&G Idaho internal technical report by R.D. Browning, "TAN, TRA, and CFA Sewage Treatment Plant Study" (Operational and Capital Projects Engineering, January 1989).

37. NRTS internal report, "Environmental Monitoring Data for the National Reactor Testing Station, Calendar Year 1959 and 1st Quarter of 1960," p. 1; see also report for Calendar Year 1963.

38. NRTS internal report, "Environmental Monitoring Data for the National Reactor Testing Station, Calendar Year 1963."

39. "Environmental Monitoring Report No. 17; Third and Fourth Quarter and Annual Summary, 1965," (Idaho Falls: AEC Idaho Operations Health and Safety Division, NRTS; 1965), p. 1-2.

40. For additional background, see Stacy, Proving the Principle, Chapter 3, "The Uranium Trail Leads to Idaho," p. 18-27. 
fission could provide a nearly unlimited source of energy. It could also be designed for bombs with unimaginably powerful explosions. As Hitler advanced, scientists feared that German scientists might be first to discover how to control it for the production of bombs. Several of them petitioned President Franklin Roosevelt to support atomic energy research in the United States. By 1942 the Manhattan Project was underway.

The scientists working on CP-1 knew they would not be able to continue pile research in the basement of Stagg Field. Their assignment, once the chain reaction was achieved, was to experiment with uranium pile size and configuration, searching for the most effective pile design for plutonium production, (an activity that took place at Hanford, Washington). For improved safety, security, and working space, the Met Lab group moved in 1943 to the Argonne Forest Preserve, a site near Chicago. Enrico Fermi was named director of the new Argonne Laboratory. ${ }^{41}$

Manhattan Project scientists had always discussed the future of nuclear research. Atomic science was new. It had potential for power production and other uses, but to advance these, further research was needed in materials, efficiency, operating methods, and safety.

The Manhattan Project laboratories were the likely centers for such research. In 1946, a committee formed by General Leslie Groves, head of the Manhattan Project, recommended distributing various research needs among the existing laboratories and a new one to be located in the Northeast. Argonne would pursue atomic pile, or reactor research. Walter H. Zinn became director after Enrico Fermi moved to Los Alamos. ${ }^{42}$

By August 1, 1946, when President Harry S. Truman signed the Atomic Energy Act, the newly named Argonne National Laboratory (ANL) was one month old. It would focus on two major AEC objectives: developing reactor concepts and the safety of commercial power plant reactors.

Establishing A Test Site for Nuclear Reactors: 1949-1951. One of Walter Zinn's earliest proposals was to design and construct an experimental "breeder" reactor, a reactor that would produce more fuel than it consumed. In those early days of nuclear research, scientists believed that uranium was a scarce resource. Only uranium could be used to fuel reactors, and less than $1 \%$ of natural uranium is fissionable uranium-235 (U-235). A breeder reactor could make uranium scarcity a non-issue. In 1947 the AEC's General Advisory Committee listed the breeder reactor as one of its high-priority projects.

Zinn and others realized that reactor experiments were too dangerous to expose large population centers to possible accidents. The AEC Reactor Safeguards Committee recommended in 1949 that reactor experiments take place at a remote location. After a search for a suitable location, the AEC settled on Idaho's Navy Proving Ground and set out to transform it as a National Reactor Testing Station. ${ }^{43}$

Having settled this matter, the AEC was ready to execute its reactor-research priorities. Argonne became one of the first clients of the NRTS, responsible for Zinn's breeder reactor experiment, sometimes referred to by his colleagues as "Zinn's infernal pile."

Experimental Breeder Reactor I. EBR-I, the first reactor constructed at the NRTS, was located in the southwest corner of the site south of U.S. Highway 20/26). Zinn selected the location after a test well

41. Jack M. Holl, Argonne National Laboratory, 1946-96 (University of Illinois Press, 1997), p. 22-23. Hereafter cited as "Holl, Argonne." After the war a larger site in Du Page County, Illinois, became the current location of Argonne National Laboratory.

42. "Atomic pile" was the early term for a reactor, coined because the materials used in the chain reaction experiments were piled on top of each other. The word "reactor" came into use after World War II. Holl, Argonne, p. 7, 35-44.

43. Stacy, Proving the Principle, p. 26-27. 
began to produce water. At the time, site engineers did not realize that the Snake River Plain aquifer underlaid nearly the entire NRTS site and could have supplied water just about anywhere.

Construction of EBR-I began early in 1950, although a local contractor had poured building foundations in the fall of 1949 to expedite the project. The reactor design, developed at Argonne, already had been approved by the AEC. The Austin Company of Cleveland, Ohio, was architect/engineer. The Bechtel Corporation of San Francisco was named construction contractor and took over construction in the spring of $1950 .{ }^{44}$

The multi-level building, completed in April 1951, was made of steel, brick, and concrete. A single building housed the reactor and control room, as well as utilities and the equipment used for handling, storing, and cleaning nuclear fuel elements. The building, $122 \mathrm{ft}$ long by $77 \mathrm{ft}$ wide, included a basement, main floor, and mezzanine level. It was fifty feet high, with subgrade areas thirty feet deep. The project cost $\$ 2,500,000 .^{45}$

By January 1951, the building was ready for action. A team of nine scientists arrived at the NRTS from ANL to assemble the reactor. The reactor was expected to prove the validity of the breeding principle and demonstrate the use of liquid metal as a coolant. Unmoderated, the reactor was cooled by an eutectic potassium-sodium alloy $(\mathrm{NaK})$. The reactor was small, with a core the size of a "regulation football." The creation of plutonium (breeding) was to occur in two "blankets" of uranium-238 (U-238) surrounding the core. The reactor was operated with twelve stainless-steel-jacketed U-238 control rods, eight of which also functioned as safety rods. ${ }^{46}$

Once the team had assembled the reactor and installed the fuel, it was time to bring the reactor to criticality. Walter Zinn arrived in May 1951 to begin criticality tests. Unfortunately the first test failed. More uranium fuel was needed. Finally, on August 24, the reactor went critical. Zinn's associate Harold Lichtenberger continued to run tests until late December. ${ }^{47}$

On December 20, 1951, energy generated by EBR-I lit four light bulbs in the reactor building - the first time a nuclear plant had ever produced electricity. The next evening, the reactor provided electrical power for the entire reactor building. The Argonne team had demonstrated that nuclear power could be a source of electricity. ${ }^{48}$

Despite the historic lighting of the four light bulbs, electric power production was not the primary mission of EBR-I. Later experiments with its original core (Mark I) and a later core (Mark II) went on to

44. Richard G. Hewlett \& Francis Duncan, Atomic Shield, 1947-1952: Volume II of a History of the United States Atomic Energy Commission (University Park, Penn.: Pennsylvania State University Press, 1969) p. 495-496; Holl, Argonne, p. 87; "Breeder Design Completed, Contractor Selected," Nucleonics (January 1950), p. 93.

45. "Breeder Design Completed, Contractor Selected," Nucleonics (January 1950), p. 93.; and E.W. Kendall, D. K. Wang, Decontamination and Decommissioning of the EBR-I Complex, Final Report (Idaho Falls: Aerojet Nuclear Company Report ANCR-1242, July 1975), p. 7.

46. W. H. Zinn, "Basic Problems in Central-Station Nuclear Power," Nucleonics (September, 1952), p. 10-13; Robert L. Loftness, Nuclear Power Plants: Design, Operating Experience, and Economics (Princeton, New Jersey: D. Van Nostrand Company, Inc., 1964), p. 335. Hereafter cited as "Loftness, Nuclear Power Plants."

47. "Critical" means that the reactor is able to achieve the nuclear chain reaction; "criticality" is the point at which the reactor is just capable of sustaining a chain reaction.

48. Stacy, Proving the Principle, p. 64-66. 
demonstrate the breeder principle: the reactor could produce as much fissionable material as it used. The AEC announced this landmark in June 1953, after core and blanket samples had been examined. ${ }^{49}$

The success of EBR-I in breeding fuel also led to the construction of a commercial breeder reactor. In 1956, Detroit Edison began building the Enrico Fermi reactor at Lagoona Beach, Michigan, on Lake Michigan near Detroit.

Boiling Water Reactor Experiments. In 1952, Argonne scientist Samuel Untermeyer suggested that steam formation in the core of a light-water reactor during a power excursion (sudden rapid rise in the power level of a reactor) might shut down the reactor. He wondered if boiling water could be used as a reactor control mechanism. ${ }^{50}$

His theory was that boiling produced a negative coefficient; that is, as the temperature rises, reactivity decreases. Steam bubbles decrease the water's effectiveness as a moderator. As more bubbles are formed, the reactivity slows until the reactor shuts itself down. This theory was contrary to the widely accepted belief that steam bubbles in a reactor core would cause instability. Untermeyer presented his idea to Walter Zinn, who supported a series of boiling water reactor experiments (BORAX) at the NRTS. The first experiments in the BORAX series began in the summer of $1953 .{ }^{51}$

BORAX-I was an open-top boiling water reactor located about a half mile northwest of EBR-I. No building was constructed to contain the reactor. The core was placed in a ten-foot diameter shield tank surrounded by a shield of soil piled ten feet deep and layered at a 45-degree angle. Access to the reactor was from an exterior stairway and platform. During the experiments, personnel were in a control trailer located outside the immediate area.

Arrington Construction built the facility in May 1953. The first in a series of more than 200 experiments began immediately. BORAX-I demonstrated that boiling-water reactors of the same or similar design would shut down if the power were suddenly increased. During the experiments, clouds of steam and streams of water shot up from the reactor core as high as fifty feet. R. O. Haroldsen, who was present for the experiments, said that when the BORAX-I experiments were running, motorists on the highway could observe the steam and water shooting out of the top of the reactor and reported that the Arco Desert had produced a new Old Faithful. ${ }^{52}$

The last BORAX-I experiment took place in July 1954. It was designed to push the reactor to its limits, that is, to destroy it. On July 22, a crowd of scientists and AEC officials gathered to observe. When the crew in the control trailer quickly removed the excursion rod, the sudden change caused a tremendous steam explosion. Although the reactor runaway was planned - all BORAX-I experiments involved a runaway reactor - the explosion was something of a surprise. Debris, including reactor rods, plywood sheets, and dirt, shot high into the air. The guests and a number of workers were told to take shelter while a cloud containing small amounts of radioactivity passed over the site.

49. Stacy, Proving the Principle, p. 135.

50. "Light water" is ordinary water (H20). As a moderator, it slows down fast-moving neutrons and helps maintain the chain reaction. It also absorbs some neutrons, so light-water reactors require enriched uranium, which has more neutrons than natural uranium. Reactors that use "heavy" water (D2O), which does not absorb neutrons, can operate with natural uranium. See Richard Wolfson, Nuclear Choices (Cambridge: MIT, 1991), p. 155-160.

51. Holl, Argonne, p. 118; Andrew W. Kramer, Understanding the Nuclear Reactor (Barrington, Illinois: Technical Publishing Co., 1970), p. 37, 70.

52. J. R. Dietrich and D. C. Laymans, Transient and Steady State Characteristics of a Boiling Reactor: The Borax Experiments, 1953, ANL-5211, February 1954; Holl, Argonne, p. 118; Ben Plastino, Coming of Age: Idaho Falls and the Idaho National Engineering Laboratory, 1949-1990 (Idaho Falls: Margaret Plastino, 1998), p. 64. 
The results of the final experiment were regarded as inconclusive, but BORAX-I demonstrated that boiling water in the reactor core did not cause instability. A later series of experiments with boiling water reactors (the SPERT tests, discussed later in this report) included modifications of the reactor design to safeguard against excursions. ${ }^{53}$

The BORAX-I reactor debris was buried in place - entombed. The uncontaminated control equipment was salvaged for use in a later series of BORAX experiments. In the fall of 1954, a site a short distance from BORAX-I was selected as the location for the remaining BORAX experiments.

The early BORAX experiments contributed to the design of Argonne's Experimental Boiling Water Reactor (EBWR), the country's first power production pilot plant. EBWR, which operated at the Argonne site in Illinois from 1956 to 1967, successfully supplied power for the national laboratory in $1966 .{ }^{54}$

The later experiments in the BORAX series (BORAX-II through BORAX-V) were housed in a prefabricated corrugated metal reactor building erected in late 1954 by the Morrison-Knudsen Company a short distance from the site of BORAX-I. A turbine generator brought in for experiments with power production was placed in a separate building, also made of prefabricated corrugated metal. ${ }^{55}$

BORAX-II and BORAX-IV (1954-1955 and 1956-1958 respectively) tested various core combinations and fuel elements. The BORAX-III series, operated in 1955, tested the reactor's power production capabilities. For these, researchers installed the turbine generator for the experiments. According to R.J. Haroldsen, the team scrounged up an old "wet steam" turbine at an abandoned mining site in New Mexico to use for the power production tests. On July 17, 1955, BORAX-III was patched into the Utah Power \& Light power grid. For two hours (11 p.m. to 1 a.m.) BORAX-III produced power for the town of Arco, part of the CFA, and the BORAX reactor complex. Although the power to Arco from BORAX-III was discontinued after the first brief run, BORAX-III continued to supply power for the BORAX complex and the CFA whenever it was running. It ceased operating later in $1955 .{ }^{56}$

BORAX-V, the final experiment in the BORAX series, operated from 1962 to 1964 . Although BORAX-V was housed in the same reactor building as the earlier experiments, the structure and the reactor both were modified. The original reactor vessel was buried in place, covered with a deep layer of sand, and capped with concrete. A new reactor vessel was placed in a new addition to the reactor building.

The purpose of BORAX-V was to demonstrate the feasibility of producing integral superheated steam in a reactor facility. "Integral" means that the boiling water and the superheated ("dry") steam are produced in the same core. It was thought that superheated steam would prove more efficient and economical than a simple boiling water reactor system. BORAX-V went critical on February 9, 1962, and produced its first superheated steam on October 1963. During the course of experiments, BORAX-V

53. Holl, Argonne, p. 199-121; Loftness, Nuclear Power Plants, p. 156-158; Richard L. Doan, "Two Decades of Reactor Safety Evaluation," Memorial lecture in honor of Dr. C. Rogers McCullough, prepared for delivery at the Winter Meeting of the American Nuclear Society (Washington, D.C.: November 15-18, 1970), p. 5.

54. Argonne National Laboratory, Frontiers, Research Highlights, 1946-1996 (ANL 1996), p. 16; Loftness, Nuclear Power Plants, p. 167-213.

55. The two buildings and associated support structures (including a redwood cooling tower and a guardhouse) were located in an area about 75 mile north of EBR-I. A control trailer was located about one-half mile from the BORAX area for BORAX II-IV. A control building was built outside the EBR-I complex for BORAX-V. D. L. Smith, Decontamination and Decommissioning Plan for the BORAX-V Facility. (Idaho Falls: EG\&G Idaho, Inc., Nov. 1988).

56. Glenn R. Rodman, Final Report of the Decontamination and Dismantlement of the BORAX-V Facility Reactor Building (Idaho Falls: INEL, Inactive Sites Dept., Lockheed Martin Idaho Technologies Company, INEL-96/0325, May 1997), p. 1-2; Loftness, Nuclear Power Plants, p. 2-4; Holl, Argonne, p. 139; Plastino, p. 64. 
tested the safety and effectiveness of superheated steam. The tests also examined safety problems related to damaged or corrupted fuel elements. At the end of a number of successful runs, BORAX-V was placed on stand -by in late $1964 .{ }^{57}$

The BORAX experiments helped persuade the AEC that the deliberate inducement of power excursions and the deliberate withdrawal of coolant to a reactor could be tested under controlled conditions without disaster. Many more followed BORAX. Such tests yielded valuable safety information, which at a time when the modeling capability of computers was long into the future, could be acquired no other way. They established for the NRTS a unique and primary role in the development of safe nuclear power reactors. BORAX proved the principle enabling pressurized water reactors to be further developed. ${ }^{58}$

The Argonne-West Facility Grows: 1955-1965. In addition to the landmark event of BORAX-III lighting the town of Arco, the year 1955 also brought a milestone of another sort to Argonne's Idaho Division. ${ }^{59}$ In November, EBR-I experienced an unintentional core meltdown - the first such accident in a nuclear reactor. Walter Zinn viewed the accident as a source of important information about fuel rod configuration and operating procedures, but the AEC's failure to publicize the accident gave rise to questions about reactor safety and the credibility of the AEC. ${ }^{60}$

Nevertheless, Argonne expanded its facilities at the NRTS. A second breeder reactor, EBR-II, was proposed by Walter Zinn and approved by the AEC in 1954. Based on experimental results and operating experience with EBR-I, EBR-II would be an intermediate-sized reactor, capable of producing twenty megawatts of electricity. Design of EBR-II began in 1955 and construction began late in 1957.

Zinn located the new complex at "Site 16," on the eastern edge of the NRTS site, a location nearest to Idaho Falls. It soon was known as Argonne National Laboratory-West or ANL-W (now MFC). Argonne planned to operate EBR-II for several years and knew that there would be frequent visits from scientists based in Chicago. Time saved in driving to and from Idaho Falls, after flying in from Chicago, was the most important factor in the site selection. ${ }^{61}$

Although Argonne was poised to lead the nuclear industry in the development of breeder reactors, differences of opinion between AEC and Argonne somewhat stunted Argonne's role in the development of major test reactors. In 1965, the AEC canceled Argonne's Fast Reactor Test Facility that had been approved in 1962. To the dismay of Argonne supporters, the AEC went on to build the Fast Flux Test Facility at Hanford, Washington. When the AEC decided to focus its resources on a breeder concept known as the Liquid Metal Fast Breeder Reactor (LMFBR), Argonne's assignment was to do safety research in its support, using EBR-II and its other facilities for that purpose.

EBR-I after 1955. After the EBR-I accidental meltdown, Argonne examined the reactor core and found that its fuel elements had bowed in the high temperatures. The materials and design had not allowed for heat expansion. When a new core (Mark III) was installed in 1957, design modifications included zirconium spacers in the fuel elements, cluster-mounted control rods, and clamping of the inner core

57. Rodman, p. 2; Loftness, Nuclear Power Plants, p. 217-218.

58. Stacy, Proving the Principle, p. 132.

59. The name "ANL-West" did not come into usage until later. According to Richard Lindsay, ANL-West Public Information officer, "Idaho Division" and "Idaho Branch Administration" were used to describe different activities, and the similarity of the names caused confusion. He believes that ANL-West was used unofficially to describe all of the operations and may have been made an official name when the headquarters lab was reorganized.

60. Stacy, Proving the Principle, p. 135-136.

61. Richard Lindsay, public information officer, ANL-West, Personal communication with Elizabeth Jacox, Sept. 2, 1997. 
assembly. The modifications prevented unwanted mechanical movement within the assembly, which was seen as the cause of the meltdown. Thus, the accident contributed to the accumulation of knowledge about the safe design of nuclear reactors.

Five years later, in 1962, a new core (Mark IV) was installed, loaded with plutonium fuel elements, the first plutonium fuel elements used in a power reactor. EBR-I operated successfully with the Mark IV core until it was shut down in $1964 .{ }^{62}$

Argonne West Reactors 1955-1970. The Argonne-West complex expanded steadily with the addition of several new reactors and their support facilities. Activities originally located at the site of EBR-I gradually migrated to the new complex.

Zero Power Reactor III-Reactor development depended partly upon tests in "critical assemblies," which are low-power or zero-power reactors (ZPRs) that allow the chain reaction to occur without a significant accumulation of heat or hazard. Using zero-power reactors, experiments were conducted with various configurations of fuel to help test critical size, operating, and control features of a new or proposed reactor design. ${ }^{63}$ ZPR-III was built near EBR-I in 1955 to test core designs for EBR-II. It also tested designs for the EBR-I MARK-III core and for the Enrico Fermi Reactor. ${ }^{64}$

The critical assembly of ZPR-III consisted of two tables mounted on a platform, one table movable, the other fixed. Drawers or trays for fissionable materials allowed the reactor to be loaded manually with different fuel configurations. The reactor was brought to criticality by moving the two halves together. ${ }^{65}$

Argonne eventually built two additional critical assemblies at its Illinois site to ease the demand on ZPR-III, but ZPR-III remained in operation until 1970, when it was replaced by the ZPPR a larger, more versatile critical assembly at the Argonne-West site near EBR-II. In 1975, the ZPR-III critical assembly was decontaminated, dismantled, and moved to the EBR-I building for display. The ZPR-III containment building was decontaminated and dismantled.

Argonne Fast Source Reactor-The Argonne Fast Source Reactor (AFSR), a low-power, fast spectrum reactor, achieved criticality October 29, 1959. Associated with instrumentation tests for EBR-II, AFSR was originally located in a metal building southeast of ZPR-III. In 1965, AFSR was moved to the new Zero Power Plutonium Reactor Facility at Argonne-West, where it was used for instrumentation and operation tests until the late 1970 s. $^{66}$

Transient Reactor Test Facility-In 1958, construction began on the TREAT. A project of Argonne's Fast Reactor Safety Program, TREAT had a similar purpose as the BORAX tests, but for breeder-type reactors. TREAT was designed to test the behavior of various fuels and structural materials in breeder reactors under extreme or "transient" conditions.

62. Loftness, Nuclear Power Plants, p. 339; Kendall \& Wang, p. 7; “EBR-II since 1964,” unpublished ms., historical files, INEEL Cultural Resources Office.

63. ZPR-I, designed and built by Argonne in 1950, provided basic physics studies for the Navy's S1W submarine prototype reactor. ZPR-II was built to help test reactor designs for Du Pont's proposed reactor at Savannah River, South Carolina in 1951.

64. Holl, Argonne, p. 149.

65. J. K. Long et al, Hazard Evaluation Report on the Fast Reactor Zero Power Experiment (ZPR-III) (ANL Report, October 1969), p. 11-17.

66. Personal communication from Richard Lindsay, September 12, 1997; Thumbnail Sketch 1965; Harry Lawroski, "Zero Power Plutonium Reactor Facility," Nuclear News (February 1968), p. 47. See also Appendix A in Proving the Principle for estimated dates of operation of AFSR, p. 260. 
The Teller Construction Company of Portland, Oregon, built the TREAT reactor and control buildings. Located just less than a mile northwest of EBR-II, it is built of aluminum-sided steel with a high bay and service wing. The reactor and associated instrument and utility areas are on the main floor. The basement is an equipment storage area and also contains the subreactor room, where control rod drive mechanisms are located. The control building, located approximately a half mile northwest of EBR-II, is a one-story concrete block structure. In 1982, the building was enlarged to accommodate larger reactor components and fuel elements. ${ }^{67}$

TREAT performed safety tests on samples of nuclear fuel. The reactor was graphite-moderated and air-cooled, using uranium oxide fuel. The reactor was designed to allow simulations of severe accidents, including meltdown or fuel element vaporization, without damage to the reactor. Slots through the core allowed a camera to record events taking place in the test hole during the excursion. Beginning in 1960, tests of fuel element designs for EBR-II were run in TREAT. ${ }^{6}$

EBR-II-After EBR-I had validated the idea that a breeder reactor could produce nuclear fuel; Argonne developed a design proposal for a second breeder reactor, EBR-II. EBR-II would serve as a prototype for commercial breeder reactors, but it was also designed to test and develop fuel-reprocessing systems. EBR-II had a notable new feature: the reactor was submerged in a pool of sodium during operation.

Adjacent was a fuel reprocessing plant, at which spent reactor fuel would be removed from the reactor, sent through the reprocessing cycle, and returned to the reactor. Construction of the basic components of the EBR-II began in 1958, and the reactor was completed at Argonne-West in 1961. The architect/engineer for the project was the H. K. Ferguson Company of Cleveland, Ohio. ${ }^{69}$

The EBR-II complex includes four closely related facilities: reactor, power plant, sodium-boiler plant, and the Fuel Cycle Facility (FCF). The reactor building is a dome-shaped structure of one-inch-thick stainless steel, identified as "a gas tight containment shell" built to withstand an explosion the equivalent of 300 pounds of dynamite. The building houses the reactor facility, the primary sodium cooling system, and support systems. Because of the potential danger of explosion when sodium and water mix, there is no water system in the reactor plant.

Early in 1962, before the sodium coolant was added to the system, the reactor was brought to "dry criticality," and a number of tests were run at low power to provide comparison data for later experiments with the coolant present. Following the dry critical tests, the sodium coolant was added to the system in 1963. EBR-II achieved "wet" criticality in November 1963. The reactor operated at less-than-full power until 1969. Its spent fuel was reprocessed for the first time in 1964. EBR-II produced electricity for the first time in 1964. The reactor produced all of the power used at ANL-W and had power left over, so it supplied the NRTS as well. Argonne-West was able to "sell" power to Idaho Power, saving the AEC more than a million dollars each year.

The original design objectives for EBR-II - to demonstrate the feasibility of a central-station fast breeder reactor and on-site fuel reprocessing - were met by 1965. In a new phase of experimentation, the reactor was used as an irradiation facility to produce study samples for use in design of new reactors. Thousands of fuel elements, reactor components, and other reactor materials were irradiated and tested in EBR-II.

67. G. A. Freund et al, Design Summary Report on the Transient Reactor Test Facility (TREAT) (Argonne National Laboratory, June 1960, ANL-6034).

68. Stacy, Proving the Principle, p. 136.

69. Frontiers, p. 16; "EBR-II since 1964." 
Zero Power Plutonium Reactor-In 1965 Argonne requested funding for the ZPPR, a facility for testing fast reactor plutonium cores. The design of ZPPR allowed testing large core volumes (up to 5,000 liters), much larger than the facility at ZPR-III. The $\$ 3$ million dollar request was granted and in August 1966, construction of the facility began. The reactor and ancillary systems were designed by Argonne, the structure was designed and built by Mason-Hanger Silas-Mason Company. ${ }^{70}$

The ZPPR facility consists of an earth- and- gravel containment mound and a support building. The support building houses the control room, staff offices, and the Argonne Fast Source Reactor. The ZPPR, a split table critical assembly similar to ZPR-III, but much larger, is housed within the containment mound. The 2,000-square-foot roof of the cell is a sand-and-gravel filter, which varies from 16 to $21 \mathrm{ft}$ in depth. A bank of 28 HEPA (high-efficiency particulate air) filters backs up the sand-and-gravel roof to prevent the escape of airborne particles. Inside the mound, the reactor assembly was originally $10 \times 10 \times$ $8 \mathrm{ft}$, but was later expanded to $14 \times 14 \times 10 \mathrm{ft}$.

The work of the ZPPR was to carry out safety tests of reactor cores for fast breeder reactors. Some of the work that had been conducted in earlier, smaller critical assemblies was confirmed with additional testing in the ZPPR. ${ }^{71}$

Fuel Cycle Facility. EBR-II was the first nuclear reactor with on-site fuel reprocessing incorporated into its design. The exterior of the building is concrete block and steel. Inside are two hot cells where the fuel elements from EBR-II were disassembled, reprocessed, and reassembled for use in the reactor.

The fuel elements were highly radioactive, so all work was done by remote control. Operating personnel worked behind heavy shielding. The hot cell walls were of concrete five feet thick. Materials were handled with bridge cranes, mechanical manipulators, and master-slave manipulators. One hot cell was doughnut-shaped and contained argon gas instead of air. This shape allowed workers access to the cell from workstations around the perimeter of the cell or from the center. The argon atmosphere was necessary to avoid problems when sodium or other reactive elements were present in the fuel elements. The atmosphere of the second, rectangular cell was air. In the original facility, the argon cell was used to disassemble fuel elements, the air cell, to fabricate the recycled elements. ${ }^{72}$

Argonne-West and the Breeder Concept 1965-1970. Argonne National Laboratory's national role in reactor development shifted its emphasis in the 1960s, and the shift affected ANL-W. By 1960, fully half of the ANL budget and staff were devoted to reactor development. ANL expected to work on the fledgling breeder reactor program throughout the 1960s, or "a full ten years," as the AEC told the Joint Committee on Atomic Energy in 1960. The optimistic projections were that the breeder concept could create as much fuel as its original supply in five to ten years of operation. (It takes time for the new fuel to accumulate in the blankets surrounding the reactor core.) EBR-II and its FCF were operating in 1964, putting the projections to the test.

ANL had several proposals for development of reactor concepts other than the breeder and sought AEC funding to pursue them, but change was in the air. In 1965, with the appointment of Milton Shaw as the AEC's director of reactor development, the AEC decided to adopt the LMFBR as its top priority for

70. Holl, Argonne, p. 269, mentions that ZPPR was the forty-sixth reactor built at the NRTS and was one of twenty-two in operation in 1969.

71. Lawroski, “Zero Power Plutonium Reactor Facility,” Nuclear News (Feb 1968); “Zero Power — But Large Purpose,” Nuclear News (January 1970; "ZPPR - Zero Power Plutonium Reactor," Argonne National Lab brochure, no date; "Contributions of the Zero Power Plutonium Reactor (ZPPR) to the LMFBR Program," anon, no date.

72. D. C. Hesson, et al., ANL-6605; ANL-West brochure, "Hot Fuel Examination Facility," 1974). 
commercial reactor development. The LMFBR was to be a demonstration reactor, operated on a larger scale than reactors operated up to that time. ANL was obliged to focus exclusively on the LMFBR. "Scaling up" the technology of EBR-II for commercial operation brought new problems of design, engineering, and safety controls. In 1971 President Richard Nixon confirmed the AEC's direction and called for construction of a commercial demonstration Liquid Metal Breeder Reactor by $1980 .^{73}$

EBR-II and the ZPPR became the centers for LMFBR research. EBR-II, which by then had met its original objective of demonstrating the feasibility of a central-station breeder reactor and an on-site fuel reprocessing system auxiliary to it, became an irradiation facility, used to test fuels and materials. It produced study samples used in the design of new reactors. EBR-II irradiated thousands of fuel elements, reactor components, and other materials. The ZPPR, the largest critical assembly facility in the world, helped develop and test core mock-ups for commercial breeders. Information derived from the testing conducted in EBR-II and ZPPR provided the basis for design of the Fast Flux Test Facility, the next step on the ladder to a demonstrator for a commercial LMFBR. ${ }^{74}$

The LMFBR program led to a reorganization of the ANL reactor development staff, construction of new facilities, and funneling of funds into the LMFBR program. Argonne-West grew substantially, and by 1967 , the facility employed 275 people. $^{75}$

Fuel Cycle Facility Modified as Hot Fuel Examination Facility. Argonne renamed the FCF several times as its mission shifted over the years. By 1968 the original studies planned for the facility had been successfully completed. More than 400 fuel sub-assemblies, containing more than 35,000 individual fuel elements, had been prepared for EBR-II.

The FCF was modified, renamed the Hot Fuel Examination Facility (HFEF), and dedicated by Idaho Congressman Orval Hansen on July 5, 1972. The HFEF was a hot cell capable of examining large irradiated specimens, part of the research for the Liquid Metal Fast Breeder Reactor program. The HFEF contained two shielded cells, one with an air atmosphere, and one with an argon atmosphere for reprocessing fuel elements. The walls of the cells are $4 \mathrm{ft}$ thick, and the cells are 70 - $\mathrm{ft}$ long, $33 \mathrm{ft}$ high, and 30 - $\mathrm{ft}$ wide. Work in the HFEF was done entirely by remote control, using master-slave manipulators and other automated or semi-automated equipment. Maintenance of the equipment is also remote-controlled and the design has been successful for more than twenty years.

Specimens brought to the HFEF were examined using either non-destructive or destructive techniques. If a specimen was to be returned for further testing, non-destructive examination such as photography, weighing, measuring, and gamma-ray spectroscopy recorded information for comparison after further testing. When a specimen arrived for destructive, or final, examination, samples were cut and prepared for a smaller HFEF hot cell or sent to the Analytical Laboratory. ${ }^{76}$

Expansion of the facility in 1975 brought another name change. The FCF was modified and its name changed to Hot Fuel Examination Facility, North in 1975 when the Hot Fuel Examination Facility, South

73. Holl, Argonne, p. 230-235, 265-270, 272; "The Future Role of the Atomic Energy Commission Laboratories, a Report to the Joint Committee on Atomic Energy," (Washington: Atomic Energy Commission, January 1960), Vol. 1, Analysis and Conclusions, Section five, p. 80; Vol. 2, Supplementary Materials, p. 21.

74. Glenn T. Seaborg and Justin L. Bloom, "Fast Breeder Reactors," (Scientific American, Vol. 223, No. 5), p. 19-20.

75. Holl, Argonne, p. 273-277; "Employee Distribution by Work Location and Residence," February 1967, in vertical file, subject: Idaho National Engineering Laboratory, Idaho State Historical Society, Library and Archives, Boise.

76. "Fuel," Nuclear News (August 1972); ANL brochure "Hot Fuel Examination Facility," 1974; "Hot Fuel Examination Facility (HFEF)," ANL web site, June, 1997. 
was built. HFEF-N handled and examined irradiated specimens from EBR-II, TREAT, and other facilities. $^{77}$

Argonne-West Significance. The cluster of reactors and support facilities at ANL-W have played a historically significant role in the history of nuclear reactor research in the United States. Argonne National Laboratory was the country's first national laboratory; its Idaho Division was an integral part of its operation. Argonne was a leader and innovator in the AEC's breeder reactor development program.

The silver containment dome of EBR-II dominates the ANL-W complex. The reactor produced electrical power for ANL-W for thirty years, demonstrating the feasibility of a liquid metal reactor as a central power plant. Power production was so successful that EBR-II became the first co-generator in the State of Idaho. Also, it was the first reactor in the country to employ on-site fuel reprocessing, a function that operated successfully for six years of operation at the FCF.

Argonne's BORAX reactors provided the basic information leading to the design and construction of the EBWR, the country's first nuclear power production pilot plant. BORAX-I proved that under extreme conditions the boiling water would shut the reactor down before heat could melt the fuel plates. BORAXIII was the first nuclear reactor to provide electricity to an American town (Arco, Idaho). The BORAX experiments laid the groundwork for SPERT, the next series of boiling water reactor safety tests. Private industry moved ahead with construction of the Vallecitos Boiling Water Reactor (California, 1957); the Bodega Bay Reactor (California, 1964), and the Pathfinder Reactor (North Dakota, 1964), all building on the experience and data gathered in the BORAX experiments. In short, the BORAX tests were a necessary precursor to the establishment of a commercial nuclear power industry that could operate within known safety parameters. All of the buildings associated with BORAX experiments have been demolished.

EBR-I has a unique historical importance. It was the first reactor built at the newly established NRTS. By the time it was decommissioned in 1964, the small reactor had been the first nuclear reactor in the world to produce usable electrical power, the first to employ a liquid metal as a coolant, the first to produce more fuel than it consumed, the first power-producing reactor to use plutonium fuel, and the first to experience a meltdown of the core. EBR-I provided basic information about nuclear reactors and power production.

As noted earlier, the National Park Service designated EBR-I as a National Historic Landmark in August 1966 in ceremonies that included President Lyndon B. Johnson and AEC Chairman Glenn T. Seaborg. EBR-I was placed on the National Register of Historic Places in 1975, recognized as a National Historic Engineering Landmark by the American Society of Mechanical Engineers in 1979, and named a Historic Landmark by the American Nuclear Society in 1994. The only original buildings remaining at the EBR-I site are the reactor building and the guardhouse.

\section{Sub-Theme: Reactor Testing, Experimentation, and Development}

\section{Test Reactor Area}

Establishment of the Test Reactor Area: 1944-1954. After World War II, nuclear scientists hoped to apply nuclear knowledge for peaceful purposes. They understood how to apply a chain reaction to an

77. When the Integral Fast Reactor (IFR) program took shape in the 1980s, HFEF-N was modified and renamed Fuel Cycle Facility. In 1994, the facility's name became Fuel Conditioning Facility, its mission to treat spent EBR-II fuel prior to planned disposal at a geologic waste repository. 
explosive weapon, but very little about the best way to design reactors and reactor fuel for electrical power generation, propulsion, or other useful purposes. The list of unknowns was exceedingly long.

Even though physicists could design reactors that would generate enough heat to produce steam and generate electricity, engineers had yet to perfect the pipes, valves, fittings, and instruments that would keep the coolant moving, exchange its heat, and maintain the fuel at a constant and safe temperature. The limiting factor in the size or power level of a nuclear reactor is the ability of the coolant to carry away heat. ${ }^{78}$

At that time, chemists and engineers did not know much about how various materials would react in a nuclear environment. They didn't know the best materials to use for power reactors. They didn't know if their computations predicting how something would work were accurate. They didn't know how long metal, rubber, glass, and other fabrication materials would last under the constant bombardment of radiation. They didn't know how long a fuel element itself would last under the impact of radiation. Would a material react differently depending on whether the neutron was fast or slow? How? Would the fuel element change shape or lose strength? How? Bow inward? Bow outward? Crumble? Crack?

They didn't know how certain materials would perform as absorbers or reflectors of neutrons. They didn't know how serious a problem it might be if some materials had impurities in their manufacture or were of uneven quality. They didn't know the best shape for the fuel — rods? plates? curved? straight? They didn't know the best material to clad the fuel and hold it in position in the reactor core. For coolant piping, they didn't know what alloys of aluminum and steel would resist the corrosion caused by fission particles and extremely high temperatures. Of all the elements in the periodic table, they knew "cross sections" for only a few of them. (A cross section is the probability that neutrons at a given speed and temperature would strike the element's atoms.) Indeed, they didn't even know what materials would absorb neutrons or scatter them. Yet this knowledge was essential to designing reactors. ${ }^{79}$

In addition to everything else they didn't know, they had few safety procedures, standard practices, or efficient operating routines. Until they answered all these questions and hundreds more like them, nuclear scientists could not fulfill their hopes for the safe and peaceful use of atomic energy.

A Materials Testing Reactor. The scientists needed a reactor that could function as a kind of "mother reactor" to facilitate the design of other reactors. They needed to research how different temperature, pressure, and coolant conditions would affect various kinds of fuel assemblies. The reactor would be designed explicitly to test materials by exposing them to a high flow (flux) of neutrons and gamma radiation. In addition to solving these "urgent and practical" problems, they needed a reactor that could produce radioactive isotopes in sufficient quantity for medical treatment and experiments. ${ }^{80}$

Scientists needed to accumulate information quickly, considering the AEC's interest in developing the use of nuclear energy for power generation. A testing reactor could subject a material to the equivalent of months or years of radiation exposure in a much shorter period of time, simulating the expected period of time the material might be exposed to radiation in a power reactor.

78. Samuel Glasstone, Sourcebook on Atomic Energy, 3rd edition (Princeton, N.J.: D. Van Norstrand Company, Inc., 1967), p. 562566.

79. 1965 Thumbnail Sketch, p. 16.

80. Phillips Petroleum, The Materials Testing Reactor (New York: United Nations, a reprint from Chapter 3, Research Reactors, presented to delegates at the International Conference on Peaceful Uses of the Atom, August 1955), p. 160-163. Hereafter referred to as The MTR. 
The Progress of the MTR - As early as 1944, scientists at the Clinton Laboratory at Oak Ridge began designing what they called a "high flux" or "reactor development reactor," the Materials Testing Reactor, or simply the MTR. Just to design it required experimentation, and the Clinton Lab built small low-power assemblies to conduct such experiments.

In 1946 the Clinton Lab proposed that the AEC build a test reactor and a companion chemical processing plant to recover uranium from the reactor's spent fuel. The AEC agreed and assigned the Kellex Corporation to design it. By 1947, the project "was well advanced." ${ }^{11}$ Naturally, the scientists at Oak Ridge expected that this reactor would be built there. But the AEC decided in 1948 to centralize its reactor development program at Argonne National Laboratory near Chicago and build it there. Overcoming intense disappointment ("[Argonne] stole all our reactors," was the bitter sentiment), ${ }^{82}$ they cooperated with a five-member steering committee whose task it was to manage the final design and construction of the MTR. ${ }^{83}$

In the end, Argonne did not house the MTR either. The AEC's Reactor Safeguards Committee decided that the proposed power level of 30 megawatts was too high to risk operating near the four million people living in the Chicago area. Argonne's director, Walter Zinn, felt that the proposed chemical plant ought not to be near such dense population either. The MTR and the Idaho Chemical Processing Plant (ICPP; now INTEC) became two of the first four projects built at the new NRTS in Idaho. ${ }^{84}$

Because the Idaho site was not yet organized, the steering committee completed the design of the reactor and its associated support facilities, created a site plan, approved construction drawings, and began procuring materials and supplies. Blaw-Knox was chosen the architect/engineer in July 1949, and preliminary plans were ready a few months later. ${ }^{85}$

While Blaw-Knox was at work, Kellex constructed a full-scale mock-up of the reactor at Oak Ridge. Its main purpose was to perfect the hydraulic performance of coolant and air circulation systems without the reactor producing neutrons. After initial simulations, the mockup operated on real fuel and ran as a low-power reactor, going critical for the first time on February 4, $1950{ }^{86}$

That same month, the AEC chose the Fluor Corporation to construct the MTR complex in Idaho. Fluor broke ground in May, and in July the AEC's Idaho Operations Office took the project over from the steering committee. ${ }^{87}$ Construction proceeded somewhat unevenly, sometimes getting ahead of blueprints. Progress was interrupted further by an unusually cold winter in $1950-51 .^{88}$

Siting the MTR-The AEC Safeguards Committee required that two concentric zones surround any reactor site. The near zone would be a controlled-access area where an accident could pose severe danger. The radius of this area was determined by a formula based on the reactor's power level. The second zone

81. John R. Buck and Carl F. Leyse, eds., The Materials Testing Reactor Project Handbook (Lemont, Illinois, and Oak Ridge, Tennessee: Argonne National Laboratory and Oak Ridge National Laboratory, 1951), p. 37. Hereafter referred to as MTR Handbook.

82. Atomic Shield, p. 126. The other Clinton Laboratory reactor to be relocated was a Navy submarine reactor.

83. Its members were S. McLain, chairman; M. M. Mann, ORNL; J. R. Huffman, ANL; W. H. Zinn, ANL; A. M. Weinberg, ORNL. MTR Handbook, p. 28.

84. See Atomic Shield, p. 185.

85. MTR Handbook, p. 38.

86. The MTR, p. 210. The MTR was a tank reactor with a steel lid over the top. It was water-cooled, beryllium reflected, and used aluminum-clad fuel plates.

87. MTR Handbook, p. 43.

88. Atomic Shield, p. 496. 
would be a "hazard area" to be determined by a combination of reactor type, meteorology, hydrology, and seismology. Danger within this zone would be much smaller; nevertheless, it should contain only a limited population.

In addition, an informal practice appears to have evolved during the Manhattan Project of siting reactors no closer than five miles from one another when this was feasible. John Horan, who arrived at the NRTS in 1952 and later served as director of Health Physics, said in an interview that this practice may explain why the MTR was located about five miles from the CFA and why the Navy's propulsion reactor was subsequently located five miles beyond the MTR. ${ }^{89}$

The civil engineers surveying for a specific location for the MTR wanted to build on solid lava rock. They noticed that as the distance increased from the gravel creekbed of the Big Lost River, the depth to bedrock decreased. Therefore, knowing the depth of the MTR basement, they simply placed the building at a point where the gravel overburden matched the basement depth. They cleared the gravel and anchored the building to the lava. Horan said these engineers "bragged for years" about how this strategy saved the considerable costs of building footings or blasting through lava rock. They employed the same procedure in siting the ICPP and the Navy's first reactor. At the time, less was understood than today about the boundaries of the river's floodplain, so the legacy of the siting strategy is a location that requires vigilance with respect to potential floods. ${ }^{90}$

The MTR steering committee liked the terrain around the selected site. Because one of the proposed experiments would project a neutron beam a quarter of a mile from the MTR, the committee wanted a site that was flat for at least that distance around the reactor. The site also provided access to water and had natural drainage for retention basins. Finally, a convenient site for the ICPP - at the right elevation above bedrock - was available about one and a half miles away and would not be downwind of prevailing winds from the MTR.

The principle of isolation applied to all future NRTS reactor experiments (if not always at five-mile increments), so the NRTS characteristic land-use pattern of widely distributed clusters of buildings established itself from the beginning. The MTR, the ICPP, the Navy propulsion project, and EBR-I each settled in its own "desert island," connected to the CFA by roads and utility lines.

Designing the MTR Complex-Taking Account of its Natural Setting. Within the rectangular MTR complex, buildings and their future expansions were oriented with respect to predominant winds, which came from the southwest during the daytime. This dictated the location for the exhaust stack on the east side of the compound. And the stack had to be high. Contaminated air had to be discharged high enough to disperse and dilute over a large uninhabited area. For security reasons, it had no aircraft warning lights. $^{91}$

One of the major features of the MTR was its "canal," an underwater facility for storing spent fuel until it could be sent to the ICPP and processed to recover its uranium. The below-grade canal projected $871 / 2 \frac{1}{2} \mathrm{ft}$ from the east side of the main reactor building. The canal was built $25 \mathrm{ft}$ longer than called for in the original plan because during 1951 the managers were not sure that the ICPP would be operational in time to take delivery of the first several months' accumulation of MTR spent fuel. The extra length would accommodate extra fuel. ${ }^{92}$ The ceiling of the canal tunnel, made of reinforced concrete, was

89. John Horan, in telephone interview with Susan Stacy, July 29, 1997.

90. John Horan, July 29, 1997.

91. MTR Reactor, p. 352.

92. MTR Handbook, p. 287. 
slightly below ground level. The road that passed over the canal was reinforced to support the heavy trucks and crane used to lift the transport casks. The unloading hatch was at an offset, widened portion of the road located where traffic had the least impact on loading operations.

The MTR auxiliary buildings were oriented to each other for the shortest feasible extensions of piping, air ducts, wiring, fencing, roads, and walkways. ${ }^{93}$ The entire complex was surrounded by a barbed-wire perimeter fence with the parking lot outside. Just inside the fence was a 10-foot wide patrol road. The reactor building and other buildings containing radiation hazards were further fenced within an "exclusion" area.

Thus, by intentional design, the buildings in the most intimate association with reactor operations in the exclusion area were the reactor building, its laboratory wing, the storage canal, the hot cell building, plug storage building, process water building, fan house, and stack. A 150,000-gallon water reservoir also was in the area.

On the upwind side were the pumps and wells, storage tanks, substation, demineralizing building, emergency diesel generator, steam plant, cooling tower, warehouses, administration and service building, and canteen. Downwind and outside the perimeter fence were the sewage plant and evaporation ponds.

The MTR Goes Critical-The Korean War began in June 1950. The AEC's peaceful intentions for the MTR had to yield to the demands of national defense. The MTR could help speed the development of plutonium-producing reactors for weapons and propulsion reactors for Navy submarines. ${ }^{94}$ In fact, during 1950, the study groups working at Argonne considered how the MTR could be modified to produce plutonium should this be necessary. The ICPP, originally intended to reprocess only MTR fuel, also was recruited for defense. Design changes enabled it to process U-235 fuel slugs used at Hanford's tritiumproduction reactors, Naval reactor fuel, and later the fuel for the Air Force's turbojet experiments. ${ }^{95}$

At the end of 1950, after considering 34 candidates, the AEC contracted with Phillips Petroleum Company to operate the MTR, partly because it wanted physicist Richard L. Doan, director of research at Phillips (and who had previously been loaned to the Manhattan Project) to be the manager. Doan brought with him 42 other Phillips specialists. ${ }^{96}$ The group spent several months at Oak Ridge training in nuclear physics, health and safety, and reactor operation and management. There they practiced operating Oak Ridge's High Flux Training Facility, the new name for the MTR mock-up.

The MTR went critical for the first time on March 31, 1952, with Fred McMillan, the reactor manager, at the controls. Operators carefully increased its power, making adjustments as needed, until it reached its full power operation of 30,000 kilowatts. On August 5, 1952, the MTR opened for business as the first test reactor in the world designed to test components for future reactors. ${ }^{97}$

MTR Work-The MTR was an instant hit. Like Sun Valley, another Idaho landmark, the MTR became so essential and so famous that nuclear literature at the time often dropped references to its country and state. MTR test loops were busy irradiating proposed fuels for the Navy's Nautilus and other reactor

93. MTR Handbook, p. 356.

94. Atomic Shield, p. 419.

95. Atomic Shield, p. 496, 499.

96. Atomic Shield, p. 496. See also Phillips Petroleum, Phillips, The First 66 Years (Bartlesville, Oklahoma: PPCo, 1983 ), p. 140. Other Phillips employees who moved to Idaho with Doan were Alene Carter, fuel tester; Hugh Burton, physicist; Harry Markee, safety specialist; Ed Fast, physicist. See also Rich Bolton, "Fast Enters Retirement at same well-known pace," INEL News (Sept 7, 1993), p. 5.

97. Atomic Shield, p. 515. See also "INEL Pioneers set high standards," INEL News (March 19, 1991), p. 4. 
prototypes, for the proposed nuclear-powered bomber, and for reactors at the AEC's Savannah River weapons plant. It developed non-destructive techniques for the ICPP to assay the uranium in fuel assemblies that were to be dissolved. It irradiated thousands of materials. ${ }^{98}$

One example will illustrate how the MTR was instrumental in the design of nearly every reactor later built in the country. Sylvania Electric Products Company wished to manufacture fuel slugs for the AEC. Using two different techniques, Sylvania fabricated eighteen fuel slugs made of natural uranium. MTR operators subjected them to prolonged high flux exposure - and observed both types gradually change their shape and size, increasing in diameter and decreasing in length. ${ }^{99}$ Findings such as these were of critical importance in safe reactor operations. If fuel slugs were spaced too close together in a reactor and expanded, they could choke off the flow of coolant, cause a hot spot, melt the fuel, damage the reactor, and cause a serious accident.

By the time the MTR shut down for the last time in 1970, it had performed more than 15,000 different irradiation experiments, and its operators had disseminated the findings to a large community of nuclear scientists.

The Test Reactor Mission Grows. As the steering committee had anticipated, the MTR site expanded. A Hot Cell Building (TRA-632) went into use in the summer of 1954. Here, operators, while shielded safely behind thick concrete walls and special viewing windows, could handle, photograph, mill, measure, and weigh radioactive samples using remotely operated manipulators.

The AEC authorized a Reactivity Measurement Facility (RMF) in February 1954. This was a small (very low power) reactor located in the east end of the MTR canal, where water was its moderator, reflector, and shield. It complemented the MTR in that it had a high sensitivity to subtle changes in reactivity, unlike the MTR. The author of the proposal suggested that the small facility would function as a "detector," whereas the large MTR functioned as a "source" of neutrons. The two functions could not be maximized in the same reactor. The RMF enabled studies of reactivity changes in hafnium, zirconium, and other fuel materials as a function of their total irradiation - without having to transport the experiment to some other more distant facility on the NRTS site. ${ }^{100}$

Demand for space in the MTR grew to such an extent that merely expanding its adjunct facilities was not enough to satisfy it. By the end of 1954, the scientists were making preliminary calculations for a new, larger, more convenient, and higher power test reactor.

In 1954 the United States was entering a new phase of its atomic energy program. Congress passed a new Atomic Energy Act, superseding the old act of 1946. Due largely to the successful research program carried out at the MTR and other AEC facilities, the time had arrived for private enterprise to become more involved in the development of a nuclear power industry. Up to this point, private ownership of atomic facilities had been forbidden. The new law provided for private licensing of reactors and nuclear fuel. Further, it allowed industry scientists access to information that heretofore had been classified. ${ }^{101}$

98. J. R. Huffman, MTR Technical Quarterly Report, First Quarter 1954 (Idaho Falls: PPCo Report IDO-16181), p. 5-13.

99. J. R. Huffman, MTR Technical Quarterly Report, Second Quarter, 1954 (Idaho Falls: PPCo Report No. IDO-16191), p. 17; and Huffman's Third Quarter 1954 Report, PPCo No. IDO-209, p. 12.

100. W. E. Nyer, et al. Proposal for a Reactivity Measurement Facility at the MTR (Idaho Falls: Phillips Petroleum Report No. ID)16108), p. 6-8. Reactivity is a measure of the departure of a nuclear reactor from criticality. The measure is either positive or negative and indicates whether neutron density will rise or fall over time. An RMF is also called a "critical facility."

101. Public Law 83-703 was enacted by the 83rd Congress, 2nd session, and signed into law by President Eisenhower August 30, 1954. 
TRA Programs Expand: 1955-1970. The pace of activity at the NRTS in general picked up markedly in 1955. National defense made continued demands on the MTR. The Korean War had ended, but the Cold War competition for weapons supremacy between the United States and the Soviet Union was an escalating pressure at TRA (now RTC).

New activity centers had sprouted up at the NRTS. One was Test Area North, site of General Electric's turbojet experiments for the U.S. Air Force, where the first Heat Transfer Reactor Experiment went critical on November 4, 1955. Another was the SPERT program, a series of experiments begun in 1955 that examined the safety and stability of water moderated reactor systems when their power levels increased unexpectedly.

The MTR played a role in most of the new experiments. For SPERT I, for example, the Argonne experimenters predicted what would happen when power levels rose as high as 2400 megawatts. When the results of the actual test were other than expected, the MTR helped determine why the calculated prediction was in poor agreement with that obtained in the experiment. ${ }^{102}$

To accommodate a growing demand for gamma irradiation experiments by commercial interests, the AEC's Idaho Operations Office designed a gamma irradiation facility (TRA-641). Because of the classified military work conducted at MTR, commercial scientists without security clearance could not be admitted to the MTR exclusion area. However, to provide them access to gamma radiation for tests, the Gamma Irradiation Facility was located outside the security fence.

The Gamma Facility opened in 1955. The facility took advantage of the MTR spent fuel, a valuable research asset. After removal from the MTR core, it radiated gamma rays, a penetrating form of energy (and hazardous to human health.) Very active when first removed from the reactor, the gamma source would gradually decay. An experimenter could specify the degree of "freshness" required for a given test. $^{103}$

Fuel was transported to the facility from the MTR in 26,000-pound fuel-element carriers made of lead, steel, concrete, and water. Once the fuel was in the facility's 6-ft-wide storage canal and shielded by $16 \mathrm{ft}$ of water, operators maneuvered the elements into cadmium boxes and positioned them at safe distances from the adjacent elements (to prevent an accidental chain reaction). Packages containing the materials to be tested were wrapped in water-tight containers and dipped into the canal at a selected distance from the fuel element. Depending on the length of time the material was to be exposed, packaging could be a plastic bag, a can, or a special container with a corrosion-resistant coating.

Experimenters paid non-profit rates (40 cents per million roentgens plus shipping; $\$ 10$ minimum charge) to be scheduled on a first-come, first-served basis. They subjected nearly everything imaginable to gamma radiation - potatoes, meat, plastics, heat-sensitive pharmaceuticals, diamonds - anything for which there was a hope that irradiation would improve it, make it last longer, or increase its value. At any given time, the canal contained forty to fifty fuel elements. ${ }^{104}$

102 IDO-16259, p. 13.

103. J. R. Huffman, MTR Technical Branch Quarterly Report for First Quarter, 1955 (Idaho Falls: PPCo Report No. IDO-16229), p. 24.

104. Gamma Irradiation Facility, A Fact Sheet, no author, p. 3-5. Pamphlet found attached to the 1957 version of Thumbnail Sketch. 
In September 1955, the MTR reached a milestone when Phillips increased the power level in the reactor to 40 megawatts. Higher levels permitted more rapid irradiation of materials and thus increased the speed at which an experiment could deliver results. ${ }^{105}$

Phillips' quarterly technical reports detail a constant barrage of research problems and questions. From the ICPP: Will it be safe to put 250 kilograms of two-percent enriched slugs into C Cell's 30-inch dissolver? From a reactor development program: Will these fuel pellets made of aluminum-uranium alloy melt under irradiation? From the medical community: Can thulium-170 be used as a source for radiography? Do impurities in the thulium produce undesirable effects? From the Bureau of Mines: Will neutron and gamma radiation improve the coking characteristics of Sewickley coal? From SPERT: What's the best way to design SPERT III so it will operate at temperatures of $650^{\circ} \mathrm{C}$ ? From fuel manufacturers: Congress is allowing the U.S. to sell $20 \%$ enriched fuel to foreign interests. How will it perform in a high flux reactor? ${ }^{106}$ And, because the MTR itself was an experiment, Phillips conducted tests on how the MTR reactor components were holding up. Had the fast flux of neutrons caused any structural weakness in the materials within the core area? Using its findings on this and other accumulated experience, Phillips designed the next test reactor. ${ }^{107}$

The Engineering Test Reactor. By 1957, higher neutron fluxes than what the MTR could provide were in demand all over the country. Higher fluxes meant that an experiment could be carried out in a shorter period of time. Lower fluxes, such as those provided in the MTR low flux graphite zone, were no longer in demand except as a "mine" for isotope production.

In addition, test requirements were growing more sophisticated. Using MTR beam holes involved complicated and time-consuming handling problems. Also, in situations where it was important to have a uniform rate of flux, it was hard to supply this to the sample. Many experiments needed more room in order to be in the proper test environment and not impact the MTR operation. Phillips designed the Engineering Test Reactor to solve these problems. It provided large spaces in the highest flux zone in the core. Further, the flux was uniform along the entire 36-inch length of the fuel elements. ${ }^{108}$

After the AEC approved Phillips' conceptual design, it hired Kaiser Engineers to design and build the ETR. Kaiser had General Electric design the reactor core and its controls. From design to completion, the project took two years. The reactor was a standard tank design except that its control rods were driven through the core from below the reactor, not from above. This left the area above the reactor available for experimentation. ${ }^{109}$

Siting the ETR - Phillips situated the airtight ETR building about $420 \mathrm{ft}$ south of the MTR (center to center) so that it could share the MTR auxiliary facilities while positioning its cooling towers to the east. Here it would be convenient to the MTR operational centers (such as the Hot Cell, Hot Plug Storage, and Reactor Services Building) and yet be free of the facilities and services associated solely with MTR operations. Many of the shared facilities - raw water, electrical and steam distribution, fuel oil, sewer,

105. IDO-16254, p. 6.

106. See series of Phillips Technical Branch quarterly reports for 1955 through 1957.

107. IDO-16297, p. 5.

108. "Test Reactors - The Larger View," Nucleonics (March 1957), p. 55.

109. Philip D. Bush, "ETR: More Space for Radiation Tests," Nucleonics (March 1957), p. 41-42. The extra depth required for the control rods meant that a portion of the foundation had to be blasted through lava rock. See also R. M. Jones, An Engineering Test Reactor for the MTR Site (A Preliminary Study) (Idaho Falls: Phillips Petroleum Report No. IDO-16197, 1954), p. 7. 
standby power, waste disposal - then were extended or enlarged. This arrangement still left space available for even further expansion of both ETR and MTR facilities. ${ }^{110}$

The single most critical design driver for the reactor building was the size of the reactor vessel. When that was determined in October 1955, the rest of the planning continued. (The vessel is $35 \mathrm{ft}$ long, with a diameter ranging between twelve and eight feet. It had to withstand a pressure of 250 pounds per square inch at a temperature of $200^{\circ} \mathrm{F}$.) Building height had to account for the bridge crane that would manipulate and place the vessel. ${ }^{111}$

Other design features of the complex were based on experience with the MTR. The MTR had provided insufficient office space for both visitors and resident technical personnel. Desks cluttered the reactor floor, balconies, and any free space near the experimental equipment. To address this, three-level "lean-to" extensions were added to the ETR building on the east and west sides to prevent similar frustrations. Partitioning of the reactor floor was avoided, leaving the entire area free for experimental equipment. $^{112}$

Because the reactor would operate at a power level of 175 megawatts, it generated considerably more heat than the MTR. The primary coolant loop contained demineralized water. To keep it from boiling, it had to be kept pressurized. Pressure was maintained by pumping the water through the core and withdrawing it at a rate that would maintain the desired pressure. A secondary loop discharged the heat to the atmosphere. Exhaust gases were filtered and vented to a new stack. Because the coolant accumulated radionuclides, the pipes between the reactor building and the heat exchanger building were shrouded with concrete shielding.

ETR Work-The typical life of a fuel element was eighteen days, in which time about $27 \%$ of the uranium fissioned. Like the MTR, the ETR required a water-filled canal where spent fuel elements could cool down before transport elsewhere. ${ }^{113}$ ETR operators, like their colleagues at MTR, where the cycle also was 18 days, lived a cyclical lifestyle, taking three days to unload and refuel the reactor. Using remote manipulators, an operator could lift a fuel assembly part way up the side of the tank, tilt it, and slide it through an opening and down a chute. The element "flopped" into the 18-foot deep canal, where technicians used grappling poles to guide the element to a resting place on a rack. Here, the fuel sat for several months to cool off, its radioactive constituents continuing to decay. With the help of a 30-ton crane, it would be maneuvered into a special shielded transport cask, called a "coffin," and shipped down the road to the Gamma Facility or the ICPP to recover the valuable U-235 still remaining in the fuel element. ${ }^{114}$

The ETR went critical for the first time at its full power level of 175 megawatts on April 19, 1957; the ETR Critical Facility (ETRC), on May 20, $1957 .{ }^{115}$ This low-power reactor did the same for ETR as did the MTR Critical Facility. In order to run the reactor safely and efficiently, operators had to know how the experiments would affect power distribution, whether the reactivity effects of experiments would impact

110. R. M. Jones, An Engineering Test Reactor for the MTR Site (A Preliminary Study (Idaho Falls: Phillips Petroleum Report No. IDO-16197, 1954), p. 7.

111. R. H. Dempsey, “ETR: Core and Facilities,” Nucleonics (March 1957), p. 54; and Kaiser Engineers, Engineering Test Reactor Project, Part I

112. R. M. Jones, An Engineering Test Reactor for the MTR Site (A Preliminary Study) (Idaho Falls: Phillips Petroleum Report No. IDO-16197, 1954).

113. Bush, p. 41-56. See also 1965 Thumbnail Sketch, p. 15.

114. R. H. Dempsey, "ETR: Core and Facilities,” Nucleonics (March 1957), p. 54.

115. R. L. Doan, “MTR-ETR Operating Experience,” Nuclear Science and Engineering (January 1962), p. 23. 
the reactor or generate potential hazards. This information had to be available before each new cycle was begun. It used fuel and control rods like the ETR and had the same type of beryllium-beryllium oxide reflector. $^{116}$

The ETR mission was to evaluate proposed reactor fuels, coolants, and moderators. It was designed especially to simulate environments like those expected in civilian nuclear power reactors. ETR had more test space and more flexibility than the MTR. Over $20 \%$ of the head volume over the vessel was filled with test voids - like a "large cake of Swiss cheese," as one writer put it. ${ }^{117}$

During its lifetime, the ETR had less on-stream time than the MTR because its experiments were more elaborate and required more time to plan, pre-test, and install. They were more expensive, too. Various test "sponsors" invested over $\$ 17$ million to adapt 18 of the test loops for their experiments. ${ }^{118}$ Fabricating the tests required the services of welders, pipe fitters, heavy equipment operators, carpenters, mechanics, and many other specialists. These craft specialties explain the numerous shop buildings erected at TRA and at CFA to support these activities.

Demand for test space kept growing, calling for more than the MTR and ETR could supply. Use of space was prioritized and allocated by the Washington Irradiation Board. Military and AEC priorities came first. After that, the rule was "first come, first served." If private test space were available elsewhere, the Board rejected commercial requests for irradiations in the ETR.$^{119}$ Nevertheless, ETR customers included research and educational institutions, and the civilian power industry.

Advance Test Reactor. Even before the ETR went critical for the first time, the AEC had been requesting studies for an "advanced" general purpose test reactor, one that would supply the AEC's needs long into the future. ${ }^{120}$ In addition, high demand from the Naval Reactors Program continued to press the capacity of the MTR and ETR test reactors. A new reactor, while planned for multiple purposes, would specifically meet the long term needs of the Naval Reactors program, with many of its test loops reserved for Navy work. ${ }^{121}$

Phillips prepared the conceptual design, combining its MTR and ETR operating experience with ideas from physicists at laboratories all over the country. One of the "advanced" features of the ATR was its ability to test several samples in the reactor at the same time, but exposing each one to different absolute flux levels. And flux levels were intense. The MTR designers had been reluctant to place test materials within the reactor core; but the ETR had a fuel grid that permitted just that. The ATR went further. With its "serpentine" or clover-leaf arrangement of fuel, a test material could receive a level of exposure in a few weeks, instead of years of equivalent exposure in the ETR. To accommodate varying power levels in its seven test loops, the ATR required an extremely sophisticated control system. A built-in computeran innovation at TRA — reported continuously on reactor conditions. ${ }^{122}$

The AEC announced in October 1960 that Ebasco Services would be the architect/engineer, with Babcock \& Wilcox preparing the nuclear core of the reactor. The reactor would operate at 250 megawatts,

116. 1965 Thumbnail Sketch, p. 15.

117. Bush, p. 43.

118. Doan, p. 24.

119. Doan, p. 32. See also 1965 Thumbnail Sketch, p. 13.

120. See J. R. Huffman, W. P. Connor, G. H. Hanson, “Advanced Testing Reactors,” (Idaho Falls: Phillips Petroleum Company Report No. IDO-16353, May 28, 1956.)

121. D. R. deBoisblank, “The Advanced Test Reactor-ATR Final Conceptual Design,” (Idaho Falls: Phillips Petroleum Company Report No. IDO-16667, 1961), p. 11-12.

122. Advanced Test Reactor, pamphlet, undated (Idaho Falls: Idaho Nuclear Corporation), p. 3. 
nearly 1.5 times the power level of the ETR — and the highest operating power level of any test reactor in the world. In addition to the special Navy program loops, it would have a gas test loop, a pressurized water test loop, and sodium-cooled test loops for fast and thermal reactors. Although it considered other sites for the project, the AEC chose the NRTS for practical reasons: the Navy program already was established there; having the three test reactors operated as a single complex would be efficient and economical; Phillips was a highly competent operator; and the NRTS was the least limiting AEC site with respect to safety. ${ }^{123}$

Siting and Building the ATR-With Idaho Governor Robert Smylie attending the ground-breaking ceremony on November 6, 1961, the ATR became the largest single construction project ever undertaken in the State of Idaho, eclipsing the earlier record-holder, Mountain Home Air Force Base. ${ }^{124}$ The Fluor Corporation built the project, situating the ATR building about 200 yards northwest of the MTR. A cooling tower, critical facility, metallurgical research facility, labs, and other structures supported the new reactor. ${ }^{125}$

The ATR complex opened up a new TRA quadrangle northwest of the MTR-ETR area. The site plan repeated earlier patterns of compact placement of support buildings around the reactor, although the large reactor building, with a first- floor area of 27,000 square feet, enclosed several functions: the reactor and working area, the Advanced Test Reactor Critical Facility (to determine in advance the nuclear experiments to be programmed), decontamination room, office area, experimental labs, health physics labs, tool rooms, and heating/ventilating equipment. A common canal served for the critical facility reactor, for fuel element storage, for conducting irradiations, and for transferring fuel from one work area to another without using transport casks. ${ }^{126}$

Other buildings in the complex included a shielded process-water building immediately north of the reactor building with an enclosed driveway connecting it to the reactor building. This building contained the piping and controls for a heat exchanger, transferring heat from the primary to secondary coolant. A utility building containing diesel generators and demineralized water equipment was located east of the process-water building. Laboratories and engineering space were housed in a one-story building east of the reactor.

After years of delay caused by the failure of heat exchangers, valves, emergency pumps, and instrumentation cables, Fluor completed the reactor in 1967. It began operating at zero power on July 2 , 1967. On August 16, 1969, it operated at full power for the first time. Nuclear experiments began on Christmas Day. By this time, Phillips no longer was the TRA contractor; Idaho Nuclear Corporation had assumed control in $1966 .{ }^{127}$ The ATR has continued routine operation since then.

ATR Work-The ATR routine was similar to that of the MTR and ETR. At the end of seventeen days operating at full power, about $15 \%$ of the U-235 in the core was consumed. The reactor shut down for refueling, to change experiments, and make other modifications. To conserve time during the shut-down

123. Letter to Clinton P. Anderson, chairman JCAE from office of the General Manager, AEC. No date, 1960. Idaho Historical Society, U.S. Senator Henry Dworshak Papers, MS 84, Box 112, File "AEC-Miscellaneous."

124. "Idaho Rites Start Record Atom Job," newsclip with no date, Post-Register, p. 1, 12. Found in Idaho Historical Society, Senator Henry Dworshak Papers, MS 84, Box 124, File "AEC_-Idaho Plant (1961)."

125. AEC announcement, October 25, 1960; Idaho Historical Society, Senator Henry Dworshak Papers, MS 84, Box 112, File "AEC Miscellaneous." See also 1965 Thumbnail Sketch, p. 15-17.

126. The ATR Critical Facility went critical for the first time on May 19, 1964.

127. “Advanced Test Reactor Now Running at Full Power,” Nuclear News (October 1969), p. 17. 
interval, the crews of engineers, welders, electricians, and health physicists operated around the clock in three shifts. $^{128}$

Compared to the long line of customers clamoring for the MTR and ETR in their early years, the clients of the ATR shrank to a small group. The major user was the Navy, which had grown its Nautilus submarine into a huge nuclear fleet consisting of submarines and surface ships in many classes and sizes. ATR analysis of Navy fuel led to continuous improvements in extending the operational life of a ship's fuel. The civilian power programs and the national space program also were looking to advance the science of fuel systems and materials. They, too, made use of ATR test loops. ${ }^{129}$

MTR Retires in 1970-Reluctantly. In 1968, the AEC announced it would shut down the MTR in 1970. In response, other interests tried to develop commercial possibilities, hoping to keep the venerable MTR operating. The State of Idaho had formed an Idaho Nuclear Energy Commission in 1967 to promote nuclear applications in agriculture, mining, lumbering, and other fields. In 1969 a Western Interstate Nuclear Compact formed to promote nuclear commerce and trade in all the western states. These two groups tried to continue the life of the MTR as a "Western Beam Research Reactor." The problem was funding.

The Associated Western Universities proposed that the AEC finance some fifty research projects at the MTR, but the AEC was unwilling or unable to fund the proposal. The National Science Foundation considered the MTR as a possible "National Neutron Center of Interdisciplinary Studies," but concluded in 1972 that high-flux neutron beam capability would be cheaper at its Brookhaven, New York, or Oak Ridge laboratories than at the MTR. ${ }^{130}$ Efforts to find a private buyer or renter for the MTR also failed.

For a brief period in 1970, all three test reactors at TRA operated at the same time. The last MTR experiment was called the Phoenix, in which the reactor was loaded with plutonium fuel. The test verified that this particular mix of isotopes would create more fuel than it consumed - thus vindicating its name "rising from the ashes." Officially, the last day of operation for MTR was April 23, 1970.

But later in the year, the State of Idaho appealed for two days of operation in order to irradiate samples of pheasant and other wildlife. The Idaho Department of Fish and Game had recently discovered mercury in pheasant flesh and needed information quickly as to the potential extent of this problem. At the time, some farmers used grain fungicides containing methyl mercury. If mercury poisoning were widespread, the Department of Fish and Game would have to cancel the forthcoming hunting season. The NRTS obliged the state and loaded up the reactor with about a thousand samples of fowl and fish from several locations, irradiating them for about two days in August $1970 .{ }^{131}$ That was MTR's final service; it was decommissioned in 1974.

Significance of the MTR, ETR, and ATR. Because the MTR was the first multipurpose test reactor in the world, it moved the boundaries of nuclear knowledge constantly outward. Providing the world's most intense neutron flux available, the MTR performed its tests in relatively short times and produced radioisotopes of higher specific activity than any other reactor.

It accomplished its test mission safely. It logged 125,000 operating hours, sometimes with 600 samples loaded at a time. It conducted more than 19,000 irradiations in 800 different programs. The AEC

128. 1965 Thumbnail Sketch, p. 15.

129. 1965 Thumbnail Sketch, p. 15.

130. “Annual Report of the Idaho Nuclear Energy Commission, Report No. 6, 1972,” (Boise: INEC, 1973), p. 14-15.

131. "INEL Programs set high safety standards," INEL News (March 19, 1993), p. 4. See also Annual Report of the Idaho Nuclear Energy Commission, No. 4, 1970, p. 6; Darrell W. Brock, "Application for Funding for a Proposed Study of Mercury Poisoning in Idaho," May 28, 1970, copy in Senator Len B. Jordan Papers, Boise State University, Box 174, File 32. 
had sponsored most of them, but many commercial clients had been served as well. In addition, MTR had accommodated ten major Air Force experiments, fifty major Navy experiments, and several for the Army. ${ }^{132}$

Among its peaceful services, the MTR had supplied hospitals with irradiated Ccobalt- 60 and other radionuclides, evaluated the economics of hydrazine rocket fuel, measured the properties of known transuranic elements and helped discover new ones. MTR spent fuel provided gamma radiation to countless samples of food - testing the possibility that irradiation might extend the shelf life of food without refrigeration - and thousands of other substances.

MTR was the first reactor ever to use Plutonium-239 fuel at power levels up to 30 megawatts, demonstrating that a reactor fueled with plutonium could be satisfactorily controlled. ${ }^{133}$ Phillips physicist Deslonde deBoisblank announced this achievement at the Geneva Atoms for Peace Conference in $1958 .^{134}$

In its early years, MTR experiments contributed to the design and improvement of all commercial pressurized water reactors in the United States and many beyond its borders. Later, it contributed to the Yankee and Dresden power reactors at Rowe, Massachusetts, and Morris, Illinois, respectively; to the organic reactor; to the liquid metal fuel reactor; and to the homogenous fuel reactor. ${ }^{135}$

Behind the MTR were the people who managed, operated, maintained, and improved it. Quite simply, everything they did was new. The accomplishments of the pioneering machine were nothing less than the accomplishments of the human pioneers who devoted themselves to its success.

After all of the "firsts" accumulated by the MTR, the two reactors that followed it had a hard act to follow. Each, however, represented the most advanced designs in the world at the time for test reactors and were major landmarks in the history of test reactors. The ETR and ATR were significant and essential partners in the safe operation and success of the American nuclear fleet - and in the development of the commercial power industry and the space program. In addition, they incorporated highly advanced and unique designs unlikely to have been replicated anywhere else in the world. When the fortunes of the commercial reactor industry began to decline in the 1970s, their role in scientific innovation also declined. Much of the ATR work involved the analysis and improvement of performance rather than expanding the universe of knowledge.

The closure of the MTR - and, most particularly, its failure to find either a commercial or institutional champion - signaled the beginning of a different era in nuclear research at the NRTS. Until that time, NRTS research reactors had slaked an urgent thirst for nuclear knowledge. Its mission to "mother" other reactors had succeeded, but the nation was changing its mind about nuclear power. The role of nuclear research in the development of "atoms for peace" began what now appears to be a 26-year decline.

\section{Sub-Theme: Reactor Testing, Experimentation, and Development \\ Organic Moderated Reactor Experiment}

The Organic Moderated Reactor Experiment: 1957-1963. Among the many experimental reactor concepts that the AEC tested was a reactor that would use a liquid hydrocarbon as a coolant and a moderator. It contracted Atomics International - which had conceived the concept - to develop the

132. 1961 Thumbnail Sketch, p. 23-25; 1973 Thumbnail Sketch, p. 7.

133. 1959 Thumbnail Sketch, p. 22.

134. AEC Press release, September 11, 1958; IHS, MS 84, Box 83, File “AEC_-Idaho Plant."

135. Dresden was the first large-scale privately owned boiling water nuclear power station to go into operation (in 1959) in the United States; Yankee soon followed as the first pressurized water power reactor (in 1960). 
reactor at the NRTS. From 1957 to 1963 the OMRE was in operation. OMRE was notable as the first experimental reactor constructed at the NRTS with partial funding by private industry. ${ }^{136}$

Most reactor concepts at the time used water - either light or heavy, pressurized or boiling — as a coolant. During the late 1950s scientists began to consider materials other than water for use as coolants in reactors. Water has the disadvantage of becoming corrosive at the high temperatures to which it is subjected in the reactor. It was necessary to use stainless steel or zirconium alloys to clad the fuel elements over which the heat-removing water passed. The advantage of organic substances over water is their low vapor pressure and low corrosion effects. Initial studies and experiments at the MTR inspired scientists to try the concept of an organic fluid. ${ }^{137}$

The OMRE complex consisted of a 4,300- $\mathrm{ft}^{2}$ steel process and control building, a large airblast heat exchanger, a storage area, an auxiliary heat exchanger, a pipe gallery, several underground tanks, and extensive piping and electrical systems. ${ }^{138}$ The complex was located east of the CFA (in the south central section of the NRTS) about halfway between the CFA and the Army Reactors Area.

The organic material used for OMRE was called Santo-wax-R, a mixture of terphenyl and diphenyl isomers. ${ }^{139}$ This mixture is solid at room temperature, but becomes liquid when exposed to high temperatures. Experiments simulated the conditions of heat transfer, temperature, and coolant flow which would exist in a power reactor. The reactor went critical for the first time on September 17, 1957. OMRE operated at full-power beginning in February of $1958 .{ }^{140}$ A second core went critical for the first time on May 9, 1959.

One consequence of the OMRE experiments was the construction at Piqua, Ohio, of the first organiccooled and moderated nuclear power plant. It went critical in $1963 .{ }^{141}$ This plant, built for a municipally owned utility company, operated until 1966. It shut down when organic matter built up in the reactor core, making it difficult to maintain and operate. ${ }^{142}$

The OMRE experiment was phased out in 1963 after its tests had established the feasibility of operating this type of reactor - provided that the organic coolant-moderator be kept clean. The reactor was shut down, and the nuclear fuel and reactor vessel internal piping were removed. The facility remained in deactivated condition until $1977 .{ }^{143}$

Experimental Organic Cooled Reactor Extends OMRE Studies. The EOCR, built adjacent to the OMRE, was designed to advance the OMRE studies. It was viewed as a link between the early OMRE experiments and an economically viable power reactor. "Scaling up" the concept to a commercial size required more advanced experiments. The OMRE had been built at a (relatively low) cost of $\$ 1,800,000$ and was insufficiently sophisticated to perform such advanced experiments, so the EOCR was planned to advance the concept.

136. Thumbnail Sketch, November 1958, p. 23.

137. Thumbnail Sketch, November 1958, p. 23.

138. Robert E. Hine, Contamination and Decommissioning of the Organic Moderated Reactor Experiment Facility, EGG-2059 (Idaho Falls: EG\&G Idaho, Inc., September, 1980), p. 2.

139. Terphenyl and diphenyl are hydrocarbons. Those known as polyphenyls were considered for reactor use.

140. Thumbnail Sketch, November 1958, p. 23.

141. The Piqua, Ohio, plant was part of the second round of demonstrations associated with the Power Reactor Development Program initiated by the AEC to invite industry to develop and finance power reactors.

142. One source that describes the Piqua, Ohio, plant is Controlled Nuclear Chain Reaction: The First 50 Years (La Grange Park, Illinois: American Nuclear Society, 1992), p. 41; see also numerous editions of Thumbnail Sketch.

143. Robert E. Hine, Contamination and Decommissioning of the Organic Moderated Reactor Experiment Facility OMRE EGG-2059 (Idaho Falls: EG\&G Idaho Report EGG-2095, 1980), p. 2. 
The EOCR was designed by the Fluor Corporation and Atomics International. It provided five large in-pile experimental loops (facilities in the reactor that allowed for the test irradiation of various materials) that would be used to advance the coolant and fuel-element technology for the concept. ${ }^{144}$ The facility consisted of a reactor building (STF-601), storage tanks, and pumphouses - all of which went under construction in 1961. The reactor building was the only large building in the complex, the others being pumphouses and other auxiliary buildings. The portion of the building below grade was constructed of reinforced concrete and the portion above grade was built of pumice block covered with corrugated sheet metal.

Construction on the facility was $90 \%$ complete when the AEC canceled the organic coolant program in December 1962. It had concluded that the concept was not likely to improve significantly the performance of nuclear power plants beyond that already achieved by other reactor concepts. Thus, this reactor never was completed and never went critical.

OMRE and EOCR after 1963. Following the demise of the Organic Reactor Program in 1962 both the OMRE and the EOCR were placed in standby status. In 1977 workers proceeded to decontaminate and dismantle the OMRE and all of its support buildings. This was the first such dismantlement at INL and therefore, constituted a learning experience for everyone involved in the procedure. Even in its dismantlement, the OMRE was used for experimental purposes.

The DD\&D process took two years and ended in September 1979. There were two major objectives to the DD\&D at OMRE. One was to remove the entire facility by disposing of all contaminated articles and the second was to determine what techniques, procedures, and special tools should be developed for other DD\&D projects. ${ }^{145}$ Both objectives were met and demonstrated the need for further research into special tools, decontamination of soils, and ways to meet acceptable standards preventing the release of radioactive materials.

The EOCR, still in standby status, in 1963 was considered for conversion to a water-cooled and moderated reactor. But this did not occur; the equipment and parts that had been ordered were used elsewhere. During 1978 and 1979 a portion of the building was used as office space auxiliary to the DD\&D of the OMRE. The facility then was used as a training facility for the security force at INL. The vicinity was equipped for target practice and other security training procedures.

All of the structures at the EOCR site have been demolished. The organic-cooled reactor concept was a significant symbol of the AEC reactor program despite its status as a concept that ended up as "a path not chosen" for commercial development. Pursuant to a Memorandum of Agreement with the Idaho SHPO, photographs were taken of the buildings prior to demolition in anticipation of HABS/HAER recordation.

\section{Sub-Theme: Cold War Weapons and Military Applications}

\section{Naval Reactors Facility}

The Navy's Quest for Nuclear Propulsion: 1939-1948. The Navy's dream of nuclear power for propulsion predated both the existence of the AEC and the entrance of the United States into World War II. As early as 1939, the Naval Research Laboratory became involved in budding atomic research, and

144. W. E. Nyer and J. H. Rainwater, Experimental Organic Cooled Reactor Conceptual Design (Idaho Falls: Report IDO-16570, December 1959), p. 7.

145. Robert E. Hine, Contamination and Decommissioning of the Organic Moderated Reactor Experiment Facility OMRE EGG-2059 (Idaho Falls: EG\&G Idaho Report EGG-2095, 1980), p. 3. 
thereafter participated in the Manhattan Project. Navy research, shared with the Army, led to the production of Uranium-235, which the Manhattan Project used for the bomb dropped on Hiroshima.

After World War II, some Naval leaders, particularly Admiral Earle Mills of the Bureau of Ships, envisioned nuclear propulsion as the key to ocean-warfare supremacy. In 1946 Admiral Mills sent Navy researchers to Oak Ridge to learn the fundamentals of nuclear technology. Mills selected Captain Hyman Rickover, known for his excellent work on shipboard electrical problems, as senior officer. Rickover embarked on a career known for combining his formidable personality with the goal of developing nuclear propulsion. ${ }^{146}$

The Atomic Energy Act of 1946 and the formation of the AEC in 1947 obliged the Navy to work in close cooperation with the new civilian agency. Admiral Mills and Captain Rickover worked on procedures for cooperation between Navy and AEC staff. These arrangements stayed essentially the same for the next thirty years. The Navy focused more on engineering, while the AEC oversaw reactor research, initial design, and plant and shipboard safety. The Navy designed, built, and operated its ships. The AEC also received Navy funds for the naval features required on a shipboard plant. All land prototypes of the shipboard nuclear plants were funded by the AEC, with some supporting funds from the Navy. All actual shipboard plants were paid for by the Navy with the exception of the first two - the submarines USS Nautilus and USS Seawolf. ${ }^{147}$

Several AEC national laboratories were responsible for developing various aspects of naval nuclear power. The Bettis Laboratory (operated by Westinghouse) near Pittsburgh, Pennsylvania, was chosen as the site for the design and development of a naval nuclear plant. Knolls Laboratory in Schenectady, New York, (operated by General Electric) was the site chosen for an intermediate naval reactor, with technical assistance supplied by the Argonne National Laboratory. Knolls engineers worked on the feasibility of a liquid-metal cooled reactor. Oak Ridge investigated the use of high-pressure, water-cooled reactors. A plant at Shippingport, Pennsylvania, was planned to demonstrate the feasibility of nuclear power for civilian use.

Submarines in the Desert: 1948-1955. After the AEC decided to build the NRTS, it determined that the Navy's water-cooled reactor prototype would be one of the first four projects built at the new testing station (the others being EBR-I, the MTR, and the Chemical Processing Plant). Argonne and Westinghouse designed and developed components for the reactor. The village of West Milton, New York, was chosen for the liquid metal-cooled reactor prototype, since it was close to the Schenectady laboratory. A small-submarine prototype plant was developed later at Windsor, Connecticut, in $1957 .{ }^{148}$

At the NRTS, Rust Engineering Company chose a site for the submarine thermal reactor about five miles north of the MTR site. In August 1950, F. H. McGraw \& Company broke ground for the Submarine Thermal Reactor (STR, also referred to as the Mark I or the S1W Prototype - S for submarine, 1 for first model, and W for the designer, Westinghouse). With this, Idaho's association with the Nuclear Navy officially began. NRTS Manager Leonard E. Johnston and his staff often clashed with Captain Rickover, who came out personally to oversee the construction plans and who missed few, if any, details. In the midst of the Korean conflict, the pressure was on both men to get the prototype operating by 1952 .

The buildings at the Navy complex, which eventually became known as the Naval Reactors Facility, followed the same principles that guided the NPG and CFA: simplicity, ruggedness, and reliability. However simple the designs were, construction was often slow because the building blueprints were not ready on time. The reactor prototype was housed in a large steel building; inside was a full-scale section

146. Hewlett, Atomic Shield, p. 74-76.

147. Francis Duncan, Rickover and the Nuclear Navy (Annapolis, Maryland: Naval Institute Press, 1990), 4. Hereafter cited as "Duncan, Rickover." See also Hewlett, Atomic Shield, p. 189.

148. Hewlett, Atomic Shield, p. 418-419; see also Duncan, Rickover, p. 5. 
of a submarine hull surrounded by a 300,000-gallon tank of water. Following Rickover's insistence, the hull was identical to that of a regular Navy submarine, down to its "Battleship Gray" paint. ${ }^{149}$

By 1952, the Electric Boat Company, builder of USS Nautilus in Groton, Connecticut, had installed the main turbine, condenser, reduction gear, and other parts in the submarine's engine room. The pressure vessel was installed in the reactor compartment. In June of that year, President Harry Truman presided at keel-laying ceremonies for the Nautilus, destined to be the world's first nuclear-powered sea vessel. Meanwhile, during the hot Idaho summer of 1952, Westinghouse engineers worked two shifts, then eventually three shifts around the clock. They installed systems and began leak tests. Reactor control equipment and coolant pumps came from Pittsburgh's Bettis Laboratory in the autumn. By November 1952, the reactor prototype was complete except for its nuclear fuel and two heat exchangers. ${ }^{150}$

By March 1953, the S1W Prototype achieved criticality, the world's first criticality of a pressurized water reactor. On June 25, 1953, the S1 W achieved full design power and immediately embarked on a successful 96-hour sustained run, simulating a submerged crossing of the Atlantic Ocean. Two years later the S1W sustained a 66-day, continuous full-power run. This run was equivalent to a submarine traveling at high speed twice around the world - without having to stop and refuel. The S1W Prototype created two other "firsts" for the young nuclear industry and the Navy. It was the first use of highly enriched uranium as a fuel and the first use of zirconium alloy as a construction material in nuclear reactors.

The S1W Prototype was the model for the nuclear core of the submarine USS Nautilus, the first nuclear-powered submarine in the world. The Nautilus proved its capabilities in 1958 when it became the first vessel to travel under the North Pole ice cap.

The success of this 1958 sea trial reflected glory on the S1W Prototype. Nautilus commander, Bill Anderson, sent the following telegram to NRF workers from the White House upon his triumphant return to Washington, D.C.:

“... during Nautilus' North Pole submerged transit from Pacific to Atlantic the performance of our engineering plant exceeded all expectations. To the first manufacturer of naval nuclear propulsion our sincere thanks for providing the plant that made possible this first transpolar crossing." 151

The S1W Prototype's early success was a prelude to the further development of naval reactor prototypes at the NRTS. A nuclear-powered aircraft carrier was in the design stage by 1952. The AEC and the Navy decided that Westinghouse would build the reactor and that the Newport News Shipbuilding and Drydock Company would develop the shipboard features. Westinghouse already had a good technical base for the project from its work on the reactor prototype in Idaho.

However, Rickover had to win over President Dwight D. Eisenhower and Congress, who were cutting budgets. The carrier was initially approved under President Truman in 1950, but was cut from the budget in 1953. The skyrocketing costs of nuclear ships (in all, the Nautilus program cost $\$ 65$ million) caused both the Department of Defense and Congress to question their cost-effectiveness. But the Korean conflict gave Rickover, by this time an admiral, the opportunity to defend his request for a nuclear carrier. He was victorious in 1954, when funds for the nuclear carrier were reinstated and the USS Enterprise resulted, the first nuclear-powered surface ship. Years later, Rickover referred to this experience in a 1968

149. Hewlett, Atomic Shield, p. 495-496; see also unpublished binder entitled "Naval Reactors Facility, 1994," on file at INEEL Cultural Resources Department.

150. Hewlett, Atomic Shield, p. 515; "Naval Reactors Facility, 1994."

151. The telegram is contained within the NRF "Historical Scrapbook" for 1958. 
speech to Congress, where he fought against withdrawing funds for the nuclear carriers USS South Carolina and USS Virginia. To support his arguments, he cited the Enterprise's many accomplishments in the Vietnam conflict. ${ }^{152}$

New Prototypes, Personnel Training, and Spent Fuel: 1956-1969. On April 1, 1956, construction of the Enterprise prototype reactor began at the NRF. The ship itself was being erected in Newport News, Virginia. Two years later the Idaho reactor achieved criticality. Called the A1W (A for Aircraft Carrier, 1 for first model, and $\mathrm{W}$ for Westinghouse), the plant included two pressurized water reactors and associated steam equipment. Both reactors achieved full power in 1959. The NRF and the Bettis Laboratory used the A1W to test and develop different reactor materials. The information gained from A1W was used to design the C1W plant for the cruiser USS Long Beach, under construction in Quincy, Massachusetts. The A1W reactors continued in use after the carrier had been launched and were modified from May 1963 to November 1964 for a new surface-ship prototype. The new A1W core reached criticality in April of 1965. ${ }^{153}$

Having the submarine and aircraft carrier prototypes on the same site presented superb training opportunities. Rickover established an intensive nuclear training program in 1956 to support the growing inventory of nuclear-powered ships. Shipboard plant operators, specifically officers, first had to undergo six months of classroom instruction, then six months at a land prototype such as at the NRF. The prototypes gave the most realistic training possible because students learned their procedures and principles on operating reactors. If an officer passed this training, he was usually assigned to a nuclear ship and then undertook further study.

In a 1957 address to Congress, Rickover praised the Idaho training program: "The Arco Navy nuclear submarine training facility is most valuable.... We have no better training facility in the Navy than we have there and it is absolutely essential for the future of nuclear power in the Navy that we train the people there...." ${ }^{154}$ More than 12,500 Navy and civilian students received training at the S1W during its thirty-six years of operation. Approximately 14,500 were trained at A1W during its thirty-five-year life span. $^{155}$

The next prototype built at the NRF was the S5G (S for submarine, 5 for fifth model, and $\mathrm{G}$ for General Electric), a natural-circulation reactor. In the natural circulation mode, coolant water flowed through the reactor by thermal circulation. The natural-circulation reactor was a quieter and simpler system because large coolant pumps were no longer needed. "Silent" running was a distinct advantage in stealth operations. In 1956, Bettis Laboratory had completed preliminary studies for a small, naturalcirculation reactor. After further testing had been completed, Rickover pressured the AEC to build a prototype at the Idaho site. Again, the new facility would match shipboard conditions, but with a new addition - the prototype would simulate the motion of an operating ship at sea. His main concern was whether the natural circulation reactor could function properly under those realistic circumstances. ${ }^{156}$

Rickover went to Congress in 1957 to ask for funding. He used strong Cold-War rhetoric to make his point. Growing Soviet naval strength gave impetus to his words:

152. United States Congress, Hearing before the Joint Commission on Atomic Energy Congress of the U.S. eighty-ninth congress 2nd session on Naval Nuclear Propulsion Program, Jan. 26, 1966, p. 3. See also Duncan, Rickover, p. 162-163.

153. Duncan, Rickover, p. 104-105; and "Naval Reactors Facility."

154. United States Congress, U.S. Congress, Joint Committee on Atomic Energy, Naval Reactor Program and Shippingport Reactor. 85th Congress, First Session, March 7 and April 12, 1957 (Washington, D.C.: USGPO, 1957), p. iii.

155. Duncan, Rickover, p. 247-248; and "Naval Reactors Facility."

156. Duncan, Rickover, p. 24. 
"The efforts of the Naval Reactors Branch of the AEC...have given our Nation world leadership in the development of atomic power for naval propulsion....We believe that a fleet of nuclear powered underwater vessels capable of firing long-range missiles will ultimately decide the balance of world power and the maintenance of the peace."

After Congress and the AEC approved funding for the prototype, Westinghouse, which was in charge of Bettis Laboratory, moved several key personnel from Bettis to work on the space program. Furious about this, Rickover persuaded the AEC to take the natural-circulation project away from Westinghouse and give it to General Electric's Knolls Laboratory. Thus, General Electric arrived at the NRF as a contractor at the NRTS.

Construction of the natural circulation submarine prototype plant began in September, 1961. Four years later it achieved criticality. In June 1966, the S5G completed a simulated cruise of 4,256 nautical miles from New London, Connecticut, to London, England. In November, the natural circulation system performed well under normal seagoing circumstances. The next year the test was performed for AEC officials. They were pleased with the results. The Navy began building ships using the natural circulation system. Rickover immediately sent 114 men to train at the S5G. The prototype continued operating for the next thirty years. ${ }^{158}$

Handling the Navy's Spent Fue/-The Expended Core Facility, 1957-1969. When the S1W Prototype commenced power operations in 1953, it had its own hot cell, a heavily shielded enclosure for remote handling of radioactive material, and water pit for examining its own spent nuclear fuel. Using remote handling methods, workers first placed the spent fuel assemblies into the water pit and then cut them apart using a special hack saw. Selected subassemblies were moved into the hot cell for detailed examination and measurement. Of particular interest was the amount of distortion or other anomalies in the fuel as a result of its use. After this data had been gathered, the fuel components were loaded into casks for the short trip to the ICPP, where it was processed and its uranium recovered.

In 1957 a new set of hot cells and pools were built at the northwest perimeter of the NRF complex. Bettis Laboratory established design criteria for the Expended Core Facility (ECF). The engineer was Arthur G. McKee Company;, and Paul Hardeman, Inc., the contractor. Its original dimensions were $340 \mathrm{ft}$ $\times 190 \mathrm{ft}$ with a 58 - $\mathrm{ft}$ high bay down the center. The water pit, $34 \mathrm{ft} \times 50 \mathrm{ft}$ under the high bay, dominated the center of the building. It was $30-\mathrm{ft}$ deep at the fuel unloading area. Nine hot cells north of the water pit were connected to the pit by a transfer tunnel. Radiochemistry laboratories were north of the hot cells.

Railroad cars transported spent fuel from the other Navy facilities to the ECF. It arrived packaged in heavily shielded casks. The rail spur entered the high bay at the west end of ECF, into an area called the decontamination shop. The fuel was unloaded into the water pit, where it was separated from its structural material by a milling machine and core saw. From the pits, the fuel assemblies went to the hot cells for analysis.

Initially, the Navy sent about three fuel cores a year to the ECF; later, the shipments increased to five a year. The ECF also received irradiated materials from other NRTS facilities. Around 1960, MTR test specimens (plant materials, core structural materials, and naval reactor fuel) began going to the ECF for analysis. The specimens were first assembled at ECF, irradiated at the MTR (after 1970 at the ATR) at the Test Reactor Area, then sent back to the ECF for disassembly and examination. To handle these, the Navy

157. Naval Reactor Program and Shippingport Reactor, p. iii.

158. Duncan, Rickover, p. 22-25; see also "Naval Reactors Facility." 
built an additional hot cell and a water pit with a below-water-level observation room and a lead glass viewing window.

As the NRF developed additional prototypes, the workload at ECF grew. The number of ships in the Nuclear Navy also grew. With this growth, the ECF had to grow to keep pace - eventually doubling in size from its original dimensions. ${ }^{159}$

The buildings at the NRF are managed by DOE-Pittsburgh, not DOE-ID. The scope of this report did not include a building inventory or assessment of historic significance. However, such an inventory and assessment was accomplished in $2000 .^{160}$

It is clear that the NRF reactors, particularly the S1W Prototype, were of great significance in providing the United States with supremacy of the seas in the early decades of the Cold War. The three prototypes at the NRF are a major reason why INL was of exceptional historical significance during the 1950s and 1960s. The primary mission of the NRF has been the research and development of nuclear propulsion plants. It should be noted that no new reactors were constructed at NRF after 1966, although new cores were inserted into the existing reactors.

\section{Sub-Theme: Weapons and Military Applications}

\section{Army Reactor Area (Auxiliary Reactor Area)}

Origin of the Army Reactors Program: 1957-1965. The conventional method of supplying electricity to an isolated U.S. Army base or mobile field station was to transport a diesel generator to the site and operate a supply line to keep diesel fuel flowing from the nearest depot. Trucking or flying fuel to some bases, such as to Arctic locations where road access was impossible and flying was restricted, could be difficult, hazardous, and costly.

After World War II, the possibilities of atomic power tantalized the Army like it did the other military services. The allure was that a tiny handful of nuclear fuel might replace the logistical headache of fuel transport to remote locations. Or a nuclear power plant might be mobile, able to move with a field hospital or command center. Perhaps it could be portable, mounted on a barge and towable from one port to another as needed. Ideally, reactors could vary in capacity to serve a wide range of applications. They only needed to be small enough, light-weight enough, and cheap enough. The Army's nuclear power program aimed to meet these three challenges.

The Army organized an Office of Research and Development in 1951 to begin a nuclear research program. Its chief, General K. D. Nichols, thought the Army's pursuit of small reactors might help to speed up the ultimate development of a commercial industry; he and others often used this argument as they sought support. The Army placed the Nuclear Development program under the supervision of the U.S. Army Corps of Engineers. ${ }^{161}$

159. Information about the ECF came from Edgar L. Juell, "A Short History of the Expended Core Facility, (Idaho Falls: Naval Reactors Facility, 1990). See also "Naval Reactors Facility” and "Idaho Test Will Propel Huge Ship,” Idaho Falls Post-Register, December 11, 1958.

160. Madeline Buckendorf, A Historic Context of the Naval Reactors Facility: Including Historic Building Inventories and Assessments (Idaho Falls: Prepared for the U.S. Department of Energy Pittsburgh Operations Office and Bechtel Bettis, Inc., by the Arrowrock Group, Inc., Boise, Idaho, November 2000).

161. Lawrence H. Suid, The Army's Nuclear Power Program, The Evolution of a Support Agency (New York: Glenwood Press, 1990), p. 3-8. This book is the most complete and useful source on the history of the Army nuclear program. 
Meeting initial resistance from the AEC staff, which desired to retain the initiative in developing a commercial industry, the Army gradually acquired allies in Alvin Weinberg, director of Oak Ridge National Laboratory; Admiral Lewis Strauss, an AEC Commissioner after July 1953; and the Joint Chiefs of Staff, who declared an official military "requirement" for a nuclear power plant in December of 1953. The AEC and the Army organized its first project, which the AEC approved for funding in July $1954{ }^{162}$

The Army's goal was to develop a family of three basic types of power plants. A stationary plant would be a permanent installation that could serve as a base in a remote area otherwise difficult to supply with fuel. It would not be designed for relocation elsewhere. A portable power plant would be preassembled for rapid erection in the field. A limited number of "packages" would make up the plant, each of which could fit in an air cargo transport or truck. The plant could be disassembled and then relocated to another site. A mobile power plant could move intact from one site to another without being broken down and reassembled at all - possibly operate even while being moved. ${ }^{163}$

Further refining its goals, the Army selected operating ranges for its nuclear plants. A "low-power" reactor would produce in the range of 100 to 1,000 kilowatts. "Medium-power" reactors would supply from 1,000 to 10,000 kilowatts, and "high-power" facilities could range between 10 megawatts to about 40 megawatts. ${ }^{164}$

The Army institutionalized these concepts in the names of its prototypes and experiments. Its first prototype, which went on line at Fort Belvoir, Virginia, thus carried the designation SM-1, a "stationary medium-power" reactor. Until it canceled its nuclear development program, the Army planned 17 different projects. Of these, seven went into service, seven others were designed, and three were experiments built at the NRTS in Idaho. ${ }^{165}$

The Army Comes to the National Reactor Testing Station. The Fort Belvoir reactor, within eighteen miles of The White House, was a pressurized water reactor, the same type that Admiral Hyman Rickover had installed in the USS Nautilus prototype. Although other reactor concepts promised to embody virtues of light weight and simplicity so eagerly sought by the Army, pressurized water technology was the proven state of the art at the time. The Army dedicated the reactor in April 1957. To symbolize its potential for both peaceful and military uses, the first electricity generated by the reactor was used to run a printing press and a radar antenna. ${ }^{166}$

Reactors cooled with pressurized water had several disadvantages, however. The coolant circulated in a primary loop through the reactor and exchanged heat with water in a secondary loop. The secondary loop transferred heat to a boiler, which produced steam to run a turbine/generator. The coolant piping, pumps, valves, controls, and instrumentation added considerable weight, bulk, and complexity to the total outfit.

The Army, therefore, set out to experiment with two alternatives. The first was a boiling water reactor. In this design, ordinary water boils as it passes through the hot reactor core. The steam generated here powers the turbine. The system eliminates the secondary loop and the heat exchanger equipment.

162. Suid, p. 20-24.

163. “The Army Reactor Program,” Nucleonics (February 1959), p. 54; and John F. Hogerton, The Atomic Energy Deskbook (New York: Reinhold Publishing, 1963), p. 32.

164. Hogerton, p. 32.

165. Hogerton, p. 33. Plants on the line were: SM-1 at Fort Belvoir; SM-1A at Fort Greeley, Alaska; PM-2A at Camp Century, Greenland; PM-1 at Sundance Air Force Base, Wyoming; PM-3A at McMurdo Sound, Antarctica; PL-3 at Byrd Station; and the Sturgis, a barge.

166. Suid, p. 36-37. 
The Army and AEC engaged Argonne National Laboratory to design a stationary reactor in the "low" power range that might be suitable for a remote location. It had the Defense Early Warning (DEW) Line (later the Ballistic Missile Early Warning System) in mind, dozens of radar stations ringing the Arctic Circle on the watch for Soviet invasion. The Army wanted the plant small enough to haul on a 30-ton trailer. The prototype was named SL-1, and it was built on the NRTS at the ARA. ${ }^{167}$

The second alternative was a Gas-Cooled Reactor (GCRE). In this concept, a gas circulates in a closed loop through a water-moderated reactor to carry off the heat. The loop passes through a steam generator, which then runs the turbine. The system promised to be smaller and lighter than either of the other concepts. The Army hoped that ambient air might eventually be used as the coolant. The Army and AEC selected Aerojet-General Corporation to design it. As this would be the country's first gas-cooled reactor, testing had to determine its operating parameters and best fuel element design. Once that information was available, the plan was for Aerojet to build a prototype of a Mobile Low-Power (ML) reactor - the ML-1. Both of these alternatives and the ML-1 became clusters of activity at ARA. ${ }^{168}$

Siting the Army Reactor Area. The SL-1 was ready to be built first. In August 1955, the AEC chose Pioneer Services and Engineering Company of Chicago as the architect/engineer. Bid requests began to go out in 1956, including one to build the circular steel tank that would house the reactor. ${ }^{169}$ Construction began in 1957 and was finished in July 1958.

By this time, the NRTS no longer was a tabula rasa (i.e., erased tablet) upon which a contractor could pick and choose a construction spot at will. Reactors and tests dotted the terrain, and each new experiment had to meet siting criteria administered by a Site Selection Committee at the NRTS and approved by the AEC in Washington. The Committee knew from the outset that the Army program would consist of three experiments. (The first name for the site was Army Reactor Experiment Area; the word "experiment" later was dropped.) The site was placed a few miles west of Argonne West and five miles east of the Central Facilities Area.

The area was a master-planned four-cluster complex. The first cluster, ARA-I, was the administrative center. The three experiments were strung out along a connecting road and as close together as possible without compromising rules establishing minimum distances between reactors. The GCRE and SL-1 each required one mile; the ML-1, only a half a mile. (SL-1 was closer than one mile to the public highway, but it commenced before the one-mile rule was applied.) The four-cluster string was perpendicular to the direction of the most prevalent winds. This way, the risk of accidental releases from one reactor blowing over the other centers was reduced as much as possible. ${ }^{170}$

ARA-1 was the southern-most cluster of the four. It contained a hot cell building, a shop and maintenance building, guardhouse, pumphouse, hydraulic test power facility, and water and electrical utilities. Office trailers and a crew training building eventually were added. Its earliest buildings were constructed in 1959 and 1960.

167. Suid, p. 82. For more technical detail on the SL-1 reactor, see “Army Reactor Program,” Nucleonics (February 1969), p. 53-54 and insert.

168. The GCRE was the eighth reactor type developed by the AEC Nuclear Reactor development program, selected for both military and civilian potential. U.S. AEC press release, June 6, 1956; Papers of Senator Henry Dworshak, Idaho Historical Society, MS 84, Box 55, File "AEC - Idaho Plant." Hereafter referred to as "Dworshak Papers."

169. U.S. AEC/Idaho Operations press release, December 11, 1956. Dworshak Papers, Box 55, File “AEC—Idaho Plant.” The SL-1 was originally known as the Argonne Low Power Reactor, or ALPR.

170. Norman Engineering Co., Master Plan Study for the Army Reactor Experimental Area (Idaho Falls: Norman Engineering Report No. IDO-24033, 1959), Section II (no page numbers). The master plan also provided for other facilities that the Army never did build. 
SL-1, the first of the three projects, was next up the road at ARA-II. Completed in 1958, the site consisted of the cylindrical reactor building, a control room building with auxiliary equipment, and several small service buildings. The cylinder, made of quarter-inch thick steel plate, was part of the experiment. It was set on dummy piles to simulate construction methods used at DEW Line radar stations in permafrost. The reactor vessel, fuel storage well, and demineralizer for the water were in the lower part of the cylinder and shielded with gravel. Other equipment and shielding were in the upper two thirds of the building. The Army planned to use the SL-1 for training, so its operating contractor, Combustion Engineering, employed a military crew. Several earth berms were constructed at strategic places at the site. As at every other test area at the NRTS, a security fence and guard gate controlled entry.

The GCRE, at ARA-III was the next complex, ready for action in 1959. The reactor was in a rectangular building. Inside, the reactor operated within a sunken "swimming pool" filled with the moderating water. At the northern corner of the site stood a large tank for contaminated water, heavily bermed. The layout included a control and test building, a service building, a warehouse, gatehouse, petroleum storage, nitrogen storage tanks, and cooling tower along with fire protection, water, and sewer utilities. One of the buildings was a laboratory and fabrication center related to the development of the next project down the line at ARA-IV, the ML-1 prototype.

The ML-1 reactor was assembled in Downey, California, put on an Army semi-trailer, and hauled to Idaho, where it arrived in February 1961. ${ }^{171}$ The ML-I site (ARA-IV) was intended to simulate field conditions for training; therefore, it was relatively undeveloped. For example, water was trucked to the site from ARA-III. ${ }^{172}$ The reactor control building was $500 \mathrm{ft}$ away from the reactor, and only one or two other buildings were erected at the site. Most of the study work connected with ML-1 took place within GCRE buildings at ARA-III.

The Progress of the NRTS Experiments. SL-1 went critical for the first time on August 11, 1958, and produced electricity two months later on October 24. It was the first power plant reactor to use aluminum-clad fuel elements, which heretofore had been used only in test reactors like the MTR. It used a new alloy that overcame the low melting point of aluminum. After SL-1, aluminum alloys were used widely.

The GCRE, which went critical for the first time on February 23, 1960, tested two types of fuel elements, plate-type and then pin-type. The object was to find a fuel configuration that would have a long run before depletion. The pin-type promised to produce 300 to 500 kilowatts for a year without refueling. This design also reduced the shielding requirements for the reactor, which meant that the ML-1 prototype might meet the Army's goal of being transportable in four packages totaling no more than 38 tons. ${ }^{173}$ The GCRE had frequent maintenance problems, and on April 6, 1961, the reactor was shut down for the last time because of a leak in some of its stainless steel piping. It was deactivated by July 1, 1962.

The Army then turned ARA-III to the support and testing of the ML-1 prototype reactor. The GCRE pool was converted to a dry pit with shielding on top to accommodate the ML-1. On September 21, 1962, ML-1 operated as a power plant for the first time in a short two-hour run, making history as the smallest nuclear power plant on record to produce electricity. Also, it produced the highest core temperature of any previous reactor $-1,225^{\circ} \mathrm{F}$. Furthermore, this was the first time a reactor was connected to a closed-

171. AEC/Idaho Operations press release, February 11, 1961. Dworshak Papers, Box 122 B, File “AEC—Press Releases.”

172. ID0-24033, Section II.

173. To James T. Ramey from Richard X. Donovan, November 21, 1960. Dworshak Papers, Box 112, File “AEC Idaho Plant.” See also Thumbnail Sketch, April 1960, p. 17 
cycle, gas-driven turbo-generator. It reached full-power operation on February 28, $1963 .{ }^{174}$ During ML-1 tests, the operators trucked the reactor into a weather-sheltering metal building in the center of the ARAIV area. The reactor control building was $500 \mathrm{ft}$ away from the reactor just outside the perimeter fence. Evaluation, repair, and studies of the ML-1 took place within the GCRE buildings at ARA-III. ${ }^{175}$

The ML-1 proved to be disappointing, typically operating only a few days or hours before shutting down because of leaks, failed welds, or other problems. Only four days after it reached full power, a leak shut it down. It was out of action until spring 1964. After that, operations continued, but still with breakdowns. Radioactive releases were typical of ML-1; the experimenters realized that if it were to operate in the field, it would place its operators in danger. ML-1 tests ended in $1965 .{ }^{176}$

Meanwhile, in Washington, D.C., the Army Reactor Group had placed several prototype reactors on line in Greenland, Alaska, Wyoming, and Antarctica. Even though these had acquitted themselves well, the Group was having trouble persuading any of the services, including the Army, to order any of the plants. It appeared that the "life time" cost of a nuclear plant was lower than that of a conventional one, but the initial cost was far higher. When it came time actually to set a budget, the services opted for low first-cost alternatives. Economists suggested that this was false economy, but "balance the budget" pressures were more powerful. ${ }^{177}$

The SL-1 Accident. On January 3, 1961, the SL-1 had been shut down for maintenance since December 23, 1960. Three military crew members on an evening shift were preparing the reactor for another run. A violent explosion occurred in the reactor vessel, killing all three men. This was the first and continues to be the only - fatal accident in the history of American reactor operations.

The AEC immediately appointed an investigating committee to discover what had caused the accident. After interviewing hundreds of people, the committee never could say conclusively what had caused it. High levels of radioactivity in the building prohibited a detailed examination of its contents, although the technicians did manage to photograph parts of it remotely.

It seemed plausible that one of the crew had moved a control rod farther out of the reactor than was specified in the maintenance procedures. In four milliseconds, the reactor went critical, heated rapidly, and caused water in the core to flash to steam. The column of steam slammed into the lid of the pressure vessel, causing the entire vessel to jump from its foundation, shearing all of its piping connections and blowing shield plugs and shielding material from the top of the vessel. The men died from the impacts of the explosion rather than from the effects of nuclear radiation (although radiation in the reactor building was at lethal levels after the accident). Most of the radiation released from the reactor vessel by the explosion remained inside the building. ${ }^{178}$

\section{Suid, p. 91.}

175. See Photos from ARA HAER report: Nos. ID-33-D-96 through ID-33-D-102. These views show the ML-1 being moved from ARA-IV to ARA-III and set up for examination at in the GCRE pool.

176. Suid, p. 92-93.

177. "Economic Military Power Arrives, But Pentagon Hesitates," Nucleonics (April 1960), p. 27.

178. Many sources describe and discuss the SL-1 accident, among them "SL-1 Explosion Kills 3; Cause and Significance Still Unclear," Nucleonics (February 1961), p. 17-23; a series of press releases in Dworshak Papers, Box 122B, File "AEC-Idaho Press Releases;" "Summary of the SL-1 Reactor Incident at the National Reactor Testing Station in Idaho on January 3, 1961," prepared by the Staff of the JCAE, January 10, 1961, also in Dworshak Papers, Box 122B, File "AEC-Idaho Press Releases;" "SL-1 Accident, Findings of the Board of Investigation," published verbatim in Nuclear News (July 1961), p. 13-16. A videotape The SL-1 Accident produced by the NRTS Idaho Operations Office shows film of the recovery effort and the disposition of the reactor building. See also William McKeown, Idaho Falls, The Untold Story of America's First Nuclear Accident (Toronto: ECW Press, 2003). 
The investigating committee identified many problems with the management of the SL-1 reactor. One of the worst, and possibly a contributing cause of the accident, was that the fuel elements had been allowed to deteriorate "to such an extent that a prudent operator would not have allowed operation of the reactor to continue without a thorough analysis and review, and subsequent appropriate corrective action." 179

The AEC hired General Electric to evaluate options for disposal of the reactor building. The reactor core, vessel, and fuel went to the TAN Hot Shop for analysis. The rest of the lower-level radioactive debris and contaminated soil was placed in a "burial ground" approximately 1,600 ft from its original location. Two pits and a trench dug to bedrock accepted the waste. Backfill over the debris provided shielding, and an exclusion fence surrounded the burial zone. This on-site burial was considered a better approach than transporting the material sixteen miles on a public highway to the RWMC and risking public exposure.

The AEC decided that the cost of continuing to fund tests of boiling water reactors like SL-1 would not produce worthwhile benefits. It phased out the program and shelved it for possible future use. The Army felt that the concept had progressed "quite well," but it also stopped funding the concept. ${ }^{180}$

After decontamination, the ARA-II buildings were converted for use as offices. The NRTS contractor set up a welding shop to provide training and qualification testing for welders and braziers.

The accident may have aroused doubts in the minds of some about the Army's nuclear power plant program, but if so, the effects were not immediate. Editorials from nuclear industry publications such as Nucleonics said that accidents should be considered inevitable, but that the industry should do everything it could to protect its outstanding safety record to date. The AEC soon prohibited reactors that were controllable with only one control rod. The accident aroused protests from the local Oil, Chemical, and Atomic Workers International Union, which urged Congress to enact legislation to improve safety of nuclear workers. The Union also protested the lack of an isolation ward at the NRTS dispensary, lack of shielded lead caskets for burials, and lack of instruments available to read radiation levels higher than 500 roentgens. ${ }^{181}$ Site managers agreed that it was ill-equipped to deal with high-radiation casualties, but also felt that their pre-planned emergency procedures had been carried out appropriately during the SL-1 accident. ${ }^{182}$

Perhaps the long-term impact of the SL-1 accident is best measured by the frequency with which it was mentioned by anti-nuclear writers in the 1970s and 1980s. Books appeared containing lists of nuclear accidents, near-accidents, and mishaps, described in language aimed to outrage or frighten the reader. Sometimes the accounts of the SL-1 accident were quite inaccurate, but they helped alarm the public and inspire protests against nuclear power plants. ${ }^{183}$

The End of the Army Reactor Program. In view of the continuing difficulty finding missions for their small reactors - and the continuing difficulty in keeping the ML-1 from breaking down — the

179. "Findings of the Board of Investigation," Nuclear News (July 1961), p. 13.

180. Suid, p. 87.

181. To Senator Henry Dworshak from Donald E. Seifert and George Drazich for Local 2-652, May 11, 1961. Dworshak Papers, Box 122B, File "AEC-Idaho Plant."

182. John R. Horan and C. Wayne Bills, "What Have We Learned? Health Physics at SL-1," Nucleonics (December 1961), p. 43-46.

183. See for example, Harvey Wasserman and Norman Solomon, Killing Our Own, The Disaster of America's Experience with Atomic Radiation (New York: Delacorte Press, 1982); John Fuller, We Almost Lost Detroit (New York: Reader's Digest Press, 1975); John May, The Greenpeace Book of the Nuclear Age (New York: Pantheon Books, 1989); Leslie J. Freeman, Nuclear Witnesses: Insiders Speak Out (New York: W.W. Norton and Co., 1981). 
Army and the AEC concluded that the ML-1 program might eventually achieve its objectives, but that it would cost too much. Nuclear plants, particularly in the low-power end of the spectrum, could not compete with diesel plants: Using the Army's Antarctica reactor as an example, the initial cost of the nuclear plant was $\$ 6-7$ million; for diesel, $\$ 350,000$. A nuclear plant required a crew of 20 highly trained men; a diesel plant, six.

Partly behind the Army's reluctance to continue financing nuclear experiments was the country's growing involvement in the Vietnam War. The Department of Defense needed funds to prosecute the war. First the AEC and then the Army phased out the funding for the ML-1 development program by June 1966. ${ }^{184}$ This action effectively ended the involvement of the NRTS in the Army's nuclear development program.

An Army Ad Hoc Study Group took up the question of the rest of its program in 1969. One of the participants summed up the situation by saying, "Nuclear power is a solution in search of a problem." Basically, no military requirements existed for nuclear power. In the end, the group decided that it was only in selected remote situations that nuclear systems were cost-competitive with conventional diesel plants, that experiments should stop, but that study groups could continue. ${ }^{185}$

However, the Chief of Engineers, Lt. Gen. Frederick J. Clarke, could see little reason even to continue study groups. He permitted existing plants to operate until major problems forced them to shut down. In 1971, the Army Engineer Reactor Group lost its name and became the Engineer Power Group. Soon this group was examining excess generators returning from Vietnam. The Army experiment with nuclear reactors was over. ${ }^{186}$

The ARA Complex at INL. All ARA buildings were dismantled in the 1990s except for the ML-1 Control Building at ARA-IV, which continues in use. As mitigation, INL prepared a HAER report, HAER No. ID-33-D, which was approved and accepted by the National Park Service in 2001. The HAER report was required to document ARA-I, ARA-II, and ARA-III, but in the judgment of the author, the HAER would be more complete with documentation of ARA-IV as well. Thus, ARA-IV history, documentation, and photographs were included in the HAER report.

\section{Sub-Theme: Cold War Weapons and Military Applications}

\section{Advanced Reentry Vehicle Fuzing System Bunker}

The Advanced Reentry Vehicle Fuzing System (ARVFS) facility was built at the NRTS for the U.S. Air Force to evaluate the impact of gamma radiation on certain packages of instruments related to the fuzing system of guided missile warheads. The facility consisted of a below-grade Quonset hut covered with earth, a subsurface water tank open to the sky and built to shield spent fuel elements, and a support framework from which to suspend test packets over the gamma source. The bunker served as the control room during gamma exposures. The facility was on the east side of Lincoln Boulevard and northeast of the NRF.

During the mid-1960s, the American missile program was developing both offensive and defensive capabilities with respect to guided missiles. The ARVFS bunker and the gamma exposure of a fuzing

\footnotetext{
184. Suid, p. 93.

185. Suid, p. 103-105. The quotation comes from an individual, unnamed by Suid, who prepared a briefing for the Ad Hoc Study Group.

186. Suid, p. 108.
} 
system were a very small part of a major national priority to maintain weapons superiority over the Soviet Union.

After its initial use, the facility was used for a similar test in 1968 by health physicists at the NRTS to evaluate computer-generated codes (which predicted gamma radiation exposure in certain situations) against an actual exposure. The test exposed dosimeter film.

Other opportunistic uses of the facility occurred thereafter. In 1980, fuel rod pellets were subjected to various kinds of charges, including a shaped charge, in the water storage tank at the facility. In 1974 four containers of contaminated $\mathrm{NaK}$, previously stored at EBR-I, were moved to the bunker for safekeeping and isolation.

The ARVFS bunker site was decontaminated and dismantled in 1997. As mitigation for this potentially historic property, the Department of Energy contracted for a Historic American Engineering Record report on the facility. ${ }^{187}$

The ARVFS facility, which was of such short-term usefulness that neither electricity nor telephone were extended to the site, was a small part of the Arms Race. It represents one of a nearly infinite list of details executed to guarantee a weapon that would do the destructive work for which it had been designed.

\section{Sub-Theme: Cold War Weapons and Military Applications}

\section{Test Area North}

Beginnings of the Aircraft Nuclear Propulsion Program: 1951. The idea for a nuclear-powered aircraft was envisioned before the end of World War II. Military advocates fought to have the idea given serious attention in the years after the war. The Aircraft Nuclear Propulsion program — as it would involve the NRTS - began in 1951 when the Department of Defense decided that a nuclear-powered bomber was a military requirement. The concept for the weapon system was that a bomber would be able to remain aloft for at least five days, approach its target from any circuitous route, deliver the payload, evade enemy fire, and return home by any route desired.

When the AEC and the U.S. Air Force undertook the ANP program, they assigned the General Electric Company (GE) the task of developing a "direct cycle" heat exchange system for a turbojet aircraft. The NRTS opened up for GE a new site at the far northeastern end of the site - Test Area North, or TAN. TAN is about twenty-seven miles from the CFA. ${ }^{188}$

The Utah Construction Company broke ground for the first buildings at TAN in 1953. They were equipped and ready for serious experiments by Christmas of 1955. GE's objective was to set up a turbojet engine, connect it to a reactor, and prove that the heat from the reactor could propel the engine.

Major Facilities of the ANP Program. The project would require many support buildings in discrete activity areas. One of the first large buildings completed was the Assembly and Maintenance (A\&M) building (TAN-607). A sprawling one-story structure, it would be the place to construct, assemble, repair, and modify the experiment. The A\&M building contained a variety of fabrication shops and laboratories. The metallurgical lab contained X-ray machines for inspecting welds; the radioactive materials lab would

187. Susan M. Stacy, Idaho National Engineering Laboratory, HAER ID-32-B, Advanced Reentry Vehicle Fuzing System (Idaho Falls: INEL Report INEL-97-00066, 1997.) The summary of ARVFS activities in this section are drawn from this HAER.

188. Stacy, Proving the Principle, p. 118-120. 
examine spent fuel elements from the reactor and other radioactive samples. A Hot Shop, $52 \mathrm{ft}$ wide by $160 \mathrm{ft}$ long by $60 \mathrm{ft}$ high, with its six-feet-thick shielded windows and master-slave manipulators, allowed for the remote handling of "industrial-scale work" and radioactive substances. A chemical lab handled other chemicals, and a photographic lab was available. "Cold" shops were equipped to repair jet engines, make and calibrate instrumentation, and assemble (prior to their initial test) the nuclear power plants that would be the subject of the experiments. This building was separated from administrative and other nonresearch functions by a 15 -foot-high earth embankment located atop a natural ridge formation. ${ }^{189}$

The ANP support facilities were connected to each other by shielded roadways, tunnels, and a fourtrack railroad that would allow safe transport of people and heavy equipment from one area to another. ${ }^{190}$ GE built a unique shielded locomotive with the driver's cab surrounded by lead and water for the safety of the operator and passengers while transporting radioactively hot items. ${ }^{191}$

The Initial Engine Test (IET) facilities were located north of the A\&M building. When it was ready for a test, the reactor/engine assembly was moved to the "test pad" from the assembly area. Mounted on a dolly, the assembly could be moved in any weather enclosed in a moveable all-aluminum building. Because of the weight of the reactor assembly, the railroad tracks consisted of four rails. Operators conducted the test from a shielded underground Control and Equipment Building (TAN-620). When an experiment had been concluded and the reactor shut down, the locomotive hauled the assembly back to the A\&M building for post-test examination and further study. ${ }^{192}$

The ANP Experiments. GE built three major Heat Transfer Reactor Experiments. On December 30, 1955, HTRE-1 demonstrated that a nuclear reactor could be the exclusive source of power for an aircraft engine. This was the first time that heat from a nuclear power reaction operated a J-47 turbojet engine. The reactor generated heat, the heat was compressed and forced through the nozzle of the turbojet. In an aircraft, the nozzle exhaust would provide thrust. Measurements and additional tests continued through January 1957. The reactor/engine plant accumulated a total of 150.8 hours of operation.

In later experiments, engineers modified HTRE-1 so that they could test the impact of temperatures up to $2,800^{\circ} \mathrm{F}$. for sustained periods of time (and at even higher temperatures for shorter periods of time) on various materials within and near the reactor. ${ }^{193}$

The first two experiments had been built without regard to the space or arrangement limitations that would be relevant in the body of an airplane. The third experiment, HTRE-3, was built with the components arranged as they would be in an aircraft. Full nuclear power was achieved in 1959 and for the first time, an experiment ran two engines at the same time on nuclear power. In the course of these experiments, ANP research advanced scientific understanding of ceramics, alloys, and other materials subject to high heat. ${ }^{194}$

As the experiments progressed, GE built additional facilities at TAN. The Flight Engine Test facility was to house an anticipated airframe with typical crew compartments and aircraft control systems. The

189. APEX-15, ANPP Engineering Program Progress Report No. 15, March 1955 (Cincinnati, Ohio: GE ANPP Department, Atomic Products Division), p. 10; see also Thumbnail Sketch March 1959, p. 13.

190. Susan M. Stacy, Idaho National Engineering Laboratory, Test Area North, Hangar 629, HAER No. ID-32-A, 1995 , p. 22. Hereafter cited as "Stacy, Hangar HAER."

191. APEX-13, ANPP Engineering Program Report No. 13, September 1954 (Cincinnati, Ohio: GE ANPP Department, Atomic Products Division), p. 10-11, 195.

192. Thumbnail Sketch 1958, p. 14.

193. Stacy, Hangar HAER, p. 46.

194. Stacy, Hangar HAER, p. 46. 
major structure was a hangar building (TAN-629) with a barrel-vaulted roof and open-span interior dimensions of $320 \mathrm{ft} \times 234 \mathrm{ft}$. Associated with the hangar was a shielded control building (TAN-630) and additional four-rail track leading into the hangar. The hangar was completed in $1959 .{ }^{195}$

The project required additional test reactors to perform a variety of studies. The Shield Test Pool Facility (SUSIE), which included the SUSIE reactor, was used to examine the problems associated with shielding a human crew on an aircraft with an operating nuclear reactor aboard. Engineers tested prototypes or mock-ups of various shielding materials and configurations. The facility was located some distance from the other TAN facilities and was known as the "swimming pool" because it had two waterfilled compartments into which reactors could be submerged for the tests. Near the pool was a platform and gantry crane for "in air" tests. A control building served both the pool and the platform. Construction began in 1958 and was completed in $1959 .{ }^{196}$

Another support facility, the Low-Power Test Facility (LPTF), was located about one and one-fourth miles southeast of the A\&M area and near the Shield Test Facility. Reactor assemblies were preliminarily tested here at "zero" or low power. Two low-power reactors, the Hot Critical Experiment, and the Critical Experiment Tank were operated in the LPTF in 1958, both associated with ANP research. Several buildings were constructed there including a single-story cinder block building (TAN-640) which contained two poured-concrete test cells. A wall five feet thick served as a shield between the cells and the rest of the facility. The walls between the cells were four feet thick, allowing personnel to work in one cell while the reactor was operating in the other. ${ }^{197}$

Although GE demonstrated the principle of nuclear-powered flight, one of its major disappointments was to find that the reactor could not heat the engine air to the desired high temperatures, a requirement for fast bomber speeds. A nuclear airplane might be able to fly, but if it could not sprint at rapid speeds to evade the enemy or maneuver quickly, it could not serve as a military weapon. ${ }^{198}$

The End of the ANP Program: 1961. During the course of ANP experiments, the Department of Defense was simultaneously improving the technology of long-range guided missiles, another method of delivering a bomb to a far-away target. It proved to be more reliable and safer than a manned nuclearpowered bomber. In 1961 the new president, John F. Kennedy, was looking for funds to beef up the military's conventional forces and build the country's supply of Minuteman rockets and Polaris-firing submarines. He canceled the ANP program because, he said, "nearly fifteen years and about \$1 billion have been devoted to the attempted development of a nuclear-powered aircraft; but the possibility a militarily useful aircraft in the foreseeable future is still very remote..." The ANP cut would save \$35 million. Other military programs would, he felt, produce more tangible and immediate benefits. ${ }^{199}$

Following the cancellation of the program in 1961, which came as a shock and a surprise to the unprepared GE employees, the mission of TAN facilities changed considerably. The hangar and its control building were never beneficially used for an airplane, for example. But the hot shops, laboratories, fabrication and assembly shops could be turned to other demands and other programs. Many ANP

195. Pursuant to a Memorandum of Agreement with the Idaho SHPO, the TAN Hangar was the subject of a HAER in 1995. This document includes further design details of the Flight Engine Test Facility. See Susan M. Stacy, Idaho National Engineering Laboratory, Test Area North, Hangar 629, HAER No. ID-32-A.

196. Thumbnail Sketch March 1959, p. 14.

197. R. E. Wood et al, Operating Manual for the Low Power Test Facility (Idaho Falls: General Electric Report DC 59-8-718, 1959), p. 6.

198. Stacy, Hangar HAER, p. 46.

199. "Kennedy Asks \$2 Billion Defense Insurance Hike,” and “A-Plane Work Halt Asked by JFK in Defense Message,” Idaho Daily Statesman, March 29, 1961, p. 1 and p. 6 respectively. 
facilities were altered and reused for purposes other than their original ones. Others remained vacant or underused for years. In 1970, a private industrial council based in Idaho Falls, interested in marketing the vacant spaces at NRTS, estimated that 20 vacant buildings with over 223,000 square feet of floor space were available - most of them at TAN. ${ }^{200}$

False Starts and New Programs at TAN in the 1960s. Another nuclear-technology program that had been underway in the United States during the 1950s was a program called Systems for Nuclear Auxiliary Power (SNAP). The object of this research was to devise a compact auxiliary power system for space vehicles and satellites. By the 1960s SNAP was a joint project of the AEC and the National Aeronautics and Space Administration (NASA).

Related to the SNAP program, the AEC prepared to conduct experiments with a Lithium Cooled Reactor (LCRE). The AEC envisioned a nuclear reactor that could power an electrical generator. It would have to be small and light-weight, but able to generate high-power levels. The AEC contracted Pratt and Whitney (P\&W) in 1962 to modify the TAN hangar building for the lithium-cooled-reactor concept. $\mathrm{P} \& \mathrm{~W}$ already had done preliminary development of the concept.

P\&W started on the modifications. The hangar building would house the experiment, while the hangar's control building, parts of the A\&M building, the Health and Safety Building (TAN-607), and other buildings would house ancillary features of the project. But the work had barely begun before the AEC and NASA redirected the SNAP program, and the remodeling stopped abruptly. ${ }^{201}$

After the SL-1 reactor accident in January 1961, many TAN shops and laboratories were used in the analysis and clean-up that followed the accident. The AEC gave GE the contract to decontaminate and dispose of the debris, and GE used its many hot shops and laboratories for this work, glad to supply employment to at least a few of its ANP personnel. ${ }^{202}$

With its truncated staff, GE also took overflow work from some of the other contractors at the NRTS and did hot cell work for them. SUSIE was particularly popular. Now that the unique "swimming pool" was available to the rest of NRTS, it was in demand 24 hours a day all week long. ${ }^{203}$

GE operated the Fast Spectrum Refractory Metals Reactor, a low-power critical facility, in the LPTF from March 1962 to 1968. The main work of this reactor was to collect data for a proposed reactor concept called the 710 Reactor. This was another concept for developing a compact, high-temperature reactor for generating power in space. The reactor was to use tungsten and tantalum. The project was discontinued in 1969 when it was determined that existing non-nuclear technology could provide power needs in space. ${ }^{204}$

Also at the LPTF, GE operated the 630-A Reactor Critical Experiment to explore the feasibility of an air-cooled, water-moderated system for nuclear-powered merchant ships. Further development was discontinued in December 1964 when decisions were made to lower the priority of the entire nuclearpowered merchant ship program.

200. Dr. E. Fast, compiler, Potentially Available Facilities at the National Reactor Testing Station (Idaho Falls: Eastern Idaho Nuclear Industrial Council, February 1970), p. 14.

201. Stacy, Hangar HAER, p. 57.

202. Stacy, Hangar HAER, p. 56.

203. To Henry Dworshak from John W. Morfitt, GE Idaho Test Station, September 26, 1961; Dworshak Papers, Box 122 B, File: AEC Idaho Plant.

204. Thumbnail Sketch 1969, p. 38. 
Other experiments at TAN in the late 1960s were the Cavity Reactor Critical Experiment (CRCE) and Thermal Reactor Idaho Test Station (THRITS). Both of these were operated for the AEC by the Idaho Nuclear Corporation. The CRCE was installed in one cell of the LPTF. It was a nuclear mock-up of a reactor having complete spatial separation of its low-fuel-density core and surrounding moderator - a concept proposed by the NASA Lewis Research Laboratory for more efficient rocket propulsion. The THRITS experiment was housed in the second cell of the LPTF and served as a thermal neutron source for several short-term tests. ${ }^{205}$

In May 1963, modifications were made to the Shield Test Pool Facility to house the Experimental Beryllium Oxide Reactor (EBOR). The project's objective was to develop the technology for using beryllium oxide as a neutron moderator in high-temperature, gas-cooled reactors. TAN-645 was built as the control and administration center, and TAN-646 was for the reactor building. While EBOR was under construction, progress was made elsewhere on developing graphite as a moderator, reducing the importance of developing an alternate moderator.

Following a now-familiar pattern, the AEC terminated the EBOR program in 1966 soon after it redirected its policy toward a much narrower scope of reactor research. Only those reactor concepts that held promise for economical (commercial) power production and were efficient users of nuclear materials were of interest to the AEC. (See discussion above relating to Argonne West and the breeder reactor.) ${ }^{206}$

The ANP program represented the expenditure of about $\$ 1$ billion across a period of fifteen years, a huge commitment of the national treasure in pursuit of weapons supremacy over the Soviet Union during the Cold War. The buildings and experiments at TAN represent a remarkable legacy of the Cold War, both nationally and in Idaho history. Although not all of the money was spent in Idaho, this was the place where engineers proved that nuclear-powered flight could be achieved. Some of the buildings and facilities were one-of-a-kind creations: the hangar building, the "swimming pool" reactor, the industrial sized hot shop.

Within the last decade, a number of TAN buildings have been decommissioned and dismantled. The Initial Engine Test Facility, with its test pad, exhaust stack, railroad turntable, guard house, utility support buildings, and control bunker have been demolished. A 1956 Administration Building was dismantled, and one of the maintenance and assembly buildings (TAN-615) has been demolished. Many other buildings are in "shutdown" status awaiting further mission or other disposition.

With the end of the Air Force program in 1961, the TAN buildings lost most of their functions with respect to the "Cold War and Military Applications," one of the four themes describing reactor research at INL in the 1950s and 1960s. A few NASA-related programs came and went, but much of the work at TAN shifted to another theme entirely, that of supporting the growing commercial nuclear power industry by doing research that would improve "Commercial Reactor Safety."

\section{Sub-Theme: Commercial Reactor Safety}

\section{The SPERT/PBF Reactor Area}

The AEC Reactor Safety Program: 1955-1962. With the Atomic Energy Act of 1954, Congress and the AEC aimed to encourage the development of a commercial nuclear power industry. Of great

205. For an illustration of the gas-core reactor concept, see p. 127 of Stacy, Proving the Principle.

206. Thumbnail Sketch 1969, p. 37-38. 
concern was the safe operation of future nuclear power plants. Clearly, reactors would be located near their markets in heavily populated areas.

In 1953 the AEC's Advisory Committee on Reactor Safeguards (ACRS) had formed from a merger of two safety groups: the Reactor Hazards Committee with members appointed by the AEC, and the Industrial Committee on Reactor Location Problems, whose members came from private industry. These groups concerned themselves with the location of reactors, their operational safety, radioactive fallout, and related issues. ${ }^{207}$ The AEC and ACRS undertook safety research experiments on different reactor concepts. The incipient new private industry had a long way to go before reactor operations, even boiling water reactor operations then considered the most promising concept for commercial development, could be considered safe in locations other than isolated western deserts.

An early series of tests were the SPERT that began in 1955. Originally conceived as a program to explore the operational limits of small study reactors used in university settings, the experiments moved on evaluate the safety limits of other types of reactors as well. Testing reactors to their point of destruction continued the tradition established uniquely at the NRTS with the earlier BORAX experiments. $^{208}$

The SPERT experiments took place at a site built and operated by Phillips Petroleum Company about sixteen miles from the eastern NRTS boundary at a point where dominant winds would not carry radioactive materials across other activity areas at the NRTS in the event of a destructive reactor test. The site was a few miles northeast of the OMRE site and a few miles northwest of the Army's reactors. ${ }^{209}$

Research examined the safety requirements of containment buildings and the behavior dynamics of reactors should their power levels change rapidly. ${ }^{210}$ A major objective was to postulate various kinds of "accidents" that could occur in a nuclear power plant, determine how the reactor would respond to them, and work out ways to control or prevent such accidents. Additional goals of the SPERT program were to design power plants with improved operational flexibility and at less cost. ${ }^{211}$

SPERT experiments began in 1955 and continued until 1970. A series of specially designed and instrumented reactors were deliberately operated beyond normal safety limits to answer the simple question, "What will happen?" The data that was gathered and analyzed throughout the period was used to help design commercial reactors. ${ }^{212}$

The SPERT Control Area. The purpose of SPERT was to find basic explanations for reactor behavior under runaway conditions. The SPERT complex was therefore arranged so that the reactors could be controlled from a safe distance. The control building was located half a mile from the reactors in a fenced area $250 \mathrm{ft} \times 250 \mathrm{ft}$. This area also included a supply of raw water. ${ }^{213}$ The Control Building (later converted to a conference room in PBF-601) housed the SPERT-I reactor controls, administrative offices,

207. Richard Doan, “Two Decades of Reactor Safety Evaluation”, Memorial Lecture in honor of Dr. C. Rogers McCullough prepared for delivery at the Winter Meeting of The American Nuclear Society in Washington, D.C. November 15-18, 1970.

208. Stacy, Proving the Principle, p. 133-134.

209. T. R. Wilson An Engineering Description of the SPERT-1 Reactor Facility (Idaho Falls: Report IDO 16318), p. 8.

210. Special Power Excursion Reactor Tests (Idaho Falls: Phillips Petroleum Company, no date) no page. Hereafter cited as "Phillips, SPERT."

211. Thumbnail Sketch 1969, p. 31.

212. Phillips, SPERT.

213. Thumbnail Sketch 1962, p. 31. 
instrument and mechanical work areas, and dark room. It included sufficient expansion space for the controls and instruments of the SPERT reactors that would follow in later experiments.

The Terminal Building was about 2,800 ft from the Control Building. It housed the service facilities for the reactor, including necessary water and air equipment and a personnel decontamination and change room. It was located such that additional SPERT reactors could be built on an arc having a radius of about $400 \mathrm{ft}$ from the building.

SPERT-1. The SPERT-I experiment was located 3,000 ft northwest of the control building and included two adjacent structures - the Reactor Building and the Instrument Bunker, the latter being an earthcovered concrete structure that housed relays and other auxiliary equipment for the reactor. The two buildings were enclosed within a fenced area $150 \mathrm{ft} \times 150 \mathrm{ft}$. SPERT-I tested reactor transient behavior and performed safety studies on light-water moderated, enriched-fuel reactor systems. SPERT-I went into operation June 11, 1955. It was a simple reactor, consisting of the core in an open tank of water. ${ }^{214}$

A plate-type, enriched uranium-aluminum core was placed into the open vessel. The assembly had no provisions for heat removal or coolant circulation through the core. Total energy released during the anticipated lifetime of the facility was expected to be small, so no special biological shield was installed. The tank was four feet in diameter by ten feet high. ${ }^{215}$

The Reactor Building was a $24 \mathrm{ft} \times 18 \mathrm{ft}$ galvanized iron structure which housed the reactor and associated equipment, electrical switchgear, and other auxiliary facilities. The structure was unimposing and built to afford the minimum required to protect personnel and equipment from extreme dust conditions and winter weather. The reactor vessel and tank were in a pit embedded in the floor. The pit had a drain and sump pump for automatic removal of waste water to a leaching pond outside the building. On the northwest side of the reactor pit, and also embedded in the building floor, were eighteen tubes used for the temporary storage of reactor fuel.

The Instrument Bunker was a $10 \mathrm{ft} \times 12 \mathrm{ft}$, earth-covered, concrete block structure. Openings for instrument and electrical leads entered the bunker from the Reactor and Control buildings. SPERT-I had two instrumentation systems, one for controlling the reactor and one for studying transients. Observers in the control room watched the reactor on closed-circuit television. The camera was mounted above the tank in the reactor building. ${ }^{216}$

The SPERT-I reactor could produce bursts of high-energy neutrons for very short time periods. The reactor successfully demonstrated in 1958 that a safety device called a reactor fuse was capable of preventing a reactor runaway. The fuse worked independently of the mechanical control system and shut down the reactor by rapidly injecting a neutron absorbing gas into a chamber located within the reactor whenever the power level rose at an excessive rate. ${ }^{217}$

The SPERT-I tests showed that the reactor typically shut down following a surge of power. But in some cases, instabilities were observed following the power peaks. These divergent oscillations would probably destroy the reactor despite its self-limiting characteristics if they were allowed to continue. Determining the precise causes of these oscillations in the face of inherent shutdown tendencies in water reactors was one of the important research goals that justified the construction of additional reactors in the

214. During the start of the SPERT project, water-cooled and -moderated reactors were the most common type of reactor in the United States, and tests would be of immediate value to reactor designers.

215. Thumbnail Sketch April 1958, p. 8.

216. Thumbnail Sketch July 1962, p. 31.

217. Thumbnail Sketch June 1961, p. 32-34. 
SPERT family. By 1960 SPERT-1 had been put through more than 1,000 tests using six different reactor cores. $^{218}$

More complex SPERT reactors were under design and construction after 1958. Knowing this, researchers felt they could take greater risks with SPERT-I tests. Beginning in November 1962 SPERT-I was deliberately destroyed in a test that simulated an extreme reactor accident. SPERT-I was decommissioned in 1964. All but the outer vessel of the reactor, which had internal contamination, was dismantled. The SPERT-I site was then occupied by the Power Burst Facility. ${ }^{219}$

SPERT-III. Both SPERT-II and SPERT-III went under construction about the same time. But SPERT-III was ready for its initial criticality before SPERT-II. It consisted of a reactor vessel, a pressurizing tank, two primary coolant loops with pumps and heat exchangers. The reactor building consisted of the main section for the reactor and coolant systems and a wing for electrical switchgear, process controls, instrumentation, and other equipment. The main reactor building, a pumice-block structure, steel-girded, was $40 \times 80 \times 30 \mathrm{ft}$ high. A ten-ton crane spanned the 40 - $\mathrm{ft}$ width and served the entire length of the building. The reactor vessel was located below floor level in a pit centered twenty feet from the south wall. A process-equipment pit extended from the reactor pit to the north wall and was separated from the reactor pit by a concrete wall three feet thick.

The reactor was designed for versatility, allowing cores of different shapes and sizes to be placed in the vessel for investigation. To accommodate the different designs, the internal structure was easily removable and could be replaced by a structure that would accept a different core design. The reactor vessel and control rod drive could accommodate cores having a minimum active core height of 42 inches. $^{220}$

SPERT-III went critical on December 19, 1958, and continued to operate until the completion of its programmed operations in June of 1968. The first core in SPERT III was similar to some of the early SPERT-I cores, but the emphasis now was to vary the flow, temperature, and pressure of the coolant water in the reactor vessel to see what effect these had on excursions. The tests subjected plate-type fuels to a range of coolant temperatures and pressures, for example.

The results of the tests encouraged the nuclear power industry because they showed that operating a reactor under power-plant conditions did not significantly affect the self-shutdown of a reactor after an excursion. Beginning in 1965, SPERT-III tested another type of fuel, low-enriched uranium-oxide rods. ${ }^{221}$

SPERT-II. SPERT-II achieved criticality March 11, 1960. This pressurized water reactor had cost $\$ 4$ million and featured removable fuel plates and variable coolant flow rate and direction. The system could use heavy or light water as a coolant. It had removable internal absorber shells so that the thickness of the reflector could be varied. SPERT-II tested various moderators and various core sizes. ${ }^{222}$

SPERT-II tested the behavior of heavy-water-moderated reactors, a reactor concept that was important in Canada and potentially important in the United States. ${ }^{223}$ The tests also studied the effects of

218. "SPERT-2 Features Versatility," Nucleonics (June 1960), p. 120.

219. Site Characteristics, Volume II, Site Development Plan, 1983.

220. C.R. Montgomery, J. A. Norberg, and T. R. Wilson, Summary of the SPERT-I. -II. and-III Reactor Facilities (Idaho Falls: AEC Report No. IDO-16418, November 1957), p. 25.

221. Special Power Excursion Reactor Tests (Idaho Falls: National Reactor Testing Station, 1965), p. 31.

222. "Second SPERT Reactor in Idaho Goes Critical," Idaho Daily Statesman, March 13, 1960.

223. Only one heavy water reactor was built as a part of the Power Demonstration Reactor Program (PWDR). The Carolina Virginia Tube Reactor (CVTR) used heavy water as a moderator and coolant and operated from 1964 to 1967. 
neutron lifetime on power excursions. The reactor went on standby status in October 1964 after completing its program in August 1964.

SPERT-IV. SPERT-IV was built partly because the tank of SPERT-I was too small for further investigations of instability phenomena. Construction of the facility was completed in October 1961; initial criticality was achieved on July $24,1962 .{ }^{224}$

One of the important SPERT-IV activities involved the Capsule Driver Core (CDC), the testing of representative power reactor fuels to obtain information on the various mechanisms resulting in the destruction of reactor fuel. The information helped reactor designers provide safeguards needed to meet safety requirements. The CDC program at SPERT-IV ended in $1970 .^{225}$

Significance of SPERT. SPERT reactors at the NRTS carried out the major portion of the AEC's reactor safety program during the early part of the 1960s. They provided the nuclear industry with information needed to design and operate boiling water, pressurized water, heavy water, and open pool reactors. The work was essential in establishing the commercial nuclear power industry in the United States (and Canada.) The contributions of the program to the evolution of nuclear technology are a major reason for the significance of the NRTS in American history.

\section{Sub-Theme: Commercial Reactor Safety}

\section{The SPERT/PBF Reactor Area and the TAN Area}

The AEC Launches the Safety Test Engineering Program: PBF and LOFT Reactors. To explain the distinction among the AEC's many series of safety tests, J. A. Lieberman, AEC assistant director for Nuclear Safety, once said that SPERT tests had investigated "why" a reactor would behave abnormally, while the Safety Test Engineering Program (STEP) tests at the Power Burst Facility and Loss-of Fluid Test facility would examine "what" would happen to a reactor in a full-scale accident. ${ }^{226}$

To find out "what" would happen, the experimenters originally conceived tests that would involve full-scale reactor systems and accidents. STEP was planned as a two-phase program. One phase - the PBF reactor - would involve oxide core destructive excursion tests to be conducted in an open tank and in a closed pressure vessel. SPERT I, south of TAN, would be modified for the this phase.

The other phase would consist of the Loss-of-Fluid (LOFT) project and take place at the Flight Engine Test Facility (FETF) at TAN. New facilities would be constructed and some existing facilities modified and adapted. ${ }^{227}$ This phase would simulate loss-of-coolant (or loss-of-fluid) accidents, in which a coolant pipe would rupture. The test would deliberately initiate a rapid accumulation of heat in the reactor core and cause a subsequent release of fission products from the melting fuel. This accident was considered highly improbable to occur in a commercial reactor, but nevertheless it was posited as a worstcase accident and referred to as the "maximum credible accident."

The Power Burst Facility. The PBF reactor program advanced beyond the capabilities of the SPERT reactors. It was equipped to examine in great detail how fuel reacted under accident conditions. The reactor produced intense bursts of power capable of melting (and thus destroying) samples of fuel without

224. R. E. Heffner, et al, SPERT-IV Facility (Idaho Falls: Report No. IDO-16745, no date), p. 2.

225. Special Power Excursion Reactor Tests (Idaho Falls: National Reactor Testing Station, 1965), p. $42-44$.

226. J. A. Lieberman quoted in “AEC Plans Reactor-Safety Engineering Test Programs,” Nucleonics (February 1963 ), p. 19.

227. "Test Area North," Nuclear News, May 1969. 
damaging the rest of the assembly. A loop carrying pressurized water through the core of the PBF reactor permitted the testing of irradiated fuel samples containing highly radioactive fission products in a controlled environment.

The research and experiments conducted during these programs extended the information base upon which safety criteria, procedures, and regulations were developed. The PBF reactor was scheduled for a series of forty tests. ${ }^{228}$

Construction of the PBF reactor complex began near the old SPERT-I site on October 1965 and was completed in October 1970. ${ }^{229}$ The single-story PBF Control Center building, made of pumice block, was located at the SPERT-I control area. The reactor console was in this building. The Reactor Building, about half a mile from the control building, was $119 \mathrm{ft} \times 82 \mathrm{ft}$ and had two annex wings, a main reactor room, basement, and a sub-reactor room. . $^{23}$

The complex included a variety of support and auxiliary buildings, including a well house, substation, fabrication and development building, storage warehouses, emergency generator building, and others. Many of these buildings remain in use. Additional buildings were constructed in the PBF area after the PBF experiments ended and mission of the PBF area changed.

The PBF reactor had an open-tank reactor vessel, a driver core region where the test fuel was located, and a loop coolant system. The loop coolant system provided temperatures and pressures typical of pressurized water reactors. The water in the open pool provided cooling. The main core, usually referred to as the driver core, was fueled with $18.5 \%$ enriched uranium-235 contained in approximately 2,400 fuel rods, grouped in assemblies containing 28 to 64 rods each. ${ }^{231}$

The PBF reactor achieved its first criticality on September 22, 1972. Subsequent experiments supplemented the tests carried out in the LOFT phase of the program. The Power Burst Facility shut down after completing its mission. It is currently inactive.

Significance of the PBF Reactor. The PBF reactor was a one-of-a-kind facility. It was the only reactor in the world where severe fuel rod burst tests were performed, where rapid power changes were performed on the order of milliseconds, and where loss-of-coolant accidents could be simulated within a special assembly that fit inside the main reactor core. Like the SPERT series, it advanced the safety of commercial power reactors.

Loss-of-Fluid Test. The Loss-of-Fluid Test was commissioned in 1962 when Congress authorized $\$ 19.4$ million for the project. ${ }^{232}$ The Phillips Petroleum Company was the major contractor when construction started in the fall of 1964. The original plan for LOFT was to study a single, full power, lossof-coolant accident that would cause a full melt down of the reactor core. The concept for the test was the question: "What is the life of all the components of a commercial reactor and how good are they?" Components included the pumps, valves, pipes, conversions to power, and all the other gadgetry involved in a reactor. A fair test was thought to require a full-scale model of a commercial reactor using

228. Power Burst Facility (Idaho Falls: Prepared for the U.S. Department of Energy's, Idaho Operations Office by EG\&G Idaho, Inc. no date).

229. SPERT-I was decommissioned in 1964.

230. A. A. Wasserman, et al, Power-Burst Facility (PBF) Conceptual Design (Idaho Falls: Phillips Petroleum Report No. PTR-590, no date).

231. Power Burst Facility (Idaho Falls: EG\&G), n.p.

232. A Historical Brief of the LOFT Project at the Idaho National Engineering Laboratory (Idaho Falls: Aerojet Nuclear Company, December 1975), p.1. Hereafter cited as "LOFT Historical Brief." 
commercially available components, not the highly engineered and specialized components used by engineers doing research.

The experiment was scheduled for completion in 1967, but the project was redirected and changed several times because of debates in the nuclear industry about what kind of testing would be most useful and valuable. Eventually, it was decided that a test of safeguards intended to prevent a loss-of-coolant accident would be more valuable than a test of components, for which other testing techniques had arisen. Revising the test objective required time to modify the designs. By 1968, all construction had stopped in order to await redesign instructions. Frequent stop-starts caused by design lags, contractor problems, changes in management, the need for more funds from Congress, a labor strike, and other problems, occurred until the summer of 1976, when the facility was at last ready to have the core loaded into the reactor. $^{233}$

LOFT employed a scaled-down model (50,000 thermal kilowatts, one-fiftieth the size of a commercial reactor) of a commercial power reactor. It was placed inside a steel-and-concrete containment building (TAN-650) located just east of the ANP hangar control building (TAN-630). The experiment was mounted on the Mobile Test Assembly (MTA), a dolly pulled by a shielded locomotive over the four-track rails, so it could be shuttled between the containment building and the TAN Hot Shop for posttest analysis. (In actual practice, however, the LOFT reactor was not moved in and out of the building.) LOFT also required a service building, control and equipment building, large storage building, radioactive waste tank building, electrical equipment, water wells, a liquid waste disposal pond, and other support facilities. ${ }^{234}$

In conjunction with the revamped LOFT project, non-nuclear tests known as "semiscale" were underway elsewhere at TAN. The semiscale apparatus consisted of a small reactor mock-up equipped with an Emergency Core Cooling System (ECCS). (An ECCS was a system intended to flush coolant into a reactor core in the event that an accident interrupted the flow of the normal coolant.) Previous tests had suggested that water in the ECCS did not circulate as designed. Critics of the nuclear industry argued that the tests proved that emergency cooling systems would not work and that commercial reactors were at risk of releasing catastrophic amounts of radioactivity to the environment. The semiscale tests thus became part of the national debate over the safety of commercial nuclear power plants. ${ }^{235}$

Each LOFT experiment required time to construct and set up. The reactor vessel was installed on the MTA on November 6, 1972; the steam generator was set in place in December. In November 1973, the MTA moved into the LOFT containment vessel. During 1975, workers conducted functional testing of the LOFT systems. Non-nuclear large-break loss-of-coolant accidents (known as the L-1 series) took place from 1976 to 1978. At last, first LOFT nuclear experiment began at the end of 1978 and continued into 1979 and 1982 as the L-2 series of nuclear large-break loss-of-coolant accidents. ${ }^{236}$

The containment building was a new domed building. Its substantial 200-ton doors were ready to withstand the force arising from a flash to steam when coolant was withdrawn from the reactor core. To begin the first simulation in December 1978 scientists opened a valve to imitate a "large break" in the cooling pipe. It was over in thirty minutes. The scientists learned that water flowed into the reactor vessel

233. See LOFT Historical Brief.

234. For a full description of the planned LOFT site see Preliminary Site Evaluation Report LOFT Facility PTR-544, Phillips Petroleum Company, 1963.

235. U.S. Department of Energy, Human Radiation Experiments: The Department of Energy Roadmap to the Story and the Records (Washington, D.C.: Assistant Secretary to Environment, Safety and Health, February 1995), p. 96.

236. LOFT Historical Brief. 
faster than it was expelled in the crucial first seconds after the "break," which kept the core cooler than they had expected.

Before a second test could be arranged the following May, an accident at a commercial nuclear power plant at Three-Mile Island (TMI) in Pennsylvania caused a partial meltdown of the reactor core. LOFT scientists altered their work schedule and used their models (Semiscale) and computer programs to help determine how a potentially dangerous hydrogen bubble inside the TMI reactor could be dissipated. When the crisis was over, LOFT returned to its own test program, but as a result of TMI accelerated its study of "small breaks." The TMI experience had demonstrated that these, combined with the inappropriate intervention of human operators, potentially could be as dangerous as larger coolant-flow breaks. $^{237}$

In 1982 federal financing for the LOFT experiment ran out after thirty tests. An international consortium arranged to fund several more tests, including the last one in 1985, when scientists tried to simulate the TMI accident and melt the core. The test (numbered LP-FP-2) was performed with a specially insulated center fuel module that was the subject of the test. The main core was set up as a driver core, which created the desired experimental environment in a central fuel module. The center fuel module was the only portion of the core that simulated the "small-break" loss-of-coolant accident that occurred at TMI. The driver core of LOFT did not melt, nor did it experience conditions much different than normal operating conditions. The temperature rose to $4,000^{\circ} \mathrm{F}$, but the core did not melt. The safety system operated to flood the core and cool it off. After the analysis of this last experiment, the LOFT program ended in $1986 .{ }^{238}$

Significance of LOFT. The significance of the LOFT tests can hardly be overstated in the history of the nuclear power industry. A coincidence of historical timing linked the long-planned tests of reactor safety with the real-world accident at the TMI plant. The final LOFT tests validated the effectiveness of the safety systems that had been built into the TMI and other nuclear power plants.

The buildings associated most importantly with LOFT are the containment building (TAN-650) and the aluminum building (originally made to protect the ANP reactors from the weather) recycled as an entry into the containment building (TAN-624). The LOFT building should be preserved in place as an exceptionally significant part of American nuclear history.

\section{Sub-Theme: Commercial Reactor Safety}

\section{Experimental Dairy Farm}

Studying the Effects of Radioactive Fallout: 1957-1970. Not all nuclear research at the NRTS took place at reactors. With the growing frequency of the destructive types of tests done at SPERT, the Health and Safety Division of the AEC's Idaho Operations Office felt it would be wise to understand the potential health impacts of the radioactive releases that accompanied such tests. In the event of a large accidental release, the NRTS wished to be prepared with a plan of action aimed at protecting site employees and persons off-site and downwind of the release. ${ }^{239}$

237. Bob Passaro, "TAN has Colorful, Secretive Past, to be mothballed by 2000," Post Register, May 15, 1994, p. H-12. The damaged core and tons of other contaminated waste from TMI was sent to the Site for analysis and study.

238. Stacy, Hangar HAER, p. 62.

239. Stacy, Proving the Principle, p. 167. 
The Health and Safety division initiated a program called Controlled Environmental Radioiodine Tests (CERT). Related issues and concerns included the potential impact of radioactive releases at nuclear power plants operating at normal conditions. At the time little was known about such effects. Even less was known about the impact of accidental releases. The CERT program used radioactive I-131, one of the release products in destructive reactor tests, and gathered data on how it moved through the food chain in areas on and adjacent to the NRTS.

The Health and Safety Division already had previous experience during the early 1950s monitoring radioiodine in wildlife, natural vegetation, and on nearby farms and ranches. A number of studies had been made on the local jackrabbit population. In 1958 thyroid measurements were taken from two goats pastured near the Chemical Processing Plant (discussed below) for several days. The CERT program extended these studies, collecting its data under more controlled conditions.

The experiments involved releasing clouds of radioiodine over specific locations to answer certain questions. For example, the first tests examined what percentage of the radioiodine accumulated in the soil, grasses, and other vegetation and what percentage drifted off into the airshed. Then, when cows grazed on the grass, what percentage of the radioiodine was excreted and how much went into the cow's thyroid or milk. A final question involved determining what percentage of the material would end up in a human thyroid after drinking the cow's milk. ${ }^{240}$

To gather data on the human thyroid, the experiments had to involve volunteers who would drink the milk and then be measured for the iodine. The first experiment using cows and humans was conducted in May and June of 1963. Because permanent facilities were not yet available, CERT I took place on the "open range," an unirrigated section of land near the southern boundary of the NRTS. A temporary barn, corral, and control trailers were placed in the area on temporary foundations. Two pasture areas were established, one "hot," or radioiodine-contaminated and one "cold," where the cattle could be grazed prior to the experiment. Seven human volunteers drank the contaminated milk. Their thyroid activity was measured over a six-week period. ${ }^{241}$

The Experimental Dairy Farm, located about seven miles northeast of the ICPP, was built during the summer of 1963. The site was selected for its location relative to reactors and roads, water availability an adequate well already existed - and because the land was unused and available. The farm was intended to duplicate regional farming methods. Facilities included a dairy barn, pumphouse, sprinkler system and corral. A twenty-seven acre pasture was established, and grass seed was planted.

The CERT experiments waited until the following September when the grass had matured. Six cattle were again grazed on the hot pasture following the release of radioiodine. Humans again participated in drinking contaminated milk. Related experiments measured thyroid activity following inhalation of I-131 by three people who sat in the pasture as the radioiodine cloud passed over it. ${ }^{242}$

240. John R. Horan, editor. Annual Report of the Health and Safety Division, Idaho Operations Office (Idaho Falls: 1958), p. 95; D. F. Bunch, editor. Controlled Environmental Radioiodine Tests, Progress Report Number Three (Idaho Falls: Health and Safety Division, Idaho Operations Office, U.S. AEC Report IDO-12063 1968), p. 2-4; Human Radiation Experiments: Department of Energy Roadmap to the Story and The Records (United States Department of Energy, Assistant Secretary for Environment, Safety and Health Report No. DOE/EH-0445, February 1995.)

241. C.A. Hawley, et al, Controlled Environmental Radioiodine Tests, National Reactor Testing Station (Health and Safety Division, Idaho Operations Office, U.S. AEC Report IDO-12035, 1964), p. 2-10; C.A. Hawley, editor, Controlled Environmental Radioiodine Tests at the National Reactor Testing Station, 1965 Progress Report (Health and Safety Division, Idaho Operations Office, U.S. AEC Report No. IDO-12047, February 1966) p. 2.

242. Hawley, IDO-12047, p. 4-5. 
Later experiments measured radioiodine deposits and dispersion under various weather conditions and in different seasons or times of day. In 1967 the experiments were modified to provide more detailed information. Stalls built in the barn allowed individual monitoring of each cow's water and feed. Careful measuring of feed and use of a "chopper" allowed more accurate measurement of iodine dosage than was possible when cattle grazed freely. These refinements reflected the growing sophistication of the investigation. ${ }^{243}$

The CERT program contributed to the worldwide efforts of scientists to learn more about the environmental effects of nuclear power plant operation. Previous studies at Hanford, Washington, and Oak Ridge, Tennessee, had provided some information about the dispersion of radioiodine, but the field and laboratory studies at the NRTS were more comprehensive. They provided data for computer models that predicted the transfer of iodine through the food chain to milk and subsequently as doses to human beings. The CERT study helped, in fact, to illuminate the key role of the food chain in the transfer of radioiodine and other substances. CERT data laid a basis for understanding the impacts of releases that might occur after an accidental release. CERT provided some of the most comprehensive and useful data available in the United States or anywhere else. The findings, in conjunction with data from other studies, helped scientists realize that the allowable releases of radioactive materials from nuclear power plants had to be reduced. CERT studies eventually led to regulatory changes reducing such discharges from lightwater reactors. $^{244}$

Two buildings related to CERT are extant, the barn (B16-603) and a pumphouse (B16-604). The barn has been converted for use as a storage building. They are a remnant of a frontier-like period in nuclear research when the impact of radionuclides on human health through the food chain and direct inhalation involved people and animals, helping to set parameters for future computer modeling, commercial reactor operations, and emergency planning.

\section{Sub-Theme: Chemical Reprocessing}

\section{Idaho Chemical Processing Plant}

Establishment of the Chemical Processing Plant: 1949-1954. The ICPP (now INTEC) was designed by the same group of physicists and chemists who had designed the MTR. As a companion facility for the MTR, it was equipped to receive the MTR spent fuel elements and extract valuable U-235 from them. The spent fuel contained radioactive elements such as Strontium-90, Cesium-137, and other substances dangerous to human life. At the end of extraction process, the ICPP shipped the recovered U235 to Oak Ridge, Tennessee, for further steps leading to the remanufacturing of fuel elements. The uranium was not a hazard, but the ICPP had to store or otherwise dispose of the dangerous materials left behind. $^{245}$

The ICPP was one of the four original areas developed at the NRTS. Although its originators conceived it as an auxiliary to the MTR - to recover the uranium in its highly enriched fuel — its mission expanded to include processing of spent fuel from other sources. With the escalation of tensions between the United States and the Soviet Union, aggravated by the Korean War, the AEC shifted the

243. J. D. Zimbrick and P. G. Voilleque, editors, Controlled Environmental Radioiodine Tests at the National Reactor Testing Station, Progress Report Number Four (Health and Safety Division, Idaho Operations Office, U.S. AEC Report IDO-12065, January 1969), p. 2, 5.

244. J. Newell Stannard, Radioactivity and Health, A History (Hanford, Washington: Pacific Northwest Laboratory, 1988 ), p. 1358.

245. The ICPP was renamed Idaho Nuclear Technology and Engineering Center (INTEC) in 1999. This report will use the historic name. 
majority of its resources to developing atomic weapons. The plutonium-producing reactors at Hanford, Washington, sent some of their spent fuel to Idaho. ${ }^{246}$

During normal operations, the MTR shut down every 17 days to remove its depleted fuel. By this time, less than a fourth of the U-235 had fissioned, leaving a substantial amount of U-235 in the fuel elements. Rather than discarding this costly material, it was possible to extract it from the aluminum cladding and other substances that had accumulated in the fuel in order to reuse it for new fuel elements. $^{247}$

Establishing the ICPP required hiring and training its operators and then running "cold" operations with simulated waste to test the facility. After that, the first hot runs began processing spent Hanford fuel on February 16, 1953, with fewer than 100 employees. ${ }^{248}$

The Modified PUREX Process. Uranium was extracted from the fuel elements in a multi-step chemical treatment process known as a modified PUREX (Plutonium and URanium EXtraction) process. (The PUREX process had been developed during the Manhattan Project.) The fuel was dissolved in a solution of nitric acid. This liquid then was "run" by steam-jet suction through three extraction processes or "cycles," in which chemical additives, catalysts, and mechanical actions produce a sequence of chemical reactions resulting in the separation of uranium from the other metals, acids, and fissionable products in the solution. "Waste" products - solids, gases, and liquids - accumulated upon completion of each cycle. The uranium product was then shipped to Oak Ridge, where it was further prepared for remanufacture into new fuel elements. ${ }^{249}$

Siting and Designing the ICPP. The ICPP was located to be convenient to the MTR and to the CFA. Initially consisting of 82 acres, the plant was located about three and a half miles north of the Central Facilities Area and on the east side of Lincoln Highway. TRA (now RTC) is another mile and a half further northwest on the west side of the highway.

The Foster-Wheeler Company designed the plant. The Bechtel Corporation built it. The first operating contractor, American Cyanamid, managed construction, recruited and hired operating personnel, and developed the first operating manuals. On October 1, 1953, Phillips Petroleum Company took over the plant and continued managing it until 1966, the first in a series of five operating contractors. $^{250}$

The plant buildings were contained mostly within the rectangular perimeter boundaries of a security fence. By no means did these consume the entire 82 acres; the designers planned for growth and expansion. Today the perimeter fence encloses 210 acres, and an additional 55 acres lie outside the fence. ${ }^{251}$

246. Stacy, Proving the Principle, p. 94-97.

247. Stacy, Proving the Principle, p. 69.

248. Stacy, Proving the Principle, p. 101.

249. For a more detailed description of the ICPP's modified PUREX process, see Brewer F. Boardman, The ICPP (A Factsheet) (Idaho Falls: Idaho Operations Office, 1957). For a general description of the plant and its operations, see R. B. Lemon and D. G. Reid, "Experience With a Direct Maintenance Radiochemical Processing Plant," Proceedings of the International Conference on the Peaceful Uses of Atomic Energy, Volume 9 (New York: United Nations, 1956), p. 532-545.

250. Succeeding operators were Idaho Nuclear Corporation, 1966-1971; Allied Chemical, 1971-1979; Exxon Nuclear Corporation, 1979-1984; Westinghouse Idaho Nuclear Corporation, 1984-1994; Lockheed Martin Idaho Corporation, 1994-present.

251. "Land Use Information, www.inel.gov/resources/flup/icpp.html. 
One way to identify the main features of the site is to follow a shipment of fuel as it arrived at the ICPP gate. The fuel arrived packed in heavily shielded transport casks carried in specially equipped carrier trucks or by rail. After passing through the main guard gate at the west side of the plant, the truck headed south about a third of a mile away to CPP-603, the Fuel Storage Facility, isolated from the main activity area for safety. The truck entered special bays for the transfer operation. Unloading of the fuel to one of two transfer basins was handled remotely. The fuel elements were placed in stainless-steel buckets, suspended from overhead racks, and the whole apparatus placed in a water-filled basin. At least $15 \mathrm{ft}$ of water was above the submerged fuel at all times. This water was recirculated and refreshed daily, the overflow going to a percolation pond just to the south of CPP-603 and on the outside of the perimeter fence. The Fuel Storage Facility had its own heating and air cleaning system and its own generator for emergency power supply. Water came from the main plant source, but was metered and filtered with separate equipment. The structural-steel building was covered with Transite siding. Before arriving at the ICPP, the fuel typically had had at least 90 days of cooling time. Here it cooled off for another 120 days or more.

When the proper time had elapsed and the operators had accumulated sufficient fuel to "run" the extraction process at the Fuel Processing Complex (CPP-601), a "straddle carrier" transferred the fuel to the "head end" (south end) of CPP-601. The first step was to dump the fuel element into a vessel of nitric acid to dissolve it - cladding, fuel, and all. From there it went via a complex system of piping from one process cell to another, each step producing various waste products. Each product in this waste stream required treatment before it could be released to the atmosphere or stored. All vessels and piping were sized (small) to prevent the accidental accumulation of a critical mass of fissionable fuel.

The process complex was designed for direct maintenance. This meant that during periodic shutdowns, workers could decontaminate work areas and perform maintenance tasks on the equipment. A minimum of moving parts made for simplicity, although essential items such as transfer jets, valves, and pumps were installed in pairs, one being a spare. High-maintenance equipment was placed in crewaccessible lead-shielded cubicles outside the hot process cells. Cleaning solutions were sprayed into the cells, flushed out, and then entered by maintenance personnel via ladders.

The portion of the building above grade contained no uranium-processing equipment. It was constructed of steel framing and insulated with Transite siding. Chemicals added to the process feed were stored in tanks on this level. ${ }^{252}$

Waste products left the process building in underground pipes eastward to the Waste Treatment Complex, which included three main waste processing buildings and a tank farm. One of the buildings (CPP-604) housed the equipment necessary to recover Krypton-85 gas and generally reduce the volume of waste. Another (CPP-605) housed blowers which provided vacuum to process cells and exhausted filtered off-gases to the 250-ft-tall main stack (CPP-708). The Complex recovered all of the nitrogen and oxygen needed at the ICPP and other parts of the NRTS site. Further east of the Waste Complex downwind of operations - was the 250 -ft stack. ${ }^{253}$

North of the Waste Treatment Complex is the Waste Tank Farm, constructed in 1953. Buried here were two 300,000-gallon stainless-steel tanks for storing high-level radioactive liquid wastes. Each was enclosed in a concrete vault and buried under ten feet of earth. One tank, which received the very "hot" first-cycle waste, was equipped with cooling coils; the other was not. A large empty area was left near

252. The progress of fuel to be reprocessed is extracted from "Chemical Processing of Reactor Fuel Elements at the Idaho Chemical Processing Plant," Proceedings of the Geneva Conference (New York: United Nations, 1955), reprint pages 14-23.

253. R.D. Logan, INEL Building Study, Idaho Chemical Processing Plant (Idaho Falls: INEL Energy Management, 1990), p. 33-36. 
these two tanks for future expansion. This restricted area contains structures housing instrumentation for monitoring the contents of the tanks.

The rest of the site was developed to complement and serve the main process. A laboratory and administrative building (CPP-602) adjoined the process building on the north. This building contained offices, cafeteria, health physics services, first-aid facilities, low-level and high-level laboratories, and a machine shop. A service building (CPP-606) at the north side of the laboratory housed the steam plant, electrical equipment, and ventilating equipment for the laboratory buildings. This too was built of structural steel and sided with Transite. Outside the perimeter fence on the northeast side was the sewage lagoon for sanitary wastes. ${ }^{254}$

As the ICPP was designed to be a "multi-purpose" plant, it was adapted from time to time to improve or perform specialized functions. One of them was the recovery of radioactive Barium from day-old MTR fuel. The L Cell in CPP-601 — with extra-thick concrete shielding - contained centrifuges and other equipment related to this process and also to the handling of the off-gas byproducts. The researchers hoped to find a way to precipitate only the target element from a more complex solution. A Fuel Element Cutting Facility was attached to CPP-603 near the railroad siding to aid in the handling of fuel casks and fuel elements. ${ }^{255}$

The operation of the plant and its processes required substantial quantities of water. This was pumped from the Snake River Plain aquifer into two 500,000-gallon storage tanks at the north end of the site. As needed, water was demineralized or otherwise treated depending on its particular use.

The Role of the ICPP in the Cold War. As the Cold War and the arms race progressed, the United States poured its resources into weapons development, striving to assure its supremacy. Elsewhere in the country, the AEC's plutonium-production reactors were expanding. At the NRTS, all research missions bent to the compelling needs of national defense. From its original mission of reprocessing only MTR and Hanford fuel, the ICPP was adapted for more flexibility as a multiple-purpose processing plant.

Eventually, it would process fuel from a wide variety of research, test, propulsion, and power reactors. In addition to aluminum clad fuels, it would dissolve fuels clad in zirconium, stainless steel, and other materials. It handled fuel from EBR-I, BORAX, and other experiments around the NRTS site. ${ }^{256}$

ICPP Adds New Processing Functions: 1955-1970. By the deliberate effort of Congress and the AEC, the supply of spent fuel was destined to grow as a consequence of reactor development. Congress passed the Atomic Energy Act of 1954, and the AEC and Congress's Joint Committee on Atomic Energy did what they could to nurture a commercial atomic power industry. The U.S. Navy launched the USS Nautilus submarine in the 1950s and then built a large fleet of ships propelled by nuclear reactors. Shippingport, an AEC demonstration reactor, went on line in Pennsylvania in 1957, the first large reactor to be built for civilian purposes. Research programs at the NRTS tested the safety limits of reactor fuels and core constructions. General Electric and Westinghouse scaled up the demonstration and began to sell reactors to electric utility companies. A commercial industry began to grow. Clearly, this success meant that spent fuel would need reprocessing.

With every processing run at CPP-601, a stream of high-level waste inevitably flowed into the stainless-steel tanks at the ICPP tank farm. After the first one was filled, another was made ready, and

254. "Chemical Processing of Reactor Fuel Elements at the Idaho Chemical Processing Plant," Proceedings of the Geneva Conference (New York: United Nations, 1955), reprint p. 19

255. Thumbnail Sketch 1956, p. 6.

256. Thumbnail Sketch November 1958, p. 15. 
then another. By 1960, 13 tanks populated the ICPP tank farm. Nine 300,000-gallon vessels held aluminum-type wastes; the other four each held 30,000 gallons of zirconium and stainless steel. Awash in a million gallons of liquid were only ten gallons of radioactive material. ${ }^{257}$

Scientists knew that metal tanks could not serve as a long-term method for storing the waste. They regarded the life of a stainless-steel tank to be no longer than 50 years because the acids from within or moisture from without would eventually corrode the metal. The hazard they wished to avoid was to have the radioactive liquid leak into surrounding soils and ground water. Far more than 50 years were required to sequester the waste - several centuries would have to elapse before the process of radioactive decay could reduce the hazard potential significantly. ${ }^{258}$

Therefore, chemists in the AEC's national laboratories launched investigations into "interim" and "ultimate" disposal of these wastes. One of the concepts for dealing with the growing volume of liquid waste was to transform it somehow into a dry solid, eliminating the water. This meant designing a process that would concentrate radioactive substances into a dry form, leaving the water clean enough to discharge into the environment. This could be an "interim" step in storing the waste. The volume could be reduced and the hazard of corrosion and leakage minimized. It was also conceivable that the solid form might be rendered even more inert or stable using processes as yet unproven.

Scientists proposed several ideas for transforming liquid into an inert solid-carrier waste. A 1954 study from Brookhaven National Laboratory suggested that radioactive ions could be made to adsorb and fix upon montmorillonite clay. Other studies proposed fixation in ceramic glazes or "gelling" liquids above the sludges that form in the tanks. Various techniques for solidifying the waste included pot calcining, radiant heat-spray, and rotary-ball kilns. Some proposed to incorporate the wastes into lowmelting salts and store the material in underground salt caverns equipped to remove heat. Another optimistic hope was that some breakthrough chemical means of decontaminating the radioactive constituents might be found. At Oak Ridge National Laboratory, workers were investigating the possibility of mixing waste with shale, limestone and soda ash and allowing decay heat to fix the material in a ceramic mass. Still other proposals sidestepped the problem altogether and proposed to discharge it into the oceans or outer space. ${ }^{259}$

The Waste Calcining Facility. The first liquid-to-solid procedure that the AEC decided to fund for actual demonstration, however, was the "fluidized-bed calcination process," built at the ICPP. The development program began in 1955. Originally conceived by scientists at Argonne National Laboratory, the method was first tested using small-scale models and then built by Phillips Petroleum at the ICPP. The process not only solidified the waste, but the solid was granular, free-flowing, and easily handled by

257. To Senator Henry Dworshak from John B. Huff, August 21, 1958; Senator Dworshak Papers, Box 83, File "AEC—Idaho Plant.” Also, "Idaho Falls: Atoms in the Desert," Chemical Engineering (January 25, 1960), p. 5 (of reprint.)

258. The half-life of Strontium-90 is 29 years; of Cesium-137, 30 years. A half-life is the time required for one-half of the atoms of a radioactive substance to disintegrate. The process is independent of temperature, pressure, or surrounding chemical conditions.

259. See W. S. Ginnell, J. J. Martin, and L. P. Hatch, "Ultimate Disposal of Radioactive Wastes," Nucleonics ( December, 1954), p. 14-18; "Outlook for Waste Disposal," Nucleonics (November 1957), p. 155-164; The Waste Calcining Facility at the Idaho Chemical Processing Plant, pamphlet, no date, no author, p. 2; Joseph A. Lieberman, "Treatment and Disposal of FuelReprocessing Waste," Nucleonics ( February 1958), p. 86; and J. I. Stevens, et al, Preliminary Process Criteria and Designs for Waste Calcining Facilities at the Idaho Chemical Processing Plant (Idaho Falls: Phillips Petroleum Company Report No. PTR177, February 25, 1957), p. 5. 
pneumatic transport techniques. Phillips engineers proposed early conceptual designs for the process in $1956 .^{260}$

The concept of fluidized bed technology was not new. It had been applied in the petroleum, iron and steel, and limestone industries. As applied to liquid radioactive wastes at the WCF, it involved placing a bed of sand-like granular material at the bottom of a cylindrical vessel - the calciner vessel. The grains are then heated to temperatures of $400^{\circ} \mathrm{C}$ or more by a heat exchanger placed directly in the bed. A flow of hot air was introduced into the bed through fourteen holes at the bottom of the vessel and evenly distributed to the grains, placing the grains in motion, or "fluidizing" them. Liquid waste was fed as a fine mist into the vessel by pneumatic atomizing spray nozzles. In the hot environment, the water vaporized and the solids adhered to the small starter grains tumbling around in the fluidized bed. As the process continues, the solids knock against each other, causing particles to flake off and form the starter grains for the continuously sprayed liquid feed.

Congress appropriated funds in 1957 for the early phases of the WCF design. The AEC awarded a contract to Fluor Corporation to be architect/engineer for the project. In 1958, the AEC asked Fluor to complete and construct the system. The facility cost about $\$ 6$ million. Fluor commenced construction in 1958 and completed the facility in 1961. Phillips took control of the building and began two years of "cold" trouble-shooting operations using simulated waste. ${ }^{261}$ Hot operations began with the first run, called a "campaign," on December 23, 1963.

The WCF expanded the ICPP area to the east. The building (CPP-633) was placed southeast of the stack, where room still further east was available for the special tanks that would store the calcine. The building handled the entire process, receiving its fluid feed from underground piping extended from the main process building. The dry calcine - called alumina - exited the facility propelled by pneumatic pressure to storage facilities called "bin sets" about a hundred feet east of the building.

Each bin set contained from three to seven vertically positioned stainless-steel tanks. Partially above grade level, they were shielded by an earthen berm. On top of each bin set was an "instrument shack" and other devices designed to monitor the accumulation of waste heat and detect leaks or other problems. Seven bin sets have been constructed at the site. Experience with calcine led to modifications of the earliest bin set design. It was not known just what products in the solid might prove to have future value, so the storage containers were designed so that the calcine could be retrieved for some future purpose. All operations had to take place so that radioactive particles could not enter the air or water supply. ${ }^{262}$

The over-riding imperative guiding the design of any process dealing with hazardous radioactive waste is to protect workers from danger. The calcining building followed the same principles that had been implemented in the design of the Fuel Processing Complex (CPP-601). Process equipment was decontaminated using automated methods, and then maintained "directly" by crews. Radioactively hazardous areas were located below grade, while the non-radioactive service areas were on the ground floor.

260. See C. E. Stevenson, et al, Waste Calcination and Fission Product Recovery Facilities-ICPP, A Conceptual Design (Idaho Falls: Phillips Petroleum Company Report PTR-106, August 2, 1956); and D. R. Evans, Pilot Plant Studies with a Six-Inch Diameter Fluidized Bed Calciner (Idaho Falls: Phillips Petroleum Company Report No. IDO-14539), p. 2.

261. News release from Idaho Operations Office of the AEC, February 5, 1957; Senator Dworshak Papers, Box 74, File "Legislation-AEC-Idaho Releases." See also "Fluor Gets Contract to Complete Calcination System," Nucleonics (November 1958), p. 27; and L. T. Lakey, et al, ICPP Waste Calcining Facility Safety Analysis Report (Idaho Falls: Phillips Petroleum Company Report No. IDO-14620, 1963), p. ii-1.

262. PTR-177, p. 7-8. 
The WCF building contained everything required for the calcining process except for the tanks that stored fuel oil and the bins that would store the calcined product. Filtered off-gases went up the main stack, and other wastes were sent through the calciner along with the fresh liquid feed.

The ICPP Operating Routine. With the calciner the ICPP had two major chemical processing operations underway. Phillips established a routine whereby the two processes alternated their "run" operations. While the main processor operated, a crew decontaminated and maintained the calciner. Likewise, when the calciner ran, the main processor was shut down for repair and cleaning. A traveler on Highway 20, just outside the NRTS site, could always tell when the calciner was operating because the stack exhausted an orange-yellow plume of nitric oxide gas, a byproduct of the calcine operation.

A range of laboratories complimented the site. In analytical laboratories, chemists routinely examined samples of solutions from various stages of chemical processing. They checked for uranium isotope content, acidity, and other parameters. To accommodate the type of analysis required, laboratories were "hot," "warm," or "cold," and designed accordingly. In addition, some laboratories were devoted to "wet" chemistry, examining primarily liquid solutions. Equipment such as mass spectrometers and x-ray devices sometimes required special enclosures or shielded cells.

Meanwhile, in the ICPP laboratories, chemists and engineers conducted tests and studies aimed at increasing the productivity and effectiveness of each process. One of the problems with the calciner, for example, was that the fluidized bed was heated by means of a circulating loop of NaK. Unplanned plant shutdowns frequently occurred because of leaks in the NaK piping. In 1970, in time for the fourth calciner campaign, the $\mathrm{NaK}$ system was replaced by a direct combustion system. Engineers refitted the calciner vessel so that kerosene and oxygen could be sprayed into it. Nitrates from the waste feed would ignite it, placing the heat in intimate contact with the moving particles in the bed. This method supplied steady temperatures of $450^{\circ} \mathrm{C}$. Overall, the new system was less hazardous because hydrocarbon fuel piping was more reliable than $\mathrm{NaK}$ piping. ${ }^{263}$

Other improvements took place at the main process facility. Better head-end equipment was installed for "cutting" fuel elements, reducing the amount of nonirradiated metal cladding dumped into the acid dissolver. A railroad track was built between the ICPP and the Naval Reactors Facility to facilitate the transfer of USS Nautilus and other fuels from that area. ${ }^{264}$

By 1959, the ICPP was engaged in a joint project with the United States Geological Survey to monitor the aquifer downstream of the ICPP injection wells, into which the plant pumped low-level liquid wastes. Fifteen such wells sampled water downstream.

Failure of Commercial Processing. ICPP scientists also contributed to the government's effort to develop a fuel processing capability in the growing commercial nuclear power industry. The AEC hoped that private industry would handle fuel from civilian power reactors. In January of 1956, the NRTS sponsored a conference to which 600 representatives from industry were invited to learn more about the costs and problems involved in processing spent fuel. ${ }^{265}$

263. C. L. Bendixsen, Safety Analysis Report for the Conceptual In-Bed Combustion System for the Waste Calcining Facility (Idaho Falls: Idaho Nuclear Corporation Report No. CI-1119), p. 1, 27; and Bendixsen, Safety Review Report for the In-Bed Combustion System for the Waste Calcining Facility (Idaho Falls: Idaho Nuclear Corporation Report No. CI-1175, March 1970), p. 1-2. Nitrates in the waste feed interact with the kerosene to produce more benign nitrogen compounds.

264. AEC-Idaho Operations Office Press Release, December 7, 1956, in Dworshak Papers, Box 55, File "AEC_-Idaho Plant."

265. W. K. Davis to "Gentlemen," December 1, 1955, letter of announcement in Dworshak Papers, Box 55, File "AEC—Idaho Plant." See also Harold S. Vance, testimony before the JCAE, February 1958, p. 30-31. Copy in Dworshak Papers, Box 88, File "AECCommittee Reports 1958." 
By 1960, government efforts to encourage a commercial fuel processing facility had failed to have the desired result. Therefore, the AEC reluctantly developed a plan for processing the spent fuel from civilian reactors. Because of the growing variety of fuel, it assigned certain kinds of fuel to each of its reprocessing plants and laid plans to expand the capabilities of the plants. To Idaho, it assigned highly enriched fuels, aluminum clad fuels from forty test reactors around the country, zircaloy-clad, and stainless-steel-clad fuels. ${ }^{266}$

Then, still hoping private industry would take hold, it held off making the improvements. However, in June 1961, the AEC signed a contract to process highly enriched U-235 spent fuel from the Vallecitos Boiling Water Reactor in California, a commercial reactor owned and operated by Pacific Gas and Electric Company. The unburned fuel was worth $\$ 500$ an ounce. In 1963, the ICPP began receiving rail shipments containing $90 \%$ enriched fuel from the R-2, a test reactor in Sweden. ${ }^{267}$

With an increasing number of reactors, more fuel was on the nation's roads and railways traveling farther distances. (The Swedish fuel took twelve days to arrive from the port of Savannah, Georgia.) Safety requirements for fuel shipping casks became more stringent. Casks became larger and heavier, requiring retrofitting of transport bays, docks, and cranes at the ICPP Fuel Receiving Facility. ${ }^{268}$

Finally, as commercial power plants went on line all over the country during the 1960s, a private processing plant began operating at West Valley, New York. Although it was subsidized by the AEC, which had guaranteed West Valley a certain amount of fuel at a low price, the plant was not a success. It lost money in each of the six years it operated. The AEC shared with the operators its PUREX formulas, but the contractors were unable to operate the plant safely. The plant operated only until $1972 .{ }^{269}$

Meanwhile, the ICPP continued to adapt its process for new fuels. The main process building was modified in 1973 so it could process the stainless-steel-clad elements from EBR-II. The graphite matrix fuels from Project Rover (an effort to use nuclear power to propel a rocket tested in Nevada) eventually came to Idaho, where a new head-end process had to be designed for those fuels. ${ }^{270}$

Peach Bottom Fuel Arrives at the ICPP. During the 1960s, the AEC encouraged the development of a reactor concept in which the coolant was a gas. It built an Experimental Gas-Cooled Reactor at Oak Ridge and then licensed a privately financed demonstration gas-cooled reactor at Peach Bottom, Pennsylvania. Spent fuel from these reactors had graphite cladding, which reacted unacceptably with water. It could not be stored in the underwater basins of the Fuel Storage Building (CPP-603).

Therefore, the ICPP added special dry storage facilities to its landscape. In 1971, the first Peach Bottom fuel was stored in 47 underground steel-lined vaults. Each was $3-\mathrm{ft}$ in diameter, $20 \mathrm{ft}$ deep, and topped with a heavy shielded concrete cover. Later, fuel arrived from the High Temperature Gas Cooled Reactor (HTGR) at Fort St. Vrain, Colorado. This fuel, and part of the Peach Bottom fuel, was placed in a

266. C. E. Stevenson, "How AEC Plans to Process Power Reactor Fuels," Nucleonics (February 1960), p. 72-73; and "Two CivilianFuel Reprocess Plants to Begin," Nucleonics (September 1959), p. 29. The AEC in 1959 began two projects to handle civilian fuels at Hanford and Oak Ridge. To these and a plant at Hanford, it assigned specific types or sources of fuel.

267. “AEC Takes Two Steps to Encourage Private Industry,” Nucleonics (May 1960), p. 27; "Fuels Reprocessing: Will Davison Build First Private Plant?" Nucleonics (December 1960), p. 23; and AEC Press Release, June 6, 1981, Dworshak Papers, Box 122B, File "AEC Press Releases;" and "U.S. Fuel Back for Reprocessing," Nucleonics (August 1963), p. 49.

268. "AEC to Adopt Rules for Shipping Spent Fuel," Nucleonics (November 1961), p. 46; "The First Foreign Shipment of Spent U.S.Supplied Reactor Fuel Arrives in Savannah," Nucleonics (September 1963), p. 18-20.

269. Walter C. Patterson, The Plutonium Business and the Spread of the Bomb (San Francisco: Sierra Club Books, 1984), p. 45-46.

270. Thumbnail Sketch 1973, p. 13-15. 
special concrete building (constructed in 1975) attached to CPP-603. The building had manipulators and storage racks arranged so that an accidental criticality could not occur. ${ }^{271}$

With the arrival of Peach Bottom fuel in 1971, the role of the ICPP rounded itself out not only as the operator of two major processing activities, but also as the warehouser of a wide variety of fuels in both wet and dry conditions. And, of course, the plant contained eleven huge stainless steel tanks of liquid wastes and a gradually growing inventory of calcine bin sets. Thus established, the plant continued to refine its methods, replace aging facilities, and research methods of processing nuclear fuels and the waste it generated.

Significance of the ICPP. ICPP has played a groundbreaking role in the process of recovering and reprocessing unburned, enriched uranium from "spent" reactor fuel elements, and has been a leader in the development of new technologies to manage nuclear wastes. Although fuel reprocessing at ICPP ended in 1992 and the final waste calcining campaign occurred in June, 2000, their contributions to the history of nuclear science have been significant.

Waste Calcining Facility-The significance of the Waste Calcining Facility already has been acknowledged by the preparation of a HAER study. (The WCF was demolished in 1984.) The WCF was the first plant in the world to demonstrate successfully a practical method of transforming liquid highlevel radioactive waste into a solid form. The process reduced the volume of the waste by a ratio of up to 10:1. The solid form was easier and safer to transport. The stability of the solid form reduced the likelihood that storage tanks would corrode, causing accidental releases into the environment (as has happened at Hanford and other DOE facilities). The storage containers for solids have a design life of 500 years, whereas the tanks holding the waste in its liquid form had a design life of only 50 years. Further, the process proved adaptable to a variety of chemicals deriving from different types of reprocessed fuels. The success of the WCF has meant a highly significant reduction in risk in managing high-level liquid waste at INL.

The quest for a workable calcining process at INL began early. Once operating, it continued reliably, and operated regularly. Partly because of it, INL has no record of highly-radioactive liquid waste leaks into the soil or groundwater from tank leakage, a record not shared by the other AEC waste sites.

Calcining constituted a significant reason for optimism in the pursuit by scientists of a safe nuclear-fuel cycle. Although the costs of development and operation of the calcining process were high, calcining may prove to have been the lowest-cost, long-term choice because it has avoided the much higher cost of remediating serious leaks into the environment.

Fuel Reprocessing Facility-The other major process of the ICPP is significant for the steady and successful recovery of spent uranium from reactor fuels. Although other facilities in the United States reprocessed spent fuel, the ICPP was equipped and modified to handle certain fuel types uniquely. The ICPP has been an integral part of the operations of the NRTS from its very beginning in 1949. Few of the other facilities at the NRTS could have operated as effectively as they did without the fuel reprocessing, fuel handling, and fuel and waste storage facilities at the ICPP.

271. Thumbnail Sketch 1973, p. 16. 


\section{CONTEXT IV: MULTI-PROGRAM RESEARCH: 1971-PRESENT}

\section{Sub-Theme: Reactor Testing, Experimentation, and Development}

\section{Central Facilities Area}

CFA and Changing Missions: 1970s-Present. Political upheavals during the 1970s affected how government controlled the nuclear industry. The AEC was abolished, replaced briefly with the Energy Research and Development Administration (ERDA), and then by the Department of Energy (DOE) in 1977. The NRTS changed its name to Idaho National Engineering Laboratory in 1974, emphasizing its status as a national laboratory. ${ }^{272} \mathrm{New}$ environmental laws, the energy crisis, and nuclear power plant accidents obliged the INL to focus its resources on energy efficiency, nuclear waste cleanup and increased worker safety requirements.

EG\&G became the primary Maintenance and Operations contractor of the INL in 1976. Until about 1979, very little new construction had taken place at CFA - a few additional storage facilities, utility buildings, and craft shops. Then the pace quickened. In 1979, a new High Bay Lab (CF-686) and office buildings for Morrison-Knudsen and EG\&G were constructed. The old hot laundry facility was remodeled to meet DOE standards for energy efficiency.

Similar changes occurred in the 1980s. New office buildings were needed to deal with health and safety issues: office buildings (CF-612 and -614), and Hazardous Waste Storage Facility Field Offices (CF-655). New multicraft shops replaced several outdated facilities.

By 1990 several CFA buildings were forty years old or more. The DOE site manager decided to dismantle many old structures and replace them with new ones. The quality of construction and the heavy-duty materials in the older structures created challenges for dismantlement teams. Those composed of reinforced concrete, especially the structures at the NPG Proof Area, were constructed with rebar that was typically doubled and crisscrossed. Asbestos insulation covered many old pipes and walls. Buried fuel tanks, contaminated water pipes, drainage pumps, and entire buildings required special handling. In the Proof Area, old naval ordnance had to be found and recovered.

Between 1990 and 1995, two new buildings appeared at the CFA: the Core Storage Library (CF-663), in which geological core samples were stored by the United States Geological Survey; and a new office complex called Office \#3 (CF-615).

Beginning in 1995, after Lockheed Technologies became the consolidated contractor for the INL, construction continued. Several old facilities were replaced and new ones constructed in connection with waste processing activities. Most were prefabricated metal structures. A new Transportation Complex (CF-696), Medical Dispensary (CF-1612), Fire Station, pumphouse and concrete-slab training facility (CF-1611, -1603, -1606), and more offices (CF-1608 through -1610) were completed. New chlorine injection facilities (CF-1601) and waste water labs (CF-1605) reflected INL's emphasis on environmental remediation. A Health Physics Instrument Laboratory (CF-1618) was completed in 2002. ${ }^{273}$

Significance of CFA. As a centralized service center for contractors elsewhere at INL, the CFA typically was not the scene of scientific discovery or historic breakthroughs in nuclear knowledge. Its labs, shops, transportation terminals, personnel services, storage warehouses, utility centers, and

272. Stacy, Proving the Principle, p. 217-218.

273. Hollie Gilbert, "Building/Structure” Data Base, 2003 version. 
administrative offices all supported experiments elsewhere. As scientific inquiry shifted from nuclear reactor concepts and safety to waste remediation, CFA facilities shifted the burden of their support accordingly. Compelling demands by DOE to operate with energy efficiency and without excessive maintenance costs dictated that obsolete buildings be replaced.

Aside from changing missions, the extant buildings at CFA also reflect national trends in industrial vernacular architecture. When DOE mandated that all of its facilities reduce their energy consumption after the oil shortages of the early 1970s, vendors had to supply buildings that would meet new energy efficiency standards at costs low enough to win bids. Invariably this meant that pumice- block, woodframe, and brick- veneered buildings became a thing of the past. Prefabricated all-metal buildings tended to meet construction and energy conservation standards at lower costs.

Office buildings CF-612 and CF-614, built in the 1980s, are among the few buildings on the entire INL site to meld a defined architectural style (International and Contemporary) with the functional nature of industrial structures.

The blending of old NPG military structures in a setting with later nuclear-era buildings offers a rare opportunity to examine a landscape shaped by the federal government and its civilian contractors. The CFA exhibits the adaptation and reuse of military buildings and residences. The contrast between the Navy's approach to housing its employees on-site - providing them with permanent housing, landscaping, and trees - contrasts sharply with the AEC's determination not to house its employees onor off-site and not to construct permanent buildings. Yet both the Navy and AEC were engaged in government-financed scientific experimentation and testing. Each created similar clustering of activity in this desert environment.

Because of the rarity of World War-II era military housing located in its original site, the extant NPG buildings are recommended for HABS/HAER-level documentation. These buildings are also historically significant because the NPG was one of only a few sites in the United States where military weapons research occurred and one of the few military sites of any kind in Idaho. They have survived adaptation and reuse in the nuclear era.

\section{Sub-Theme: Reactor Testing, Experimentation, and Development}

\section{Argonne National Laboratory West}

The End of the Liquid Metal Fast Breeder Reactor. As mentioned earlier in Context IV, the AEC altered its reactor development objectives radically around 1965. Instead of continuing research on many different reactor concepts, the AEC selected one concept for further development - the LMFBR. This development tended to quench the start-up of new testing experiments at the NRTS in general, but some of the research on the LMFBR continued to involve ANL-W (now MFC).

By 1970, LMFBR supporters felt ready to demonstrate the concept. They planned for the Clinch River Breeder Reactor (CRBR), to be located in Tennessee. It would be the joint effort of the AEC and a consortium of 700 private utility companies. The project would finally, it was hoped, prove the feasibility and safety of the LMFBR for commercial power production. The concept promised to breed plutonium fuel at a rate to double the initial fuel input in eight to ten years of operation. After years of debate and promotion, the federal government and the consortium companies committed funds for the project. ${ }^{274}$

274. William Lanouette, “Dream Machine,” Atlantic Monthly (April 1983), p. 48-52. 
The plan to build CRBR had developed despite the fact that Detroit Edison's small commercial breeder, the Enrico Fermi, shut down in 1972. The Fermi reactor had suffered a meltdown in 1966 when a metal plate below the core broke off and blocked the coolant flow. The reactor was repaired and continued operating until its fuel was depleted.

Other national forces, however, conspired to prevent the CRBR from being built, although site preparation was initiated in 1983. High demand for electrical power, which utility companies and the AEC had been predicting for years, did not materialize. Consumers responded to energy shortages in the early 1970s by reducing their use of electricity. Fossil fuels were not being depleted as quickly as had been predicted, and new sources of supply were discovered. Segments of the public began to worry that terrorists or "rogue states" might acquire plutonium for weapons. The 1979 accident at Three Mile Island - and, many scientists believe, the inaccurate and incomplete way in which information about it was delivered to the public - aroused fears among other citizens that nuclear power plants were unreasonably dangerous. ${ }^{275}$

In this atmosphere, critics of the Clinch River project became more vocal and organized. Even among those who supported nuclear power, there were questions as to whether it was the best demonstration plant. The reactor was based on early designs, and some scientists, including nuclear pioneer Walter Zinn, believed that the CRBR design was obsolete. In their view, the demonstration would be neither efficient nor cost effective. Design changes, regulatory compliance, and the passage of time all increased the costs of building the reactor. Although the funding for CRBR survived years of budget battles in Congress, private support weakened. In 1983, Congress canceled the funding. ${ }^{276}$

The Integral Fast Reactor Concept: 1984-1994. Research at ANL-W facilities contributed to the LMFBR program up until 1983, although ANL-W funding was not tied directly to the Clinch River project. The public's concerns about plutonium theft and, after the accident at Three Mile Island, power plant safety - along with a universal concern for effective methods of handling nuclear waste - inspired ANL to redirect its research goals.

Scientists and engineers at ANL had been considering a new breeder reactor concept named the Integral Fast Reactor (IFR). By 1984 the IFR had become new ANL priority in reactor development, with tests and research centered at ANL-W. The project grew steadily. By 1994 employment levels at ANL-W reached a peak of approximately 850 people. ${ }^{277}$

Argonne was so interested in the IFR because it seemed to overcome many public concerns: its safety was derived from the operation of laws of nature, not the absence of human error; its fuel cycle reduced the volume of waste and the length of time it would be a hazard; and the nature of the residual plutonium was not in a form attractive for diversion to weapons. IFR proponents hoped to fulfill the early promise of nuclear energy for the peaceful and economic generation of electricity. ${ }^{278}$

The fuel for the IFR was a metallic fuel (in contrast to the ceramic fuel typically used in commercial reactors) with high thermal conductivity. The processing of spent fuel elements, which could be accomplished on-site without shipping the material to a processing plant, separated the unused fuel from most of the other waste, making the waste less highly radioactive than conventional spent fuel. Scientists

275. See Stacy, Proving the Principle, chapters 23 and 24, “The Endowment of Uranium" and "The Uranium Trail Fades," for a synopsis of the impact of world events on the nuclear enterprise in Idaho, p. 222-243.

276. "Breeder Program: Bethe Panel Calls for Reorientation,” Science (182:1236), p. 1237; Lanouette, p. 46-52.

277. “Argonne Proposes 'Proliferation-resistant' breeder,” Physics Today (August 1984), p. 62; Holl, p. 446; Lindsay, personal communication, Sept. 16, 1997.

278. Stacy, Proving the Principle, p. 232-237. 
hoped that the IFR, with this "closed" fuel cycle might ease public concerns about transporting nuclear fuels and wastes. ${ }^{279}$

Testing of the new fuel elements took place at ANL-W. The fuel, a combination of uranium, plutonium, and zirconium, appeared to perform more safely, economically, and efficiently than earlier designs. The fuel had greater thermal conductivity than earlier fuels and could transfer heat from the center of the reactor to the coolant more efficiently. This improved safety, because if heat should build up in the core, the fuel elements would expand, slowing the fission reaction, and resulting in a natural shutdown of the chain reaction.

The new "integral" fuel recycling process also added to efficiency and safety. It produced a conglomerate of plutonium, uranium, and other heavier-than-uranium elements that could be refabricated into new fuel elements in special hot cells located near the reactor. The ANL-W scientists believed this system could neutralize the threat of plutonium theft. Weapons production requires a supply of "pure" plutonium which could not be obtained from IFR fuel without additional reprocessing. Separating the plutonium from the highly radioactive mix would require heavy investment in very large facilities that would be difficult to hide.

In April 1986, the scientists at ANL-W loaded up the EBR-II reactor with IFR fuel and conducted a Loss-of-Flow Test and a Loss-of-Heat-Sink Test to simulate a complete station blackout and a loss of ability to remove heat from the core. In both tests, no operator interventions or emergency safety systems were brought into action. The reactor shut itself down because of the natural laws of physics, not a set of human-engineered or human-operated safety procedures. ${ }^{280}$

Three weeks after ANL-W's 1986 tests, an explosion occurred at the Chernobyl nuclear power plant in the Soviet Union. The alarming accident released substantial radiation into the environment and reinforced the opponents of nuclear power plants who argued they were not safe. Despite the good news about IFR and its inherent safety features, ANL was unable to gain sufficient support for the studies that would allow for scaling up of the concept. President Bill Clinton and the U.S. Congress, responding to calls for budget reductions, eliminated all funding for nuclear reactor research in 1994. In that year, EBR-II was shut down after thirty years of operation. ${ }^{281}$

The EBR-II reactor is in the process of dismantlement. Its fuel was removed and its liquid sodium coolant has been drained from the reactor vessel. In 2000, ANL-W began treating EBR-II sodium-bonded spent fuel. The electrometallurgical process is expected to have applications for the treatment of the Fermi reactor fuel currently in storage at INL. Elsewhere on the ANL-W site, soils contaminated with Cesium137 have been subject to experimental phyto-remediation efforts, in which specific plants take up the cesium in their root systems. $^{282}$

279. At ANL-West, EBR-II and the Fuel Cycle Facility (FCF) were modified. The changes made power production, fuel reprocessing, and waste treatment possible at a single location. See Holl, p. 45-446.

280. Stacy, Proving the Principle, p. 234-237.

281. "Argonne Proposes 'Proliferation-resistant' breeder," Physics Today (August 1984), p. 62; Holl, p. 450-456; Brandon Loomis, "End of an Era at Argonne, EBR-II Reactor Ends 30-year Run," (Idaho Falls) Post Register, Sept. 29, 2994, p. 1.

282. From a November 24, 2003, review of website http://www.inel. gov/facilities/anl-w-status.shtml. 


\section{Sub-Theme: Reactor Testing, Experimentation, and Development}

\section{Test Reactor Area}

TRA Retrenches: 1971-Present. The AEC's focus on the LMFBR affected operations at TRA (now RTC). ETR was designated as a key test vehicle for the breeder's safety program. In the spring of 1973, the Aerojet Nuclear Corporation, the RTC operating contractor at the time, began developing special sodium-cooled test loops for the breeder project. This conversion of the ETR reactor required a new closure to the top of the reactor vessel, a special helium coolant system, and a sodium handling system. Once the reactor was properly equipped, ANL would begin testing in mid-1974. The object of the tests would be to verify safety characteristics of the fuel and core design of the Clinch River breeder reactor. ${ }^{283}$

However, Clinch River became a very uncertain project even before Congress refused in 1983 to fund it further. DOE shut down ETR in December 1981. It never ran again and was placed on inactive standby in January 1982.

When the Cold War ended in 1990, the Navy's demands on the ATR declined. National motivation to keep the frontier of nuclear knowledge moving ahead weakened.

The operation of test reactors at TRA had not ended, however. The ATR and its critical facility reactor continued to serve research needs originating both on and off the site. In 1985, for example, the critical facility tested electronic components needed for decontamination work around the site. For offsite customers, the ATR has been a source of neutrons for measuring thermal cross sections of geological samples in uranium and oil exploration. ${ }^{284}$ The U.S. Navy continues as a major ATR customer. In 1996, the isotope production mission was commercialized. The ATR continues to produce isotopes used by medical, industrial, and agricultural customers. ${ }^{285}$

DOE is actively seeking new customers and missions for the Test Reactor Area, not only from within the United States, but all over the world. In 1999, the ATR was equipped with a new test feature, the Irradiation Test Vehicle, which is capable of accommodating fifteen separate tests at a time, speeding up research results for customers. The improvements are marketed to universities, among other research customers. $^{286}$

In the meantime, DOE is ordering the decontamination and dismantling of unused TRA buildings to reduce maintenance expenses, remediate contaminated sites, and reduce the potential for further environmental hazards from occurring.

\section{Sub-Theme: Cold War Weapons and Military Applications}

\section{Auxiliary Reactor Area (Army Reactor Area)}

The ARA sites after 1971. After the Army effort to create very small nuclear power generators collapsed in 1965, the NRTS contractor changed the name of the area to Auxiliary Reactor Area. The

283. Thumbnail Sketch 1973, p. 9

284. Site Development Plan, Volume 2, TRA.

285. “ATR Celebrates 30 years of testing,” Lockheed Star (July 1, 1997), p. 1.

286. Raymond V. Furstenau and S. Blaine Glover, "The Advanced Test Reactor Irradiation Facilities and Capabilities," found on November 24, 2003, at http://www.anes2002.org/proceedingcd/ 58Fur.pdf. 
name was an apt indicator of the new mission of ARA buildings and facilities - to provide technical support for other programs at the NRTS. ${ }^{287}$

At ARA-I, some of the buildings were remodeled to support various study programs taking place elsewhere on the site. A Plant Applications and Engineering Tests program was set up to ascertain the reliability, capability, and durability of safety system performance. Related work included taking fatigue measurements on irradiated materials, studying ways to extend fuel life of the Advanced Test Reactor, and analyzing component failures. ${ }^{288}$

The welding shop at ARA-II closed in 1987, and the rest of the complex remained idle until it was declared excess and prepared for dismantlement. In 1996 the Department of Energy, Environmental Protection Agency, and the State of Idaho agreed to improve the safety of the SL-1 burial ground by recontouring the site to direct water away from it and constructing an impermeable cap over it. ${ }^{289}$

After the Army deactivated the Gas Cooled Reactor Experiment and ML-1 tests in 1965, its buildings were likewise adapted for other uses. After the reactor was removed, the pipes were closed off, and the reactor pit was covered with concrete blocks. From 1966-1986, technicians used the building as a component and instrument lab to test and evaluate items used in reactor experiments elsewhere on the site. Such business was declining, however, and by 1987 this area too went idle. ${ }^{290}$

ARA-IV, the erstwhile home of the ML-1 reactor, was home for a short time to a small reactor sent from DOE's Nevada Test Site, a nuclear effects reactor, known as the Fast Burst Reactor (FRAN). This small reactor could supply bursts of high-intensity fast neutrons and gamma radiation. Its first criticality at the NRTS was August 28, 1968. Its mission was to test new detection instruments developed for reactor controls. But the program was phased out, and the AEC sent the reactor to Lawrence Livermore Laboratory in 1970.

ARA-IV was renamed the Reactives Storage and Treatment Area (RSTA) in 1987. The purpose of RSTA was to provide a remote, safe location to store potentially reactive and explosive waste before shipping it off the INL site or treating it further on-site. The activities carried on at RSTA site included detonation, open burning, and the chemical reaction of reactive and explosive waste. The cost of maintaining required operating permits for RSTA was high, and the amount of reactive waste diminished. INL decided to close the site. The waste and the containers were characterized and classified as nonreactive and nonhazardous, and moved to an excess-materials storage yard at the CFA.

Decontamination and dismantling of the ARA clusters began in 1988. DOE, the Idaho SHPO, and the NPS signed a Memorandum of Agreement to preserve the photographic and engineering record of the Army programs and prepare a HAER report. All ARA buildings except a small control building at ARAIV have been dismantled. Because the HAER study documented the Army program, ARA buildings were not included in the inventory accompanying this report. ${ }^{291}$

287. Site Characteristic Idaho Falls: Idaho Operations, 1990), p. 14 of "Sitewide."

288. Site Characteristics, p. 14 of "INEL Sitewide.” Also, “Auxiliary Reactor Area,” Nuclear News (May 1969), p. 60.

289. Erik Simpson, "Agencies agree to cap reactor burial grounds," INEL News (February 6, 1996), p. 7. A similar treatment was agreed to for the BORAX-1 burial ground.

290. Julie Braun, Draft Historic Resource Management Plan for Historic Architectural Properties on the INEL (Idaho Falls: U.S. DOE, 1994), p. 71.

291. "Memorandum of Agreement Among the United States Department of Energy, Idaho Field Office, the Idaho State Historic Preservation Office, and the Advisory Council on Historic Preservation," August 13, 1993. 


\section{Sub-Theme: Cold War Weapons and Military Applications}

\section{Naval Reactors Facility}

Maintaining the Status Quo: 1971-present. The 1970s and the 1980s marked the maturing of the NRF. New initiatives were much reduced, and most developmental work consisted of placing new cores in the existing reactors. In 1973, a prototype core for a two-reactor carrier was installed in the A1W plant and brought to power. In October 1984 the S5G Prototype completed end-of-life testing, and a new core containing a reused module from the submarine USS Narwhal was installed. It achieved criticality in 1986. Meanwhile, in 1973, the S1W prototype exceeded its originally estimated twenty-year design lifetime, and was still operating successfully.

In the 1970s, the Nuclear Navy was focusing its efforts on the improvement of submarine performance. The Navy was competing with Soviet nuclear submarines that were feared to be faster and deeper-diving than the Navy's. Admiral Rickover and Navy contractors were dealing with accusations of corruption and bribery in relation to defense contracts. The entire defense industry, in particular General Dynamics, was under attack for overspending and fraud. ${ }^{292}$

Throughout the 1970s, the workload at the ECF increased substantially. Additional hot cells with a transfer tunnel to the storage pools were constructed. By 1977, the first off-site reactor control rods were received for examination and repair. In 1979, the S1W demonstrated the feasibility of reusing all radioactive water, and discontinued discharging any radioactive liquids into the environment. By 1980, the ECF was sending liquid wastes to the ICPP for evaporation.

In 1981, the ECF expanded again with a fourth storage pool, this one designed to examine the reactor core from the Shippingport Power Station. ${ }^{293}$ The ECF also continued receiving irradiated materials from TRA. Since 1957, approximately 3600 transfers have been made between ECF and TRA in shipping casks transported by exclusive-use truck.

International events soon affected the course of the Navy's reactor programs. Tensions began easing between the United States and the Soviet Union even before President George Bush declared the end of the Cold War in November 1990. Nuclear disarmament treaties reduced the buildup of a nuclear arsenal on both sides. The Navy no longer needed to maintain the vast nuclear fleet of surface ships and submarines that had been the legacy of the USS Nautilus. And consequently, it no longer needed to run the S1W Prototype to train operators of nuclear ships. On Oct. 17, 1989, the S1W concluded its last power operation. The prototype had operated for 36 years, longest of any nuclear reactor in the world at the time. The A1W shut down in 1994; the S5G, in 1995.

The three prototypes are presently inactive. The Navy's spent nuclear fuel shipments continue to arrive at the ECF, but an agreement with the State of Idaho has established milestones for final storage at an off-site repository. The involvement of the State of Idaho in the conduct of DOE affairs in Idaho has been a relatively new influence at INL, arising out of concerns about the water quality of the Snake River Plain Aquifer and the indefinite plans of DOE for permanent disposal of nuclear waste. ${ }^{294}$

292. These issues were the subject of Patrick Tyler, Running Critical, The Silent War, Rickover, and General Dynamics (New York: Harper and Row, 1986).

293. Naval Reactors Facility, 1994.

294. United States Department of Energy, INEL Comprehensive Facility and Land Use Plan (Idaho Falls, Idaho: DOE/ID10514, March 1996), p. 21-23. 
Historic Significance of the NRF. Idaho's NRF played an important role in establishing the "Nuclear Navy," allowing the United States to attain early naval supremacy in opposition to the Soviet Union during the Cold War. Careful engineering, testing, and training under the rigorous procedures laid out by Admiral Hyman Rickover gave the NRF and the U.S. Navy an excellent reputation for nuclear safety.

Several world "firsts" occurred at the NRF. The S1W prototype of the USS Nautilus, the first "atomic machine" was constructed there. As Westinghouse executive John Simpson observed, "This was the Kittyhawk of the Atomic Age." ${ }^{, 295}$ Navy executives, including Admiral Rickover and USS Nautilus Commander William Anderson, credited NRF workers and on-site training of naval personnel for the success of the Navy's nuclear propulsion program. The site's initial success with the S1W prototype inspired the Navy to invest in further prototype projects in Idaho. These included the world's first nuclear aircraft carrier prototype (A1W), and the $\mathrm{S} 5 \mathrm{G}$, the first natural-circulation reactor. Both prototypes proved successful and helped the United States maintain its naval strength. These "firsts," it should be noted, all occurred before 1970 .

\section{Sub-Theme: Military (and other) Applications}

\section{Test Area North}

Specific Manufacturing Capability. Even before the LOFT experiments ended in 1986, the buildings at TAN were modified for new uses. In 1983 the U.S. Army became one of INL's customers when it initiated a secret project using depleted uranium to manufacture a special armor for its M1-A1 Abrams tank. The project, named Specific Manufacturing Capability (SMC), was classified, so secret that many employees in the plant did not know the purpose of the work they were doing.

The project made use of the expansive space inside the old ANP hangar building, TAN-629. Essentially, the main manufacturing building was erected inside the hangar, hidden from possible overhead spy satellites. The project remained classified until 1990 when the Army made public the purpose of the program. ${ }^{296}$ Numerous other TAN buildings support the SMC. The activity is notable as one of the few "production" activities at INL (in contrast to "research and development").

The Deactivation of TAN Activities and Facilities. A complete history of TAN would include a long list of general research customers, partly because of the presence of the TAN Hot Shop, still in use by various research programs at INL. The Hot Shop, in the group of buildings referred to as the Technical Support area of TAN, includes programs dealing with the Three Mile Island Unit 2 Core Offsite Examination Program, the Spent Fuel Program, and others.

The Spent Fuel Program concerns itself with the casks that transport spent fuel from one place to another. This research involves not just the casks, but the entire range of testing, security, manufacturing, and certifying transfer systems related to cask transport.

The damaged core from Three Mile Island was shipped to TAN between 1986 and 1990. TAN facilities received the wreckage, examined it, and prepared it for temporary storage. In a multi-year process that ended in 2001, the material was moved from TAN to a dry-storage facility at INTEC to await its next move to a national repository for spent fuel.

295. John W. Simpson, Nuclear Power from Undersea to Outer Space (LaGrange Park, Illinois.: American Nuclear Society), p. 53.

296. Stacy, Hangar HAER, p. 63. See also Stacy, Proving the Principle, p. 228-229. 
However, many TAN facilities are no longer in use. The facilities at the ANP "Initial Engine Test Area" have been demolished. The buildings that were part of the LOFT program - the Containment and Service Building, the Reactor Control and Equipment Building, and numerous auxiliary support buildings - are shut down and facing deactivation. The buildings used in connection to the tank armor project will continue in use for the foreseeable future.

Part of the LOFT program included a Water Reactor Research Test Facility, a group of buildings that supported the tests occurring in the LOFT containment building. These buildings include the ThermalHydraulic Experimental Facility Assembly and Test Building (TAN-640, earlier known the LPTF), its related Control Building (TAN-641), the Semiscale Control and Administrative Building (TAN-645), and the Semiscale Assembly and Test Building (TAN-646). The future of these buildings is uncertain.

Significance of TAN. The evolution of program uses at TAN exemplifies the flexible adaptation of DOE nuclear research facilities from military uses to peaceful uses - and back to military uses. After the failure and cancellation of the ANP program, the facilities were readily reincarnated for other research themes. Of all of them, the LOFT program and the contribution it made to reactor safety was perhaps the most important.

The LOFT reactor was the only reactor in the world that could repeatedly simulate different kinds of loss-of-coolant accidents that might occur in commercial power plants. The experiments conducted from 1978 to 1986 contributed to the safe operation of nuclear reactors all over the world. DOE, recognizing that the Nuclear Energy Agency (NEA) of the Organization for Economic Cooperation and Development (OECD) had considerable experience in sponsoring international research programs, invited NEA to establish such a program with LOFT. In addition to the experiments already carried out, the program investigated more severe transients in which fuel disruption and release of fission products would occur. These experiments began in October of 1983. The OECD member countries participating were Austria, Finland, West Germany, Italy, Japan, Spain, Sweden, Switzerland, the United Kingdom, and the United States. In exchange for financial and technical collaboration, the OECD received valuable data on eight accident simulations, including reactor recovery to safe conditions. The experience of working closely together on post-test analysis forged enduring links among analysts in the member countries.

\section{Sub-Theme: Chemical Reprocessing}

\section{Chemical Processing Plant}

The 1970s and 1980s: The Second Generation of ICPP Buildings. The decade of the 1970s began what the ICPP managers called a "facelift" of the plant. Safety standards for nuclear workers had become more stringent, as had standards for environmental protection. Decontaminating the process cells became more and more difficult - a consequence of the fact that the main process and waste calcining buildings had been adapted to operate with chemical solutions that they had not been designed initially to handle. Aside from that, equipment simply was aging.

Design engineers addressed the ICPP shortcomings by replacing and improving one system after another. New buildings appeared all over the campus. A new Waste Disposal Building, to wash and filter low-level gases and liquid wastes before release to the environment, was one of the first. An Atmospheric Protection System (CPP-649), a central filtering center that collected air and off-gases to preclude accidental releases, appeared in $1976 .{ }^{297}$ Monitoring stations went up to detect and impound any waste water that became accidentally contaminated. Electrical distribution was revamped in a systematic

297. Thumbnail Sketch 1973, p. 17. 
upgrade. And a coal-fired steam generator plant went on line in 1984 to supply plant heat for the entire ICPP complex. Changes in waste management practices ended the use of wells for the injection of lowlevel radioactive liquid waste. Such liquid went instead to evaporation ponds. These new practices led to new monitoring stations housing new instrumentation and new pumps.

More significantly, four major new buildings replaced and modernized the original plant. The first to be replaced was the old Waste Calcining Facility (CPP-633). The old plant ended its ninth and last campaign in March 1981 after a run of nearly two years that had been interrupted several times by failing equipment. A new calciner had been under development and design since before 1975. It opened for its first hot run in September 1982. The building (CPP-659) had many features similar to the old one, but could process 3,000 gallons of feed per day, had better protection for workers and the environment, and could handle waste streams from a wide range of standard and exotic fuels. The building was placed northeast of the old calciner building between part of the tank farm and the oldest bin sets.

Next, the Fluorinel Dissolution Process (CPP-666) replaced the head-end portion of the original fuel reprocessing complex at CPP-601. Designed by the Ralph M. Parsons Company, it reversed the "direct maintenance" philosophy upon which the earlier process plants were based. The Fluorinel plant was to be operated and maintained by remote and computerized control. Under construction for four years, it was completed in 1984. The huge building — its roof covers $23 / 4$ acres — integrated fuel storage with the dissolution process, meaning that fuel could be transferred underwater directly from its storage place to the process area without the use of transport casks. (At the time, site managers expected CPP-603, the original fuel storage complex, to be discontinued in the 1990s.)

The fuel storage facility at the Fluorinel Dissolution Process and Fuel Storage (FAST) facility contained six pools containing three million gallons of water. The pools, connected by transfer channels, were arranged in a north-south row. Within the pools were 2600 fuel storage positions. A cask-handling pool and two isolation pools were at the north end. To the east of the pools was the processing area, which contained a shielded process cell, operating galleries, and a chemical makeup area. Features such as shielded process cells, viewing windows, below-grade locations for process cells followed principles established in the earlier building. One of the building's innovative features was a plan to use decay heat (from the fission products in stored fuel) to heat the plant and other ICPP buildings in the future. ${ }^{298}$

The new plant began receiving fuel in 1984. Dissolution began in the spring of 1985. At the time, DOE expected the plant to pay back the cost of its construction ( $\$ 200$ million) within five years based on then-current values of enriched uranium and Krypton- 85 gas. ${ }^{299}$

The third major improvement was a new laboratory, also designed by Ralph M. Parsons. The Remote Analytical Laboratory (CPP-684) joined the new processing and calcining facilities in 1986. Containing a hot cell, the lab examines and evaluates samples of highly radioactive waste. The samples arrive at the lab via a pneumatic transfer system similar to those used at drive-up bank windows. Compressed air moves the samples through an overhead pipe system connecting the laboratory to the new calciner and new processing buildings. Inside the laboratory, a small cart motivated by a magnetic drive system beneath the hot cell floor moves the samples from one manipulator station to another. ${ }^{300}$

The final phase of the upgrade began in 1988 with the commencement of the Fuel Processing Restoration project, which would completely replace the old uranium extraction plant, CPP-601, the

298. Logan, p. 205; and Westinghouse, FDP Facts (Fluorinel Dissolution Process) pamphlet (Idaho Falls: WINCO, 1986); and INEL, FAST Facility at ICPP (Idaho Falls: DOE/INEL, circa 1983), no page numbers.

299. FDP Facts.

300. Westinghouse, RAL Facts (Idaho Falls: WINCO, 1986). 
original 1951 process building. This building was expected to take six to seven years before it was ready to start up in $1996 .^{301}$

In accordance with President Ronald Reagan's determination to continue producing nuclear weapons, the Department of Energy decided to locate a Special Isotope Separation (SIS) process at the ICPP in 1989. The process was to accumulate Plutonium for nuclear weapons using lasers to separate isotopes from a metal vapor. The anticipated project brought a new wave of work to the area, opening up a new cluster of buildings at the north end of the ICPP. The SIS was never built, but the buildings remain. ${ }^{302}$

One of the legacies of the long FAST facility construction periods was a substantial collection of construction- and contractor-related buildings - offices, craft shops, warehouses, quality assurance labs, and waste accumulation structures. Temporary trailers and guard houses appeared on the scene, hauled to a useful (or available) place and parked on skids or bolted to concrete pads. Construction activity has been somewhat constant at the site, so these buildings have been re-used by the INL manager or subsequent contractors. In the summer of 1997, a general clearance was underway. Several trailers were sent to the Arco School District for use at Arco High School.

Retrofitting and Remediation. The fuel processing and waste calcining equipment at the ICPP shut down in October 1989. Among the many laws, orders, and agreements pertaining to environmental protection was the Resource Conservation and Recovery Act of 1976 (RCRA). RCRA set forth standards for cleanup of hazardous waste sites and regulated the transport of hazardous wastes to prevent further contamination of the environment. It was now time for the vast kingdom of underground piping at the ICPP to be upgraded and retrofitted. The new standards specified that pipes carrying hazardous chemicals must be surrounded by a secondary containment - a pipe surrounding the pipe that would catch the hazard should the primary pipe leak or break. Site workers took inventory and began years of work digging up and relaying pipes all over the plant. ${ }^{303}$

The Comprehensive Environmental Response, Compensation, and Liability Act of 1980 (CERCLA, also known as "Superfund") provides mechanisms for the Environmental Protection Agency (EPA) to force agencies such as DOE to clean up sites where accidents or usage have contaminated the soil or water. The State of Idaho passed a Hazardous Waste Management Act in 1983 which incorporated procedures and standards for dealing with asbestos and radioactive hazards.

The State of Idaho and the EPA pressed their interests, and DOE itself issued various orders regarding the clean up of hazardous waste sites. On December 9, 1991, those three parties signed a Federal Facility Agreement and Consent Order, setting forth mutual goals on a wide range of activities. Since then the ICPP (and other INL areas) have cleaned up asbestos, petroleum products, heavy metals, radionuclides, and other wastes. ${ }^{304}$

The ICPP operators have undertaken a systematic survey and characterization of their site, identifying contaminated soils, buildings, and structures. After analyzing alternative approaches to the cleanup of a site, they undertake decontamination and dismantlement activities. In addition, obsolete or surplused properties are being eliminated in accordance with DOE orders to reduce annual maintenance expenses at DOE laboratories.

301. "40th Anniversary Package,” p. 13.

302. "40th Anniversary Package," p. 14.

303. Kevin Richert, "Chem Plant closures will be indefinite, officials say,” Post-Register (October 23, 1989).

304. "INEL completes first 5 years of cleanup," DOE This Month (December 1996), p. 8. 
The Cold War Ends - The ICPP Acquires a New Mission and a New Name. After President George Bush declared the end of the Cold War in 1990, the Secretary of Energy ordered DOE facilities to terminate the recovery of uranium from spent fuel. The big new building under construction at the ICPP came to a halt, unfinished and suddenly irrelevant. And the State of Idaho - after years of resisting the transport of nuclear waste and nuclear fuel into the state - demanded that DOE perform a site-wide Environmental Impact Statement. The state filed for an injunction against any further receipt or storage of spent nuclear fuel until such an EIS was completed.

The conflict was resolved on October 16, 1995, with an agreement between DOE, the State of Idaho, and the U.S. Navy as to the future of fuel storage and management of liquid wastes at the INL. ${ }^{305}$ The agreement handed the ICPP a big job. It set forth compliance dates for calcining all of the remaining 1.7 million gallons of high-level liquid waste in the stainless-steel tanks. In pursuit of this target, the New Waste Calcining Facility began a campaign during the summer of 1997 to calcine 287,000 gallons of nonsodium bearing waste, an effort that was completed in February 1998. The next goal is to calcine sodiumbearing waste, with an end date expected by the end of 2012. When that task has been accomplished, the waste calcining process will likewise be irrelevant. ${ }^{306}$

The fuel left in wet storage when the 1992 order shut down the process must be relocated to dry storage facilities by December 2000. Fuels in the basins of CPP-603 and in CPP-666 must move to dry storage by the end of the year 2023. This meant another modification at CPP-603 to expand its capacity for dry storage of fuels then at the ICPP and also for the Three Mile Island fuels then stored at TAN.

INL expects to receive a maximum of 575 shipments of Navy fuel between 1995 and $2035 .{ }^{307}$ By that time, the federal government is expected to have a permanent waste repository for the country's stockpile of spent nuclear fuel.

With the evolution of a fuel storage mission, which features dry storage rather than storage shielded by water in pools or tanks, ICPP research has focused on new storage technologies and procedures, not new concepts for reprocessing spent fuel. Its engineers work on new technologies for waste management, better ways to store spent fuel, better ways to decontaminate and dismantle, and ways to scale up waste processing technologies to production-sized operations.

In 1999 the ICPP changed its name to Idaho Nuclear Technology and Engineering Center (INTEC). The mission of INTEC continues to focus on the technologies of receiving and storing spent fuel or calcining the waste still remaining at the plant.

Significance of Context IV, Multi-Program Research. Much INL research since 1970 has not been related to nuclear reactors. Nor has it taken place on INL desert site. After the MTR shut down in 1970, scientists looked for other projects. They found one at Raft River, Idaho, where they established the Raft River Pilot Plant, an investigation into geothermal energy. ${ }^{308}$

305. "Settlement Agreement between the State of Idaho, the Department of Energy, and Department of the Navy, October 16, 1995, to resolve issues in the action of Public Service Company of Colorado v. Governor Phil Batt [of Idaho]," No. CV910035-S. EJL (D.Id.) and U.S. v. Batt, No. CV-01-0054-S-IJL (D.Id.) Section C.1 of the agreement says, "DOE shall remove all spent fuel, including naval spent fuel and Three Mile Island spent fuel from Idaho by January 1, 2035. Spent fuel being maintained for purposes of testing shall be excepted from removal, subject to the limitations [expressed elsewhere in the Agreement.]"

306. "INEEL restarts calcining liquid high-level waste," LMITCO Star (July 1, 1997).

307. Section D.1.b. of Settlement Agreement.

308. Stacy, Proving the Principle, p. 212-216. 
Other alternative energy explorations soon followed. Site scientists sought and found customers interested in a variety of research projects, including industrial energy conservation, the production of alcohol fuel, solar energy, and batteries for electric vehicles, and energy from biomass. INL became DOE's lead laboratory for hydropower programs and helped the city of Idaho Falls install a low-head bulb-turbine system in the Snake River. ${ }^{309}$

Looking for new customers, helping private industry take advantage of government research ("technology transfer"), and diversifying research beyond nuclear questions - these were new directions for INL. Most of these activities no longer required an isolated "test station" in the desert, although the desert continued to offer a practical laboratory for waste remediation research.

In 2002 DOE declared that INL and ANL were to be its "lead laboratories" for nuclear energy research and development. At the same time, it began planning to "accelerate" the cleanup of and remediation of wastes at INL. Heretofore, INL has been managed from DOE's federal center in Washington, D.C., by its Division of Environmental Management (EM).

To better organize for new research initiatives - which may include the construction of a new reactor-DOE is identifying buildings that will be placed under the management of its Division of Nuclear Energy, Science, and Technology (NE). Buildings that will remain under EM purview, but which will no longer be needed, are slated for dismantlement or demolition. ${ }^{310}$

Context IV, "Multi-Program Research" is, in general, a period that requires the passage of time - at least fifty years - before historians will discern how the historic patterns at work at INL ought to be further described and characterized. Likewise, that time must pass before they should assess whether the buildings erected during this period are significant enough to qualify for preservation or recognition for their contributions to the broad scope of American history.

\section{CONTEXT V: REMEDIATION OF WASTE: 1970-PRESENT Sub-Theme: Waste Management}

\section{Radioactive Waste Management Complex (RWMC)}

Early Disposal Practices: 1952-1959. Environmental monitoring began at the NRTS before any radioactive material was even produced. In 1949, a one-year study documented natural background radiation. The study provided a starting point from which any radioactivity increase could be recognized and measured in air, water, cow's milk, soil, and animal flesh. With the beginning of NRTS operations, so did air and personnel monitoring. Quarterly or semi-annual reports were distributed to the Idaho Department of Health and the members of the Idaho Congressional delegation. In 1952, the United States Geological Survey reported a further base of useful information about the Snake River Plain Aquifer. This report expressed concern about potential contamination of the aquifer, but considered it a remote possibility. $^{311}$

309. Stacy, Proving the Principle, p. 216.

310. For an articulation of the new NE-related mission, see INEEL, Strategic Plan, January 2003.

311. B.C. Anderson et al, A History of the Radioactive Waste Management Complex at the Idaho National Engineering Laboratory (Idaho Falls: DOE-ID, Report PR-W-79-038, 1979), p. 21, 35, 101, 102. Hereafter referred to as "Anderson, History of the RWMC." Authors cite the USGS report secondarily from sources such as an article by John Horan and Herman J. Paas, Jr., "Environmental Surveillance a the National Reactor Testing Station," Health Physics 12: 1039-1045 Pergamon Press, 1966; and a letter from Bruce L. Schmalz to F. M. Empson, "Information on Burial Ground,” August 30, 1961. 
Among the many issues facing the youthful nuclear industry — safety, industrial security, and reliable performance - scientists also knew that the disposal of hazardous nuclear waste eventually would become a serious concern. In the 1950s, however, hazardous waste was not a ranking priority of the AEC. Each of the AEC's nuclear facilities made its own decisions about how to handle nuclear waste. ${ }^{312}$ The AEC expected that by the time a commercial nuclear power industry had come into existence, further research and new technologies would have solved waste disposal problems. ${ }^{313}$

As the Cold War escalated, the number of nuclear power plants and testing facilities nationwide increased. With this expansion came the generation of tons of radioactive waste and the growing dilemma of how to manage it. The NRTS expanded dramatically between 1950 and 1955 . Radioactive waste came in the form of solids, liquids, and gases. Initially, some low-level liquid wastes were disposed of on-site at each reactor area via injection wells or settling ponds. The test reactors and ICPP released radioactive gases into the air, although releases were monitored and coordinated with favorable weather patterns so as to meet acceptable air-dilution levels.

The on-site airborne releases were relatively small compared to releases from weapons tests at the Nevada Test Site. The NRTS air monitors and other monitoring stations in Southern Idaho detected high amounts of airborne waste from the Nevada tests. One such test generated readings in Idaho so high that technicians attributed them to equipment error. ${ }^{314}$

Agricultural use of the land surrounding the NRTS site continued to grow. The 1950s advent of sprinkler irrigation and subsequent deep-well drilling made the desert surrounding the Site more attractive to farmers than it had been before. In addition, electricity was cheap. This caused the NRTS landlords concern, for they needed land as a safety buffer between the reactor complexes and local land use. In 1955 , Congress authorized $\$ 1$ million to purchase 140,000 acres north and east of the site. During this time, the AEC also made the level of "acceptable risk" for airborne releases eight times less stringent than it had been originally, so the acreage had the effect of adding additional protection. The purchase also included more area for expansion of the original waste burial grounds, which grew to 88 acres by $1957 .{ }^{315}$

In the late 1940s and early 1950s, the AEC thought that standard processes for domestic sewage treatment promised cost-effective radioactive waste treatment. In those early years, nuclear engineers and building designers viewed such low-level waste (composed of all radioactive waste not classified as highlevel waste, transuranic waste, spent nuclear fuel, or natural uranium and thorium byproducts) in the same light as conventional chemical, or even domestic waste, particularly in dry climates. ${ }^{316}$ The Hanford nuclear site used several separate sewer systems, for example, to carry plutonium-process wastes into

312. Jack M. Holl, Argonne National Laboratory, 1946-96 (Chicago: University of Illinois Press, 1997), p. 73.

313. For discussions of the AEC's early priorities, see, for example, see Michele Gerber, On the Home Front: The Cold War Legacy of the Hanford Nuclear Site (Lincoln: University of Nebraska Press, 1992); John Horan, George Wehmann, and Bruce L. Schmalz, "Experience in Site Selection at the National Reactor Testing Station, USA" (Idaho Falls: AEC, Health and Safety Division, 1962), hereafter referred to as "Horan, Wehmann, and Schmalz;" and Gerard H. Clarfield and William M. Wiecek, Nuclear America: Military and Civilian Nuclear Power in the United States, 1940-1980 (New York: Harper and Row, 1984).

314. Phillips Petroleum Co. Atomic Energy Division, internal report. Survey of Fall-out of Radioactive Material in South and South-East Idaho Following the Las Vegas, Nevada Tests of October and November, 1951 (Prepared by the Site Survey Section of the Health Physics Division, NRTS, USAEC. January, 1952).

315. Anderson, A History of RWMC, p. 8. See also Horan, Wehmann, and Schmalz, p. 17-18.

316. For example, see A.D. Mackintosh, “Architectural Problems in Atomic Labs,” Architectural Forum (January 1952), p. 159-164; A. L. Biladeau, "Radioactive Waste Removal in a Trickling Filter Sewage Plant" (Idaho Falls: Idaho Operations Office of AEC, 1953); H.R. Zietlin, E. D. Arnold, and J. W. Ullmann (of Chemical Technology Division, Oak Ridge National Laboratory), "Economics of Waste Disposal" in Manual on Nuclear Reactor Facilities (New York: McGraw-Hill and Nucleonics Magazine, 1957), p. 101-103; and INEL Comprehensive Facility and Land Use Plan (Idaho Falls: DOE/ID-10514, 1996), p. 177. 
drainage ditches and settling ponds. Increased radioactivity levels in these ditches and ponds led to Hanford's 1952 decision to phase out these ponds and use shallow trenches and subsurface rock "cribs." 317

In 1952, NRTS engineers constructed a new sewage plant at the CFA. They used a "combination unit," also serving the "Hot Laundry" facility, which handled contaminated protective clothing. Although the Hot Laundry facility had a separate sewer line, it entered the same septic tank as the other CFA effluent and then went to the drain field. This process had evidently been tested at Los Alamos in 1952 and was considered an effective way to handle low-level waste. Eventually the sludge lines and drain field became contaminated. ${ }^{318}$

Following the practice at other nuclear laboratories, the NRTS set aside a "Waste Burial Ground" for the disposal of contaminated wastes. The thirteen-acre site, isolated from the reactor facilities, was recommended by the U.S. Geological Survey. It had good surface drainage and clay sediments that would resist saturation. ${ }^{319}$ On July 28, 1952, the first burial trench was opened, and low-level waste was placed in it. This waste consisted mainly of contaminated paper, laboratory glassware, filters, and metal pipe fittings. According to one 1953 internal report, liquid waste in sealed containers was also placed in the trench. ${ }^{320}$ Between 1952 and 1957, nine more trenches were excavated to basalt bedrock. The trenches were enclosed with a barbed wire fence; metal tags marked the general location of the trenches. Lowlevel, site-generated waste was picked up twice a week, placed in sealed cardboard boxes, and randomly dumped into the trenches. Earth was placed over the boxes at the end of each week. ${ }^{321}$ High-level waste also was dumped into trenches during this time. The material was contained in wooden boxes or 30gallon garbage cans, shielded by a cask and lead open-top box container. These were immediately covered with earth.

Wastes from another AEC facility began arriving at the Burial Ground in March 1954. The Rocky Flats Fuel Fabricating Facility in Golden, Colorado, which manufactured trigger devices made of plutonium for nuclear warheads. The facility at Golden was small in size (four square miles), had a high water table, and was near a densely populated area. After studying the merits and economics of alternative sites, the AEC decided to ship the waste to the NRTS. Plutonium is a "transuranic" waste, an alphaemitting element with a half-life greater than twenty years whose combined activity level is at least 100 nanocuries per gram of waste. ${ }^{322}$ TRU waste can remain radioactive for hundreds of thousands of years. Rocky Flats shipped metal drums of TRU waste by rail to Idaho, where it was interspersed with NRTS waste in Trenches 1 through $10 .^{323}$

317. National Register of Historic Places Multiple Property Documentation Form-Historic, Archaeological and Traditional Cultural Properties of the Hanford Site, Washington (Richland, Washington: USDOE, February, 1997), Section 5, page 59. See also Gerber, On the Home Front.

318. Idaho Operations Office, Engineering and Construction Division report by A. L. Biladeau, "Radioactive Waste Removal in A Trickling Filter Sewage Plant," May 1953; and EG\&G Idaho report by R. D. Browning, "TAN, TRA, and CFA Sewage Treatment Plant Study" (Operational and Capital Projects Engineering, January 1989).

319. Anderson, History of the RWMC, p. 11, 21. See notes No. 1 and No. 19. Also see "History, Radioactive Waste Management Complex," INEL Technical Site Information, 1993.

320. Anderson, History of the RWMC, p. 4, citing a report by P. T. Voegeli and Morris Deutsch, Geology, Water Supply, and Waste Disposal at Sites 11 and 11A, Burial Ground D, and Vicinity (Idaho Falls: NRTS ID)-22027, 1953).

321. Anderson, History of the RWMC. [np] See also "History, Radioactive Waste Management Complex," INEL Technical Site Information, 1993.

322. U.S. Department of Energy, Linking Legacies: Connecting the Cold War Nuclear Weapons Production Processes to Their Environmental Consequences (Washington, D.C.: Office of Environmental Management, January 1997), p. 40. Hereafter referred to as "Linking Legacies."

323. Anderson, History of the RWMC, p. 16-21. 
In using shallow land burial methods, the NRTS followed practices used by most other AEC facilities. It was the main disposal method throughout the 1950s. Other methods included underground injection, sea burial, and large pit disposal. ${ }^{324}$ In 1957 Nucleonics magazine published a series of articles on the economics of efficient waste disposal. One of them said, "One of the potentially attractive schemes for the ultimate disposal of radioactive waste is simply to pour the waste into pits." The pits should not be located near processing plants for geological reasons, and some transport might be required. The authors of the report considered the possible benefits of processing nuclear waste, writing, "It may be necessary or desirable to remove some fission products from the waste, particularly the long-lived activities, prior to ground disposal." AEC scientists and engineers predicted that by the year 2000 accumulated waste would be $3 \times 10^{11}$ curies, with an estimated "permissible" disposal cost of anywhere from $\$ .60$ to $\$ 64$ per gallon. ${ }^{325}$

Rocky Flats waste dramatically increased in 1957 due to a severe fire at the plant. Large quantities of bulky and contaminated fire debris was shipped to the NRTS. To accommodate this substantial new volume, the NRTS created a series of "pits" for disposal of this waste. Pit 1 opened on November 1, 1957. That year the AEC also produced formal disposal procedures for the NRTS. Solid waste was packaged in steel drums or large crates, stacked near the pits, and then lowered into the pits by crane. Reporting and record-keeping on solid waste disposal was improved. The AEC further expanded and refined these requirements in $1959 .{ }^{326}$

Occasional flooding created problems at the Waste Burial Ground (later called the "Subsurface Disposal Area"). When the U.S. Geological Survey recommended the burial ground site in 1952, it had not predicted heavy cyclic floods. When the Big Lost River overflowed in 1958, site managers quickly arranged for a dam to divert water away from the burial ground. In 1962, two inches of rain fell on frozen ground, causing localized flooding. Some open trenches filled with water, allowing low-level waste barrels and boxes to float. A few boxes broke open, their contents of contaminated gloves and bottles to settle on lands near the burial grounds. These were retrieved and reburied. Diversion ditches and diking were constructed around the site, but intermittent flooding continued over the years. ${ }^{327}$

Interim Burial Ground: 1960-1963. As the number of AEC-licensed nuclear power plants increased, so did their waste. Utility companies hired from among several firms that packaged solid waste and buried it at sea. The cheaper cost of land burial caused the AEC to re-evaluate sea burial. In January 1960, the AEC announced plans to create regional interim burial grounds for commercial wastes. Until these were established, interim sites for storing wastes would be needed. In May, the AEC chose the Oak Ridge National Laboratory in Tennessee and Idaho's NRTS as the interim sites. ${ }^{328}$ Two AEC-Idaho scientists, B. L. Schmalz and W. P. Gammill, wrote to the AEC stressing that the use of the NRTS as a burial ground be only a temporary measure. They indicated that a potential risk of water table contamination did exist and that the burial ground would soon be full. They recommended that the AEC investigate sites not

324. Linking Legacies, p. 48.

325. H.R. Zietlin, E. D. Arnold and J. W. Ullmann [Chemical Technology Division, Oak Ridge National Laboratory, Oak Ridge, Tenn.], "Economics of Waste Disposal, Manual on Nuclear Reactor Facilities (New York: McGraw-Hill); and Nucleonics (1957), p. 101, 103-104.

326. Anderson, History of the RWMC, p. 22-27. Anderson refers to the manual as an "AEC-ID Manual Chapter 0500-7."

327. Anderson, History of the RWMC, p. 33.

328. "West Coast Firm Attacks AEC Waste-Disposal Policy," Nucleonics (July 1960), p. 30; and "Luedecke Reaffirms AEC's Land Burial Waste Policy," Nucleonics (August 1960), p. 31. 
overlying an aquifer. Combined with concerns about the Interim Burial Ground program, officials on and off the site questioned the wisdom of long-term storage of TRU waste at the NRTS. ${ }^{329}$

As the AEC turned its attention to the issue, it required that Oak Ridge and the NRTS coordinate consistent procedures for land burial. No liquid waste was permitted, and fissionable material was closely supervised. Two major improvements in environmental monitoring were also implemented: increased subsurface monitoring by a system of ten monitoring holes around portions of the burial ground; and film badges placed around the perimeter to monitor direct radiation levels.

A special burial arrangement was made at a site outside of the official burial ground. An accident occurred at SL-1 in the ARA in January 1961, killing three men and damaging the reactor and much of the equipment in the reactor room. After a safety analysis indicated that it would be more hazardous to transport the debris to the burial ground than dispose of it closer to the site of the accident, a separate burial ground was opened about a quarter of a mile from the reactor. Some SL-1 materials were taken later to the interim burial ground and placed in Pit 1, which was reopened specifically for that purpose. ${ }^{330}$

The AEC closed the Oak Ridge and Idaho interim burial grounds in 1963, after commercial sites opened for business. Idaho continued to receive TRU waste from Rocky Flats because of its classified nature. That year also saw a step backwards from what later managers regarded as safe burial practices. A labor strike at the NRTS had created a limited work force. During the strike, workers dumped Rocky Flats waste randomly into the pits rather than stacking barrels in an upright and orderly way. This practice continued for seven years, long after the strike was settled, because site managers believed it minimized personnel radiation exposures. Rocky Flats waste sent to the NRTS after 1967 was dumped into Pits 9 and $10 .^{331}$

\section{Sub-Theme: Environmental Remediation}

\section{Radioactive Waste Management Complex (RWMC)}

Increasing Environmental Concern, 1964-1970. Although environmental concerns at the Burial Ground already existed, these concerns were exacerbated by national and local events during the mid- and late-1960s. In the 1950s, the popular media had focused on fears of fallout and the "monsters" that might be engendered from radioactivity, not the practical problems of accumulating waste with radioactive halflives. The national consciousness concerning environmental degradation on all fronts was raised by chemists, biologists, and other writers. Nevil Shute's grim 1957 novel On the Beach and Rachel Carson's Silent Spring, published in the 1960s, aroused public concerns about nuclear fallout and chemicals hazardous to the environment.

In 1960 and 1965, a National Academy of Sciences committee visited the NRTS and its waste burial ground. The committee felt that the ultimate leakage of plutonium waste was inevitable because the steel drums containing it would eventually corrode. Other minor incidents raised further concerns. In September 1966, two fires occurred in the waste burial ground, caused by alkali metal wastes

329. Horan, Wehmann, Schmalz, p. 17-18; see also Anderson's Notes Nos. 1, 2, and 22.

330. Anderson, History of the RWMC, p. 31-33.

331. Anderson connects the 1963 labor strike with a change in practice from stacking to random dumping of waste containers from evidence in letters, memos, and personal communications. These are cited on p. 31 of his report; see Note Nos. 10, 27, and 28. See also an internal report from Frank G. Schwartz and Paul V. Strider, "Management of Pit 9-Highlights of Accomplishments and Lessons Learned to Date" (Idaho Falls, Idaho: U.S. DOE-ID, 1997), p. 1; and "A Comprehensive Inventory of Radiological and Nonradiological Contaminants in Waste Buried in the Subsurface Disposal Area of the INEL RWMC During the Years 19521984” (Idaho Falls, Idaho: EG\&G Idaho, Inc., October 1993), p. 1-2 to 1-4. 
inadvertently included with low-level waste. Further fires were prevented by compacting and immediately covering the barrels with earth. Another flood occurred in 1969, inundating the entire burial ground. Pits 9 and 10 were flooded, along with two trenches. ${ }^{332}$

Despite these problems, Pits 9 and 10 continued to receive mixed waste (low-level waste containing hazardous waste or PCBs) from Rocky Flats. In 1969, a 12,000-gallon-metal tank filled with mixed waste from the Air Force was also placed in Pit $10 .^{333}$

By 1968, national concerns over water pollution resulted in the issuance of President Lyndon Johnson's Executive Order 11288, entitled "Prevention, Control and Abatement of Water Pollution by Federal Activities." The Federal Water Quality Administration surveyed the NRTS burial ground that year to determine if additional controls were needed to carry out this policy. Idaho Senator Frank Church also became concerned about Rocky Flats waste stored over the aquifer. He requested four federal agencies - the USGS, Bureau of Radiological Health and U.S. Public Health Service, the Federal Water Pollution Control Administration, and the Bureau of Sport Fisheries and Wildlife — to review the burial ground. 334

In 1969, water samples taken from a subsurface monitoring hole after that spring's flood indicated that small amounts of Cesium-137 were present. The NRTS Health Services Laboratory conducted further investigations in 1969 and 1970 and found that some fission products and plutonium isotopes had leached into surrounding soil, probably because of the flood. ${ }^{335}$ Although it was believed that these small amounts could not reach the aquifer, the finding stimulated operational changes. In December 1969, John Horan, director of the Health and Safety Division of the Idaho Operations Office at the NRTS, wrote to the AEC recommending that burial of Rocky Flats waste be suspended during the winter months, and that plutonium-contaminated waste be segregated. ${ }^{336}$

Early Environmental Remediation and Cleanup: 1970-1979. In 1969 Congress passed the National Environmental Policy Act. In 1970 the AEC issued "Immediate Action Directive No. 011-21," regarding solid waste burial. This directive ordered segregation of high-level waste and storage to permit retrieval of contamination-free waste containers after periods of up to twenty years. ${ }^{337}$

The NRTS gradually changed the way it stored different kinds of waste. Rocky Flats waste was carefully packed in drums and stacked once more, with Pit 11 reserved for this use. Waste contained in cardboard boxes was stored in Pit 10. Approximately 90 boxes were also placed in Pit 11, but they were stacked at the other end of the pit. Pit 11 was closed in October of 1970. That same year, TRU waste was still placed in Pit 12. The TRU waste consisted of sludge drums from Rocky Flats. The Idaho Operations

332. Anderson, discusses the report, but does not name it, citing a reference by John Horan in Note 32; see p. 35-39, 104. See also documents related to the report in the files of Idaho Governor Don Samuelson at Idaho State Historical Society, Box 50, File "Nuclear-1970." The New York Times reported that the AEC released a copy of the report to the New York Times in 1970. See clipping in file by Bob Smith, "AEC Scored on Storing Waste," March 7, 1970, no page number.

333. Anderson, History of the RWMC, p. 38-41. See also D. H. Card, "History of Buried Transuranic Waste at INEL" (Idaho Falls, Idaho: EG\&G Idaho, Inc., 1977), p. 23-31. Hereafter referred to as "Card."

334. Anderson, History of the RWMC, p. 35-36.

335. Anderson, History of the RWMC, p. 41-42.

336. Anderson, History of the RWMC, p. 37-38.

337. For the politics behind the federal environmental acts, see Mary Beth Norton, et. al., Vol. 2, A People and a Nation (Boston: Houghton Mifflin Company, 1986). See also Anderson, History of the RWMC, p. 42. 
Office decided not to bury any more Rocky Flats TRU waste in 1970 and began stacking it above ground. It expanded the waste management area to include 144 acres and closed Pit 12 closed in November. ${ }^{338}$

Until 1970, no buildings had been erected at the Waste Burial Ground and no waste had been stored above ground. In 1970, NRTS built a permanent above-ground facility, then called the Interim Transuranic Storage Area (now TSA). It consisted of a sloping asphalt pad $400 \mathrm{ft}$ long, with a 1-ft-high soil berm surrounding three sides. As the pad filled, individual cells were built and surrounded by firewall. The stacked waste was covered first with plywood, a nylon-reinforced polyvinyl, with soil two to three feet deep placed on top. ${ }^{339}$

To carry out the 1970 AEC decision to move TRU waste to above-ground storage, several studies on the waste's condition and cost of removal had to be performed first. ${ }^{340}$ The studies, conducted in 1971 , revealed varied conditions. Some drums were in good condition, while others were corroded and leaking. Buried plywood boxes and cardboard cartons were almost completely deteriorated. The NRTS assigned permanent equipment and personnel to the waste management site for the first time.

The Clean Water Act of 1972 stimulated further changes at the NRTS. A training program for operators and supervisors at the Waste Burial Ground was initiated in 1973, as was the first formal environmental surveillance plan.

In March 1974, the AEC generated is own program, the "Formerly Utilized Sites Remedial Action Program." The NRTS (renamed Idaho National Engineering Laboratory in August 1974) commenced drum retrieval operations, but only of those which were unbreached. Wooden and cardboard boxes were not retrieved because of their advanced state of deterioration. A total of 20,262 drums were repackaged and stored during the program. ${ }^{341}$

From 1975 to 1977, major changes in national oversight and regulation of the nuclear industry occurred. The AEC was abolished in 1974 upon objections that the agency was both regulator and regulated. The AEC's research and weapons production missions were given to the Energy Research and Development Administration (ERDA); its regulatory authority, to the Nuclear Regulatory Commission $(\mathrm{NRC}){ }^{342}$

In 1976, a new federal law was enacted to regulate hazardous waste disposal - The Resource Conservation and Recovery Act (RCRA). At INL, further studies were conducted on uncontained TRU waste. Workers used an air support weather shield to retrieve the waste from Pit 2. Drums and boxes were badly deteriorated, but waste had not migrated into the surrounding soil. ${ }^{343}$

During the 1970s the first buildings were constructed at the Waste Burial Site, which was renamed the Radioactive Waste Management Complex (RWMC). The Radiation Analysis Laboratory (later called the RadCon field office, WMC-601), a metal building on a concrete slab, was placed at the site. A prefabricated metal building served as the Decontamination Facility (now called the RWMC High Bay, WMC-602). Of similar construction were the Pumphouse (WMF-603), and the Supervisor's Office (WMF-604, now called the Change House and Lunch Room Facility). These buildings later were termed

338. Card, p. 31-33.

339. Anderson, History of the RWMC, p. 44.

340. Anderson, History of the RWMC, p. 42; see his Note No. 34, p. 104.

341. Anderson, History of the RWMC, p. 55.

342. Terence R. Fehner and Jack M. Holl, Department of Energy, 1977-1994, A Summary History (Washington, D.C.: U.S. Department of Energy History Division, DOE/HR-0098, 1994), p. 6, 17-20.

343. Anderson, History of the RWMC, p. 59. 
the Administrative Area of RWMC. Permanent buildings were not built because the waste burial site was intended to be relatively temporary. Temporary buildings also were easier to dispose of if they became contaminated. Meanwhile, at a national level, ERDA requested funding in 1975 to evaluate and possibly develop a site in southeastern New Mexico for the permanent storage of TRU waste. ${ }^{344}$

In 1977 DOE replaced ERDA as the cabinet-level federal agency in charge of the nuclear industry. Locally, changes were made in the way waste was stored at INL. Instead of trenches and pits, soil vaults were now used in what was now termed the Subsurface Disposal Area. Two cells in the Transuranic Storage Area (adjacent to the SDA) were then tested in 1978. This storage proved to be acceptable, especially after an air support weather shield was permanently placed over it. ${ }^{345}$ In 1978 , carbon-steel vaults were placed in the Intermediate Level Transuranic Storage Facility (ILTSF). In later years, these proved to be corrosive. Further construction occurred at the RWMC in 1979. As part of continuing efforts to monitor waste, observation well houses (WMF 606-608) were built around the site. A heavy equipment storage shed (WMF-609) was constructed, again out of steel and metal, to house cranes and other large machines. ${ }^{346}$

The Era of CERCLA and Superfund: 1980-1989. In 1980, Congress passed the Comprehensive Environmental Response Compensation and Liability Act (CERCLA), which established a "Superfund" to clean up the chemical waste sites that would be placed on a National Priority List for such cleanup. Some of the cleanup involved moving waste from one site to another. That same year, the Argonne National Laboratory (East) started sending its low-level waste to INL's RWMC site.

The Superfund effort lagged in 1981 under the Reagan Administration. Virtually no Congressional authorizations effected any change at INL during the early 1980s. Only a guardhouse (WMF-611) was constructed at RWMC. ${ }^{347}$

In 1982 Congress passed the Nuclear Waste Policy Act. This law provided for the development of geologic repositories for high-level waste and spent nuclear fuel disposal. The act also established research, development, and demonstration programs regarding disposal of these particular wastes. On the heels of this act came the April 1983 Leaf v. Hodel decision, which subjected DOE to the 1976 RCRA requirements for handling hazardous waste disposal. Also during this time, DOE had chosen Carlsbad, New Mexico, for a Waste Isolation Pilot Plant (WIPP) as its permanent TRU waste repository. After protracted controversy, WIPP opened, and INL began shipping qualified waste for permanent storage in 1999.

The need to qualify waste suited for WIPP storage led to plans for two waste disposal projects at INL. In 1984 the SWEPP opened. It provided operations capabilities for nondestructive examination and certification of TRU waste stored at the INL. The RWMC SWEPP facility was the first of its kind in the United States. Once the waste was certified at SWEPP, it was ready to be shipped to the New Mexico WIPP site. Waste that did not meet the WIPP waste acceptance criteria would be shipped to the proposed Process Experimental Pilot Plant (PREPP) for processing. PREPP, to be located at TAN, was planned as

344. R.D. Logan and D. Jacobson, Internal Technical Report, "INEL Building Study, Perimeter Area Buildings" (Idaho Falls, Idaho: EG\&G Idaho, Inc., December 1990). Some construction dates in this report conflict slightly with 1993 and 1996 INEL Technical Site Information reports.

345. Anderson, History of the RWMC, p. 54-59.

346. Logan and Jacobson, (1990).

347. “A Comprehensive Inventory, 1952-184” (October 1993), p. 1-4; "INEL Building Study” (1990). 
an experimental program to devise methods of processing wastes into acceptable forms. The proposed program would involve the shredding and incinerating of waste, then immobilizing it in concrete. ${ }^{348}$

SWEPP started operating in 1985. The SWEPP program generated another "first" for the INL-it was the first United States facility to perform nondestructive examination and certification of defensegenerated TRU waste. However, the PREPP facility was never started, partly because of questions about the program's capabilities. DOE eventually decided to prepare transuranic wastes for shipment to a thenundecided national waste burial site elsewhere than at INL. The emphasis at INL shifted to preparation and packaging of the material for shipment. In 1988 and 1989, the TRUPACT II (transuranic waste package containers) loading station, work control trailers, and communications building were constructed at RWMC.

\section{SPERT/Power Burst Facility}

New Mission for the Power Burst Facility. In the 1980s SPERT/PBF took on a new research mission directed to waste management. In 1968 SPERT-III had been put in standby condition. In 1980 it was decontaminated, and its system components recovered. The process pit, reactor pit, dry storage houses, reactor head dock, main reactor floor, and the storage canal all were decontaminated. In 1982 it was renamed the Waste Experimental Reduction Facility (WERF) and converted to include an incinerator, melting furnace, compactor, and sizing shop where metallic waste was cut up and resized. The WERF mission was to reduce the volume of low-level radioactive waste and mixed waste before it was shipped to a disposal site. ${ }^{349}$

In 1985 the SPERT-I reactor, which had been located in a below-grade pit, was dismantled and the area returned to its original state. In 1986 the SPERT-II Facility was renamed the Waste Engineering Development Facility (WEDF). It served as a place for investigating radioactive and mixed waste treatment technologies and processes. SPERT-IV also entered the waste management arena in 1986. It was renamed the Mixed Waste Storage Facility (MWSF) and modified to provide interim storage space for low-level mixed waste until the waste was dispatched to a more permanent waste site. ${ }^{350}$

INL's Post-Cold War Mission: 1990-1997. On December 9, 1991, DOE-ID, Region 10 of the Environmental Protection Agency, and the Idaho Department of Health and Welfare signed the INL Federal Facility Agreement and Consent Order. This document supplied all parties with a goal to restore the environment at INL and guidelines for a variety of cleanup activities. The sites to be cleaned up included those contaminated with asbestos, petroleum products, acids and bases, radionuclides, unexploded ordnance and explosive residues, PCBs, heavy metals and other hazardous wastes. It was hoped that INL could be removed from the National Priorities List by 2006.

This legally binding document has provided numerous benchmarks and milestones in the remediation of hazardous residues of many kinds. Each facility complex in the desert was given a new label as a "Waste Area Group," or WAG. The resulting ten WAGs were then further inventoried as to their "Operable Units," or individual targets for clean up. WAG 10 covered the desert land beyond the fences of the Site's nine complexes. Under that name, the Navy's unexploded ordnance, chunks of TNT, and other debris were targeted for cleanup. Other projects involve the removal and treatment of organic

348. Video Script, "Processing Experimental Pilot Plant (PREPP)" (Idaho Falls, Idaho: EG\&G Idaho, 1984).

349. Comprehensive Facility and Land use Plan. (Idaho Falls: Idaho National Engineering Laboratory, March 1996), p.157.

350. Comprehensive Facility and Land use Plan, p.157. 
vapors beneath the Radioactive Waste Management Complex, the excavation and treatment of buried mixed transuranic waste from Pit 9 and the treatment of contaminated groundwater from beneath TAN. ${ }^{351}$

The laboratory building to which many of the scientists who worked on waste cleanup reported was located in Idaho Falls. The Idaho Research Center (IRC), created in the 1980s during the national interest in fuel efficiency, expanded as INL research efforts moved in directions such as fuel alcohol, the biological processing of ores, development of special metal alloys, and welding. For these types of work the INL hired its first microbiologists and biochemists. When the INL later faced its many complex cleanup challenges, the appropriate personnel and laboratory facilities were available. The desert, former site of explosives tests, nuclear experiments, industrial and nuclear waste disposals of many kinds, and myriad forms of contamination large and small, became the new laboratory for IRC scientists charged to remediate it all. ${ }^{352}$

The federal support of cleanup grew. During the 1990s, about $60 \%$ of the total INL budget was for "Environmental Management," or cleanup. John Wilcynski, DOE manager during between 1994 and 1999, used to simplify INL's path forward with the slogan, "Finish the sixty, and grow the forty," meaning that as the cleanup tasks were accomplished, the research mission of the laboratory could resume a larger share of the total effort. ${ }^{353}$

In 2003, DOE and its regulatory partners, the State of Idaho and the Environmental Protection Agency, were considering a cleanup schedule that would "accelerate" many of the target dates and deadlines to which they had previously agreed. This administrative thrust has the potential to accelerate the rate at which buildings and facilities - many of them of historic significance - are being decommissioned and dismantled. Even whole building clusters, which made up such a significant part of INL's historic "landscape," are proposed for complete erasure. The Army Reactors Area already has been eliminated in this fashion (although this was done prior to the "accelerated" schedule).

Significance of the Remediation of Waste Context. Though the history of the RWMC is relatively brief, the facility highlights a major turning point for INL and the national nuclear industry. The early optimism engendered by nuclear energy's peaceful potential gradually became clouded by controversy about the disposition of waste and spent reactor fuel. In the 1970s the issues of burial, cleanup, and remediation of nuclear waste came to the national forefront. After the Cold War ended in 1990, interest (and funding) for nuclear science rapidly waned. The development of the RWMC and its constantly evolving technologies reflect this important shift in the history of INL and the national atomic energy program.

INL provided early experimental prototypes for nuclear waste remediation. In 1984, the SWEPP began operation at INL, the first United States facility of its kind to provide capabilities for nondestructive examination and certification of TRU waste. Whether this prototype will prove to have lasting historical significance or, indeed, whether the Remediation of Waste context itself, will survive the fifty-year benchmark for the National Register shall have to await the passage of time.

351. INEL Reporter (November/December 1996), p. 1.

352. Stacy, Proving the Principle, p. 247-249.

353. Stacy, Proving the Principle, p. 253. 


\section{Appendix G}

\section{Programmatic Agreement}




\section{PROGRAMMATIC AGREEMENT \\ BETWEEN \\ THE DEPARTMENT OF ENERGY DAHO OPERATIONS OFFICE \\ THE IDAHO STATE HISTORIC PRESERVATION OFFICE \\ AND}

THE ADVISORY COUNCIL ON HISTORIC PRESERVATION

CONCERNING MANAGEMENT OF CULTURAL RESOURCES ON

THE IDAHO NATIONAL ENGINEERING AND ENVIRONMENTAL LABORATORY

WHEREAS, the United States Department of Energy, Idaho Operations Office (DOE) shall continue to operate and maintain the Idaho National Engineering and Environmental Laboratory (herein referred to as "INEEL") located within Butte, Bingham, Clark, Fremont, and Bonneville Counties, in Idaho; and,

WHEREAS, DOE recognizes the rich history that exists on the INEEL, the importance of properties associated with this history (herein referred to as "historic properties") that are included in or eligible for nomination to the National Register of Historic Places and their legal responsibility to identify, protect, and preserve such properties on or under their jurisdiction, consistent with the mission and mandates of the INEEL; and

WHEREAS, DOE, in consultation with the Idaho State Historic Preservation Office (herein referred to as the SHPO) and the Advisory Council on Historic Preservation (herein referred to as the Council), has determined that some INEEL activities (herein referred to as undertakings) may adversely affect INEEL historic properties; and

WHEREAS, Section 110 of the National Historic Preservation Act (NHPA) sets out the broad historic preservation responsibilities of Federal agencies and is intended to ensure that historic preservation is fully integrated into the ongoing programs of all Federal agencies; and

WHEREAS, DOE intends to satisfy their NHPA Section 110 responsibilities;

NOW, THEREFORE, in order to satisfy the responsibilities of DOE for complying with Section 106 of the NHPA, DOE, the SHPO, and Council agree that upon signature of this Agreement by all parties, the undertakings performed at the INEEL will be accomplished in accordance with the following stipulations.

\section{STIPULATIONS}

The DOE shall ensure the following measures are carried out:

\section{INEEL Cultural Resources Management Plan}

A. DOE will incorporate the "INEEL Historic Architectural Properties Management Plan" (HAPMP) dated October 2003 into, and finalize, its Cultural Resources Management Plan (CRMP) in consultation with the SHPO, National Park Service, Council, and Shoshone-Bannock Tribes. In so doing, DOE shall take into consideration Council comments on the INEEL HAPMP, dated October 16, 2003 and earlier SHPO and Shoshone-Bannock Tribes comments. The CRMP will include, at a minimum, the components outlined in Attachment A.

B. DOE shall provide the draft CRMP to the SHPO, National Park Service (NPS), and Council for review and comment by April 15, 2004. The draft CRMP and comment response document will also be provided to the Shoshone-Bannock Tribes.

C. The SHPO, NPS, and Council shall review the CRMP and provide comments to DOE by May 15 , 2004. If comments are not received by this date, DOE shall assume concurrence with the CRMP as written. 
D. DOE shall, as appropriate, resolve and incorporate SHPO, NPS, and Council comments into the final CRMP and provide it to the SHPO and Council for final review by May 28, 2004.

E If no further SHPO, NPS, and/or Council comments are provided to DOE by June 30, 2004, DOE shall assume acceptance by the Council and SHPO. If DOE receives comments from the SHPO or Council meriting further review and revisions to the CRMP, DOE will consult with the parties to this agreement to resolve these issues. If the issues cannot be resolved within 15 (fifteen) days to the mutual satisfaction of the parties, DOE will initiate dispute resolution, as described in Stipulation IV, to this agreement.

F. Upon finalization of the CRMP, the Council and SHPO shall provide DOE with a letter of acceptance. DOE shall then implement the CRMP in lieu of compliance with 36 CFR 800.3-800.7.

G. DOE shall consult with the Council, SHPO, Shoshone-Bannock Tribes and interested parties annually, or as needed, to consider revisions to the CRMP.

\section{Interim Provisions}

A. DOE shall follow 36 CFR 800.3-800.7, with the exception of 36 CFR 800.6(a)(1), until acceptance of the CRMP by the SHPO and Council. Copies of all Memoranda of Agreement that are developed between the SHPO and DOE will be filed with the Council.

B. DOE shall notify the Council and assume their nonparticipation for each undertaking (36 CFR $800.6(a)(1))$ prior to acceptance and implementation of the CRMP. However, if disagreements or questions arise between DOE and SHPO during the review of individual undertakings, DOE will notify the Council of the dispute and invite the Council to participate in its resolution pursuant to Stipulation III. (36 CFR 800.2(b).

C. DOE shall communicate with the Shoshone-Bannock Tribes, where they have expressed interest, and interested parties to obtain their views on each undertaking until acceptance of the INEEL Cultural Resources Management Plan (36 CFR 800.3 - 800.7).

\section{m. General Provisions}

A. Cultural resource management professionals, meeting the Secretary of Interior's standards and guidelines (36 CFR 61) and referenced in DOE Headquarter's Policy "Management of Cultural Resource" (DOE P141.1), shall perform or closely oversee work toward compliance with this Agreement.

B. In accordance with $36 \mathrm{CFR} 800.10, \mathrm{DOE}$ agrees that the NPS, as an interested party representing the Secretary of the Interior, will be provided an opportunity to comment on proposed undertakings that will affect significant features of the Experimental Breeder Reactor I National Historic Landmark and DOE will take any such comments into consideration before reaching a final decision on the matter.

\section{Dispute Resolution}

Should any signatory to this Agreement or member of the public object to any action(s) or plans provided for review pursuant to this Agreement, DOE shall communicate with the objecting party within 30 days to begin resolution of the objection. The objection must be specifically identified, and the reasons for the objection documented. If DOE determines that the objection cannot be resolved, DOE shall forward all documentation relevant to the dispute to the Council and notify the SHPO as to the nature of the dispute. Within 30 days of receipt of all pertinent documentation, the Council shall either:

A. provide DOE with recommendations which DOE shall take into consideration in reaching a final decision regarding the dispute; or 
B. notify DOE that it will comment within an additional 30 days. Any Council comment provided in response to such a request will be considered by DOE in accordance with 36 CFR 800.7(c)(4) with reference to the subject of the dispute; or

C. any recommendation or comment provided by the Council will be understood to pertain only to the subject dispute. DOE's responsibility to carry out all actions under this agreement that are not the subject of the dispute will remain unchanged.

\section{Amendment}

Any signatory to this Agreement may request that it be amended, whereupon the parties will consult to consider such proposed amendment in accordance with 36 CFR 800.

\section{Termination}

DOE, the SHPO, or the Council may terminate this Programmatic Agreement by providing 30 days written notice to the other parties that DOE, the SHPO, and the Council consult during the 30 day notice period in order to seek agreement on amendments or other actions that would avoid termination. In the event of termination, DOE will comply with 36 CFR 800 for all actions otherwise covered under the terms of this agreement.

\section{Scope of Agreement}

Execution of this Agreement is limited in scope to undertakings that may adversely impact historic properties under the jurisdiction of DOE and is entered into solely for that purpose. Properties located at the Naval Reactors Facility, under the jurisdiction of the Naval Nuclear Propulsion Program are excluded under this Agreement. Execution and implementation of this Agreement by DOE, the Council, and SHPO evidences that DOE has afforded the Council an opportunity to comment on the undertakings and their effects on historic properties, and has taken into account the effects of the undertakings on those properties, and has, therefore, satisfied its Section 106 responsibilities for these undertakings.

\section{Duration}

If the terms of this Programmatic Agreement have not been executed by September 30, 2005, this Programmatic Agreement shall be considered null and void. In such an event, DOE shall notify the parties to this Programmatic Agreement, and comply with 36 CFR 800 for individual undertakings. 
Execution of this Programmatic Agreement by the U.S. Department of Energy, Idaho Operations Office, the Idaho State Historic Preservation Office, and, if they so choose, the Advisory Council on Historic Preservation and implementation of its terms shall constitute evidence that the U.S. Department of Energy, Idaho Operations Office has taken into account the effects of their undertakings on historic properties under their jurisdiction as per requirements of Section 106 of the National Historic Preservation Act.

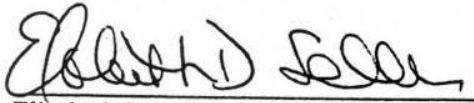

Elizabeth D. Sellers, Manager

Department of Energy, Idaho Operations Office

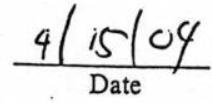

Page 4 of 6 
Execution of this Programmatic Agreement by the U.S. Department of Energy, Idaho Operations Office, the Idaho State Historic Preservation Office, and, if they so choose, the Advisory Council on Historic Preservation and implementation of its terms shall constitute evidence that the U.S. Department of Energy Idaho Operations Office has taken into account the effects of their undertakings on historic properties under their jurisdiction as per requirements of Section 106 of the National Historic Preservation Act.

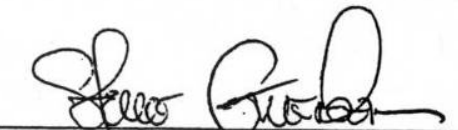

Steve Guerber, State Historic Preservation Officer for Idaho Idaho State Historic Preservation Office

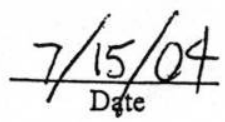

Page 5 of 6 
Execution of this Programmatic Agreement by the U.S. Department of Energy, Idaho Operations Office, the Idaho State Historic Preservation Office, and, if they so choose, the Advisory Council on Historic

Preservation and implementation of its terms shall constitute evidence that the U.S. Department of Energy, Idaho Operations Office has taken into account the effects of their undertakings on historic properties under their jurisdiction as per requirements of Section 106 of the National Historic Preservation Act.

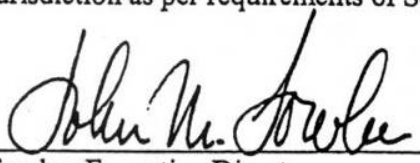

John Fowler, Executive Director Advisory Council on Historic Preservation

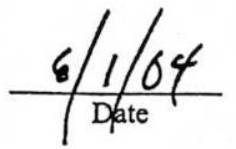

Page 6 of 6 


\section{Appendix $\mathrm{H}$}

\section{Inventory of Known INL Archaeological Resources}




\section{Appendix H}

\section{Inventory of Known INL Archaeological Resources}

The following inventories are up to date through fiscal year 2006, although information from some resources originally recorded by subcontractors is incomplete. Three inventory tables are provided: Table 5 lists prehistoric archaeological sites, Table 6 lists prehistoric isolated finds, and Table 7 lists historic archaeological sites and isolated finds. Resources that contain both prehistoric and historic artifacts (multicomponent) are also listed in Table 7.

Table 5. INL prehistoric archaeological sites.

\begin{tabular}{|c|c|c|}
\hline \multicolumn{3}{|c|}{ INL Prehistoric Archaeological Sites } \\
\hline Site Number & Field Number & Project Name \\
\hline 10-BM-034 & BRB-70-16 & NRTS Surveys 1967-1969 \\
\hline 10-BM-035 & BRB-70-38A & NRTS Surveys 1967-1969 \\
\hline 10-BM-036 & BRB-70-38B & NRTS Surveys 1967-1969 \\
\hline 10-BM-037 & BRB-70-38C & NRTS Surveys 1967-1969 \\
\hline 10-BM-038 & BRB-70-38D & NRTS Surveys 1967-1969 \\
\hline 10-BM-039 & BRB-70-38E & NRTS Surveys 1967-1969 \\
\hline 10-BM-040 & BRB-70-38F & NRTS Surveys 1967-1969 \\
\hline 10-BM-041 & BRB-70-38G & NRTS Surveys 1967-1969 \\
\hline 10-BM-042 & BRB-71-54 & NRTS Surveys 1970-1971 \\
\hline 10-BM-043 & BRB-71-55 & NRTS Surveys 1970-1971 \\
\hline 10-BM-044 & BRB-71-56 & NRTS Surveys 1970-1971 \\
\hline 10-BM-045 & BRB-71-57 & NRTS Surveys 1970-1971 \\
\hline 10-BM-047 & BRB-70-01 & NRTS Surveys 1967-1969 \\
\hline 10-BM-048 & BRB-70-A & NRTS Surveys 1967-1969 \\
\hline 10-BM-052 & BRB-70-B & NRTS Surveys 1967-1969 \\
\hline 10-BM-079 & SJM-84-02-002 & Grazing Boundary \\
\hline 10-BM-080 & SJM-84-02-003 & Grazing Boundary \\
\hline 10-BM-081 & SJM-84-02-004 & Grazing Boundary \\
\hline 10-BM-084 & SJM-84-02-008 & Grazing Boundary \\
\hline 10-BM-085 & SJM-84-02-009 & Grazing Boundary \\
\hline 10-BM-086 & SJM-84-02-010 & Grazing Boundary \\
\hline 10-BM-089 & SJM-84-01-SP-02 & Perimeter Boundary \\
\hline 10-BM-093 & SJM-84-01-SEP-02 & Perimeter Boundary \\
\hline 10-BM-094 & SJM-84-01-SEP-03 & Perimeter Boundary \\
\hline 10-BM-096 & SJM-84-01-EP-02 & Perimeter Boundary \\
\hline 10-BM-098 & SJM-84-02-097 & Grazing Boundary \\
\hline 10-BM-106 & ISU-85-11.91-21 & FOC T-24 \\
\hline 10-BM-109 & ISU-85-11.85-18 & FOC-CFA to ANL \\
\hline
\end{tabular}


Table 5. (continued).

\begin{tabular}{|c|c|c|}
\hline \multicolumn{3}{|c|}{ INL Prehistoric Archaeological Sites } \\
\hline Site Number & Field Number & Project Name \\
\hline 10-BM-110 & ISU-85-11.85-19 & FOC-CFA to ANL \\
\hline 10-BM-112 & ISU-85-11.85-21 & FOC-CFA to ANL \\
\hline 10-BM-115 & ISU-85-11.85-24 & FOC-CFA to ANL \\
\hline 10-BM-116 & ISU-85-11.85-25 & FOC-CFA to ANL \\
\hline 10-BM-117 & ISU-85-11.85-26 & FOC-CFA to ANL \\
\hline 10-BM-118 & ISU-85-11.85-27 & FOC-CFA to ANL \\
\hline 10-BM-122 & ISU-85-11.85-17 & FOC-CFA to ANL \\
\hline $10-B M-123$ & ISU-85-11.81-04 & FOC-ANL to TAN \\
\hline 10-BM-124 & ISU-85-11.81-05 & FOC-ANL to TAN \\
\hline 10-BM-126 & ISU-85-11.81-01 & FOC-ANL to TAN \\
\hline 10-BM-136 & SJM-84-21-01 & Taylor Blvd Guard Station \\
\hline 10-BM-137 & ISU-86-08-02 & FOC-ANL TO IF \\
\hline 10-BM-148 & ISU-92-08-01 & Cedar Butte \\
\hline 10-BM-156 & ISU-87-12-32 & $\mathrm{SSC}$ \\
\hline 10-BM-217 & ISU-88-09-01 & ANL-W Administrative Boundary \\
\hline $10-B M-223$ & ISU-88-09-07 & ANL-W Administrative Boundary \\
\hline 10-BM-229 & ISU-88-09-13 & ANL-W Administrative Boundary \\
\hline 10-BM-231 & ISU-88-09-15 & ANL-W Administrative Boundary \\
\hline 10-BM-235 & ISU-88-09-18 & ANL-W Administrative Boundary \\
\hline 10-BM-241 & ISU-88-09-25 & ANL-W Administrative Boundary \\
\hline 10-BM-244 & ISU-88-09-28 & ANL-W Administrative Boundary \\
\hline 10-BM-245 & ISU-88-09-29 & ANL-W Administrative Boundary \\
\hline 10-BM-247 & ISU-88-09-31 & ANL-W Administrative Boundary \\
\hline 10-BM-248 & ISU-88-09-32 & ANL-W Administrative Boundary \\
\hline $10-\mathrm{BM}-250$ & ISU-88-09-34 & ANL-W Administrative Boundary \\
\hline 10-BM-263 & ISU-90-08-Z & NPR Sample Survey \\
\hline 10-BM-264 & ISU-90-08-AA & NPR Sample Survey \\
\hline 10-BM-265 & ISU-90-08-BB & NPR Sample Survey \\
\hline 10-BM-267 & ISU-90-08-DD & NPR Sample Survey \\
\hline 10-BM-275 & ISU-90-08-W1 & NPR Sample Survey \\
\hline 10-BM-276 & ISU-90-08-X1 & NPR Sample Survey \\
\hline 10-BM-608 & SJM-84-01-BNDRY-17 & Perimeter Boundary \\
\hline 10-BT-0001 & EHS-54-1 & Little Lost River Cave Excavation \\
\hline 10-BT-0003 & EHS-58-01 & Earl Swanson Surveys \\
\hline 10-BT-0019 & EHS-58-02 & Earl Swanson Surveys \\
\hline 10-BT-0029/10-BT-0102 & EHS-58-03 & Earl Swanson Surveys \\
\hline
\end{tabular}


Table 5. (continued).

\begin{tabular}{|c|c|c|}
\hline \multicolumn{3}{|c|}{ INL Prehistoric Archaeological Sites } \\
\hline Site Number & Field Number & Project Name \\
\hline 10-BT-0033 & EHS-61-01 & Birch Creek Surveys \\
\hline 10-BT-0034 & EHS-61-02 & Birch Creek Surveys \\
\hline 10-BT-0037 & EHS-61-03 & Birch Creek Surveys \\
\hline 10-BT-0038 & EHS-61-04 & Birch Creek Surveys \\
\hline 10-BT-0039 & EHS-61-05 & Birch Creek Surveys \\
\hline 10-BT-0040 & EHS-61-06 & Birch Creek Surveys \\
\hline 10-BT-0041 & EHS-61-07 & Birch Creek Surveys \\
\hline 10-BT-0042 & EHS-61-08 & Birch Creek Surveys \\
\hline 10-BT-0046 & EHS-62-01 & Jackknife Cave Excavation \\
\hline 10-BT-0047 & EHS-61-09 & Birch Creek Surveys \\
\hline 10-BT-0048 & LAK-77-11 & Lost River/Birch Creek Planning Unit \\
\hline 10-BT-0049 & LAK-77-12 & Lost River/Birch Creek Planning Unit \\
\hline 10-BT-0050 & EHS-61-10 & Birch Creek Surveys \\
\hline 10-BT-0051 & EHS-61-11 & Birch Creek Surveys \\
\hline 10-BT-0064 & EHS-61-12 & Birch Creek Surveys \\
\hline 10-BT-0079 & ISU-85-11.90-29 & FOC-Lincoln Blvd \\
\hline 10-BT-0092 & BRB-70-02 & NRTS Surveys 1967-1969 \\
\hline 10-BT-0095 & BRB-70-06 & NRTS Surveys 1967-1969 \\
\hline 10-BT-0096 & BRB-70-07 & NRTS Surveys 1967-1969 \\
\hline 10-BT-0097 & BRB-70-08 & NRTS Surveys 1967-1969 \\
\hline 10-BT-0098 & BRB-70-09 & NRTS Surveys 1967-1969 \\
\hline 10-BT-0099 & BRB-70-10 & NRTS Surveys 1967-1969 \\
\hline 10-BT-0100 & ISU-85-11.2-02 & CFA Perimeter and Landfill \\
\hline 10-BT-0101 & BRB-70-12 & NRTS Surveys 1967-1969 \\
\hline 10-BT-0102 & BRB-70-13 & NRTS Surveys 1967-1969 \\
\hline 10-BT-0103 & BRB-70-14 & NRTS Surveys 1967-1969 \\
\hline 10-BT-0104 & BRB-70-15 & NRTS Surveys 1967-1969 \\
\hline 10-BT-0106 & BRB-71-17 & NRTS Surveys 1970-1971 \\
\hline 10-BT-0107 & BRB-71-18 & NRTS Surveys 1970-1971 \\
\hline 10-BT-0109 & BRB-70-20 & NRTS Surveys 1967-1969 \\
\hline 10-BT-0110 & BRB-70-21 & NRTS Surveys 1967-1969 \\
\hline 10-BT-0111 & BRB-70-22 & NRTS Surveys 1967-1969 \\
\hline 10-BT-0112 & BRB-70-23 & NRTS Surveys 1967-1969 \\
\hline 10-BT-0113 & BRB-70-24 & NRTS Surveys 1967-1969 \\
\hline 10-BT-0114 & BRB-70-25 & NRTS Surveys 1967-1969 \\
\hline 10-BT-0115 & BRB-70-27 & NRTS Surveys 1967-1969 \\
\hline
\end{tabular}


Table 5. (continued).

\begin{tabular}{|c|c|c|}
\hline \multicolumn{3}{|c|}{ INL Prehistoric Archaeological Sites } \\
\hline Site Number & Field Number & Project Name \\
\hline 10-BT-0116 & BRB-70-28 & NRTS Surveys 1967-1969 \\
\hline 10-BT-0117 & BRB-70-29 & NRTS Surveys 1967-1969 \\
\hline 10-BT-0118 & BRB-70-30 & NRTS Surveys 1967-1969 \\
\hline 10-BT-0119 & BRB-70-31 & NRTS Surveys 1967-1969 \\
\hline 10-BT-0120 & BRB-70-32 & NRTS Surveys 1967-1969 \\
\hline 10-BT-0121 & BRB-71-46 & NRTS Surveys 1970-1971 \\
\hline 10-BT-0122 & BRB-71-47 & NRTS Surveys 1970-1971 \\
\hline 10-BT-0123 & BRB-71-48 & NRTS Surveys 1970-1971 \\
\hline 10-BT-0125 & BRB-71-50 & NRTS Surveys 1970-1971 \\
\hline 10-BT-0126 & BRB-71-51 & NRTS Surveys 1970-1971 \\
\hline 10-BT-0127 & BRB-71-52 & NRTS Surveys 1970-1971 \\
\hline 10-BT-0128 & BRB-71-53 & NRTS Surveys 1970-1971 \\
\hline 10-BT-0129 & BRB-71-59A & NRTS Surveys 1970-1971 \\
\hline 10-BT-0131/ 10-BT-0093 & BRB-71-59B & NRTS Surveys 1970-1971 \\
\hline 10-BT-0132/ 10-BT-0094 & BRB-71-59C & NRTS Surveys 1970-1971 \\
\hline 10-BT-0133 & BRB-70-05 & NRTS Surveys 1967-1969 \\
\hline 10-BT-0134 & BRB-71-45 & NRTS Surveys 1970-1971 \\
\hline 10-BT-0149 & BRB-70-03 & NRTS Surveys 1967-1969 \\
\hline 10-BT-0150 & BRB-70-04 & NRTS Surveys 1967-1969 \\
\hline 10-BT-0187 & LAK-77-01 & Lost River/Birch Creek Planning Unit \\
\hline 10-BT-0188 & LAK-77-02 & Lost River/Birch Creek Planning Unit \\
\hline 10-BТ-0189 & LAK-77-03 & Lost River/Birch Creek Planning Unit \\
\hline 10-BT-0190 & LAK-77-04 & Lost River/Birch Creek Planning Unit \\
\hline 10-BТ-0191 & LAK-77-05 & Lost River/Birch Creek Planning Unit \\
\hline 10-BT-0192 & LAK-77-06 & Lost River/Birch Creek Planning Unit \\
\hline 10-BT-0194 & LAK-77-07 & Lost River/Birch Creek Planning Unit \\
\hline 10-BT-0196 & LAK-77-08 & Lost River/Birch Creek Planning Unit \\
\hline 10-BT-0197 & LAK-77-09 & Lost River/Birch Creek Planning Unit \\
\hline 10-BT-0233 & LAK-77-10 & Lost River/Birch Creek Planning Unit \\
\hline 10-BT-0255 & JGF-80-01 & Big Desert Planning Unit \\
\hline 10-BT-0371 & SJM-84-11-E01 & NPR Area E \\
\hline 10-BT-0373 & SJM-84-11-E03 & NPR Area E \\
\hline 10-BT-0375 & SJM-84-11-E05 & NPR Area E \\
\hline 10-BT-0377 & SJM-84-11-E07 & NPR Area E \\
\hline 10-BT-0378 & SJM-84-11-E08 & NPR Area E \\
\hline 10-BT-0380 & SJM-84-11-E10 & NPR Area E \\
\hline
\end{tabular}


Table 5. (continued).

\begin{tabular}{|c|c|c|}
\hline \multicolumn{3}{|c|}{ INL Prehistoric Archaeological Sites } \\
\hline Site Number & Field Number & Project Name \\
\hline 10-BT-0383 & SJM-84-11-E13 & NPR Area E \\
\hline 10-BT-0385 & SJM-84-11-E15 & NPR Area E \\
\hline 10-BT-0386 & SJM-84-11-E16 & NPR Area E \\
\hline 10-BT-0387 & SJM-84-11-E17 & NPR Area E \\
\hline 10-BT-0388 & SJM-84-11-E18 & NPR Area E \\
\hline 10-BT-0390 & SJM-84-11-E20 & NPR Area E \\
\hline 10-BT-0393 & SJM-84-11-E23 & NPR Area E \\
\hline 10-BT-0394 & SJM-84-11-E24 & NPR Area E \\
\hline 10-BT-0395 & SJM-84-11-E25 & NPR Area E \\
\hline 10-BT-0396 & SJM-84-11-E26 & NPR Area E \\
\hline 10-BT-0397 & SJM-84-11-E27 & NPR Area E \\
\hline 10-BT-0398 & SJM-84-11-E28 & NPR Area E \\
\hline 10-BT-0400 & SJM-84-11-E30 & NPR Area E \\
\hline 10-BT-0415 & SJM-84-11-E45/76 & NPR Area E \\
\hline 10-BT-0420 & SJM-84-11-E49 & NPR Area E \\
\hline 10-BT-0422 & SJM-84-11-E51 & NPR Area E \\
\hline 10-BT-0423 & SJM-84-11-E52 & NPR Area E \\
\hline 10-BT-0424 & SJM-84-11-E53 & NPR Area E \\
\hline 10-BT-0425 & SJM-84-11-E54 & NPR Area E \\
\hline 10-BT-0427 & SJM-84-11-E56 & NPR Area E \\
\hline 10-BT-0428 & SJM-84-11-E57 & NPR Area E \\
\hline 10-BT-0429 & SJM-84-11-E58 & NPR Area E \\
\hline 10-BT-0430 & SJM-84-11-E59 & NPR Area E \\
\hline 10-BT-0431 & SJM-84-11-E60 & NPR Area E \\
\hline 10-BT-0432 & SJM-84-11-E61 & NPR Area E \\
\hline 10-BT-0435 & SJM-84-11-E64 & NPR Area E \\
\hline 10-BT-0436 & SJM-84-11-E65 & NPR Area E \\
\hline 10-BT-0437 & SJM-84-11-E66 & NPR Area E \\
\hline 10-BT-0438 & SJM-84-11-E67 & NPR Area E \\
\hline 10-BT-0439 & SJM-84-11-E68 & NPR Area E \\
\hline 10-BT-0443 & SJM-84-11-E72 & NPR Area E \\
\hline 10-BT-0448 & SJM-84-11-E77 & NPR Area E \\
\hline 10-BT-0453 & SJM-84-11-E82 & NPR Area E \\
\hline 10-BT-0457 & SJM-84-11-E86 & NPR Area E \\
\hline 10-BT-0481 & SJM-84-11-A & NPR Area E \\
\hline 10-BT-0482 & SJM-84-11-B & NPR Area E \\
\hline
\end{tabular}


Table 5. (continued).

\begin{tabular}{|c|c|c|}
\hline \multicolumn{3}{|c|}{ INL Prehistoric Archaeological Sites } \\
\hline Site Number & Field Number & Project Name \\
\hline 10-BT-0538 & SJM-84-02-041 & Grazing Boundary \\
\hline 10-BT-0541 & SJM-84-02-051 & Grazing Boundary \\
\hline 10-BT-0542 & SJM-84-02-052 & Grazing Boundary \\
\hline 10-BT-0543 & SJM-84-02-053 & Grazing Boundary \\
\hline 10-BT-0546 & SJM-84-02-056 & Grazing Boundary \\
\hline 10-BT-0547 & SJM-84-02-057 & Grazing Boundary \\
\hline 10-BT-0551 & SJM-84-02-064 & Grazing Boundary \\
\hline 10-BT-0553 & SJM-84-02-066 & Grazing Boundary \\
\hline 10-BT-0554 & SJM-84-02-067 & Grazing Boundary \\
\hline 10-BT-0555 & SJM-84-02-068 & Grazing Boundary \\
\hline 10-BT-0558 & SJM-84-02-072 & Grazing Boundary \\
\hline 10-BT-0559 & SJM-84-02-073 & Grazing Boundary \\
\hline 10-BT-0561 & SJM-84-02-075 & Grazing Boundary \\
\hline 10-BT-0562 & SJM-84-02-076 & Grazing Boundary \\
\hline 10-BT-0563 & SJM-84-02-077 & Grazing Boundary \\
\hline 10-BT-0564 & SJM-84-02-078 & Grazing Boundary \\
\hline 10-BT-0567 & SJM-84-02-082 & Grazing Boundary \\
\hline 10-BT-0568 & SJM-84-02-083 & Grazing Boundary \\
\hline 10-BT-0569 & SJM-84-02-084 & Grazing Boundary \\
\hline 10-BT-0570 & SJM-84-02-085 & Grazing Boundary \\
\hline 10-BT-0571 & SJM-84-02-086 & Grazing Boundary \\
\hline 10-BT-0572 & SJM-84-02-087 & Grazing Boundary \\
\hline 10-BT-0584 & SJM-84-01-SP-31 & Perimeter Boundary \\
\hline 10-BT-0588 & SJM-84-01-SWP-01 & Perimeter Boundary \\
\hline 10-BT-0589 & SJM-84-01-SWP-03 & Perimeter Boundary \\
\hline 10-BT-0590 & SJM-84-01-SWP-02 & Perimeter Boundary \\
\hline 10-BT-0591 & SJM-84-01-SP-24 & Perimeter Boundary \\
\hline 10-BT-0592 & SJM-84-01-SP-26 & Perimeter Boundary \\
\hline 10-BT-0594 & SJM-84-01-SP-22 & Perimeter Boundary \\
\hline 10-BT-0595 & SJM-84-01-SP-23 & Perimeter Boundary \\
\hline 10-BT-0596 & SJM-84-01-WP-02 & Perimeter Boundary \\
\hline 10-BT-0597 & SJM-84-01-WP-01 & Perimeter Boundary \\
\hline 10-BT-0598 & SJM-84-01-WP-03 & Perimeter Boundary \\
\hline 10-BT-0600 & SJM-84-01-SWP-06 & Perimeter Boundary \\
\hline 10-BT-0603 & SJM-84-01-NWP-03 & Perimeter Boundary \\
\hline 10-BT-0604 & SJM-84-01-NWP-08 & Perimeter Boundary \\
\hline
\end{tabular}


Table 5. (continued).

\begin{tabular}{|c|c|c|}
\hline \multicolumn{3}{|c|}{ INL Prehistoric Archaeological Sites } \\
\hline Site Number & Field Number & Project Name \\
\hline 10-BT-0605 & SJM-84-01-NWP-01 & Perimeter Boundary \\
\hline 10-BT-0606 & SJM-84-01-NWP-02A & Perimeter Boundary \\
\hline 10-BT-0607 & SJM-84-01-NWP-05 & Perimeter Boundary \\
\hline 10-BT-0608 & SJM-84-01-SP-06 & Perimeter Boundary \\
\hline 10-BT-0610 & SJM-84-01-SP-17 & Perimeter Boundary \\
\hline 10-BT-0612 & SJM-84-01-SP-15 & Perimeter Boundary \\
\hline 10-BT-0614 & SJM-84-01-SP-12 & Perimeter Boundary \\
\hline 10-BT-0615 & SJM-84-01-SP-13 & Perimeter Boundary \\
\hline 10-BT-0616 & SJM-84-01-SP-09 & Perimeter Boundary \\
\hline 10-BT-0617 & SJM-84-01-SP-10 & Perimeter Boundary \\
\hline 10-BT-0618 & SJM-84-01-SP-08 & Perimeter Boundary \\
\hline 10-BT-0619 & SJM-84-01-SP-05 & Perimeter Boundary \\
\hline 10-BT-0620 & SJM-84-01-SP-18 & Perimeter Boundary \\
\hline 10-BT-0621 & SJM-84-01-SP-19 & Perimeter Boundary \\
\hline 10-BT-0623 & SJM-84-02-063 & Grazing Boundary \\
\hline 10-BT-0627 & SJM-84-01-WP-05 & Perimeter Boundary \\
\hline 10-BT-0628 & SJM-84-01-WP-06 & Perimeter Boundary \\
\hline 10-BT-0629 & SJM-84-01-WP-07 & Perimeter Boundary \\
\hline 10-BT-0630 & SJM-84-01-WP-08 & Perimeter Boundary \\
\hline 10-BT-0632 & SJM-84-01-WP-04 & Perimeter Boundary \\
\hline 10-BT-0640 & SJM-84-02-096 & Grazing Boundary \\
\hline 10-BT-0641 & SJM-84-02-070 & Grazing Boundary \\
\hline 10-BT-0646 & SJM-84-15-A & Geological Studies \\
\hline 10-BT-0647 & SJM-84-15-07 & Geological Studies \\
\hline 10-BT-0648 & SJM-84-15-08 & Geological Studies \\
\hline 10-BT-0649 & SJM-84-15-09 & Geological Studies \\
\hline 10-BT-0650 & SJM-84-15-10 & Geological Studies \\
\hline 10-BT-0651 & SJM-84-15-11 & Geological Studies \\
\hline 10-BT-0652 & SJM-84-15-12 & Geological Studies \\
\hline 10-BT-0653 & SJM-84-15-13 & Geological Studies \\
\hline 10-BT-0654 & SJM-84-15-14 & Geological Studies \\
\hline 10-BT-0657 & SJM-84-15-17 & Geological Studies \\
\hline 10-BT-0658 & SJM-84-15-18 & Geological Studies \\
\hline 10-BT-0659 & SJM-84-15-19 & Geological Studies \\
\hline 10-BT-0661 & SJM-84-15-21 & Geological Studies \\
\hline 10-BT-0662 & SJM-84-15-22 & Geological Studies \\
\hline
\end{tabular}


Table 5. (continued).

\begin{tabular}{|c|c|c|}
\hline \multicolumn{3}{|c|}{ INL Prehistoric Archaeological Sites } \\
\hline Site Number & Field Number & Project Name \\
\hline 10-BT-0663 & SJM-84-15-23 & Geological Studies \\
\hline 10-BT-0665 & SJM-84-15-25 & Geological Studies \\
\hline 10-BT-0668 & SJM-84-15-28 & Geological Studies \\
\hline 10-BT-0669 & SJM-84-15-29 & Geological Studies \\
\hline 10-BT-0670 & SJM-84-15-30 & Geological Studies \\
\hline 10-BT-0673 & SJM-84-15-B & Geological Studies \\
\hline 10-BT-0674 & SJM-84-02-2GB-08 & Grazing Boundary \\
\hline 10-BT-0675 & SJM-84-02-2GB-09 & Grazing Boundary \\
\hline 10-BT-0677 & SJM-84-02-2GB-11 & Grazing Boundary \\
\hline 10-BT-0678 & SJM-84-02-2GB-12 & Grazing Boundary \\
\hline 10-BT-0679 & SJM-84-02-2GB-13 & Grazing Boundary \\
\hline 10-BT-0680 & SJM-84-03-01 & Diversion Area \\
\hline 10-BT-0683 & SJM-84-03-04 & Diversion Area \\
\hline 10-BT-0684 & SJM-84-03-05 & Diversion Area \\
\hline 10-BT-0685 & SJM-84-03-06 & Diversion Area \\
\hline 10-BT-0696 & SJM-84-03-17 & Diversion Area \\
\hline 10-BT-0699 & SJM-84-03-20 & Diversion Area \\
\hline 10-BT-0700 & SJM-84-03-21 & Diversion Area \\
\hline 10-BT-0701 & SJM-84-03-22 & Diversion Area \\
\hline 10-BT-0702 & SJM-84-03-23 & Diversion Area \\
\hline 10-BT-0703 & SJM-84-01-BNDRY-5 & Perimeter Boundary \\
\hline 10-BT-0704 & SJM-83-01-01 & RWMC Wind Gap \#2 \\
\hline 10-BT-0705 & SJM-83-01-02 & RWMC Wind Gap \#2 \\
\hline 10-BT-0707 & SJM-83-01-04 & RWMC Wind Gap \#2 \\
\hline 10-BT-0708 & SJM-83-01-05 & RWMC Wind Gap \#2 \\
\hline 10-BT-0711 & SJM-83-01-08 & RWMC Wind Gap \#2 \\
\hline 10-BT-0712 & SJM-83-01-09 & RWMC Wind Gap \#2 \\
\hline 10-BT-0716 & SJM-83-01-13 & RWMC Wind Gap \#2 \\
\hline 10-BT-0717 & SJM-83-01-14 & RWMC Wind Gap \#2 \\
\hline 10-BT-0718 & SJM-83-01-15 & RWMC Wind Gap \#2 \\
\hline 10-BT-0719 & SJM-83-01-16 & RWMC Wind Gap \#2 \\
\hline 10-BT-0720 & SJM-84-03-24 & Diversion Area \\
\hline 10-BT-0721 & SJM-84-03-25 & Diversion Area \\
\hline 10-BT-0726 & SJM-84-03-30 & Diversion Area \\
\hline 10-BT-0727 & SJM-84-03-31 & Diversion Area \\
\hline 10-BT-0729 & SJM-84-03-33 & Diversion Area \\
\hline
\end{tabular}


Table 5. (continued).

\begin{tabular}{|c|c|c|}
\hline \multicolumn{3}{|c|}{ INL Prehistoric Archaeological Sites } \\
\hline Site Number & Field Number & Project Name \\
\hline 10-BT-0731 & SJM-84-03-35 & Diversion Area \\
\hline 10-BT-0732 & SJM-84-03-36 & Diversion Area \\
\hline 10-BT-0738 & SJM-84-01-BNDRY-7 & Perimeter Boundary \\
\hline 10-BT-0740 & SJM-84-19-01 & TAN Powerlines and Parking Lot \\
\hline 10-BT-0742 & SJM-84-01-BNDRY-9 & Perimeter Boundary \\
\hline 10-BT-0743 & SJM-84-01-BNDRY-10 & Perimeter Boundary \\
\hline 10-BT-0744 & SJM-84-01-BNDRY-11 & Perimeter Boundary \\
\hline 10-BT-0745 & SJM-84-05-01 & CFA Heliport \\
\hline 10-BT-0747 & SJM-84-15-33 & Geological Studies \\
\hline 10-BT-0748 & SJM-84-15-34 & Geological Studies \\
\hline 10-BT-0751 & ISU-85-07-039 & Firing Range \\
\hline 10-BT-0752 & ISU-85-07-012 & Firing Range \\
\hline 10-BT-0753 & ISU-85-07-080 & Firing Range \\
\hline 10-BT-0754 & ISU-85-07-082 & Firing Range \\
\hline 10-BT-0755 & ISU-85-07-090 & Firing Range \\
\hline 10-BT-0756 & ISU-85-07-163 & Firing Range \\
\hline 10-BT-0757 & ISU-85-07-168 & Firing Range \\
\hline 10-BT-0758 & ISU-85-07-177 & Firing Range \\
\hline 10-BT-0759 & ISU-85-07-097 & Firing Range \\
\hline 10-BT-0760 & ISU-85-07-178 & Firing Range \\
\hline 10-BT-0762 & ISU-85-07-034 & Firing Range \\
\hline 10-BT-0763 & ISU-85-07-035 & Firing Range \\
\hline 10-BT-0764 & ISU-85-07-049 & Firing Range \\
\hline 10-BT-0765 & ISU-85-07-050 & Firing Range \\
\hline 10-BT-0766 & ISU-85-07-055 & Firing Range \\
\hline 10-BT-0767 & ISU-85-07-056 & Firing Range \\
\hline 10-BT-0768 & ISU-85-07-071 & Firing Range \\
\hline 10-BT-0769 & ISU-85-07-073 & Firing Range \\
\hline 10-BT-0770 & ISU-85-07-099 & Firing Range \\
\hline 10-BT-0771 & ISU-85-07-106 & Firing Range \\
\hline 10-BT-0772 & ISU-85-07-111 & Firing Range \\
\hline 10-BT-0773 & ISU-85-07-116 & Firing Range \\
\hline 10-BT-0774 & ISU-85-07-126 & Firing Range \\
\hline 10-BT-0775 & ISU-85-07-007 & Firing Range \\
\hline 10-BT-0776 & ISU-85-07-010 & Firing Range \\
\hline 10-BT-0778 & ISU-85-07-075 & Firing Range \\
\hline
\end{tabular}


Table 5. (continued).

\begin{tabular}{|c|c|c|}
\hline \multicolumn{3}{|c|}{ INL Prehistoric Archaeological Sites } \\
\hline Site Number & Field Number & Project Name \\
\hline 10-BT-0779 & ISU-85-07-084 & Firing Range \\
\hline 10-BT-0780 & ISU-85-07-088 & Firing Range \\
\hline 10-BT-0782 & ISU-85-07-005 & Firing Range \\
\hline 10-BT-0783 & ISU-85-07-015 & Firing Range \\
\hline 10-BT-0784 & ISU-85-07-020 & Firing Range \\
\hline 10-BT-0785 & ISU-85-07-021 & Firing Range \\
\hline 10-BT-0786 & ISU-85-07-022 & Firing Range \\
\hline 10-BT-0787 & ISU-85-07-023 & Firing Range \\
\hline 10-BT-0788 & ISU-85-07-025 & Firing Range \\
\hline 10-BT-0789 & ISU-85-07-026 & Firing Range \\
\hline 10-BT-0790 & ISU-85-07-029 & Firing Range \\
\hline 10-BT-0791 & ISU-85-07-030 & Firing Range \\
\hline 10-BT-0792 & ISU-85-07-032 & Firing Range \\
\hline 10-BT-0793 & ISU-85-07-033 & Firing Range \\
\hline 10-BT-0794 & ISU-85-07-041 & Firing Range \\
\hline 10-BT-0795 & ISU-85-07-042 & Firing Range \\
\hline 10-BT-0796 & ISU-85-07-043 & Firing Range \\
\hline 10-BT-0797 & ISU-85-07-046 & Firing Range \\
\hline 10-BT-0798 & ISU-85-07-047 & Firing Range \\
\hline 10-BT-0799 & ISU-85-07-052 & Firing Range \\
\hline 10-BT-0801 & ISU-85-07-064 & Firing Range \\
\hline 10-BT-0802 & ISU-85-07-065 & Firing Range \\
\hline 10-BT-0803 & ISU-85-07-132 & Firing Range \\
\hline 10-BT-0807 & ISU-85-07-138 & Firing Range \\
\hline 10-BT-0808 & ISU-85-07-139 & Firing Range \\
\hline 10-BT-0809 & ISU-85-07-141 & Firing Range \\
\hline 10-BT-0810 & ISU-85-07-143 & Firing Range \\
\hline 10-BT-0811 & ISU-85-07-144 & Firing Range \\
\hline 10-BT-0812 & ISU-85-07-157 & Firing Range \\
\hline 10-BT-0813 & ISU-85-07-158 & Firing Range \\
\hline 10-BT-0814 & ISU-85-07-159 & Firing Range \\
\hline 10-BT-0816 & ISU-85-07-130 & Firing Range \\
\hline 10-BT-0817 & ISU-85-07-146 & Firing Range \\
\hline 10-BT-0818 & ISU-85-07-147 & Firing Range \\
\hline 10-BT-0820 & ISU-85-07-153 & Firing Range \\
\hline 10-BT-0821 & ISU-85-07-154 & Firing Range \\
\hline
\end{tabular}


Table 5. (continued).

\begin{tabular}{|c|c|c|}
\hline \multicolumn{3}{|c|}{ INL Prehistoric Archaeological Sites } \\
\hline Site Number & Field Number & Project Name \\
\hline 10-BT-0822 & ISU-85-07-155 & Firing Range \\
\hline 10-BT-0933 & ISU-85-12-09 & NRF Perimeter \\
\hline 10-BT-0934 & ISU-85-12-10 & NRF Perimeter \\
\hline 10-BT-0937 & ISU-85-12-13 & NRF Perimeter \\
\hline 10-BT-0940 & ISU-85-12-16 & NRF Perimeter \\
\hline 10-BT-0941 & ISU-85-12-17 & NRF Perimeter \\
\hline 10-BT-0944 & ISU-85-12-02 & NRF Perimeter \\
\hline 10-BT-0945 & ISU-85-12-03 & NRF Perimeter \\
\hline 10-BT-0947 & ISU-85-12-05 & NRF Perimeter \\
\hline 10-BT-0948 & ISU-85-12-06 & NRF Perimeter \\
\hline 10-BT-0949 & ISU-85-12-07 & NRF Perimeter \\
\hline 10-BT-0950 & ISU-85-12-18 & NRF Perimeter \\
\hline 10-BT-0953 & ISU-85-11.90-03 & FOC-Lincoln Blvd \\
\hline 10-BT-0954 & ISU-85-11.90-01 & FOC-Lincoln Blvd \\
\hline 10-BT-0956 & ISU-85-11.90-14 & FOC-Lincoln Blvd \\
\hline 10-BT-0957 & ISU-85-11.90-15 & FOC-Lincoln Blvd \\
\hline 10-BT-0958 & ISU-85-11.90-16 & FOC-Lincoln Blvd \\
\hline 10-BT-0959 & ISU-85-11.90-17 & FOC-Lincoln Blvd \\
\hline 10-BT-0967 & ISU-85-11.90-04 & FOC-Lincoln Blvd \\
\hline 10-BT-0968 & ISU-85-11.90-05 & FOC-Lincoln Blvd \\
\hline 10-BT-0970 & ISU-85-11.90-34 & FOC-Lincoln Blvd \\
\hline 10-BT-0974 & ISU-85-11.90-32 & FOC-Lincoln Blvd \\
\hline 10-BT-0975 & ISU-85-11.90-27 & FOC-Lincoln Blvd \\
\hline 10-BT-0980 & ISU-85-11.90-22 & FOC-Lincoln Blvd \\
\hline 10-BT-0981 & ISU-85-11.90-24 & FOC-Lincoln Blvd \\
\hline 10-BT-0983 & ISU-85-11.90-26 & FOC-Lincoln Blvd \\
\hline 10-BT-0990 & ISU-85-11.90-47 & FOC-Lincoln Blvd \\
\hline 10-BT-0995 & ISU-85-11.90-45 & FOC-Lincoln Blvd \\
\hline 10-BT-0996 & ISU-85-11.90-46 & FOC-Lincoln Blvd \\
\hline 10-BT-0997 & ISU-85-11.90-42 & FOC-Lincoln Blvd \\
\hline 10-BT-0998 & ISU-85-11.90-41 & FOC-Lincoln Blvd \\
\hline 10-BT-1002 & ISU-85-11.91-09 & FOC-T-24 \\
\hline 10-BT-1003 & ISU-85-11.91-10 & FOC-T-24 \\
\hline 10-BT-1004 & ISU-85-11.91-11 & FOC-T-24 \\
\hline 10-BT-1006 & ISU-85-11.91-05 & FOC-T-24 \\
\hline 10-BT-1008 & ISU-85-11.91-06 & FOC-T-24 \\
\hline
\end{tabular}


Table 5. (continued).

\begin{tabular}{|c|c|c|}
\hline \multicolumn{3}{|c|}{ INL Prehistoric Archaeological Sites } \\
\hline Site Number & Field Number & Project Name \\
\hline 10-BT-1009 & ISU-85-11.91-07 & FOC-T-24 \\
\hline 10-BT-1010 & ISU-85-11.91-01 & FOC-T-24 \\
\hline 10-BT-1011 & ISU-85-11.85-02 & FOC-CFA to ANL \\
\hline 10-BT-1012 & ISU-85-11.91-26 & FOC-T-24 \\
\hline 10-BT-1013 & ISU-85-11.91-04 & FOC-T-24 \\
\hline 10-BT-1015 & ISU-85-11.91-14 & FOC-T-24 \\
\hline 10-BT-1016 & ISU-85-11.91-15 & FOC-T-24 \\
\hline 10-BT-1018 & ISU-85-11.91-17 & FOC-T-24 \\
\hline 10-BT-1020 & ISU-85-11.91-19 & FOC-T-24 \\
\hline 10-BT-1021 & ISU-85-11.91-20 & FOC-T-24 \\
\hline 10-BT-1022 & ISU-85-11.91-23 & FOC-T-24 \\
\hline 10-BT-1025 & ISU-85-11.91-13 & FOC-T-24 \\
\hline 10-BT-1028 & ISU-85-11.90-40 & FOC-Lincoln Blvd \\
\hline 10-BT-1029 & ISU-85-11.84-05 & FOC-CFA to TAN \\
\hline 10-BT-1030 & ISU-85-11.84-06 & FOC-CFA to TAN \\
\hline 10-BT-1032 & ISU-85-11.84-01 & FOC-CFA to TAN \\
\hline 10-BT-1036 & ISU-85-11.84-07 & FOC-CFA to TAN \\
\hline 10-BT-1038 & ISU-85-11.84-08 & FOC-CFA to TAN \\
\hline 10-BT-1039 & ISU-84-02-01 & WERF Perimeter \\
\hline 10-BT-1041 & ISU-84-02-03 & WERF Perimeter \\
\hline 10-BT-1043 & ISU-85-11.85-03 & FOC-CFA to ANL \\
\hline 10-BT-1044 & ISU-85-11.85-04 & FOC-CFA to ANL \\
\hline 10-BT-1045 & ISU-85-11.85-05 & FOC-CFA to ANL \\
\hline 10-BT-1046 & ISU-85-11.85-06 & FOC-CFA to ANL \\
\hline 10-BT-1049 & ISU-85-11.85-37 & FOC-CFA to ANL \\
\hline 10-BT-1052 & ISU-85-11.85-36 & FOC-CFA to ANL \\
\hline 10-BT-1053 & ISU-85-11.85-40 & FOC-CFA to ANL \\
\hline 10-BT-1059 & ISU-85-11.85-11 & FOC-CFA to ANL \\
\hline 10-BT-1062 & ISU-85-11.85-14 & FOC-CFA to ANL \\
\hline 10-BT-1063 & ISU-85-11.85-15 & FOC-CFA to ANL \\
\hline 10-BT-1066 & ISU-85-11.42-02 & RWMC Borrow Area \\
\hline 10-BT-1068 & ISU-85-11.42-04 & RWMC Borrow Area \\
\hline 10-BT-1069 & ISU-85-11.42-05 & RWMC Borrow Area \\
\hline 10-BT-1075 & ISU-85-11.42-11 & RWMC Borrow Area \\
\hline 10-BT-1076 & ISU-85-11.42-12 & RWMC Borrow Area \\
\hline 10-BT-1078 & ISU-85-11.42-14 & RWMC Borrow Area \\
\hline
\end{tabular}


Table 5. (continued).

\begin{tabular}{|c|c|c|}
\hline \multicolumn{3}{|c|}{ INL Prehistoric Archaeological Sites } \\
\hline Site Number & Field Number & Project Name \\
\hline 10-BT-1079 & ISU-85-11.42-15 & RWMC Borrow Area \\
\hline 10-BT-1082 & ISU-85-11.42-18 & RWMC Borrow Area \\
\hline 10-BT-1083 & ISU-85-11.42-19 & RWMC Borrow Area \\
\hline 10-BT-1085 & ISU-85-11.42-21 & RWMC Borrow Area \\
\hline 10-BT-1086 & ISU-85-11.42-23 & RWMC Borrow Area \\
\hline 10-BT-1087 & ISU-85-11.42-25 & RWMC Borrow Area \\
\hline 10-BT-1091 & ISU-85-11.42-27 & RWMC Borrow Area \\
\hline 10-BT-1101 & ISU-85-11.41-09 & RWMC Borrow Area \\
\hline 10-BT-1102 & ISU-85-11.41-10 & RWMC Borrow Area \\
\hline 10-BT-1104 & ISU-85-11.41-12 & RWMC Borrow Area \\
\hline 10-BT-1106 & ISU-85-11.41-14 & RWMC Borrow Area \\
\hline 10-BT-1108 & ISU-85-11.41-16 & RWMC Borrow Area \\
\hline 10-BT-1109 & ISU-85-11.41-17 & RWMC Borrow Area \\
\hline 10-BT-1110 & ISU-85-11.41-18 & RWMC Borrow Area \\
\hline 10-BT-1112 & ISU-85-11.41-20 & RWMC Borrow Area \\
\hline 10-BT-1122 & ISU-85-11.60-07 & PBF Administrative Area \\
\hline 10-BT-1123 & ISU-85-11.60-08 & PBF Administrative Area \\
\hline 10-BT-1128 & ISU-85-11.60-13 & PBF Administrative Area \\
\hline 10-BT-1129 & ISU-85-11.60-38 & PBF Administrative Area \\
\hline 10-BT-1130 & ISU-85-11.60-39 & PBF Administrative Area \\
\hline 10-BT-1131 & ISU-85-11.60-41 & PBF Administrative Area \\
\hline 10-BT-1133 & ISU-85-11.60-43 & PBF Administrative Area \\
\hline 10-BT-1134 & ISU-85-11.60-44 & PBF Administrative Area \\
\hline 10-BT-1135 & ISU-85-11.60-45 & PBF Administrative Area \\
\hline 10-BT-1137 & ISU-85-11.60-47 & PBF Administrative Area \\
\hline 10-BT-1139 & ISU-85-11.60-49 & PBF Administrative Area \\
\hline 10-BT-1140 & ISU-85-11.60-50 & PBF Administrative Area \\
\hline 10-BT-1141 & ISU-85-11.60-51 & PBF Administrative Area \\
\hline 10-BT-1142 & ISU-85-11.60-52 & PBF Administrative Area \\
\hline 10-BT-1143 & ISU-85-11.60-53 & PBF Administrative Area \\
\hline 10-BT-1145 & ISU-85-11.60-55 & PBF Administrative Area \\
\hline 10-BT-1146 & ISU-85-11.60-56 & PBF Administrative Area \\
\hline 10-BT-1147 & ISU-85-11.60-57 & PBF Administrative Area \\
\hline 10-BT-1148 & ISU-85-11.60-62 & PBF Administrative Area \\
\hline 10-BT-1149 & ISU-85-11.60-14 & PBF Administrative Area \\
\hline 10-BT-1152 & ISU-85-11.60-17 & PBF Administrative Area \\
\hline
\end{tabular}


Table 5. (continued).

\begin{tabular}{|c|c|c|}
\hline \multicolumn{3}{|c|}{ INL Prehistoric Archaeological Sites } \\
\hline Site Number & Field Number & Project Name \\
\hline 10-BT-1156 & ISU-85-11.60-18 & PBF Administrative Area \\
\hline 10-BT-1157 & ISU-85-11.60-59 & PBF Administrative Area \\
\hline 10-BT-1160 & ISU-85-11.60-03 & PBF Administrative Area \\
\hline 10-BT-1161 & ISU-85-11.60-04 & PBF Administrative Area \\
\hline 10-BT-1166 & ISU-85-11.60-25 & PBF Administrative Area \\
\hline 10-BT-1167 & ISU-85-11.60-26 & PBF Administrative Area \\
\hline 10-BT-1170 & ISU-85-11.60-29 & PBF Administrative Area \\
\hline 10-BT-1171 & ISU-85-11.60-31 & PBF Administrative Area \\
\hline 10-BT-1172 & ISU-85-11.60-32 & PBF Administrative Area \\
\hline 10-BT-1173 & ISU-85-11.60-34 & PBF Administrative Area \\
\hline 10-BT-1174 & ISU-85-11.60-35 & PBF Administrative Area \\
\hline 10-BT-1177 & ISU-85-11.60-40 & PBF Administrative Area \\
\hline 10-BT-1181 & ISU-85-11.60-30 & PBF Administrative Area \\
\hline 10-BT-1185 & ISU-85-11.2-16 & CFA Perimeter and Landfill \\
\hline 10-BT-1188 & ISU-85-11.87-02 & FOC-EOCR to PBF \\
\hline 10-BT-1189 & ISU-85-11.87-03 & FOC-EOCR to PBF \\
\hline 10-BT-1190 & ISU-85-11.87-04 & FOC-EOCR to PBF \\
\hline 10-BT-1191 & ISU-85-11.2-01 & CFA Perimeter and Landfill \\
\hline 10-BT-1192 & ISU-85-11.2-03 & CFA Perimeter and Landfill \\
\hline 10-BT-1193 & ISU-85-11.2-04 & CFA Perimeter and Landfill \\
\hline 10-BT-1194 & ISU-85-11.2-05 & CFA Perimeter and Landfill \\
\hline 10-BT-1200 & ISU-85-11.2-12 & CFA Perimeter and Landfill \\
\hline 10-BT-1202 & ISU-85-11.2-14 & CFA Perimeter and Landfill \\
\hline 10-BT-1205 & ISU-85-11.61-02 & PBF Administrative Area \\
\hline 10-BT-1207 & ISU-85-11.61-06 & PBF Administrative Area \\
\hline 10-BT-1208 & ISU-85-11.61-07 & PBF Administrative Area \\
\hline 10-BT-1209 & ISU-85-11.61-08 & PBF Administrative Area \\
\hline 10-BT-1211 & ISU-85-11.61-10 & PBF Administrative Area \\
\hline 10-BT-1212 & ISU-85-11.61-11 & PBF Administrative Area \\
\hline 10-BT-1214 & ISU-85-11.61-13 & PBF Administrative Area \\
\hline 10-BT-1215 & ISU-85-11.61-14 & PBF Administrative Area \\
\hline 10-BT-1216 & ISU-85-11.61-15 & PBF Administrative Area \\
\hline 10-BT-1221 & ISU-85-11.61-20 & PBF Administrative Area \\
\hline 10-BT-1222 & ISU-85-11.61-21 & PBF Administrative Area \\
\hline 10-BT-1223 & ISU-85-11.61-22 & PBF Administrative Area \\
\hline 10-BT-1224 & ISU-85-11.61-03 & PBF Administrative Area \\
\hline
\end{tabular}


Table 5. (continued).

\begin{tabular}{|c|c|c|}
\hline \multicolumn{3}{|c|}{ INL Prehistoric Archaeological Sites } \\
\hline Site Number & Field Number & Project Name \\
\hline 10-BT-1225 & ISU-85-11.61-04 & PBF Administrative Area \\
\hline 10-BT-1226 & ISU-85-11.5-01 & BORAX Gravel Pit \\
\hline 10-BT-1227 & ISU-85-11.5-03 & BORAX Gravel Pit \\
\hline 10-BT-1230 & ISU-85-08-03 & TRU Waste \\
\hline 10-BT-1232 & ISU-84-03-01 & CFA-EBR I Powerline \\
\hline 10-BT-1233 & ISU-85-11.91-27 & FOC T-24 \\
\hline 10-BT-1234 & ISU-85-11.31-02 & LOFT Perimeter \\
\hline 10-BT-1236 & ISU-85-11.3-03 & LOFT Perimeter \\
\hline 10-BT-1247 & ISU-85-11.85-32 & FOC-CFA to ANL \\
\hline 10-BT-1250 & SJM-84-15-01 & Geological Studies \\
\hline 10-BT-1251 & SJM-84-15-02 & Geological Studies \\
\hline 10-BT-1252 & SJM-84-15-03 & Geological Studies \\
\hline 10-BT-1272 & ISU-86-06-11 & NRF, TAN, CFA Gravel Pits \\
\hline 10-BT-1273 & ISU-86-06-14 & NRF, TAN, CFA Gravel Pits \\
\hline 10-BT-1274 & ISU-86-06-20 & NRF, TAN, CFA Gravel Pits \\
\hline 10-BT-1279 & ISU-86-06-18 & NRF, TAN, CFA Gravel Pits \\
\hline 10-BT-1280 & ISU-86-06-19 & NRF, TAN, CFA Gravel Pits \\
\hline 10-BT-1281 & ISU-86-06-16 & NRF, TAN, CFA Gravel Pits \\
\hline 10-BT-1282 & ISU-86-06-17 & NRF, TAN, CFA Gravel Pits \\
\hline 10-BT-1283 & ISU-86-06-02 & NRF, TAN, CFA Gravel Pits \\
\hline 10-BT-1284 & ISU-86-06-05 & NRF, TAN, CFA Gravel Pits \\
\hline 10-BT-1285 & ISU-86-06-08 & NRF, TAN, CFA Gravel Pits \\
\hline 10-BT-1286 & ISU-86-06-09 & NRF, TAN, CFA Gravel Pits \\
\hline 10-BT-1289 & ISU-86-06-06 & NRF, TAN, CFA Gravel Pits \\
\hline 10-BT-1297 & SJM-84-01-NWP-02B & Perimeter Boundary \\
\hline 10-BT-1314 & ISU-87-20-05 & Perimeter Sign Maintenance \\
\hline 10-BT-1315 & ISU-87-20-06 & Perimeter Sign Maintenance \\
\hline 10-BT-1317 & ISU-87-20-08 & Perimeter Sign Maintenance \\
\hline 10-BT-1318 & ISU-87-20-09 & Perimeter Sign Maintenance \\
\hline 10-BT-1319 & ISU-87-20-10 & Perimeter Sign Maintenance \\
\hline 10-BT-1321 & ISU-87-20-12 & Perimeter Sign Maintenance \\
\hline 10-BT-1322 & ISU-87-20-13 & Perimeter Sign Maintenance \\
\hline 10-BT-1324 & ISU-87-20-16 & Perimeter Sign Maintenance \\
\hline 10-BT-1327 & ISU-87-20-19 & Perimeter Sign Maintenance \\
\hline 10-BT-1328 & ISU-87-20-20 & Perimeter Sign Maintenance \\
\hline 10-BT-1329 & ISU-87-20-21 & Perimeter Sign Maintenance \\
\hline
\end{tabular}


Table 5. (continued).

\begin{tabular}{|c|c|c|}
\hline \multicolumn{3}{|c|}{ INL Prehistoric Archaeological Sites } \\
\hline Site Number & Field Number & Project Name \\
\hline 10-BT-1330 & ISU-87-20-22 & Perimeter Sign Maintenance \\
\hline 10-BT-1332 & ISU-87-20-24 & Perimeter Sign Maintenance \\
\hline 10-BT-1333 & ISU-87-20-25 & Perimeter Sign Maintenance \\
\hline 10-BT-1334 & ISU-87-20-26 & Perimeter Sign Maintenance \\
\hline 10-BT-1335 & ISU-87-20-27 & Perimeter Sign Maintenance \\
\hline 10-BT-1336 & ISU-87-20-28 & Perimeter Sign Maintenance \\
\hline 10-BT-1341 & ISU-87-12-10 & $\mathrm{SSC}$ \\
\hline 10-BT-1345 & ISU-87-12-14 & $\mathrm{SSC}$ \\
\hline 10-BT-1346 & ISU-87-12-15 & $\mathrm{SSC}$ \\
\hline 10-BT-1348 & ISU-87-12-17 & $\mathrm{SSC}$ \\
\hline 10-BT-1349 & ISU-87-12-18 & $\mathrm{SSC}$ \\
\hline 10-BT-1351 & ISU-87-12-20 & $\mathrm{SSC}$ \\
\hline 10-BT-1352 & ISU-87-12-21 & $\mathrm{SSC}$ \\
\hline 10-BT-1353 & ISU-87-12-22 & SSC \\
\hline 10-BT-1354 & ISU-87-12-25 & $\mathrm{SSC}$ \\
\hline 10-BT-1357 & ISU-87-12-28 & $\mathrm{SSC}$ \\
\hline 10-BT-1359 & ISU-87-12-30 & $\mathrm{SSC}$ \\
\hline 10-BT-1363 & ISU-87-12-38 & $\mathrm{SSC}$ \\
\hline 10-BT-1375 & ISU-87-15-06 & $\mathrm{SSC}$ \\
\hline 10-BT-1377 & ISU-87-15-02 & Ant Study Plots \\
\hline 10-BT-1378 & ISU-87-15-01 & Ant Study Plots \\
\hline 10-BT-1380 & ISU-88-01-02 & NRF Waste Ditch \\
\hline 10-BT-1382 & ISU-88-01-04 & NRF Waste Ditch \\
\hline 10-BT-1383 & ISU-88-01-05 & NRF Waste Ditch \\
\hline 10-BT-1385 & ISU-88-01-07 & NRF Waste Ditch \\
\hline 10-BT-1389 & ISU-88-01-11 & NRF Waste Ditch \\
\hline 10-BT-1390 & ISU-88-01-12 & NRF Waste Ditch \\
\hline 10-BT-1397 & ISU-88-01-19 & NRF Waste Ditch \\
\hline 10-BT-1398 & ISU-88-01-20 & NRF Waste Ditch \\
\hline 10-BT-1399 & ISU-88-01-21 & NRF Waste Ditch \\
\hline 10-BT-1402 & ISU-88-01-24 & NRF Waste Ditch \\
\hline 10-BT-1403 & ISU-88-01-25 & NRF Waste Ditch \\
\hline 10-BT-1404 & ISU-88-01-26 & NRF Waste Ditch \\
\hline 10-BT-1408 & ISU-88-01-30 & NRF Waste Ditch \\
\hline 10-BT-1413 & ISU-88-01-35 & NRF Waste Ditch \\
\hline 10-BT-1417 & ISU-88-01-39 & NRF Waste Ditch \\
\hline
\end{tabular}


Table 5. (continued).

\begin{tabular}{|c|c|c|}
\hline \multicolumn{3}{|c|}{ INL Prehistoric Archaeological Sites } \\
\hline Site Number & Field Number & Project Name \\
\hline 10-BT-1419 & ISU-88-01-41 & NRF Waste Ditch \\
\hline 10-BT-1420 & ISU-88-01-42 & NRF Waste Ditch \\
\hline 10-BT-1421 & ISU-88-01-43 & NRF Waste Ditch \\
\hline 10-BT-1422 & ISU-88-01-44 & NRF Waste Ditch \\
\hline 10-BT-1424 & ISU-88-01-46 & NRF Waste Ditch \\
\hline 10-BT-1425 & ISU-88-01-47 & NRF Waste Ditch \\
\hline 10-BT-1426 & ISU-88-01-48 & NRF Waste Ditch \\
\hline 10-BT-1428 & ISU-88-01-50 & NRF Waste Ditch \\
\hline 10-BT-1429 & ISU-88-01-51 & NRF Waste Ditch \\
\hline 10-BT-1431 & ISU-88-01-53 & NRF Waste Ditch \\
\hline 10-BT-1432 & ISU-88-01-54 & NRF Waste Ditch \\
\hline 10-BT-1434 & ISU-88-01-56 & NRF Waste Ditch \\
\hline 10-BT-1436 & ISU-88-01-58 & NRF Waste Ditch \\
\hline 10-BT-1437 & ISU-88-01-59 & NRF Waste Ditch \\
\hline 10-BT-1438 & ISU-88-01-60 & NRF Waste Ditch \\
\hline 10-BT-1442 & ISU-88-03-01 & ICPP Gravel Pit \\
\hline 10-BT-1445 & ISU-88-07-04 & Gravel Haul Road \\
\hline 10-BT-1449 & ISU-88-13-01 & RWMC Wind Gap \\
\hline 10-BT-1450 & ISU-88-13-03 & RWMC Wind Gap \\
\hline 10-BT-1451 & ISU-88-13-02 & RWMC Wind Gap \\
\hline 10-BT-1454 & ISU-88-14-02 & RWMC Inactive Borrow Area \\
\hline 10-BT-1455 & ISU-88-14-03 & RWMC Inactive Borrow Area \\
\hline 10-BT-1460 & ISU-89-02-B01 & Hunting Boundary \\
\hline 10-BT-1462 & ISU-89-02-A02 & Hunting Boundary \\
\hline 10-BT-1464 & ISU-89-02-A04 & Hunting Boundary \\
\hline 10-BT-1466 & ISU-89-02-A07 & Hunting Boundary \\
\hline 10-BT-1467 & ISU-89-02-B02 & Hunting Boundary \\
\hline 10-BT-1468 & ISU-89-02-B03 & Hunting Boundary \\
\hline 10-BT-1469 & ISU-89-02-B04 & Hunting Boundary \\
\hline 10-BT-1471 & ISU-89-02-B06 & Hunting Boundary \\
\hline 10-BT-1473 & ISU-89-02-B08 & Hunting Boundary \\
\hline 10-BT-1476 & ISU-89-02-A10 & Hunting Boundary \\
\hline 10-BT-1478 & ISU-89-02-A13 & Hunting Boundary \\
\hline 10-BT-1479 & ISU-89-02-A14 & Hunting Boundary \\
\hline 10-BT-1483 & ISU-89-02-A16 & Hunting Boundary \\
\hline 10-BT-1484 & ISU-89-04-02 & NPR Seismic Stations \\
\hline
\end{tabular}


Table 5. (continued).

\begin{tabular}{|c|c|c|}
\hline \multicolumn{3}{|c|}{ INL Prehistoric Archaeological Sites } \\
\hline Site Number & Field Number & Project Name \\
\hline 10-BT-1486 & ISU-89-05-1-01 & NPR Survey and Testing \\
\hline 10-BT-1487 & ISU-89-05-1-02 & NPR Survey and Testing \\
\hline 10-BT-1488 & ISU-89-05-1-03 & NPR Survey and Testing \\
\hline 10-BT-1489 & ISU-89-05-1-04 & NPR Survey and Testing \\
\hline 10-BT-1490 & ISU-89-05-1-05 & NPR Survey and Testing \\
\hline 10-BT-1494 & ISU-89-05-1-09 & NPR Survey and Testing \\
\hline 10-BT-1497 & ISU-89-05-2-01 & NPR Survey and Testing \\
\hline 10-BT-1498 & ISU-89-05-2-02 & NPR Survey and Testing \\
\hline 10-BT-1499 & ISU-89-05-2-03 & NPR Survey and Testing \\
\hline 10-BT-1500 & ISU-89-05-2-04 & NPR Survey and Testing \\
\hline 10-BT-1502 & ISU-89-05-2-06 & NPR Survey and Testing \\
\hline 10-BT-1503 & ISU-89-05-2-07 & NPR Survey and Testing \\
\hline 10-BT-1505 & ISU-89-05-2-09 & NPR Survey and Testing \\
\hline 10-BT-1509 & ISU-89-05-3-03 & NPR Survey and Testing \\
\hline 10-BT-1513 & ISU-89-05-3-09 & NPR Survey and Testing \\
\hline 10-BT-1515 & ISU-89-05-4-04 & NPR Survey and Testing \\
\hline 10-BT-1518 & ISU-89-06-01 & Fast Attack Vehicle Range \\
\hline 10-BT-1521 & ISU-89-06-04 & Fast Attack Vehicle Range \\
\hline 10-BT-1522 & ISU-89-06-05 & Fast Attack Vehicle Range \\
\hline 10-BT-1526 & ISU-89-06-09 & Fast Attack Vehicle Range \\
\hline 10-BT-1534 & ISU-89-06-17 & Fast Attack Vehicle Range \\
\hline 10-BT-1535 & ISU-89-06-18 & Fast Attack Vehicle Range \\
\hline 10-BT-1536 & ISU-89-06-19 & Fast Attack Vehicle Range \\
\hline 10-BT-1537 & ISU-89-06-20 & Fast Attack Vehicle Range \\
\hline 10-BT-1538 & ISU-89-06-21 & Fast Attack Vehicle Range \\
\hline 10-BT-1539 & ISU-89-06-22 & Fast Attack Vehicle Range \\
\hline 10-BT-1540 & ISU-89-06-23 & Fast Attack Vehicle Range \\
\hline 10-BT-1541 & ISU-89-06-24 & Fast Attack Vehicle Range \\
\hline 10-BT-1545 & ISU-89-06-28 & Fast Attack Vehicle Range \\
\hline 10-BT-1546 & ISU-89-06-29 & Fast Attack Vehicle Range \\
\hline 10-BT-1548 & ISU-89-06-31 & Fast Attack Vehicle Range \\
\hline 10-BT-1550 & ISU-89-06-33 & Fast Attack Vehicle Range \\
\hline 10-BT-1551 & ISU-89-06-34 & Fast Attack Vehicle Range \\
\hline 10-BT-1553 & ISU-89-06-36 & Fast Attack Vehicle Range \\
\hline 10-BT-1554 & ISU-89-06-37 & Fast Attack Vehicle Range \\
\hline 10-BT-1556 & ISU-89-06-39 & Fast Attack Vehicle Range \\
\hline
\end{tabular}


Table 5. (continued).

\begin{tabular}{|c|c|c|}
\hline \multicolumn{3}{|c|}{ INL Prehistoric Archaeological Sites } \\
\hline Site Number & Field Number & Project Name \\
\hline 10-BT-1559 & ISU-89-06-42 & Fast Attack Vehicle Range \\
\hline 10-BT-1560 & ISU-89-06-43 & Fast Attack Vehicle Range \\
\hline 10-BT-1561 & ISU-89-06-44 & Fast Attack Vehicle Range \\
\hline 10-BT-1563 & ISU-89-06-46 & Fast Attack Vehicle Range \\
\hline 10-BT-1565 & ISU-89-06-48 & Fast Attack Vehicle Range \\
\hline 10-BT-1566 & ISU-89-06-49 & Fast Attack Vehicle Range \\
\hline 10-BT-1567 & ISU-89-06-50 & Fast Attack Vehicle Range \\
\hline 10-BT-1573 & ISU-89-06-56 & Fast Attack Vehicle Range \\
\hline 10-BT-1574 & ISU-89-06-57 & Fast Attack Vehicle Range \\
\hline 10-BT-1585 & ISU-89-05-3-06 & NPR Survey and Testing \\
\hline 10-BT-1592 & ISU-90-02-21 & RWMC Section 18 \\
\hline 10-BT-1593 & ISU-89-05-4-02 & NPR Survey and Testing \\
\hline 10-BT-1595 & ISU-90-02-A & RWMC Section 18 \\
\hline 10-BT-1605 & ISU-90-02-K & RWMC Section 18 \\
\hline 10-BT-1608 & ISU-90-02-01 & RWMC Section 18 \\
\hline 10-BT-1609 & ISU-90-02-02 & RWMC Section 18 \\
\hline 10-BT-1613 & ISU-90-02-06 & RWMC Section 18 \\
\hline 10-BT-1616 & ISU-90-02-16 & RWMC Section 18 \\
\hline 10-BT-1617 & ISU-90-02-20 & RWMC Section 18 \\
\hline 10-BT-1619 & ISU-90-02-11 & RWMC Section 18 \\
\hline 10-BT-1622 & ISU-90-02-14 & RWMC Section 18 \\
\hline 10-BT-1625 & ISU-90-02-23 & RWMC Section 18 \\
\hline 10-BT-1638 & ISU-90-08-D & NPR Sample Survey \\
\hline 10-BT-1639 & ISU-90-08-E & NPR Sample Survey \\
\hline 10-BT-1641 & ISU-90-08-G & NPR Sample Survey \\
\hline 10-BT-1642 & ISU-90-08-H & NPR Sample Survey \\
\hline 10-BT-1644 & ISU-90-08-J & NPR Sample Survey \\
\hline 10-BT-1646 & ISU-90-08-L & NPR Sample Survey \\
\hline 10-BT-1647 & ISU-90-08-M & NPR Sample Survey \\
\hline 10-BT-1651 & ISU-90-08-Q & NPR Sample Survey \\
\hline 10-BT-1653 & ISU-90-08-S & NPR Sample Survey \\
\hline 10-BT-1656 & ISU-90-08-V2 & NPR Sample Survey \\
\hline 10-BT-1657 & ISU-90-08-W2 & NPR Sample Survey \\
\hline 10-BT-1659 & ISU-90-08-Y & NPR Sample Survey \\
\hline 10-BT-1660 & ISU-90-08-KK & NPR Sample Survey \\
\hline 10-BT-1662 & ISU-90-08-MM & NPR Sample Survey \\
\hline
\end{tabular}


Table 5. (continued).

\begin{tabular}{|c|c|c|}
\hline \multicolumn{3}{|c|}{ INL Prehistoric Archaeological Sites } \\
\hline Site Number & Field Number & Project Name \\
\hline 10-BT-1664 & ISU-90-08-OO & NPR Sample Survey \\
\hline 10-BT-1665 & ISU-90-08-PP & NPR Sample Survey \\
\hline 10-BT-1666 & ISU-90-08-QQ & NPR Sample Survey \\
\hline 10-BT-1667 & ISU-90-08-RR & NPR Sample Survey \\
\hline 10-BT-1670 & ISU-90-08-UU & NPR Sample Survey \\
\hline 10-BT-1671 & ISU-90-08-VV & NPR Sample Survey \\
\hline 10-BT-1672 & ISU-90-08-XX & NPR Sample Survey \\
\hline 10-BT-1673 & ISU-90-08-YY & NPR Sample Survey \\
\hline 10-BT-1676 & ISU-90-08-02B & NPR Sample Survey \\
\hline 10-BT-1677 & ISU-90-08-03B & NPR Sample Survey \\
\hline 10-BT-1678 & ISU-90-08-01A & NPR Sample Survey \\
\hline 10-BT-1679 & ISU-90-08-02A & NPR Sample Survey \\
\hline 10-BT-1682 & ISU-90-08-05A & NPR Sample Survey \\
\hline 10-BT-1685 & ISU-90-08-B6 & NPR Sample Survey \\
\hline 10-BT-1687 & ISU-90-08-B8 & NPR Sample Survey \\
\hline 10-BT-1688 & ISU-90-08-B9 & NPR Sample Survey \\
\hline 10-BT-1690 & ISU-90-08-B11 & NPR Sample Survey \\
\hline 10-BT-1692 & ISU-90-08-B13 & NPR Sample Survey \\
\hline 10-BT-1693 & ISU-90-08-B14 & NPR Sample Survey \\
\hline 10-BT-1694 & ISU-90-08-B15 & NPR Sample Survey \\
\hline 10-BT-1696 & EGG-90-09-01 & ICPP-NPR Road \\
\hline 10-BT-1697 & EGG-90-09-02 & ICPP-NPR Road \\
\hline 10-BT-1698 & EGG-90-09-03 & ICPP-NPR Road \\
\hline 10-BT-1700 & EGG-90-08-01 & INEL Sewer Upgrade \\
\hline 10-BT-1713 & EGG-90-08-14 & INEL Sewer Upgrade \\
\hline 10-BT-1722 & EGG-90-08-23 & INEL Sewer Upgrade \\
\hline 10-BT-1723 & EGG-90-08-24 & INEL Sewer Upgrade \\
\hline 10-BT-1732 & EGG-90-11-04 & RWMC-CFA Powerline \\
\hline 10-BT-1733 & EGG-90-11-05 & RWMC-CFA Powerline \\
\hline 10-BT-1734 & EGG-90-11-06 & RWMC-CFA Powerline \\
\hline 10-BT-1735 & EGG-90-11-07 & RWMC-CFA Powerline \\
\hline 10-BT-1736 & EGG-90-11-08 & RWMC-CFA Powerline \\
\hline 10-BT-1737 & EGG-90-11-09 & RWMC-CFA Powerline \\
\hline 10-BT-1738 & EGG-90-11-10 & RWMC-CFA Powerline \\
\hline 10-BT-1754 & ISU-91-04-01 & NPR Area E \\
\hline 10-BT-1755 & ISU-91-04-02 & NPR Area E \\
\hline
\end{tabular}


Table 5. (continued).

\begin{tabular}{|c|c|c|}
\hline \multicolumn{3}{|c|}{ INL Prehistoric Archaeological Sites } \\
\hline Site Number & Field Number & Project Name \\
\hline 10-BT-1756 & ISU-91-04-03 & NPR Area E \\
\hline 10-BT-1757 & ISU-91-04-04 & NPR Area E \\
\hline 10-BT-1759 & ISU-91-04-06 & NPR Area E \\
\hline 10-BT-1763 & ISU-91-04-10 & NPR Area E \\
\hline 10-BT-1769 & ISU-91-04-17 & NPR Area E \\
\hline 10-BT-1770 & ISU-91-04-18 & NPR Area E \\
\hline 10-BT-1772 & ISU-91-04-20 & NPR Area E \\
\hline 10-BT-1773 & ISU-91-04-21 & NPR Area E \\
\hline 10-BT-1776 & ISU-91-04-24 & NPR Area E \\
\hline 10-BT-1783 & ISU-91-04-28 & NPR Area E \\
\hline 10-BT-1784 & ISU-91-04-29 & NPR Area E \\
\hline 10-BT-1786 & ISU-91-04-31 & NPR Area E \\
\hline 10-BT-1788 & ISU-91-04-33 & NPR Area E \\
\hline 10-BT-1790 & ISU-91-04-35 & NPR Area E \\
\hline 10-BT-1791 & ISU-91-04-36 & NPR Area E \\
\hline 10-BT-1792 & ISU-91-04-37 & NPR Area E \\
\hline 10-BT-1808 & EGG-91-22-B & WAG 7 Wells \\
\hline 10-BT-1809 & EGG-91-22-C & WAG 7 Wells \\
\hline 10-BT-1812 & EGG-92-30-01 & RWMC Power Upgrade \\
\hline 10-BT-1815 & EGG-92-30-04 & RWMC Power Upgrade \\
\hline 10-BT-1816 & EGG-92-30-05 & RWMC Power Upgrade \\
\hline 10-BT-1818 & EGG-92-30-06 & RWMC Power Upgrade \\
\hline 10-BT-1821 & EGG-92-30-08 & RWMC Power Upgrade \\
\hline 10-BT-1836 & EGG-93-07-02 & INEL Ordnance Cleanup \\
\hline 10-BT-1837 & EGG-93-07-03 & INEL Ordnance Cleanup \\
\hline 10-BT-1840 & EGG-93-07-06 & INEL Ordnance Cleanup \\
\hline 10-BT-1841 & EGG-93-07-07 & INEL Ordnance Cleanup \\
\hline 10-BT-1843 & EGG-93-07-09 & INEL Ordnance Cleanup \\
\hline 10-BT-1844 & EGG-93-07-10 & INEL Ordnance Cleanup \\
\hline 10-BT-1846 & EGG-93-07-12 & INEL Ordnance Cleanup \\
\hline 10-BT-1847 & EGG-93-07-13 & INEL Ordnance Cleanup \\
\hline 10-BT-1848 & EGG-93-07-14 & INEL Ordnance Cleanup \\
\hline 10-BT-1853 & EGG-93-07-20 & INEL Ordnance Cleanup \\
\hline 10-BT-1855 & EGG-93-15-02 & Soil Borrowing from Spreading Area B \\
\hline 10-BT-1861 & EGG-93-15-08 & Soil Borrowing from Spreading Area B \\
\hline 10-BT-1864 & EGG-93-15-11 & Soil Borrowing from Spreading Area B \\
\hline
\end{tabular}


Table 5. (continued).

\begin{tabular}{|c|c|c|}
\hline \multicolumn{3}{|c|}{ INL Prehistoric Archaeological Sites } \\
\hline Site Number & Field Number & Project Name \\
\hline 10-BT-1865 & EGG-93-15-12 & Soil Borrowing from Spreading Area B \\
\hline 10-BT-1866 & EGG-93-15-13 & Soil Borrowing from Spreading Area B \\
\hline 10-BT-1883 & EGG-93-06-01-06 & IWPF LLMWPF Alternates \\
\hline 10-BT-1887 & EGG-93-06-01-10 & IWPF LLMWPF Alternates \\
\hline 10-BT-1888 & EGG-93-06-01-11 & IWPF LLMWPF Alternates \\
\hline 10-BT-1891 & EGG-93-06-01-14 & IWPF LLMWPF Alternates \\
\hline 10-BT-1892 & EGG-93-06-01-15 & IWPF LLMWPF Alternates \\
\hline 10-BT-1893 & EGG-93-06-01-16 & IWPF LLMWPF Alternates \\
\hline 10-BT-1895 & EGG-93-06-01-18 & IWPF LLMWPF Alternates \\
\hline 10-BT-1898 & EGG-93-06-01-21 & IWPF LLMWPF Alternates \\
\hline 10-BT-1901 & EGG-93-06-01-24 & IWPF LLMWPF Alternates \\
\hline 10-BT-1903 & EGG-93-06-01-26 & IWPF LLMWPF Alternates \\
\hline 10-BT-1904 & EGG-93-06-01-27 & IWPF LLMWPF Alternates \\
\hline 10-BT-1907 & EGG-93-06-01-30 & IWPF LLMWPF Alternates \\
\hline 10-BT-1912 & EGG-93-06-01-35 & IWPF LLMWPF Alternates \\
\hline 10-BT-1915 & EGG-93-06-01-38 & IWPF LLMWPF Alternates \\
\hline 10-BT-1917 & EGG-93-06-03-02 & IWPF LLMWPF Alternates \\
\hline 10-BT-1918 & EGG-93-06-03-03 & IWPF LLMWPF Alternates \\
\hline 10-BT-1922 & EGG-93-06-03-07 & IWPF LLMWPF Alternates \\
\hline 10-BT-1924 & EGG-93-06-03-09 & IWPF LLMWPF Alternates \\
\hline 10-BT-1926 & EGG-93-06-03-11 & IWPF LLMWPF Alternates \\
\hline 10-BT-1927 & EGG-93-06-03-12 & IWPF LLMWPF Alternates \\
\hline 10-BT-1929 & EGG-93-06-03-14 & IWPF LLMWPF Alternates \\
\hline 10-BT-1936 & EGG-93-06-09-01 & IWPF LLMWPF Alternates \\
\hline 10-BT-1939 & EGG-93-06-09-04 & IWPF LLMWPF Alternates \\
\hline 10-BT-1941 & EGG-93-06-09-06 & IWPF LLMWPF Alternates \\
\hline 10-BT-1942 & EGG-93-06-09-07 & IWPF LLMWPF Alternates \\
\hline 10-BT-1945 & EGG-93-06-14-03 & IWPF LLMWPF Alternates \\
\hline 10-BT-1949 & EGG-93-06-14-07 & IWPF LLMWPF Alternates \\
\hline 10-BT-1953 & EGG-93-06-18-01 & IWPF LLMWPF Alternates \\
\hline 10-BT-1967 & EGG-92-43-03 & Alternate CFA Sewage Ponds \\
\hline 10-BT-1969 & EGG-92-43-05 & Alternate CFA Sewage Ponds \\
\hline 10-BT-1970 & EGG-92-43-06 & Alternate CFA Sewage Ponds \\
\hline 10-BT-1974 & EGG-94-20-NODA-01 & Ordnance Cleanup at NODA and ANL-W \\
\hline 10-BT-1976 & EGG-94-20-NODA-03 & Ordnance Cleanup at NODA and ANL-W \\
\hline 10-BT-1979 & EGG-94-21-01 & Goodale's Cutoff Survey \\
\hline
\end{tabular}


Table 5. (continued).

\begin{tabular}{|c|c|c|}
\hline \multicolumn{3}{|c|}{ INL Prehistoric Archaeological Sites } \\
\hline Site Number & Field Number & Project Name \\
\hline 10-BT-1980 & EGG-94-21-04 & Goodale's Cutoff Survey \\
\hline 10-BT-1981 & EGG-94-21-05 & Goodale's Cutoff Survey \\
\hline 10-BT-1982 & EGG-94-21-08 & Goodale's Cutoff Survey \\
\hline 10-BT-1983 & EGG-94-21-09 & Goodale's Cutoff Survey \\
\hline 10-BT-1984 & EGG-94-21-11 & Goodale's Cutoff Survey \\
\hline 10-BT-1985 & EGG-94-05-SAB-02 & INEL Gravel Sources \\
\hline 10-BT-1986 & EGG-94-05-SAB-03 & INEL Gravel Sources \\
\hline 10-BT-1987 & EGG-94-21-02 & INEL Gravel Sources \\
\hline 10-BT-1988 & EGG-94-21-07 & Goodale's Cutoff Survey \\
\hline 10-BT-1989 & EGG-94-21-10 & Goodale's Cutoff Survey \\
\hline 10-BT-1990 & EGG-94-21-12 & Goodale's Cutoff Survey \\
\hline 10-BT-1991 & EGG-94-24-01 & PBF Remains \\
\hline 10-BT-1996 & EGG-94-05-TRA-01 & INEL Gravel Sources \\
\hline 10-BT-1997 & EGG-94-05-TRA-02 & INEL Gravel Sources \\
\hline 10-BT-2000 & EGG-94-05-NRF-02 & INEL Gravel Sources \\
\hline 10-BT-2006 & EGG-94-05-TAN-01 & INEL Gravel Sources \\
\hline 10-BT-2046 & LMIT-96-27-01 & WERF Remains \\
\hline 10-BT-2050 & LMIT-96-51-04 & Ordnance Removal Actions \\
\hline 10-BT-2051 & LMIT-96-51-05 & Ordnance Removal Actions \\
\hline 10-BT-2052 & LMIT-96-51-06 & Ordnance Removal Actions \\
\hline 10-BT-2053 & LMIT-96-51-07 & Ordnance Removal Actions \\
\hline 10-BT-2070 & LMIT-96-34-01 & Test Excavation at TAN \\
\hline 10-BT-2076 & LMIT-97-46-04 & INEEL Road Upgrades \\
\hline 10-BT-2080 & LMIT-97-46-08 & INEEL Road Upgrades \\
\hline 10-BT-2095 & LMIT-99-08-02 & INTEC Service Wastewater Facility \\
\hline 10-BT-2099 & LMIT-99-31-04 & RWMC Wells \\
\hline 10-BT-2108 & LMIT-99-31-13 & RWMC Wells \\
\hline 10-BT-2109 & LMIT-99-31-14 & RWMC Wells \\
\hline 10-BT-2120 & LMIT-99-08-13 & RWMC Wells \\
\hline 10-BT-2189 & BBWI-01-28-05 & Big Lost River Trenches \\
\hline 10-BT-2191 & BBWI-01-28-02 & Big Lost River Trenches \\
\hline 10-BT-2192 & BBWI-01-28-03 & Big Lost River Trenches \\
\hline 10-BT-2193 & BBWI-01-28-04 & Big Lost River Trenches \\
\hline 10-BT-2194 & BBWI-01-35-01 & Big Lost River Trenches \\
\hline 10-BT-2195 & BBWI-01-35-02 & Big Lost River Trenches \\
\hline 10-BV-83 & SJM-84-01-EP-16 & Perimeter Boundary \\
\hline
\end{tabular}


Table 5. (continued).

\begin{tabular}{|c|c|c|}
\hline \multicolumn{3}{|c|}{ INL Prehistoric Archaeological Sites } \\
\hline Site Number & Field Number & Project Name \\
\hline $10-B V-85$ & SJM-84-01-EP-13 & Perimeter Boundary \\
\hline $10-B V-86$ & SJM-84-01-EP-14 & Perimeter Boundary \\
\hline 10-CL-418 & SJM-84-01-NWP-06 & Perimeter Boundary \\
\hline 10-CL-420 & SJM-84-01-NP-03 & Perimeter Boundary \\
\hline 10-JF-002 & EHS-61-13 & Birch Creek Surveys \\
\hline 10-JF-003 & EHS-61-14 & Birch Creek Surveys \\
\hline 10-JF-004 & EHS-61-15 & Birch Creek Surveys \\
\hline 10-JF-005 & EHS-61-16 & Birch Creek Surveys \\
\hline 10-JF-007 & EHS-61-18 & Birch Creek Surveys \\
\hline 10-JF-008 & EHS-61-19 & Birch Creek Surveys \\
\hline 10-JF-010 & BRB-70-33 & NRTS Surveys 1967-1969 \\
\hline 10-JF-011 & BRB-70-34 & NRTS Surveys 1967-1969 \\
\hline 10-JF-012 & BRB-70-35 & NRTS Surveys 1967-1969 \\
\hline 10-JF-014 & BRB-70-36 & NRTS Surveys 1967-1969 \\
\hline 10-JF-070 & SJM-84-02-007 & Grazing Boundary \\
\hline 10-JF-072 & SJM-84-02-012 & Grazing Boundary \\
\hline 10-JF-075 & SJM-84-02-015 & Grazing Boundary \\
\hline 10-JF-076 & SJM-84-02-016 & Grazing Boundary \\
\hline 10-JF-077 & SJM-84-02-017 & Grazing Boundary \\
\hline 10-JF-078 & SJM-84-02-018 & Grazing Boundary \\
\hline 10-JF-080 & SJM-84-02-020 & Grazing Boundary \\
\hline 10-JF-084 & SJM-84-02-024 & Grazing Boundary \\
\hline 10-JF-088 & SJM-84-02-028 & Grazing Boundary \\
\hline 10-JF-089 & SJM-84-02-029 & Grazing Boundary \\
\hline 10-JF-090 & SJM-84-02-030 & Grazing Boundary \\
\hline 10-JF-092 & SJM-84-02-032 & Grazing Boundary \\
\hline 10-JF-094 & SJM-84-02-034 & Grazing Boundary \\
\hline 10-JF-095 & SJM-84-02-035 & Grazing Boundary \\
\hline 10-JF-096 & SJM-84-02-036 & Grazing Boundary \\
\hline 10-JF-097 & SJM-84-02-037 & Grazing Boundary \\
\hline 10-JF-098 & SJM-84-02-038 & Grazing Boundary \\
\hline 10-JF-099 & SJM-84-02-039 & Grazing Boundary \\
\hline $10-J F-100$ & SJM-84-02-040 & Grazing Boundary \\
\hline 10-JF-105 & SJM-84-02-090 & Grazing Boundary \\
\hline 10-JF-106 & SJM-84-02-091 & Grazing Boundary \\
\hline 10-JF-107 & SJM-84-02-092 & Grazing Boundary \\
\hline
\end{tabular}


Table 5. (continued).

\begin{tabular}{|c|c|c|}
\hline \multicolumn{3}{|c|}{ INL Prehistoric Archaeological Sites } \\
\hline Site Number & Field Number & Project Name \\
\hline 10-JF-111 & SJM-84-02-101 & Grazing Boundary \\
\hline 10-JF-112 & SJM-84-02-102 & Grazing Boundary \\
\hline 10-JF-113 & SJM-84-02-103 & Grazing Boundary \\
\hline 10-JF-114 & SJM-84-02-104 & Grazing Boundary \\
\hline 10-JF-115 & SJM-84-02-105 & Grazing Boundary \\
\hline 10-JF-116 & SJM-84-02-106 & Grazing Boundary \\
\hline 10-JF-118 & SJM-84-02-108 & Grazing Boundary \\
\hline 10-JF-120 & SJM-84-01-EP-08 & Perimeter Boundary \\
\hline 10-JF-121 & SJM-84-01-EP-07 & Perimeter Boundary \\
\hline 10-JF-122 & SJM-84-01-EP-06 & Perimeter Boundary \\
\hline 10-JF-123 & SJM-84-01-EP-09 & Perimeter Boundary \\
\hline 10-JF-128 & SJM-84-01-EP-20 & Perimeter Boundary \\
\hline 10-JF-131 & SJM-84-01-NEP-03 & Perimeter Boundary \\
\hline 10-JF-135 & ISU-85-11.81-08 & FOC-ANL to TAN \\
\hline 10-JF-137 & ISU-85-11.81-11 & FOC-ANL to TAN \\
\hline 10-JF-138 & ISU-85-11.81-13 & FOC-ANL to TAN \\
\hline 10-JF-140 & ISU-85-11.81-02 & FOC-ANL to TAN \\
\hline 10-JF-142 & ISU-85-11.81-12 & FOC-ANL to TAN \\
\hline 10-JF-149 & SJM-84-01-EP-18 & Perimeter Boundary \\
\hline 10-JF-158 & ISU-87-12-01 & $\mathrm{SSC}$ \\
\hline 10-JF-166 & ISU-87-12-47 & $\mathrm{SSC}$ \\
\hline 10-JF-168 & ISU-87-12-49 & $\mathrm{SSC}$ \\
\hline 10-JF-174 & ISU-89-02-B16 & Hunting Boundary \\
\hline 10-JF-175 & ISU-89-02-A20 & Hunting Boundary \\
\hline 10-JF-176 & ISU-89-02-A21 & Hunting Boundary \\
\hline 10-JF-177 & ISU-89-02-B21 & Hunting Boundary \\
\hline 10-JF-182 & ISU-89-02-A23 & Hunting Boundary \\
\hline 10-JF-185 & ISU-89-02-B18 & Hunting Boundary \\
\hline 10-JF-187 & ISU-89-02-B20 & Hunting Boundary \\
\hline 10-JF-188 & ISU-89-02-A27 & Hunting Boundary \\
\hline 10-JF-321 & LMIT-99-29-01 & $\begin{array}{l}\text { Mud Lake Sheep Experiment Station } \\
\text { Wells }\end{array}$ \\
\hline 10-JF-325 & SJM-00-01-CB01 & Circular Butte Cell Tower \\
\hline & BBWI-00-01-01 & ARA-INTEC Haul Road \\
\hline & BBWI-00-01-02 & ARA-INTEC Haul Road \\
\hline & BBWI-00-01-04 & ARA-INTEC Haul Road \\
\hline & BBWI-00-01-05 & ARA-INTEC Haul Road \\
\hline
\end{tabular}


Table 5. (continued).

\begin{tabular}{|c|c|c|}
\hline \multicolumn{3}{|c|}{ INL Prehistoric Archaeological Sites } \\
\hline Site Number & Field Number & Project Name \\
\hline & BBWI-00-01-07 & ARA-INTEC Haul Road \\
\hline & BBWI-00-01-09 & ARA-INTEC Haul Road \\
\hline & BBWI-00-18-01 & BORAX Ecosampling \\
\hline & BBWI-01-33-01 & Ryegrass Flats Roads \\
\hline & BBWI-01-33-rye-4 & Ryegrass Flats Roads \\
\hline & BBWI-01-33-rye-5 & Ryegrass Flats Roads \\
\hline & BBWI-01-33-rye-8 & Ryegrass Flats Roads \\
\hline & BBWI-01-36-02 & BLM Fire Fence \\
\hline & BBWI-02-25-01 & Scott Fire \\
\hline & BBWI-02-25-03 & Scott Fire \\
\hline & BBWI-02-25-04 & Scott Fire \\
\hline & BBWI-03-22-01 & TAN Demolition Landfill \\
\hline & EGG-90-10-01 & Cinder Butte Snake Study \\
\hline & EGG-91-12-01 & NRF Boreholes \\
\hline & EGG-91-12-02 & NRF Boreholes \\
\hline & EGG-91-12-05 & NRF Boreholes \\
\hline & EGG-92-22-01 & SNTP Tank Farm at Quest Crater \\
\hline & LITCO-95-52-01 & NRF Surveys \\
\hline & LITCO-95-52-02 & NRF Surveys \\
\hline & LITCO-95-52-08 & NRF Surveys \\
\hline & LITCO-95-52-09 & NRF Surveys \\
\hline & LITCO-95-52-10 & NRF Surveys \\
\hline & LMIT-96-24-01 & CFA Landfill Borrow Source \\
\hline & LMIT-96-28-03 & ANL-W Burn Remediation \\
\hline & LMIT-96-28-13 & ANL-W Burn Remediation \\
\hline & LMIT-96-28-16 & ANL-W Burn Remediation \\
\hline & LMIT-97-16-02 & ACETS/PNDR \\
\hline & LMIT-97-16-05 & ACETS/PNDR \\
\hline & LMIT-97-16-06 & ACETS/PNDR \\
\hline & LMIT-97-16-13 & ACETS/PNDR \\
\hline & LMIT-97-16-14 & ACETS/PNDR \\
\hline & LMIT-97-16-23 & ACETS/PNDR \\
\hline & LMIT-97-16-29 & ACETS/PNDR \\
\hline & LMIT-97-16-41 & ACETS/PNDR \\
\hline & LMIT-97-16-42 & ACETS/PNDR \\
\hline & LMIT-97-16-43 & ACETS/PNDR \\
\hline
\end{tabular}


Table 5. (continued).

\begin{tabular}{|c|c|c|}
\hline \multicolumn{3}{|c|}{ INL Prehistoric Archaeological Sites } \\
\hline Site Number & Field Number & Project Name \\
\hline & LMIT-97-16-45 & ACETS/PNDR \\
\hline & LMIT-97-16-47 & ACETS/PNDR \\
\hline & LMIT-97-16-48 & ACETS/PNDR \\
\hline & LMIT-97-16-50 & ACETS/PNDR \\
\hline & LMIT-97-16-53 & ACETS/PNDR \\
\hline & LMIT-97-16-55 & ACETS/PNDR \\
\hline & LMIT-97-21-05 & Ordnance Removal Actions \\
\hline & LMIT-97-21-06 & Ordnance Removal Actions \\
\hline & LMIT-97-21-09 & Ordnance Removal Actions \\
\hline & LMIT-97-21-11 & Ordnance Removal Actions \\
\hline & LMIT-97-21-14 & Ordnance Removal Actions \\
\hline & LMIT-97-40-01 & ARA Soil Sampling \\
\hline & LMIT-97-40-02 & ARA Soil Sampling \\
\hline & LMIT-98-31-11 & Highway 20/26 Controlled Burn \\
\hline & LMIT-98-34-01 & Highway 20/26 Controlled Burn \\
\hline & LMIT-98-34-03 & Highway 20/26 Controlled Burn \\
\hline & LMIT-99-02-04 & Deadman Grazing Allotment Fence \\
\hline & LMIT-99-02-05 & Deadman Grazing Allotment Fence \\
\hline & LMIT-99-02-06 & Deadman Grazing Allotment Fence \\
\hline & LMIT-99-02-08 & Deadman Grazing Allotment Fence \\
\hline & LMIT-99-39-04 & OMRE Wells \\
\hline & LMIT-99-39-07 & OMRE Wells \\
\hline & LMIT-99-40-3 & Stormwater Release Sites \\
\hline & SJM-99-01-SIC-02 & Farragut Blvd Modifications \\
\hline & SJM-99-01-SIC-03 & Farragut Blvd Modifications \\
\hline \multirow[t]{11}{*}{ 10-BT-2087 } & SJM-99-01-SIC-04 & Farragut Blvd Modifications \\
\hline & SJM-99-01-SIC-09 & Farragut Blvd Modifications \\
\hline & SJM-99-01-SIC-10 & Farragut Blvd Modifications \\
\hline & SJM-99-01-SIC-11 & Farragut Blvd Modifications \\
\hline & ISU-2002-1-M10 & INL Predictive Model 2002 \\
\hline & ISU-2002-1-M14 & INL Predictive Model 2002 \\
\hline & ISU-2002-1-M19 & INL Predictive Model 2002 \\
\hline & ISU-2002-1-M02 & INL Predictive Model 2002 \\
\hline & ISU-2002-1-M24 & INL Predictive Model 2002 \\
\hline & ISU-2002-1-M29 & INL Predictive Model 2002 \\
\hline & ISU-2002-1-M30 & INL Predictive Model 2002 \\
\hline
\end{tabular}


Table 5. (continued).

\begin{tabular}{|c|c|c|}
\hline \multicolumn{3}{|c|}{ INL Prehistoric Archaeological Sites } \\
\hline Site Number & Field Number & Project Name \\
\hline & ISU-2002-1-M33 & INL Predictive Model 2002 \\
\hline & ISU-2002-1-M37 & INL Predictive Model 2002 \\
\hline & ISU-2002-1-M38 & INL Predictive Model 2002 \\
\hline & ISU-2002-1-M04 & INL Predictive Model 2002 \\
\hline & ISU-2002-1-M42 & INL Predictive Model 2002 \\
\hline & ISU-2002-1-M44 & INL Predictive Model 2002 \\
\hline & ISU-2002-1-M46 & INL Predictive Model 2002 \\
\hline & ISU-2002-1-M49 & INL Predictive Model 2002 \\
\hline & ISU-2002-1-M51 & INL Predictive Model 2002 \\
\hline & ISU-2002-1-M55 & INL Predictive Model 2002 \\
\hline & ISU-2002-1-M06 & INL Predictive Model 2002 \\
\hline & ISU-2002-1-M61 & INL Predictive Model 2002 \\
\hline & ISU-2002-1-M62 & INL Predictive Model 2002 \\
\hline & ISU-2002-1-M63 & INL Predictive Model 2002 \\
\hline & ISU-2002-1-M65 & INL Predictive Model 2002 \\
\hline & ISU-2002-1-M66 & INL Predictive Model 2002 \\
\hline & ISU-2002-1-M07 & INL Predictive Model 2002 \\
\hline & ISU-2002-1-G12 & INL Predictive Model 2002 \\
\hline & ISU-2002-1-G13 & INL Predictive Model 2002 \\
\hline & ISU-2002-1-G14 & INL Predictive Model 2002 \\
\hline & ISU-2002-1-G02 & INL Predictive Model 2002 \\
\hline & ISU-2002-1-G22 & INL Predictive Model 2002 \\
\hline & ISU-2002-1-G26 & INL Predictive Model 2002 \\
\hline & ISU-2002-1-G29 & INL Predictive Model 2002 \\
\hline & ISU-2002-1-G33 & INL Predictive Model 2002 \\
\hline & ISU-2002-1-G35 & INL Predictive Model 2002 \\
\hline & ISU-2002-1-G36 & INL Predictive Model 2002 \\
\hline & ISU-2002-1-G46 & INL Predictive Model 2002 \\
\hline & ISU-2002-1-G49 & INL Predictive Model 2002 \\
\hline & ISU-2002-1-G50 & INL Predictive Model 2002 \\
\hline & ISU-2002-1-G51 & INL Predictive Model 2002 \\
\hline & ISU-2002-1-G53 & INL Predictive Model 2002 \\
\hline & ISU-2002-1-G55 & INL Predictive Model 2002 \\
\hline & ISU-2002-1-G07 & INL Predictive Model 2002 \\
\hline & ISU-2002-1-G08 & INL Predictive Model 2002 \\
\hline & ISU-2003-1-W004 & INL Predictive Model 2003 \\
\hline
\end{tabular}


Table 5. (continued).

\begin{tabular}{|c|c|c|}
\hline \multicolumn{3}{|c|}{ INL Prehistoric Archaeological Sites } \\
\hline Site Number & Field Number & Project Name \\
\hline & ISU-2003-1-W007 & INL Predictive Model 2003 \\
\hline & ISU-2003-1-W008 & INL Predictive Model 2003 \\
\hline & ISU-2003-1-W011 & INL Predictive Model 2003 \\
\hline & ISU-2003-1-W012 & INL Predictive Model 2003 \\
\hline & ISU-2003-1-W013 & INL Predictive Model 2003 \\
\hline & ISU-2003-1-W014 & INL Predictive Model 2003 \\
\hline & ISU-2003-1-W015 & INL Predictive Model 2003 \\
\hline & ISU-2003-1-W017 & INL Predictive Model 2003 \\
\hline & ISU-2003-1-W018 & INL Predictive Model 2003 \\
\hline & ISU-2003-1-R004 & INL Predictive Model 2003 \\
\hline & ISU-2003-1-R007 & INL Predictive Model 2003 \\
\hline & ISU-2003-1-R008 & INL Predictive Model 2003 \\
\hline & ISU-2003-1-R009 & INL Predictive Model 2003 \\
\hline & ISU-2003-1-R010 & INL Predictive Model 2003 \\
\hline & ISU-2003-1-R012 & INL Predictive Model 2003 \\
\hline & ISU-2003-1-R018 & INL Predictive Model 2003 \\
\hline & ISU-2003-1-R024 & INL Predictive Model 2003 \\
\hline & ISU-2003-1-R025 & INL Predictive Model 2003 \\
\hline & ISU-2003-1-R031 & INL Predictive Model 2003 \\
\hline & ISU-2003-1-R032 & INL Predictive Model 2003 \\
\hline & ISU-2003-1-R036 & INL Predictive Model 2003 \\
\hline & ISU-2003-1-R038 & INL Predictive Model 2003 \\
\hline & ISU-2003-1-R039 & INL Predictive Model 2003 \\
\hline & ISU-2003-1-P001 & INL Predictive Model 2003 \\
\hline & ISU-2003-1-P003 & INL Predictive Model 2003 \\
\hline & ISU-2003-1-P006 & INL Predictive Model 2003 \\
\hline & ISU-2003-1-P008 & INL Predictive Model 2003 \\
\hline & ISU-2003-1-P012 & INL Predictive Model 2003 \\
\hline & ISU-2003-1-P013 & INL Predictive Model 2003 \\
\hline & ISU-2003-1-P014 & INL Predictive Model 2003 \\
\hline & ISU-2003-1-P015 & INL Predictive Model 2003 \\
\hline & ISU-2003-1-P019 & INL Predictive Model 2003 \\
\hline & ISU-2003-1-P020 & INL Predictive Model 2003 \\
\hline & ISU-2003-1-P021 & INL Predictive Model 2003 \\
\hline & ISU-2003-1-P023 & INL Predictive Model 2003 \\
\hline & ISU-2003-1-P025 & INL Predictive Model 2003 \\
\hline
\end{tabular}


Table 5. (continued).

\begin{tabular}{|c|c|c|}
\hline \multicolumn{3}{|c|}{ INL Prehistoric Archaeological Sites } \\
\hline Site Number & Field Number & Project Name \\
\hline & ISU-2003-1-P028 & INL Predictive Model 2003 \\
\hline & ISU-2003-1-P033 & INL Predictive Model 2003 \\
\hline & BBWI-2004-40-110-02 & FY2004 Section 110 Surveys \\
\hline & BBWI-2004-40-110-07 & FY2004 Section 110 Surveys \\
\hline & BBWI-2004-40-110-3-01 & FY2004 Section 110 Surveys \\
\hline & BBWI-2004-40-110-3-03 & FY2004 Section 110 Surveys \\
\hline & BBWI-2004-40-110-4-01 & FY2004 Section 110 Surveys \\
\hline & BBWI-2004-40-110-4-03 & FY2004 Section 110 Surveys \\
\hline & BBWI-2004-40-110-4-05 & FY2004 Section 110 Surveys \\
\hline & BBWI-2004-40-110-4-06 & FY2004 Section 110 Surveys \\
\hline & BBWI-2004-40-110-4-08 & FY2004 Section 110 Surveys \\
\hline & BEA-2005-41-110-01 & FY2005 Section 110 Surveys \\
\hline & BEA-2005-41-110-02 & FY2005 Section 110 Surveys \\
\hline & BEA-2005-41-110-03 & FY2005 Section 110 Surveys \\
\hline & BEA-2005-41-110-06 & FY2005 Section 110 Surveys \\
\hline & BEA-2006-17-01 & $\begin{array}{l}\text { Science and Technology Campus in Id. } \\
\text { Falls }\end{array}$ \\
\hline & BEA-2006-20-07 & Large Scale Explosive Test Range \\
\hline & BEA-2006-20-12 & Large Scale Explosive Test Range \\
\hline & BEA-2006-31-110-01 & FY2006 Section 110 Surveys \\
\hline & BEA-2006-31-110-03 & FY2006 Section 110 Surveys \\
\hline & BEA-2006-31-110-04 & FY2006 Section 110 Surveys \\
\hline & BEA-2006-31-110-06 & FY2006 Section 110 Surveys \\
\hline & BEA-2006-31-110-10 & FY2006 Section 110 Surveys \\
\hline & BEA-2006-31-110-01 & FY2006 Section 110 Surveys \\
\hline & BEA-2006-31-110-11 & FY2006 Section 110 Surveys \\
\hline & BEA-2006-31-110-12 & FY2006 Section 110 Surveys \\
\hline & BEA-2006-31-110-16 & FY2006 Section 110 Surveys \\
\hline & BEA-2006-31-110-20 & FY2006 Section 110 Surveys \\
\hline & BEA-2006-31-110-22 & FY2006 Section 110 Surveys \\
\hline & BEA-2006-31-110-28 & FY2006 Section 110 Surveys \\
\hline
\end{tabular}


Table 6. INL prehistoric isolated finds.

\begin{tabular}{|c|c|c|}
\hline \multicolumn{3}{|c|}{ INL Prehistoric Isolated Finds } \\
\hline Site Number & Field Number & Project Name \\
\hline 10-BM-078 & SJM-84-02-001 & Grazing Boundary \\
\hline 10-BM-082 & SJM-84-02-005 & Grazing Boundary \\
\hline 10-BM-087 & SJM-84-02-100 & Grazing Boundary \\
\hline 10-BM-090 & SJM-84-01-SP-03 & Perimeter Boundary \\
\hline 10-BM-091 & SJM-84-01-SP-04 & Perimeter Boundary \\
\hline 10-BM-092 & SJM-84-01-SEP-01 & Perimeter Boundary \\
\hline 10-BM-095 & SJM-84-01-EP-03 & Perimeter Boundary \\
\hline 10-BM-097 & SJM-84-01-EP-01 & Perimeter Boundary \\
\hline 10-BM-099 & SJM-84-02-098 & Grazing Boundary \\
\hline 10-BM-100 & SJM-84-02-099 & Grazing Boundary \\
\hline 10-BM-102 & SJM-84-01-SP-01 & Perimeter Boundary \\
\hline 10-BM-111 & ISU-85-11.85-20 & FOC-CFA to ANL \\
\hline 10-BM-113 & ISU-85-11.85-22 & FOC-CFA to ANL \\
\hline 10-BM-114 & ISU-85-11.85-23 & FOC-CFA to ANL \\
\hline 10-BM-119 & ISU-85-11.85-28 & FOC-CFA to ANL \\
\hline 10-BM-125 & ISU-85-11.81-06 & FOC-ANL to TAN \\
\hline 10-BM-127 & ISU-85-11.81-07 & FOC-ANL to TAN \\
\hline 10-BM-128 & ISU-85-13-01 & Helicopter Pads \\
\hline 10-BM-138 & ISU-86-08-04 & FOC-ANL TO IF \\
\hline 10-BM-139 & ISU-86-08-01 & FOC-ANL TO IF \\
\hline 10-BM-151 & ISU-87-20-14 & Perimeter Sign Maintenance \\
\hline 10-BM-154 & ISU-87-12-23 & $\mathrm{SSC}$ \\
\hline 10-BM-155 & ISU-87-12-24 & $\mathrm{SSC}$ \\
\hline 10-BM-157 & ISU-87-12-33 & $\mathrm{SSC}$ \\
\hline 10-BM-158 & ISU-87-12-34 & $\mathrm{SSC}$ \\
\hline 10-BM-159 & ISU-87-12-35 & $\mathrm{SSC}$ \\
\hline 10-BM-218 & ISU-88-09-02 & ANL-W Administrative Boundary \\
\hline 10-BM-220 & ISU-88-09-04 & ANL-W Administrative Boundary \\
\hline 10-BM-221 & ISU-88-09-05 & ANL-W Administrative Boundary \\
\hline 10-BM-222 & ISU-88-09-06 & ANL-W Administrative Boundary \\
\hline 10-BM-224 & ISU-88-09-08 & ANL-W Administrative Boundary \\
\hline 10-BM-226 & ISU-88-09-10 & ANL-W Administrative Boundary \\
\hline 10-BM-227 & ISU-88-09-11 & ANL-W Administrative Boundary \\
\hline 10-BM-228 & ISU-88-09-12 & ANL-W Administrative Boundary \\
\hline $10-\mathrm{BM}-230$ & ISU-88-09-14 & ANL-W Administrative Boundary \\
\hline 10-BM-232 & ISU-88-09-16 & ANL-W Administrative Boundary \\
\hline 10-BM-234 & ISU-88-09-20 & ANL-W Administrative Boundary \\
\hline $10-\mathrm{BM}-236$ & ISU-88-09-19 & ANL-W Administrative Boundary \\
\hline 10-BM-237 & ISU-88-09-21 & ANL-W Administrative Boundary \\
\hline $10-\mathrm{BM}-238$ & ISU-88-09-22 & ANL-W Administrative Boundary \\
\hline
\end{tabular}


Table 6. (continued).

\begin{tabular}{|c|c|c|}
\hline \multicolumn{3}{|c|}{ INL Prehistoric Isolated Finds } \\
\hline Site Number & Field Number & Project Name \\
\hline 10-BM-239 & ISU-88-09-23 & ANL-W Administrative Boundary \\
\hline 10-BM-240 & ISU-88-09-24 & ANL-W Administrative Boundary \\
\hline 10-BM-242 & ISU-88-09-26 & ANL-W Administrative Boundary \\
\hline 10-BM-243 & ISU-88-09-27 & ANL-W Administrative Boundary \\
\hline 10-BM-246 & ISU-88-09-30 & ANL-W Administrative Boundary \\
\hline 10-BM-249 & ISU-88-09-33 & ANL-W Administrative Boundary \\
\hline 10-BM-266 & ISU-90-08-CC & NPR Sample Survey \\
\hline 10-BM-268 & ISU-90-08-EE & NPR Sample Survey \\
\hline 10-BM-269 & ISU-90-08-FF & NPR Sample Survey \\
\hline 10-BM-270 & ISU-90-08-GG & NPR Sample Survey \\
\hline 10-BM-271 & ISU-90-08-HH & NPR Sample Survey \\
\hline 10-BM-272 & ISU-90-08-II & NPR Sample Survey \\
\hline 10-BM-273 & ISU-90-08-JJ & NPR Sample Survey \\
\hline 10-BM-274 & ISU-90-08-V1 & NPR Sample Survey \\
\hline 10-BM-347 & EGG-94-20-ANLW-01 & Ordnance Cleanup at NODA and ANL-W \\
\hline 10-BM-348 & EGG-94-20-ANLW-02 & Ordnance Cleanup at NODA and ANL-W \\
\hline 10-BM-349 & EGG-94-20-ANLW-03 & Ordnance Cleanup at NODA and ANL-W \\
\hline $10-\mathrm{BM}-350$ & EGG-94-20-ANLW-04 & Ordnance Cleanup at NODA and ANL-W \\
\hline 10-BM-352 & EGG-94-20-ANLW-06 & Ordnance Cleanup at NODA and ANL-W \\
\hline 10-BM-481 & LMIT-97-46-09 & INEEL Road Upgrades \\
\hline 10-BM-482 & LMIT-97-46-10 & INEEL Road Upgrades \\
\hline 10-BM-483 & LMIT-97-46-11 & INEEL Road Upgrades \\
\hline 10-BM-484 & LMIT-97-46-12 & INEEL Road Upgrades \\
\hline 10-BM-485 & LMIT-97-46-13 & INEEL Road Upgrades \\
\hline 10-BM-736 & SJM-84-01-BNDRY-18 & Perimeter Boundary \\
\hline 10-BT-0372 & SJM-84-11-E02 & NPR Area E \\
\hline 10-BТ-0374 & SJM-84-11-E04 & NPR Area E \\
\hline 10-BT-0376 & SJM-84-11-E06 & NPR Area E \\
\hline 10-BT-0379 & SJM-84-11-E09 & NPR Area E \\
\hline 10-BT-0381 & SJM-84-11-E11 & NPR Area E \\
\hline 10-BT-0382 & SJM-84-11-E12 & NPR Area E \\
\hline 10-BT-0384 & SJM-84-11-E14 & NPR Area E \\
\hline 10-BT-0389 & SJM-84-11-E19 & NPR Area E \\
\hline 10-BT-0391 & SJM-84-11-E21 & NPR Area E \\
\hline 10-BT-0392 & SJM-84-11-E22 & NPR Area E \\
\hline 10-BT-0399 & SJM-84-11-E29 & NPR Area E \\
\hline 10-BT-0401 & SJM-84-11-E31 & NPR Area E \\
\hline 10-BT-0402 & SJM-84-11-E32 & NPR Area E \\
\hline 10-BT-0403 & SJM-84-11-E33 & NPR Area E \\
\hline
\end{tabular}


Table 6. (continued).

\begin{tabular}{|c|c|c|}
\hline \multicolumn{3}{|c|}{ INL Prehistoric Isolated Finds } \\
\hline Site Number & Field Number & Project Name \\
\hline 10-BT-0404 & SJM-84-11-E34 & NPR Area E \\
\hline 10-BT-0405 & SJM-84-11-E35 & NPR Area E \\
\hline 10-BT-0406 & SJM-84-11-E36 & NPR Area E \\
\hline 10-BT-0407 & SJM-84-11-E37 & NPR Area E \\
\hline 10-BT-0408 & SJM-84-11-E38 & NPR Area E \\
\hline 10-BТ-0409 & SJM-84-11-E39 & NPR Area E \\
\hline 10-BT-0410 & SJM-84-11-E40 & NPR Area E \\
\hline 10-BT-0411 & SJM-84-11-E41 & NPR Area E \\
\hline 10-BT-0412 & SJM-84-11-E42 & NPR Area E \\
\hline 10-BT-0413 & SJM-84-11-E43 & NPR Area E \\
\hline 10-BT-0414 & SJM-84-11-E44 & NPR Area E \\
\hline 10-BT-0416 & SJM-84-11-E46 & NPR Area E \\
\hline 10-BT-0417 & SJM-84-11-E47 & NPR Area E \\
\hline 10-BT-0418 & SJM-84-11-E48A & NPR Area E \\
\hline 10-BT-0419 & SJM-84-11-E48B & NPR Area E \\
\hline 10-BT-0421 & SJM-84-11-E50 & NPR Area E \\
\hline 10-BT-0426 & SJM-84-11-E55 & NPR Area E \\
\hline 10-BT-0433 & SJM-84-11-E62 & NPR Area E \\
\hline 10-BT-0434 & SJM-84-11-E63 & NPR Area E \\
\hline 10-BT-0440 & SJM-84-11-E69 & NPR Area E \\
\hline 10-BT-0441 & SJM-84-11-E70 & NPR Area E \\
\hline 10-BT-0442 & SJM-84-11-E71 & NPR Area E \\
\hline 10-BT-0444 & SJM-84-11-E73 & NPR Area E \\
\hline 10-BT-0445 & SJM-84-11-E74 & NPR Area E \\
\hline 10-BT-0446 & SJM-84-11-E75 & NPR Area E \\
\hline 10-BТ-0449 & SJM-84-11-E78 & NPR Area E \\
\hline 10-BT-0450 & SJM-84-11-E79 & NPR Area E \\
\hline 10-BT-0451 & SJM-84-11-E80 & NPR Area E \\
\hline 10-BT-0452 & SJM-84-11-E81 & NPR Area E \\
\hline 10-BT-0454 & SJM-84-11-E83 & NPR Area E \\
\hline 10-BT-0455 & SJM-84-11-E84 & NPR Area E \\
\hline 10-BT-0456 & SJM-84-11-E85 & NPR Area E \\
\hline 10-BT-0522 & SJM-84-02- & Grazing Boundary \\
\hline 10-BT-0540 & SJM-84-02-043 & Grazing Boundary \\
\hline 10-BT-0544 & SJM-84-02-054 & Grazing Boundary \\
\hline 10-BT-0545 & SJM-84-02-055 & Grazing Boundary \\
\hline 10-BT-0548 & SJM-84-02-059 & Grazing Boundary \\
\hline 10-BT-0549 & SJM-84-02-061 & Grazing Boundary \\
\hline 10-BT-0550 & SJM-84-02-062 & Grazing Boundary \\
\hline
\end{tabular}


Table 6. (continued).

\begin{tabular}{|c|c|c|}
\hline \multicolumn{3}{|c|}{ INL Prehistoric Isolated Finds } \\
\hline Site Number & Field Number & Project Name \\
\hline 10-BT-0552 & SJM-84-02-065 & Grazing Boundary \\
\hline 10-BT-0556 & SJM-84-02-069 & Grazing Boundary \\
\hline 10-BT-0557 & SJM-84-02-071 & Grazing Boundary \\
\hline 10-BT-0560 & SJM-84-02-074 & Grazing Boundary \\
\hline 10-BT-0583 & SJM-84-01-SP-30 & Perimeter Boundary \\
\hline 10-BT-0585 & SJM-84-01-SP-27 & Perimeter Boundary \\
\hline 10-BT-0586 & SJM-84-01-SP-28 & Perimeter Boundary \\
\hline 10-BT-0587 & SJM-84-01-SP-25 & Perimeter Boundary \\
\hline 10-BT-0593 & SJM-84-01-SP-21 & Perimeter Boundary \\
\hline 10-BT-0599 & SJM-84-01-SWP-05 & Perimeter Boundary \\
\hline 10-BT-0601 & SJM-84-01-SWP-04 & Perimeter Boundary \\
\hline 10-BT-0602 & SJM-84-01-SWP-07 & Perimeter Boundary \\
\hline 10-BТ-0609 & SJM-84-01-SP-16 & Perimeter Boundary \\
\hline 10-BT-0611 & SJM-84-01-SP-14 & Perimeter Boundary \\
\hline 10-BТ-0613 & SJM-84-01-SP-11 & Perimeter Boundary \\
\hline 10-BT-0622 & SJM-84-01-SP-20 & Perimeter Boundary \\
\hline 10-BT-0624 & SJM-84-01-WP-11 & Perimeter Boundary \\
\hline 10-BT-0625 & SJM-84-01-WP-09 & Perimeter Boundary \\
\hline 10-BT-0626 & SJM-84-01-WP-10 & Perimeter Boundary \\
\hline 10-BT-0631 & SJM-84-01-WP-12 & Perimeter Boundary \\
\hline 10-BT-0633 & SJM-84-01-WP-14 & Perimeter Boundary \\
\hline 10-BT-0634 & SJM-84-01-WP-13 & Perimeter Boundary \\
\hline 10-BT-0636 & SJM-84-01-WP-15 & Perimeter Boundary \\
\hline 10-BT-0637 & SJM-84-01-BNDRY-4 & Perimeter Boundary \\
\hline 10-BT-0638 & SJM-84-02-2GB-04 & Grazing Boundary \\
\hline 10-BT-0642 & SJM-84-02-060 & Grazing Boundary \\
\hline 10-BТ-0643 & SJM-84-15-04 & Geological Studies \\
\hline 10-BT-0644 & SJM-84-15-05 & Geological Studies \\
\hline 10-BT-0645 & SJM-84-15-06 & Geological Studies \\
\hline 10-BT-0655 & SJM-84-15-15 & Geological Studies \\
\hline 10-BT-0656 & SJM-84-15-16 & Geological Studies \\
\hline 10-BT-0660 & SJM-84-15-20 & Geological Studies \\
\hline 10-BT-0664 & SJM-84-15-24 & Geological Studies \\
\hline 10-BT-0666 & SJM-84-15-26 & Geological Studies \\
\hline 10-BT-0667 & SJM-84-15-27 & Geological Studies \\
\hline 10-BT-0671 & SJM-84-15-31 & Geological Studies \\
\hline 10-BT-0672 & SJM-84-15-32 & Geological Studies \\
\hline 10-BT-0681 & SJM-84-03-02 & Diversion Area \\
\hline 10-BT-0682 & SJM-84-03-03 & Diversion Area \\
\hline
\end{tabular}


Table 6. (continued).

\begin{tabular}{|c|c|c|}
\hline \multicolumn{3}{|c|}{ INL Prehistoric Isolated Finds } \\
\hline Site Number & Field Number & Project Name \\
\hline 10-BT-0686 & SJM-84-03-07 & Diversion Area \\
\hline 10-BT-0687 & SJM-84-03-08 & Diversion Area \\
\hline 10-BT-0688 & SJM-84-03-09 & Diversion Area \\
\hline 10-BT-0689 & SJM-84-03-10 & Diversion Area \\
\hline 10-BT-0690 & SJM-84-03-11 & Diversion Area \\
\hline 10-BT-0691 & SJM-84-03-12 & Diversion Area \\
\hline 10-BT-0692 & SJM-84-03-13 & Diversion Area \\
\hline 10-BT-0693 & SJM-84-03-14 & Diversion Area \\
\hline 10-BT-0694 & SJM-84-03-15 & Diversion Area \\
\hline 10-BT-0697 & SJM-84-03-18 & Diversion Area \\
\hline 10-BT-0698 & SJM-84-03-19 & Diversion Area \\
\hline 10-BT-0706 & SJM-83-01-03 & RWMC Wind Gap \#2 \\
\hline 10-BТ-0709 & SJM-83-01-06 & RWMC Wind Gap \#2 \\
\hline 10-BT-0710 & SJM-83-01-07 & RWMC Wind Gap \#2 \\
\hline 10-BT-0713 & SJM-83-01-10 & RWMC Wind Gap \#2 \\
\hline 10-BT-0714 & SJM-83-01-11 & RWMC Wind Gap \#2 \\
\hline 10-BT-0715 & SJM-83-01-12 & RWMC Wind Gap \#2 \\
\hline 10-BT-0722 & SJM-84-03-26 & Diversion Area \\
\hline 10-BT-0723 & SJM-84-03-27 & Diversion Area \\
\hline 10-BT-0724 & SJM-84-03-28 & Diversion Area \\
\hline 10-BT-0725 & SJM-84-03-29 & Diversion Area \\
\hline 10-BT-0728 & SJM-84-03-32 & Diversion Area \\
\hline 10-BT-0730 & SJM-84-03-34 & Diversion Area \\
\hline 10-BT-0733 & SJM-84-03-37 & Diversion Area \\
\hline 10-BT-0734 & SJM-84-03-38 & Diversion Area \\
\hline 10-BT-0735 & SJM-84-03-39 & Diversion Area \\
\hline 10-BТ-0736 & SJM-84-01-SP-07 & Perimeter Boundary \\
\hline 10-BT-0737 & SJM-84-01-BNDRY-6 & Perimeter Boundary \\
\hline 10-BТ-0739 & SJM-84-01-BNDRY-8 & Perimeter Boundary \\
\hline 10-BT-0741 & SJM-84-19-02 & TAN Powerlines and Parking Lot \\
\hline 10-BT-0746 & SJM-84-05-02 & CFA Heliport \\
\hline 10-BT-0761 & ISU-85-07-011A & Firing Range \\
\hline 10-BT-0777 & ISU-85-07-074 & Firing Range \\
\hline 10-BT-0781 & ISU-85-07-089 & Firing Range \\
\hline 10-BT-0800 & ISU-85-07-054 & Firing Range \\
\hline 10-BT-0804 & ISU-85-07-133 & Firing Range \\
\hline 10-BТ-0819 & ISU-85-07-149 & Firing Range \\
\hline 10-BT-0823 & ISU-85-07-169 & Firing Range \\
\hline 10-BT-0824 & ISU-85-07-164 & Firing Range \\
\hline
\end{tabular}


Table 6. (continued).

\begin{tabular}{|c|c|c|}
\hline \multicolumn{3}{|c|}{ INL Prehistoric Isolated Finds } \\
\hline Site Number & Field Number & Project Name \\
\hline 10-BT-0825 & ISU-85-07-165 & Firing Range \\
\hline 10-BT-0826 & ISU-85-07-167 & Firing Range \\
\hline 10-BT-0827 & ISU-85-07-081 & Firing Range \\
\hline 10-BT-0828 & ISU-85-07-086 & Firing Range \\
\hline 10-BT-0829 & ISU-85-07-087 & Firing Range \\
\hline 10-BT-0830 & ISU-85-07-093 & Firing Range \\
\hline 10-BT-0831 & ISU-85-07-094 & Firing Range \\
\hline 10-BT-0832 & ISU-85-07-170 & Firing Range \\
\hline 10-BT-0833 & ISU-85-07-171 & Firing Range \\
\hline 10-BT-0834 & ISU-85-07-172 & Firing Range \\
\hline 10-BT-0835 & ISU-85-07-176 & Firing Range \\
\hline 10-BT-0836 & ISU-85-07-179 & Firing Range \\
\hline 10-BT-0837 & ISU-85-07-180 & Firing Range \\
\hline 10-BT-0838 & ISU-85-07-181 & Firing Range \\
\hline 10-BT-0839 & ISU-85-07-011B & Firing Range \\
\hline 10-BT-0840 & ISU-85-07-013 & Firing Range \\
\hline 10-BT-0841 & ISU-85-07-079 & Firing Range \\
\hline 10-BT-0842 & ISU-85-07-083 & Firing Range \\
\hline 10-BT-0843 & ISU-85-07-166 & Firing Range \\
\hline 10-BT-0844 & ISU-85-07-098 & Firing Range \\
\hline 10-BT-0845 & ISU-85-07-100 & Firing Range \\
\hline 10-BT-0846 & ISU-85-07-101 & Firing Range \\
\hline 10-BT-0847 & ISU-85-07-122 & Firing Range \\
\hline 10-BT-0849 & ISU-85-07-161 & Firing Range \\
\hline $10-\mathrm{BT}-0850$ & ISU-85-07-162 & Firing Range \\
\hline 10-BT-0851 & ISU-85-07-173 & Firing Range \\
\hline 10-BT-0852 & ISU-85-07-182 & Firing Range \\
\hline 10-BT-0853 & ISU-85-07-183 & Firing Range \\
\hline 10-BT-0854 & ISU-85-07-009 & Firing Range \\
\hline 10-BT-0855 & ISU-85-07-037 & Firing Range \\
\hline 10-BT-0856 & ISU-85-07-038 & Firing Range \\
\hline 10-BT-0857 & ISU-85-07-109 & Firing Range \\
\hline 10-BT-0858 & ISU-85-07-110 & Firing Range \\
\hline 10-BT-0859 & ISU-85-07-112 & Firing Range \\
\hline 10-BT-0860 & ISU-85-07-113 & Firing Range \\
\hline 10-BT-0861 & ISU-85-07-095 & Firing Range \\
\hline 10-BT-0862 & ISU-85-07-119 & Firing Range \\
\hline 10-BT-0863 & ISU-85-07-120 & Firing Range \\
\hline 10-BT-0864 & ISU-85-07-121 & Firing Range \\
\hline
\end{tabular}


Table 6. (continued).

\begin{tabular}{|c|c|c|}
\hline \multicolumn{3}{|c|}{ INL Prehistoric Isolated Finds } \\
\hline Site Number & Field Number & Project Name \\
\hline 10-BT-0865 & ISU-85-07-125 & Firing Range \\
\hline 10-BT-0866 & ISU-85-07-036 & Firing Range \\
\hline 10-BT-0867 & ISU-85-07-063 & Firing Range \\
\hline 10-BT-0868 & ISU-85-07-066 & Firing Range \\
\hline 10-BT-0869 & ISU-85-07-067 & Firing Range \\
\hline 10-BT-0870 & ISU-85-07-102 & Firing Range \\
\hline 10-BT-0871 & ISU-85-07-104 & Firing Range \\
\hline 10-BT-0872 & ISU-85-07-044 & Firing Range \\
\hline 10-BT-0873 & ISU-85-07-096 & Firing Range \\
\hline 10-BT-0874 & ISU-85-07-103 & Firing Range \\
\hline 10-BT-0875 & ISU-85-07-105 & Firing Range \\
\hline 10-BT-0876 & ISU-85-07-107 & Firing Range \\
\hline 10-BT-0877 & ISU-85-07-108 & Firing Range \\
\hline 10-BT-0878 & ISU-85-07-076 & Firing Range \\
\hline 10-BT-0879 & ISU-85-07-077 & Firing Range \\
\hline 10-BT-0880 & ISU-85-07-078 & Firing Range \\
\hline 10-BT-0882 & ISU-85-07-091 & Firing Range \\
\hline 10-BT-0883 & ISU-85-07-092 & Firing Range \\
\hline 10-BT-0884 & ISU-85-07-114 & Firing Range \\
\hline 10-BT-0885 & ISU-85-07-115 & Firing Range \\
\hline 10-BT-0886 & ISU-85-07-117 & Firing Range \\
\hline 10-BT-0887 & ISU-85-07-118 & Firing Range \\
\hline 10-BT-0888 & ISU-85-07-124 & Firing Range \\
\hline 10-BT-0889 & ISU-85-07-174 & Firing Range \\
\hline 10-BT-0890 & ISU-85-07-175 & Firing Range \\
\hline 10-BT-0891 & ISU-85-07-014 & Firing Range \\
\hline 10-BТ-0892 & ISU-85-07-048 & Firing Range \\
\hline 10-BT-0893 & ISU-85-07-060 & Firing Range \\
\hline 10-BТ-0894 & ISU-85-07-061 & Firing Range \\
\hline 10-BT-0895 & ISU-85-07-068 & Firing Range \\
\hline 10-BT-0896 & ISU-85-07-069 & Firing Range \\
\hline 10-BT-0897 & ISU-85-07-070 & Firing Range \\
\hline 10-BТ-0899 & ISU-85-07-016 & Firing Range \\
\hline 10-BT-0900 & ISU-85-07-017 & Firing Range \\
\hline 10-BT-0901 & ISU-85-07-024 & Firing Range \\
\hline 10-BT-0902 & ISU-85-07-027 & Firing Range \\
\hline 10-BT-0903 & ISU-85-07-028 & Firing Range \\
\hline 10-BT-0904 & ISU-85-07-045 & Firing Range \\
\hline 10-BT-0905 & ISU-85-07-051 & Firing Range \\
\hline
\end{tabular}


Table 6. (continued).

\begin{tabular}{|c|c|c|}
\hline \multicolumn{3}{|c|}{ INL Prehistoric Isolated Finds } \\
\hline Site Number & Field Number & Project Name \\
\hline 10-BT-0906 & ISU-85-07-019 & Firing Range \\
\hline 10-BT-0908 & ISU-85-07-053 & Firing Range \\
\hline 10-BT-0909 & ISU-85-07-057 & Firing Range \\
\hline 10-BT-0910 & ISU-85-07-058 & Firing Range \\
\hline 10-BT-0911 & ISU-85-07-062 & Firing Range \\
\hline 10-BT-0912 & ISU-85-07-003 & Firing Range \\
\hline 10-BT-0913 & ISU-85-07-004 & Firing Range \\
\hline 10-BT-0918 & ISU-85-07-001 & Firing Range \\
\hline 10-BT-0919 & ISU-85-07-137 & Firing Range \\
\hline 10-BT-0920 & ISU-85-07-131 & Firing Range \\
\hline 10-BT-0921 & ISU-85-07-134 & Firing Range \\
\hline 10-BT-0922 & ISU-85-07-140 & Firing Range \\
\hline 10-BT-0923 & ISU-85-07-142 & Firing Range \\
\hline 10-BT-0924 & ISU-85-07-156 & Firing Range \\
\hline 10-BT-0925 & ISU-85-07-160 & Firing Range \\
\hline 10-BT-0926 & ISU-85-07-002 & Firing Range \\
\hline 10-BT-0927 & ISU-85-07-018 & Firing Range \\
\hline 10-BT-0928 & ISU-85-07-145 & Firing Range \\
\hline 10-BТ-0929 & ISU-85-07-148 & Firing Range \\
\hline 10-BT-0930 & ISU-85-07-150 & Firing Range \\
\hline 10-BT-0931 & ISU-85-07-151 & Firing Range \\
\hline 10-BT-0932 & ISU-85-07-152 & Firing Range \\
\hline 10-BT-0935 & ISU-85-12-11 & NRF Perimeter \\
\hline 10-BT-0936 & ISU-85-12-12 & NRF Perimeter \\
\hline 10-BT-0938 & ISU-85-12-14 & NRF Perimeter \\
\hline 10-BT-0939 & ISU-85-12-15 & NRF Perimeter \\
\hline 10-BT-0942 & ISU-85-12-08 & NRF Perimeter \\
\hline 10-BT-0943 & ISU-85-12-01 & NRF Perimeter \\
\hline 10-BT-0946 & ISU-85-12-04 & NRF Perimeter \\
\hline 10-BT-0952 & ISU-85-11.90-02 & FOC-Lincoln Blvd \\
\hline 10-BT-0955 & ISU-85-11.90-13 & FOC-Lincoln Blvd \\
\hline 10-BT-0960 & ISU-85-11.90-10 & FOC-Lincoln Blvd \\
\hline 10-BT-0961 & ISU-85-11.90-11 & FOC-Lincoln Blvd \\
\hline 10-BT-0962 & ISU-85-11.90-12 & FOC-Lincoln Blvd \\
\hline 10-BT-0963 & ISU-85-11.90-09 & FOC-Lincoln Blvd \\
\hline 10-BT-0964 & ISU-85-11.90-08 & FOC-Lincoln Blvd \\
\hline 10-BT-0965 & ISU-85-11.90-06 & FOC-Lincoln Blvd \\
\hline 10-BT-0966 & ISU-85-11.90-07 & FOC-Lincoln Blvd \\
\hline 10-BТ-0969 & ISU-85-11.90-33 & FOC-Lincoln Blvd \\
\hline
\end{tabular}


Table 6. (continued).

\begin{tabular}{|c|c|c|}
\hline \multicolumn{3}{|c|}{ INL Prehistoric Isolated Finds } \\
\hline Site Number & Field Number & Project Name \\
\hline 10-BT-0971 & ISU-85-11.90-36 & FOC-Lincoln Blvd \\
\hline 10-BT-0972 & ISU-85-11.90-37 & FOC-Lincoln Blvd \\
\hline 10-BT-0973 & ISU-85-11.90-31 & FOC-Lincoln Blvd \\
\hline 10-BT-0976 & ISU-85-11.90-28 & FOC-Lincoln Blvd \\
\hline 10-BT-0977 & ISU-85-11.90-30 & FOC-Lincoln Blvd \\
\hline 10-BT-0978 & ISU-85-11.90-21 & FOC-Lincoln Blvd \\
\hline 10-BT-0982 & ISU-85-11.90-25 & FOC-Lincoln Blvd \\
\hline 10-BT-0984 & ISU-85-11.90-18 & FOC-Lincoln Blvd \\
\hline 10-BT-0985 & ISU-85-11.90-19 & FOC-Lincoln Blvd \\
\hline 10-BT-0986 & ISU-85-11.90-20 & FOC-Lincoln Blvd \\
\hline 10-BT-0987 & ISU-85-11.90-23 & FOC-Lincoln Blvd \\
\hline 10-BT-0988 & ISU-85-11.90-50 & FOC-Lincoln Blvd \\
\hline 10-BТ-0989 & ISU-85-11.90-51 & FOC-Lincoln Blvd \\
\hline 10-BT-0991 & ISU-85-11.90-48 & FOC-Lincoln Blvd \\
\hline 10-BТ-0992 & ISU-85-11.90-49 & FOC-Lincoln Blvd \\
\hline 10-BT-0993 & ISU-85-11.90-43 & FOC-Lincoln Blvd \\
\hline 10-BT-0994 & ISU-85-11.90-44 & FOC-Lincoln Blvd \\
\hline 10-BT-0999 & ISU-85-11.90-39 & FOC-Lincoln Blvd \\
\hline 10-BT-1000 & ISU-85-11.90-38 & FOC-Lincoln Blvd \\
\hline 10-BT-1001 & ISU-85-11.90-35 & FOC-Lincoln Blvd \\
\hline 10-BT-1005 & ISU-85-11.91-12 & FOC-T-24 \\
\hline 10-BT-1007 & ISU-85-11.91-03 & FOC-T-24 \\
\hline 10-BT-1014 & ISU-85-11.91-22 & FOC-T-24 \\
\hline 10-BT-1017 & ISU-85-11.91-16 & FOC-T-24 \\
\hline 10-BT-1019 & ISU-85-11.91-18 & FOC-T-24 \\
\hline 10-BT-1023 & ISU-85-11.91-24 & FOC-T-24 \\
\hline 10-BT-1024 & ISU-85-11.91-25 & FOC-T-24 \\
\hline 10-BT-1027 & ISU-85-11.91-08 & FOC-T-24 \\
\hline 10-BT-1033 & ISU-85-11.84-02 & FOC-CFA to TAN \\
\hline 10-BT-1034 & ISU-85-11.84-03 & FOC-CFA to TAN \\
\hline 10-BT-1040 & ISU-84-02-02 & WERF Perimeter \\
\hline 10-BT-1042 & ISU-84-02-04 & WERF Perimeter \\
\hline 10-BT-1047 & ISU-85-11.85-07 & FOC-CFA to ANL \\
\hline 10-BT-1048 & ISU-85-11.85-08 & FOC-CFA to ANL \\
\hline 10-BT-1050 & ISU-85-11.85-38 & FOC-CFA to ANL \\
\hline 10-BT-1051 & ISU-85-11.85-39 & FOC-CFA to ANL \\
\hline 10-BT-1054 & ISU-85-11.85-33 & FOC-CFA to ANL \\
\hline 10-BT-1055 & ISU-85-11.85-34 & FOC-CFA to ANL \\
\hline 10-BT-1057 & ISU-85-11.85-09-01 & FOC-CFA to ANL \\
\hline
\end{tabular}


Table 6. (continued).

\begin{tabular}{|c|c|c|}
\hline \multicolumn{3}{|c|}{ INL Prehistoric Isolated Finds } \\
\hline Site Number & Field Number & Project Name \\
\hline 10-BT-1058 & ISU-85-11.85-10 & FOC-CFA to ANL \\
\hline 10-BT-1060 & ISU-85-11.85-12 & FOC-CFA to ANL \\
\hline 10-BT-1061 & ISU-85-11.85-13 & FOC-CFA to ANL \\
\hline 10-BT-1064 & ISU-85-11.85-16 & FOC-CFA to ANL \\
\hline 10-BT-1065 & ISU-85-11.42-01 & RWMC Borrow Area \\
\hline 10-BT-1067 & ISU-85-11.42-03 & RWMC Borrow Area \\
\hline 10-BT-1070 & ISU-85-11.42-06 & RWMC Borrow Area \\
\hline 10-BT-1071 & ISU-85-11.42-07 & RWMC Borrow Area \\
\hline 10-BT-1072 & ISU-85-11.42-08 & RWMC Borrow Area \\
\hline 10-BT-1073 & ISU-85-11.42-09 & RWMC Borrow Area \\
\hline 10-BT-1074 & ISU-85-11.42-10 & RWMC Borrow Area \\
\hline 10-BT-1077 & ISU-85-11.42-13 & RWMC Borrow Area \\
\hline 10-BT-1080 & ISU-85-11.42-16 & RWMC Borrow Area \\
\hline 10-BT-1081 & ISU-85-11.42-17 & RWMC Borrow Area \\
\hline 10-BT-1084 & ISU-85-11.42-20 & RWMC Borrow Area \\
\hline 10-BT-1088 & ISU-85-11.42-26 & RWMC Borrow Area \\
\hline 10-BT-1089 & ISU-85-11.42-28 & RWMC Borrow Area \\
\hline 10-BT-1090 & ISU-85-11.42-30 & RWMC Borrow Area \\
\hline 10-BT-1092 & ISU-85-11.42-29 & RWMC Borrow Area \\
\hline 10-BT-1093 & ISU-85-11.42-31 & RWMC Borrow Area \\
\hline 10-BТ-1094 & ISU-85-11.41-02 & RWMC Borrow Area \\
\hline 10-BT-1095 & ISU-85-11.41-03 & RWMC Borrow Area \\
\hline 10-BT-1096 & ISU-85-11.41-04 & RWMC Borrow Area \\
\hline 10-BТ-1097 & ISU-85-11.41-05 & RWMC Borrow Area \\
\hline 10-BТ-1098 & ISU-85-11.41-06 & RWMC Borrow Area \\
\hline 10-BТ-1099 & ISU-85-11.41-07 & RWMC Borrow Area \\
\hline 10-BT-1100 & ISU-85-11.41-08 & RWMC Borrow Area \\
\hline 10-BT-1103 & ISU-85-11.41-11 & RWMC Borrow Area \\
\hline 10-BT-1105 & ISU-85-11.41-13 & RWMC Borrow Area \\
\hline 10-BT-1107 & ISU-85-11.41-15 & RWMC Borrow Area \\
\hline 10-BT-1111 & ISU-85-11.41-19 & RWMC Borrow Area \\
\hline 10-BT-1113 & ISU-85-11.41-21 & RWMC Borrow Area \\
\hline 10-BT-1114 & ISU-85-11.41-22 & RWMC Borrow Area \\
\hline 10-BT-1116 & ISU-85-11.41-24 & RWMC Borrow Area \\
\hline 10-BT-1117 & ISU-85-11.41-27 & RWMC Borrow Area \\
\hline 10-BT-1118 & ISU-85-11.41-01 & RWMC Borrow Area \\
\hline 10-BT-1119 & ISU-85-11.41-25 & RWMC Borrow Area \\
\hline 10-BT-1120 & ISU-85-11.41-26 & RWMC Borrow Area \\
\hline 10-BT-1121 & ISU-85-11.60-05 & PBF Administrative Area \\
\hline
\end{tabular}


Table 6. (continued).

\begin{tabular}{|c|c|c|}
\hline \multicolumn{3}{|c|}{ INL Prehistoric Isolated Finds } \\
\hline Site Number & Field Number & Project Name \\
\hline 10-BT-1124 & ISU-85-11.60-09 & PBF Administrative Area \\
\hline 10-BT-1125 & ISU-85-11.60-10 & PBF Administrative Area \\
\hline 10-BT-1126 & ISU-85-11.60-11 & PBF Administrative Area \\
\hline 10-BT-1127 & ISU-85-11.60-12 & PBF Administrative Area \\
\hline 10-BT-1132 & ISU-85-11.60-42 & PBF Administrative Area \\
\hline 10-BT-1136 & ISU-85-11.60-46 & PBF Administrative Area \\
\hline 10-BT-1138 & ISU-85-11.60-48 & PBF Administrative Area \\
\hline 10-BT-1144 & ISU-85-11.60-54 & PBF Administrative Area \\
\hline 10-BT-1150 & ISU-85-11.60-15 & PBF Administrative Area \\
\hline 10-BT-1151 & ISU-85-11.60-16 & PBF Administrative Area \\
\hline 10-BT-1153 & ISU-85-11.60-58 & PBF Administrative Area \\
\hline 10-BT-1154 & ISU-85-11.60-60 & PBF Administrative Area \\
\hline 10-BT-1155 & ISU-85-11.60-61 & PBF Administrative Area \\
\hline 10-BT-1158 & ISU-85-11.60-01 & PBF Administrative Area \\
\hline 10-BT-1159 & ISU-85-11.85-09-02 & FOC-CFA to ANL \\
\hline 10-BT-1162 & ISU-85-11.60-19 & PBF Administrative Area \\
\hline 10-BT-1163 & ISU-85-11.60-20 & PBF Administrative Area \\
\hline 10-BT-1164 & ISU-85-11.60-23 & PBF Administrative Area \\
\hline 10-BT-1165 & ISU-85-11.60-24 & PBF Administrative Area \\
\hline 10-BT-1168 & ISU-85-11.60-27 & PBF Administrative Area \\
\hline 10-BT-1169 & ISU-85-11.60-28 & PBF Administrative Area \\
\hline 10-BT-1175 & ISU-85-11.60-36 & PBF Administrative Area \\
\hline 10-BT-1176 & ISU-85-11.60-37 & PBF Administrative Area \\
\hline 10-BT-1178 & ISU-85-11.60-06 & PBF Administrative Area \\
\hline 10-BT-1179 & ISU-85-11.60-21 & PBF Administrative Area \\
\hline 10-BT-1180 & ISU-85-11.60-22 & PBF Administrative Area \\
\hline 10-BT-1182 & ISU-85-11.60-33 & PBF Administrative Area \\
\hline 10-BT-1183 & ISU-85-11.60-63 & PBF Administrative Area \\
\hline 10-BT-1184 & ISU-85-11.2-07 & CFA Perimeter and Landfill \\
\hline 10-BT-1186 & ISU-85-11.2-17 & CFA Perimeter and Landfill \\
\hline 10-BT-1187 & ISU-85-11.87-01 & FOC-EOCR to PBF \\
\hline 10-BT-1195 & ISU-85-11.2-06 & CFA Perimeter and Landfill \\
\hline 10-BT-1196 & ISU-85-11.2-08 & CFA Perimeter and Landfill \\
\hline 10-BT-1197 & ISU-85-11.2-09 & CFA Perimeter and Landfill \\
\hline 10-BT-1198 & ISU-85-11.2-10 & CFA Perimeter and Landfill \\
\hline 10-BT-1199 & ISU-85-11.2-11 & CFA Perimeter and Landfill \\
\hline 10-BT-1201 & ISU-85-11.2-13 & CFA Perimeter and Landfill \\
\hline 10-BT-1203 & ISU-85-11.2-15 & CFA Perimeter and Landfill \\
\hline 10-BT-1204 & ISU-85-11.61-01 & PBF Administrative Area \\
\hline
\end{tabular}


Table 6. (continued).

\begin{tabular}{|c|c|c|}
\hline \multicolumn{3}{|c|}{ INL Prehistoric Isolated Finds } \\
\hline Site Number & Field Number & Project Name \\
\hline 10-BT-1206 & ISU-85-11.61-05 & PBF Administrative Area \\
\hline 10-BT-1210 & ISU-85-11.61-09 & PBF Administrative Area \\
\hline 10-BT-1213 & ISU-85-11.61-12 & PBF Administrative Area \\
\hline 10-BT-1217 & ISU-85-11.61-16 & PBF Administrative Area \\
\hline 10-BT-1218 & ISU-85-11.61-17 & PBF Administrative Area \\
\hline 10-BT-1219 & ISU-85-11.61-18 & PBF Administrative Area \\
\hline 10-BT-1220 & ISU-85-11.61-19 & PBF Administrative Area \\
\hline 10-BT-1228 & ISU-85-11.5-02 & BORAX Gravel Pit \\
\hline 10-BT-1229 & ISU-85-08-01 & TRU Waste \\
\hline 10-BT-1231 & ISU-84-05-01 & RWMC Monitoring Wells \\
\hline 10-BT-1235 & ISU-85-11.31-01 & LOFT Perimeter \\
\hline 10-BT-1237 & ISU-85-10-02 & TAN IET \\
\hline 10-BT-1238 & ISU-85-10-01 & TAN IET \\
\hline 10-BT-1239 & ISU-84-05-02 & RWMC Monitoring Wells \\
\hline 10-BT-1240 & ISU-85-02-01 & BORAX Perimeter \\
\hline 10-BT-1243 & ISU-86-02-01 & ICPP Perimeter \\
\hline 10-BT-1244 & ISU-86-02-02 & ICPP Perimeter \\
\hline 10-BT-1245 & ISU-86-02-03 & ICPP Perimeter \\
\hline 10-BT-1246 & ISU-85-11.85-31 & FOC-CFA to ANL \\
\hline 10-BT-1248 & ISU-85-11.85-29 & FOC-CFA to ANL \\
\hline 10-BT-1249 & ISU-85-11.85-30 & FOC-CFA to ANL \\
\hline 10-BT-1253 & ISU-85-08-02 & TRU Waste \\
\hline 10-BT-1254 & ISU-86-05-02 & CFA Substation \\
\hline 10-BT-1255 & ISU-86-05-01 & CFA Substation \\
\hline 10-BT-1276 & ISU-86-06-12 & NRF, TAN, CFA Gravel Pits \\
\hline 10-BT-1277 & ISU-86-06-13 & NRF, TAN, CFA Gravel Pits \\
\hline 10-BT-1278 & ISU-86-06-15 & NRF, TAN, CFA Gravel Pits \\
\hline 10-BT-1287 & ISU-86-06-03 & NRF, TAN, CFA Gravel Pits \\
\hline 10-BT-1288 & ISU-86-06-04 & NRF, TAN, CFA Gravel Pits \\
\hline 10-BT-1290 & ISU-86-06-01 & NRF, TAN, CFA Gravel Pits \\
\hline 10-BT-1291 & ISU-86-06-07 & NRF, TAN, CFA Gravel Pits \\
\hline 10-BT-1292 & ISU-86-06-10 & NRF, TAN, CFA Gravel Pits \\
\hline 10-BT-1298 & SJM-84-01-BNDRY-3 & Perimeter Boundary \\
\hline 10-BT-1311 & ISU-87-20-02 & Perimeter Sign Maintenance \\
\hline 10-BT-1312 & ISU-87-20-03 & Perimeter Sign Maintenance \\
\hline 10-BT-1313 & ISU-87-20-04 & Perimeter Sign Maintenance \\
\hline 10-BT-1316 & ISU-87-20-07 & Perimeter Sign Maintenance \\
\hline 10-BT-1320 & ISU-87-20-11 & Perimeter Sign Maintenance \\
\hline 10-BT-1323 & ISU-87-20-15 & Perimeter Sign Maintenance \\
\hline
\end{tabular}


Table 6. (continued).

\begin{tabular}{|c|c|c|}
\hline \multicolumn{3}{|c|}{ INL Prehistoric Isolated Finds } \\
\hline Site Number & Field Number & Project Name \\
\hline 10-BT-1325 & ISU-87-20-17 & Perimeter Sign Maintenance \\
\hline 10-BT-1331 & ISU-87-20-23 & Perimeter Sign Maintenance \\
\hline 10-BT-1337 & ISU-87-20-29 & Perimeter Sign Maintenance \\
\hline 10-BT-1339 & ISU-87-12-08 & $\mathrm{SSC}$ \\
\hline 10-BT-1340 & ISU-87-12-09 & $\mathrm{SSC}$ \\
\hline 10-BT-1342 & ISU-87-12-11 & $\mathrm{SSC}$ \\
\hline 10-BT-1343 & ISU-87-12-12 & $\mathrm{SSC}$ \\
\hline 10-BT-1344 & ISU-87-12-13 & $\mathrm{SSC}$ \\
\hline 10-BT-1347 & ISU-87-12-16 & $\mathrm{SSC}$ \\
\hline 10-BT-1350 & ISU-87-12-19 & $\mathrm{SSC}$ \\
\hline 10-BT-1355 & ISU-87-12-26 & $\mathrm{SSC}$ \\
\hline 10-BT-1356 & ISU-87-12-27 & $\mathrm{SSC}$ \\
\hline 10-BT-1358 & ISU-87-12-29 & $\mathrm{SSC}$ \\
\hline 10-BT-1360 & ISU-87-12-31 & $\mathrm{SSC}$ \\
\hline 10-BT-1361 & ISU-87-12-36 & $\mathrm{SSC}$ \\
\hline 10-BT-1362 & ISU-87-12-37 & $\mathrm{SSC}$ \\
\hline 10-BT-1364 & ISU-87-12-39 & $\mathrm{SSC}$ \\
\hline 10-BT-1365 & ISU-87-12-40 & $\mathrm{SSC}$ \\
\hline 10-BT-1367 & ISU-87-12-42 & $\mathrm{SSC}$ \\
\hline 10-BT-1368 & ISU-87-12-43 & $\mathrm{SSC}$ \\
\hline 10-BT-1369 & ISU-87-12-44 & $\mathrm{SSC}$ \\
\hline 10-BT-1371 & ISU-87-15-04 & Ant Study Plots \\
\hline 10-BT-1372 & ISU-87-15-05 & Ant Study Plots \\
\hline 10-BT-1373 & ISU-87-15-07 & Ant Study Plots \\
\hline 10-BT-1374 & ISU-87-15-08 & Ant Study Plots \\
\hline 10-BT-1376 & ISU-87-15-03 & Ant Study Plots \\
\hline 10-BT-1379 & ISU-88-01-01 & NRF Waste Ditch \\
\hline 10-BT-1381 & ISU-88-01-03 & NRF Waste Ditch \\
\hline 10-BT-1384 & ISU-88-01-06 & NRF Waste Ditch \\
\hline 10-BT-1386 & ISU-88-01-08 & NRF Waste Ditch \\
\hline 10-BT-1387 & ISU-88-01-09 & NRF Waste Ditch \\
\hline 10-BT-1388 & ISU-88-01-10 & NRF Waste Ditch \\
\hline 10-BT-1391 & ISU-88-01-13 & NRF Waste Ditch \\
\hline 10-BT-1392 & ISU-88-01-14 & NRF Waste Ditch \\
\hline 10-BT-1393 & ISU-88-01-15 & NRF Waste Ditch \\
\hline 10-BT-1395 & ISU-88-01-17 & NRF Waste Ditch \\
\hline 10-BT-1396 & ISU-88-01-18 & NRF Waste Ditch \\
\hline 10-BT-1400 & ISU-88-01-22 & NRF Waste Ditch \\
\hline 10-BT-1401 & ISU-88-01-23 & NRF Waste Ditch \\
\hline
\end{tabular}


Table 6. (continued).

\begin{tabular}{|c|c|c|}
\hline \multicolumn{3}{|c|}{ INL Prehistoric Isolated Finds } \\
\hline Site Number & Field Number & Project Name \\
\hline 10-BT-1405 & ISU-88-01-27 & NRF Waste Ditch \\
\hline 10-BT-1406 & ISU-88-01-28 & NRF Waste Ditch \\
\hline 10-BT-1407 & ISU-88-01-29 & NRF Waste Ditch \\
\hline 10-BT-1409 & ISU-88-01-31 & NRF Waste Ditch \\
\hline 10-BT-1411 & ISU-88-01-33 & NRF Waste Ditch \\
\hline 10-BT-1412 & ISU-88-01-34 & NRF Waste Ditch \\
\hline 10-BT-1414 & ISU-88-01-36 & NRF Waste Ditch \\
\hline 10-BT-1415 & ISU-88-01-37 & NRF Waste Ditch \\
\hline 10-BT-1416 & ISU-88-01-38 & NRF Waste Ditch \\
\hline 10-BT-1418 & ISU-88-01-40 & NRF Waste Ditch \\
\hline 10-BT-1423 & ISU-88-01-45 & NRF Waste Ditch \\
\hline 10-BT-1427 & ISU-88-01-49 & NRF Waste Ditch \\
\hline 10-BT-1430 & ISU-88-01-52 & NRF Waste Ditch \\
\hline 10-BT-1433 & ISU-88-01-55 & NRF Waste Ditch \\
\hline 10-BT-1435 & ISU-88-01-57 & NRF Waste Ditch \\
\hline 10-BT-1439 & ISU-88-01-61 & NRF Waste Ditch \\
\hline 10-BT-1440 & ISU-88-01-62 & NRF Waste Ditch \\
\hline 10-BT-1441 & ISU-88-01-63 & NRF Waste Ditch \\
\hline 10-BT-1443 & ISU-88-05-01 & FOC-TRA to Lincoln Blvd \\
\hline 10-BT-1446 & ISU-88-07-01 & Gravel Haul Road \\
\hline 10-BT-1452 & ISU-88-13-04 & RWMC Wind Gap \\
\hline 10-BT-1453 & ISU-88-14-01 & RWMC Inactive Borrow Area \\
\hline 10-BT-1456 & ISU-89-01-01 & ICPP/TRA Gravel Pit \\
\hline 10-BT-1457 & ISU-89-03-01 & Los River Fault Trench \\
\hline 10-BT-1461 & ISU-89-02-A01 & Hunting Boundary \\
\hline 10-BT-1463 & ISU-89-02-A03 & Hunting Boundary \\
\hline 10-BT-1465 & ISU-89-02-A05 & Hunting Boundary \\
\hline 10-BT-1470 & ISU-89-02-B05 & Hunting Boundary \\
\hline 10-BT-1472 & ISU-89-02-B07 & Hunting Boundary \\
\hline 10-BT-1475 & ISU-89-02-A09 & Hunting Boundary \\
\hline 10-BT-1481 & ISU-89-02-B09 & Hunting Boundary \\
\hline 10-BT-1485 & ISU-89-04-01 & NPR Seismic Stations \\
\hline 10-BT-1491 & ISU-89-05-1-06 & NPR Survey and Testing \\
\hline 10-BT-1492 & ISU-89-05-1-07 & NPR Survey and Testing \\
\hline 10-BT-1493 & ISU-89-05-1-08 & NPR Survey and Testing \\
\hline 10-BT-1495 & ISU-89-05-1-11 & NPR Survey and Testing \\
\hline 10-BT-1496 & ISU-89-05-1-12 & NPR Survey and Testing \\
\hline 10-BT-1501 & ISU-89-05-2-05 & NPR Survey and Testing \\
\hline 10-BT-1504 & ISU-89-05-2-08 & NPR Survey and Testing \\
\hline
\end{tabular}


Table 6. (continued).

\begin{tabular}{|c|c|c|}
\hline \multicolumn{3}{|c|}{ INL Prehistoric Isolated Finds } \\
\hline Site Number & Field Number & Project Name \\
\hline 10-BT-1506 & ISU-89-05-2-12 & NPR Survey and Testing \\
\hline 10-BT-1507 & ISU-89-05-2-13 & NPR Survey and Testing \\
\hline 10-BT-1508 & ISU-89-05-2-14 & NPR Survey and Testing \\
\hline 10-BT-1510 & ISU-89-05-3-04 & NPR Survey and Testing \\
\hline 10-BT-1511 & ISU-89-05-3-15 & NPR Survey and Testing \\
\hline 10-BT-1512 & ISU-89-05-3-07 & NPR Survey and Testing \\
\hline 10-BT-1514 & ISU-89-05-3-10 & NPR Survey and Testing \\
\hline 10-BT-1516 & ISU-89-05-3-02 & NPR Survey and Testing \\
\hline 10-BT-1517 & ISU-89-05-3-14 & NPR Survey and Testing \\
\hline 10-BT-1519 & ISU-89-06-02 & Fast Attack Vehicle Range \\
\hline 10-BT-1520 & ISU-89-06-03 & Fast Attack Vehicle Range \\
\hline 10-BT-1523 & ISU-89-06-06 & Fast Attack Vehicle Range \\
\hline 10-BT-1524 & ISU-89-06-07 & Fast Attack Vehicle Range \\
\hline 10-BT-1525 & ISU-89-06-08 & Fast Attack Vehicle Range \\
\hline 10-BT-1527 & ISU-89-06-10 & Fast Attack Vehicle Range \\
\hline 10-BT-1529 & ISU-89-06-12 & Fast Attack Vehicle Range \\
\hline 10-BT-1531 & ISU-89-06-14 & Fast Attack Vehicle Range \\
\hline 10-BT-1532 & ISU-89-06-15 & Fast Attack Vehicle Range \\
\hline 10-BT-1533 & ISU-89-06-16 & Fast Attack Vehicle Range \\
\hline 10-BT-1542 & ISU-89-06-25 & Fast Attack Vehicle Range \\
\hline 10-BT-1543 & ISU-89-06-26 & Fast Attack Vehicle Range \\
\hline 10-BT-1544 & ISU-89-06-27 & Fast Attack Vehicle Range \\
\hline 10-BT-1547 & ISU-89-06-30 & Fast Attack Vehicle Range \\
\hline 10-BT-1549 & ISU-89-06-32 & Fast Attack Vehicle Range \\
\hline 10-BT-1552 & ISU-89-06-35 & Fast Attack Vehicle Range \\
\hline 10-BT-1555 & ISU-89-06-38 & Fast Attack Vehicle Range \\
\hline 10-BT-1557 & ISU-89-06-40 & Fast Attack Vehicle Range \\
\hline 10-BT-1558 & ISU-89-06-41 & Fast Attack Vehicle Range \\
\hline 10-BT-1564 & ISU-89-06-47 & Fast Attack Vehicle Range \\
\hline 10-BT-1568 & ISU-89-06-51 & Fast Attack Vehicle Range \\
\hline 10-BT-1569 & ISU-89-06-52 & Fast Attack Vehicle Range \\
\hline 10-BT-1570 & ISU-89-06-53 & Fast Attack Vehicle Range \\
\hline 10-BT-1571 & ISU-89-06-54 & Fast Attack Vehicle Range \\
\hline 10-BT-1576 & ISU-89-06-59 & Fast Attack Vehicle Range \\
\hline 10-BT-1577 & ISU-89-06-60 & Fast Attack Vehicle Range \\
\hline 10-BT-1578 & ISU-89-06-61 & Fast Attack Vehicle Range \\
\hline 10-BT-1579 & ISU-89-06-62 & Fast Attack Vehicle Range \\
\hline 10-BT-1580 & ISU-89-06-63 & Fast Attack Vehicle Range \\
\hline 10-BT-1583 & ISU-89-05-1-10 & NPR Survey and Testing \\
\hline
\end{tabular}


Table 6. (continued).

\begin{tabular}{|c|c|c|}
\hline \multicolumn{3}{|c|}{ INL Prehistoric Isolated Finds } \\
\hline Site Number & Field Number & Project Name \\
\hline 10-BT-1584 & ISU-89-05-3-16 & NPR Survey and Testing \\
\hline 10-BT-1586 & ISU-89-05-2-10 & NPR Survey and Testing \\
\hline 10-BT-1587 & ISU-89-05-2-11 & NPR Survey and Testing \\
\hline 10-BT-1588 & ISU-89-05-2-A & NPR Survey and Testing \\
\hline 10-BT-1589 & ISU-89-05-2-B & NPR Survey and Testing \\
\hline 10-BT-1590 & ISU-89-05-2-C & NPR Survey and Testing \\
\hline 10-BT-1591 & ISU-89-05-4-01 & NPR Survey and Testing \\
\hline 10-BT-1594 & ISU-89-05-4-03 & NPR Survey and Testing \\
\hline 10-BT-1597 & ISU-90-02-C & RWMC Section 18 \\
\hline 10-BT-1598 & ISU-90-02-D & RWMC Section 18 \\
\hline 10-BT-1599 & ISU-90-02-E & RWMC Section 18 \\
\hline 10-BT-1600 & ISU-90-02-F & RWMC Section 18 \\
\hline 10-BT-1601 & ISU-90-02-G & RWMC Section 18 \\
\hline 10-BT-1602 & ISU-90-02-H & RWMC Section 18 \\
\hline 10-BT-1603 & ISU-90-02-I & RWMC Section 18 \\
\hline 10-BT-1604 & ISU-90-02-J & RWMC Section 18 \\
\hline 10-BT-1607 & ISU-90-02-M & RWMC Section 18 \\
\hline 10-BT-1610 & ISU-90-02-03 & RWMC Section 18 \\
\hline 10-BT-1611 & ISU-90-02-04 & RWMC Section 18 \\
\hline 10-BT-1612 & ISU-90-02-05 & RWMC Section 18 \\
\hline 10-BT-1614 & ISU-90-02-07 & RWMC Section 18 \\
\hline 10-BT-1615 & ISU-90-02-08 & RWMC Section 18 \\
\hline 10-BT-1618 & ISU-90-02-22 & RWMC Section 18 \\
\hline 10-BT-1620 & ISU-90-02-12 & RWMC Section 18 \\
\hline 10-BT-1621 & ISU-90-02-13 & RWMC Section 18 \\
\hline 10-BT-1623 & ISU-89-08-01 & Fenceline and Demonstration Area \\
\hline 10-BT-1624 & ISU-89-08-02 & Fenceline and Demonstration Area \\
\hline 10-BT-1627 & EGG-90-01-01 & ICPP Percolation Pond \\
\hline 10-BT-1628 & EGG-90-01-02 & ICPP Percolation Pond \\
\hline 10-BT-1629 & EGG-90-01-03 & ICPP Percolation Pond \\
\hline 10-BT-1630 & EGG-90-02-01 & CFA Wells \\
\hline 10-BT-1631 & ISU-90-08-01 & NPR Sample Survey \\
\hline 10-BT-1632 & ISU-90-08-02 & NPR Sample Survey \\
\hline 10-BT-1633 & ISU-90-08-03 & NPR Sample Survey \\
\hline 10-BT-1634 & ISU-90-08-04 & NPR Sample Survey \\
\hline 10-BT-1635 & ISU-90-08-A & NPR Sample Survey \\
\hline 10-BT-1636 & ISU-90-08-B & NPR Sample Survey \\
\hline 10-BT-1637 & ISU-90-08-C & NPR Sample Survey \\
\hline 10-BT-1640 & ISU-90-08-F & NPR Sample Survey \\
\hline
\end{tabular}


Table 6. (continued).

\begin{tabular}{|c|c|c|}
\hline \multicolumn{3}{|c|}{ INL Prehistoric Isolated Finds } \\
\hline Site Number & Field Number & Project Name \\
\hline 10-BT-1643 & ISU-90-08-I & NPR Sample Survey \\
\hline 10-BT-1645 & ISU-90-08-K & NPR Sample Survey \\
\hline 10-BT-1648 & ISU-90-08-N & NPR Sample Survey \\
\hline 10-BT-1649 & ISU-90-08-O & NPR Sample Survey \\
\hline 10-BT-1650 & ISU-90-08-P & NPR Sample Survey \\
\hline 10-BT-1652 & ISU-90-08-R & NPR Sample Survey \\
\hline 10-BT-1654 & ISU-90-08-T & NPR Sample Survey \\
\hline 10-BT-1658 & ISU-90-08-X2 & NPR Sample Survey \\
\hline 10-BT-1661 & ISU-90-08-LL & NPR Sample Survey \\
\hline 10-BT-1663 & ISU-90-08-NN & NPR Sample Survey \\
\hline 10-BT-1668 & ISU-90-08-SS & NPR Sample Survey \\
\hline 10-BT-1669 & ISU-90-08-TT & NPR Sample Survey \\
\hline 10-BT-1674 & ISU-90-08-ZZ & NPR Sample Survey \\
\hline 10-BT-1675 & ISU-90-08-01B & NPR Sample Survey \\
\hline 10-BT-1680 & ISU-90-08-03A & NPR Sample Survey \\
\hline 10-BT-1681 & ISU-90-08-04A & NPR Sample Survey \\
\hline 10-BT-1683 & ISU-90-08-B4 & NPR Sample Survey \\
\hline 10-BT-1684 & ISU-90-08-B5 & NPR Sample Survey \\
\hline 10-BT-1686 & ISU-90-08-B7 & NPR Sample Survey \\
\hline 10-BT-1689 & ISU-90-08-B10 & NPR Sample Survey \\
\hline 10-BT-1691 & ISU-90-08-B12 & NPR Sample Survey \\
\hline 10-BT-1699 & EGG-90-09-04 & ICPP-NPR Road \\
\hline 10-BT-1701 & EGG-90-08-02 & INEL Sewer Upgrade \\
\hline 10-BT-1702 & EGG-90-08-03 & INEL Sewer Upgrade \\
\hline 10-BT-1703 & EGG-90-08-04 & INEL Sewer Upgrade \\
\hline 10-BT-1704 & EGG-90-08-05 & INEL Sewer Upgrade \\
\hline 10-BT-1705 & EGG-90-08-06 & INEL Sewer Upgrade \\
\hline 10-BT-1707 & EGG-90-08-08 & INEL Sewer Upgrade \\
\hline 10-BT-1708 & EGG-90-08-09 & INEL Sewer Upgrade \\
\hline 10-BT-1709 & EGG-90-08-10 & INEL Sewer Upgrade \\
\hline 10-BT-1710 & EGG-90-08-11 & INEL Sewer Upgrade \\
\hline 10-BT-1711 & EGG-90-08-12 & INEL Sewer Upgrade \\
\hline 10-BT-1712 & EGG-90-08-13 & INEL Sewer Upgrade \\
\hline 10-BT-1714 & EGG-90-08-15 & INEL Sewer Upgrade \\
\hline 10-BT-1716 & EGG-90-08-17 & INEL Sewer Upgrade \\
\hline 10-BT-1717 & EGG-90-08-18 & INEL Sewer Upgrade \\
\hline 10-BT-1718 & EGG-90-08-19 & INEL Sewer Upgrade \\
\hline 10-BT-1719 & EGG-90-08-20 & INEL Sewer Upgrade \\
\hline 10-BT-1720 & EGG-90-08-21 & INEL Sewer Upgrade \\
\hline
\end{tabular}


Table 6. (continued).

\begin{tabular}{|c|c|c|}
\hline \multicolumn{3}{|c|}{ INL Prehistoric Isolated Finds } \\
\hline Site Number & Field Number & Project Name \\
\hline 10-BT-1721 & EGG-90-08-22 & INEL Sewer Upgrade \\
\hline 10-BT-1724 & EGG-90-08-25 & INEL Sewer Upgrade \\
\hline 10-BT-1725 & EGG-90-08-26 & INEL Sewer Upgrade \\
\hline 10-BT-1727 & EGG-90-08-28 & INEL Sewer Upgrade \\
\hline 10-BT-1728 & EGG-90-08-29 & INEL Sewer Upgrade \\
\hline 10-BT-1729 & EGG-90-11-01 & RWMC-CFA Powerline \\
\hline 10-BT-1730 & EGG-90-11-02 & RWMC-CFA Powerline \\
\hline 10-BT-1731 & EGG-90-11-03 & RWMC-CFA Powerline \\
\hline 10-BT-1739 & EGG-90-11-11 & RWMC-CFA Powerline \\
\hline 10-BT-1740 & EGG-90-11-12 & RWMC-CFA Powerline \\
\hline 10-BT-1741 & EGG-90-11-13 & RWMC-CFA Powerline \\
\hline 10-BT-1743 & ISU-91-01-01 & NPR To PBF Road \\
\hline 10-BT-1744 & ISU-91-01-02 & NPR To PBF Road \\
\hline 10-BT-1745 & ISU-91-01-03 & NPR To PBF Road \\
\hline 10-BT-1746 & ISU-91-01-04 & NPR To PBF Road \\
\hline 10-BT-1750 & EGG-91-07-01 & PBF-NPR Road \\
\hline 10-BT-1751 & EGG-91-07-02 & PBF-NPR Road \\
\hline 10-BT-1752 & EGG-91-07-03 & PBF-NPR Road \\
\hline 10-BT-1753 & EGG-91-07-04 & PBF-NPR Road \\
\hline 10-BT-1758 & ISU-91-04-05 & NPR Area E \\
\hline 10-BT-1760 & ISU-91-04-07 & NPR Area E \\
\hline 10-BT-1761 & ISU-91-04-08 & NPR Area E \\
\hline 10-BT-1762 & ISU-91-04-09 & NPR Area E \\
\hline 10-BT-1764 & ISU-91-04-11 & NPR Area E \\
\hline 10-BT-1765 & ISU-91-04-12 & NPR Area E \\
\hline 10-BT-1766 & ISU-91-04-13 & NPR Area E \\
\hline 10-BT-1767 & ISU-91-04-14 & NPR Area E \\
\hline 10-BT-1768 & ISU-91-04-15 & NPR Area E \\
\hline 10-BT-1771 & ISU-91-04-19 & NPR Area E \\
\hline 10-BT-1774 & ISU-91-04-22 & NPR Area E \\
\hline 10-BT-1775 & ISU-91-04-23 & NPR Area E \\
\hline 10-BT-1777 & ISU-91-04-25 & NPR Area E \\
\hline 10-BT-1778 & ISU-91-04-26 & NPR Area E \\
\hline 10-BT-1782 & ISU-91-04-27 & NPR Area E \\
\hline 10-BT-1785 & ISU-91-04-30 & NPR Area E \\
\hline 10-BT-1787 & ISU-91-04-32 & NPR Area E \\
\hline 10-BT-1789 & ISU-91-04-34 & NPR Area E \\
\hline 10-BT-1807 & EGG-91-22-A & WAG 7 Wells \\
\hline 10-BT-1810 & EGG-91-22-D & WAG 7 Wells \\
\hline
\end{tabular}


Table 6. (continued).

\begin{tabular}{|c|c|c|}
\hline \multicolumn{3}{|c|}{ INL Prehistoric Isolated Finds } \\
\hline Site Number & Field Number & Project Name \\
\hline 10-BT-1811 & EGG-91-22-F & WAG 7 Wells \\
\hline 10-BT-1813 & EGG-92-30-02 & RWMC Power Upgrade \\
\hline 10-BT-1814 & EGG-92-30-03 & RWMC Power Upgrade \\
\hline 10-BT-1827 & EGG-92-34-01 & SNTP Tank Farm at LOFT \\
\hline 10-BT-1828 & EGG-93-09-01 & INEL Central Connector \\
\hline 10-BT-1829 & EGG-93-09-02 & INEL Central Connector \\
\hline 10-BT-1830 & EGG-93-09-03 & INEL Central Connector \\
\hline 10-BT-1838 & EGG-93-07-04 & INEL Ordnance Cleanup \\
\hline 10-BT-1839 & EGG-93-07-05 & INEL Ordnance Cleanup \\
\hline 10-BT-1842 & EGG-93-07-08 & INEL Ordnance Cleanup \\
\hline 10-BT-1845 & EGG-93-07-11 & INEL Ordnance Cleanup \\
\hline 10-BT-1849 & EGG-93-07-15 & INEL Ordnance Cleanup \\
\hline 10-BT-1850 & EGG-93-07-16 & INEL Ordnance Cleanup \\
\hline 10-BT-1851 & EGG-93-07-17 & INEL Ordnance Cleanup \\
\hline 10-BT-1852 & EGG-93-07-18 & INEL Ordnance Cleanup \\
\hline 10-BT-1854 & EGG-93-15-01 & Soil Borrowing from Spreading Area B \\
\hline 10-BT-1856 & EGG-93-15-03 & Soil Borrowing from Spreading Area B \\
\hline 10-BT-1857 & EGG-93-15-04 & Soil Borrowing from Spreading Area B \\
\hline 10-BT-1858 & EGG-93-15-05 & Soil Borrowing from Spreading Area B \\
\hline 10-BT-1859 & EGG-93-15-06 & Soil Borrowing from Spreading Area B \\
\hline 10-BT-1860 & EGG-93-15-07 & Soil Borrowing from Spreading Area B \\
\hline 10-BT-1862 & EGG-93-15-09 & Soil Borrowing from Spreading Area B \\
\hline 10-BT-1863 & EGG-93-15-10 & Soil Borrowing from Spreading Area B \\
\hline 10-BT-1880 & EGG-93-06-01-03 & IWPF LLMWPF Alternates \\
\hline 10-BT-1881 & EGG-93-06-01-04 & IWPF LLMWPF Alternates \\
\hline 10-BT-1884 & EGG-93-06-01-07 & IWPF LLMWPF Alternates \\
\hline 10-BT-1885 & EGG-93-06-01-08 & IWPF LLMWPF Alternates \\
\hline 10-BT-1886 & EGG-93-06-01-09 & IWPF LLMWPF Alternates \\
\hline 10-BT-1890 & EGG-93-06-01-13 & IWPF LLMWPF Alternates \\
\hline 10-BT-1894 & EGG-93-06-01-17 & IWPF LLMWPF Alternates \\
\hline 10-BT-1896 & EGG-93-06-01-19 & IWPF LLMWPF Alternates \\
\hline 10-BT-1897 & EGG-93-06-01-20 & IWPF LLMWPF Alternates \\
\hline 10-BT-1899 & EGG-93-06-01-22 & IWPF LLMWPF Alternates \\
\hline 10-BT-1900 & EGG-93-06-01-23 & IWPF LLMWPF Alternates \\
\hline 10-BT-1902 & EGG-93-06-01-25 & IWPF LLMWPF Alternates \\
\hline 10-BT-1905 & EGG-93-06-01-28 & IWPF LLMWPF Alternates \\
\hline 10-BT-1906 & EGG-93-06-01-29 & IWPF LLMWPF Alternates \\
\hline 10-BT-1908 & EGG-93-06-01-31 & IWPF LLMWPF Alternates \\
\hline 10-BT-1909 & EGG-93-06-01-32 & IWPF LLMWPF Alternates \\
\hline
\end{tabular}


Table 6. (continued).

\begin{tabular}{|c|c|c|}
\hline \multicolumn{3}{|c|}{ INL Prehistoric Isolated Finds } \\
\hline Site Number & Field Number & Project Name \\
\hline 10-BT-1910 & EGG-93-06-01-33 & IWPF LLMWPF Alternates \\
\hline 10-BT-1911 & EGG-93-06-01-34 & IWPF LLMWPF Alternates \\
\hline 10-BT-1913 & EGG-93-06-01-36 & IWPF LLMWPF Alternates \\
\hline 10-BT-1914 & EGG-93-06-01-37 & IWPF LLMWPF Alternates \\
\hline 10-BT-1916 & EGG-93-06-03-01 & IWPF LLMWPF Alternates \\
\hline 10-BТ-1919 & EGG-93-06-03-04 & IWPF LLMWPF Alternates \\
\hline 10-BT-1920 & EGG-93-06-03-05 & IWPF LLMWPF Alternates \\
\hline 10-BT-1921 & EGG-93-06-03-06 & IWPF LLMWPF Alternates \\
\hline 10-BT-1923 & EGG-93-06-03-08 & IWPF LLMWPF Alternates \\
\hline 10-BT-1925 & EGG-93-06-03-10 & IWPF LLMWPF Alternates \\
\hline 10-BT-1928 & EGG-93-06-03-13 & IWPF LLMWPF Alternates \\
\hline 10-BT-1930 & EGG-93-06-03-15 & IWPF LLMWPF Alternates \\
\hline 10-BT-1932 & EGG-93-06-05-01 & IWPF LLMWPF Alternates \\
\hline 10-BT-1933 & EGG-93-06-05-02 & IWPF LLMWPF Alternates \\
\hline 10-BT-1934 & EGG-93-06-05-03 & IWPF LLMWPF Alternates \\
\hline 10-BT-1935 & EGG-93-06-05-04 & IWPF LLMWPF Alternates \\
\hline 10-BT-1937 & EGG-93-06-09-02 & IWPF LLMWPF Alternates \\
\hline 10-BT-1938 & EGG-93-06-09-03 & IWPF LLMWPF Alternates \\
\hline 10-BT-1940 & EGG-93-06-09-05 & IWPF LLMWPF Alternates \\
\hline 10-BT-1943 & EGG-93-06-14-01 & IWPF LLMWPF Alternates \\
\hline 10-BТ-1944 & EGG-93-06-14-02 & IWPF LLMWPF Alternates \\
\hline 10-BT-1946 & EGG-93-06-14-04 & IWPF LLMWPF Alternates \\
\hline 10-BТ-1947 & EGG-93-06-14-05 & IWPF LLMWPF Alternates \\
\hline 10-BТ-1948 & EGG-93-06-14-06 & IWPF LLMWPF Alternates \\
\hline 10-BТ-1950 & EGG-93-06-14-08 & IWPF LLMWPF Alternates \\
\hline 10-BT-1951 & EGG-93-06-14-09 & IWPF LLMWPF Alternates \\
\hline 10-BT-1952 & EGG-93-06-14-10 & IWPF LLMWPF Alternates \\
\hline 10-BT-1954 & EGG-93-06-18-02 & IWPF LLMWPF Alternates \\
\hline 10-BT-1955 & EGG-93-06-18-03 & IWPF LLMWPF Alternates \\
\hline 10-BT-1956 & EGG-93-06-18-04 & IWPF LLMWPF Alternates \\
\hline 10-BT-1957 & EGG-93-06-18-05 & IWPF LLMWPF Alternates \\
\hline 10-BT-1958 & EGG-93-06-18-06 & IWPF LLMWPF Alternates \\
\hline 10-BT-1959 & EGG-93-06-18-07 & IWPF LLMWPF Alternates \\
\hline 10-BT-1965 & EGG-92-43-01 & Alternate CFA Sewage Ponds \\
\hline 10-BT-1966 & EGG-92-43-02 & Alternate CFA Sewage Ponds \\
\hline 10-BT-1968 & EGG-92-43-04 & Alternate CFA Sewage Ponds \\
\hline 10-BT-1975 & EGG-94-20-NODA-02 & Ordnance Cleanup at NODA and ANL-W \\
\hline 10-BT-1977 & EGG-94-05-SAB-01 & INEL Gravel Sources \\
\hline 10-BT-1978 & EGG-94-05-SAA-01 & INEL Gravel Sources \\
\hline
\end{tabular}


Table 6. (continued).

\begin{tabular}{|c|c|c|}
\hline \multicolumn{3}{|c|}{ INL Prehistoric Isolated Finds } \\
\hline Site Number & Field Number & Project Name \\
\hline 10-BT-2001 & EGG-94-05-T12-01 & INEL Gravel Sources \\
\hline 10-BT-2002 & EGG-94-05-T12-02 & INEL Gravel Sources \\
\hline 10-BT-2003 & EGG-94-05-BRX-01 & INEL Gravel Sources \\
\hline 10-BT-2004 & EGG-94-05-BRX-02 & INEL Gravel Sources \\
\hline 10-BT-2005 & EGG-94-05-BRX-03 & INEL Gravel Sources \\
\hline 10-BT-2007 & EGG-94-05-SAB-TST & INEL Gravel Sources \\
\hline 10-BT-2031 & LITCO-95-36-01 & RWMC-CFA Powerline \\
\hline 10-BT-2032 & LITCO-95-36-02 & RWMC-CFA Powerline \\
\hline 10-BT-2034 & LITCO-95-36-04 & RWMC-CFA Powerline \\
\hline 10-BT-2035 & LITCO-95-36-05 & RWMC-CFA Powerline \\
\hline 10-BT-2043 & EGG-95-57-01 & Firing Range Upgrades \\
\hline 10-BT-2047 & LMIT-96-51-01 & Ordnance Removal Actions \\
\hline 10-BT-2048 & LMIT-96-51-02 & Ordnance Removal Actions \\
\hline 10-BT-2071 & LMIT-96-01-01 & New Borrow Sources \\
\hline 10-BT-2072 & LMIT-96-01-02 & New Borrow Sources \\
\hline 10-BT-2075 & LMIT-97-46-03 & INEEL Road Upgrades \\
\hline 10-BT-2077 & LMIT-97-46-05 & INEEL Road Upgrades \\
\hline 10-BT-2078 & LMIT-97-46-06 & INEEL Road Upgrades \\
\hline 10-BT-2079 & LMIT-97-46-07 & INEEL Road Upgrades \\
\hline 10-BT-2096 & LMIT-99-31-01 & RWMC Wells \\
\hline 10-BT-2097 & LMIT-99-31-02 & RWMC Wells \\
\hline 10-BT-2098 & LMIT-99-31-03 & RWMC Wells \\
\hline 10-BT-2100 & LMIT-99-31-05 & RWMC Wells \\
\hline 10-BT-2101 & LMIT-99-31-06 & RWMC Wells \\
\hline 10-BT-2102 & LMIT-99-31-07 & RWMC Wells \\
\hline 10-BT-2103 & LMIT-99-31-08 & RWMC Wells \\
\hline 10-BT-2104 & LMIT-99-31-09 & RWMC Wells \\
\hline 10-BT-2105 & LMIT-99-31-10 & RWMC Wells \\
\hline 10-BT-2106 & LMIT-99-31-11 & RWMC Wells \\
\hline 10-BT-2107 & LMIT-99-31-12 & RWMC Wells \\
\hline 10-BT-2110 & LMIT-99-08-03 & INTEC Service Wastewater Facility \\
\hline 10-BT-2111 & LMIT-99-08-04 & INTEC Service Wastewater Facility \\
\hline 10-BT-2113 & LMIT-99-08-06 & INTEC Service Wastewater Facility \\
\hline 10-BT-2114 & LMIT-99-08-07 & INTEC Service Wastewater Facility \\
\hline 10-BT-2124 & LMIT-99-08-17 & INTEC Service Wastewater Facility \\
\hline 10-BT-2190 & BBWI-01-28-01 & Big Lost River Trenches \\
\hline 10-BV-87 & SJM-84-01-EP-15 & Perimeter Boundary \\
\hline 10-CL-419 & SJM-84-01-NWP-07 & Perimeter Boundary \\
\hline 10-CL-421 & SJM-84-01-NP-02 & Perimeter Boundary \\
\hline
\end{tabular}


Table 6. (continued).

\begin{tabular}{|c|c|c|}
\hline \multicolumn{3}{|c|}{ INL Prehistoric Isolated Finds } \\
\hline Site Number & Field Number & Project Name \\
\hline 10-CL-422 & SJM-84-01-NP-01 & Perimeter Boundary \\
\hline 10-CL-550 & ISU-89-02-B11 & Hunting Boundary \\
\hline 10-JF-071 & SJM-84-02-011 & Grazing Boundary \\
\hline 10-JF-074 & SJM-84-02-014 & Grazing Boundary \\
\hline 10-JF-079 & SJM-84-02-019 & Grazing Boundary \\
\hline 10-JF-081 & SJM-84-02-021 & Grazing Boundary \\
\hline 10-JF-082 & SJM-84-02-022 & Grazing Boundary \\
\hline $10-J F-085$ & SJM-84-02-025 & Grazing Boundary \\
\hline 10-JF-086 & SJM-84-02-026 & Grazing Boundary \\
\hline 10-JF-087 & SJM-84-02-027 & Grazing Boundary \\
\hline 10-JF-091 & SJM-84-02-031 & Grazing Boundary \\
\hline 10-JF-093 & SJM-84-02-033 & Grazing Boundary \\
\hline $10-J F-103$ & SJM-84-02-088 & Grazing Boundary \\
\hline 10-JF-104 & SJM-84-02-089 & Grazing Boundary \\
\hline 10-JF-108 & SJM-84-02-093 & Grazing Boundary \\
\hline 10-JF-109 & SJM-84-02-094 & Grazing Boundary \\
\hline 10-JF-110 & SJM-84-02-095 & Grazing Boundary \\
\hline $10-J F-117$ & SJM-84-02-107 & Grazing Boundary \\
\hline 10-JF-119 & SJM-84-02-109 & Grazing Boundary \\
\hline $10-J F-124$ & SJM-84-01-EP-10 & Perimeter Boundary \\
\hline $10-J F-125$ & SJM-84-01-EP-11 & Perimeter Boundary \\
\hline $10-J F-126$ & SJM-84-01-EP-12 & Perimeter Boundary \\
\hline $10-J F-127$ & SJM-84-01-EP-19 & Perimeter Boundary \\
\hline $10-J F-129$ & SJM-84-01-EP-21 & Perimeter Boundary \\
\hline $10-J F-130$ & SJM-84-01-NEP-02 & Perimeter Boundary \\
\hline 10-JF-132 & SJM-84-01-NEP-01 & Perimeter Boundary \\
\hline 10-JF-136 & ISU-85-11.81-10 & FOC-ANL to TAN \\
\hline 10-JF-139 & ISU-85-11.81-09 & FOC-ANL to TAN \\
\hline 10-JF-141 & ISU-85-11.81-03 & FOC-ANL to TAN \\
\hline 10-JF-143 & ISU-85-11.81-14 & FOC-ANL to TAN \\
\hline $10-J F-150$ & SJM-84-01-EP-17 & Perimeter Boundary \\
\hline 10-JF-157 & ISU-87-20-01 & Perimeter Sign Maintenance \\
\hline 10-JF-159 & ISU-87-12-02 & $\mathrm{SSC}$ \\
\hline $10-J F-160$ & ISU-87-12-03 & $\mathrm{SSC}$ \\
\hline 10-JF-161 & ISU-87-12-04 & $\mathrm{SSC}$ \\
\hline $10-J F-162$ & ISU-87-12-05 & $\mathrm{SSC}$ \\
\hline 10-JF-163 & ISU-87-12-06 & $\mathrm{SSC}$ \\
\hline 10-JF-164 & ISU-87-12-07 & $\mathrm{SSC}$ \\
\hline 10-JF-165 & ISU-87-12-46 & $\mathrm{SSC}$ \\
\hline
\end{tabular}


Table 6. (continued).

\begin{tabular}{|c|c|c|}
\hline \multicolumn{3}{|c|}{ INL Prehistoric Isolated Finds } \\
\hline Site Number & Field Number & Project Name \\
\hline 10-JF-171 & ISU-89-02-B12 & Hunting Boundary \\
\hline 10-JF-173 & ISU-89-02-A19 & Hunting Boundary \\
\hline 10-JF-179 & ISU-89-02-B14 & Hunting Boundary \\
\hline 10-JF-181 & ISU-89-02-B17 & Hunting Boundary \\
\hline 10-JF-183 & ISU-89-02-A24 & Hunting Boundary \\
\hline 10-JF-184 & ISU-89-02-A25 & Hunting Boundary \\
\hline 10-JF-186 & ISU-89-02-B19 & Hunting Boundary \\
\hline 10-JF-322 & LMIT-99-29-02 & Mud Lake Sheep Experiment Station Wells \\
\hline 10-JF-322 & LMIT-99-29-02 & Mud Lake Sheep Experiment Station Wells \\
\hline 10-JF-323 & LMIT-99-29-03 & Mud Lake Sheep Experiment Station Wells \\
\hline 10-JF-326 & SJM-00-01-CB02 & Circular Butte Cell Tower \\
\hline 10-JF-327 & SJM-00-01-CB03 & Circular Butte Cell Tower \\
\hline & EGG-90-15-01 & PBF Soil Coring \\
\hline & EGG-91-12-04 & NRF Boreholes \\
\hline & EGG-91-24-01 & Offsite Deep Wells \\
\hline & EGG-92-36-01 & TAN Sanitary System \\
\hline & EGG-94-09-01 & WAG 10-06 Soil Remediation \\
\hline & LITCO-95-21-01 & RWMC-CFA Ethernet \\
\hline & LITCO-95-21-02 & RWMC-CFA Ethernet \\
\hline & LITCO-95-21-03 & RWMC-CFA Ethernet \\
\hline & LITCO-95-52-04 & NRF Surveys \\
\hline & LITCO-95-52-05 & NRF Surveys \\
\hline & LITCO-95-52-06 & NRF Surveys \\
\hline & LITCO-95-52-07 & NRF Surveys \\
\hline & LMIT-96-28-01 & ANL-W Burn Remediation \\
\hline & LMIT-96-28-02 & ANL-W Burn Remediation \\
\hline & LMIT-96-28-04 & ANL-W Burn Remediation \\
\hline & LMIT-96-28-05 & ANL-W Burn Remediation \\
\hline & LMIT-96-28-06 & ANL-W Burn Remediation \\
\hline & LMIT-96-28-07 & ANL-W Burn Remediation \\
\hline & LMIT-96-28-08 & ANL-W Burn Remediation \\
\hline & LMIT-96-28-09 & ANL-W Burn Remediation \\
\hline & LMIT-96-28-10 & ANL-W Burn Remediation \\
\hline & LMIT-96-28-11 & ANL-W Burn Remediation \\
\hline & LMIT-96-28-12 & ANL-W Burn Remediation \\
\hline & LMIT-96-28-14 & ANL-W Burn Remediation \\
\hline & LMIT-96-28-15 & ANL-W Burn Remediation \\
\hline & LMIT-96-28-17 & ANL-W Burn Remediation \\
\hline & LMIT-96-28-18 & ANL-W Burn Remediation \\
\hline
\end{tabular}


Table 6. (continued).

\begin{tabular}{|c|c|c|}
\hline \multicolumn{3}{|c|}{ INL Prehistoric Isolated Finds } \\
\hline Site Number & Field Number & Project Name \\
\hline & LMIT-97-16-03 & ACETS/PNDR \\
\hline & LMIT-97-16-04 & ACETS/PNDR \\
\hline & LMIT-97-16-08 & ACETS/PNDR \\
\hline & LMIT-97-16-09 & ACETS/PNDR \\
\hline & LMIT-97-16-10 & ACETS/PNDR \\
\hline & LMIT-97-16-11 & ACETS/PNDR \\
\hline & LMIT-97-16-12 & ACETS/PNDR \\
\hline & LMIT-97-16-15 & ACETS/PNDR \\
\hline & LMIT-97-16-17 & ACETS/PNDR \\
\hline & LMIT-97-16-18 & ACETS/PNDR \\
\hline & LMIT-97-16-20 & ACETS/PNDR \\
\hline & LMIT-97-16-21 & ACETS/PNDR \\
\hline & LMIT-97-16-24 & ACETS/PNDR \\
\hline & LMIT-97-16-25 & ACETS/PNDR \\
\hline & LMIT-97-16-26 & ACETS/PNDR \\
\hline & LMIT-97-16-27 & ACETS/PNDR \\
\hline & LMIT-97-16-28 & ACETS/PNDR \\
\hline & LMIT-97-16-30 & ACETS/PNDR \\
\hline & LMIT-97-16-32 & ACETS/PNDR \\
\hline & LMIT-97-16-33 & ACETS/PNDR \\
\hline & LMIT-97-16-34 & ACETS/PNDR \\
\hline & LMIT-97-16-37 & ACETS/PNDR \\
\hline & LMIT-97-16-38 & ACETS/PNDR \\
\hline & LMIT-97-16-44 & ACETS/PNDR \\
\hline & LMIT-97-16-46 & ACETS/PNDR \\
\hline & LMIT-97-16-49 & ACETS/PNDR \\
\hline & LMIT-97-16-51 & ACETS/PNDR \\
\hline & LMIT-97-16-54 & ACETS/PNDR \\
\hline & LMIT-97-21-01 & Ordnance Removal Actions \\
\hline & LMIT-97-21-02 & Ordnance Removal Actions \\
\hline & LMIT-97-21-03 & Ordnance Removal Actions \\
\hline & LMIT-97-21-04 & Ordnance Removal Actions \\
\hline & LMIT-97-21-07 & Ordnance Removal Actions \\
\hline & LMIT-97-21-08 & Ordnance Removal Actions \\
\hline & LMIT-97-21-10 & Ordnance Removal Actions \\
\hline & LMIT-97-21-12 & Ordnance Removal Actions \\
\hline & LMIT-97-21-15 & Ordnance Removal Actions \\
\hline & LMIT-98-31-01 & ARA/PBF Environmental Restoration \\
\hline & LMIT-98-31-02 & ARA/PBF Environmental Restoration \\
\hline
\end{tabular}


Table 6. (continued).

\begin{tabular}{|c|c|c|}
\hline \multicolumn{3}{|c|}{ INL Prehistoric Isolated Finds } \\
\hline Site Number & Field Number & Project Name \\
\hline & LMIT-98-31-03 & ARA/PBF Environmental Restoration \\
\hline & LMIT-98-31-04 & ARA/PBF Environmental Restoration \\
\hline & LMIT-98-31-05 & ARA/PBF Environmental Restoration \\
\hline & LMIT-98-31-06 & ARA/PBF Environmental Restoration \\
\hline & LMIT-98-31-07 & ARA/PBF Environmental Restoration \\
\hline & LMIT-98-31-08 & ARA/PBF Environmental Restoration \\
\hline & LMIT-98-31-09 & ARA/PBF Environmental Restoration \\
\hline & LMIT-98-31-10 & ARA/PBF Environmental Restoration \\
\hline & LMIT-98-34-02 & Highway 20/26 Controlled Burn \\
\hline & LMIT-98-34-04 & Highway 20/26 Controlled Burn \\
\hline & LMIT-98-34-05 & Highway 20/26 Controlled Burn \\
\hline & LMIT-98-34-06 & Highway 20/26 Controlled Burn \\
\hline & LMIT-98-34-07 & Highway 20/26 Controlled Burn \\
\hline & LMIT-99-39-01 & OMRE Wells \\
\hline & LMIT-99-39-02 & OMRE Wells \\
\hline & LMIT-99-39-03 & OMRE Wells \\
\hline & LMIT-99-39-05 & OMRE Wells \\
\hline & LMIT-99-39-06 & OMRE Wells \\
\hline & LMIT-99-39-08 & OMRE Wells \\
\hline & LMIT-99-39-09 & OMRE Wells \\
\hline & LMIT-99-40-1 & Stormwater Release Sites \\
\hline & LMIT-99-40-2 & Stormwater Release Sites \\
\hline & SJM-99-01-SIC-01 & Farragut Blvd Modifications \\
\hline & SJM-99-01-SIC-05 & Farragut Blvd Modifications \\
\hline & SJM-99-01-SIC-06 & Farragut Blvd Modifications \\
\hline & SJM-99-01-SIC-07 & Farragut Blvd Modifications \\
\hline & SJM-99-01-SIC-08 & Farragut Blvd Modifications \\
\hline & BBWI-00-01-03 & ARA-INTEC Haul Road \\
\hline & BBWI-00-01-06 & ARA-INTEC Haul Road \\
\hline & BBWI-00-01-08 & ARA-INTEC Haul Road \\
\hline & BBWI-00-37-01 & SMC Production Equipment Upgrade \\
\hline & BBWI-00-37-04 & SMC Production Equipment Upgrade \\
\hline & BBWI-00-37-05 & SMC Production Equipment Upgrade \\
\hline & BBWI-01-33-02 & Ryegrass Flats Roads \\
\hline & BBWI-01-33-03 & Ryegrass Flats Roads \\
\hline & BBWI-01-33-04 & Ryegrass Flats Roads \\
\hline & BBWI-01-33-05 & Ryegrass Flats Roads \\
\hline & BBWI-01-33-rye-1 & Ryegrass Flats Roads \\
\hline & BBWI-01-33-rye-2 & Ryegrass Flats Roads \\
\hline
\end{tabular}


Table 6. (continued).

\begin{tabular}{|c|c|c|}
\hline \multicolumn{3}{|c|}{ INL Prehistoric Isolated Finds } \\
\hline Site Number & Field Number & Project Name \\
\hline & BBWI-01-33-rye-3 & Ryegrass Flats Roads \\
\hline & BBWI-01-33-rye-6 & Ryegrass Flats Roads \\
\hline & BBWI-01-33-rye-7 & Ryegrass Flats Roads \\
\hline & BBWI-01-36-01 & BLM Fire Fence \\
\hline & BBWI-01-36-04 & BLM Fire Fence \\
\hline & BBWI-01-36-05 & BLM Fire Fence \\
\hline & BBWI-01-36-06 & BLM Fire Fence \\
\hline & BBWI-02-13-01 & Tin Cup Burn Veg Studies \\
\hline & BBWI-02-13-02 & Tin Cup Burn Veg Studies \\
\hline & BBWI-02-13-03 & Tin Cup Burn Veg Studies \\
\hline & BBWI-02-13-04 & Tin Cup Burn Veg Studies \\
\hline & BBWI-02-25-02 & Scott Fire \\
\hline & ISU-2002-1-G01 & INL Predictive Model 2002 \\
\hline & ISU-2002-1-G15 & INL Predictive Model 2002 \\
\hline & ISU-2002-1-G18 & INL Predictive Model 2002 \\
\hline & ISU-2002-1-G19 & INL Predictive Model 2002 \\
\hline & ISU-2002-1-G20 & INL Predictive Model 2002 \\
\hline & ISU-2002-1-G23 & INL Predictive Model 2002 \\
\hline & ISU-2002-1-G25 & INL Predictive Model 2002 \\
\hline & ISU-2002-1-G27 & INL Predictive Model 2002 \\
\hline & ISU-2002-1-G03 & INL Predictive Model 2002 \\
\hline & ISU-2002-1-G32 & INL Predictive Model 2002 \\
\hline & ISU-2002-1-G34 & INL Predictive Model 2002 \\
\hline & ISU-2002-1-G38 & INL Predictive Model 2002 \\
\hline & ISU-2002-1-G39 & INL Predictive Model 2002 \\
\hline & ISU-2002-1-G04 & INL Predictive Model 2002 \\
\hline & ISU-2002-1-G41 & INL Predictive Model 2002 \\
\hline & ISU-2002-1-G42 & INL Predictive Model 2002 \\
\hline & ISU-2002-1-G43 & INL Predictive Model 2002 \\
\hline & ISU-2002-1-G44 & INL Predictive Model 2002 \\
\hline & ISU-2002-1-G45 & INL Predictive Model 2002 \\
\hline & ISU-2002-1-G47 & INL Predictive Model 2002 \\
\hline & ISU-2002-1-G48 & INL Predictive Model 2002 \\
\hline & ISU-2002-1-G05 & INL Predictive Model 2002 \\
\hline & ISU-2002-1-G52 & INL Predictive Model 2002 \\
\hline & ISU-2002-1-M01 & INL Predictive Model 2002 \\
\hline & ISU-2002-1-M11 & INL Predictive Model 2002 \\
\hline & ISU-2002-1-M12 & INL Predictive Model 2002 \\
\hline & ISU-2002-1-M15 & INL Predictive Model 2002 \\
\hline
\end{tabular}


Table 6. (continued).

\begin{tabular}{|c|c|c|}
\hline \multicolumn{3}{|c|}{ INL Prehistoric Isolated Finds } \\
\hline Site Number & Field Number & Project Name \\
\hline & ISU-2002-1-M16 & INL Predictive Model 2002 \\
\hline & ISU-2002-1-M17 & INL Predictive Model 2002 \\
\hline & ISU-2002-1-M18 & INL Predictive Model 2002 \\
\hline & ISU-2002-1-M20 & INL Predictive Model 2002 \\
\hline & ISU-2002-1-M21 & INL Predictive Model 2002 \\
\hline & ISU-2002-1-M22 & INL Predictive Model 2002 \\
\hline & ISU-2002-1-M23 & INL Predictive Model 2002 \\
\hline & ISU-2002-1-M25 & INL Predictive Model 2002 \\
\hline & ISU-2002-1-M26 & INL Predictive Model 2002 \\
\hline & ISU-2002-1-M03 & INL Predictive Model 2002 \\
\hline & ISU-2002-1-M31 & INL Predictive Model 2002 \\
\hline & ISU-2002-1-M32 & INL Predictive Model 2002 \\
\hline & ISU-2002-1-M34 & INL Predictive Model 2002 \\
\hline & ISU-2002-1-M35 & INL Predictive Model 2002 \\
\hline & ISU-2002-1-M39 & INL Predictive Model 2002 \\
\hline & ISU-2002-1-M40 & INL Predictive Model 2002 \\
\hline & ISU-2002-1-M41 & INL Predictive Model 2002 \\
\hline & ISU-2002-1-M43 & INL Predictive Model 2002 \\
\hline & ISU-2002-1-M45 & INL Predictive Model 2002 \\
\hline & ISU-2002-1-M47 & INL Predictive Model 2002 \\
\hline & ISU-2002-1-M48 & INL Predictive Model 2002 \\
\hline & ISU-2002-1-M05 & INL Predictive Model 2002 \\
\hline & ISU-2002-1-M50 & INL Predictive Model 2002 \\
\hline & ISU-2002-1-M56 & INL Predictive Model 2002 \\
\hline & ISU-2002-1-M57 & INL Predictive Model 2002 \\
\hline & ISU-2002-1-M58 & INL Predictive Model 2002 \\
\hline & ISU-2002-1-M64 & INL Predictive Model 2002 \\
\hline & ISU-2002-1-M67 & INL Predictive Model 2002 \\
\hline & ISU-2002-1-M68 & INL Predictive Model 2002 \\
\hline & ISU-2002-1-M69 & INL Predictive Model 2002 \\
\hline & ISU-2002-1-M70 & INL Predictive Model 2002 \\
\hline & ISU-2002-1-M08 & INL Predictive Model 2002 \\
\hline & BBWI-03-22-02 & TAN Demolition Landfill \\
\hline & ISU-2003-1-P004 & INL Predictive Model 2003 \\
\hline & ISU-2003-1-P009 & INL Predictive Model 2003 \\
\hline & ISU-2003-1-P010 & INL Predictive Model 2003 \\
\hline & ISU-2003-1-P016 & INL Predictive Model 2003 \\
\hline & ISU-2003-1-P017 & INL Predictive Model 2003 \\
\hline & ISU-2003-1-P018 & INL Predictive Model 2003 \\
\hline
\end{tabular}


Table 6. (continued).

\begin{tabular}{|c|c|c|}
\hline \multicolumn{3}{|c|}{ INL Prehistoric Isolated Finds } \\
\hline Site Number & Field Number & Project Name \\
\hline & ISU-2003-1-P022 & INL Predictive Model 2003 \\
\hline & ISU-2003-1-P029 & INL Predictive Model 2003 \\
\hline & ISU-2003-1-P030 & INL Predictive Model 2003 \\
\hline & ISU-2003-1-P034 & INL Predictive Model 2003 \\
\hline & ISU-2003-1-R001 & INL Predictive Model 2003 \\
\hline & ISU-2003-1-R002 & INL Predictive Model 2003 \\
\hline & ISU-2003-1-R003 & INL Predictive Model 2003 \\
\hline & ISU-2003-1-R015 & INL Predictive Model 2003 \\
\hline & ISU-2003-1-R016 & INL Predictive Model 2003 \\
\hline & ISU-2003-1-R017 & INL Predictive Model 2003 \\
\hline & ISU-2003-1-R019 & INL Predictive Model 2003 \\
\hline & ISU-2003-1-R020 & INL Predictive Model 2003 \\
\hline & ISU-2003-1-R021 & INL Predictive Model 2003 \\
\hline & ISU-2003-1-R026 & INL Predictive Model 2003 \\
\hline & ISU-2003-1-R028 & INL Predictive Model 2003 \\
\hline & ISU-2003-1-R029 & INL Predictive Model 2003 \\
\hline & ISU-2003-1-R034 & INL Predictive Model 2003 \\
\hline & ISU-2003-1-R035 & INL Predictive Model 2003 \\
\hline & ISU-2003-1-W001 & INL Predictive Model 2003 \\
\hline & ISU-2003-1-W003 & INL Predictive Model 2003 \\
\hline & ISU-2003-1-W002 & INL Predictive Model 2003 \\
\hline & ISU-2003-1-W005 & INL Predictive Model 2003 \\
\hline & ISU-2003-1-W006 & INL Predictive Model 2003 \\
\hline & ISU-2003-1-W009 & INL Predictive Model 2003 \\
\hline & ISU-2003-1-W016 & INL Predictive Model 2003 \\
\hline & ISU-2003-1-W010 & INL Predictive Model 2003 \\
\hline & BBWI-2004-16-01 & WRRTF Road \\
\hline & BEA-2006-03-01 & Expanded Surveys of T-24 and the Power Line Road \\
\hline & BEA-2006-03-02 & Expanded Surveys of T-24 and the Power Line Road \\
\hline & BEA-2006-03-03 & Expanded Surveys of T-24 and the Power Line Road \\
\hline & BEA-2006-20-01 & Large Scale Explosive Test Range \\
\hline & BEA-2006-20-02 & Large Scale Explosive Test Range \\
\hline & BEA-2006-20-03 & Large Scale Explosive Test Range \\
\hline & BEA-2006-20-04 & Large Scale Explosive Test Range \\
\hline & BEA-2006-20-05 & Large Scale Explosive Test Range \\
\hline & BEA-2006-20-06 & Large Scale Explosive Test Range \\
\hline & BEA-2006-20-10 & Large Scale Explosive Test Range \\
\hline & BEA-2006-31-110-02 & FY2006 Section 110 Surveys \\
\hline & BEA-2006-31-110-07 & FY2006 Section 110 Surveys \\
\hline
\end{tabular}


Table 6. (continued).

\begin{tabular}{|c|c|c|}
\hline \multicolumn{3}{|c|}{ INL Prehistoric Isolated Finds } \\
\hline Site Number & Field Number & Project Name \\
\hline & BEA-2006-31-110-13 & FY2006 Section 110 Surveys \\
\hline & BEA-2006-31-110-23 & FY2006 Section 110 Surveys \\
\hline & BEA-2006-31-110-24 & FY2006 Section 110 Surveys \\
\hline & BEA-2006-31-110-25 & FY2006 Section 110 Surveys \\
\hline & BEA-2006-31-110-26 & FY2006 Section 110 Surveys \\
\hline & BEA-2006-31-110-27 & FY2006 Section 110 Surveys \\
\hline & BEA-2007-12-09 & Unmanned Ground Vehicle Test Range \\
\hline & BEA-2007-12-11 & Unmanned Ground Vehicle Test Range \\
\hline & BEA-2007-12-12 & Unmanned Ground Vehicle Test Range \\
\hline & BEA-2007-12-13 & Unmanned Ground Vehicle Test Range \\
\hline & BEA-2007-12-14 & Unmanned Ground Vehicle Test Range \\
\hline & BEA-2007-30-01 & Twin Buttes Fire \\
\hline & BEA-2007-30-02 & Twin Buttes Fire \\
\hline & BEA-2007-30-05 & Twin Buttes Fire \\
\hline & BEA-2007-30-12 & Twin Buttes Fire \\
\hline & BEA-2007-32-110-02 & FY2007 Section 110 Surveys \\
\hline & BEA-2007-32-110-06 & FY2007 Section 110 Surveys \\
\hline & BEA-2007-32-110-09 & FY2007 Section 110 Surveys \\
\hline & BEA-2007-32-110-11 & FY2007 Section 110 Surveys \\
\hline & BEA-2007-32-110-21 & FY2007 Section 110 Surveys \\
\hline & BEA-2007-32-110-29 & FY2007 Section 110 Surveys \\
\hline & BEA-2007-32-110-32 & FY2007 Section 110 Surveys \\
\hline & BEA-2008-03-11 & NSTR Safety Fan and other Developments \\
\hline & BEA-2008-03-12 & NSTR Safety Fan and other Developments \\
\hline & BEA-2008-03-14 & NSTR Safety Fan and other Developments \\
\hline & BEA-2008-03-15 & NSTR Safety Fan and other Developments \\
\hline & BEA-2008-03-18 & NSTR Safety Fan and other Developments \\
\hline & BEA-2008-03-19 & NSTR Safety Fan and other Developments \\
\hline & BEA-2008-03-20 & NSTR Safety Fan and other Developments \\
\hline & BEA-2008-05-110-01-01 & FY2008 Section 110 Surveys \\
\hline & BEA-2008-05-110-01-02 & FY2008 Section 110 Surveys \\
\hline & BEA-2008-05-110-01-06 & FY2008 Section 110 Surveys \\
\hline & BEA-2008-05-110-07-01 & FY2008 Section 110 Surveys \\
\hline & BEA-2008-05-110-A-03 & FY2008 Section 110 Surveys \\
\hline & BEA-2008-05-110-A-05 & FY2008 Section 110 Surveys \\
\hline & BEA-2008-05-110-D-01 & FY2008 Section 110 Surveys \\
\hline & BEA-2008-05-110-D-03 & FY2008 Section 110 Surveys \\
\hline & BEA-2008-05-110-D-04 & FY2008 Section 110 Surveys \\
\hline & BEA-2008-05-110-D-08 & FY2008 Section 110 Surveys \\
\hline
\end{tabular}


Table 6. (continued).

\begin{tabular}{|c|c|c|}
\hline \multicolumn{3}{|c|}{ INL Prehistoric Isolated Finds } \\
\hline Site Number & Field Number & Project Name \\
\hline & BEA-2008-05-110-D-10 & FY2008 Section 110 Surveys \\
\hline & BEA-2008-05-110-D-14 & FY2008 Section 110 Surveys \\
\hline & BEA-2008-05-110-D-15 & FY2008 Section 110 Surveys \\
\hline & BEA-2008-05-110-D-16 & FY2008 Section 110 Surveys \\
\hline & BEA-2008-05-110-D-18 & FY2008 Section 110 Surveys \\
\hline & BEA-2008-05-110-D-19 & FY2008 Section 110 Surveys \\
\hline & BEA-2008-05-110-D-20 & FY2008 Section 110 Surveys \\
\hline & BEA-2008-05-110-D-28 & FY2008 Section 110 Surveys \\
\hline & BEA-2008-05-110-D-30 & FY2008 Section 110 Surveys \\
\hline & BEA-2008-05-110-D-32 & FY2008 Section 110 Surveys \\
\hline & BEA-2008-08-01 & Temporary Wind Towers \\
\hline & BEA-2008-11-01 & Gun Range Expansions CFA \\
\hline & BEA-2008-11-03 & Gun Range Expansions CFA \\
\hline & BEA-2008-11-06 & Gun Range Expansions CFA \\
\hline & BEA-2008-11-07 & Gun Range Expansions CFA \\
\hline & BEA-2008-11-09 & Gun Range Expansions CFA \\
\hline & BEA-2008-11-10 & Gun Range Expansions CFA \\
\hline & BEA-2008-11-13 & Gun Range Expansions CFA \\
\hline & BEA-2008-11-14 & Gun Range Expansions CFA \\
\hline & BEA-2008-11-MFC-01 & Gun Range Expansions MFC \\
\hline & BEA-2008-11-MFC-02 & Gun Range Expansions MFC \\
\hline & BEA-2008-11-MFC-04 & Gun Range Expansions MFC \\
\hline & BEA-2008-11-MFC-05 & Gun Range Expansions MFC \\
\hline & BEA-2008-11-MFC-06 & Gun Range Expansions MFC \\
\hline & BEA-2008-11-MFC-09 & Gun Range Expansions MFC \\
\hline & BEA-2008-11-MFC-11 & Gun Range Expansions MFC \\
\hline & BEA-2008-11-MFC-12 & Gun Range Expansions MFC \\
\hline & BEA-2008-11-MFC-14 & Gun Range Expansions MFC \\
\hline & BEA-2008-11-MFC-15 & Gun Range Expansions MFC \\
\hline & BEA-2008-11-MFC-18 & Gun Range Expansions MFC \\
\hline & BEA-2008-27-01 & Powerline Tests at Dairy Farm and WRRTF \\
\hline & BEA-2008-27-03 & Powerline Tests at Dairy Farm and WRRTF \\
\hline & BEA-2008-27-04 & Powerline Tests at Dairy Farm and WRRTF \\
\hline & BEA-2008-27-05 & Powerline Tests at Dairy Farm and WRRTF \\
\hline & BEA-2008-27-06 & Powerline Tests at Dairy Farm and WRRTF \\
\hline & BEA-2008-29-01 & Cell Site 8 Upgrade \\
\hline
\end{tabular}


Table 7. INL historic and multi-component archaeological sites and isolated finds.

\begin{tabular}{|c|c|c|c|}
\hline \multicolumn{4}{|c|}{ INL Historic and Multi-Component Archaeological Sites and Isolated Finds } \\
\hline Site Type & Site Number & Field Number & Project \\
\hline Site & 10-BM-081X & SJM-84-01-SP-XX & Perimeter Boundary \\
\hline Site & 10-BM-219 & ISU-88-09-03 & ANL-W Administrative Boundary \\
\hline IF & $10-\mathrm{BM}-225$ & ISU-88-09-09 & ANL-W Administrative Boundary \\
\hline IF & 10-BM-233 & ISU-88-09-17 & ANL-W Administrative Boundary \\
\hline Site & 10-BM-351 & EGG-94-20-ANLW-05 & Ordnance Cleanup at NODA and ANL-W \\
\hline Site & 10-BT-0269 & SJM-81-02-01 & ICPP Drain Field \\
\hline Site & 10-BT-0539 & SJM-84-02-042 & Grazing Boundary \\
\hline Site & $10-\mathrm{BT}-0565$ & SJM-84-02-079 & Grazing Boundary \\
\hline Site & 10-BT-0566 & SJM-84-02-080 & Grazing Boundary \\
\hline Site & 10-BT-0635 & SJM-84-01-WP-16 & Perimeter Boundary \\
\hline Site & 10-BT-0676 & SJM-84-02-2GB-10 & Grazing Boundary \\
\hline Site & 10-BT-0695 & SJM-84-03-16 & Diversion Area \\
\hline Site & 10-BT-0805 & ISU-85-07-135 & Firing Range \\
\hline Site & 10-BT-0806 & ISU-85-07-136 & Firing Range \\
\hline Site & 10-BT-0815 & ISU-85-07-129 & Firing Range \\
\hline IF & 10-BT-0848 & ISU-85-07-123 & Firing Range \\
\hline IF & 10-BT-0881 & ISU-85-07-085 & Firing Range \\
\hline IF & 10-BT-0898 & ISU-85-07-006 & Firing Range \\
\hline IF & 10-BT-0907 & ISU-85-07-040 & Firing Range \\
\hline Site & 10-BT-0951 & ISU-85-12-19 & NRF Perimeter \\
\hline Site & 10-BT-1031 & ISU-85-11.84-04 & FOC-Lincoln Blvd \\
\hline Site & 10-BT-1035 & ISU-85-11.84-10 & FOC-CFA to TAN \\
\hline Site & 10-BT-1037 & ISU-85-11.84-09 & FOC-Lincoln Blvd \\
\hline Site & 10-BT-1056 & ISU-85-11.85-35 & FOC-CFA to ANL \\
\hline IF & 10-BT-1115 & ISU-85-11.41-23 & RWMC Borrow Area \\
\hline Site & 10-BT-1242 & ISU-85-11.42-24 & RWMC Borrow Area \\
\hline IF & 10-BT-1275 & ISU-86-06-21 & NRF, TAN, CFA Gravel Pits \\
\hline IF & 10-BT-1326 & ISU-87-20-18 & Perimeter Sign Maintenance \\
\hline Site & 10-BT-1338 & ISU-87-20-30 & Perimeter Sign Maintenance \\
\hline Site & 10-BT-1366 & ISU-87-12-41 & SSC \\
\hline Site & 10-BT-1370 & ISU-88-01-64 & NRF Waste Ditch \\
\hline IF & 10-BT-1394 & ISU-88-01-16 & NRF Waste Ditch \\
\hline Site & 10-BT-1410 & ISU-88-01-32 & NRF Waste Ditch \\
\hline IF & 10-BT-1444 & ISU-88-05-02 & FOC-TRA to Lincoln Blvd \\
\hline IF & 10-BT-1447 & ISU-88-07-02 & Gravel Haul Road \\
\hline Site & 10-BT-1448 & ISU-88-07-03 & Gravel Haul Road \\
\hline Site & 10-BT-1474 & ISU-89-02-A08 & Hunting Boundary \\
\hline Site & 10-BT-1477 & ISU-89-02-A11 & Hunting Boundary \\
\hline IF & 10-BT-1480 & ISU-89-02-A15 & Hunting Boundary \\
\hline IF & 10-BT-1482 & ISU-89-02-B10 & Hunting Boundary \\
\hline IF & 10-BT-1528 & ISU-89-06-11 & Fast Attack Vehicle Range \\
\hline IF & 10-BT-1530 & ISU-89-06-13 & Fast Attack Vehicle Range \\
\hline Site & 10-BT-1562 & ISU-89-06-45 & Fast Attack Vehicle Range \\
\hline IF & 10-BT-1572 & ISU-89-06-55 & Fast Attack Vehicle Range \\
\hline
\end{tabular}


Table 7. (continued).

\begin{tabular}{|c|c|c|c|}
\hline \multicolumn{4}{|c|}{ INL Historic and Multi-Component Archaeological Sites and Isolated Finds } \\
\hline Site Type & Site Number & Field Number & Project \\
\hline IF & $10-\mathrm{BT}-1575$ & ISU-89-06-58 & Fast Attack Vehicle Range \\
\hline IF & 10-BT-1596 & ISU-90-02-B & RWMC Section 18 \\
\hline Site & 10-BT-1606 & ISU-90-02-L & RWMC Section 18 \\
\hline IF & 10-BT-1655 & ISU-90-08-U & NPR Sample Survey \\
\hline IF & 10-BT-1706 & EGG-90-08-07 & INEL Sewer Upgrade \\
\hline IF & 10-BT-1715 & EGG-90-08-16 & INEL Sewer Upgrade \\
\hline IF & 10-BT-1726 & EGG-90-08-27 & INEL Sewer Upgrade \\
\hline Site & 10-BT-1742 & EGG-90-11-14 & RWMC-CFA Powerline \\
\hline IF & 10-BT-1817 & EGG-92-30-09 & RWMC Power Upgrade \\
\hline Site & 10-BT-1835 & EGG-93-07-01 & INEL Ordnance Cleanup \\
\hline Site & 10-BT-1878 & EGG-93-06-01-01 & IWPF LLMWPF Alternates \\
\hline Site & 10-BT-1879 & EGG-93-06-01-02 & IWPF LLMWPF Alternates \\
\hline Site & 10-BT-1882 & EGG-93-06-01-05 & IWPF LLMWPF Alternates \\
\hline IF & 10-BT-1889 & EGG-93-06-01-12 & IWPF LLMWPF Alternates \\
\hline IF & 10-BT-1931 & EGG-93-06-03-16 & IWPF LLMWPF Alternates \\
\hline Site & 10-BT-1998 & EGG-94-05-TRA-03 & INEL Gravel Sources \\
\hline Site & 10-BT-1999 & EGG-94-05-NRF-01 & INEL Gravel Sources \\
\hline Site & 10-BT-2030 & LITCO-95-29-01 & Van Buren Upgrade \\
\hline Site & 10-BT-2033 & LITCO-95-36-03 & RWMC-CFA Powerline \\
\hline Site & 10-BT-2049 & LMIT-96-51-03 & Ordnance Removal Actions \\
\hline Site & 10-BT-2112 & LMIT-99-08-05 & INTEC Service Wastewater Facility \\
\hline Site & 10-BT-2115 & LMIT-99-08-08 & INTEC Service Wastewater Facility \\
\hline IF & 10-BT-2116 & LMIT-99-08-09 & INTEC Service Wastewater Facility \\
\hline Site & 10-BT-2117 & LMIT-99-08-10 & INTEC Service Wastewater Facility \\
\hline Site & 10-BT-2118 & LMIT-99-08-11 & INTEC Service Wastewater Facility \\
\hline Site & 10-BT-2119 & LMIT-99-08-12 & INTEC Service Wastewater Facility \\
\hline Site & 10-BT-2121 & LMIT-99-08-14 & INTEC Service Wastewater Facility \\
\hline Site & 10-BT-2122 & LMIT-99-08-15 & INTEC Service Wastewater Facility \\
\hline Site & 10-BT-2123 & LMIT-99-08-16 & INTEC Service Wastewater Facility \\
\hline Site & 10-BT-2125 & LMIT-99-08-18 & INTEC Service Wastewater Facility \\
\hline Site & $10-\mathrm{BV}-82$ & SJM-84-01-EP-05 & Perimeter Boundary \\
\hline IF & $10-B V-84$ & SJM-84-01-EP-04 & Perimeter Boundary \\
\hline Site & 10-BV-178 & LMIT-98-05-01 & $\begin{array}{l}\text { Environmental Engineering and Science Center } \\
\text { in Idaho Falls }\end{array}$ \\
\hline Site & 10-JF-069/10-BM-083 & EHS-61-17 & Birch Creek Surveys \\
\hline Site & 10-JF-073 & SJM-84-02-013 & Grazing Boundary \\
\hline Site & $10-J F-083$ & SJM-84-02-023 & Grazing Boundary \\
\hline Site & $10-J F-102$ & SJM-84-02-058 & Grazing Boundary \\
\hline Site & 10-JF-169 & ISU-89-02-A17 & Hunting Boundary \\
\hline Site & $10-J F-170$ & ISU-89-02-A18 & Hunting Boundary \\
\hline Site & 10-JF-172 & ISU-89-02-B15 & Hunting Boundary \\
\hline IF & $10-J F-178$ & ISU-89-02-B13 & Hunting Boundary \\
\hline Site & $10-J F-180$ & ISU-89-02-A22 & Hunting Boundary \\
\hline
\end{tabular}


Table 7. (continued).

INL Historic and Multi-Component Archaeological Sites and Isolated Finds

\begin{tabular}{|c|c|c|c|}
\hline Site Type & Site Number & Field Number & Project \\
\hline IF & & EGG-91-12-03 & NRF Boreholes \\
\hline Site & & EGG-93-16 & Health Physics Instrumentation Lab at CFA \\
\hline Site & & LITCO-95-52-03 & NRF Surveys \\
\hline Site & & LMIT-97-16-01 & ACETS/PNDR \\
\hline Site & & LMIT-97-16-16 & ACETS/PNDR \\
\hline Site & & LMIT-97-16-22 & ACETS/PNDR \\
\hline Site & & LMIT-97-16-35 & ACETS/PNDR \\
\hline Site & & LMIT-97-16-40 & ACETS/PNDR \\
\hline Site & & LMIT-97-16-52 & ACETS/PNDR \\
\hline IF & & LMIT-97-16-07 & ACETS/PNDR \\
\hline IF & & LMIT-97-16-19 & ACETS/PNDR \\
\hline IF & & LMIT-97-16-31 & ACETS/PNDR \\
\hline IF & & LMIT-97-16-36 & ACETS/PNDR \\
\hline IF & & LMIT-97-16-39 & ACETS/PNDR \\
\hline Site & & LMIT-97-21-13 & Ordnance Removal Actions \\
\hline IF & & LMIT-97-21-16 & Ordnance Removal Actions \\
\hline IF & & LMIT-97-21-17 & Ordnance Removal Actions \\
\hline Site & & LMIT-99-02-01 & Deadman Grazing Allotment Fence \\
\hline Site & & LMIT-99-02-07 & Deadman Grazing Allotment Fence \\
\hline Site & & LMIT-99-02-09 & Deadman Grazing Allotment Fence \\
\hline Site & & BBWI-00-37-02 & SMC Production Equipment Upgrade \\
\hline IF & & BBWI-00-37-03 & SMC Production Equipment Upgrade \\
\hline Site & & BBWI-01-36-03 & BLM Fire Fence \\
\hline Site & & ISU-2002-1-M13 & INL Predictive Model 2002 \\
\hline Site & & ISU-2002-1-M27 & INL Predictive Model 2002 \\
\hline Site & & ISU-2002-1-M28 & INL Predictive Model 2002 \\
\hline Site & & ISU-2002-1-M52 & INL Predictive Model 2002 \\
\hline Site & & ISU-2002-1-M53 & INL Predictive Model 2002 \\
\hline Site & & ISU-2002-1-M54 & INL Predictive Model 2002 \\
\hline Site & & ISU-2002-1-M59 & INL Predictive Model 2002 \\
\hline Site & & ISU-2002-1-M60 & INL Predictive Model 2002 \\
\hline Site & & ISU-2002-1-M71 & INL Predictive Model 2002 \\
\hline Site & & ISU-2002-1-G11 & INL Predictive Model 2002 \\
\hline Site & & ISU-2002-1-G24 & INL Predictive Model 2002 \\
\hline Site & & ISU-2002-1-G28 & INL Predictive Model 2002 \\
\hline Site & & ISU-2002-1-G30 & INL Predictive Model 2002 \\
\hline Site & & ISU-2002-1-G31 & INL Predictive Model 2002 \\
\hline Site & & ISU-2002-1-G37 & INL Predictive Model 2002 \\
\hline Site & & ISU-2002-1-G40 & INL Predictive Model 2002 \\
\hline Site & & ISU-2002-1-G57 & INL Predictive Model 2002 \\
\hline Site & & ISU-2002-1-G06 & INL Predictive Model 2002 \\
\hline IF & & ISU-2002-1-G16 & INL Predictive Model 2002 \\
\hline
\end{tabular}


Table 7. (continued).

INL Historic and Multi-Component Archaeological Sites and Isolated Finds

\begin{tabular}{|c|c|c|c|}
\hline Site Type & Site Number & Field Number & Project \\
\hline IF & & ISU-2002-1-G17 & INL Predictive Model 2002 \\
\hline IF & & ISU-2002-1-G21 & INL Predictive Model 2002 \\
\hline IF & & ISU-2002-1-G54 & INL Predictive Model 2002 \\
\hline IF & & ISU-2002-1-G56 & INL Predictive Model 2002 \\
\hline IF & & ISU-2002-1-G09 & INL Predictive Model 2002 \\
\hline IF & & ISU-2003-1-P002 & INL Predictive Model 2003 \\
\hline IF & & ISU-2003-1-P026 & INL Predictive Model 2003 \\
\hline IF & & ISU-2003-1-P031 & INL Predictive Model 2003 \\
\hline IF & & ISU-2003-1-P032 & INL Predictive Model 2003 \\
\hline IF & & ISU-2003-1-R027 & INL Predictive Model 2003 \\
\hline IF & & ISU-2003-1-R033 & INL Predictive Model 2003 \\
\hline IF & & ISU-2003-1-R037 & INL Predictive Model 2003 \\
\hline Site & & ISU-2003-1-R005 & INL Predictive Model 2003 \\
\hline Site & & ISU-2003-1-R006 & INL Predictive Model 2003 \\
\hline Site & & ISU-2003-1-R011 & INL Predictive Model 2003 \\
\hline Site & & ISU-2003-1-R013 & INL Predictive Model 2003 \\
\hline Site & & ISU-2003-1-R014 & INL Predictive Model 2003 \\
\hline Site & & ISU-2003-1-R022 & INL Predictive Model 2003 \\
\hline Site & & ISU-2003-1-R023 & INL Predictive Model 2003 \\
\hline Site & & ISU-2003-1-R030 & INL Predictive Model 2003 \\
\hline Site & & ISU-2003-1-P005 & INL Predictive Model 2003 \\
\hline Site & & ISU-2003-1-P007 & INL Predictive Model 2003 \\
\hline Site & & ISU-2003-1-P011 & INL Predictive Model 2003 \\
\hline Site & & ISU-2003-1-P024 & INL Predictive Model 2003 \\
\hline Site & & ISU-2003-1-P027 & INL Predictive Model 2003 \\
\hline Site & & BBWI-04-12-01 & Long Term Eco Monitoring \\
\hline Site & & BEA-2005-41-110-10 & FY2005 Section 110 Surveys \\
\hline Site & & BEA-2005-41-110-11 & FY2005 Section 110 Surveys \\
\hline Site & & BEA-2005-41-110-12 & FY2005 Section 110 Surveys \\
\hline Site & & BEA-2005-41-110-07 & FY2005 Section 110 Surveys \\
\hline Site & & BEA-2005-41-110-08 & FY2005 Section 110 Surveys \\
\hline Site & & BEA-2005-41-110-09 & FY2005 Section 110 Surveys \\
\hline Site & & BEA-2006-31-110-05 & FY2006 Section 110 Surveys \\
\hline Site & & BEA-2006-31-110-08 & FY2006 Section 110 Surveys \\
\hline Site & & BEA-2006-31-110-09 & FY2006 Section 110 Surveys \\
\hline Site & & BEA-2006-31-110-14 & FY2006 Section 110 Surveys \\
\hline Site & & BEA-2006-31-110-15 & FY2006 Section 110 Surveys \\
\hline Site & & BEA-2006-31-110-17 & FY2006 Section 110 Surveys \\
\hline Site & & BEA-2006-31-110-21 & FY2006 Section 110 Surveys \\
\hline Site & & BEA-2006-31-110-31 & FY2006 Section 110 Surveys \\
\hline
\end{tabular}


Table 7. (continued).

INL Historic and Multi-Component Archaeological Sites and Isolated Finds

\begin{tabular}{|c|c|c|c|}
\hline Site Type & Site Number & Field Number & Project \\
\hline Site & & BEA-2006-31-Richards & FY2006 Section 110 Surveys \\
\hline Site & & BEA-2007-12-01 & Unmanned Ground Vehicle Test Range \\
\hline Site & & BEA-2007-12-05 & Unmanned Ground Vehicle Test Range \\
\hline Site & & BEA-2007-12-10 & Unmanned Ground Vehicle Test Range \\
\hline IF & & BEA-2007-30-04 & Twin Buttes Fire \\
\hline Site & & BEA-2007-30-07 & Twin Buttes Fire \\
\hline Site & & BEA-2007-30-10 & Twin Buttes Fire \\
\hline IF & & BEA-2007-30-14 & Twin Buttes Fire \\
\hline Site & & BEA-2007-30-15 & Twin Buttes Fire \\
\hline Site & & BEA02007-32-007 & FY2007 Section 110 Surveys \\
\hline Site & & BEA02007-32-101 & FY2007 Section 110 Surveys \\
\hline Site & & BEA02007-32-102 & FY2007 Section 110 Surveys \\
\hline Site & & BEA02007-32-103 & FY2007 Section 110 Surveys \\
\hline Site & & BEA-2007-32-104 & FY2007 Section 110 Surveys \\
\hline Site & & BEA-2007-32-105 & FY2007 Section 110 Surveys \\
\hline Site & & BEA-2007-32-106 & FY2007 Section 110 Surveys \\
\hline Site & & BEA-2007-32-107 & FY2007 Section 110 Surveys \\
\hline Site & & BEA-2007-32-108 & FY2007 Section 110 Surveys \\
\hline Site & & BEA-2007-32-109 & FY2007 Section 110 Surveys \\
\hline Site & & BEA-2007-32-110 & FY2007 Section 110 Surveys \\
\hline Site & & BEA-2007-32-111 & FY2007 Section 110 Surveys \\
\hline Site & & BEA-2007-32-112 & FY2007 Section 110 Surveys \\
\hline Site & & BEA-2007-32-114 & FY2007 Section 110 Surveys \\
\hline Site & & BEA-2007-32-115 & FY2007 Section 110 Surveys \\
\hline IF & & BEA-2008-03-04 & NSTR Safety Fan and other Developments \\
\hline IF & & BEA-2008-03-05 & NSTR Safety Fan and other Developments \\
\hline IF & & BEA-2008-03-06 & NSTR Safety Fan and other Developments \\
\hline IF & & BEA-2008-03-08 & NSTR Safety Fan and other Developments \\
\hline IF & & BEA-2008-03-13 & NSTR Safety Fan and other Developments \\
\hline IF & & BEA-2008-MFC-03 & Gun Range Expansions MFC \\
\hline Site & & BEA-2008-25-01 & July 9th Fire \\
\hline
\end{tabular}




\section{Appendix I}

\section{INL Architectural Properties Inventory}




\section{Appendix I}

\section{INL Architectural Properties Inventory}

The table in this appendix contains a complete list of surveyed properties by area, including:

- Year built

- Eligibility to the National Register

- Historical context

- SHPO concurrence with the eligibility determination

- Section 106 status, if appropriate

- Property type

- Present condition

- Proposed disposition

- Owner.

Those properties owned by Environmental Management (EM) are scheduled for eventual demolition. However, they may be removed in the event a reuse for them is identified. Those properties owned by Nuclear Energy (NE) have been transferred from EM and the DD\&D list and are continuing in use. 
Table 8. Surveyed INL properties.

\begin{tabular}{|c|c|c|c|c|c|c|c|c|c|c|}
\hline \multicolumn{11}{|c|}{ Surveyed INL Architectural Properties } \\
\hline $\begin{array}{c}\text { Building or } \\
\text { Structure } \\
\text { ID }\end{array}$ & Building or Structure Name & $\begin{array}{l}\text { Date } \\
\text { Built }\end{array}$ & $\begin{array}{c}\text { National } \\
\text { Register } \\
\text { Evaluation }\end{array}$ & Context & $\begin{array}{c}\text { SHPO } \\
\text { Concur }\end{array}$ & Section 106 Status & Status & $\begin{array}{c}\text { Property } \\
\text { Type } \\
\text { Category }\end{array}$ & Condition & Owner \\
\hline \multicolumn{11}{|c|}{ Material and Fuels Complex (MFC; formerly ANL-W) } \\
\hline ANL-701 & Security Building & 1981 & Not Eligible & TBD & No & TBD & Operating & NA & NA & $\mathrm{NE}$ \\
\hline ANL-702 & Plant Services Equip. Storage & 1982 & Not Eligible & TBD & No & TBD & Operating & NA & NA & $\mathrm{NE}$ \\
\hline ANL-703 & Sodium Storage Building & 1984 & Not Eligible & TBD & No & TBD & Operating & NA & NA & $\mathrm{NE}$ \\
\hline ANL-704 & Fuel Manufacturing Facility & 1986 & Not Eligible & TBD & No & TBD & Operating & NA & NA & $\mathrm{NE}$ \\
\hline ANL-706 & Construction Shop/Storage & 1986 & Not Eligible & TBD & No & TBD & Operating & NA & NA & $\mathrm{NE}$ \\
\hline ANL-707 & Fire Pump house & 1984 & Exempt & TBD & No & TBD & Operating & NA & NA & $\mathrm{NE}$ \\
\hline ANL-709 & Safety Equipment Building & 1992 & Not Eligible & TBD & No & TBD & Operating & NA & NA & $\mathrm{NE}$ \\
\hline ANL-710 & Engineering Office Building & 1991 & Not Eligible & TBD & No & TBD & Operating & NA & NA & $\mathrm{NE}$ \\
\hline ANL-713 & Modular Office Building (T-13) & 1978 & Exempt & TBD & No & TBD & Operating & NA & NA & $\mathrm{NE}$ \\
\hline ANL-714 & Modular Office Building (T-12) & 1977 & Exempt & TBD & No & TBD & Operating & NA & NA & $\mathrm{NE}$ \\
\hline ANL-715 & Modular Office Building (T-15) & 1980 & Exempt & TBD & No & TBD & Operating & NA & NA & NE \\
\hline ANL-716 & Modular Office Building (T-16A) & 1990 & Exempt & TBD & No & TBD & Operating & NA & NA & NE \\
\hline ANL-717 & Modular Office Building (T-2) & 1985 & Exempt & TBD & No & TBD & Operating & NA & NA & $\mathrm{NE}$ \\
\hline ANL-718 & Modular Office Building (T-3) & 1985 & Exempt & TBD & No & TBD & Operating & NA & NA & $\mathrm{NE}$ \\
\hline ANL-719 & Security Inspector Post (T-4) & 1988 & Exempt & TBD & No & TBD & Operating & NA & NA & NE \\
\hline ANL-720 & TREAT Reactor Building & 1959 & Eligible & NRT & No & TBD & Operating & 1 & Adequate & $\mathrm{NE}$ \\
\hline ANL-721 & TREAT Office Building & 1958 & Eligible & NRT & No & TBD & Operating & 3 & Fair & $\mathrm{NE}$ \\
\hline ANL-722 & TREAT Guardhouse & 1980 & Not Eligible & TBD & No & TBD & Operating & NA & NA & $\mathrm{NE}$ \\
\hline ANL-723 & TREAT Warehouse & 1980 & Not Eligible & TBD & No & TBD & Operating & NA & NA & $\mathrm{NE}$ \\
\hline ANL-724 & TREAT Control Building & 1979 & Not Eligible & TBD & No & TBD & Operating & NA & NA & $\mathrm{NE}$ \\
\hline ANL-725 & Fire Station & 1998 & Not Eligible & TBD & No & TBD & Operating & NA & NA & $\mathrm{NE}$ \\
\hline ANL-742 & Gas/Diesel Dispensary & 1979 & Not Eligible & TBD & No & TBD & Operating & NA & NA & $\mathrm{NE}$ \\
\hline ANL-751 & Safety Storage Building & 1961 & Eligible & NRT & No & TBD & Operating & 3 & Excellent & $\mathrm{NE}$ \\
\hline ANL-752 & Laboratory and Office Building & 1962 & Eligible & NRT & No & TBD & Operating & 3 & Excellent & $\mathrm{NE}$ \\
\hline
\end{tabular}


Table 8. (continued).

\begin{tabular}{|c|c|c|c|c|c|c|c|c|c|c|}
\hline \multicolumn{11}{|c|}{ Surveyed INL Architectural Properties } \\
\hline $\begin{array}{l}\text { Building or } \\
\text { Structure } \\
\text { ID }\end{array}$ & Building or Structure Name & $\begin{array}{l}\text { Date } \\
\text { Built }\end{array}$ & $\begin{array}{c}\text { National } \\
\text { Register } \\
\text { Evaluation }\end{array}$ & Context & $\begin{array}{l}\text { SHPO } \\
\text { Concur }\end{array}$ & Section 106 Status & Status & $\begin{array}{c}\text { Property } \\
\text { Type } \\
\text { Category }\end{array}$ & Condition & Owner \\
\hline ANL-752A & Diesel Generator Building & 1973 & Exempt & TBD & No & TBD & Operating & NA & NA & $\mathrm{NE}$ \\
\hline ANL-753 & Plant Services Building & 1961 & Eligible & NRT & No & TBD & Operating & 3 & Adequate & $\mathrm{NE}$ \\
\hline ANL-754 & Well Pump House No. 1 & 1961 & Exempt & TBD & No & TBD & Operating & NA & NA & $\mathrm{NE}$ \\
\hline ANL-755 & Fuel Oil Pump House & 1977 & Exempt & TBD & No & TBD & Operating & NA & NA & $\mathrm{NE}$ \\
\hline ANL-756 & Well Pump House No. 2 & 1961 & Exempt & TBD & No & TBD & Operating & NA & NA & $\mathrm{NE}$ \\
\hline ANL-757 & Cooling Tower & 1959 & Eligible & NRT & UK & TBD & Demolished & 2 & NA & NA \\
\hline ANL-757A & $\begin{array}{l}\text { Main Cooling Tower Acid System } \\
\text { Building }\end{array}$ & 1959 & Eligible & NRT & No & TBD & Operating & 3 & UK & NE \\
\hline ANL-758 & Electrical Substation & 1960 & Exempt & TBD & No & TBD & Operating & NA & NA & $\mathrm{NE}$ \\
\hline ANL-759 & Old Fire House & 1959 & Eligible & NRT & No & TBD & Operating & 3 & Fair & $\mathrm{NE}$ \\
\hline ANL-760 & $\begin{array}{l}\text { Sanitary and Industrial Waste Pump } \\
\text { house }\end{array}$ & 1961 & Exempt & TBD & No & TBD & Operating & NA & NA & $\mathrm{NE}$ \\
\hline ANL-765 & Fuel Conditioning Facility & 1963 & Eligible & NRT & No & TBD & Operating & 2 & Adequate & $\mathrm{NE}$ \\
\hline ANL-766 & Sodium Boiler Plant & 1962 & Eligible & NRT & No & TBD & Operating & 3 & Adequate & $\mathrm{NE}$ \\
\hline ANL-767 & Experimental Breeder Reactor II & 1963 & Eligible & NRT & No & TBD & Shutdown & 1 & NA & $\mathrm{NE}$ \\
\hline ANL-768 & Power Plant & 1961 & Eligible & NRT & No & TBD & Operating & 3 & Fair & NE \\
\hline ANL-768B & Water Chemistry Laboratory & 1969 & Eligible & NRT & No & TBD & Operating & 2 & UK & NE \\
\hline ANL-769 & Dangerous Material Storage & 1963 & Eligible & NRT & No & TBD & Operating & 3 & Poor & $\mathrm{NE}$ \\
\hline ANL-770B & Sodium Components Storage & 1962 & Eligible & NRT & No & TBD & Operating & 3 & Adequate & $\mathrm{NE}$ \\
\hline ANL-770C & Nuclear Calibration Laboratory & 1963 & Eligible & NRT & No & TBD & Operating & 3 & Adequate & $\mathrm{NE}$ \\
\hline ANL-772 & EBR II Engineering Laboratory & 1966 & Eligible & NRT & No & TBD & Operating & 2 & Excellent & $\mathrm{NE}$ \\
\hline ANL-774 & ZPPR Support Wing & 1967 & Eligible & NRT & No & TBD & Operating & 3 & Good & NE \\
\hline ANL-775 & ZPPR Work/Equipment Room & UK & Eligible & NRT & No & TBD & Operating & 3 & Adequate & $\mathrm{NE}$ \\
\hline ANL-776 & ZPPR Cell & 1968 & Eligible & NRT & No & TBD & Operating & 2 & Good & $\mathrm{NE}$ \\
\hline ANL-777 & ZPPR Equipment Building & 1968 & Eligible & NRT & No & TBD & Operating & 3 & Good & $\mathrm{NE}$ \\
\hline ANL-778 & Sanitary Sewage Lift Station & 1966 & Exempt & TBD & No & TBD & Operating & NA & NA & $\mathrm{NE}$ \\
\hline
\end{tabular}


Table 8. (continued).

\begin{tabular}{|c|c|c|c|c|c|c|c|c|c|c|}
\hline \multicolumn{11}{|c|}{ Surveyed INL Architectural Properties } \\
\hline $\begin{array}{c}\text { Building or } \\
\text { Structure } \\
\text { ID }\end{array}$ & Building or Structure Name & $\begin{array}{l}\text { Date } \\
\text { Built }\end{array}$ & $\begin{array}{c}\text { National } \\
\text { Register } \\
\text { Evaluation }\end{array}$ & Context & $\begin{array}{l}\text { SHPO } \\
\text { Concur }\end{array}$ & Section 106 Status & Status & $\begin{array}{l}\text { Property } \\
\text { Type } \\
\text { Category }\end{array}$ & Condition & Owner \\
\hline ANL-778A & Industrial Waste Lift Station & 1966 & Exempt & TBD & No & TBD & Operating & NA & NA & $\mathrm{NE}$ \\
\hline ANL-780 & Laundry Sorting Building & 1966 & Eligible & NRT & No & TBD & Operating & 3 & Adequate & $\mathrm{NE}$ \\
\hline ANL-781 & Material Handling Warehouse & 1968 & Eligible & NRT & No & TBD & Operating & 3 & Adequate & $\mathrm{NE}$ \\
\hline ANL-782 & Machine Shop Facility & 1968 & Eligible & NRT & No & TBD & Operating & 3 & Excellent & $\mathrm{NE}$ \\
\hline ANL-783 & Rigging Test Facility & 1968 & Eligible & NRT & No & TBD & Operating & 3 & Excellent & NE \\
\hline ANL-784 & ZPPR Materials Control Building & 1968 & Eligible & NRT & No & TBD & Operating & 2 & Adequate & NE \\
\hline ANL-785 & Hot Fuel Examination Facility & 1972 & Eligible & NRT & No & TBD & Operating & 2 & Adequate & NE \\
\hline ANL-786 & HFEF Substation & 1973 & Exempt & TBD & No & TBD & Operating & NA & NA & $\mathrm{NE}$ \\
\hline ANL-787 & Fuel Assembly and Storage Bldg & 1970 & Eligible & NRT & No & TBD & Operating & 3 & Excellent & $\mathrm{NE}$ \\
\hline ANL-788 & EBR II Maintenance Shop & 1955 & Eligible & NRT & No & TBD & Operating & 3 & Good & NE \\
\hline ANL-789 & EBR II Engineering Laboratory & 1959 & Eligible & NRT & No & TBD & Operating & 3 & Excellent & $\mathrm{NE}$ \\
\hline ANL-789A & Equipment Building & ca.1959 & Eligible & NRT & No & TBD & Operating & 3 & Good & $\mathrm{NE}$ \\
\hline ANL-790 & $\begin{array}{l}\text { Interim Contaminated Equipment } \\
\text { Building }\end{array}$ & 1953 & Eligible & NRT & No & TBD & Operating & 3 & Good & NE \\
\hline ANL-791 & Instrument and Maintenance Facility & 1972 & Not Eligible & TBD & No & TBD & Operating & NA & NA & $\mathrm{NE}$ \\
\hline ANL-792 & ZPPR Mockup Building & 1972 & Eligible & NRT & No & TBD & Operating & 3 & Adequate & NA \\
\hline ANL-792A & $\begin{array}{l}\text { Security and Space Power Source } \\
\text { Facility }\end{array}$ & 2004 & Not Eligible & TBD & No & TBD & Operating & NA & NA & $\mathrm{NE}$ \\
\hline ANL-793 & Sodium Components Maintenance Shop & 1960 & Eligible & NRT & No & TBD & Operating & 3 & Adequate & $\mathrm{NE}$ \\
\hline ANL-793B & $\begin{array}{l}\text { Sodium Components Maintenance Shop } \\
\text { Alcohol Recovery Annex }\end{array}$ & UK & Eligible & NRT & No & TBD & Operating & 3 & Excellent & $\mathrm{NE}$ \\
\hline ANL-793C & Contaminated Storage Building & 1984 & Not Eligible & TBD & No & TBD & Operating & NA & NA & NE \\
\hline ANL-794 & $\begin{array}{l}\text { Contaminated Equipment Storage } \\
\text { Building }\end{array}$ & 1975 & Not Eligible & TBD & No & TBD & Operating & NA & NA & $\mathrm{NE}$ \\
\hline ANL-795 & EBR II Cleanup System Building & 1978 & Not Eligible & TBD & No & TBD & Operating & NA & NA & NE \\
\hline ANL-796 & Metal Stock Control Building & 1978 & Not Eligible & TBD & No & TBD & Operating & NA & NA & $\mathrm{NE}$ \\
\hline
\end{tabular}


Table 8. (continued).

\begin{tabular}{|c|c|c|c|c|c|c|c|c|c|c|}
\hline \multicolumn{11}{|c|}{ Surveyed INL Architectural Properties } \\
\hline $\begin{array}{c}\text { Building or } \\
\text { Structure } \\
\text { ID }\end{array}$ & Building or Structure Name & $\begin{array}{l}\text { Date } \\
\text { Built }\end{array}$ & $\begin{array}{c}\text { National } \\
\text { Register } \\
\text { Evaluation }\end{array}$ & Context & $\begin{array}{l}\text { SHPO } \\
\text { Concur }\end{array}$ & Section 106 Status & Status & $\begin{array}{c}\text { Property } \\
\text { Type } \\
\text { Category }\end{array}$ & Condition & Owner \\
\hline ANL-798 & $\begin{array}{l}\text { Radioactive Liquid Waste Treatment } \\
\text { Facility Building }\end{array}$ & 1983 & Not Eligible & TBD & No & TBD & Operating & NA & NA & NE \\
\hline ANL-799 & Sodium Process Facility Building & 1987 & Not Eligible & TBD & No & TBD & Operating & NA & NA & NE \\
\hline ANL-799A & Caustic Storage Tank Building & UK & Not Eligible & TBD & No & TBD & Operating & NA & NA & NE \\
\hline ANL-TR1 & Bus Drivers Trailer & UK & Exempt & TBD & No & TBD & Operating & NA & NA & NE \\
\hline ANL-TR17 & Electrical Equipment Storage Trailer & UK & Exempt & TBD & No & TBD & Operating & NA & NA & NE \\
\hline ANL-TR20 & EBR II Engineering Laboratory Trailer & 1992 & Exempt & TBD & No & TBD & Operating & NA & NA & NE \\
\hline ANL-TR22 & $\begin{array}{l}\text { Environmental Safety and Waste } \\
\text { Management Office Trailer }\end{array}$ & 1988 & Exempt & TBD & No & TBD & Operating & NA & NA & NE \\
\hline ANL-TR30 & Training and Procedures Trailer & 1990 & Exempt & TBD & No & TBD & Operating & NA & NA & NE \\
\hline ANL-TR31 & Office Trailer & 1990 & Exempt & TBD & No & TBD & Operating & NA & NA & NE \\
\hline ANL-TR46 & $\begin{array}{l}\text { Radioactive Scrap and Waste Facility } \\
\text { Office }\end{array}$ & UK & Exempt & TBD & No & TBD & Operating & NA & NA & NE \\
\hline ANL-TR47 & $\begin{array}{l}\text { Sodium Process Facility Change Rooms } \\
\text { and Offices }\end{array}$ & UK & Exempt & TBD & No & TBD & Operating & NA & NA & NE \\
\hline \multicolumn{11}{|c|}{ Army Reactors Area (ARA) } \\
\hline ARA-601 & Well House (ARA II) & 1959 & Eligible & NRT & Yes & MOA - HABS/HAER complete & Demolished & NA & NA & NA \\
\hline ARA-602 & Gas Dynamics Building (ARA II) & 1959 & Eligible & NRT & Yes & MOA - HABS/HAER complete & Demolished & NA & NA & NA \\
\hline ARA-603 & Reactor Building & 1959 & Eligible & NRT & Yes & MOA - HABS/HAER complete & Demolished & NA & NA & NA \\
\hline ARA-604 & Guardhouse (ARA II) & 1959 & Eligible & NRT & Yes & MOA - HABS/HAER complete & Demolished & NA & NA & NA \\
\hline ARA-605 & Chlorination House (ARA II) & UK & Eligible & NRT & Yes & MOA - HABS/HAER complete & Demolished & NA & NA & NA \\
\hline ARA-606 & $\begin{array}{l}\text { Administration and Technical Support } \\
\text { (ARA II) }\end{array}$ & UK & Eligible & NRT & Yes & MOA - HABS/HAER complete & Demolished & NA & NA & NA \\
\hline ARA-607 & Control Building (ARA III) & UK & Eligible & NRT & Yes & MOA - HABS/HAER complete & Demolished & NA & NA & NA \\
\hline ARA-608 & Reactor Building (ARA III) & UK & Eligible & NRT & Yes & MOA - HABS/HAER complete & Demolished & NA & NA & NA \\
\hline ARA-609 & Gatehouse (ARA III) & 1959 & Eligible & NRT & Yes & MOA - HABS/HAER complete & Demolished & NA & NA & NA \\
\hline
\end{tabular}


Table 8. (continued).

\begin{tabular}{|c|c|c|c|c|c|c|c|c|c|c|}
\hline \multicolumn{11}{|c|}{ Surveyed INL Architectural Properties } \\
\hline $\begin{array}{l}\text { Building or } \\
\text { Structure } \\
\text { ID }\end{array}$ & Building or Structure Name & $\begin{array}{l}\text { Date } \\
\text { Built }\end{array}$ & $\begin{array}{c}\text { National } \\
\text { Register } \\
\text { Evaluation }\end{array}$ & Context & $\begin{array}{c}\text { SHPO } \\
\text { Concur }\end{array}$ & Section 106 Status & Status & $\begin{array}{l}\text { Property } \\
\text { Type } \\
\text { Category }\end{array}$ & & Owner \\
\hline ARA-610 & Service Building (ARA III) & 1959 & Eligible & NRT & Yes & MOA - HABS/HAER complete & Demolished & NA & NA & NA \\
\hline ARA-611 & Well House (ARA III) & UK & Eligible & NRT & Yes & MOA - HABS/HAER complete & Demolished & NA & NA & NA \\
\hline ARA-612 & $\begin{array}{l}\text { Contaminated Water Pump House } \\
\text { (ARA III) }\end{array}$ & UK & Eligible & NRT & Yes & MOA - HABS/HAER complete & Demolished & NA & NA & NA \\
\hline ARA-613 & $\begin{array}{l}\text { Support Facilities Building Addition } \\
\text { (ARA III) }\end{array}$ & UK & Eligible & NRT & Yes & MOA - HABS/HAER complete & Demolished & NA & NA & NA \\
\hline ARA-614 & $\begin{array}{l}\text { Decontamination and Laydown } \\
\text { Building (ARA II) }\end{array}$ & UK & Eligible & NRT & Yes & MOA - HABS/HAER complete & Demolished & NA & NA & NA \\
\hline ARA-615 & $\begin{array}{l}\text { Power Extrapolation Building } \\
\text { (ARA II) }\end{array}$ & UK & Eligible & NRT & Yes & MOA - HABS/HAER complete & Demolished & NA & NA & NA \\
\hline ARA-616 & ML-1 Change House (ARA IV) & UK & Eligible & NRT & Yes & MOA - HABS/HAER complete & Demolished & NA & NA & NA \\
\hline ARA-617 & ML-1 Control Building (ARA IV) & 1961 & Eligible & NRT & No & & Operating & 2 & UK & NE \\
\hline ARA-621 & $\begin{array}{l}\text { Instrument Development Building } \\
\text { (ARA III) }\end{array}$ & UK & Eligible & NRT & Yes & MOA - HABS/HAER complete & Demolished & NA & NA & NA \\
\hline ARA-622 & Warehouse Building (ARA III) & 1962 & Eligible & NRT & Yes & MOA - HABS/HAER complete & Demolished & NA & NA & NA \\
\hline ARA-623 & Acid Storage Building (ARA III) & UK & Eligible & NRT & Yes & MOA - HABS/HAER complete & Demolished & NA & NA & NA \\
\hline ARA 624 & Fire Hose House (ARA III) & UK & Eligible & NRT & Yes & MOA - HABS/HAER complete & Demolished & NA & NA & NA \\
\hline ARA-626 & Hot Cell Building (ARA I) & 1960 & Eligible & NRT & Yes & MOA - HABS/HAER complete & Demolished & NA & NA & NA \\
\hline ARA-627 & $\begin{array}{l}\text { Shop and Maintenance Building } \\
\text { (ARA I) }\end{array}$ & UK & Eligible & NRT & Yes & MOA - HABS/HAER complete & Demolished & NA & NA & NA \\
\hline ARA-628 & Guardhouse (ARA I) & 1960 & Eligible & NRT & Yes & MOA - HABS/HAER complete & Demolished & NA & NA & NA \\
\hline ARA-629 & Pump House (ARA I) & UK & Eligible & NRT & Yes & MOA - HABS/HAER complete & Demolished & NA & NA & NA \\
\hline ARA-630 & Laboratory Building (ARA III) & UK & Eligible & NRT & Yes & MOA - HABS/HAER complete & Demolished & NA & NA & NA \\
\hline ARA-631 & Hydraulic Test Tower Facility & UK & Eligible & NRT & Yes & MOA - HABS/HAER complete & Demolished & NA & NA & NA \\
\hline
\end{tabular}


Table 8. (continued).

\begin{tabular}{|c|c|c|c|c|c|c|c|c|c|c|}
\hline \multicolumn{11}{|c|}{ Surveyed INL Architectural Properties } \\
\hline $\begin{array}{c}\text { Building or } \\
\text { Structure } \\
\text { ID }\end{array}$ & Building or Structure Name & $\begin{array}{l}\text { Date } \\
\text { Built }\end{array}$ & $\begin{array}{c}\text { National } \\
\text { Register } \\
\text { Evaluation }\end{array}$ & Context & $\begin{array}{l}\text { SHPO } \\
\text { Concur }\end{array}$ & Section 106 Status & Status & $\begin{array}{c}\text { Property } \\
\text { Type } \\
\text { Category }\end{array}$ & Condition & \\
\hline \multicolumn{11}{|c|}{ Central Facilities Area (CFA) } \\
\hline CF-601 & Warehouse & 1950 & Eligible & NRT & Yes & No MOA - No Adverse Effect & Operating & 3 & Excellent & NE \\
\hline CF-602 & Materials Testing Laboratory and Office & 1969 & Eligible & NRT & Yes & Programmatic Agreement & Operating & 3 & Excellent & $\mathrm{NE}$ \\
\hline CF-603 & Dispensary & 1943 & Not Eligible & Ord WW2 & Yes & $\begin{array}{c}\text { Lacks Integrity-Post } 1970 \\
\text { modifications }\end{array}$ & Demolished & 3 & NA & NA \\
\hline CF-604 & Emergency Generator Building & 1983 & Exempt & Multi-Prog & Yes & NA & Demolished & NA & NA & NA \\
\hline CF-605 & Materials Testing Laboratory and office & 1950 & Not Assessed & Multi-Prog & No & No MOA & Demolished & NA & NA & NA \\
\hline CF-606 & Office Building & 1942 & Eligible & Ord WW2 & No & $\begin{array}{c}\text { Consultation started 1996, } \\
\text { ongoing }\end{array}$ & Shutdown & Signature & UK & $\mathrm{NE}$ \\
\hline CF-607 & Office Building & 1942 & Eligible & Ord WW2 & No & $\begin{array}{c}\text { Consultation started 1996, } \\
\text { ongoing }\end{array}$ & Shutdown & Signature & UK & NE \\
\hline CF-608 & $\begin{array}{l}\text { Security Helicopter } \\
\text { Storage/Maintenance Facility }\end{array}$ & 1984 & Not Eligible & Multi-Prog & Yes & NA & Operating & NA & UK & NE \\
\hline CF-609 & Security Headquarters & 1988 & Not Eligible & Multi-Prog & Yes & NA & Operating & NA & Excellent & NE \\
\hline CF-611 & Change House (Trailer) & 1991 & Exempt & Multi-Prog & Yes & NA & Demolished & NA & NA & NE \\
\hline CF-612 & CF Office Building \#1 & 1983 & Not Eligible & Multi-Prog & Yes & NA & Operating & NA & Excellent & NE \\
\hline CF-613 & Bunkhouse & 1943 & Eligible & Ord WW2 & No & $\begin{array}{c}\text { Consultation started 1996, } \\
\text { ongoing }\end{array}$ & Shutdown & Signature & UK & $\mathrm{NE}$ \\
\hline CF-614 & CF Office Building \#2 & 1986 & Not Eligible & Multi-Prog & Yes & NA & Operating & NA & NA & NE \\
\hline CF-615 & CF Office Building \#3 & 1991 & Not Eligible & Multi-Prog & Yes & NA & Operating & NA & NA & $\mathrm{NE}$ \\
\hline CF-616 & NOAA Storage Building & 1983 & Not Eligible & Multi-Prog & Yes & NA & Demolished & NA & NA & NE \\
\hline CF-617 & Laundry Decontamination Facility & 1981 & Not Eligible & Waste & Yes & NA & Demolished & NA & NA & NA \\
\hline CF-619 & Utility Building & 1989 & Not Eligible & Multi-Prog & Yes & NA & Operating & NA & NA & NE \\
\hline CF-621 & Multi-craft Shop \#1 & 1983 & Not Eligible & Multi-Prog & Yes & NA & Operating & NA & NA & NE \\
\hline CF-622 & Multi-craft Shop \#2 & 1984 & Not Eligible & Multi-Prog & Yes & NA & Operating & NA & NA & NE \\
\hline CF-623 & Multi-craft Shop \#3 & 1986 & Not Eligible & Multi-Prog & Yes & NA & Operating & NA & NA & $\mathrm{NE}$ \\
\hline
\end{tabular}


Table 8. (continued).

\begin{tabular}{|c|c|c|c|c|c|c|c|c|c|c|}
\hline \multicolumn{11}{|c|}{ Surveyed INL Architectural Properties } \\
\hline $\begin{array}{l}\text { Building or } \\
\text { Structure } \\
\text { ID }\end{array}$ & Building or Structure Name & $\begin{array}{l}\text { Date } \\
\text { Built }\end{array}$ & $\begin{array}{c}\text { National } \\
\text { Register } \\
\text { Evaluation }\end{array}$ & Context & $\begin{array}{l}\text { SHPO } \\
\text { Concur }\end{array}$ & Section 106 Status & Status & $\begin{array}{c}\text { Property } \\
\text { Type } \\
\text { Category }\end{array}$ & Condition & Owner \\
\hline CF-624 & Multi-craft Shop \#4 & 1986 & Not Eligible & Multi-Prog & Yes & NA & Operating & NA & NA & $\mathrm{NE}$ \\
\hline CF-625 & CF Laboratory Complex & 1989 & Not Eligible & Waste & Yes & NA & Operating & NA & NA & $\mathrm{NE}$ \\
\hline CF-629 & Office Building & 1979 & Not Eligible & Multi-Prog & Yes & NA & Operating & NA & NA & $\mathrm{NE}$ \\
\hline CF-632 & $\begin{array}{l}\text { Boiler Operations Lunch Room/Storage } \\
\text { Building }\end{array}$ & 1945 & Eligible & Ord WW2 & No & $\begin{array}{c}\text { Consultation started 1996, } \\
\text { ongoing }\end{array}$ & Shutdown & Signature & UK & $\mathrm{NE}$ \\
\hline CF-633 & Instrument Laboratory & 1943 & Eligible & Ord WW2 & No & $\begin{array}{l}\text { Consultation started } 1996, \\
\text { ongoing }\end{array}$ & Shutdown & Signature & UK & $\mathrm{NE}$ \\
\hline CF-634 & Acid Storage Building & UK & Not Assessed & Multi-Prog & No & No MOA & Demolished & NA & NA & NA \\
\hline CF-635 & $\begin{array}{l}\text { Hazardous Mix Waste Storage/Igloo/ } \\
\text { Bunker }\end{array}$ & 1943 & Eligible & Ord WW2 & Yes & $\begin{array}{l}\text { Programmatic Agreement-large } \\
\text { format photos completed }\end{array}$ & Demolished & 2 & UK & NE \\
\hline CF-637 & Hazardous Chemical Storage & 1943 & Eligible & Ord WW2 & Yes & Programmatic Agreement & Operating & 2 & Excellent & $\mathrm{NE}$ \\
\hline CF-638 & $\begin{array}{l}\text { Dosimetry Calibration Lab/Ordnance } \\
\text { Storage }\end{array}$ & 1943 & Eligible & Ord WW2 & Yes & Consultation 1997, No Effect & Operating & 2 & Excellent & $\mathrm{NE}$ \\
\hline CF-639 & Storage & 1950 & Eligible & Multi-Prog & Yes & MOA photos taken & Demolished & NA & NA & NA \\
\hline CF-640 & Storage (former Locomotive Shed) & ca. 1943 & Not Assessed & Ord WW2 & Yes & MOA photos taken & Demolished & NA & NA & NA \\
\hline CF-642 & Pump House & ca.1943 & Eligible & Ord WW2 & No & MOA required & Operating & Signature & UK & NE \\
\hline CF-643 & Office Trailer & 1977 & Exempt & Multi-Prog & Yes & NA & Removed & NA & NA & NA \\
\hline CF-645 & Service Station & 1960 & Eligible & Multi-Prog & Yes & MOA photos taken & Demolished & NA & NA & NA \\
\hline CF-646 & Storage Building & 1960 & Eligible & NRT & Yes & $\begin{array}{l}\text { Programmatic Agreement- } 35 \mathrm{~mm} \\
\text { photos completed }\end{array}$ & Demolished & 3 & UK & NE \\
\hline CF-649 & Storage & 1950 & Eligible & Multi-Prog & No & No MOA & Demolished & NA & NA & NA \\
\hline CF-650 & Heating Plant & 1943 & Eligible & Ord WW2 & Yes & Programmatic Agreement & Operating & 2 & UK & $\mathrm{NE}$ \\
\hline CF-651 & Pump House (CF Well No. 1) & 1943 & Eligible & Ord WW2 & No & MOA required & Operating & Signature & UK & NE \\
\hline CF-652 & Office Trailer & 1977 & Exempt & Multi-Prog & Yes & NA & Removed & NA & NA & NA \\
\hline CF-654 & Old Craft Shop & 1950 & Not Assessed & Multi-Prog & No & No MOA & Demolished & NA & NA & NA \\
\hline CF-655 & Office Trailer & 1986 & Exempt & Multi-Prog & Yes & NA & Removed & NA & NA & NA \\
\hline
\end{tabular}


Table 8. (continued).

\begin{tabular}{|c|c|c|c|c|c|c|c|c|c|c|}
\hline \multicolumn{11}{|c|}{ Surveyed INL Architectural Properties } \\
\hline $\begin{array}{l}\text { Building or } \\
\text { Structure } \\
\text { ID }\end{array}$ & Building or Structure Name & $\begin{array}{l}\text { Date } \\
\text { Built }\end{array}$ & $\begin{array}{c}\text { National } \\
\text { Register } \\
\text { Evaluation }\end{array}$ & Context & $\begin{array}{c}\text { SHPO } \\
\text { Concur }\end{array}$ & Section 106 Status & Status & $\begin{array}{c}\text { Property } \\
\text { Type } \\
\text { Category }\end{array}$ & Condition & Owner \\
\hline CF-656 & Generator Auxiliary & 1950 & Eligible & Multi-Prog & No & No MOA & Demolished & NA & NA & NA \\
\hline CF-657 & Pump House & 1953 & Eligible & Multi-Prog & Yes & MOA photos taken & Demolished & NA & NA & NA \\
\hline CF-660 & $\begin{array}{l}\text { Laborers \& Equipment Operators } \\
\text { Building }\end{array}$ & 1963 & Eligible & NRT & Yes & Letter from SHPO 9/16/1993 & Demolished & 3 & NA & NA \\
\hline CF-661 & Material Storage Building & 1963 & Eligible & NRT & Yes & Programmatic Agreement & Operating & 3 & Excellent & NE \\
\hline CF-662 & Cafeteria & 1952 & Eligible & NRT & Yes & Programmatic Agreement & Operating & 3 & Fair & $\mathrm{NE}$ \\
\hline CF-663 & Core Storage Library & 1990 & Not Eligible & Waste & Yes & NA & Operating & & Excellent & NE \\
\hline CF-664 & $\begin{array}{l}\text { Service Station (Vehicle Inspection } \\
\text { Building) }\end{array}$ & 1951 & Eligible & NRT & Yes & Programmatic Agreement & Operating & 3 & UK & NE \\
\hline CF-665 & Equipment Repair & 1951 & Eligible & Multi-Prog & Yes & MOA photos taken & Demolished & NA & NA & NA \\
\hline CF-666 & Fire Station & 1951 & Eligible & NRT & Yes & Letter from SHPO 9/13/1994 & Operating & 3 & UK & $\mathrm{NE}$ \\
\hline CF-667 & Storage Building & 1951 & Eligible & NRT & No & NA & Demolished & 3 & NA & NA \\
\hline CF-668 & Communications Building & 1951 & Eligible & NRT & Yes & Programmatic Agreement & Operating & 3 & UK & $\mathrm{NE}$ \\
\hline CF-669 & Old Laundry & 1950 & Not Assessed & NRT & No & No MOA & Demolished & NA & NA & NA \\
\hline CF-671 & Boiler Building & 1951 & Eligible & NRT & Yes & Programmatic Agreement & Operating & 3 & UK & $\mathrm{NE}$ \\
\hline CF-674 & Warehouse & 1952 & Eligible & NRT & Yes & Programmatic Agreement & Operating & 3 & UK & NE \\
\hline CF-675 & Generator Building & 1963 & Exempt & Multi-Prog & Yes & NA & Demolished & NA & NA & NE \\
\hline CF-676 & Storage Building & 1963 & Eligible & NRT & Yes & Programmatic Agreement & Operating & 3 & Excellent & NE \\
\hline CF-677 & Pump House, Tank Farm & 1951 & Eligible & NRT & Yes & Letter from SHPO, 11/20/1997 & Demolished & NA & NA & NA \\
\hline CF-678 & Gas Storage Building & 1951 & Eligible & NRT & Yes & MOA photos taken & Demolished & NA & NA & NA \\
\hline CF-679 & Fire Station Emergency Generator & 1951 & Exempt & Multi-Prog & Yes & NA & Operating & NA & UK & NE \\
\hline CF-680 & Storage Building & 1951 & Eligible & NRT & No & NA & Demolished & 3 & NA & NA \\
\hline CF-681 & Control House, Substation & 1951 & Exempt & Multi-Prog & Yes & NA & Operating & NA & UK & NE \\
\hline CF-684 & Storage Building & 1952 & Eligible & NRT & Yes & $\begin{array}{l}\text { Programmatic Agreement-35mm } \\
\text { photos completed }\end{array}$ & Demolished & 3 & NA & NE \\
\hline CF-685 & Bus Depot & 1952 & Eligible & NRT & Yes & Programmatic Agreement & Operating & 3 & Adequate & $\mathrm{NE}$ \\
\hline
\end{tabular}


Table 8. (continued).

\begin{tabular}{|c|c|c|c|c|c|c|c|c|c|c|}
\hline \multicolumn{11}{|c|}{ Surveyed INL Architectural Properties } \\
\hline $\begin{array}{c}\text { Building or } \\
\text { Structure } \\
\text { ID }\end{array}$ & Building or Structure Name & $\begin{array}{l}\text { Date } \\
\text { Built }\end{array}$ & $\begin{array}{c}\text { National } \\
\text { Register } \\
\text { Evaluation }\end{array}$ & Context & $\begin{array}{l}\text { SHPO } \\
\text { Concur }\end{array}$ & Section 106 Status & Status & $\begin{array}{c}\text { Property } \\
\text { Type } \\
\text { Category }\end{array}$ & Condition & Owner \\
\hline CF-686 & High Bay Lab Building & 1979 & Not Eligible & Multi-Prog & Yes & NA & Operating & NA & NA & NE \\
\hline CF-687 & Old Lead Shop & 1953 & Eligible & Multi-Prog & Yes & MOA photos taken & Demolished & NA & NA & NA \\
\hline CF-688 & Engineering Building CFA Tech Center & 1963 & Eligible & NRT & Yes & Programmatic Agreement & Operating & 3 & Excellent & $\mathrm{NE}$ \\
\hline CF-689 & Engineering Building CFA Tech Center & 1963 & Eligible & NRT & Yes & Programmatic Agreement & Operating & 3 & UK & $\mathrm{NE}$ \\
\hline CF-690 & $\begin{array}{l}\text { Radiological and Environmental } \\
\text { Science Lab }\end{array}$ & 1963 & Eligible & NRT & Yes & Programmatic Agreement & Operating & 3 & Good & $\mathrm{NE}$ \\
\hline CF-691 & $\begin{array}{l}\text { Pump House/Old Sewage Treatment } \\
\text { Plant }\end{array}$ & 1953 & Eligible & Multi-Prog & Yes & MOA photos taken & Demolished & NA & NA & NA \\
\hline CF-692 & Scale House at Truck Weighing Scales & 1950 & Eligible & NRT & Yes & Programmatic Agreement & Shutdown & 3 & UK & NE \\
\hline CF-695 & Life Safety Test Facility & 1966 & Eligible & NRT & Yes & Programmatic Agreement & Operating & 3 & Excellent & $\mathrm{NE}$ \\
\hline CF-696 & CFA Transportation Complex & 1995 & Not Eligible & Multi-Prog & Yes & NA & Operating & NA & Adequate & $\mathrm{NE}$ \\
\hline CF-697 & CF Equipment Storage Building & 1960 & Eligible & NRT & Yes & Programmatic Agreement & Operating & 3 & Excellent & $\mathrm{NE}$ \\
\hline CF-698 & Standard Calibration Laboratory & 1969 & Eligible & NRT & Yes & Programmatic Agreement & Operating & 3 & Adequate & $\mathrm{NE}$ \\
\hline CF-699 & Communications and Alarm Building & 1969 & Eligible & NRT & Yes & Programmatic Agreement & Operating & 3 & Good & $\mathrm{NE}$ \\
\hline CF-1601 & Chlorine Injection Facility & ca. 1990 & Not Eligible & Waste & Yes & NA & Demolished & NA & NA & NA \\
\hline CF-1602 & Hydrant and Standpipe Facility & 1990 & Not Eligible & Multi-Prog & Yes & NA & Operating & NA & NA & $\mathrm{NE}$ \\
\hline CF-1603 & Firewater Pump House & 1995 & Not Eligible & Multi-Prog & No & NA & Operating & NA & NA & $\mathrm{NE}$ \\
\hline CF-1605 & CFA Waste Water Laboratory & 1995 & Not Eligible & Waste & Yes & NA & Operating & NA & NA & $\mathrm{NE}$ \\
\hline CF-1606 & CFA Training Facility & 1995 & Not Eligible & Multi-Prog & Yes & NA & Operating & NA & NA & $\mathrm{NE}$ \\
\hline CF-1607 & Antifreeze and Oil Dispensing Building & 1995 & Not Eligible & Multi-Prog & Yes & NA & Operating & NA & NA & $\mathrm{NE}$ \\
\hline CF-1608 & CFA Modular Office & 1995 & Not Eligible & Multi-Prog & Yes & NA & Operating & NA & NA & $\mathrm{NE}$ \\
\hline CF-1609 & CFA/DOE Modular Office & 1995 & Not Eligible & Multi-Prog & Yes & NA & Operating & NA & NA & $\mathrm{NE}$ \\
\hline CF-1610 & $\begin{array}{l}\text { CFA Waste Management Modular } \\
\text { Office }\end{array}$ & 1995 & Not Eligible & Multi-Prog & Yes & NA & Operating & NA & NA & $\mathrm{NE}$ \\
\hline CF-1611 & CFA Fire Station 1 & 1996 & Not Eligible & Multi-Prog & Yes & NA & Operating & NA & NA & $\mathrm{NE}$ \\
\hline CF-1612 & CFA Medical Facility & 1996 & Not Eligible & Multi-Prog & Yes & NA & Operating & NA & NA & NE \\
\hline
\end{tabular}


Table 8. (continued).

\begin{tabular}{|c|c|c|c|c|c|c|c|c|c|c|}
\hline \multicolumn{11}{|c|}{ Surveyed INL Architectural Properties } \\
\hline $\begin{array}{c}\text { Building or } \\
\text { Structure } \\
\text { ID }\end{array}$ & Building or Structure Name & $\begin{array}{l}\text { Date } \\
\text { Built }\end{array}$ & $\begin{array}{c}\text { National } \\
\text { Register } \\
\text { Evaluation }\end{array}$ & Context & $\begin{array}{l}\text { SHPO } \\
\text { Concur }\end{array}$ & Section 106 Status & Status & $\begin{array}{c}\text { Property } \\
\text { Type } \\
\text { Category }\end{array}$ & Condition & Owner \\
\hline CF-1613 & Chlorination Facility & 1996 & Not Eligible & Multi-Prog & Yes & NA & Demolished & NA & NA & NA \\
\hline CF-1614 & Fire Training Facility & 1997 & Not Eligible & Multi-Prog & Yes & NA & Operating & NA & NA & $\mathrm{NE}$ \\
\hline CF-1616 & Truck Scale House North of 629 & 1997 & Not Eligible & Multi-Prog & Yes & NA & Operating & NA & NA & $\mathrm{NE}$ \\
\hline CF-1618 & Health Physics Instrument Laboratory & 2002 & Not Assessed & Multi-Prog & Yes & NA & Operating & NA & NA & $\mathrm{NE}$ \\
\hline \multicolumn{11}{|c|}{ Idaho Nuclear Technology and Engineering Center (INTEC; formerly ICPP) } \\
\hline CPP-601 & Process Building & 1953 & Eligible & NRT & Yes & MOA HAER ID-33-H & $\begin{array}{l}\mathrm{D} \& \mathrm{D} \text { in } \\
\text { progress }\end{array}$ & Signature & UK & EM \\
\hline СРP-602 & Laboratory and Office Building & 1953 & Eligible & NRT & Yes & $\begin{array}{l}\text { MOA-Draft HABS/HAER } \\
\text { complete }\end{array}$ & Operating & 2 & Excellent & EM \\
\hline СРP-603 & Fuel Receiving and Storage Building & $1952-77$ & Eligible & NRT & Yes & MOA HAER ID-33-H & Operating & 2 & Excellent & EM \\
\hline СРP-604 & Waste Treatment Building & 1951 & Eligible & NRT & Yes & Programmatic Agreement & Operating & 2 & Excellent & EM \\
\hline CPP-605 & Blower Building & 1953 & Exempt & Multi-Prog & Yes & NA & Operating & NA & NA & EM \\
\hline CPP-606 & Service Building/Powerhouse & 1951 & Eligible & NRT & Yes & Programmatic Agreement & Operating & 3 & Excellent & EM \\
\hline СРP-607 & Storage/Butler Building & 1953 & Not Assessed & Multi-Prog & Yes & NA & Demolished & NA & NA & NA \\
\hline CPP-608 & Storage Building (Butler Building) & 1950 & Eligible & NRT & Yes & MOA conditions met & Demolished & 3 & NA & NA \\
\hline СРP-609 & Vehicle Monitoring Facility Office & 1982 & Not Eligible & Multi-Prog & Yes & NA & Operating & NA & NA & EM \\
\hline CPP-610 & CPP 603 Area Storage Building & 1992 & Not Eligible & Multi-Prog & No & NA & Demolished & NA & NA & NA \\
\hline СРP-611 & Pump house, Deep Well Pump \#1 & 1953 & Exempt & Multi-Prog & Yes & NA & Operating & NA & NA & EM \\
\hline CPP-612 & Pump house, Deep Well Pump \#2 & 1953 & Exempt & Multi-Prog & Yes & NA & Operating & NA & NA & EM \\
\hline СРP-613 & Electrical Substation \#10 Building & 1953 & Exempt & Multi-Prog & Yes & NA & Operating & NA & NA & EM \\
\hline СРP-614 & $\begin{array}{l}\text { Pump house for Diesel-Driven Fire } \\
\text { Pump }\end{array}$ & 1984 & Exempt & Multi-Prog & Yes & NA & Operating & NA & NA & EM \\
\hline СРP-615 & $\begin{array}{l}\text { Sewage Treatment Plant Compressor } \\
\text { Building }\end{array}$ & 1982 & Not Eligible & Multi-Prog & Yes & NA & Operating & NA & NA & $\mathrm{EM}$ \\
\hline CPP-616 & Emergency Air Compressor Building & 1979 & Not Eligible & NRT & Yes & NA & Operating & NA & NA & EM \\
\hline CРP-617 & Storage Building (Butler Building) & 1954 & Eligible & NRT & Yes & MOA conditions met & Demolished & 3 & NA & NA \\
\hline
\end{tabular}


Table 8. (continued).

\begin{tabular}{|c|c|c|c|c|c|c|c|c|c|c|}
\hline \multicolumn{11}{|c|}{ Surveyed INL Architectural Properties } \\
\hline $\begin{array}{c}\text { Building or } \\
\text { Structure } \\
\text { ID }\end{array}$ & Building or Structure Name & $\begin{array}{l}\text { Date } \\
\text { Built }\end{array}$ & $\begin{array}{c}\text { National } \\
\text { Register } \\
\text { Evaluation }\end{array}$ & Context & $\begin{array}{c}\text { SHPO } \\
\text { Concur }\end{array}$ & Section 106 Status & Status & $\begin{array}{c}\text { Property } \\
\text { Type } \\
\text { Category }\end{array}$ & Condition & Owner \\
\hline CPP-618 & $\begin{array}{l}\text { Measurement and Control Building } \\
\text { Tank Farm }\end{array}$ & 1975 & Eligible & Multi-Prog & Yes & Programmatic Agreement & Operating & 3 & Excellent & EM \\
\hline CPP-619 & Waste Storage Control House & 1955 & Eligible & NRT & Yes & Programmatic Agreement & Operating & 2 & Good & EM \\
\hline СРP-620 & $\begin{array}{l}\text { Chemical Engineering Lab High Bay } \\
\text { Facility }\end{array}$ & 1964 & Eligible & NRT & Yes & MOA conditions met & Demolished & 2 & NA & NA \\
\hline CPP-620A & Annex & 1989 & Not Eligible & Multi-Prog & Yes & MOA conditions met & Demolished & NA & NA & NA \\
\hline СРP-621 & Chemical Storage Pump house & 1956 & Exempt & Multi-Prog & Yes & NA & Operating & NA & NA & EM \\
\hline CPP-622 & Instrument House (Tank Farm) & 1974 & Not Eligible & Multi-Prog & Yes & NA & Operating & NA & NA & EM \\
\hline CPP-623 & Instrument House (Tank Farm) & 1974 & Not Eligible & Multi-Prog & Yes & NA & Operating & NA & NA & EM \\
\hline CPP-625 & $\begin{array}{l}\text { Rectifier Building for Electrolytic } \\
\text { Dissolver }\end{array}$ & 1971 & Not Eligible & Multi-Prog & Yes & NA & Demolished & NA & NA & NA \\
\hline CPP-626 & Storage Basin Change Room & ca. 1975 & Not Eligible & Multi-Prog & Yes & NA & Operating & NA & NA & EM \\
\hline СРP-627 & Remote Analytical Facility Building & 1955 & Eligible & NRT & Yes & MOA - HAER ID-33-H & Demolished & 2 & NA & NA \\
\hline CPP-628 & Waste Storage Control House & 1953 & Eligible & NRT & Yes & Programmatic Agreement & Operating & 2 & Excellent & EM \\
\hline СРР-629 & MK FPR Office Building & 1984 & Not Eligible & Multi-Prog & Yes & NA & Demolished & NA & NA & NA \\
\hline СРP-630 & Safety and Spectrometry Building & 1956 & Eligible & NRT & Yes & Programmatic Agreement & Operating & 3 & Adequate & EM \\
\hline СРP-631 & "L" Cell Off-Gas Blower Room & 1956 & Eligible & Multi-Prog & Yes & MOA - HABS/HAER complete & Demolished & NA & NA & NA \\
\hline CPP-632 & Tank Farm Instrument House & 1960 & Eligible & Multi-Prog & Yes & Programmatic Agreement & Operating & 3 & Good & EM \\
\hline СРP-633 & Waste Calcining Facility & 1961 & Eligible & & Yes & MOA - HABS/HAER complete & Demolished & NA & NA & NA \\
\hline CPP-634 & Waste Storage Pipe Manifold Building & 1958 & Eligible & NRT & Yes & Programmatic Agreement & Operating & 3 & Excellent & EM \\
\hline CPP-635 & Waste Storage Pipe Manifold Building & 1957 & Eligible & NRT & Yes & Programmatic Agreement & Operating & 3 & Excellent & EM \\
\hline CPP-636 & Waste Storage Pipe Manifold Building & 1965 & Eligible & NRT & Yes & Programmatic Agreement & Operating & 3 & Excellent & EM \\
\hline СРP-637 & $\begin{array}{l}\text { Process Improvement Facility, Offices } \\
\text { and Lab }\end{array}$ & 1958 & Eligible & NRT & Yes & MOA conditions met & Demolished & 2 & NA & NA \\
\hline CPP-638 & Waste Station & 1968 & Eligible & NRT & Yes & Programmatic Agreement & Operating & 3 & Fair & EM \\
\hline CPP-639 & Blower Building & 1958 & Eligible & NRT & Yes & Programmatic Agreement & Operating & 3 & Excellent & EM \\
\hline
\end{tabular}


Table 8. (continued).

\begin{tabular}{|c|c|c|c|c|c|c|c|c|c|c|}
\hline \multicolumn{11}{|c|}{ Surveyed INL Architectural Properties } \\
\hline $\begin{array}{c}\text { Building or } \\
\text { Structure } \\
\text { ID }\end{array}$ & Building or Structure Name & $\begin{array}{l}\text { Date } \\
\text { Built }\end{array}$ & $\begin{array}{c}\text { National } \\
\text { Register } \\
\text { Evaluation }\end{array}$ & Context & $\begin{array}{c}\text { SHPO } \\
\text { Concur }\end{array}$ & Section 106 Status & Status & $\begin{array}{c}\text { Property } \\
\text { Type } \\
\text { Category }\end{array}$ & Condition & Owner \\
\hline CPP-640 & Headend Process Plant & 1961 & Eligible & NRT & Yes & MOA - HAER ID-33-H & $\begin{array}{l}\text { D\&D in } \\
\text { progress }\end{array}$ & 2 & UK & EM \\
\hline CPP-641 & $\begin{array}{l}\text { Westside Waste Holdup Tank } \\
\text { Pumphouse }\end{array}$ & 1961 & Exempt & Multi-Prog & Yes & NA & Operating & NA & NA & EM \\
\hline CPP-642 & Hot Waste Pump House and Pit & 1957 & Exempt & Multi-Prog & Yes & NA & Demolished & NA & NA & EM \\
\hline СРP-643 & ATV Storage Shed & 1992 & Not Eligible & Multi-Prog & Yes & NA & Demolished & NA & NA & NA \\
\hline CРP-644 & $\begin{array}{l}\text { Emergency Power Building Substation } \\
\# 20\end{array}$ & 1981 & Not Eligible & Multi-Prog & Yes & NA & Operating & NA & NA & EM \\
\hline CPP-645 & Office Building \#1 Quality Inspection & 1977 & Not Eligible & Multi-Prog & Yes & NA & Demolished & NA & NA & EM \\
\hline СРP-646 & Instrument Building for Bin Set II & 1965 & Eligible & NRT & Yes & Programmatic Agreement & Operating & 2 & Excellent & EM \\
\hline CPP-647 & Instrument Building for Bin Set III & 1970 & Eligible & Multi-Prog & Yes & Programmatic Agreement & Operating & 2 & Good & EM \\
\hline СРР-648 & Basin Sludge Tank Control House & 1972 & Not Eligible & Multi-Prog & Yes & NA & Demolished & NA & NA & EM \\
\hline СРP-649 & Atmospheric Protection Building & 1976 & Not Eligible & Multi-Prog & Yes & NA & Operating & NA & NA & EM \\
\hline СРP-650 & Breathing Air Compressor Building & 1985 & Not Eligible & Multi-Prog & Yes & NA & Demolished & NA & NA & NA \\
\hline CPP-651 & Unirradiated Fuels Storage Facility & 1974 & Reassess & Multi-Prog & Yes & NA & Operating & 2 & Excellent & EM \\
\hline CPP-652 & Multipurpose Building & 1975 & Not Eligible & Multi-Prog & Yes & NA & Operating & NA & NA & EM \\
\hline СРP-653 & Vehicle Monitoring Building & 1975 & Not Eligible & Multi-Prog & Yes & NA & Operating & NA & Excellent & EM \\
\hline CPP-654 & $\begin{array}{l}\text { Office Building (Purchasing \& } \\
\text { Accounting }\end{array}$ & 1977 & Not Eligible & Multi-Prog & Yes & NA & Operating & NA & Excellent & EM \\
\hline CPP-655 & Craft Shop \& Warehouse Building & 1974 & Not Eligible & Multi-Prog & Yes & NA & Operating & NA & Good & EM \\
\hline CPP-656 & Office Building \#3 Line Item Projects & 1980 & Not Eligible & Multi-Prog & Yes & NA & Demolished & NA & NA & EM \\
\hline CPP-657 & $\begin{array}{l}\text { Office Building (Nuclear Materials } \\
\text { Accountability) }\end{array}$ & 1974 & Not Eligible & Multi-Prog & Yes & NA & Demolished & NA & NA & NA \\
\hline CPP-658 & Instrument Building for Bin Set IV & 1975 & Not Eligible & Multi-Prog & Yes & NA & Operating & NA & NA & EM \\
\hline CPP-659 & New Waste Calcining Facility & 1978 & Reassess & Multi-Prog & Yes & NA & Operating & TBD & Excellent & EM \\
\hline CPP-660 & $\begin{array}{l}\text { Chemicals and Hazardous Materials } \\
\text { Storage }\end{array}$ & 1979 & Not Eligible & Multi-Prog & Yes & NA & Operating & NA & NA & EM \\
\hline
\end{tabular}


Table 8. (continued).

\begin{tabular}{|c|c|c|c|c|c|c|c|c|c|c|}
\hline \multicolumn{11}{|c|}{ Surveyed INL Architectural Properties } \\
\hline $\begin{array}{l}\text { Building or } \\
\text { Structure } \\
\text { ID }\end{array}$ & Building or Structure Name & $\begin{array}{l}\text { Date } \\
\text { Built }\end{array}$ & $\begin{array}{c}\text { National } \\
\text { Register } \\
\text { Evaluation }\end{array}$ & Context & $\begin{array}{c}\text { SHPO } \\
\text { Concur }\end{array}$ & Section 106 Status & Status & $\begin{array}{l}\text { Property } \\
\text { Type } \\
\text { Category }\end{array}$ & Condition & Owner \\
\hline СРP-661 & Modular Guard Station \#1 & 1986 & Not Eligible & Multi-Prog & Yes & NA & Operating & NA & NA & EM \\
\hline CPP-662 & Maintenance Fabrication Shop & 1976 & Not Eligible & Multi-Prog & Yes & NA & Operating & NA & NA & EM \\
\hline CPP-663 & Maintenance Building & 1980 & Not Eligible & Multi-Prog & Yes & NA & Operating & NA & NA & EM \\
\hline СРP-664 & Office Building (Quality Inspection) & 1981 & Not Eligible & Multi-Prog & Yes & NA & Demolished & NA & NA & NA \\
\hline CPP-665 & Office Building (FPR Construction) & 1980 & Not Eligible & Multi-Prog & Yes & NA & Demolished & NA & NA & NA \\
\hline CPP-666 & FAST Facility & 1983 & Reassess & Multi-Prog & Yes & NA & Operating & TBD & Excellent & EM \\
\hline СРP-667 & NWCF Office Building & 1961 & Not Eligible & Multi-Prog & No & NA & Demolished & NA & NA & NA \\
\hline CPP-668 & $\begin{array}{l}\text { Office Building \#2 (Systems } \\
\text { Engineering) }\end{array}$ & 1984 & Not Eligible & Multi-Prog & Yes & NA & Demolished & NA & NA & EM \\
\hline СРP-669 & Main Gatehouse & 1978 & Not Eligible & Multi-Prog & Yes & NA & Demolished & NA & NA & NA \\
\hline CPP-671 & Instrument Building for Bin Set V & 1981 & Not Eligible & Multi-Prog & Yes & NA & Operating & NA & NA & EM \\
\hline CPP-672 & Contaminated Tool Storage Building & 1981 & Not Eligible & Multi-Prog & Yes & NA & Demolished & NA & NA & NA \\
\hline CPP-673 & Service Building for Bin Set VI & 1986 & Not Eligible & Multi-Prog & Yes & NA & Operating & NA & NA & EM \\
\hline СРP-674 & UREP Substation \#40 Control House & 1984 & Not Eligible & Multi-Prog & Yes & NA & Shutdown & NA & NA & EM \\
\hline CPP-675 & UREP Substation \#30 Control House & 1984 & Not Eligible & Multi-Prog & Yes & NA & Demolished & NA & NA & NA \\
\hline СРP-676 & UREP Load Center \#1 YDB Area & 1984 & Not Eligible & Multi-Prog & Yes & NA & Demolished & NA & NA & NA \\
\hline СРP-677 & UREP Load Center \#2 YDB Area & 1984 & Not Eligible & Multi-Prog & Yes & NA & Operating & NA & NA & EM \\
\hline СРP-678 & UREP Load Center \#3 YDB Area & 1984 & Not Eligible & Multi-Prog & Yes & NA & Demolished & NA & NA & NA \\
\hline СРР-679 & Fast Model Building & 1983 & Not Eligible & Multi-Prog & Yes & NA & Operating & NA & NA & EM \\
\hline СРP-681 & Effluent Monitoring Building & 1981 & Not Eligible & Multi-Prog & Yes & NA & Demolished & NA & NA & NA \\
\hline СРP-682 & FPR Contractor Fabrication Shop & 1982 & Not Eligible & Multi-Prog & No & NA & Demolished & NA & NA & NA \\
\hline СРP-683 & Breathing Air Charging Station & 1981 & Not Eligible & Multi-Prog & No & NA & Demolished & NA & NA & NA \\
\hline СРP-684 & Remote Analytical Laboratory & 1985 & Reassess & Multi-Prog & Yes & NA & Operating & TBD & TBD & EM \\
\hline CPP-685 & Safeguards Data Acquisition Shelter & 1981 & Not Eligible & Multi-Prog & Yes & NA & Demolished & NA & NA & NA \\
\hline СРP-686 & Security Office Building & 1985 & Not Eligible & Multi-Prog & No & NA & Demolished & NA & NA & NA \\
\hline
\end{tabular}


Table 8. (continued).

\begin{tabular}{|c|c|c|c|c|c|c|c|c|c|c|}
\hline \multicolumn{11}{|c|}{ Surveyed INL Architectural Properties } \\
\hline $\begin{array}{l}\text { Building or } \\
\text { Structure } \\
\text { ID }\end{array}$ & Building or Structure Name & $\begin{array}{l}\text { Date } \\
\text { Built }\end{array}$ & $\begin{array}{c}\text { National } \\
\text { Register } \\
\text { Evaluation }\end{array}$ & Context & $\begin{array}{l}\text { SHPO } \\
\text { Concur }\end{array}$ & Section 106 Status & Status & $\begin{array}{c}\text { Property } \\
\text { Type } \\
\text { Category }\end{array}$ & & Owner \\
\hline СРP-687 & Boiler house, Coal-Fired & 1983 & Not Eligible & Multi-Prog & Yes & NA & Demolished & NA & NA & EM \\
\hline CPP-688 & Coal Unloading Building, Coal-Fired & 1983 & Not Eligible & Multi-Prog & Yes & NA & Demolished & NA & NA & EM \\
\hline СРP-689 & Gatehouse, Coal-Fired & 1983 & Not Eligible & Multi-Prog & Yes & NA & Demolished & NA & NA & EM \\
\hline СРР-690 & $\begin{array}{l}\text { Mobile Equipment Storage Building, } \\
\text { Coal-Fired }\end{array}$ & 1983 & Not Eligible & Multi-Prog & Yes & NA & Demolished & NA & NA & EM \\
\hline СРР-691 & $\begin{array}{l}\text { Fuel Processing Restoration Building } \\
\text { (FPR) }\end{array}$ & 1993 & Reassess & Multi-Prog & Yes & NA & Operating & TBD & Excellent & EM \\
\hline СРР-692 & Instrument Building for Stack CPP-708 & 1983 & Not Eligible & Multi-Prog & Yes & NA & Operating & NA & NA & EM \\
\hline СРP-693 & Warehouse & 1980 & Not Eligible & Multi-Prog & Yes & NA & Demolished & NA & NA & NA \\
\hline СРP-694 & $\begin{array}{l}\text { NWCF Organic Solvent Disposal } \\
\text { Building }\end{array}$ & 1982 & Not Eligible & Multi-Prog & Yes & NA & Operating & NA & NA & EM \\
\hline СРP-695 & Quality X-Ray Facility & 1984 & Not Eligible & Multi-Prog & Yes & NA & Demolished & NA & NA & NA \\
\hline СРР-696 & Office Building, Coal-Fired & 1984 & Not Eligible & Multi-Prog & Yes & NA & Demolished & NA & NA & EM \\
\hline СРP-697 & East Guardhouse and VMF & 1986 & Not Eligible & Multi-Prog & Yes & NA & Operating & NA & NA & EM \\
\hline СРР-698 & MK Warehouse and Office Building & 1984 & Not Eligible & Multi-Prog & Yes & NA & Operating & NA & NA & EM \\
\hline СРР-699 & Training Building & 1985 & Not Eligible & Multi-Prog & Yes & NA & Demolished & NA & NA & EM \\
\hline CPP-1604 & Office Building \#4 & 1986 & Not Eligible & Multi-Prog & Yes & NA & Operating & NA & NA & EM \\
\hline CPP-1605 & Document Control Building & 1986 & Not Eligible & Multi-Prog & Yes & NA & Operating & NA & NA & EM \\
\hline СРP-1606 & Plant Support Warehouse (FPR) & 1986 & Not Eligible & Multi-Prog & Yes & NA & Operating & NA & NA & EM \\
\hline CPP-1607 & $\begin{array}{l}\text { Automatic Form Fire Protection } \\
\text { Building }\end{array}$ & 1983 & Not Eligible & Multi-Prog & Yes & NA & Operating & NA & NA & EM \\
\hline CPP-1608 & $\begin{array}{l}\text { Contaminated Equip. } \\
\text { Storage/Manipulator Repair }\end{array}$ & 1987 & Not Eligible & Multi-Prog & Yes & NA & Operating & NA & NA & EM \\
\hline CPP-1609 & Modular Guard Station \#3 & 1984 & Not Eligible & Multi-Prog & No & NA & Demolished & NA & NA & NA \\
\hline CPP-1610 & Salt Pit Control Building & 1985 & Not Eligible & Multi-Prog & Yes & NA & Operating & NA & NA & EM \\
\hline CPP-1611 & Pond-327 Pump House & 1985 & Not Eligible & Multi-Prog & Yes & NA & Demolished & NA & NA & NA \\
\hline
\end{tabular}


Table 8. (continued).

\begin{tabular}{|c|c|c|c|c|c|c|c|c|c|c|}
\hline \multicolumn{11}{|c|}{ Surveyed INL Architectural Properties } \\
\hline $\begin{array}{l}\text { Building or } \\
\text { Structure } \\
\text { ID }\end{array}$ & Building or Structure Name & $\begin{array}{l}\text { Date } \\
\text { Built }\end{array}$ & $\begin{array}{c}\text { National } \\
\text { Register } \\
\text { Evaluation }\end{array}$ & Context & $\begin{array}{l}\text { SHPO } \\
\text { Concur }\end{array}$ & Section 106 Status & Status & $\begin{array}{c}\text { Property } \\
\text { Type } \\
\text { Category }\end{array}$ & Condition & Owner \\
\hline CPP-1612 & Pond-326 Pump House & 1985 & Not Eligible & Multi-Prog & Yes & NA & Demolished & NA & NA & NA \\
\hline CPP-1615 & Service Building for Bin Set VII & 1990 & Not Eligible & Multi-Prog & Yes & NA & Operating & NA & NA & EM \\
\hline CPP-1616 & Glass Shop Storage Building & 1986 & Not Eligible & Multi-Prog & Yes & NA & Demolished & NA & NA & NA \\
\hline CPP-1617 & Waste Staging Building & 1986 & Not Eligible & Multi-Prog & Yes & NA & Operating & NA & NA & EM \\
\hline CPP-1618 & $\begin{array}{l}\text { Liquid Effluent Treatment and Disposal } \\
\text { Building }\end{array}$ & 1990 & Not Eligible & Multi-Prog & Yes & NA & Operating & NA & NA & EM \\
\hline CPP-1619 & $\begin{array}{l}\text { Hazardous Chemical/Radioactive Waste } \\
\text { Facility }\end{array}$ & 1989 & Not Eligible & Multi-Prog & Yes & NA & Operating & NA & NA & EM \\
\hline CPP-1630 & Fire Protection Building & 1987 & Not Eligible & Multi-Prog & Yes & NA & Demolished & NA & NA & NA \\
\hline CPP-1631 & Production Computer Support Building & 1989 & Not Eligible & Multi-Prog & Yes & NA & Operating & NA & NA & EM \\
\hline CPP-1634 & FDP Pilot Plant & 1995 & Not Eligible & Multi-Prog & Yes & NA & Operating & NA & NA & EM \\
\hline CPP-1635 & Hazardous Chemical Storage Facility & 1992 & Not Eligible & Multi-Prog & Yes & NA & Operating & NA & NA & EM \\
\hline СРP-1636 & Contractors Warehouse FPR & 1989 & Not Eligible & Multi-Prog & Yes & NA & Operating & NA & NA & EM \\
\hline CPP-1637 & Weld Fabrication Shop FPR & 1989 & Not Eligible & Multi-Prog & Yes & NA & Operating & NA & NA & EM \\
\hline СРP-1638 & Carpenter Shop FPR & 1989 & Not Eligible & Multi-Prog & Yes & NA & Operating & NA & NA & EM \\
\hline CPP-1642 & Fire Pump House & 1992 & Not Eligible & Multi-Prog & Yes & NA & Operating & NA & NA & EM \\
\hline СРP-1643 & Fire Pump House & 1992 & Not Eligible & Multi-Prog & Yes & NA & Operating & NA & NA & EM \\
\hline CPP-1644 & Bulk Chemical Unloading & 1991 & Not Eligible & Multi-Prog & Yes & NA & Operating & NA & NA & EM \\
\hline СРP-1646 & $\begin{array}{l}\text { Anti-C Safety Handling Equipment } \\
\text { Facility }\end{array}$ & 1992 & Not Eligible & Multi-Prog & Yes & NA & Operating & NA & NA & EM \\
\hline СРP-1647 & $\begin{array}{l}\text { Demineralizer Waste Neutralizing } \\
\text { Facility }\end{array}$ & 1993 & Not Eligible & Multi-Prog & Yes & NA & Operating & NA & NA & EM \\
\hline СРP-1649 & $\begin{array}{l}\text { Instrument Storage and Maintenance } \\
\text { Facility }\end{array}$ & 1991 & Not Eligible & Multi-Prog & Yes & NA & Operating & NA & NA & EM \\
\hline CPP-1650 & Training Support Facility & 1991 & Not Eligible & Multi-Prog & Yes & NA & Operating & NA & NA & EM \\
\hline CPP-1651 & Operations Training Facility & 1994 & Not Eligible & Multi-Prog & Yes & NA & Operating & NA & NA & EM \\
\hline
\end{tabular}


Table 8. (continued).

\begin{tabular}{|c|c|c|c|c|c|c|c|c|c|c|}
\hline \multicolumn{11}{|c|}{ Surveyed INL Architectural Properties } \\
\hline $\begin{array}{c}\text { Building or } \\
\text { Structure } \\
\text { ID }\end{array}$ & Building or Structure Name & $\begin{array}{l}\text { Date } \\
\text { Built }\end{array}$ & $\begin{array}{c}\text { National } \\
\text { Register } \\
\text { Evaluation }\end{array}$ & Context & $\begin{array}{l}\text { SHPO } \\
\text { Concur }\end{array}$ & Section 106 Status & Status & $\begin{array}{c}\text { Property } \\
\text { Type } \\
\text { Category }\end{array}$ & Condition & \\
\hline CPP-1653 & Contractors Warehouse FPR & 1991 & Not Eligible & Multi-Prog & Yes & NA & Operating & NA & NA & EM \\
\hline CPP-1656 & Comstock Office/Warehouse & 1991 & Not Eligible & Multi-Prog & Yes & NA & Operating & NA & NA & EM \\
\hline CPP-1657 & $\begin{array}{l}\text { Hazardous Waste Temporary } \\
\text { Accumulation Area }\end{array}$ & 1991 & Not Eligible & Multi-Prog & Yes & NA & Removed & NA & NA & NA \\
\hline CPP-1659 & $\begin{array}{l}\text { Contaminated Equipment Maintenance } \\
\text { Building }\end{array}$ & 1994 & Not Eligible & Multi-Prog & Yes & NA & Operating & NA & NA & EM \\
\hline CPP-1662 & $\begin{array}{l}\text { Remote Inspection and Alarm System } \\
\text { Facility }\end{array}$ & 1993 & Not Eligible & Multi-Prog & Yes & NA & Operating & NA & NA & EM \\
\hline СРP-1663 & $\begin{array}{l}\text { Security and Fire Protection Support } \\
\text { Facility }\end{array}$ & 1993 & Not Eligible & Multi-Prog & Yes & NA & Operating & NA & NA & EM \\
\hline СРP-1666 & Office Building & 1993 & Not Eligible & Multi-Prog & Yes & NA & Operating & NA & NA & EM \\
\hline CPP-1671 & Protective Force Support Facility & 1994 & Not Eligible & Multi-Prog & Yes & NA & Operating & NA & NA & EM \\
\hline CPP-1672 & Access Control Building & 1993 & Not Eligible & Multi-Prog & Yes & NA & Operating & NA & NA & EM \\
\hline CPP-1673 & Utility Control Center & 1994 & Not Eligible & Multi-Prog & Yes & NA & Operating & NA & NA & EM \\
\hline CPP-1674 & SNM Vault Guardhouse & 1993 & Not Eligible & Multi-Prog & Yes & NA & Operating & NA & NA & EM \\
\hline CPP-1676 & Oil Hazardous Materials Building & 1994 & Not Eligible & Multi-Prog & Yes & NA & Operating & NA & NA & EM \\
\hline СРP-1677 & Change Room & 1993 & Not Eligible & Multi-Prog & Yes & NA & Demolished & NA & NA & EM \\
\hline СРP-1678 & $\begin{array}{l}\text { Industrial Contractors Lunch } \\
\text { Room/Shop }\end{array}$ & 1993 & Not Eligible & Multi-Prog & Yes & NA & Operating & NA & NA & EM \\
\hline CPP-1681 & Box Staging Area & 1994 & Not Eligible & Multi-Prog & Yes & NA & Operating & NA & NA & EM \\
\hline CPP-1682 & Kerosene Pump House & 1994 & Not Eligible & Multi-Prog & Yes & NA & Operating & NA & NA & EM \\
\hline CPP-1683 & $\begin{array}{l}\text { New Control Room for Waste } \\
\text { Operations }\end{array}$ & ca.1994 & Not Eligible & Multi-Prog & Yes & NA & Operating & NA & NA & EM \\
\hline CPP-1684 & Standby Generator Facility & 2000 & Not Eligible & Multi-Prog & Yes & NA & Operating & NA & NA & EM \\
\hline CPP-1686 & Access Control Building & 2000 & Not Eligible & Multi-Prog & Yes & NA & Operating & NA & NA & EM \\
\hline СРP-1689 & SSSTF Administration Building & 2003 & Not Eligible & Multi-Prog & Yes & NA & Operating & NA & NA & EM \\
\hline СРP-ТB-1 & MK Carpenter Shop & 1980 & Not Eligible & Multi-Prog & Yes & NA & Operating & NA & NA & EM \\
\hline
\end{tabular}


Table 8. (continued).

\begin{tabular}{|c|c|c|c|c|c|c|c|c|c|c|}
\hline \multicolumn{11}{|c|}{ Surveyed INL Architectural Properties } \\
\hline $\begin{array}{l}\text { Building or } \\
\text { Structure } \\
\text { ID }\end{array}$ & Building or Structure Name & $\begin{array}{l}\text { Date } \\
\text { Built }\end{array}$ & $\begin{array}{c}\text { National } \\
\text { Register } \\
\text { Evaluation }\end{array}$ & Context & $\begin{array}{l}\text { SHPO } \\
\text { Concur }\end{array}$ & Section 106 Status & Status & $\begin{array}{c}\text { Property } \\
\text { Type } \\
\text { Category }\end{array}$ & Condition & Owner \\
\hline CPP-TB-3 & FPR East Guard Gate & 1985 & Not Eligible & Multi-Prog & Yes & NA & Operating & NA & NA & EM \\
\hline CPP-TB-4 & Craft Building & 1984 & Not Eligible & Multi-Prog & Yes & NA & Demolished & NA & NA & NA \\
\hline СРP-ТВ-5 & Unloading Station & 1985 & Not Eligible & Multi-Prog & Yes & NA & Demolished & NA & NA & EM \\
\hline CPP-TB-6 & Quality Office Building & 1981 & Not Eligible & Multi-Prog & Yes & NA & Demolished & NA & NA & NA \\
\hline CPP-TB-8 & Quality Assurance Storage Shed & 1986 & Not Eligible & Multi-Prog & Yes & NA & Demolished & NA & NA & NA \\
\hline CPP T-1 & Contractors Office Space & 1965 & Eligible & NRT & Yes & Programmatic Agreement & Demolished & 3 & NA & NA \\
\hline СРP-T-2 & Temporary Storage Building & 1980 & Not Eligible & Multi-Prog & Yes & NA & Demolished & NA & NA & NA \\
\hline СРР-Т-3 & Temporary Storage Building & 1980 & Not Eligible & Multi-Prog & Yes & NA & Demolished & NA & NA & NA \\
\hline СРP-Т-5 & Contractors Office Space & 1965 & Eligible & NRT & Yes & Programmatic Agreement & Demolished & 3 & NA & NA \\
\hline \multicolumn{11}{|c|}{ Experimental Breeder Reactor I (EBR-I) } \\
\hline EBR-601 & Reactor Building and Annex & 1950 & Listed & NRT & Yes & National Historic Land Mark & Operating & Signature & Fair & NE \\
\hline EBR-602 & Security Control House & 1950 & Eligible & NRT & Yes & SHPO letter 2002 SAT grant & Shutdown & Signature & UK & NE \\
\hline \multicolumn{11}{|c|}{ Critical Infrastructure Test Range Complex (CITRC; formerly PBF) } \\
\hline PBF-601 & Office Buildings (Control Building) & 1955 & Eligible & NRT & Yes & HAER ID-33-F & Demolished & 2 & NA & NA \\
\hline PBF-602 & Pump House (Well No. 1) & 1955 & Exempt & Multi-Prog & Yes & NA & Operating & NA & NA & $\mathrm{NE}$ \\
\hline PBF-604 & Terminal Building (SPERT 1) & 1955 & Eligible & NRT & Yes & HAER ID-33-F & Demolished & 3 & NA & NA \\
\hline PBF-606 & Instrument Cell & ca. 1955 & Eligible & NRT & Yes & HAER ID-33-F & Demolished & 2 & NA & NA \\
\hline PBF-608 & Electrical Substation Control House & 1957 & Exempt & Multi-Prog & Yes & NA & Operating & NA & NA & NE \\
\hline PBF-609 & $\begin{array}{l}\text { WERF Building (former SPERT III } \\
\text { Reactor Building) }\end{array}$ & 1957 & Eligible & NRT & Yes & $\begin{array}{l}\text { No MOA Equip. removal, } \\
\text { photos taken }\end{array}$ & Operating & 1 & UK & NE \\
\hline PBF-610 & Guard House & UK & Not Assessed & NRT & No & No MOA & Demolished & NA & NA & NA \\
\hline PBF-611 & Guard House & 1960 & Not Assessed & NRT & No & No MOA & Demolished & NA & NA & NA \\
\hline PBF-612 & WEDF (former SPERT II) & 1959 & Eligible & NRT & Yes & Programmatic Agreement & Operating & 1 & Excellent & NE \\
\hline PBF-613 & $\begin{array}{l}\text { Mixed Waste Storage Facility (former } \\
\text { SPERT IV) }\end{array}$ & 1960 & Eligible & $\begin{array}{l}\text { Waste } \\
\text { NRT }\end{array}$ & Yes & Programmatic Agreement & Operating & 1 & Excellent & NE \\
\hline
\end{tabular}


Table 8. (continued).

\begin{tabular}{|c|c|c|c|c|c|c|c|c|c|c|}
\hline \multicolumn{11}{|c|}{ Surveyed INL Architectural Properties } \\
\hline $\begin{array}{c}\text { Building or } \\
\text { Structure } \\
\text { ID }\end{array}$ & Building or Structure Name & $\begin{array}{l}\text { Date } \\
\text { Built }\end{array}$ & $\begin{array}{c}\text { National } \\
\text { Register } \\
\text { Evaluation }\end{array}$ & Context & $\begin{array}{l}\text { SHPO } \\
\text { Concur }\end{array}$ & Section 106 Status & Status & $\begin{array}{c}\text { Property } \\
\text { Type } \\
\text { Category }\end{array}$ & Condition & Owner \\
\hline PBF-614 & Pump House (Well No. 2) & 1960 & Exempt & Multi-Prog & Yes & NA & Operating & NA & NA & NE \\
\hline PBF-616 & Storage Building & 1967 & Eligible & Multi-Prog & Yes & HAER ID-33-F & Demolished & 3 & UK & NA \\
\hline PBF-617 & Fuel Storage Building & 1962 & Eligible & Multi-Prog & Yes & HAER ID-33-F & Demolished & 3 & UK & NA \\
\hline PBF-619 & PBF Control Building/Instrument Shop & 1955 & Eligible & NRT & Yes & HAER ID-33-F & Shutdown & 2 & UK & $\mathrm{NE}$ \\
\hline PBF-620 & PBF Reactor Building & 1966 & Eligible & NRT & Yes & HAER ID-33-F & $\begin{array}{l}\text { Awaiting } \\
\text { final DD\&D }\end{array}$ & 1 & UK & EM \\
\hline PBF-621 & Emergency Generator Building & ca 1958 & Exempt & Multi-Prog & Yes & NA & Demolished & NA & NA & NA \\
\hline PBF-622 & WERF Compaction and Sizing Facility & 1989 & Not Eligible & Waste & Yes & NA & Operating & NA & NA & NE \\
\hline PBF-623 & WERF Waste Storage Building & 1991 & Not Eligible & Waste & Yes & NA & Operating & NA & NA & $\mathrm{NE}$ \\
\hline PBF-624 & Auxiliary Building & 1973 & Not Eligible & Multi-Prog & Yes & NA & Demolished & NA & NA & NA \\
\hline PBF-625 & PBF Maintenance and Storage Building & 1966 & Eligible & Multi-Prog & Yes & Programmatic Agreement & Demolished & 3 & NA & NA \\
\hline PBF-626 & Storage Building and (Pump House) & 1972 & Exempt & Multi-Prog & Yes & NA & Demolished & NA & NA & NA \\
\hline PBF-627 & Gas Cylinder Storage Facility & 1966 & Eligible & Multi-Prog & Yes & HAER ID-33-F & Demolished & 3 & NA & NA \\
\hline PBF-629 & PBF Stack Gas Monitor Building & 1981 & Exempt & Multi-Prog & Yes & NA & Demolished & NA & NA & NA \\
\hline PBF-632 & WROC Office Building & 1980 & Not Eligible & Waste & Yes & NA & Operating & NA & NA & $\mathrm{NE}$ \\
\hline PBF-634 & PBF Firewater Pump House & 1983 & Exempt & Multi-Prog & Yes & NA & Demolished & NA & NA & NA \\
\hline PBF-635 & WERF Storage Building & 1981 & Not Eligible & Multi-Prog & Yes & NA & Demolished & NA & NA & NA \\
\hline PBF-638 & $\begin{array}{l}\text { Potable Water and Fire Water Pump } \\
\text { House }\end{array}$ & 1995 & Exempt & Multi-Prog & Yes & NA & Operating & NA & NA & NE \\
\hline PBF-641 & $\begin{array}{l}\text { Waste Reduction Operations Complex } \\
\text { Offices }\end{array}$ & 1993 & Not Eligible & Waste & Yes & NA & Operating & NA & NA & $\mathrm{NE}$ \\
\hline \multicolumn{11}{|c|}{ Security Training Facility (STF) } \\
\hline STF-601 & $\begin{array}{l}\text { Security Training Facility (former } \\
\text { EOCR reactor building.) }\end{array}$ & 1961 & Eligible & NRT & Yes & MOA photos taken & Demolished & NA & NA & NA \\
\hline STF-602 & Fuel \& Diesel Oil Pump House & 1962 & Not Assessed & NRT & No & NA & Demolished & NA & NA & NA \\
\hline STF-604 & Fire Water Pump House & 1962 & Not Assessed & NRT & No & NA & Demolished & NA & NA & NA \\
\hline
\end{tabular}


Table 8. (continued).

\begin{tabular}{|c|c|c|c|c|c|c|c|c|c|c|}
\hline \multicolumn{11}{|c|}{ Surveyed INL Architectural Properties } \\
\hline $\begin{array}{c}\text { Building or } \\
\text { Structure } \\
\text { ID }\end{array}$ & Building or Structure Name & $\begin{array}{l}\text { Date } \\
\text { Built }\end{array}$ & $\begin{array}{c}\text { National } \\
\text { Register } \\
\text { Evaluation }\end{array}$ & Context & $\begin{array}{l}\text { SHPO } \\
\text { Concur }\end{array}$ & Section 106 Status & Status & $\begin{array}{c}\text { Property } \\
\text { Type } \\
\text { Category }\end{array}$ & Condition & \\
\hline STF-605 & Deep Well Pump House & 1961 & Eligible & NRT & Yes & MOA photos taken & Demolished & NA & NA & NA \\
\hline STF-606 & Solvent Storage Pump House & 1962 & Not Assessed & NRT & No & NA & Demolished & NA & NA & NA \\
\hline STF-607 & Deluge Valve House & 1961 & Eligible & NRT & Yes & MOA photos taken & Demolished & NA & NA & NA \\
\hline STF-609 & Wash Station \& Hose House & 1962 & Not Assessed & NRT & No & NA & Demolished & NA & NA & NA \\
\hline STF-610 & Fuel Elements and Flow Test Facility & 1961 & Eligible & NRT & Yes & MOA photos taken & Demolished & NA & NA & NA \\
\hline STF-611 & Pump House (old OMRE-601) & 1961 & Eligible & NRT & Yes & MOA photos taken & Demolished & NA & NA & NA \\
\hline STF-612 & STF Shooting House & 1962 & Not Assessed & NRT & No & NA & Demolished & NA & NA & NA \\
\hline \multicolumn{11}{|c|}{ Test Area North (TAN) } \\
\hline TAN-601 & Guardhouse & 1956 & Eligible & NRT & Yes & HAER ID-33-E & Operating & 3 & Adequate & NE \\
\hline TAN-602 & Administration Building & 1956 & Eligible & Multi-Prog & Yes & HAER ID-33-E & Demolished & 3 & NA & NA \\
\hline TAN-603 & Service Building & 1956 & Eligible & NRT & Yes & $\begin{array}{l}\text { Programmatic Agreement - } \\
35 \mathrm{~mm} \text { photos completed }\end{array}$ & Demolished & 3 & UK & EM \\
\hline TAN-604 & Maintenance Shop & 1956 & Eligible & NRT & Yes & HAER ID-33-E & Demolished & 3 & NA & NA \\
\hline TAN-605 & Substation Control House & 1956 & Exempt & NRT & Yes & NA & Operating & NA & NA & NE \\
\hline TAN-606 & Carpenter Shop & 1956 & Eligible & NRT & Yes & HAER ID-33-E & Demolished & 3 & NA & NA \\
\hline TAN-607 & $\begin{array}{l}\text { Hot Shop/Manufacturing \& Assembly } \\
\text { building }\end{array}$ & 1955 & Eligible & NRT & Yes & MOA - HAER ID-33-E & Demolished & Signature & NA & EM \\
\hline TAN-608 & Water Filter Building & 1955 & Exempt & Multi-Prog & Yes & NA & Demolished & NA & NA & NA \\
\hline TAN-609 & Equipment Maintenance Shop & 1956 & Eligible & NRT & Yes & HAER ID-33-E & Demolished & 3 & NA & NA \\
\hline TAN-610 & Water Pump House & 1956 & Exempt & Multi-Prog & Yes & NA & Operating & NA & NA & NE \\
\hline TAN-611 & Fuel Pump House & 1956 & Exempt & Multi-Prog & Yes & NA & Demolished & NA & NA & EM \\
\hline TAN-612 & Deep Well Pump House \#1 & 1956 & Exempt & Multi-Prog & Yes & NA & Operating & NA & NA & $\mathrm{NE}$ \\
\hline TAN-613 & Deep Well Pump House \#2 & 1956 & Exempt & Multi-Prog & Yes & NA & Operating & NA & NA & $\mathrm{NE}$ \\
\hline TAN-614 & Water Pump House & 1965 & Exempt & Multi-Prog & Yes & NA & Operating & NA & NA & $\mathrm{NE}$ \\
\hline TAN-615 & Assembly and Maintenance Building & 1956 & Eligible & NRT & Yes & HAER ID-33-E & Demolished & NA & NA & NA \\
\hline
\end{tabular}


Table 8. (continued).

\begin{tabular}{|c|c|c|c|c|c|c|c|c|c|c|}
\hline \multicolumn{11}{|c|}{ Surveyed INL Architectural Properties } \\
\hline $\begin{array}{l}\text { Building or } \\
\text { Structure } \\
\text { ID }\end{array}$ & Building or Structure Name & $\begin{array}{l}\text { Date } \\
\text { Built }\end{array}$ & $\begin{array}{c}\text { National } \\
\text { Register } \\
\text { Evaluation }\end{array}$ & Context & $\begin{array}{l}\text { SHPO } \\
\text { Concur }\end{array}$ & Section 106 Status & Status & $\begin{array}{c}\text { Property } \\
\text { Type } \\
\text { Category }\end{array}$ & Condition & Owner \\
\hline TAN-616 & Liquid Waste Treatment Plant & 1955 & Eligible & Multi-Prog & Yes & HAER ID-33-E & Demolished & 2 & UK & EM \\
\hline TAN-618 & Data Collection Building & 1987 & Not Eligible & Multi-Prog & Yes & NA & Demolished & NA & NA & NA \\
\hline TAN-620 & Control and Equipment Building & 1956 & Eligible & NRT & Yes & HAER ID-33-E & Demolished & NA & NA & NA \\
\hline TAN-621 & Guardhouse (IET area) & ca. 1955 & Eligible & NRT & Yes & HAER ID-33-E & Demolished & NA & NA & NA \\
\hline TAN-622 & Unit Substation (IET area) & ca. 1955 & Exempt & Multi-Prog & Yes & HAER ID-33-E & Demolished & NA & NA & NA \\
\hline TAN-623 & Sewage Pump House & 1954 & Exempt & Multi-Prog & Yes & NA & Demolished & NA & NA & EM \\
\hline TAN-624 & Containment Building Entryway & 1959 & Eligible & NRT & Yes & HAER ID-33-E & Demolished & 2 & NA & NA \\
\hline TAN-625 & Fuel Pump Station (IET area) & ca. 1955 & Eligible & Multi-Prog & Yes & HAER ID-33-E & Demolished & NA & NA & NA \\
\hline TAN-626 & Chlorination Building (IET area) & ca. 1955 & Exempt & Multi-Prog & Yes & HAER ID-33-E & Demolished & NA & NA & NA \\
\hline TAN-627 & Tank Building (IET area) & ca. 1955 & Eligible & Multi-Prog & Yes & HAER ID-33-E & Demolished & NA & NA & NA \\
\hline TAN-628 & Warehouse & 1956 & Eligible & NRT & Yes & Programmatic Agreement & Demolished & 3 & NA & NA \\
\hline TAN-629 & $\begin{array}{l}\text { Warehouse Receiving Building (The } \\
\text { Hanger) }\end{array}$ & 1959 & Eligible & NRT & Yes & MOA - HAER ID-33-A & Operating & Signature & Good & NE \\
\hline TAN-630 & Control and Equipment Building & 1959 & Eligible & NRT & Yes & MOA - HAER ID-33-E & Demolished & Signature & NA & NA \\
\hline TAN-631 & Tank Building & 1959 & Eligible & NRT & Yes & HAER ID-33-E & Demolished & 3 & NA & NA \\
\hline TAN-632 & Pump House (Well \#1) & 1954 & Exempt & Multi-Prog & Yes & NA & Operating & NA & NA & $\mathrm{NE}$ \\
\hline TAN-633 & Hot Cell Annex & 1954 & Eligible & NRT & Yes & HAER ID-33-E & Demolished & 2 & NA & NA \\
\hline TAN-635 & Continuous Air Monitor Building & 1979 & Exempt & Multi-Prog & Yes & NA & Demolished & NA & NA & NA \\
\hline TAN-636 & Carpenter and Paint Shop & 1967 & Eligible & NRT & Yes & HAER ID-33-E & Demolished & 3 & NA & NA \\
\hline TAN-637 & Compressor Building & 1958 & Exempt & NRT & Yes & NA & Demolished & 3 & NA & NA \\
\hline TAN-638 & Guardhouse & 1957 & Eligible & NRT & Yes & HAER ID-33-E & Demolished & NA & NA & NA \\
\hline TAN-639 & Pump House (Well \#2) & 1954 & Exempt & Multi-Prog & Yes & NA & Operating & NA & NA & $\mathrm{NE}$ \\
\hline TAN-640 & Assembly and Test Building & 1958 & Eligible & NRT & Yes & HAER ID-33-E & Demolished & 2 & NA & NA \\
\hline TAN-641 & Control and Equipment Building & 1958 & Eligible & NRT & Yes & HAER ID-33-E & Demolished & 2 & NA & NA \\
\hline TAN-642 & Area Gatehouse & 1957 & Eligible & NRT & Yes & HAER ID-33-E & Demolished & 3 & NA & NA \\
\hline
\end{tabular}


Table 8. (continued).

\begin{tabular}{|c|c|c|c|c|c|c|c|c|c|c|}
\hline \multicolumn{11}{|c|}{ Surveyed INL Architectural Properties } \\
\hline $\begin{array}{c}\text { Building or } \\
\text { Structure } \\
\text { ID }\end{array}$ & Building or Structure Name & $\begin{array}{l}\text { Date } \\
\text { Built }\end{array}$ & $\begin{array}{c}\text { National } \\
\text { Register } \\
\text { Evaluation }\end{array}$ & Context & $\begin{array}{l}\text { SHPO } \\
\text { Concur }\end{array}$ & Section 106 Status & Status & $\begin{array}{c}\text { Property } \\
\text { Type } \\
\text { Category }\end{array}$ & Condition & Owner \\
\hline TAN-643 & Chlorination Building & 1957 & Exempt & Multi-Prog & Yes & NA & Demolished & NA & NA & NA \\
\hline TAN-644 & Well Pump House & 1957 & Exempt & Multi-Prog & Yes & NA & Demolished & NA & NA & NA \\
\hline TAN-645 & Control and Administration Building & 1960 & Eligible & NRT & Yes & HAER ID-33-E & Demolished & 3 & NA & NA \\
\hline TAN-646 & Assembly and Test Building & 1965 & Eligible & NRT & Yes & HAER ID-33-E & Demolished & 1 & NA & NA \\
\hline TAN-647 & Containment Storage Building & 1960 & Eligible & NRT & Yes & HAER ID-33-E & Demolished & 2 & NA & NA \\
\hline TAN-648 & Storage Building & 1960 & Eligible & NRT & Yes & HAER ID-33-E & Demolished & 3 & NA & NA \\
\hline TAN-649 & Water Filtration Building & 1956 & Exempt & Multi-Prog & Yes & NA & Demolished & NA & NA & NA \\
\hline TAN-650 & $\begin{array}{l}\text { Containment and Service Building } \\
\text { LOFT Dome }\end{array}$ & 1973 & Eligible & NRT & Yes & MOA - HAER ID-33-E & Demolished & Signature & NA & NA \\
\hline TAN-651 & Heat Stress Relief Structure & 1969 & Eligible & NRT & Yes & HAER ID-33-E & Demolished & 3 & NA & NA \\
\hline TAN-652 & Fire Protection Pump House & 1965 & Exempt & Multi-Prog & Yes & NA & Demolished & NA & NA & NA \\
\hline TAN-653 & Multi-craft Shop & 1985 & Not Eligible & Multi-Prog & Yes & NA & Demolished & NA & NA & NA \\
\hline TAN-654 & Storage Building & 1986 & Not Eligible & Multi-Prog & Yes & NA & Demolished & NA & NA & NA \\
\hline TAN-655 & Liquid Waste Lift Station & 1975 & Not Eligible & Multi-Prog & Yes & NA & Demolished & NA & NA & EM \\
\hline TAN-656 & Change Room (IET area) & ca. 1960 & Eligible & NRT & Yes & HAER ID-33-E & Demolished & NA & NA & NA \\
\hline TAN-657 & Heat Stress Control Building & 1969 & Eligible & Multi-Prog & Yes & HAER ID-33-E & Demolished & 3 & NA & NA \\
\hline TAN-658 & Storage Building & 1962 & Eligible & NRT & Yes & Programmatic Agreement & Operating & 3 & Excellent & $\mathrm{NE}$ \\
\hline TAN-659 & Control Shelter & 1976 & Exempt & Multi-Prog & Yes & NA & Demolished & NA & NA & NA \\
\hline TAN-660 & Maintenance Staging Building & 1976 & Not Eligible & Multi-Prog & No & NA & Demolished & NA & NA & NA \\
\hline TAN-661 & Control House for Turntable & 1970 & Eligible & Multi-Prog & Yes & HAER ID-33-E & Demolished & NA & NA & NA \\
\hline TAN-662 & Gas Cylinder and Oil Storage & 1978 & Not Eligible & Multi-Prog & Yes & NA & Demolished & NA & NA & NA \\
\hline TAN-663 & Continuous Air Monitor Building & 1979 & Exempt & Multi-Prog & Yes & NA & Demolished & NA & NA & NA \\
\hline TAN-664 & Automotive Service Attendant Building & 1954 & Eligible & NRT & Yes & Programmatic Agreement & Operating & 3 & Poor & $\mathrm{NE}$ \\
\hline TAN-665 & Fire Water Pump House & 1980 & Exempt & Multi-Prog & Yes & NA & Operating & NA & NA & $\mathrm{NE}$ \\
\hline
\end{tabular}


Table 8. (continued).

\begin{tabular}{|c|c|c|c|c|c|c|c|c|c|c|}
\hline \multicolumn{11}{|c|}{ Surveyed INL Architectural Properties } \\
\hline $\begin{array}{l}\text { Building or } \\
\text { Structure } \\
\text { ID }\end{array}$ & Building or Structure Name & $\begin{array}{l}\text { Date } \\
\text { Built }\end{array}$ & $\begin{array}{c}\text { National } \\
\text { Register } \\
\text { Evaluation }\end{array}$ & Context & $\begin{array}{l}\text { SHPO } \\
\text { Concur }\end{array}$ & Section 106 Status & Status & $\begin{array}{c}\text { Property } \\
\text { Type } \\
\text { Category }\end{array}$ & Condition & Owner \\
\hline TAN-666 & $\begin{array}{l}\text { Radioactive Liquid Waste Transfer and } \\
\text { Storage }\end{array}$ & 1980 & Not Eligible & Multi-Prog & Yes & NA & Demolished & NA & NA & NA \\
\hline TAN-667 & Small Machine Shop & 1983 & Not Eligible & Multi-Prog & Yes & NA & Demolished & NA & NA & NA \\
\hline TAN-668 & Heavy Equipment Cleaning Facility & 1985 & Not Eligible & Multi-Prog & Yes & NA & Demolished & NA & NA & EM \\
\hline TAN-669 & Non-Radioactive Storage Building & UK & Not Eligible & Multi-Prog & No & NA & Demolished & NA & NA & NA \\
\hline TAN-670 & Chlorine Treatment Building & 1954 & Not Eligible & Multi-Prog & Yes & NA & Demolished & NA & NA & NA \\
\hline TAN-671 & Office Trailer, North & 1979 & Not Eligible & Multi-Prog & Yes & NA & Operating & NA & NA & NE \\
\hline TAN-672 & Office Trailer, South & 1979 & Not Eligible & Multi-Prog & Yes & NA & Operating & NA & NA & NE \\
\hline TAN-673 & Office Trailer, West & 1979 & Not Eligible & Multi-Prog & No & NA & Demolished & NA & NA & NA \\
\hline TAN-674 & Office Complex & 1979 & Not Eligible & Multi-Prog & No & NA & Demolished & NA & NA & NA \\
\hline TAN-675 & Phase I Utility Building & 1984 & Not Eligible & Multi-Prog & Yes & NA & Operating & NA & NA & $\mathrm{NE}$ \\
\hline TAN-676 & Security Guard Building & 1985 & Not Eligible & Multi-Prog & Yes & NA & Operating & NA & NA & NE \\
\hline TAN-677 & Truck Docking Building & 1974 & Not Eligible & Multi-Prog & Yes & NA & Operating & NA & NA & NE \\
\hline TAN-678 & Cafeteria \#2 & 1985 & Not Eligible & Multi-Prog & Yes & NA & Operating & NA & NA & NE \\
\hline TAN-679 & Manufacturing and Assembly & 1986 & Not Eligible & Multi-Prog & Yes & NA & Operating & NA & NA & NE \\
\hline TAN-680 & Bus Fuel Pump Station Control Building & 1985 & Not Eligible & Multi-Prog & Yes & NA & Operating & NA & NA & $\mathrm{NE}$ \\
\hline TAN-681 & Waste Treatment Building & 1986 & Reassess & Multi-Prog & Yes & NA & Operating & TBD & Adequate & $\mathrm{NE}$ \\
\hline TAN-682 & Storage Building & 1986 & Not Eligible & Multi-Prog & Yes & NA & Operating & NA & NA & $\mathrm{NE}$ \\
\hline TAN-683 & Storage Building & 1987 & Not Eligible & Multi-Prog & No & NA & Demolished & NA & NA & NA \\
\hline TAN-684 & Storage Building & 1987 & Not Eligible & Multi-Prog & No & NA & Demolished & NA & NA & NA \\
\hline TAN-686 & Secured Entry Trailers & 1987 & Not Eligible & Multi-Prog & Yes & NA & Demolished & NA & NA & NA \\
\hline TAN-687 & Fire Station & 1989 & Not Eligible & Multi-Prog & Yes & NA & Operating & NA & NA & $\mathrm{NE}$ \\
\hline TAN-688 & SMC Warehouse & 1986 & Not Eligible & Multi-Prog & Yes & NA & Operating & NA & NA & $\mathrm{NE}$ \\
\hline TAN-689 & Office Trailer & 1988 & Exempt & Multi-Prog & No & NA & Demolished & NA & NA & NA \\
\hline TAN-690 & Oil Storage Facility & 1976 & Not Eligible & Multi-Prog & Yes & NA & Operating & NA & NA & $\mathrm{NE}$ \\
\hline
\end{tabular}


Table 8. (continued).

\begin{tabular}{|c|c|c|c|c|c|c|c|c|c|c|}
\hline \multicolumn{11}{|c|}{ Surveyed INL Architectural Properties } \\
\hline $\begin{array}{l}\text { Building or } \\
\text { Structure } \\
\text { ID }\end{array}$ & Building or Structure Name & $\begin{array}{l}\text { Date } \\
\text { Built }\end{array}$ & $\begin{array}{c}\text { National } \\
\text { Register } \\
\text { Evaluation }\end{array}$ & Context & $\begin{array}{c}\text { SHPO } \\
\text { Concur }\end{array}$ & Section 106 Status & Status & $\begin{array}{c}\text { Property } \\
\text { Type } \\
\text { Category }\end{array}$ & Condition & Owner \\
\hline TAN-692 & Waste Storage Building & 1986 & Not Eligible & Multi-Prog & Yes & NA & Operating & NA & NA & NE \\
\hline TAN-693 & Paint Shop Building & 1988 & Not Eligible & Multi-Prog & Yes & NA & Operating & NA & NA & $\mathrm{NE}$ \\
\hline TAN-694 & Tank Storage Building & 1985 & Not Eligible & Multi-Prog & Yes & NA & Demolished & NA & NA & NA \\
\hline TAN-695 & Hazardous Material Storage Facility & 1992 & Not Eligible & Multi-Prog & Yes & NA & Demolished & NA & NA & NA \\
\hline TAN-1601 & Equipment Storage & 1995 & Not Eligible & Multi-Prog & Yes & NA & Demolished & NA & NA & NA \\
\hline TAN-1611 & Pump and Treatment Facility & 2000 & Not Assessed & Multi-Prog & Yes & NA & Operating & TBD & NA & EM \\
\hline TAN-1612 & Fire Water Pump House & 2000 & Exempt & Multi-Prog & Yes & NA & Operating & NA & NA & $\mathrm{NE}$ \\
\hline TAN-1613 & Chemical Storage Building & 2002 & Not Assessed & Multi-Prog & Yes & NA & Operating & TBD & NA & $\mathrm{NE}$ \\
\hline \multicolumn{11}{|c|}{ Reactor Technology Complex (RTC; formerly TRA) } \\
\hline TRA-601 & Deep Well Pump House No. 1 & 1952 & Exempt & Multi-Prog & Yes & NA & Operating & NA & NA & $\mathrm{NE}$ \\
\hline TRA-602 & Inactive Deep Well Pump House No. 2 & 1952 & Exempt & Multi-Prog & Yes & $\begin{array}{l}\text { Programmatic Agreement: } \\
\text { requirements met }\end{array}$ & Operating & NA & NA & $\mathrm{NE}$ \\
\hline TRA-603 & Materials Test Reactor Building & 1952 & Eligible & NRT & Yes & $\begin{array}{l}\text { Programmatic Agreement: } \\
\text { requirements met }\end{array}$ & $\begin{array}{l}\mathrm{D} \& \mathrm{D} \text { in } \\
\text { progress }\end{array}$ & Signature & UK & EM \\
\hline TRA-604 & MTR Building Wing A & 1952 & Eligible & NRT & Yes & Programmatic Agreement & Operating & 2 & Excellent & EM \\
\hline TRA-605 & Process Water Building & 1952 & Eligible & NRT & Yes & Programmatic Agreement & Operating & 2 & Excellent & $\mathrm{NE}$ \\
\hline TRA-607 & Carpenter Shop & 1952 & Eligible & NRT & Yes & Programmatic Agreement & Operating & 3 & Adequate & $\mathrm{NE}$ \\
\hline TRA-608 & Demineralizer Building & 1952 & Eligible & NRT & Yes & Programmatic Agreement & Operating & 3 & Good & $\mathrm{NE}$ \\
\hline TRA-609 & Steam Plant & 1952 & Eligible & NRT & Yes & Programmatic Agreement & Operating & 3 & Adequate & $\mathrm{NE}$ \\
\hline TRA-610 & MTR Fan House & 1952 & Eligible & NRT & Yes & Programmatic Agreement & Operating & 3 & Excellent & EM \\
\hline TRA-611 & Plug Storage Building & 1952 & Eligible & NRT & No & MOA conditions met & Demolished & 3 & NA & NA \\
\hline TRA-612 & Retention Sump Pump House & 1952 & Exempt & NRT & Yes & NA & Shutdown & NA & NA & $\mathrm{NE}$ \\
\hline TRA-613 & Sampling Station Radioactive Fluid & 1996 & Not Eligible & NRT & Yes & Programmatic Agreement & Shutdown & NA & NA & $\mathrm{NE}$ \\
\hline TRA-614 & $\begin{array}{l}\text { Maintenance Office Building/ } \\
\text { Bunkhouse }\end{array}$ & 1952 & Eligible & NRT & Yes & Programmatic Agreement & Operating & 3 & Fair & NE \\
\hline TRA-615 & Meteorological Instrument Building & 1970 & Exempt & Multi-Prog & Yes & NA & Shutdown & NA & NA & NE \\
\hline
\end{tabular}


Table 8. (continued).

\begin{tabular}{|c|c|c|c|c|c|c|c|c|c|c|}
\hline \multicolumn{11}{|c|}{ Surveyed INL Architectural Properties } \\
\hline $\begin{array}{l}\text { Building or } \\
\text { Structure } \\
\text { ID }\end{array}$ & Building or Structure Name & $\begin{array}{l}\text { Date } \\
\text { Built }\end{array}$ & $\begin{array}{c}\text { National } \\
\text { Register } \\
\text { Evaluation }\end{array}$ & Context & $\begin{array}{l}\text { SHPO } \\
\text { Concur }\end{array}$ & Section 106 Status & Status & $\begin{array}{c}\text { Property } \\
\text { Type } \\
\text { Category }\end{array}$ & Condition & Owner \\
\hline TRA-616 & Cafeteria & 1952 & Eligible & NRT & Yes & Programmatic Agreement & Operating & 3 & Fair & $\mathrm{NE}$ \\
\hline TRA-617 & Warehouse & 1952 & Not Assessed & Multi-Prog & No & No MOA & Demolished & NA & NA & NA \\
\hline TRA-618 & Warehouse & 1952 & Eligible & NRT & Yes & Programmatic Agreement & Demolished & 3 & NA & NA \\
\hline TRA-619 & Raw Water Pump House & 1952 & Exempt & Multi-Prog & Yes & NA & Operating & NA & NA & $\mathrm{NE}$ \\
\hline TRA-620 & Office Building & 1952 & Eligible & NRT & Yes & Programmatic Agreement & Operating & 3 & Fair & $\mathrm{NE}$ \\
\hline TRA-621 & $\begin{array}{l}\text { Nuclear Materials Inspection and } \\
\text { Storage }\end{array}$ & 1982 & Not Eligible & Multi-Prog & Yes & NA & Operating & NA & NA & $\mathrm{NE}$ \\
\hline TRA-622 & Cold Waste Handling Facility & 1952 & Eligible & NRT & Yes & Programmatic Agreement & Operating & 3 & Adequate & $\mathrm{NE}$ \\
\hline TRA-623 & Substation Control House & 1952 & Exempt & Multi-Prog & Yes & NA & Operating & NA & NA & $\mathrm{NE}$ \\
\hline TRA-624 & Sewage Treatment Building & 1981 & Not Eligible & Multi-Prog & No & NA & Demolished & NA & NA & NA \\
\hline TRA-625 & Maintenance Storage Building & 1981 & Not Eligible & Multi-Prog & Yes & NA & Operating & NA & NA & $\mathrm{NE}$ \\
\hline TRA-626 & Storage Building & 1952 & Eligible & NRT & Yes & Programmatic Agreement & Operating & 3 & UK & EM \\
\hline TRA-627 & Fuel Oil Pump House & 1952 & Exempt & Multi-Prog & Yes & NA & Operating & NA & NA & $\mathrm{NE}$ \\
\hline TRA-628 & TRA Office Building \#1 & 1986 & Not Eligible & Multi-Prog & Yes & NA & Operating & NA & NA & $\mathrm{NE}$ \\
\hline TRA-629 & Gas Cylinder Storage Building & 1956 & Eligible & NRT & Yes & Programmatic Agreement & Operating & 3 & Excellent & $\mathrm{NE}$ \\
\hline TRA-630 & Catch Tank Pump House & 1952 & Not Eligible & NRT & Yes & Remodeled after 1970 & Shutdown & NA & NA & EM \\
\hline TRA-631 & Acid and Caustic Pump House & 1952 & Exempt & Multi-Prog & Yes & NA & Shutdown & NA & NA & $\mathrm{NE}$ \\
\hline TRA-632 & Hot Cell Building & 1953 & Eligible & NRT & Yes & Programmatic Agreement & Operating & 2 & Good & $\mathrm{NE}$ \\
\hline TRA-633 & Diesel Firewater Pump House & 1980 & Exempt & Multi-Prog & Yes & NA & Operating & NA & NA & NE \\
\hline TRA-634 & ATR Storage Facility & 1982 & Not Eligible & Multi-Prog & Yes & NA & Operating & NA & NA & $\mathrm{NE}$ \\
\hline TRA-635 & Material Receiving Area and Lab & 1952 & Eligible & NRT & Yes & HAER-ID-33-G & Demolished & 2 & NA & EM \\
\hline TRA-636 & Retention Basin Inlet Sample House & 1952 & Eligible & NRT & Yes & Programmatic Agreement & Operating & 3 & Excellent & $\mathrm{NE}$ \\
\hline TRA-637 & Bunk House Trailer & 1979 & Not Eligible & Multi-Prog & Yes & NA & Demolished & NA & NA & NA \\
\hline TRA-638 & Training Office Trailer & 1979 & Not Eligible & Multi-Prog & Yes & NA & Operating & NA & NA & NE \\
\hline TRA-639 & Sodium Safety Equipment Storage & 1980 & Not Eligible & Multi-Prog & No & NA & Demolished & NA & NA & NA \\
\hline
\end{tabular}


Table 8. (continued).

\begin{tabular}{|c|c|c|c|c|c|c|c|c|c|c|}
\hline \multicolumn{11}{|c|}{ Surveyed INL Architectural Properties } \\
\hline $\begin{array}{c}\text { Building or } \\
\text { Structure } \\
\text { ID }\end{array}$ & Building or Structure Name & $\begin{array}{l}\text { Date } \\
\text { Built }\end{array}$ & $\begin{array}{c}\text { National } \\
\text { Register } \\
\text { Evaluation }\end{array}$ & Context & $\begin{array}{l}\text { SHPO } \\
\text { Concur }\end{array}$ & Section 106 Status & Status & $\begin{array}{c}\text { Property } \\
\text { Type } \\
\text { Category }\end{array}$ & Condition & Owner \\
\hline TRA-640 & Hazardous Chemical Storage Building & 1984 & Not Eligible & Multi-Prog & Yes & NA & Operating & NA & NA & $\mathrm{NE}$ \\
\hline TRA-641 & Gamma Building & 1955 & Eligible & NRT & Yes & MOA photos taken & Operating & 2 & Fair & $\mathrm{NE}$ \\
\hline TRA-642 & Engineering Test Reactor Building & 1957 & Eligible & NRT & Yes & HAER-ID-33-G & Demolished & 1 & NA & NE \\
\hline TRA-643 & ETR Services Building & 1957 & Eligible & NRT & Yes & HAER-ID-33-G & Demolished & 2 & NA & NA \\
\hline TRA-644 & ETR Heat Exchanger Building & 1957 & Eligible & NRT & Yes & HAER-ID-33-G & Demolished & 2 & NA & NE \\
\hline TRA-645 & Storage Building & 1957 & Eligible & Multi-Prog & Yes & MOA complete & Demolished & 3 & NA & NA \\
\hline TRA-647 & ETR Office Building & 1957 & Eligible & NRT & Yes & MOA conditions met & Demolished & 3 & NA & NA \\
\hline TRA-648 & ETR Electrical Building & 1957 & Eligible & NRT & Yes & HAER-ID-33-G & Demolished & 3 & NA & EM \\
\hline TRA-649 & MTR Office Building, Wing C & 1966 & Eligible & NRT & Yes & Programmatic Agreement & Operating & 3 & Adequate & NE \\
\hline TRA-650 & Deep Well Pump House (Well \#3) & 1960 & Exempt & Multi-Prog & Yes & NA & Operating & NA & NA & $\mathrm{NE}$ \\
\hline TRA-651 & Maintenance and Storage Building & 1960 & Eligible & NRT & Yes & MOA conditions met & Demolished & 3 & NA & NA \\
\hline TRA-652 & MTR Office Building, Wing B & 1966 & Eligible & NRT & Yes & Programmatic Agreement & Operating & 3 & Fair & NE \\
\hline TRA-653 & Maintenance Building & 1957 & Eligible & NRT & Yes & Programmatic Agreement & Operating & 3 & Good & NE \\
\hline TRA-654 & ETR Critical Facility & 1959 & Eligible & NRT & Yes & HAER-ID-33-G & Demolished & 2 & NA & EM \\
\hline TRA-655 & Storage Building & 1957 & Eligible & NRT & Yes & MOA conditions met & Demolished & 3 & NA & NA \\
\hline TRA-656 & Maintenance Storage Building & 1959 & Eligible & NRT & Yes & MOA conditions met & Demolished & 3 & NA & NA \\
\hline TRA-657 & $\begin{array}{l}\text { Material Test Reactor Plug Storage } \\
\text { Building }\end{array}$ & 1952 & Eligible & NRT & Yes & HAER-ID-33-G & Demolished & 3 & NA & EM \\
\hline TRA-658 & TRA Access Control Facility & 1987 & Not Eligible & Multi-Prog & Yes & NA & Operating & NA & NA & NE \\
\hline TRA-660 & $\begin{array}{l}\text { Advanced Reactivity Measurement } \\
\text { Facility }\end{array}$ & 1957 & Eligible & NRT & Yes & Programmatic Agreement & Operating & 2 & Good & $\mathrm{NE}$ \\
\hline TRA-661 & Alpha Lab & 1962 & Eligible & NRT & Yes & Programmatic Agreement & $\begin{array}{l}\text { D\&D in } \\
\text { progress }\end{array}$ & 2 & UK & EM \\
\hline TRA-662 & Receiving and Storage Building & 1961 & Eligible & NRT & Yes & Programmatic Agreement & Operating & 3 & UK & NE \\
\hline TRA-663 & Superior Diesel Building & 1957 & Eligible & NRT & Yes & MOA conditions met & Demolished & 3 & NA & NA \\
\hline TRA-664 & Hot Storage Building & 1961 & Eligible & NRT & Yes & MOA conditions met & Demolished & 3 & NA & NA \\
\hline
\end{tabular}


Table 8. (continued).

\begin{tabular}{|c|c|c|c|c|c|c|c|c|c|c|}
\hline \multicolumn{11}{|c|}{ Surveyed INL Architectural Properties } \\
\hline $\begin{array}{c}\text { Building or } \\
\text { Structure } \\
\text { ID }\end{array}$ & Building or Structure Name & $\begin{array}{l}\text { Date } \\
\text { Built }\end{array}$ & $\begin{array}{c}\text { National } \\
\text { Register } \\
\text { Evaluation }\end{array}$ & Context & $\begin{array}{c}\text { SHPO } \\
\text { Concur }\end{array}$ & Section 106 Status & Status & $\begin{array}{c}\text { Property } \\
\text { Type } \\
\text { Category }\end{array}$ & Condition & Owner \\
\hline TRA-665 & Storage Building & 1962 & Eligible & NRT & Yes & HAER-ID-33-G & Demolished & 3 & NA & EM \\
\hline TRA-666 & Hydraulic Test Facility and Tritium Lab & 1963 & Eligible & NRT & Yes & Programmatic Agreement & Operating & 2 & Adequate & NE \\
\hline TRA-666A & Tritium Lab & ca. 1963 & Eligible & Multi-Prog & Yes & Programmatic Agreement & Operating & 2 & Good & NE \\
\hline TRA-667 & Health and Safety Building (Dispensary) & 1964 & Eligible & NRT & Yes & Programmatic Agreement & Operating & 3 & Good & NE \\
\hline TRA-668 & MTR, North Wing Extension & 1956 & Eligible & NRT & Yes & Programmatic Agreement & Operating & 3 & Excellent & EM \\
\hline TRA-669 & Cold Storage Building & 1968 & Eligible & NRT & Yes & Programmatic Agreement & Operating & 3 & Excellent & NE \\
\hline TRA-670 & ATR Building & 1964 & Eligible & NRT & Yes & Programmatic Agreement & Operating & 1 & Excellent & NE \\
\hline TRA-671 & ATR Cooling Tower Pump House & 1971 & Eligible & NRT & Yes & Programmatic Agreement & Operating & 3 & Excellent & NE \\
\hline TRA-672 & Deep Well Pump House (Well \#4) & 1963 & Exempt & NRT & Yes & NA & Operating & NA & NA & NE \\
\hline TRA-673 & Storage Building & 1971 & Not Eligible & NRT & Yes & NA & Operating & NA & NA & NE \\
\hline TRA-674 & Diesel Generator Building & 1984 & Exempt & Multi-Prog & Yes & NA & Operating & NA & NA & NE \\
\hline TRA-675 & Waste Oil Dumpster Shed & 1987 & Not Eligible & Multi-Prog & Yes & NA & Shutdown & NA & NA & $\mathrm{NE}$ \\
\hline TRA-676 & Waste Heat Recovery Building & 1989 & Not Eligible & Multi-Prog & Yes & NA & Operating & NA & NA & $\mathrm{NE}$ \\
\hline TRA-677 & Demineralization Water Facility & 1992 & Exempt & Multi-Prog & Yes & NA & Operating & NA & NA & NE \\
\hline TRA-678 & TRA Office Building \#2 & 1991 & Not Eligible & Multi-Prog & Yes & NA & Operating & NA & NA & $\mathrm{NE}$ \\
\hline TRA-679 & Nuclear Training Facility & 1991 & Not Eligible & Multi-Prog & Yes & NA & Operating & NA & NA & $\mathrm{NE}$ \\
\hline TRA-680 & Emergency Command Center & 1991 & Not Eligible & Multi-Prog & Yes & NA & Operating & NA & NA & $\mathrm{NE}$ \\
\hline TRA-681 & Temporary Accumulation Unit \#1 & 1995 & Not Eligible & Multi-Prog & Yes & NA & Operating & NA & NA & NE \\
\hline TRA-682 & Temporary Accumulation Unit \#2 & 1995 & Not Eligible & Multi-Prog & Yes & NA & Operating & NA & NA & $\mathrm{NE}$ \\
\hline TRA-683 & Temporary Accumulation Unit \#3 & 1995 & Not Eligible & Multi-Prog & Yes & NA & Operating & NA & NA & NE \\
\hline TRA-684 & Temporary Accumulation Unit \#4 & 1995 & Not Eligible & Multi-Prog & Yes & NA & Operating & NA & NA & $\mathrm{NE}$ \\
\hline TRA-685 & Temporary Accumulation Unit \#5 & 1995 & Not Eligible & Multi-Prog & Yes & NA & Operating & NA & NA & NE \\
\hline TRA-686 & Temporary Accumulation Unit \#6 & 1995 & Not Eligible & Multi-Prog & Yes & NA & Operating & NA & NA & $\mathrm{NE}$ \\
\hline TRA-687 & Gas Bottle Storage Facility & 1995 & Not Eligible & Multi-Prog & Yes & NA & Operating & NA & NA & $\mathrm{NE}$ \\
\hline TRA-688 & Firewater Pump House & 2000 & Exempt & Multi-Prog & Yes & NA & Operating & NA & NA & NE \\
\hline
\end{tabular}


Table 8. (continued).

\begin{tabular}{|c|c|c|c|c|c|c|c|c|c|c|}
\hline \multicolumn{11}{|c|}{ Surveyed INL Architectural Properties } \\
\hline $\begin{array}{l}\text { Building or } \\
\text { Structure } \\
\text { ID }\end{array}$ & Building or Structure Name & $\begin{array}{l}\text { Date } \\
\text { Built }\end{array}$ & $\begin{array}{c}\text { National } \\
\text { Register } \\
\text { Evaluation }\end{array}$ & Context & $\begin{array}{l}\text { SHPO } \\
\text { Concur }\end{array}$ & Section 106 Status & Status & $\begin{array}{c}\text { Property } \\
\text { Type } \\
\text { Category }\end{array}$ & Condition & Owner \\
\hline TRA-689 & TRA Waste Storage Facility & 1997 & Not Eligible & Multi-Prog & Yes & NA & Operating & NA & NA & $\mathrm{NE}$ \\
\hline TRA-690 & Storage Building & 1997 & Not Eligible & Multi-Prog & Yes & NA & Demolished & NA & NA & NA \\
\hline TRA-691 & East Manhole Shelter & 1996 & Exempt & Multi-Prog & Yes & NA & Operating & NA & NA & $\mathrm{NE}$ \\
\hline TRA-692 & West Manhole Shelter & 1996 & Exempt & Multi-Prog & Yes & NA & Operating & NA & NA & $\mathrm{NE}$ \\
\hline TRA-693 & TRA Switchgear Enclosure & 2004 & Exempt & Multi-Prog & Yes & NA & Operating & TBD & TBD & NE \\
\hline \multicolumn{11}{|c|}{ Waste Management Facility (WMF) } \\
\hline WMF-601 & RadCon Field Office & 1974 & Not Eligible & Waste & Yes & NA & Operating & NA & NA & EM \\
\hline WMF-602 & RWMC High Bay & 1974 & Not Eligible & Waste & Yes & NA & Operating & NA & NA & EM \\
\hline WMF-603 & Pump House & 1977 & Not Eligible & Waste & Yes & NA & Operating & NA & NA & EM \\
\hline WMF-604 & Change House and Lunch Room & 1977 & Not Eligible & Waste & Yes & NA & Operating & NA & NA & EM \\
\hline WMF-605 & Well house, Observation Well \#87 & 1979 & Exempt & Waste & Yes & NA & Operating & NA & NA & EM \\
\hline WMF-609 & Heavy Equipment Storage Shed & 1979 & Not Eligible & Waste & Yes & NA & Operating & NA & NA & EM \\
\hline WMF-610 & SWEPP Building & 1983 & Not Eligible & Waste & Yes & NA & Operating & NA & NA & EM \\
\hline WMF-611 & Guardhouse & 1981 & Not Eligible & Waste & Yes & NA & Operating & NA & NA & EM \\
\hline WMF-612 & $\begin{array}{l}\text { SWEPP Certified and Segregated Waste } \\
\text { Storage }\end{array}$ & 1984 & Not Eligible & Waste & Yes & NA & Removed & NA & NA & NA \\
\hline WMF-613 & $\begin{array}{l}\text { WMF/Office Building Operational } \\
\text { Support Facility }\end{array}$ & 1986 & Not Eligible & Waste & Yes & NA & Operating & NA & NA & EM \\
\hline WMF-614 & Propane Vaporizer Housing & 1985 & Not Eligible & Waste & Yes & NA & Operating & NA & NA & EM \\
\hline WMF-615 & SWEPP Drum Vent System Building & 1986 & Not Eligible & Waste & Yes & NA & Operating & NA & NA & EM \\
\hline WMF-617 & SWEPP Maintenance Facility & 1987 & Not Eligible & Waste & Yes & NA & Operating & NA & NA & EM \\
\hline WMF-618 & TRU-Pack II Loading Station & 1988 & Not Eligible & Waste & Yes & NA & Operating & NA & NA & EM \\
\hline WMF-619 & Communications Building & 1989 & Not Eligible & Waste & Yes & NA & Operating & NA & NA & EM \\
\hline WMF-620 & Work Control Center Trailer & 1988 & Exempt & Waste & Yes & NA & Operating & NA & NA & EM \\
\hline WMF-621 & Work Control Support Trailer & 1988 & Exempt & Waste & Yes & NA & Operating & NA & NA & EM \\
\hline
\end{tabular}


Table 8. (continued).

\begin{tabular}{|c|c|c|c|c|c|c|c|c|c|c|}
\hline \multicolumn{11}{|c|}{ Surveyed INL Architectural Properties } \\
\hline $\begin{array}{l}\text { Building or } \\
\text { Structure } \\
\text { ID }\end{array}$ & Building or Structure Name & $\begin{array}{l}\text { Date } \\
\text { Built }\end{array}$ & $\begin{array}{c}\text { National } \\
\text { Register } \\
\text { Evaluation }\end{array}$ & Context & $\begin{array}{c}\text { SHPO } \\
\text { Concur }\end{array}$ & Section 106 Status & Status & $\begin{array}{c}\text { Property } \\
\text { Type } \\
\text { Category }\end{array}$ & & Owner \\
\hline WMF-622 & Office Annex \#1 & 1985 & Not Eligible & Waste & Yes & NA & Operating & NA & NA & EM \\
\hline WMF-624 & Fire Riser Enclosure & 1996 & Not Eligible & Waste & Yes & NA & Operating & NA & NA & EM \\
\hline WMF-627 & Propane Pump Enclosure & 1997 & Exempt & Waste & Yes & NA & Operating & NA & NA & EM \\
\hline WMF-628 & Type 2 Storage Module \#1 & 1993 & Not Eligible & Waste & Yes & NA & Operating & NA & NA & EM \\
\hline WMF-629 & Type 2 Storage Module \#2 & 1993 & Not Eligible & Waste & Yes & NA & Operating & NA & NA & EM \\
\hline WMF-630 & Type 2 Storage Module \#3 & 1993 & Not Eligible & Waste & Yes & NA & Operating & NA & NA & EM \\
\hline WMF-631 & Type 2 Storage Module \#4 & 1993 & Not Eligible & Waste & Yes & NA & Operating & NA & NA & EM \\
\hline WMF-632 & Type 2 Storage Module \#5 & 1993 & Not Eligible & Waste & Yes & NA & Operating & NA & NA & EM \\
\hline WMF-633 & Type 2 Storage Module \#6 & 1993 & Not Eligible & Waste & Yes & NA & Operating & NA & NA & EM \\
\hline WMF-634 & Type 2 Storage Module \#7 & 1993 & Not Eligible & Waste & Yes & NA & Operating & NA & NA & EM \\
\hline WMF-635 & Type 1 Storage Module & 1995 & Not Eligible & Waste & Yes & NA & Operating & NA & NA & EM \\
\hline WMF-636 & TSA Retrieval Enclosure Facility & 1996 & Not Eligible & Waste & Yes & NA & Operating & NA & NA & EM \\
\hline WMF-637 & Operations Control Building & 1995 & Not Eligible & Waste & Yes & NA & Operating & NA & NA & EM \\
\hline WMF-639 & Pump House \#2 & ca. 1995 & Exempt & Waste & Yes & NA & Operating & NA & NA & EM \\
\hline WMF-640 & $\begin{array}{l}\text { Vapor Vacuum Extraction (VVE) } \\
\text { Weather Shelter }\end{array}$ & 1989 & Exempt & Waste & Yes & NA & Demolished & NA & NA & NA \\
\hline WMF-641 & VVE Monitoring Well DO2 & 1990 & Exempt & Waste & Yes & NA & Operating & NA & NA & EM \\
\hline WMF-642 & VVE Monitoring Well 8801D & 1990 & Exempt & Waste & Yes & NA & Demolished & NA & NA & NA \\
\hline WMF-643 & VVE Monitoring Well 8902D & 1990 & Exempt & Waste & Yes & NA & Operating & NA & NA & EM \\
\hline WMF-645 & Construction Support Trailer & 1991 & Exempt & Waste & Yes & NA & Operating & NA & NA & EM \\
\hline WMF-646 & Field Support Trailer & 1991 & Exempt & Waste & Yes & NA & Operating & NA & NA & EM \\
\hline WMF-648 & ILTSF Vault Monitoring Trailer & 1992 & Exempt & Waste & Yes & NA & Operating & NA & NA & EM \\
\hline WMF-649 & VVE Monitoring Well 9301 & 1993 & Exempt & Waste & Yes & NA & Demolished & NA & NA & NA \\
\hline WMF-650 & VVE Monitoring Well 9302 & 1993 & Exempt & Waste & Yes & NA & Demolished & NA & NA & NA \\
\hline WMF-651 & RadCon Trailer & 1993 & Exempt & Multi-Prog & Yes & NA & Demolished & NA & NA & NA \\
\hline
\end{tabular}


Table 8. (continued).

\begin{tabular}{|c|c|c|c|c|c|c|c|c|c|c|}
\hline \multicolumn{11}{|c|}{ Surveyed INL Architectural Properties } \\
\hline $\begin{array}{l}\text { Building or } \\
\text { Structure } \\
\text { ID }\end{array}$ & Building or Structure Name & $\begin{array}{l}\text { Date } \\
\text { Built }\end{array}$ & $\begin{array}{c}\text { National } \\
\text { Register } \\
\text { Evaluation }\end{array}$ & Context & $\begin{array}{l}\text { SHPO } \\
\text { Concur }\end{array}$ & Section 106 Status & Status & $\begin{array}{c}\text { Property } \\
\text { Type } \\
\text { Category }\end{array}$ & Condition & Owner \\
\hline WMF-652 & Security Trailer & 1993 & Not Eligible & Multi-Prog & Yes & NA & Removed & NA & NA & NA \\
\hline WMF-653 & Office Annex \#2 & 1993 & Not Eligible & Waste & Yes & NA & Operating & NA & NA & EM \\
\hline WMF-655 & Material Handling Facility & 1995 & Not Eligible & Waste & Yes & NA & Operating & NA & NA & EM \\
\hline WMF-656 & Maintenance Facility & 1995 & Not Eligible & Waste & Yes & NA & Operating & NA & NA & EM \\
\hline WMF-657 & Construction Field Support Trailer & 1995 & Exempt & Waste & Yes & NA & Operating & NA & NA & EM \\
\hline WMF-658 & DOE/RWMC Office Facility & 1995 & Not Eligible & Waste & Yes & NA & Operating & NA & NA & EM \\
\hline WMF-660 & $\begin{array}{l}\text { Automatic Transfers with Building, } \\
\text { Standby Loop }\end{array}$ & 1996 & Not Eligible & Waste & Yes & NA & Operating & NA & NA & EM \\
\hline \multicolumn{11}{|c|}{ Sitewide Buildings and Structures } \\
\hline AEF-601 & BORAX V Reactor Building Basement & ca. 1955 & Not Eligible & NRT & Yes & $\begin{array}{l}\text { per Bert Bedeau (SHPO } \\
\text { office) } 11 / 7 / 1996\end{array}$ & Demolished & NA & NA & NA \\
\hline AEF-602 & BORAX V Turbine Building & ca.1955 & $\begin{array}{c}\text { Not } \\
\text { Eligible/Moved }\end{array}$ & NRT & No & NA & Demolished & NA & NA & NA \\
\hline AEF-603 & Waste Management Building & ca. 1955 & Not Assessed & NRT & No & No MOA & Demolished & NA & NA & NA \\
\hline AEF-604 & BORAX Heating and Ventilating & ca.1955 & Not Assessed & NRT & No & No MOA & Demolished & NA & NA & NA \\
\hline AEF-605 & Washroom Facility & ca.1955 & Not Assessed & NRT & No & No MOA & Demolished & NA & NA & NA \\
\hline AEF-606 & Guard House & ca.1955 & Not Assessed & NRT & No & No MOA & Demolished & NA & NA & NA \\
\hline B8-601 & Lincoln Generator Building & 1984 & Not Eligible & Multi-Prog & Yes & NA & Operating & NA & NA & $\mathrm{NE}$ \\
\hline B8-602 & Guardhouse on Lincoln Boulevard & 1986 & Not Eligible & Multi-Prog & Yes & NA & Operating & NA & NA & NE \\
\hline B16-601 & Fire Station \#2 & ca. 1958 & Eligible & Multi-Prog & Yes & MOA photos taken & Demolished & NA & NA & NA \\
\hline B16-602 & Pump House Fire Station \#2 & 1958 & Eligible & NRT & Yes & MOA photos taken & Demolished & NA & NA & NA \\
\hline B16-603 & Experimental Dairy Farm Barn & 1964 & Eligible & NRT & Yes & Programmatic Agreement & Operating & 1 & Excellent & $\mathrm{NE}$ \\
\hline B16-604 & Experimental Dairy Farm Pump House & 1964 & Exempt & NRT & Yes & NA & Operating & NA & NA & $\mathrm{NE}$ \\
\hline B16-605 & NOAA Storage Building & 1956 & Eligible & NRT & Yes & Programmatic Agreement & Operating & 3 & Fair & NE \\
\hline B16-606 & $\begin{array}{l}\text { Experimental Dairy Farm Storage } \\
\text { (Butler Building) }\end{array}$ & 1963 & Eligible & NRT & Yes & Programmatic Agreement & Operating & 3 & Excellent & $\mathrm{NE}$ \\
\hline B16-607 & Training and Storage Building & 1982 & Not Eligible & Multi-Prog & Yes & NA & Demolished & NA & NA & NA \\
\hline B16-610 & Meteorological Balloon Shelter & 1960 & Eligible & NRT & Yes & Programmatic Agreement & Shutdown & 3 & Fair & NE \\
\hline
\end{tabular}


Table 8. (continued).

\begin{tabular}{|c|c|c|c|c|c|c|c|c|c|c|}
\hline \multicolumn{11}{|c|}{ Surveyed INL Architectural Properties } \\
\hline $\begin{array}{l}\text { Building or } \\
\text { Structure } \\
\text { ID }\end{array}$ & Building or Structure Name & $\begin{array}{l}\text { Date } \\
\text { Built }\end{array}$ & $\begin{array}{c}\text { National } \\
\text { Register } \\
\text { Evaluation }\end{array}$ & Context & $\begin{array}{c}\text { SHPO } \\
\text { Concur }\end{array}$ & Section 106 Status & Status & $\begin{array}{l}\text { Property } \\
\text { Type } \\
\text { Category }\end{array}$ & Condition & Owner \\
\hline B21-606 & Guardhouse on Van Buren & 1984 & Not Eligible & Multi-Prog & Yes & NA & Operating & NA & NA & $\mathrm{NE}$ \\
\hline B21-607 & $\begin{array}{l}\text { Weapons Range Complex (WRC) Pump } \\
\text { House }\end{array}$ & 1988 & Exempt & Multi-Prog & Yes & NA & Operating & NA & NA & $\mathrm{NE}$ \\
\hline B21-608 & WRC Range House & 1989 & Not Eligible & $\begin{array}{c}\text { Not } \\
\text { identified }\end{array}$ & Yes & NA & Operating & NA & NA & NE \\
\hline B21-609 & $\begin{array}{l}\text { WRC Range } 3 \text { Control House and Fire } \\
\text { Line Cover }\end{array}$ & 1989 & Not Eligible & $\begin{array}{c}\text { Not } \\
\text { identified }\end{array}$ & Yes & NA & Operating & NA & NA & NE \\
\hline B21-610 & $\begin{array}{l}\text { WRC Range } 5 \text { Control House and Fire } \\
\text { Line Cover }\end{array}$ & 1989 & Not Eligible & $\begin{array}{c}\text { Not } \\
\text { identified }\end{array}$ & Yes & NA & Operating & NA & NA & $\mathrm{NE}$ \\
\hline B21-611 & WRC Range 1 Firing Stand Enclosure & ca.1989 & Not Eligible & $\begin{array}{c}\text { Not } \\
\text { identified }\end{array}$ & Yes & NA & Operating & NA & NA & NE \\
\hline B25-601 & SDA Engineered Barrier Test F & 1996 & Not Eligible & $\begin{array}{c}\text { Not } \\
\text { identified }\end{array}$ & Yes & NA & Operating & NA & NA & $\mathrm{NE}$ \\
\hline B27-601 & Generator Building & 1984 & Exempt & Multi-Prog & Yes & NA & Operating & NA & NA & $\mathrm{NE}$ \\
\hline B27-602 & Guardhouse on E. Portland Avenue & 1984 & Not Eligible & Multi-Prog & Yes & NA & Operating & NA & NA & $\mathrm{NE}$ \\
\hline B27-603 & Badging Building on E. Portland & 1986 & Not Eligible & Multi-Prog & Yes & NA & Operating & NA & NA & $\mathrm{NE}$ \\
\hline B27-604 & Bus Passenger Shelter & 1985 & Not Eligible & Multi-Prog & Yes & NA & Operating & NA & NA & $\mathrm{NE}$ \\
\hline B27-605 & Deep Well Pump house & 1987 & Exempt & Multi-Prog & Yes & NA & Operating & NA & NA & NE \\
\hline B27-606 & Multipurpose Laboratory Facility & ca.2001 & Not Assessed & $\begin{array}{c}\text { Not } \\
\text { identified }\end{array}$ & Yes & NA & Operating & NA & NA & NE \\
\hline HPTF601 & Equipment Building & 1962 & Not Assessed & Multi-Prog & No & No MOA & Demolished & NA & NA & NA \\
\hline HPTF602 & Transformer Building & 1962 & Not Assessed & Multi-Prog & No & No MOA & Demolished & NA & NA & NA \\
\hline HPTF603 & Equipment Building Expansion & 1962 & Not Assessed & Multi-Prog & No & No MOA & Demolished & NA & NA & NA \\
\hline HPTF604 & Communications Facility & 1999 & Not Assessed & Multi-Prog & Yes & NA & Operating & NA & NA & NE \\
\hline
\end{tabular}


Appendix J

INL Cultural Resource Projects 


\section{Appendix $\mathbf{J}$}

\section{INL Cultural Resource Projects}

The following project tables are divided into archaeological and architectural investigations. The archaeological investigations are further subdivided into those conducted by INL CRM Office personnel and those conducted by subcontracted personnel. Some of the projects reviewed had both an archaeological and architectural review and, hence, appear twice.

Table 9. INL Cultural Resource Management Office archaeological investigations.

\begin{tabular}{|c|c|}
\hline \multicolumn{2}{|r|}{ INL Cultural Resource Management Office Archaeological Investigations } \\
\hline Project Number & Project Title \\
\hline \multicolumn{2}{|r|}{ Calendar Year 1990} \\
\hline EGG-90-01 & ICPP Percolation Pond \\
\hline EGG-90-02 & CFA Groundwater Monitoring Wells \\
\hline EGG-90-03 & RWMC Sewage Lagoon \\
\hline EGG-90-04 & RWMC Bore Holes for Environmental Restoration Project Site Characterization \\
\hline EGG-90-05 & TAN Core Drilling \\
\hline EGG-90-06 & RWMC Administrative Expansion \\
\hline EGG-90-07 & TRA Warm Water Waste Pond \\
\hline EGG-90-08 & INEL Sewer Upgrade \\
\hline EGG-90-09 & ICPP/NPR Access Road Upgrade \\
\hline EGG-90-10 & Cinder Butte Rattlesnake Study \\
\hline EGG-90-11 & RWMC/CFA Powerline \\
\hline EGG-90-12 & CFA Groundwater Monitoring Wells Expansion \\
\hline EGG-90-13 & T-12 Gravel Pit Expansion \\
\hline EGG-90-14 & Teakettle Butte Spring Development \\
\hline EGG-90-15 & Soil Coring Near PBF \\
\hline \multicolumn{2}{|r|}{$\begin{array}{r}\text { Calendar Year } 1991 \\
\end{array}$} \\
\hline EGG-91-01 & WRRTF FAA Project \\
\hline EGG-91-02 & SPERT III Building and Sewer \\
\hline EGG-91-03 & NOAA Meteorological Monitoring Stations \\
\hline EGG-91-04 & ICPP Parking Lot Extension \\
\hline EGG-91-05 & INEL Gravel Pits Long Range Plan \\
\hline EGG-91-06 & RWMC Subcontractor Laydown Area \\
\hline EGG-91-07 & PBF/NPR Access Road Final Alignment \\
\hline EGG-91-08 & WAG7/RWMC Wells Archive Search \\
\hline EGG-91-09 & ICPP Overview \\
\hline EGG-91-10 & TAN Overview \\
\hline
\end{tabular}


Table 9. (continued).

INL Cultural Resource Management Office Archaeological Investigations

\begin{tabular}{|c|c|}
\hline Project Number & Project Title \\
\hline EGG-91-11 & TRA Overview \\
\hline EGG-91-12 & NRF Boreholes \\
\hline EGG-91-13 & NPR Offsite Seismic Monitors \\
\hline EGG-91-14 & NPR Thermoluminescence Sample Plots \\
\hline EGG-91-15 & Research Design and Data Recovery Plan For 10-BT-373, NPR Drilling Program \\
\hline EGG-91-16 & WAG7/RWMC Well Survey Plan \\
\hline EGG-91-17 & ICPP Construction Staging Area \\
\hline EGG-91-18 & RWMC Overview, EA for Waste Recovery, Pit 9 \\
\hline EGG-91-19 & NRF Bore Near 10-BT-933 \\
\hline EGG-91-20 & Middle Butte Cave Seismic Monitor \\
\hline EGG-91-21 & NPR Interim Report \\
\hline EGG-91-22 & WAG7/RWMC Well Survey \\
\hline EGG-91-23 & INEL Electrical Upgrade \\
\hline EGG-91-24 & Offsite Deep Wells \\
\hline EGG-91-25 & Misc. Site Recordings (not project related) \\
\hline EGG-91-26 & RWMC Administrative Area and Access Road \\
\hline \multicolumn{2}{|r|}{ Fiscal Year 1992} \\
\hline EGG-92-01 & Elk Capture and Relocation \\
\hline EGG-92-02 & RWMC Simulated Cold Storage Pit \\
\hline EGG-92-03 & TAN Environmental Remediation Projects \\
\hline EGG-92-04 & NPR Seismic Profiling \\
\hline EGG-92-05 & BORAX V Overview \\
\hline EGG-92-06 & DOE Weapons Complex 21 \\
\hline EGG-92-07 & CFA Medical Facility \\
\hline EGG-92-08 & Spreading Area B Soil Sampling \\
\hline EGG-92-09 & RWMC Maintenance/Materials Handling Facilities \\
\hline EGG-92-10 & INEL Sitewide Ordnance Cleanup \\
\hline EGG-92-11 & Salvage Archaeology at Cedar Butte, 10-BM-148 \\
\hline EGG-92-12 & NRF Administrative Area Phase I \\
\hline EGG-92-13 & TAN Medical Facility \\
\hline EGG-92-14 & Elk Netting Program \\
\hline EGG-92-15 & RWMC Upgrade and Expansion_-Pit 9 Administrative Area-10-BT-1230 Testing \\
\hline EGG-92-16 & ICPP NOX Abatement Project \\
\hline EGG-92-17 & $\begin{array}{l}\text { RWMC Upgrade and Expansion-Operations Control Building and Powerline-10-BT- } \\
1609 \text { Testing }\end{array}$ \\
\hline
\end{tabular}


Table 9. (continued).

INL Cultural Resource Management Office Archaeological Investigations

\begin{tabular}{|c|c|}
\hline Project Number & Project Title \\
\hline EGG-92-18 & Dairy Farm Perimeter \\
\hline EGG-92-19 & NRF Railroad Spur \\
\hline EGG-92-20 & TAN Wells \\
\hline EGG-92-21 & INEL Sitewide Well Upgrade \\
\hline EGG-92-22 & SNTP Project, Quest and LOFT Alternatives \\
\hline EGG-92-23 & RWMC Upgrade and Expansion-Sewage Lagoon-10-BT-1605 Testing \\
\hline EGG-92-25 & ICPP Substation and Feeder Lines \\
\hline EGG-92-26 & RWMC Soil Erosion and Deposition Study \\
\hline EGG-92-27 & Elk Trapping near NRF \\
\hline EGG-92-28 & CFA Gravel Test Area \\
\hline EGG-92-29 & CFA Trash Dump \\
\hline EGG-92-30 & RWMC Power Upgrade \\
\hline EGG-92-31 & SDA Engineered Barriers Test Plot \\
\hline EGG-92-32 & NOAA Radar Profiler \\
\hline EGG-92-33 & TRA Parking Lot Expansion \\
\hline EGG-92-35 & ICPP Drilling \\
\hline EGG-92-36 & TAN/SMC Sanitary System Upgrade \\
\hline EGG-92-37 & Monolithic Confinement \\
\hline EGG-92-39 & Historic Dumps \\
\hline EGG-92-40 & Idaho Waste Processing Facility \\
\hline EGG-92-41 & CFA Instrument Shed \\
\hline EGG-92-42 & TAN/TSF Injection Well \\
\hline EGG-92-43 & Alternate Areas for CFA Sewage Lagoons \\
\hline EGG-92-44 & RESL Building at CFA \\
\hline EGG-92-45 & ER and WM EIS Predictive Models \\
\hline EGG-92-46 & Middle Butte/Indian Cave Documentation \\
\hline & Fiscal Year 1993 \\
\hline EGG-93-02 & TAN Potable Deep Well \\
\hline EGG-93-03 & INEL Electrical Upgrade Survey \\
\hline EGG-93-05 & Alternate Area for TAN/SMC Sanitary System \\
\hline EGG-93-06 & IWPF and LLMWPF Surveys \\
\hline EGG-93-07 & INEL Ordnance Cleanup Survey \\
\hline EGG-93-08 & TRA Warm Water Waste Pond \\
\hline EGG-93-09 & INEL Central Connector \\
\hline
\end{tabular}


Table 9. (continued).

INL Cultural Resource Management Office Archaeological Investigations

\begin{tabular}{|c|c|}
\hline Project Number & Project Title \\
\hline EGG-93-10 & East Butte Transmitter \\
\hline EGG-93-11 & CFA Overview \\
\hline EGG-93-12 & RWMC Neutron Access Tubes \\
\hline EGG-93-13 & PBF Corrosive Waste Sump and Chemical Pond \\
\hline EGG-93-14 & Grading and Gravelling Around TAN Fire Station \\
\hline EGG-93-15 & Soil Borrowing From Spreading Area B \\
\hline EGG-93-17 & Broad Band Seismic Stations \\
\hline EGG-93-18 & Grays Lake Seismic Station \\
\hline EGG-93-19 & TAN Fiber Optics \\
\hline EGG-93-20 & WRRTF Test Area \\
\hline EGG-93-21 & LCCDA Near RWMC \\
\hline EGG-93-22 & PBF Fiber Optics and Communications Upgrade \\
\hline EGG-93-23 & Cold Test Pit Access and Administrative Expansion \\
\hline EGG-93-24 & Infiltration Basin \\
\hline EGG-93-25 & CFA Medical and Emergency Response Facilities \\
\hline EGG-93-26 & Wind Gap Dumping-10-BT-1449 Survey and Testing \\
\hline EGG-93-27 & Remedial Investigations at CFA Landfills \\
\hline EGG-93-28 & STF Well Drilling \\
\hline EGG-93-30 & Highway 20/26 RR Crossing Rebuild \\
\hline EGG-93-31 & Explosives Disposal Area Near ARA IV \\
\hline EGG-93-32 & Formation of Soil Mounds Study \\
\hline EGG-93-33 & CFA Landfill Power Upgrade \\
\hline EGG-93-34 & Dry Cask Storage \\
\hline EGG-93-35 & CFA Bulky Waste Landfill Expansion \\
\hline EGG-93-36 & WAG 10 Sampling Survey \\
\hline EGG-93-37 & CFA Administrative Area \\
\hline EGG-93-38 & Idaho Falls Technology Park \\
\hline EGG-93-39 & Air Photo Markers for INEL Floodplain Study \\
\hline EGG-93-40 & ICPP Buried Utility Lines \\
\hline EGG-93-41 & INEL Boundary Sign Maintenance \\
\hline EGG-93-42 & RWMC Road Signs \\
\hline EGG-93-43 & CFA Boundary Signs \\
\hline EGG-93-44 & WRRTF Soil Sampling \\
\hline EGG-93-45 & Cold Test Pit Expansion \\
\hline EGG-93-46 & Roberts/Chilly Fiber Optics \\
\hline
\end{tabular}


Table 9. (continued).

\begin{tabular}{|c|c|}
\hline \multicolumn{2}{|r|}{ INL Cultural Resource Management Office Archaeological Investigations } \\
\hline Project Number & Project Title \\
\hline \multicolumn{2}{|r|}{ Fiscal Year 1994} \\
\hline EGG-94-01 & Middle Butte Cave Signs \\
\hline EGG-94-02 & INEL Landfill Complex Extension \\
\hline EGG-94-03 & ANL-W Seismic Stations \\
\hline EGG-94-04 & Jefferson County Landfill Land Exchange \\
\hline EGG-94-05 & INEL Gravel/Fill Sources \\
\hline EGG-94-06 & ARA Monitoring Wells \\
\hline EGG-94-07 & Salmon/Mud Lake Fiber Optics \\
\hline EGG-94-08 & CFA Septic Tank and Drain Field Monitoring Wells \\
\hline EGG-94-09 & Phase II Soil Remediation in WAG 10-06 \\
\hline EGG-94-10 & Barrier Technology Testing at Bonfire Point \\
\hline EGG-94-11 & Triumph Mine Remediation \\
\hline EGG-94-12 & Pocatello/Arco Fiber Optics \\
\hline EGG-94-13 & Another Cold Test Pit Expansion \\
\hline EGG-94-14 & INEL Sewer Upgrade EA Review \\
\hline EGG-94-15 & CFA Topsoil Pit \\
\hline EGG-94-16 & RWMC Laydown Area Expansion \\
\hline EGG-94-17 & RWMC Power Poles \\
\hline EGG-94-18 & IEDF in IF \\
\hline EGG-94-19 & Cinder Pit Fencing and Resloping \\
\hline EGG-94-20 & Ordnance Cleanup at NODA and ANL-W \\
\hline EGG-94-21 & Goodale's Cutoff Survey \\
\hline EGG-94-22 & CFA-RWMC Powerline \\
\hline EGG-94-23 & Northend Sand Pit \\
\hline EGG-94-24 & PBF Remains \\
\hline EGG-94-25 & TAN/TSF-38 Bottle Remediation \\
\hline EGG-94-26 & Misc. MK Wells \\
\hline EGG-94-27 & USGS Floodplain Cross-Sections \\
\hline EGG-94-28 & Warning Sign Near ARA IV \\
\hline EGG-94-29 & Biotic Indicator Study \\
\hline EGG-94-30 & RWMC Storage Modules \\
\hline EGG-94-31 & RWMC Office Building \\
\hline EGG-94-32 & Soil Removal at ARA II \\
\hline EGG-94-33 & Transition Plan \\
\hline
\end{tabular}


Table 9. (continued).

INL Cultural Resource Management Office Archaeological Investigations

\begin{tabular}{|c|c|}
\hline Project Number & Project Title \\
\hline EGG-94-34 & Infiltration Basin Diversion Line \\
\hline EGG-94-35 & Firing Range Vegetation Removal \\
\hline EGG-94-36 & INEL Wetlands Characterization \\
\hline EGG-94-37 & SL-1 Soil Cap \\
\hline EGG-94-38 & BORAX Soil Cap \\
\hline EGG-94-39 & Infiltration Basin Laydown Area \\
\hline EGG-94-40 & RWMC Overview \\
\hline EGG-94-41 & INEL Brush Fire \\
\hline EGG-94-42 & IWPF Phase II \\
\hline EGG-94-43 & STF Obstacle Course Replacement \\
\hline EGG-94-44 & ICPP Elk Remains \\
\hline EGG-94-45 & NRF Waste Ditch Dredging \\
\hline EGG-94-46 & PWT Units at TAN and PBF \\
\hline EGG-94-47 & Antelope Substation Fire Prevention \\
\hline EGG-94-48 & CFA Drainage Ditch \\
\hline EGG-94-49 & Environmental Baseline Survey \\
\hline EGG-94-50 & Antelope/Scoville Fiber Optics \\
\hline EGG-94-51 & MWSF Storage Pad and Access Upgrade at PBF \\
\hline EGG-94-52 & Snake Fences \\
\hline \multicolumn{2}{|r|}{ Fiscal Year 1995} \\
\hline LITCO-95-01 & RWMC Office Facility \\
\hline LITCO-95-02 & BWP Administrative Area \\
\hline LITCO-95-03 & NRF Soil Sampling \\
\hline LITCO-95-04 & IWPF Test Excavations \\
\hline LITCO-95-05 & ARA II Road Maintenance \\
\hline LITCO-95-06 & Spreading Area B Alternatives \\
\hline LITCO-95-07 & ER \& WM EIS \\
\hline LITCO-95-08 & CFA Concrete Crusher \\
\hline LITCO-95-09 & Howe Peak Seismic Station revisited \\
\hline LITCO-95-10 & Pit 9 Administrative Expansion \\
\hline LITCO-95-11 & ICPP Culvert \\
\hline LITCO-95-12 & Van Buren Test Pits for Road Maintenance \\
\hline LITCO-95-13 & State of ID Monitors at NOAA Stations \\
\hline LITCO-95-14 & LAN Upgrades RWMC/CFA and PBF \\
\hline
\end{tabular}


Table 9. (continued).

INL Cultural Resource Management Office Archaeological Investigations

\begin{tabular}{|c|c|}
\hline Project Number & Project Title \\
\hline LITCO-95-15 & TRA Sewer Upgrade \\
\hline LITCO-95-16 & Travelers' Information Radio System \\
\hline LITCO-95-17 & WERF Drainage Basin Enlargement \\
\hline LITCO-95-18 & RWMC Pipeline \\
\hline LITCO-95-19 & Fire Prevention at ARA I \\
\hline LITCO-95-21 & RWMC-CFA Ethernet \\
\hline LITCO-95-22 & More Monitoring Wells at PBF and CFA \\
\hline LITCO-95-23 & CFA Admin Support Facility \\
\hline LITCO-95-24 & Guard Gate 3 Trash Dump \\
\hline LITCO-95-25 & ARVFS Signs \\
\hline LITCO-95-26 & ICPP Substation \\
\hline LITCO-95-27 & ICPP Wells \\
\hline LITCO-95-28 & NODA Road Remediation \\
\hline LITCO-95-29 & Van Buren Upgrade \\
\hline LITCO-95-30 & Pit 9 Admin Area Well \\
\hline LITCO-95-31 & NRF Wells \\
\hline LITCO-95-32 & EBR-I Interpretive Trail \\
\hline LITCO-95-33 & Dairy Farm Powerline \\
\hline LITCO-95-34 & Idaho State University (ISU) Geology Field Trip \\
\hline LITCO-95-35 & Monitoring Wells at CF-633, CF-670, CF-690, CF-667, and CF-623 \\
\hline LITCO-95-36 & RWMC-CFA Powerline \\
\hline LITCO-95-37 & ARVFS Road \\
\hline LITCO-95-38 & CFA Waterline \\
\hline LITCO-95-39 & Landfill Utility Upgrade \\
\hline LITCO-95-40 & Environmental Restoration of PBF-10 Evaporation Pond \\
\hline LITCO-95-41 & Groundwater Remediation at TAN \\
\hline LITCO-95-42 & Phase II Bonneville County Technology Park \\
\hline LITCO-95-43 & Temporary Power at Pit 9 \\
\hline LITCO-95-44 & CFA Dry Well Search \\
\hline LITCO-95-45 & Vegetation Plot at TAN \\
\hline LITCO-95-46 & Big Lost River Modification at Pioneer \\
\hline LITCO-95-47 & Pit 9 Parking Expansion \\
\hline LITCO-95-48 & ROB/IRC Drill/Auger Holes \\
\hline LITCO-95-49 & ISU Fieldschool \\
\hline
\end{tabular}


Table 9. (continued).

INL Cultural Resource Management Office Archaeological Investigations

\begin{tabular}{|c|c|}
\hline Project Number & Project Title \\
\hline LITCO-95-50 & Site Characterization of OU 4-05 \\
\hline LITCO-95-51 & Spreading Area B Cattleguard \\
\hline LITCO-95-52 & NRF Misc. \\
\hline LITCO-95-53 & INEL Cave Survey \\
\hline LITCO-95-54 & NODA Road Culvert \\
\hline LITCO-95-55 & ESRF Vegetation Plots \\
\hline LITCO-95-56 & Removal Actions in OU 10-06 \\
\hline LITCO-95-57 & Firing Range Misc. Upgrades \\
\hline LITCO-95-58 & Adams Avenue Well \\
\hline LITCO-95-59 & Repatriation/Reinternment of PBF Remains \\
\hline LITCO-95-60 & ANL-W Brush Fire \\
\hline LITCO-95-61 & CF-609 Tower \\
\hline LITCO-95-62 & USGS Well \\
\hline LITCO-95-63 & Soil Erosion Monitors in ANL-W Burn \\
\hline LITCO-95-64 & RWMC-North Parking Area \\
\hline LITCO-95-65 & Cleanup of STR-8 Storage Area \\
\hline LITCO-95-66 & Tolo Lake Mammoth Excavation (LDRD) \\
\hline LITCO-95-67 & Elk Hunting/Trapping \\
\hline \multicolumn{2}{|r|}{ Fiscal Year 1996} \\
\hline LMIT-96-01 & Alternate Silt/Clay Source \\
\hline LMIT-96-02 & East Butte Radio Facility \\
\hline LMIT-96-03 & SL-1 Engineered Barriers Cap \\
\hline LMIT-96-04 & Tetra Tech EIS \\
\hline LMIT-96-05 & Sewer Lagoon Expansion at RWMC \\
\hline LMIT-96-07 & Gas Tracer LDRD project \\
\hline LMIT-96-08 & LESAT Pit 9 Processing of Stored Waste \\
\hline LMIT-96-09 & Plasma Hearth Process - SAIC \\
\hline LMIT-96-10 & NRF Drycell \\
\hline LMIT-96-11 & CFA $\mathrm{H}_{2} \mathrm{O}$ Lines \\
\hline LMIT-96-12 & Spreading Area B Drilling \\
\hline LMIT-96-13 & Kaho'olawe Bid \\
\hline LMIT-96-14 & Mojave Desert DOD Bid \\
\hline LMIT-96-15 & Hunting Boundary Modification \\
\hline LMIT-96-16 & Environmental Management Science Program Bid \\
\hline
\end{tabular}


Table 9. (continued).

INL Cultural Resource Management Office Archaeological Investigations

\begin{tabular}{|c|c|}
\hline Project Number & Project Title \\
\hline LMIT-96-17 & Storm $\mathrm{H}_{2} \mathrm{O}$ Pollution Prevention Plan-INEL Gravel Sources \\
\hline LMIT-96-18 & Environmental Technologies Database \\
\hline LMIT-96-19 & Windgap Laydown Area \\
\hline LMIT-96-20 & Controlled Burns at the Weapons Range \\
\hline LMIT-96-22 & Landfill Drilling \\
\hline LMIT-96-23 & Alternate road from PBF to ANL-W \\
\hline LMIT-96-24 & Landfill Soil Borrow Area \\
\hline LMIT-96-25 & South CFA Topsoil Area \\
\hline LMIT-96-26 & Sitewide Road Projects \\
\hline LMIT-96-27 & WERF Remains \\
\hline LMIT-96-28 & Argonne Burn Remediation \\
\hline LMIT-96-29 & Relocation of Trailers CF-643 and CF- 652 \\
\hline LMIT-96-30 & Spent Nuclear Fuel Dry Storage at ICPP \\
\hline LMIT-96-31 & OU 10-03 Ordnance Assessment \\
\hline LMIT-96-32 & Jefferson County Landfill Transfer '96 \\
\hline LMIT-96-33 & ISU Geology Field Trip \\
\hline LMIT-96-34 & TAN/WRRTF Monitoring Wells \\
\hline LMIT-96-35 & Monitoring of 10-BT-1605 for RWMC Sewer Lagoon Construction \\
\hline LMIT-96-36 & TRA Tank Cleanup \\
\hline LMIT-96-37 & ESRF Bat Inventory and Monitoring with Mist Nets \\
\hline LMIT-96-38 & INEL Electrical Distribution Upgrade Phase I \\
\hline LMIT-96-39 & ESRF Vegetation Monitoring Plots \\
\hline LMIT-96-40 & TAN Parking Expansion \\
\hline LMIT-96-41 & CFA and PBF Substation Upgrades \\
\hline LMIT-96-42 & NOAA Remote Optical Sensor \\
\hline LMIT-96-43 & TAN V-9 Tank Remediation \\
\hline LMIT-96-44 & CERCLA Soil Removal at CFA \\
\hline LMIT-96-45 & ICPP Electrical and Utility Systems Upgrade \\
\hline LMIT-96-46 & TAN Gravel Pit Bones \\
\hline LMIT-96-47 & ARVFS DD\&D \\
\hline LMIT-96-48 & Soil Capping at ARA-I \\
\hline LMIT-96-49 & RWMC Access Control Upgrade \\
\hline LMIT-96-50 & E. Ogden Ave. Bridge Demonstration \\
\hline LMIT-96-51 & Ordnance Removal at the Fuse Burn Area, Blown Railcar Area, and TRA Area \\
\hline
\end{tabular}


Table 9. (continued).

INL Cultural Resource Management Office Archaeological Investigations

\begin{tabular}{|c|c|}
\hline Project Number & Project Title \\
\hline LMIT-96-52 & ESRF Principal Lineament Research \\
\hline LMIT-96-53 & ISU/UI Soil Studies \\
\hline LMIT-96-54 & ANL-W Dust Remediation Projects \\
\hline & Fiscal Year 1997 \\
\hline LMIT-97-01 & INEL RipRap Sources \\
\hline LMIT-97-02 & RWMC Firebreak \\
\hline LMIT-97-03 & Comstock Canal HAER \\
\hline LMIT-97-04 & SDA Barometric Studies \\
\hline LMIT-97-05 & Seismic Velocity Logging Wells \\
\hline LMIT-97-06 & Spreading Area B Expansion \\
\hline LMIT-97-07 & Silt/Clay EA \\
\hline LMIT-97-08 & ICPP Percolation Facility \\
\hline LMIT-97-09 & TRA Sewage Treatment Plant \\
\hline LMIT-97-10 & Sampling for Cesium, Strontium, and Cobalt in INEEL Soils \\
\hline LMIT-97-11 & TAN Gravel Pit Flood Control \\
\hline LMIT-97-12 & Highway 20/26 Monitoring Wells \\
\hline LMIT-97-13 & Trenching and Boreholes at CF-04 and CF-08 \\
\hline LMIT-97-14 & DOE-Inspector General Land Grab \\
\hline LMIT-97-15 & ICPP Shallow Perched Water Investigation \\
\hline LMIT-97-16 & ACETS/PNDR \\
\hline LMIT-97-17 & PBF/WROC Local Area Network Upgrade \\
\hline LMIT-97-18 & EBR-I Domestic Water System Modifications \\
\hline LMIT-97-19 & Sampling Locations at CFA (CF-13,15,17,42, 47) \\
\hline LMIT-97-20 & PBF Wells near PBF-612 and PBF-601 \\
\hline LMIT-97-21 & 1997 Ordnance Removal Actions \\
\hline LMIT-97-22 & Long Term Corrosion Degradation Project \\
\hline LMIT-97-23 & Comprehensive Facility and Land Use Plan \\
\hline LMIT-97-24 & ARA-16 Tank Testing \\
\hline LMIT-97-25 & Groundwater Monitoring Wells at TRA \\
\hline LMIT-97-28 & Acid Pit/Cold Test Pit In Situ Stabilization Study \\
\hline LMIT-97-29 & Ryegrass Road \\
\hline LMIT-97-30 & TAN Fire Lines \\
\hline LMIT-97-31 & BLM Fence \\
\hline LMIT-97-32 & TRA Electrical Upgrade \\
\hline
\end{tabular}


Table 9. (continued).

INL Cultural Resource Management Office Archaeological Investigations

\begin{tabular}{|c|c|}
\hline Project Number & Project Title \\
\hline LMIT-97-33 & LCCDA and OMRE Soil Sampling \\
\hline LMIT-97-34 & Varsity Scout Trip to Middle Butte \\
\hline LMIT-97-35 & OU 10-04 Offsite/Onsite Soil Sampling \\
\hline LMIT-97-36 & Surplus Plutonium Disposition EIS \\
\hline LMIT-97-37 & Middle Butte Cave Fluid Flow Study \\
\hline LMIT-97-38 & Dike Improvements \\
\hline LMIT-97-39 & Argonne Burn Assessment \\
\hline LMIT-97-40 & ARA $01,02,10,23$, and 24 Sampling \\
\hline LMIT-97-41 & Soil Removal at ICPP \\
\hline LMIT-97-42 & TAN Parking \\
\hline LMIT-97-43 & ESRF Dairy Farm Ant Studies \\
\hline LMIT-97-44 & High Level Waste Facility/Low Level Mixed Waste Landfill \\
\hline LMIT-97-45 & ICPP Concrete Batch Plant \\
\hline LMIT-97-46 & FY97 Sitewide Road Upgrades \\
\hline LMIT-97-47 & ISU TAN Soil Studies \\
\hline LMIT-97-48 & ICPP Cask Storage Area \\
\hline LMIT-97-49 & ANL-PBF Powerline Road Upgrade \\
\hline LMIT-97-50 & CFA Landfill Horse \\
\hline LMIT-97-51 & PBF Rock Probes \\
\hline LMIT-97-52 & Highway 20 Parking Lot (Idaho Falls) \\
\hline LMIT-97-53 & CFA Communications Upgrade \\
\hline LMIT-97-54 & Controlled Burn East of ICPP \\
\hline LMIT-97-55 & Controlled Burn Along Highway 20/26 \\
\hline & $\begin{array}{rr}\text { Fiscal Year } 1998 \\
\end{array}$ \\
\hline LMIT-98-01 & Arco Hills Quartzite Mine \\
\hline LMIT-98-02 & Diversion Dike Peiziometers \\
\hline LMIT-98-03 & RWMC Well Modification \\
\hline LMIT-98-04 & NOAA Tower at RWMC \\
\hline LMIT-98-05 & New Idaho Falls Laboratory \\
\hline LMIT-98-06 & Job Requirements Checklist \\
\hline LMIT-98-08 & INEEL Electrical Upgrade Phases II and III \\
\hline LMIT-98-09 & Soil Gas Sampling at STF/OMRE \\
\hline LMIT-98-10 & High Level Waste EIS \\
\hline LMIT-98-11 & Monitoring Wells M11S - M14S \\
\hline
\end{tabular}


Table 9. (continued).

INL Cultural Resource Management Office Archaeological Investigations

\begin{tabular}{|c|c|}
\hline Project Number & Project Title \\
\hline LMIT-98-12 & SERDP proposal \\
\hline LMIT-98-13 & WERF Disposition Plan \\
\hline LMIT-98-14 & TRA Fire Lines \\
\hline LMIT-98-15 & RWMC Sewer Upgrade Expansion \\
\hline LMIT-98-16 & Waste Treatment EIS (ICPP) \\
\hline LMIT-98-17 & Field Study of Environmental Baseline Areas \\
\hline LMIT-98-18 & Soil and Water Conservation Society Tour \\
\hline LMIT-98-19 & ROB/IEDF Wells \\
\hline LMIT-98-20 & Billboard Near SAF on Highway 20 in Idaho Falls \\
\hline LMIT-98-21 & ESRF Revegetation Studies \\
\hline LMIT-98-22 & Site Operations Center at CFA \\
\hline LMIT-98-23 & ISU Soil Studies \\
\hline LMIT-98-24 & Bureau of Reclamation Floodplain Investigations \\
\hline LMIT-98-25 & CF-10 Transformer Yard Petroleum Cleanup \\
\hline LMIT-98-26 & INTEC Drilling \\
\hline LMIT-98-27 & USGS Well Near RWMC Dike \\
\hline LMIT-98-28 & Cooperative Efforts with Yellowstone National Park \\
\hline LMIT-98-29 & Aviators' Cave Projectile Point Analysis \\
\hline LMIT-98-30 & INTEC EA for CPP-601, $-603,-627$, and -640 \\
\hline LMIT-98-31 & ARA/PBF Environmental Restoration \\
\hline LMIT-98-32 & Nevada Street Bones \\
\hline LMIT-98-33 & INTEC Percolation Pond Modification/Expansion \\
\hline LMIT-98-34 & Highway 20/26 Controlled Burn \\
\hline LMIT-98-35 & VentureStar \\
\hline LMIT-98-36 & Firing Range Controlled Burn \\
\hline LMIT-98-37 & CFA Sidewalks \\
\hline LMIT-98-38 & Pioneer Fence \\
\hline & Fiscal Year 1999 \\
\hline LMIT-99-01 & STF Firing Range Fence \\
\hline LMIT-99-02 & Deadman Grazing Allotment Fence \\
\hline LMIT-99-03 & INEEL FOC Upgrade Activities (ANL-W Structure) \\
\hline LMIT-99-04 & RWMC Waste Treatability Project \\
\hline LMIT-99-05 & INEEL Road Rehabilitation - Implementation \\
\hline LMIT-99-06 & BORAX Gravel Pit Expansion \\
\hline
\end{tabular}


Table 9. (continued).

INL Cultural Resource Management Office Archaeological Investigations

\begin{tabular}{|c|c|}
\hline Project Number & Project Title \\
\hline LMIT-99-07 & Bulky Waste Pit \\
\hline LMIT-99-08 & New INTEC Percolation Ponds \\
\hline LMIT-99-09 & INEEL Environmental Aspects \\
\hline LMIT-99-10 & Farragut Blvd. Modifications \\
\hline LMIT-99-11 & TAN Waterlines \\
\hline LMIT-99-12 & Northstar Satellite Launch Facility \\
\hline LMIT-99-13 & RWMC Powerline \\
\hline LMIT-99-14 & TRA Summary \\
\hline LMIT-99-15 & SNF Dry Storage Area Relocation \\
\hline LMIT-99-16 & TAN Wells PNA-2 through PNA-5 \\
\hline LMIT-99-17 & NOAA Field Mills \\
\hline LMIT-99-18 & RWMC Storage Facility \\
\hline LMIT-99-19 & INTEC Entrance Guard Gate and Parking Lot \\
\hline LMIT-99-20 & ESRF Vegetation Plots near INTEC \\
\hline LMIT-99-21 & INTEC WAG 3 Geotechnical Sampling \\
\hline LMIT-99-22 & ESRF Vegetation and Insect Sampling \\
\hline LMIT-99-23 & WAG 5 Remediation \\
\hline LMIT-99-24 & Jefferson County Free Use Permit \\
\hline LMIT-99-25 & Boreholes near CPP-651 \\
\hline LMIT-99-26 & USGS Wells \\
\hline LMIT-99-27 & INTEC Cluster and Aquifer Wells \\
\hline LMIT-99-28 & Global Technology Inc. Lichen, Vegetation, and Soil Sampling \\
\hline LMIT-99-29 & Mud Lake Experimental Sheep Station Surveys \\
\hline LMIT-99-30 & New RWMC Concrete Batch Plant \\
\hline LMIT-99-31 & RWMC Wells \\
\hline LMIT-99-32 & Sagebrush Steppe Ecosystem Preserve \\
\hline LMIT-99-33 & INTEC Aquifer Wells \\
\hline LMIT-99-34 & IRC Field Activities \\
\hline LMIT-99-35 & TSF CERCLA Activities \\
\hline LMIT-99-36 & ESRF Revegetation Assessment \\
\hline LMIT-99-37 & Climate Change LDRD \\
\hline LMIT-99-38 & ANL-PBF Road Gravelling \\
\hline LMIT-99-39 & OMRE Wells \\
\hline LMIT-99-40 & SWPP Release Sites \\
\hline
\end{tabular}


Table 9. (continued).

INL Cultural Resource Management Office Archaeological Investigations

\begin{tabular}{|c|c|}
\hline Project Number & Project Title \\
\hline LMIT-99-41 & STF Firing Range \\
\hline LMIT-99-42 & CFA Sirens \\
\hline LMIT-99-43 & PBF Asphalt Repair \\
\hline LMIT-99-44 & PBF Drainfield Enlargement \\
\hline LMIT-99-45 & Cold Test Pit Soil Sampling \\
\hline \multicolumn{2}{|r|}{ Fiscal Year 2000} \\
\hline BBWI-00-01 & ARA-INTEC Road \\
\hline BBWI-00-02 & INEEL Vegetation Mapping/INPeace project \\
\hline BBWI-00-03 & Regional Groundwater Sampling \\
\hline BBWI-00-04 & U.S. Cellular Tower at Circular Butte \\
\hline BBWI-00-05 & Records Storage Facility at IRC \\
\hline BBWI-00-06 & INTEC Stormwater Basins \\
\hline BBWI-00-08 & AMWTP Powerline at RWMC \\
\hline BBWI-00-09 & Cold Test Pit Expansion (no clearance) \\
\hline BBWI-00-10 & WAG 6/10 OU 10-04 Native American Risk Assessment \\
\hline BBWI-00-11 & IRC 5-Well Investigation \\
\hline BBWI-00-12 & WAG-5 Overview \\
\hline BBWI-00-13 & CFA Remediation - pond, drainfield, transformer yard \\
\hline BBWI-00-14 & NRF Concrete Batch Plant \\
\hline BBWI-00-15 & Cold Test Pit Powerline Spur \\
\hline BBWI-00-16 & RWMC Storage Containers \\
\hline BBWI-00-17 & TAN Well PNA-1 \\
\hline BBWI-00-18 & BORAX Ecosampling \\
\hline BBWI-00-19 & Ordnance Walkdowns \\
\hline BBWI-00-20 & Spreading Area B Revegetation \\
\hline BBWI-00-21 & OMRE Sampling \\
\hline BBWI-00-22 & ARA Remediation \\
\hline BBWI-00-23 & Big Lost River Tracer Study \\
\hline BBWI-00-24 & Decontamination of CF-617 \\
\hline BBWI-00-25 & INEEL Road Rehabilitation \\
\hline BBWI-00-26 & NRF Demonstration at RR and Lincoln Blvd. \\
\hline BBWI-00-27 & INTEC Gas Cylinders Characterization and Remediation \\
\hline BBWI-00-28 & ITDF \\
\hline BBWI-00-29 & USGS Wells at INTEC Service Wastewater Facility \\
\hline
\end{tabular}


Table 9. (continued).

INL Cultural Resource Management Office Archaeological Investigations

\begin{tabular}{|c|c|}
\hline Project Number & Project Title \\
\hline BBWI-00-30 & ARA-II/SL-I Vegetation and Soil Sampling \\
\hline BBWI-00-31 & INTEC Mercury Sampling in Vegetation and Soils \\
\hline BBWI-00-32 & PER-613 Concrete Pad \\
\hline BBWI-00-33 & Expanded Monitoring Well System for New INTEC Percolation Ponds \\
\hline BBWI-00-34 & TAN Well \#M21W \\
\hline BBWI-00-35 & USGS Trenching of Bedrock Constrictions Within the Big Lost River \\
\hline BBWI-00-36 & INTEC Post Array \\
\hline BBWI-00-37 & SMC Production Equipment Upgrade \\
\hline BBWI-00-38 & Bureau of Reclamation Floodplain Mapping \\
\hline BBWI-00-39 & Cesium Sampling at ARA \\
\hline BBWI-00-40 & PER-632 Excavation \\
\hline BBWI-00-41 & Dust/Fire Suppression \\
\hline BBWI-00-42 & TAN Firebreaks \\
\hline BBWI-00-43 & Sagebrush Clearing At TRA \\
\hline BBWI-00-44 & INTEC Perched Water Wells \\
\hline BBWI-00-45 & Facility Sensitivity Analysis for Work Control Process \\
\hline BBWI-00-46 & ISU Geology Field Trip \\
\hline BBWI-00-47 & Science Action Teams \\
\hline \multicolumn{2}{|r|}{ Fiscal Year 2001} \\
\hline BBWI-01-01 & INTEC Electrical Upgrade \\
\hline BBWI-01-02 & WAG 6/10 OU 10-04 Overview \\
\hline BBWI-01-03 & DEQ Big Lost River Total Maximum Daily Load Analysis \\
\hline BBWI-01-04 & Fire EA \\
\hline BBWI-01-05 & Storm Water Permit Renewal \\
\hline BBWI-01-06 & ICDF Review including SSSTF Expansion \\
\hline BBWI-01-07 & RWMC Wells \\
\hline BBWI-01-08 & CFA Remediation \\
\hline BBWI-01-09 & INEEL ISF \\
\hline BBWI-01-10 & WAG 5 NAGPRA \\
\hline BBWI-01-11 & Firing Range Modifications-Moving Vehicle Training Area \\
\hline BBWI-01-12 & CFRD Imagery project \\
\hline BBWI-01-13 & SERDP proposal \\
\hline BBWI-01-14 & Highway 26 Parking Lot Snow and Weed Removal \\
\hline BBWI-01-15 & U.S. Army Demolition and Training Exercises \\
\hline
\end{tabular}


Table 9. (continued).

INL Cultural Resource Management Office Archaeological Investigations

\begin{tabular}{|c|c|}
\hline Project Number & Project Title \\
\hline BBWI-01-16 & WERF Waterline Break (between 641 and 609) \\
\hline BBWI-01-17 & FAA Explosives Magazine Relocation \\
\hline BBWI-01-18 & WAG 3 Hot Spot Monitoring Well \\
\hline BBWI-01-19 & V-Tank Sampling at TAN \\
\hline BBWI-01-20 & Deer Mouse Trapping \\
\hline BBWI-01-21 & INEEL Road and Parking Lot Rehab \\
\hline BBWI-01-22 & RWMC Remote Handled Low Level Waste Disposal Vaults \\
\hline BBWI-01-23 & RWMC Reseeding \\
\hline BBWI-01-24 & IRC Leased Labs \\
\hline BBWI-01-25 & DD\&D of CF-617 \\
\hline BBWI-01-26 & T-Road Grading and Mowing \\
\hline BBWI-01-27 & SDA Paleontology \\
\hline BBWI-01-28 & Floodplain Trenching \\
\hline BBWI-01-29 & Idaho Falls Fiber Optic Upgrade near University Place \\
\hline BBWI-01-30 & T-Road Training Exercises \\
\hline BBWI-01-31 & TRA Hot Cell Concrete Pad \\
\hline BBWI-01-32 & FAA Explosives Storage Facility \\
\hline BBWI-01-33 & Ryegrass Flats Roads \\
\hline BBWI-01-34 & USGS Well at EBR-I \\
\hline BBWI-01-35 & INEEL Archaeological Field School \\
\hline BBWI-01-36 & BLM Fire Fence \\
\hline BBWI-01-37 & WAG-10 New Sites \\
\hline BBWI-01-38 & Bechtel Telecom Wireless Test Bed \\
\hline BBWI-01-39 & Butte Burn \\
\hline BBWI-01-40 & CFA Cellular Tower \\
\hline BBWI-01-41 & Pebble Bed Reactor Alternatives \\
\hline BBWI-01-42 & In Situ Implosion Process Test \\
\hline BBWI-01-43 & Cold Test Pit Grouting Experiments \\
\hline BBWI-01-44 & Subsurface Geosciences Lab \\
\hline BBWI-01-45 & Relocation of ARA Explosives Disposal Operation to Firing Range \\
\hline BBWI-01-46 & Misc. NRF projects \\
\hline
\end{tabular}


Table 9. (continued).

\begin{tabular}{|c|c|}
\hline \multicolumn{2}{|r|}{ INL Cultural Resource Management Office Archaeological Investigations } \\
\hline Project Number & Project Title \\
\hline \multicolumn{2}{|r|}{ Fiscal Year 2002} \\
\hline BBWI-02-01 & SNF Dry Storage Utility Extension at INTEC \\
\hline BBWI-02-02 & Rain Gauge and Monitor at Experimental Field Station \\
\hline BBWI-02-03 & Hand Augering in Big Lost River Sinks \\
\hline BBWI-02-04 & DOE-ID Temporary Parking Lots in Idaho Falls \\
\hline BBWI-02-05 & Syringa Networks Fiber Optics, Howe to Mud Lake \\
\hline BBWI-02-06 & City Canal \\
\hline BBWI-02-08 & Sagebrush Seedling Experiment \\
\hline BBWI-02-09 & Pit 9 Glovebox Project \\
\hline BBWI-02-10 & Saddle and Big Loop Monitoring \\
\hline BBWI-02-11 & New Wells in the Vadose Zone Research Park \\
\hline BBWI-02-12 & 651 Mockup at the INEEL Gun Range \\
\hline BBWI-02-13 & Vegetation Exclosures in the Tin Cup Fire \\
\hline BBWI-02-14 & Soil Sampling Near Van Buren Blvd. \\
\hline BBWI-02-15 & ICDF Wells and Laydown Area \\
\hline BBWI-02-16 & BLM Road Grading on INEEL \\
\hline BBWI-02-17 & INTEC Low Level Waste Landfill \\
\hline BBWI-02-18 & INTEC Wells and Geobores \\
\hline BBWI-02-19 & PBF Monuments \\
\hline BBWI-02-20 & Tribal Activities at Aviators' Cave \\
\hline BBWI-02-21 & ARA Remediation \\
\hline BBWI-02-22 & Soil Sampling West and Southwest of INTEC \\
\hline BBWI-02-23 & SSSTF Cistern \\
\hline BBWI-02-24 & Pygmy Rabbit Reintroduction \\
\hline BBWI-02-25 & Scott Fire \\
\hline BBWI-02-26 & Vadose Zone Research Park' \\
\hline BBWI-02-27 & PBF-620 Excavations \\
\hline BBWI-02-28 & NRF Finds \\
\hline BBWI-02-29 & Footprint Reduction \\
\hline BBWI-02-30 & RWMC Spur Powerline \\
\hline BBWI-02-31 & Injection Well Retention Basin Enlargement Near PBF \\
\hline BBWI-02-32 & National Wireless Test Bed \\
\hline BBWI-02-33 & TRA Well \\
\hline BBWI-02-34 & INTEC Bone \\
\hline
\end{tabular}


Table 9. (continued).

INL Cultural Resource Management Office Archaeological Investigations

\begin{tabular}{|c|c|}
\hline Project Number & Project Title \\
\hline BBWI-02-35 & Ryegrass Bone \\
\hline BBWI-02-36 & Ordnance Removal \\
\hline BBWI-02-37 & PBF 626 and 601 Excavations \\
\hline BBWI-02-38 & ISU Field School \\
\hline & Fiscal Year 2003 \\
\hline BBWI-03-01 & Removal of surface soils at ARA \\
\hline BBWI-03-02 & INEEL Footprint Reduction Laboratory at INTEC \\
\hline BBWI-03-03 & Access Modifications at PBF \\
\hline BBWI-03-04 & Early Remedial Actions at TAN \\
\hline BBWI-03-05 & Seismic Station Installation Near Pocatello \\
\hline BBWI-03-06 & NRF Projects \\
\hline BBWI-03-07 & USGS Wells near CFA \\
\hline BBWI-03-08 & More Pygmy Rabbit Burrows \\
\hline BBWI-03-09 & New Parking Areas at the Site \\
\hline BBWI-03-10 & ICDF Ecological Sampling \\
\hline BBWI-03-11 & Long Term Ecological Monitoring \\
\hline BBWI-03-12 & Unpaved Road Maintenance \\
\hline BBWI-03-13 & TAN Fire Station Soil Sampling \\
\hline BBWI-03-14 & Controlled Burns at the Firing Range \\
\hline BBWI-03-15 & WTB Activities \\
\hline BBWI-03-16 & 10-BT-810 Investigations \\
\hline BBWI-03-17 & New CERCLA Sites \\
\hline BBWI-03-18 & Sage Grouse Studies \\
\hline BBWI-03-19 & IDT/BLM Highway 20/26 Gravel Pit Expansion \\
\hline BBWI-03-20 & Final Placement of Foster Wheeler ISF \\
\hline BBWI-03-21 & Revegetation of Engineered Barriers Project Area \\
\hline BBWI-03-22 & New Landfill at TAN \\
\hline BBWI-03-23 & Archaeological Sensitivity Maps for the Fire Dept. \\
\hline BBWI-03-24 & $\mathrm{DD} \& \mathrm{D}$ at $\mathrm{PBF}$ \\
\hline BBWI-03-25 & Powerpole Maintenance \\
\hline BBWI-03-26 & Chloride Sampling For Infiltration Studies \\
\hline BBWI-03-27 & Vegetation Removal Around PBF-604 \\
\hline BBWI-03-28 & IRC Fire Suppression Upgrade \\
\hline BBWI-03-29 & BLM Use of T-12 Pit \\
\hline
\end{tabular}


Table 9. (continued).

\begin{tabular}{|c|c|}
\hline \multicolumn{2}{|c|}{$\begin{array}{r}\text { INL Cultural Resource Management Office Archaeological Investigations } \\
\end{array}$} \\
\hline Project Number & Project Title \\
\hline BBWI-03-30 & GPS Tower (Coast Guard and DOE) \\
\hline BBWI-03-31 & Runway of UAVs \\
\hline BBWI-03-32 & INEEL 2003 Range Fires \\
\hline BBWI-03-33 & RWMC Well \\
\hline BBWI-03-34 & Northwind/BLM Power ROW \\
\hline BBWI-03-35 & Vadose Zone Research Park Activities \\
\hline BBWI-03-36 & Yucca Modeling at INEEL Lava Tubes \\
\hline BBWI-03-37 & Fence at Firing Range \\
\hline BBWI-03-38 & Section 110 Surveys \\
\hline BBWI-03-39 & ISU Field School \\
\hline \multicolumn{2}{|r|}{ Fiscal Year 2004} \\
\hline BBWI-04-01 & INTEC Parking Lot Extension \\
\hline BBWI-04-02 & RWMC Wells \\
\hline BBWI-04-03 & Wireless Test Bed Enhancements \\
\hline BBWI-04-04 & WAG 10 Ordnance Removal \\
\hline BBWI-04-05 & USGS Wells 132 and 133 \\
\hline BBWI-04-06 & D\&D of Ground Piping at TAN \\
\hline BBWI-04-07 & Powerpole at ARA IV \\
\hline BBWI-04-08 & National Security Projects at PBF \\
\hline BBWI-04-09 & Free Space Optic System \\
\hline BBWI-04-10 & TRA Potable Water Well System \\
\hline BBWI-04-11 & Misc. DD\&D at TAN, TRA, INTEC, PBF \\
\hline BBWI-04-12 & FY04 Long Term Ecological Sampling \\
\hline BBWI-04-13 & Pit 4 Stop Work Exemption \\
\hline BBWI-04-14 & RWMC Security Trailer and New Access Point \\
\hline BBWI-04-15 & TAN Trailer Relocation \\
\hline BBWI-04-16 & WRRTF Road and DD\&D \\
\hline BBWI-04-17 & INTEC Sewage Treatment Plant Upgrade \\
\hline BBWI-04-18 & Road Upgrade Between ANL-W and PBF \\
\hline BBWI-04-19 & Coast Guard NDGPS Tower at STF \\
\hline BBWI-04-20 & FY04 Fires \\
\hline BBWI-04-21 & Expansion of Mining at Ryegrass Flats \\
\hline BBWI-04-22 & Road Grading Along Scoville Siding \\
\hline BBWI-04-23 & E-85 Alternative Fuel Stations \\
\hline
\end{tabular}


Table 9. (continued).

INL Cultural Resource Management Office Archaeological Investigations

\begin{tabular}{|c|c|}
\hline Project Number & Project Title \\
\hline BBWI-04-24 & SMC Nurse Trailer \\
\hline BBWI-04-25 & Vadose Zone Research Park New Wells \\
\hline BBWI-04-26 & Explosive Breach Pad at Range 7 \\
\hline BBWI-04-27 & NRF Projects \\
\hline BBWI-04-28 & CFA Landfills Monitoring Wells \\
\hline BBWI-04-29 & ICDF Parking Expansion \\
\hline BBWI-04-30 & PBF Substation Modifications for SCADA Testbed \\
\hline BBWI-04-31 & Rattlesnake Cave Drift Fence \\
\hline BBWI-04-32 & PBF-632 Septic System Modifications \\
\hline BBWI-04-33 & East Butte Radio Towers \\
\hline BBWI-04-34 & Explosives Testing at MDA \\
\hline BBWI-04-35 & National Security Work on the Powerline between SPERT and CFA \\
\hline BBWI-04-36 & CITRC activities at MDA, etc. \\
\hline BBWI-04-37 & Seismic Station at Well M14S near T-12 \\
\hline BBWI-04-38 & Removal of Manganese Pile from CFA \\
\hline BBWI-04-39 & HPIL Modifications at CFA \\
\hline BBWI-04-40 & INL Section 110 Surveys \\
\hline \multicolumn{2}{|r|}{ Fiscal Year 2005} \\
\hline BBWI-05-01 & Family Care Center in Ammon \\
\hline BBWI-05-02 & UGV Obstacle Course \\
\hline BBWI-05-03 & PBF-620 D\&D \\
\hline BBWI-05-04 & RWMC Accelerated Cleanup Phase II \\
\hline BBWI-05-05 & Stormwater Ditch \\
\hline BBWI-05-06 & Seismic Stations \\
\hline BBWI-05-07 & Large Scale Explosives Testing Area \\
\hline BBWI-05-08 & USGS Wells \#134 and 135 \\
\hline BBWI-05-09 & ETR/MTR EA \\
\hline BBWI-05-10 & WTB Expansions at the Badging Station, Van Buren Blvd, and Wilson Blvd \\
\hline BBWI-05-11 & Monitoring Wells along the Big Lost \\
\hline BBWI-05-12 & Soil Remediation at STF \\
\hline BBWI-05-13 & 5-year RCRA Review \\
\hline BEA-05-14 & Closing out BLR Trenches \\
\hline BEA-05-15 & New Road Between MFC and INTEC \\
\hline BEA-05-16 & WTB Temporary Trailers \\
\hline
\end{tabular}


Table 9. (continued).

INL Cultural Resource Management Office Archaeological Investigations

\section{Project Number}

BEA-05-17

BEA-05-18

BEA-05-19

BEA-05-20

BEA-05-21

BEA-05-22

BEA-05-23

BEA-05-24

BEA-05-25

BEA-05-26

BEA-05-27

BEA-05-28

BEA-05-29

BEA-05-30

BEA-05-31

BEA-05-33

BEA-05-34

BEA-05-35

BEA-05-36

BEA-05-37

BEA-05-38

BEA-05-39

BEA-05-40

BEA-05-41:

BEA-05-42:

BEA-05-43:
BEA-05-32

\section{Project Title}

LT Ecological Monitoring

Demolition of ETR Stack

Powerpole Maintenance

NOAA Trench

New Security Roads around MFC

TAN 607 Deactivation

New ETR Fence, Gate, and Parking Lot

INTEC Security Fence Modification and DD\&D

ISFF Road and Drainage Improvement at INTEC

Pioneer Excavations

UAV Vegetation Study

Structural Collapse Rescue Training Area at CFA

Support Pad for Pump Filters at EFS

CFA Biodiesel Tank

Fiber Optic Relay Upgrade

Sampling of CERCLA Sites

Wildland Fire Protection

Drilling in IF

RWMC Activities - Parking Expansion, Trailer Relocation, Cell Tower on Wheels

PBF Fire Control During Powerline Project

Vadose Zone Research Park Trenches

INTEC Ash Pit

TRA Bones

Guard Gate 4 Vegetation and Rock Clearing

Section 110

Well Capping at INTEC and TAN

Modular Offices at RTC

\section{Fiscal Year 2006}

BEA-06-01:

PBF Monitoring: 690-632 Waterlines

BEA-06-02:

Cell Tower at ARA

BEA-06-03:

Expanded Surveys of T-24 and the Power Line Road

BEA-06-04:

Research Equipment Installation (Homeland Security) at PBF

BEA-06-05

NRF Projects

BEA-06-06: 
Table 9. (continued).

INL Cultural Resource Management Office Archaeological Investigations

\begin{tabular}{|c|c|}
\hline Project Number & Project Title \\
\hline BEA-06-07: & Structural Collapse Rescue Training Area at CFA \\
\hline BEA-06-08: & CIP R\&D Testing \\
\hline BEA-06-09: & Batch Plant Near the Coal Fire Plant at INTEC \\
\hline BEA-06-10: & MFC Design Basis Threat \\
\hline BEA-06-11: & FY 2006 Ordnance Remediation \\
\hline BEA-06-12: & Vadose Zone Research Park Improvements \\
\hline BEA-06-13: & FY 2006 Long Term Eco Studies \\
\hline BEA-06-14: & Mass Detonation Area Container Tests \\
\hline BEA-06-15: & USGS Gauging Station Repairs \\
\hline BEA-06-16: & Mars Project Drilling Area in IF \\
\hline BEA-06-17: & STC Campus in IF \\
\hline BEA-06-18: & BLR Rest Area Improvements \\
\hline BEA-06-19: & CPP-603 Basin Water Removal \\
\hline BEA-06-20: & Large Scale Explosive Test Facility \\
\hline BEA-06-21: & TAN Locomotive Relocation \\
\hline BEA-06-22: & Door Testing, Firing Range \\
\hline BEA-06-23: & PBF Reactor Complex Continued DD\&D \\
\hline BEA-06-24: & BLM Fences \\
\hline BEA-06-25: & Force-on-Force Training Activities \\
\hline BEA-06-26: & USGS Well 103 \\
\hline BEA-06-27: & Reptile Traps \\
\hline BEA-06-28: & TAN Haul Road for Landfill Access \\
\hline BEA-06-29: & TRA-724 Excavation \\
\hline BEA-06-30: & Sagebrush Study-Stoller \\
\hline BEA-06-31: & Section 110 Surveys \\
\hline BEA-06-32: & Look Ahead Sensor Tests \\
\hline BEA-06-33: & Weed Control and Revegetation Areas (ICP) \\
\hline BEA-06-34: & National Wireless Test Bed Drive Test Facility \\
\hline BEA-06-35: & Cold Test Pit Activities \\
\hline BEA-06-36: & Remote Treatment Project at MFC \\
\hline BEA-06-37: & Western Energy Corridor \\
\hline BEA-06-38: & Preliminary Activities for Next Generation Nuclear Plant and Global Nuclear Energy \\
\hline
\end{tabular}


Table 9. (continued).

INL Cultural Resource Management Office Archaeological Investigations

\begin{tabular}{|c|c|}
\hline Project Number & Project Title \\
\hline & Fiscal Year 2007 \\
\hline BEA-07-01: & ICP General DD\&D \\
\hline BEA-07-02: & INTEC Parking Lot/Integrated Waste Treatment Unit \\
\hline BEA-07-03: & T-16 Improvements \\
\hline BEA-07-04: & CERCLA Cleanup of PBF-33 and PBF-34 \\
\hline BEA-07-05: & AMWTP Yurt and Trailers South of RWMC \\
\hline BEA-07-06: & Enlarged Drive-By Test Range \\
\hline BEA-07-07: & Cell Tower north of INTEC \\
\hline BEA-07-08: & Vadose Zone Research Park Expansion \\
\hline BEA-07-09: & PER-620 Grading \\
\hline BEA-07-10: & Wireless Test Bed WRRTF Powerline \\
\hline BEA-07-11: & Big Lost River Trenches \\
\hline BEA-07-12: & Unmanned Ground Vehicle Test Range \\
\hline BEA-07-13: & Aurora Test at INTEC Substation \\
\hline BEA-07-14: & FY 2007 Ordnance Surveys \\
\hline BEA-07-15: & Instrumentation Cable Cleanup at PBF \\
\hline BEA-07-16: & FY 2007 Long Term Ecological Surveys \\
\hline BEA-07-17: & Offroad Access between PBF and INL CERCLA Disposal Facility \\
\hline BEA-07-18: & National Security Test Range Developments \\
\hline BEA-07-19: & Gamma Spec Calibration Pad at MFC \\
\hline BEA-07-20: & Accelerator Signs around PER-612 \\
\hline BEA-07-21: & RTC Parking Lot Expansion \\
\hline BEA-07-22: & Tank Removal at CFA and PBF \\
\hline BEA-07-23: & RWMC Fire Upgrade \\
\hline BEA-07-24: & Beacon Test Site East of MFC \\
\hline BEA-07-25: & Remote Handled Waste Disposition Project \\
\hline BEA-07-26: & Firing Range Safety Fan Expansion at CFA and MFC \\
\hline BEA-07-27: & 2007 Fire Prevention (mowing) \\
\hline BEA-07-28: & EBR-I Maintenance (deep well) \\
\hline BEA-07-29: & New MFC Guard Post \\
\hline BEA-07-30: & Twin Buttes and Moonshiners Fires \\
\hline BEA-07-31: & INTEC Batch Plant Improvements \\
\hline BEA-07-32: & Section 110 \\
\hline BEA-07-33: & Cell Tower at Drive By Test Facility (Cell Site 8) \\
\hline BEA-07-34: & New Lights at the Puzzle \\
\hline
\end{tabular}


Table 9. (continued).

INL Cultural Resource Management Office Archaeological Investigations

\begin{tabular}{|c|c|}
\hline Project Number & Project Title \\
\hline \multicolumn{2}{|r|}{ Fiscal Year 2008} \\
\hline BEA-08-01: & New Poles at CFA Substation \\
\hline BEA-08-02: & CERCLA Misc Sites Monitoring and Remediation \\
\hline BEA-08-03: & National Security Test Range Safety Fan and Other Developments \\
\hline BEA-08-04: & Research and Education Campus Development in Idaho Falls \\
\hline BEA-08-05: & Section 110 \\
\hline BEA-08-06: & U. S. Geological Survey FY 08 Drilling Program \\
\hline BEA-08-07: & Next Generation Nuclear Plant Contained Test Facility Siting Study \\
\hline BEA-08-08: & INL Temporary Wind Towers \\
\hline BEA-08-09: & Power Line Testing (Trail Mix) \\
\hline BEA-08-10: & Mountain States Intertie Siting Study \\
\hline BEA-08-11: & CFA and MFC Gun Range Surface Danger Zone Extensions \\
\hline BEA-08-12: & MFC Search Station Power Cable \\
\hline BEA-08-13: & NRF Misc Projects (Ponds, Administrative Boundary, Mowing, Wells) \\
\hline BEA-08-14: & Vadose Zone Research Park Auger Holes \\
\hline BEA-08-15: & Ordnance Removal at the National Oceanic and Atmospheric Administration Grid \\
\hline BEA-08-16: & ICP General DD\&D and Cleanup \\
\hline BEA-08-17: & Next Generation Nuclear Plant Siting Study \\
\hline BEA-08-18: & Misc DD\&D at PBF \\
\hline BEA-08-19: & Dairy Farm and Fuse Burn Ordnance Geophysical Surveys \\
\hline BEA-08-20: & Railroad Rebuild \\
\hline BEA-08-21: & Long Term Ecological Sampling \\
\hline BEA-08-22: & New Research Cell Towers \\
\hline BEA-08-23: & MFC Barriers \\
\hline BEA-08-24: & Power Line Loop Tests \\
\hline BEA-08-25: & July 9 Wild Fire \\
\hline BEA-08-26: & Infiltration Basin Reuse \\
\hline BEA-08-27: & Power Line Tests at Dairy Farm and WRRTF \\
\hline BEA-08-28: & National Oceanic and Atmospheric Administration Barrier Dispersion Tests \\
\hline BEA-08-29: & Cell Site 8 Upgrade \\
\hline BEA-08-30: & CITRC Evacuation Road \\
\hline BEA-08-31: & AREVA Siting Study \\
\hline BEA-08-32: & Mine Detection Technology at the INL Research Complex, Idaho Falls \\
\hline BEA-08-33: & INL Sitewide Monitoring \\
\hline
\end{tabular}


Table 9. (continued).

INL Cultural Resource Management Office Archaeological Investigations

Project Number

BEA-08-34:

BEA-08-35:

BEA-08-36:

BEA-08-37:

BEA-08-38:

BEA-08-39:

\section{Project Title}

Integrated Waste Treatment Unit Laydown Area Near INTEC

CFA Firing Range Improvements

Low Level Waste Disposal Facility EIS

Well Technology Demonstration along INL T-Roads

Idaho Fish and Game Water Troughs

Army Training at CITRC 
Table 10. Early INL archaeological investigations and subcontracts.

\begin{tabular}{|c|c|}
\hline \multicolumn{2}{|c|}{ Early INL Archaeological Investigations and Subcontracts } \\
\hline $\begin{array}{l}\text { INL CRM Office Project } \\
\text { Number }\end{array}$ & Project Title \\
\hline \multicolumn{2}{|r|}{ Calendar Year 1954} \\
\hline EHS-54-01 & Little Lost River Cave No. 1 Excavation \\
\hline \multicolumn{2}{|r|}{ Calendar Year 1958} \\
\hline EHS-58-01 & Swanson Surveys \\
\hline \multicolumn{2}{|r|}{ Calendar Year 1961} \\
\hline EHS-61-01 & Birch Creek Surveys \\
\hline \multicolumn{2}{|r|}{ Calendar Year 1962} \\
\hline EHS-62-01 & Jackknife Cave and Other Test Excavations \\
\hline \multicolumn{2}{|r|}{ Calendar Year 1969-1970 } \\
\hline BRB-70-01 & NRTS Surveys 1967-1969 \\
\hline \multicolumn{2}{|r|}{ Calendar Year 1970-1971 } \\
\hline BRB-71-01 & NRTS Surveys 1970-1971 \\
\hline \multicolumn{2}{|r|}{ Calendar Year 1975} \\
\hline SJM-75-01 & EBR-II/SAREF \\
\hline SJM-75-02 & SAREF Alternate \\
\hline \multicolumn{2}{|r|}{ Calendar Year 1976} \\
\hline SJM-76-01 & CFA-EBR-II Telephone Cable \\
\hline SJM-76-02 & Willow Creek Building in IF \\
\hline \multicolumn{2}{|r|}{ Calendar Year 1977} \\
\hline LAK-77-01 & Little Lost River/Birch Creek Planning Unit \\
\hline \multicolumn{2}{|r|}{ Calendar Year 1981} \\
\hline SJM-81-01 & CPP Coal-Fired Plant \\
\hline SJM-81-02 & CPP Drain Field \\
\hline \multicolumn{2}{|r|}{ Calendar Year 1982} \\
\hline SJM-82-01 & CPP Gravel Pit Drilling \\
\hline \multicolumn{2}{|r|}{ Calendar Year 1983} \\
\hline SJM-83-01 & RWMC Wind Gaps (\#2 and RR) \\
\hline SJM-83-02 & Vadose Zone Monitoring Wells, RWMC vicinity \\
\hline SJM-83-03 & Big Lost River Diversion Canal Expansion \\
\hline SJM-83-04 & CPP Well \#4 \\
\hline SJM-83-05 & CPP Monitoring Wells \\
\hline SJM-83-06 & Nile Ave./Lincoln Blvd. Intersection \\
\hline SJM-83-07 & Principal Lineament \\
\hline
\end{tabular}


Table 10. (continued).

\section{Early INL Archaeological Investigations and Subcontracts}

\begin{tabular}{|c|c|}
\hline $\begin{array}{l}\text { INL CRM Office Project } \\
\text { Number }\end{array}$ & Project Title \\
\hline & Calendar Year 1984 \\
\hline SJM-84-01 & INEL Perimeter Boundary \\
\hline SJM-84-02 & INEL Grazing Boundary \\
\hline SJM-84-03 & Diversion Area \\
\hline SJM-84-04 & RWMC Ditch/Culverts \\
\hline SJM-84-05 & CFA Heliport \\
\hline SJM-84-06 & CFA Temporary Heli Fuel Storage \\
\hline SJM-84-07 & E. Portland Guard Station \\
\hline SJM-84-08 & W. Portland Guard Station \\
\hline SJM-84-09 & CFA Transportation Center \\
\hline SJM-84-10 & Explosives Range \\
\hline SJM-84-11 & NPR Surveys \\
\hline SJM-84-12 & TRA Perimeter Security Road \\
\hline SJM-84-13 & NRF Security Access Trail \\
\hline SJM-84-14 & Seismic Line/Bulldozer Trail \\
\hline SJM-84-15 & Geological Studies \\
\hline SJM-84-16 & Drill Holes and Access Road \\
\hline SJM-84-17 & Playa 2 Dike Upgrade \\
\hline SJM-84-18 & WRRTF Pond \\
\hline SJM-84-19 & TAN Powerlines and Parking Lot \\
\hline SJM-84-20 & Ditch/Pond \\
\hline SJM-84-21 & S. Taylor Blvd. Guard Station \\
\hline SJM-84-22 & EBR-II Perimeter Road \\
\hline SJM-84-23 & ANL-W Firing Range \\
\hline SJM-84-24 & Clay Butte \\
\hline SJM-84-25 & CPP Perimeter Security Road \\
\hline SJM-84-26 & North Guard Station Powerline \\
\hline ISU-84-01 & CFA Power Intertie \\
\hline ISU-84-02 & WERF Perimeter \\
\hline ISU-84-03 & CFA/EBR-I Powerline \\
\hline ISU-84-04 & TRA Security Upgrade \\
\hline ISU-84-05 & RWMC Monitoring Wells \\
\hline
\end{tabular}


Table 10. (continued).

\section{Early INL Archaeological Investigations and Subcontracts}

\begin{tabular}{|c|c|}
\hline $\begin{array}{l}\text { INL CRM Office Project } \\
\text { Number }\end{array}$ & Project Title \\
\hline \multicolumn{2}{|r|}{ Calendar Year 1985} \\
\hline ISU-85-02 & BORAX V Facility \\
\hline ISU-85-03 & TAN TSF Fuel Tank \\
\hline ISU-85-07 & Weapons Ranges \\
\hline ISU-85-08 & TRU Waste Area \\
\hline ISU-85-09 & Reynolds Drill Pad \\
\hline ISU-85-10 & TAN IET Facility \\
\hline ISU-85-11.1 & TRA Perimeter \\
\hline ISU-85-11.2 & CFA Perimeter \\
\hline ISU-85-11.21 & CFA Gravel Pits and Landfill \\
\hline ISU-85-11.3 & TAN TSF Perimeter \\
\hline ISU-85-11.31 & LOFT Perimeter \\
\hline ISU-85-11.32 & WRRTF Perimeter \\
\hline ISU-85-11.4 & RWMC Office Area \\
\hline ISU-85-11.41 & RWMC Borrow Area \\
\hline ISU-85-11.5 & BORAX V Gravel Pit \\
\hline ISU-85-11.6 & PBF Administrative Area \\
\hline ISU-85-11.7 & EOCR Perimeter \\
\hline ISU-85-11.81 & Fiber Optics TAN to ANL-W \\
\hline ISU-85-11.84 & Fiber Optics CFA to ICPP to TRA to NRF to TAN \\
\hline ISU-85-11.85 & Fiber Optics $135 \mathrm{kV}$ line from CFA to ANL-W \\
\hline ISU-85-11.87 & Fiber Optics EOCR to PBF \\
\hline ISU-85-11.9 & Fiber Optics Lincoln Blvd. \\
\hline ISU-85-11.91 & Fiber Optics T-24 Rd. \\
\hline ISU-85-12 & NRF Perimeter \\
\hline ISU-85-13 & Helicopter Pads \\
\hline ISU-85-14 & W. Portland Exit Ramp \\
\hline \multicolumn{2}{|r|}{ Calendar Year 1986} \\
\hline ISU-86-02 & ICPP Perimeter \\
\hline ISU-86-05 & CFA Substation \\
\hline ISU-86-06 & CFA TAN and NRF Gravel Pits \\
\hline ISU-86-07 & CFA Landfill Expansion \\
\hline ISU-86-08 & Fiber Optics ANL-W to IF \\
\hline ISU-86-12 & NRF Topsoil Pit \\
\hline ISU-86-17 & NODA Perimeter \\
\hline ISU-86-20 & ARVFS Perimeter \\
\hline
\end{tabular}


Table 10. (continued).

\section{Early INL Archaeological Investigations and Subcontracts}

\section{INL CRM Office Project Number}

\begin{tabular}{|c|c|}
\hline \multicolumn{2}{|r|}{ Calendar Year 1987} \\
\hline ISU-87-03 & BORAX V Access Road \\
\hline ISU-87-06 & TRA Drill Pad \\
\hline ISU-87-07 & TAN Fire Station \\
\hline ISU-87-08 & RWMC Wells \\
\hline ISU-87-09 & Weapons Range Powerline \\
\hline ISU-87-12 & $\mathrm{SSC}$ \\
\hline ISU-87-14 & Weapons Range Helipad \\
\hline ISU-87-15 & Ant Study Plots \\
\hline ISU-87-16 & Highway Information Signs \\
\hline ISU-87-20 & Perimeter Sign Maintenance \\
\hline ISU-87-22 & Fiber Optics ANL-W to Highway 20 \\
\hline \multicolumn{2}{|r|}{ Calendar Year 1988} \\
\hline ISU-88-01 & NRF Waste Ditch \\
\hline ISU-88-03 & ICPP Gravel Pit \\
\hline ISU-88-04 & Weapons Range Testing \\
\hline ISU-88-05 & Fiber Optics TRA to Lincoln Blvd. \\
\hline ISU-88-06 & $135 \mathrm{kV}$ Line Testing \\
\hline ISU-88-07 & Gravel Haul Road \\
\hline ISU-88-09 & ANL-W Administrative Boundary \\
\hline ISU-88-12 & T-12 Gravel Pit \\
\hline ISU-88-13 & RWMC Wind Gap \\
\hline ISU-88-14 & RWMC Inactive Borrow Area \\
\hline ISU-88-16 & EBR-I Display Pads \\
\hline \multicolumn{2}{|r|}{ Calendar Year 1989} \\
\hline ISU-89-01 & ICPP TRA Gravel Pit \\
\hline ISU-89-02 & Hunting Boundary \\
\hline ISU-89-03 & Lost River Fault Trench \\
\hline ISU-89-04 & NPR Seismic Stations \\
\hline ISU-89-05 & NPR Survey and Testing \\
\hline ISU-89-06 & Fast Attack Vehicle Area \\
\hline ISU-89-08 & Fenceline and Demonstration Area \\
\hline
\end{tabular}

\section{Project Title}

\section{Calendar Year 1987}

BORAX V Access Road

TAN Fire Station

Wells

SSC

Ant Study Plots

Highway Information Signs

Fiber Optics ANL-W to Highway 20

\section{Calendar Year 1988}

NRF Waste Ditch

Weapons Range Testing

T-12 Gravel Pit

Wind Gap

EBR-I Display Pads

\section{Calendar Year 1989}


Table 10. (continued).

\section{Early INL Archaeological Investigations and Subcontracts}

\begin{tabular}{|c|c|}
\hline $\begin{array}{l}\text { INL CRM Office Project } \\
\text { Number }\end{array}$ & Project Title \\
\hline \multicolumn{2}{|r|}{ Calendar Year 1990} \\
\hline ISU-90-02 & RWMC Sec. 18 Area \\
\hline ISU-90-04 & NPR Sample Survey \\
\hline \multicolumn{2}{|r|}{ Calendar Year 1991} \\
\hline ISU-91-01 & PBF NPR Access Road Survey and Testing \\
\hline ISU-91-02 & NPR Survey and Testing \\
\hline ISU-91-06 & NPR Area E Testing \\
\hline \multicolumn{2}{|r|}{ Calendar Year 1992} \\
\hline ISU-92-08 & Cedar Butte Testing \\
\hline \multicolumn{2}{|r|}{ Calendar Year 1999} \\
\hline SJM-99-01 & Farragut Blvd Survey \\
\hline \multicolumn{2}{|r|}{ Calendar Year 2000} \\
\hline SJM-00-01 & US Cellular Tower on Circular Butte \\
\hline \multicolumn{2}{|r|}{ Calendar Year 2000} \\
\hline NWI-01-01 & Big Lost River Trenching Project Test Excavations \\
\hline \multicolumn{2}{|r|}{ Calendar Year 2002} \\
\hline NWI-02-01 & Syringa Networks Fiber Optics \\
\hline ISU-02-01 & INL Predictive Model \\
\hline \multicolumn{2}{|r|}{ Calendar Year 2003} \\
\hline ISU-03-01 & INL Predictive Model \\
\hline
\end{tabular}


Table 11. INL Cultural Resource Management Office architectural investigations.

\begin{tabular}{|c|c|}
\hline \multicolumn{2}{|c|}{ INL Cultural Resource Management Office Architectural Investigations } \\
\hline Project Number & Project Title \\
\hline HIST-95-009 & 1995 CFA Building Closures \\
\hline HIST-95-0012 & 1995 INEL Land Use Plan \\
\hline HIST-95-0010 & 1995 TAN Building Closures \\
\hline LITCO-95-58 & Adams Avenue Well \\
\hline HIST-95-007 & AEF-603 Demolition \\
\hline LMIT-96-1 & Alternate Silt/Clay Source \\
\hline LITCO-95-60 & ANL-W Brush Fire \\
\hline HIST-93-001 & ARA DD\&D; Demolition and MOA \\
\hline LITCO-95-05 & ARA II Road Maintenance \\
\hline LITCO-95-37 & ARVFS Road \\
\hline LITCO-95-25 & ARVFS Signs \\
\hline HIST-96-012 & B16-601 Demolition \\
\hline HIST-96-013 & B17-706 Demolition \\
\hline HIST-94-0019 & BIA Building Remodel at Fort Hall \\
\hline LITCO-95-46 & Big Lost River Modification at Pioneer \\
\hline LITCO-95-02 & BWP Administrative Area \\
\hline LITCO-95-61 & CF-609 Tower \\
\hline HIST-96-001 & CF-613 Excess or Demolition Project \\
\hline HIST-97-001 & CF-639 Demolition \\
\hline HIST-95-0011 & CF-640 Demolition \\
\hline HIST-96-014 & CF-645 Demolition \\
\hline HIST-96-015 & CF-649 Demolition \\
\hline HIST-96-016 & CF-650 Demolition \\
\hline HIST-96-011 & CF-654 Demolition \\
\hline HIST-96-028 & CF-657 Demolition \\
\hline HIST-96-017 & CF-665 Demolition \\
\hline HIST-96-018 & CF-672 Demolition \\
\hline HIST-96-019 & CF-673 Relocation \\
\hline HIST-97-002 & CF-678 Demolition \\
\hline HIST-96-004 & CF-686/688/689 Reroof \\
\hline HIST-97-003 & CF-687 Demolition \\
\hline HIST-96-005 & CF-690 Reroof \\
\hline HIST-96-020 & CF-691 Demolition \\
\hline HIST-96-003 & CF-698 Addition \\
\hline LITCO-95-23 & CFA Admin Support Facility \\
\hline
\end{tabular}


Table 11. (continued).

INL Cultural Resource Management Office Architectural Investigations

Project Number

LITCO-95-08 CFA Concrete Crusher

LITCO-95-44 CFA Dry Well Search

LITCO-95-38 CFA Waterline

HIST-93-004 CF-605 Demolition

HIST-94-0023 CF-633 Demolition

HIST-93-005 CF-654 Demolition

HIST-94-009 CF-670 Dismantlement

HIST-94-0010 CF-690 Reroof

HIST-94-008 CF-698 Addition

LITCO-95-65 Cleanup of STR-8 Storage AR

HIST-95-0015 CPP Rover Dismantlement

HIST-96-007 CPP-603 Deactivation

HIST-97-004 CPP-603 Dismantlement

HIST-96-006 CPP-606 Piping Replacement

HIST-96-021 CPP-631 Demolition

HIST-96-022 CPP-633 Dismantlement

HIST-97-005 CPP-648 Dismantlement

HIST-96-024 CPP-709 Dismantlement

HIST-96-025 CPP-734 Dismantlement

LITCO-95-20 DD\&D of EBR-I Septic Systems and Dry Wells

HIST-95-005 DD\&D Programmatic Agreement

LITCO-95-33 Dairy Farm Powerline

HIST-93-007 Draft EIS Sections $3.6 \& 4.5$

LMIT-96-1 East Butte Radio Facility

HIST-94-0012 EBR-I Air Monitor Relocation

HIST-95-0015 EBR-I Biodecontamination Experiment

LITCO-95-32 EBR-I Interpretive Trail

HIST-95-0016 EBR-I Lighting Upgrade

HIST-94-0017 EBR-I Remodel

HIST-94-0011 EBR-I Reopening

HIST-95-004 EBR-I Stack Removal

HIST-95-003 EBR-I Women's Commemorative Plaque

HIST-96-008 EBR-602 Closure

LITCO-95-40 Environmental Restoration of PBF-10 Evaporation Pond 
Table 11. (continued).

INL Cultural Resource Management Office Architectural Investigations

Project Number

LITCO-95-07

LITCO-95-55

HIST-94-004

LITCO-95-19

LITCO-95-57

LITCO-95-41

LITCO-95-24

HIST-95-001

HIST-96-002

HIST-95-002

HIST-96-001

HIST-94-0020

LITCO-95-09

LITCO-95-11

LITCO-95-26

LITCO-95-27

LITCO-95-53

HIST-94-0021

LITCO-95-49

LITCO-95-34

LITCO-95-04

LITCO-95-14

LITCO-95-39

HIST-93-002

LITCO-95-35

LITCO-95-22

HIST-94-005

LITCO-94-0018

LITCO-95-54

LITCO-95-28

HIST-94-006

LITCO-95-5

LITCO-95-O"'

LITCO-95-31

\section{Project Title}

ER \& WM EIS

ESRF Vegetation Plots

ETR Demolition

Fire Prevention at ARA I

Firing Range Misc. Upgrades

Groundwater Remediation at TAN

Guard Gate 3 Trash Dump

HBIS Historic Contexts

HBIS Phase II-TRA

Historic Building Inventory - CFA

Historic Building Inventory Survey - Phase II

Historic Resources Management Plan

Howe Peak Seismic Station Revisited

ICPP Culvert

ICPP Substation

ICPP Wells

INEL Cave Survey

Internet Home Page

ISU Field School

ISU Geology Field Trip

IWPF Test Excavations

LAN Upgrades RWMC/CFA and PBF

Landfill Utility Upgrade

LOFT Reuse - Air Force

Monitoring Wells at CF-633, CF-670, CF-690, CF-667 and CF-623

More Monitoring Wells at PBF and CFA

MTR Dismantlement

NIOSH Oral Histories

NODA Road Culvert

NODA Road Remediation

NRF A1W Cooling Tower Demolition

NRF Misc.

NRF Soil Sampling

NRF Wells 
Table 11. (continued).

INL Cultural Resource Management Office Architectural Investigations

\begin{tabular}{|c|c|}
\hline Project Number & Proje \\
\hline LITCO-95-4 & Phase II Bonneville County Technology Park \\
\hline LITCO-95-3 & Pit 9 Admin Area Well \\
\hline LITCO-95-1 & Pit 9 Administrative Expansion \\
\hline LITCO-95-4 & Pit 9 Parking Expansion \\
\hline LITCO-95-5 & Removal Actions in OU 10-06 \\
\hline LITCO-95-48 & ROB/IRC Drill Auger Holes \\
\hline HIST-95-0013 & RWMC Air Support Structures \\
\hline LITCO-95-64 & RWMC North Parking Area \\
\hline LITCO-95-01 & RWMC Office Facility \\
\hline LITCO-95-18 & RWMC Pipeline \\
\hline LITCO-95-36 & RWMC-CFA Powerline \\
\hline LITCO-95-21 & RWMC-CFA Ethernet \\
\hline LITCO-95-50 & Site Characterization of OU 4-05 \\
\hline HIST-93-006 & Sitewide programmatic agreement \\
\hline LITCO-95-63 & Soil Erosion Monitors in ANL-W Burn \\
\hline LITCO-95-06 & Spreading Area B Alternatives \\
\hline LITCO-95-51 & Spreading Area B Cattleguard \\
\hline HIST-94-0022 & SSC Dunaway House Marketing Plan \\
\hline LITCO-95-13 & State of ID Monitors at NOAA Stations \\
\hline HIST-96-026 & TAN-609 Demolition \\
\hline HIST-96-009 & TAN-616 Demolition \\
\hline HIST-97-006 & TAN-620 Demolition \\
\hline HIST-93-003 & TAN-629 Hangar Reroof and HAER Report \\
\hline HIST-97-007 & TAN-656 Demolition \\
\hline LITCO-95-43 & Temporary Power at Pit 9 \\
\hline HIST-94-0007 & TETF Demolition \\
\hline HIST-95-0016 & Tour - DOE-HQ Historians \\
\hline HIST-94-0023 & Tour - Historic Sites Review Board \\
\hline HIST-94-003 & TRA Safety and Fire Upgrades \\
\hline LITCO-95-15 & TRA Sewer Upgrade \\
\hline HIST-95-0014 & TRA-623 Reroof \\
\hline HIST-96-010 & TRA-623 Reroof \\
\hline HIST-96-027 & TRA-645 Demolition \\
\hline LITCO-95-16 & Traveler's Information Radio System \\
\hline
\end{tabular}


Table 11. (continued).

INL Cultural Resource Management Office Architectural Investigations

Project Number

LITCO-95-62 USGS Well

LITCO-95-12 Van Buren Test Pits for Road Maintenance

LITCO-95-29 Van Buren Upgrade

LITCO-95-45 Vegetation Plot at TAN

HIST-95-006 Waste Calcining Facility Demolition

LITCO-95-17 WERF Drainage Basin Enlargement

HIST-95-008 WMO-601/601A Demolition

00-001

00-002

00-003

00-004

00-005

00-006

00-007

00-008

00-009

00-010

00-011

00-012

00-013

00-014

00-015

00-016

00-017

00-018

00-019

00-020

00-021

00-022

00-023

00-025

00-026

00-027

00-028
Project Title

EBR-I Water Leak Repair

Fire Station \#2 Demolition

New Records Storage Building

CF-603 Demolition

TAN-601, 646 Security System

CF-650, 671,688 Boiler Modification

TRA-670 Regulatory Rod Control System Upgrade

CF-601 Fire Alarm Box Removal

CPP-603 Design Plugs for Floor Drains

TAN-640, -641 NuPac Debris Coolability Tests

CPP-604 PEW Feed Pump Containment

CPP-604 PEW Chemical Addition Piping

TRA-629 Relocation of Storage Tank from TRA-777A

TRA Molten Salt/Tritium Research in TRL

CPP-606, 1647 Chemical Feed Tanks Relocation

TRA Potable Water Well System

TAN-607 Alarm System

TAN-604, 607 Change of Operations Administration

TRA-631 Trench Piping Removal and Remediation

TAN-629 Remove Deburner

PEW Feed Sampler Upgrade

CPP-699 Antennae Placement

CPP-602 Telecommunications Removal

CPP-657, 669, 686 Demolition Project

TRA-604 Circuit Re-routing

PBF-609 Waste Vitrification Upgrades

Conceptual Design 
Table 11. (continued).

INL Cultural Resource Management Office Architectural Investigations

\begin{tabular}{|c|c|}
\hline Project Number & Project Title \\
\hline 00-029 & MTR Canal Water Removal \\
\hline $00-030$ & TAN DD\&D $(602,531,634,635,638,651,659,657,660,661,663,670)$ \\
\hline $00-031$ & WMF-711 Air Support \\
\hline $00-032$ & TAN-674 Trailer Foundation Removal \\
\hline $00-033$ & EBR-I Exit Sign \\
\hline $00-034$ & TRA-632 Decon of Interior Hot Cell \\
\hline $00-035$ & TRA-635 Alarm Installation \\
\hline $00-036$ & TRA-670 Fire Tank Computer System Mod \\
\hline $00-037$ & TAN-602, 609, 615 Characterizations \\
\hline $00-038$ & TRA-654 ETRC Internal Reconfiguration for New Experiment \\
\hline 00-039 & EBR-I Fire Alarms \\
\hline $00-040$ & TAN-604 Temporary Wall Construction \\
\hline $00-041$ & CPP-602 Install USC Consoles \\
\hline $00-042$ & TRA-670 Replace Air Conditioning System \\
\hline $00-043$ & EBR-I Emergency Planning Exercise \\
\hline $00-044$ & TRA-618 Firewater Line \\
\hline $00-045$ & Autopsy Table MOA \\
\hline $00-046$ & TRA-670 ATR Feeder Breaker Upgrade \\
\hline $00-047$ & TAN-629 SMC Equipment Removal \\
\hline $00-048$ & CF-633 X-Ray Room Lock and Safety Lights \\
\hline 00-049 & TAN-607 Dewatering System (built 1998) \\
\hline $00-050$ & TRA-670 Roof Hatch Modification \\
\hline $00-051$ & TRA-670 DCS Upgrade \\
\hline $00-052$ & CPP Tank Farm Closure \\
\hline $00-053$ & WERF Closure \\
\hline $00-054$ & CPP-637 Interior Remodel/Air Conditioning \\
\hline $00-055$ & EBR-I IEEE Plaque \\
\hline $00-056$ & TRA-642 FS\&R Equipment Removal \\
\hline $00-057$ & CPP-642 Water Sampling \\
\hline $01-001$ & CPP-657, 669, 686 \\
\hline $01-002$ & ATR Electrical Upgrade \\
\hline $01-003$ & TRA-604 \& 605 Electrical Upgrade \\
\hline $01-004$ & Army Projects: WRRTF Concrete Blocks (Farragut?) \\
\hline 01-005 & TAN-616 DD\&D \\
\hline
\end{tabular}


Table 11. (continued).

INL Cultural Resource Management Office Architectural Investigations

\begin{tabular}{|c|c|}
\hline Project Number & Project Title \\
\hline 01-006 & TAN-607A Lab Remodel \\
\hline 01-007 & TRA-670 Experiment Installation \\
\hline 01-008 & RWMC Concrete Disposal Vaults \\
\hline 01-009 & MTR Canal Fuel Repackaging \& Transportation \\
\hline 01-010 & TRA-605 Sample Port \\
\hline 01-011 & TAN-616 Demolition \\
\hline 01-012 & CF-617 Demolition \\
\hline $01-013$ & EBR-I Light Bulb Change Out \\
\hline $01-014$ & TRA-666 STAR Operations EC \\
\hline $01-015$ & WRRTF Transfer to Inactive Status \\
\hline 01-016 & none \\
\hline 01-017 & TRA-632 Pad Repair/Pipe Modifications \\
\hline 01-018 & MTR Piping Removal \\
\hline 01-019 & EBR-I Lighting Fixtures \\
\hline $01-20$ & TRA-666 Sodium Loop Equipment Removal \\
\hline $01-21$ & TRA-670 ATR Reactor Core Changeout \\
\hline $01-22$ & TRA-630 and TRA-730 Tank Vault DD\&D Project \\
\hline $01-23$ & TAN-615 DD\&D \\
\hline $01-24$ & TRA-670/679 \\
\hline $01-25$ & CPP-666 Sodium Hydroxide Sample/Removal \\
\hline $01-26$ & PBF-609 RCRA Closure \\
\hline $02-001$ & CF-617 DD\&D \\
\hline $02-02$ & EBR-I Guardhouse Circuit Breaker Panel \\
\hline 02-003 & TRA-608 Floor Drain Replacement \\
\hline 02-004 & PBF-620 Canal \\
\hline $02-005$ & TAN Closure \\
\hline $02-06$ & TRA SE Closure \\
\hline $02-07$ & TRA-632 Modification \\
\hline 02-08 & TAN/TRA Inactivation (several buildings) \\
\hline 02-09 & CF-646, -660, -667, -684; PBF-601, 616, 617, 41 Building Footprint Reduction (see 02-24) \\
\hline $02-10$ & TAN-607 Storage Pool Deactivation Project \\
\hline $02-11$ & EBR-I Pipe Removal \\
\hline $02-12$ & CF-633 Wall Removal and Replacement \\
\hline $02-13$ & EBR-I Brick Replacement \\
\hline
\end{tabular}


Table 11. (continued).

INL Cultural Resource Management Office Architectural Investigations

Project Number

02-14

$02-15$

$02-16$

02-17

$02-18$

02-20

$02-21$

$02-22$

02-0023

02-24

$02-25$

02-026

02-027

02-28

02-029

03-01

03-02

03-03

03-04

03-05

03-06

03-07

03-08

03-09

03-10

03-11

03-12

03-13

03-14

03-15

04-01

04-02

04-03

04-04
EBR-I Cell Tower Project

PBF-620 Defueling

TAN-602, 609 DD\&D

INTEC ICDF/SSSTF Gravel/West of CPP-603

Upgrade Utilities/CPP-660

INEEL Artifact Donation to the Bonneville Museum

SMC Paint Booth Removal TAN-606

TAN DD\&D 638, 705

MTR DD\&D Canal

2003-05 Footprint Reduction

INTEC CPP-602 Mass Specs Removal

TAN BCP/Footprint Reduction

Maintenance/Craft Shop Consolidation

INTEC VCO Tanks

APMP/programmatic agreement

EBR-I Guardhouse Hantavirus Cleanup

EBR-I Water Drainage Project 7/2/02

CFA/NPG Lights DD\&D

EBR-I Gate Replacement

CFA New Parking

OCVZ Unit B Demolition

PBF Footprint Reduction DD\&D

INTEC/Foster-Wheeler Request

CPP-659 Sample Cell Work

CPP-603 Ultra Violet Equipment Removal

IRC Fire Suppression System

PBF-613 Systems Removal Affected

TRA-602 Deep Well Abandonment and Removal and Replacement of Pumphouse Roof

TAN-607 Yucca Mountain Experiment

CF-633 Deactivation

Move TAN-604 lab equipment to CFA-622

Proposed Demolition CFA-633 Complex

Proposed Demolition CFA-633 Complex

Upgrade utilities (HVAC; water) 
Table 11. (continued).

INL Cultural Resource Management Office Architectural Investigations

Project Number

04-05

04-06

04-07

04-08

04-09

04-10

04-11

04-12

04-13

04-14

04-15

04-16

04-17

05-01

05-02

05-03

05-04

05-05

05-06

05-07

05-08

05-09

05-10

05-11

05-12

05-13

05-14

05-15

05-16

05-17

05-18

05-19

06-01
Project Title

Update EBR I Interpretive Displays

Demolished

MTR/ETR Proposed Demolition

MTR/ETR Env. Assessment

ANP Locomotive Proposed move to EBR I

Mitigation completed for INTEC - eight buildings

Mitigation completed for PBF - seven buildings

Mitigation completed for TAN - 23 buildings and structure

Mitigation completed for TRA - eight buildings

Review for INTEC ineligible and exempt properties - 21 buildings and structures

Review for PBF ineligible and exempt properties - six buildings and structures

Review for TAN ineligible and exempt properties - 23 buildings and structures

Review for TRA ineligible and exempt properties - seven buildings and structures

INTEC Dry Storage Cask Area Disposition -Exempt

INTEC ICDF RAD CON Trailer Disposition - Exempt

INTEC Office Trailer Disposition - Exempt

TAN LANDFILL Trailer Disposition - Exempt

OFFICE Trailer Disposition- Exempt

RWMC Systems and Infrastructure Disposition - HAER report completed prior to CWI contract termination

RWMC WORK CONTROL CENTER Trailer Disposition - Exempt

RWMC Office Trailer Disposition - Exempt

RWMC Office Trailer Disposition - Exempt

RWMC Office Trailer Disposition - Exempt

RWMC Office Trailer Disposition - Exempt

RWMC ILTSF Trailer Disposition - Exempt

MATERIAL HANDLING FACILITY Disposition - HAER report completed prior to CWI contract termination

MAINTENANCE FACILITY Disposition - HAER report completed prior to CWI contract termination

RWMC Office Trailer DBL-WIDE Disposition - Exempt

RWMC Building Trailer Disposition (2) - Exempt

RWMC ARP SAMPLE Support Trailer (2) Disposition - Exempt

RWMC ARP Men's Change Trailer Disposition - Exempt

RWMC Leased ARP Women's Change Trailer Disposition - Exempt

Removal of PER-706 Evaporation Tank at PBF - Exempt 
Table 11. (continued).

\section{INL Cultural Resource Management Office Architectural Investigations}

\begin{tabular}{|c|c|}
\hline Project Number & Project Title \\
\hline 06-02 - n & Completion of final TRA HAER report. \\
\hline $06-03$ & Completion of draft INTEC HAER report. \\
\hline 06-04 & Pacific Northwest Fieldschool funding \\
\hline 06-05 & Draft Big Lost River Rest Area signs \\
\hline 06-06 & $\begin{array}{l}\text { Modifications to MFC Bldg. } 774 \text { for Protective Force Consolidation Support - eligible; } \\
\text { Cat. } 2\end{array}$ \\
\hline 06-07 & Maintenance of Stream Gauging Sites at the INL-exempt \\
\hline 06-08 & CPP-603 cold, dark, dry - eligible; 1998 MOA; 2004 PA \\
\hline 06-09 & TAN Shielded Locomotive move to EBR I - SHPO and NPS concurrence \\
\hline $06-10$ & $\begin{array}{l}\text { CF-603 Autopsy/Surgical Room and Contents - building ineligible; surgical table-eligible } \\
\text { and moved to interim storage at CFA }\end{array}$ \\
\hline 06-11 & $\begin{array}{l}\text { TAN- } 630 \text { and TAN- } 650 \text { LOFT-NHPA consultation completed; MOA in place and } \\
\text { mitigation completed }\end{array}$ \\
\hline $06-12$ & TRA-603 (MTR) - eligible; NHPA mitigation completed \\
\hline $06-13$ & $\begin{array}{l}\text { TAN-607 Hot Shop - eligible; was included in MOA with LOFT and MTR and NHPA } \\
\text { mitigation completed }\end{array}$ \\
\hline $06-14$ & $\begin{array}{l}\text { CPP-651 temporary ducting, equipment, and a new door to room 107-eligible; no adverses } \\
\text { impact }\end{array}$ \\
\hline $06-15$ & INTEC - CPP-601 PEW Isolation and Reroute-eligible; 1998 MOA and 2004 PA \\
\hline 06-16 & MFC FASB glove box project - eligible; no adverse impact \\
\hline 07-01 & Removal of ZPPR IV Compressor - Exempt \\
\hline 07-02 & $\begin{array}{l}\text { Replacement of walkway atop and external to CPP- } 646 \text {, CPP- } 647 \text {, CPP- } 747 \text { - no adverse } \\
\text { impact }\end{array}$ \\
\hline 07-03 & Removal of TAN-607A - eligible; mitigation completed \\
\hline 07-04 & Partial demolition/remodel of TRA- 609 - eligible; mitigation completed \\
\hline 07-05 & Hood relocated from CF-689 to CF-666 - exempt activity \\
\hline 07-06 & WAASP System Installation at MFC - eligible; mitigation completed \\
\hline 07-07 & Above ground cable removal between PBF-612 and PBF-619 -exempt \\
\hline 07-08 & Installation of fire suppression system in TRA-660 - eligible; mitigation completed \\
\hline 07-09 & Removal of TRA- 615 - exempt property \\
\hline $07-10$ & TRA-608 and TRA-609 upgrades - eligible; mitigation completed \\
\hline 07-11 & TRA-630 tank system closure - ineligible; exempt activity \\
\hline $07-12$ & TAN-629 ventilation upgrade - eligible; exempt activity \\
\hline $07-13$ & $\begin{array}{l}\text { HFEF Metal Waste Form (MWF) Furnace Installation and Operations - eligible; exempt } \\
\text { activity }\end{array}$ \\
\hline $07-14$ & Replace EBR I septic system - NHL; no adverse impact \\
\hline $07-15$ & TRA-670 Reactivation of Pressurized Water Loop 2A - eligible; exempt activity \\
\hline $07-16$ & CF-668 Exterior painting - eligible; exempt activity \\
\hline 07-17 & Oil cedar shingles on CFA World War II roofs - eligible; no adverse impact \\
\hline
\end{tabular}


Table 11. (continued).

INL Cultural Resource Management Office Architectural Investigations

Project Number

07-18

07-19

$07-20$

$07-21$

$07-22$

08-01

08-02

08-03

08-04

08-05

08-06

08-07

08-08

08-09

08-10

08-11

08-12

08-13

08-14

08-15

08-16

08-17

08-18

08-19

08-20

08-21

08-22

08-23

08-24

08-25

08-26

08-27 Project Title

Reroof CFA-601, CFA-612, PER-612, PER-613, TRA-604,- eligible; no adverse impact

Removal of TAN-609 - eligible; mitigation completed

ZPPR IV removal - ineligible but of historic importance; large format photographs completed

PBF-632 modifications - ineligible

Training activities at PBF-609, PBF-612, and PBF-613 - eligible; no adverse impact

Removal of MFC-705 trailer - exempt

Removal of TRA-603-eligible; mitigation completed

Removal of CF-635 - eligible; mitigation completed

Removal of CF-646 - eligible; mitigation completed

Removal of CF-650 - eligible; mitigation completed

Removal of CF-675 - exempt property

Removal of CF-684 - eligible; mitigation completed

Removal of CF-692 - eligible; mitigation completed

Removal of MFC-795 - TBD; ongoing

Removal of TRA-612 - exempt property

Removal of TRA-613 - ineligible

Removal of TRA-631 - exempt property

Removal of TRA-669 - eligible; mitigation completed

Removal of TRA-675 - ineligible

Removal of B-23-602 - exempt property

INL/BLM Wind project - ongoing

Removal of TRA-761 - exempt property

Removal of TRA-613 - ineligible

Removal of TRA-713 - exempt property

Removal of CF-662 - eligible; mitigation completed

CORS installation of EBR I - NHL; potential for adverse impact; project moved to another facility

Assess the historical importance of geologist logbooks

Identification of lead box located near SMC at TAN - associated with ANP project

Assessed importance of CP-1 graphite blocks - recommended keeping sample

ARP operations monitors near EBR I - no impact determination to EBR I or view of and to Big Southern Butte

TRA-670 (ATR) new roof - eligible; exempt activity

MFC-774 new roof - eligible; exempt activity 


\section{Appendix K}

\section{Goals and Tasks}




\section{Appendix K}

\section{Goals and Tasks}

\section{INTRODUCTION}

This appendix contains overarching long-term goals, short-term goals, and ongoing and recurring tasks to achieve them. As short-term goals and specific activities are achieved, they will be dropped from the list or become ongoing and recurring activities. New goals are added and prioritized in response to changes in INL mission and operations, the regulatory framework that drives compliance activities, and in consideration of comments and advice from stakeholders such as interested members of the general public and tribal partners, and as funding allows.

The following lists reflect identified opportunities for programmatic involvement, ongoing cultural resource management responsibilities, and the need to retain a comprehensive, effective, and compliant Cultural Resource Management program. The intent is to respond to the letter and spirit of legal and policy requirements consistent with long-term stewardship, stakeholder involvement, and tribal interests as tailored and outlined in this Plan. Specific tasks for the present fiscal year and those planned for the following fiscal year are included in the "INL Cultural Resource Management Annual Report." This report is issued each spring and is intended to facilitate discussions regarding goals, tasks, and specific activities during annual stakeholder meetings.

\section{Long-term Goals and Ongoing and Recurring Tasks}

There are ten long-term goals for the INL CRM program. A variety of ongoing and recurring tasks are associated with each goal.

\section{Goal 1: Identify and Manage INL Cultural Resources}

- Task 1. Reevaluate and update program requirements

- $\quad$ Task 2. Seek and maintain preservation partners

- Task 4. Inventory and record INL cultural resources

- Task 5. Maintain program and project files and records, electronic databases, and GIS data

- $\quad$ Task 6. Conduct oral histories

\section{Goal 2: Evaluate INL Properties for Historic Significance}

- Task 1. Conduct research to develop and update prehistoric and historic contexts required to identify themes and establish the relative importance of specific resources.

- Task 2. Prepare National Register of Historic Places nomination documentation.

\section{Goal 3: Monitor the Condition of INL Cultural Resources}

- Task 1. Establish baseline condition of select INL cultural resources

- Task 2. Assess condition of select INL cultural resources, including at a minimum, Aviators' Cave, Prickly Cave, Middle Butte Cave, and WERF burial 
- Task 3. Collect data for yearly report (Routine visits to archaeological sites and project-specific visits).

\section{Goal 4: Protect INL Cultural Resources}

- Task 1. Participate in legal and regulatory reviews of INL documents and policies to ensure integration and maximize effectiveness of overall regulatory compliance

- Task 2. Develop and update historic structures preservation plans

- Task 3. Respond to unanticipated discovery of cultural resources

- Task 4. Review, approve, and archive external investigator permits and data use agreements and oversee subcontracts

- Task 5. Establish and maintain INL Archive Center by gathering and archiving, using professional standards, INL historical data (i.e., photographs, architectural drawings, maps) and make data readily accessible

- Task 6. Develop and implement specific site protection and stabilization plans, as needed.

\section{Goal 5: INL Artifact Curation}

- Task 1. Prepare pre-1942 artifacts in INL interim storage and associated documentation for accession into an accredited curatorial facility

- Task 2. Ensure security of artifacts and associated documentation in interim INL storage

- Task 3. Review and coordinate requests for use of INL artifact collections

- $\quad$ Task 4. Prepare for and participate in annual inspection of curatorial facilities.

\section{Goal 6: Stakeholder Involvement/Public Outreach}

- Task 1. Participate in educational outreach programs (i.e., INL Speakers Bureau and Science Expo)

- Task 2. Coordinate and conduct public and employee tours of cultural resource sites

- Task 3. Present information on INL cultural resources and prehistoric and historic contexts

- Task 4. Host and conduct annual stakeholder meeting to report on previous fiscal year activities

- Task 5. Present at professional events (i.e., conferences, meetings)

- $\quad$ Task 6. Publish peer-reviewed articles.

\section{Goal 7: Interact with Native Americans}

- Task 1. Comply with cultural resource-related stipulations in the Agreement-in-Principle between DOE-ID and Shoshone-Bannock Tribes

- Task 2. Participate in monthly Cultural Resource Working Group meetings

- Task 3. Invite Sho-Ban Heritage Tribal Office (HeTO) representative participation on archaeological fieldwork when possible.

\section{Goal 8: Conduct Work Safely}

- Task 1. Hold pre-job briefings to identify and discuss hazard mitigation

- Task 2. Inspect equipment regularly

- Task 3. Conform to all ISMS requirements 
- Task 4. Comply with all field requirements.

Goal 9: Maintain Professional Qualifications and Relationships

- Task 1. Identify and attend training to enhance/maintain skills

- Task 2. Maintain memberships in professional societies and organizations, interact with other cultural resource professionals (i.e., State Historic Preservation Office, National Park Service, professionals at other DOE labs).

\section{Goal 10: Activities Reports}

- Task 1. Complete annual report of activities

- Task 2. Complete annual Dept. of Interior questionnaire

- $\quad$ Task 3. Complete annual monitoring report

- Task 4. Complete regular reports to Shoshone-Bannock HeTO.

\section{Short-term Goals (1-5 Years) and Associated Tasks}

In the short term, four major goals with a variety of associated tasks are recognized in the INL CRM program.

\section{Goal 1: Establish, Maintain, and Expand Research Partnerships and Grow the Program}

- Task 1. Establish relationships with universities, private companies and individuals, and other government agencies to advance research in the areas of history, archaeology, and anthropology

- $\quad$ Task 2. Develop and/or update research questions and designs

- $\quad$ Task 3. Develop and submit proposals to procure funding to conduct research

- Task 4. Report on research progress annually or more often as required by funding institution

- Task 5. Publish research findings in peer-reviewed journals or other discipline-appropriate publications

- Task 6. Continue to serve on DOE-HQ History Program Executive Committee.

\section{Goal 2: Expand INL Interpretive/Education Program}

- Task 1. Maintain existing internal and external partners, and establish new partners, to pursue interpretive opportunities

- Task 2. Develop interpretive signs for INL cultural landscape and associated artifacts and sites.

\section{Goal 3: Establish Formal INL Archive}

- Task 1. Obtain funding and expand INL Records Storage Center to accommodate INL Archive

- Task 2. Enhance skills of existing Program employees to gain professional archivist certification

- Task 3. Protect archival materials in compliance with pertinent laws and requirements

- Task 4. Develop INL Archive Management Plan.

Goal 4: Identify or Establish Permanent Curation Facility for post-1942 INL Artifacts and Records

- Task 1. Identify post-1942 INL artifacts and temporary storage for them 
- Task 2. Investigate existing and new options for permanent storage, curation, and interpretation of post-1942 INL artifacts

- Task 3. Curate post-1942 INL artifacts in compliance with pertinent laws and requirements. 


\section{Appendix L}

\section{Idaho National Laboratory Cultural Resource Monitoring Plan}




\section{Appendix L}

\section{Idaho National Laboratory Cultural Resource Monitoring Plan}

\section{INTRODUCTION}

INL has been a federal reservation with public access restricted since the early 1940s. Due to both its continuous access restriction and geographic remoteness, many prehistoric and historic resources within the INL boundaries are relatively well preserved. However, access restrictions and security patrols do not prevent all impacts, and damage to cultural resources does occur through five primary sources:

1. Natural processes (e.g. erosion from wind or water, animal burrowing)

2. Livestock grazing, herding, and associated operations

3. Unauthorized access to highly sensitive areas and unauthorized artifact collection by individuals unaware of the penalties associated with these activities

4. INL projects that fail to comply with recommendations to protect cultural resources as outlined in Environmental Checklists or other environmental guidance

5. Lack of regular maintenance or inappropriate preservation treatments for historic architectural properties.

The INL CRM Office maintains an ongoing program for monitoring, assessing, and developing strategies to mitigate impacts to cultural resources as a result of these sources of impact.

\section{PURPOSE}

The purpose of the INL cultural resource monitoring program is twofold:

1. Monitoring targeted cultural resources during and after completion of INL site projects that may affect those resources ensures compliance with site contractor management commitments to mitigate project impacts to INL cultural resources. Other special project-related circumstances, such as soil disturbance in known sensitive areas, may require monitoring on a case-by-case basis.

2. Monitoring cultural resources allows the opportunity to assess their integrity, thereby fulfilling federal stewardship responsibility. Monitoring enables DOE-ID to document whether the integrity of resources is being compromised and implement protections, as necessary.

By identifying impacts to INL cultural resources, site contractors can implement the appropriate actions to prevent or minimize further deterioration. Cultural resources will be monitored in accordance with an annual schedule. This schedule will be based on the selection criteria listed in the following section and may vary and/or be amended as warranted and determined by the INL CRM Office.

\section{Process of Selection}

Specific cultural resources are chosen for monitoring based on feedback from DOE-ID, the Shoshone-Bannock Tribes Heritage Tribal Office (HeTO), and INL stakeholders. The INL CRM archives, which include documentation of over 2,500 archaeological resources and more than 200 historic 
architectural properties on the INL, are also consulted for appropriate candidates for yearly monitoring. Both DOE-ID and the Shoshone-Bannock Tribes are often directly involved in fieldwork during the monitoring activities and INL project managers and other stakeholders, such as the Idaho State Historic Preservation Office (SHPO), also participate occasionally. Certain resources, like Middle Butte, Prickly, and Aviators' Caves, sensitive localities inside the Power Burst Facility (PBF, now Critical Infrastructure Test Range Complex-CITRC), and the Experimental Breeder Reactor-I (EBR-I) National Historic Landmark, are monitored every year. Others, such as historic homesteads and some prehistoric archaeological sites are also visited routinely because of their location in highly visible areas where trespassing has been documented in the past. Each year INL CRM staff also conducts surveillance of resources in a wide variety of settings to address ongoing research interests and the overall focus of INL construction and project activities for the year.

Monitoring of INL projects is completed under direct project funding and may be included as part of an INL Environmental Checklist or other environmental guidance. Project-specific monitoring is also routinely completed in the sandy aeolian soils inside the boundaries of the PBF-CITRC area, where Native American human remains have been discovered in both primary and secondary contexts. Cultural resource monitoring of projects that involve soil disturbance within this facility complex is routine and required by company procedures (e.g., BEA's LWP-8000 and CWI's MCP-3480). This level of cultural resource oversight ensures that any new discoveries of human remains will be managed appropriately.

Forms developed by INL CRM Office staff are completed for every cultural resource monitoring trip (Figure 38). Hard-copy and electronic versions of these documents are maintained in the INL CRM files. INL CRM files also include a variety of photographic documentation of monitoring efforts.

\section{Findings and Documentation}

Under the INL CRM monitoring program, there are four possible findings for a given monitoring trip, based on the level of disturbance noted:

1. Type 1: No visible changes to a cultural resource and/or a project that is operating within the limits of cultural resource clearance recommendations

2. Type 2: Impacts are noted but do not threaten the National Register eligibility of a cultural resource and/or a project is operating outside of culturally cleared limitations but no cultural resources have been adversely impacted

3. Type 3: Impacts are noted that threaten the National Register eligibility of a cultural resource and/or a project has been operating outside of culturally cleared limitations and impacts to non-eligible cultural resources have occurred

4. Type 4: Impacts that threaten the National Register eligibility of a cultural resource are occurring during the monitoring visit, justifying the use of the INL Stop Work Authority (LWP-14002, MCP553).

If Type 2, 3, or 4 impacts are documented during a monitoring trip, notifications are made to project managers, the DOE-ID cultural resources coordinator, and various other parties, as appropriate, according to the severity of the disturbance. Typically, Type 2 impacts can be corrected at once with the cooperation of INL project managers, security personnel, and/or landlord organizations. In these instances, the impacts are only reported in summary fashion in year-end reports. Some Type 2 and all Type 3 or 4 impacts prompt formal investigations by the INL CRM Office. INL project managers, security, and/or landlord organizations, DOE-ID, and Shoshone-Bannock tribal representatives may also participate in these investigations. 
Results of all monitoring and formal impact investigations are summarized annually in a year-end report to DOE-ID and also appear in a higher level summary of INL CRM Office yearly activities that is sent to DOE-ID and other parties such as the Idaho State Historic Preservation Office, the ShoshoneBannock Tribes, and stakeholders.

\title{
Idaho National Laboratory Cultural Resource Management Office Field Monitoring Form
}

\begin{abstract}
Monitor Number:
Monitor Name(s):

Monitor Date:
\end{abstract}

Project:

Site Name/Number:

Reason for monitoring:
Findings:
Type 1
Type 2
Type 3
Type 4

Impact Agent(s):

Significance of Impact:

Did disturbance or impact extend into undisturbed areas?

If yes, describe:

Yes

No

Work Halted?

If yes, describe:

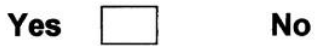

Notifications:

Primary contact(s):

Date contacted:

Contact Method:

E-mail

Phone

Official correspondence, CCN\#:

Cultural Materials
If yes, describe:

Yes

No

Cultural Materials collected?

If yes, describe:

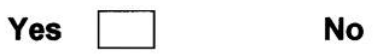

General Comments:

Recommendations:

Attach additional documentation, as warranted (photos, profiles, etc.)

If yes, describe:

Yes

No

Initials:

Date:

Figure 38. Example of INL Cultural Resource Management Office field monitoring form. 


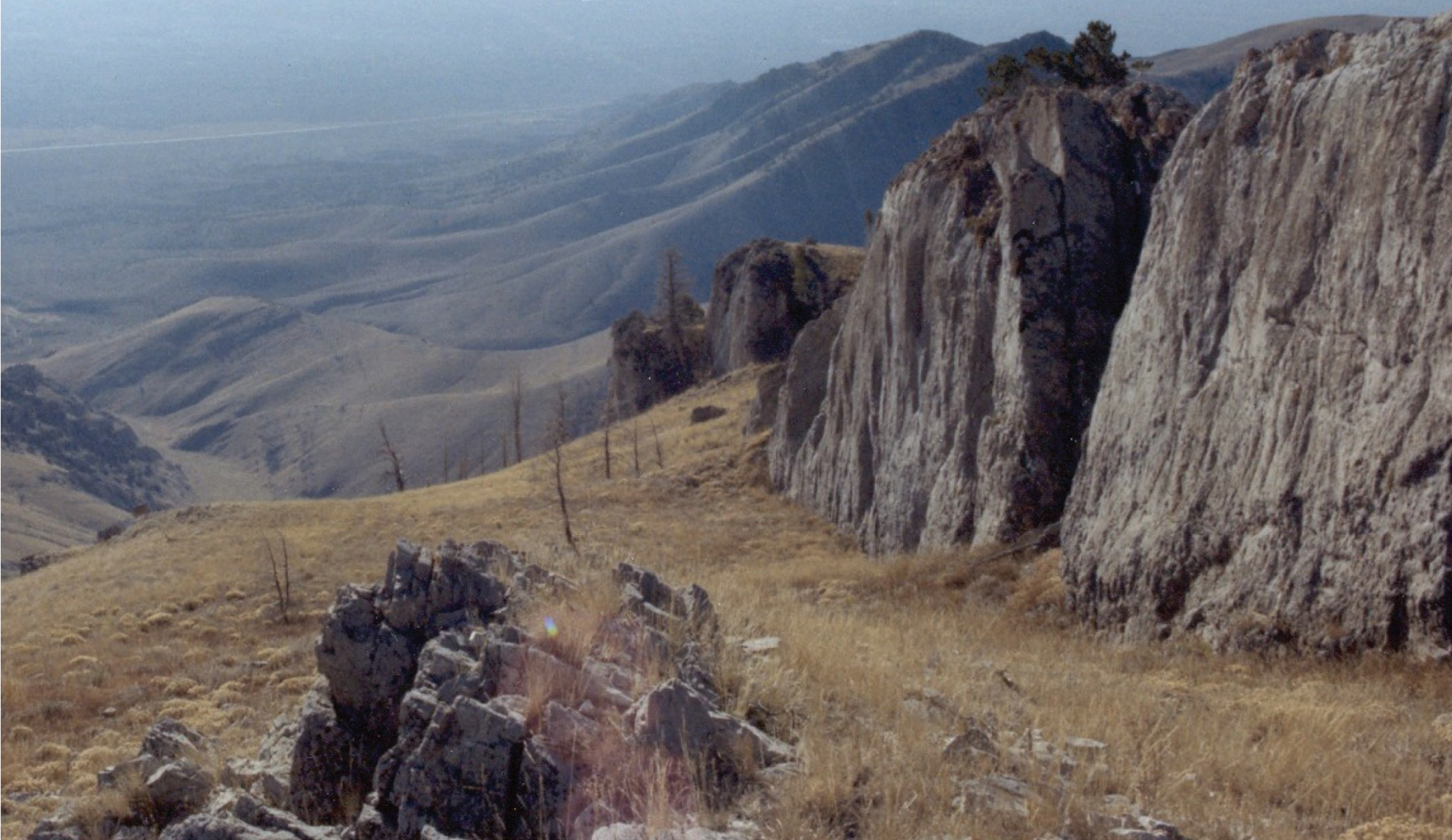
$-x^{2}+x^{2}+\infty$

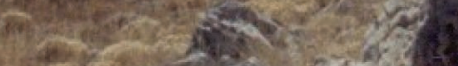

and

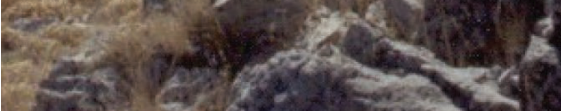

est

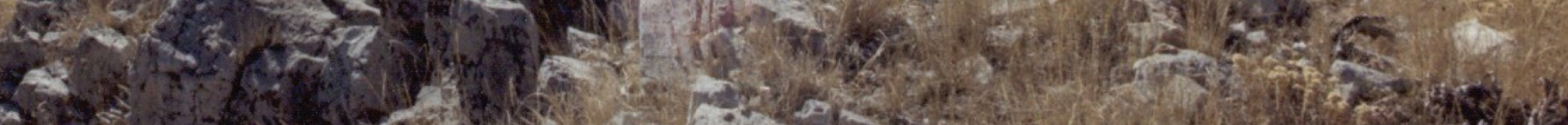

menct

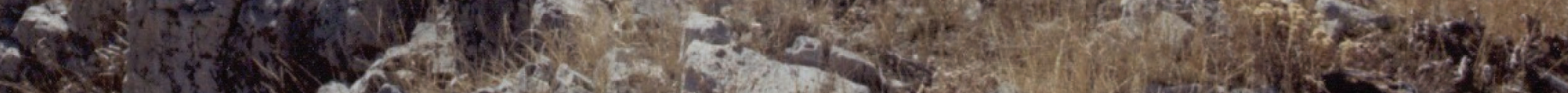

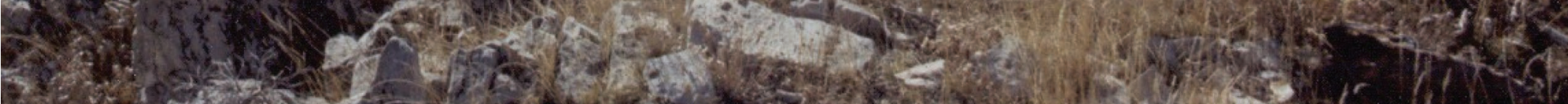

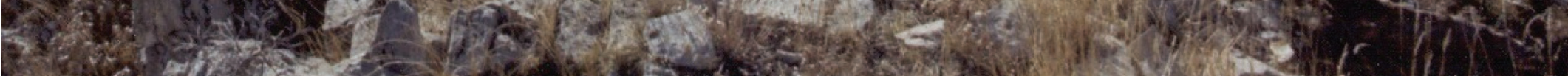

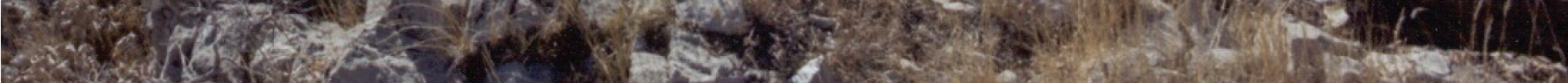

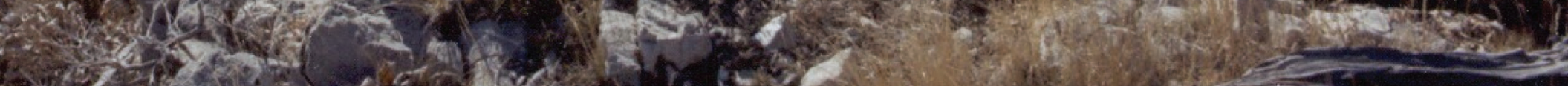

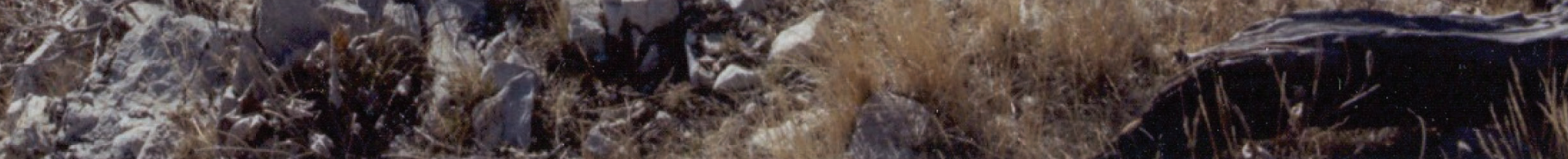

